PATRICIA LUSTOSA BRITO

SENSORIAMENTO REMOTO NA IDENTIFICAÇÃO DE ELEMENTOS E TIPOLOGIAS URBANAS RELACIONADOS À OCORRÊNCIA DA LEPTOSPIROSE NO SUBÚRBIO FERROVIÁRIO DE SALVADOR, BAHIA.

São Paulo

2010 
PATRICIA LUSTOSA BRITO

\section{SENSORIAMENTO REMOTO NA IDENTIFICAÇÃO DE ELEMENTOS E TIPOLOGIAS URBANAS RELACIONADOS À OCORRÊNCIA DA LEPTOSPIROSE NO SUBÚRBIO FERROVIÁRIO DE SALVADOR, BAHIA.}

Tese apresentada à Escola Politécnica da Universidade de São Paulo para obtenção do título de Doutor em Engenharia.

Área de concentração: Engenharia de Transportes - Informações Espaciais.

Orientador: Prof. Livre-Docente José Alberto Quintanilha.

São Paulo

Junho de 2010 
Autorizo a reprodução e divulgação total ou parcial deste trabalho, por qualquer meio convencional ou eletrônico, para fins de estudo e pesquisa, desde que citada a fonte.

Este exemplar foi revisado e alterado em relação à versão original, sob responsabilidade única do autor e com a anuência de seu orientador.

São Paulo, 8 de junho de 2010.

Assinatura do autor

Assinatura do orientador

FICHA CATALOGRÁFICA

Brito, Patrícia Lustosa

Sensoriamento remoto na identificação de elementos e tipologias urbanas relacionados à ocorrência da leptospirose no subúrbio ferroviário de Salvador, Bahia / P.L. Brito. -- ed.rev. -- São Paulo, 2010. $268 \mathrm{p}$.

Tese (Doutorado) - Escola Politécnica da Universidade de São Paulo. Departamento de Engenharia de Transportes.

1.Sensoriamento remoto 2.Epistemologia 3.Infra-estrutura urbana 4.Leptospirose 5.Favelas 6.Planejamento territorial urbano I.Universidade de São Paulo. Escola Politécnica. Departamento de Engenharia de Transportes II.t. 
Nome: BRITO, Patricia Lustosa

Título: Sensoriamento remoto na identificação de elementos e tipologias urbanas relacionados à ocorrência da leptospirose no Subúrbio Ferroviário de Salvador, Bahia.

Tese apresentada à Escola Politécnica da Universidade de São Paulo para obtenção do título de Doutor em Engenharia.

Aprovado em: 17 de maio de 2010.

\section{Banca Examinadora}

1. Prof. Dra. Maria Emília Bavia. Instituição: Escola de Veterinária, UFBA.

Julgamento: Aprovada.

2. Prof. Dra. Virgínia Ragoni de M. Correia. Instituição: INPE.

Julgamento: Aprovada.

3. Prof. Dr. Jorge G. G. Raffo. Instituição: Departamento de Geografia, USP. Julgamento: Aprovada.

4. Prof. Dr. Alex Kenya Abiko. Instituição: Dept. Engenharia Civil, USP. Julgamento: Aprovada.

5. Prof. Dr. José Alberto Quintanilha. Instituição: Dept. Engenharia de Transportes, USP. Julgamento: Aprovada. 
Aos meus "anjos", desencarnados e encarnados, que sempre me ajudaram, me dando forças, apontando e iluminando o meu caminho para o bem.

Ao meu amor, cujo olhar, abraços ou voz, mesmo que tantas vezes fisicamente distantes nessa empreitada, foi e é a minha paz.

Aos meus irmãos pela torcida e incentivo, à minha mãe pelo amor incondicional e ao meu pai pelo apoio, suporte, exemplo de responsabilidade e por valorizar sempre e tanto nosso crescimento intelectual, riqueza que ninguém nos tira. 


\section{AGRADECIMENTOS}

Ao Prof. Dr. José Alberto Quintanilha pela orientação desta pesquisa e aos professores Dr. Andrew Curtis e Dra. Nina Lam pela co-orientação no período em que a pesquisa foi desenvolvida no exterior.

Ao Laboratório de Geoprocessamento (LabGeo/EP/USP), do Departamento de Engenharia de Transportes da Escola Politécnica da Universidade de São Paulo, pela infra-estrutura cedida e aos colegas e professores desta instituição, em especial: Alessandra Knopik, Claudia Machado, Eduardo Jun, Leonardo Ercolin, Mariana Giannotti, Olga Iwai, Rodrigo Nóbrega, Prof. Dr. Marcos Rodrigues, Prof. Dr. Denizar Blitzkow e Prof. Dr. Claudio Barbieri.

Aos laboratórios World Health Organization Colaborate Center for GIS and RS for Public Health (WHOCC/LSU), Departamento de Geografia e Antropologia, e ao Laboratório de SR e SIG da Escola de Estudos Ambientais na Universidade da Louisiana, também pela infraestrutura cedida e aos colegas e professores destas instituições, em especial: Prof. Dr. Patrick Hesp, Prof. DeWitt Braud, Prof.Dr. Fahui Wang, Me. Helbert Arenas, Me. Willian Arden, Me. Gerardo Boquin.

Ao Dr. Albert Ko e sua equipe da FioCruz/Bahia, em especial Me. Ridalva Felzemburgh e Me. Renato Reis, pela parceria e confiança em compartilhar os dados de saúde. Os resultados desse trabalho são uma contribuição às pesquisas que vêm sendo desenvolvidas nessa instituição, no âmbito do projeto "História Natural da Leptospirose Urbana", que tem a parceria da Universidade de Cornell, Estados Unidos. A base de dados de saúde e fotografias aéreas utilizada nesse estudo foi gentilmente cedida pela FioCruz/Ba.

Aos professores e amigos que de diferentes formas colaboraram com este trabalho Me. Ronaldo Lyrio, Arqto. Floriano Freaza, Prof. Dr. Alex Abiko, Dra. Virgínia Ragoni, Me. Wagner Tassinari, Liana Montenegro, Murilo Martins e Moara Martins.

Ao Conselho Nacional de Desenvolvimento Científico e Tecnológico (CNPq) pelo financiamento desta pesquisa através de bolsa de doutorado no país e bolsa de sanduíche no exterior. 
É tão contrastante ver uma cidade tão naturalmente linda. Que insistentemente, quase que diariamente nos rouba um elogio. Em oposição a uma cidade tão naturalmente sofrida, triste, Que parece roubar o brilho do seu generoso sol.

São caixas desbotadas de armazenar gente. Tapetes escuros e borbulhantes de expulsar gente, arquivos gigantes de cuspir carros contra a gente, Paredes-campos de força que repelem gente. Buracos criadouros de bixos, doenças e gente.

Uma cidade tão linda, tão rica, tão viva, que sucumbe e se vende a quem não the vê, não Ihe entende, não Ihe quer bem.

Vamos Salvador, arme-se de palavras, de idéias, de ciência e não se renda! Eu não me rendo!

Patricia Lustosa Brito 


\section{RESUMO}

BRITO, Patricia Lustosa. Sensoriamento remoto na identificação de elementos e tipologias urbanas relacionados à ocorrência da leptospirose no Subúrbio Ferroviário de Salvador, Bahia.Tese (Doutorado) - Escola Politécnica, Universidade de São Paulo, São Paulo, 2010.

Em países em desenvolvimento, doenças infecciosas se constituem ainda um grave problema de saúde pública. Muitas vezes, essas doenças estão altamente relacionadas a condições urbanas que podem ser encontradas em áreas mais pobres. Nesses casos, o sensoriamento remoto (SR) pode ser utilizado como uma poderosa ferramenta de estudo. Novos produtos de SR se encontram disponíveis no mercado, permitindo o desenvolvimento de análises espaciais cada vez mais profundas e precisas. No entanto, a complexidade que envolve a epidemiologia de doenças, a irregularidade de ocupações urbanas e a heterogeneidade das imagens de alta resolução espacial têm restringido o desenvolvimento de estudos nesse campo científico. $O$ desafio de identificar elementos e tipologias urbanas em imagens de sensoriamento remoto relacionadas à ocorrência da leptospirose justifica-se pela crença de que ferramentas de SR podem ser mais amplamente utilizadas no monitoramento de carências urbanísticas e, consequentemente, na gestão de ações e investimentos públicos.

A metodologia contempla uma revisão bibliográfica sistemática, com base na qual foram criados modelos de transmissão da leptospirose e investigadas tipologias urbanas presentes na área de estudo. As variáveis baseadas em dados de SR que formam os indicadores dos modelos e que caracterizam as tipologias foram usadas para definir objetos e atributos, alvos das investigações em imagens de alta resolução espacial. Os procedimentos de SR adotados baseiam-se na segmentação multi-nível, classificação baseada em objeto, e utilizam ortofotografias aéreas, imagem QuickBird e base cartográfica do eixo viário do Subúrbio Ferroviário de Salvador. Para o cálculo das variáveis utilizou-se produtos do processamento da imagem QuickBird. Procedimentos de geoprocessamento foram realizados em sistema de informações geográficas. Por fim, realizaram-se as primeiras análises epidemiológicas que investigam a relação da leptospirose com os elementos e tipologias urbanas identificados por meio de SR, cujos resultados apontam maior influência do percentual de pavimentação das vias, sua largura e qualidade da edficação na possibilidade de ocorrência da leptospirose no Subúrbio.

Possíveis fontes de viés são discutidas ao lado de propostas de continuação da pesquisa. Apesar dos problemas e limitações identificados no processo, o estudo mostra que a metodologia desenvolvida baseada em SR se constitui uma poderosa ferramenta de análise do espaço intra-urbano, uma vez que permite a identificação de elementos e tipologias relacionados a situações de risco, apoiando assim, o direcionamento de investimentos públicos que venham refletir na melhoria das condições de saúde da população.

Palavras-chave: Sensoriamento remoto, Epidemiologia, Infra-estrutura urbana, Classificação de imagens, Ortofotografia, Imagem QuickBird, Áreas precárias, Leptospirose, Salvador. 


\begin{abstract}
BRITO, Patricia Lustosa. Using remote sensing to identify urban elements and patterns related to Leptospirosis occurrence at the Railroad Suburb of Salvador, Brazil.Tese (Doutorado) - Escola Politécnica, Universidade de São Paulo, São Paulo, 2010.
\end{abstract}

In developing countries, infeccious diseases are still a serious public health problem. These diseases are often and highly related to urban conditions found in poor areas. In these cases, remote sensing (RS) can be used as a powerfull tool. New RS products are now available alowing the development of more complex and precise spatial analysis. On the other hand, the complexity of epidemiological studies, the lack of regularity of precarious urban settlements and the heterogenity of high spatial resolution images have been restricting the development of studies in this areas. The chalenge of identifying urban elements and tipologies related to the leptospirosis using RS products is persued due the beleif that RS can be more used among pofessional and researchers in the task of monitoring the urban invironment, and directing public investiments and actions.

The methodology presented consists in a broad literature review, which was used to support leptostirosis transmition risk models and to find urban tipologies at the study area. Variables based on RS were identified in the disease models and in the tipologies charachterization. This models and tipologies also defined targuets to look for in the high spatial resolution images. RS procedures were based on multi-level segmentation, object-based classification, aereal photography, QuickBird satelite images and street axis vector data of the Railroad Suburb of Salvador. In order to obtain the variable's values, results of QuickBird image processing were added to a geographic database and processed using vector and raster overlayering technics. At last, epidemiological analysis were iniciated aiming to find its relationship with the urban elements and typologies identified using RS. The results points paved streets, streets wideness and house quality as the RS variables that have more influence on the leptospirosis transmition chance.

The dissertation also presents reseach restrains, potentials, possible sources of bias and future studies proposals. It concludes that the RS based methodology presented is a powerful tool for urban analysis, due to its capabilities for identifying urban targuets related to risky situations, and, therefore, for helping direct public investiments to improve life conditions an unprivileged city areas.

Keywords: Remote Sensing, Epidemiology, Urban infra structure, Image classification, Ortophotographs, QuickBird images, Precarious settlements, Leptospirosis, Salvador, Brazil. 


\section{LISTA DE QUADROS}

Quadro 2.1. Revisão Bibliográfica - Fatores de risco de transmissão da leptospirose relacionado ao ambiente urbano.

Quadro 2.2. Amostras de padrões espaciais em diferentes cidades. Imagens caputuradas do Google Earth .29

Quadro 2.3. Taxonomia dos sistemas de sensoriamento remoto. .46

Quadro 2.4. Principais sistemas sensores multiespectrais para imageamento de áreas urbanas em operação em 2008 e sistemas de referência .52

Quadro 2.5. Custo(U\$) de produtos e mão de obra utilizada para um projeto de mapeamento de biomassa em uma área de $50 \mathrm{~km}^{2}$, Hong Kong.

Quadro 2.6. Levantamento bibliográfico, 2001-2008, de características urbanas e métodos de classificação em produtos de sensores passivos utilizados para análise do espaço intraurbano.

Quadro 2.7. Revisão Bibliográfica - Fatores de risco epidemiológico, relacionado ao ambiente urbano, identificados com uso de processamento de imagens satélite multiespectrais ou fotografias aéreas.

Quadro 4.2. Tabulação dos dados observados na Imagem satélite (QuickBird 2005) e grupos de tipologias de acordo com análise de cluster

Quadro 4.3. Distância Euclidiana entre o centróide do grupo e o centróide principal por variável, agrupamento empírico. 120

Quadro 4.4. Macro grupos de tipologia baseado em dados de sensoriamento remoto 122

Quadro 5.1. Dimensionamento e descrição do raio de abrangência utilizado para a análise dos Indicadores do modelo FPEEEA/L 130

Quadro 5.2. Variáveis baseadas em SR que podem ser utilizadas para o cálculo dos indicadores de pressão e suas escalas de análise. 132

Quadro 5.3. Variáveis baseadas em SR que podem ser utilizadas para o cáculo dos indicadores de Estado e suas escalas de análise 133

Quadro 5.4. Amostras com imagens de campo e imagens verticais de variáveis baseadas em SR do modelo FPEEEA/L 134 
Quadro 6.1. Levantamento dos alvos e suas características de interesse para o estudo, de acordo com as variáveis baseadas em SR, indicadores do modelo FPEEEA/L, tipologias encontradas no Subúrbio e escalas de análise. 138

Quadro 6.2. Descrição dos alvos e classes 139

Quadro 6.3. Ortofotografias e imagens QuickBird de áreas teste e áreas controle. 147

Quadro 6.4. Parâmetros da segmentação em ortofotografias 152

Quadro 6.5. Resumo das principais classes e suas principais funções descritoras Ortofotografias 156

Quadro 6.6. Avaliação de acurácia da classificação em Ortofotografia 159

Quadro 6.7. Matriz de confusão da classificação em Ortofotografia 160

Quadro 6.8. Matriz de erros de omissão da classificação em Ortofotografia 160

Quadro 6.9. Matriz de erros de comissão da classificação em Ortofotografia 161

Quadro 6.10. Parâmetros da segmentação em imagem QuickBird 166

Quadro 6.11. Resumo das principais classes e suas principais funções descritoras QuickBird. 170

Quadro 6.12. Avaliação de acurácia de classificação em imagens 174

Quadro 6.13. Matriz de confusão da imagem QuickBird. 176

Quadro 6.14. Matriz de erros de omissão da imagem QuickBird 176

Quadro 6.15. Matriz de erros de comissão da imagem QuickBird 177

Quadro 6.16. Representatividade das classes de interesse segundo acurácia por pixel, área classificada e variáveis 183

Quadro 7.1. Matriz de correlação das variáveis calculadas para os buffers de $50 \mathrm{~m}$ 189

Quadro 7.2. Resumo da classificação com validação cruzada, 5 grupos 190

Quadro 7.3. Resumo da classificação com validação cruzada, 9 grupos 190

Quadro 7.4. Análise de centróides, cinco grupos. 191

Quadro 7.5. Classificação das amostras de tipologia segundo formação de cinco grupos.192

Quadro 7.6. Análise de centróides, nove grupos. 193

Quadro 7.7. Características dos nove grupos formados segundo métodos k-Médias. 194

Quadro 7.8. Função discriminante linear para os nove grupos 196 
Quadro 7.9. Classificação das amostras de tipologia, nove grupos. 196

Quadro 7.10. Distância quadrática entre os grupos. 197

Quadro 7.11. Média e mediana das variáveis. 201

Quadro 7.12. Estatísticas, regras, exemplos e descrição básica dos grupos formados pela árvore de regressão 202 


\section{LISTA DE FIGURAS}

Figura 1.1. Diagrama de formulação da hipótese

Figura 2.1. Diferentes formas de apresentação do mapa de investigação de casos de cólera em Londres de John Snow

Figura 2.2. Diagramas de estudos ecológicos 16

Figura 2.3. Ciclo, ambiente e sintomas da leptospirose. 20

Figura 2.4. Características urbanas $x$ número de artigos. Frequência com que as características urbanas foram investigadas ou mencionadas. 23

Figura 2.5. Formas de ocupação e expansão urbana das metrópoles: Londres, Tokio, Nova York, Barcelona, Zurique e Salvador 28

Figura 2.6. A cidade heterogênea que parece homogênea e o mosaico de subculturas .30

Figura 2.7. Tipos de elementos que formam a imagem da cidade: caminhos, bordas, distritos, nós e marcos 30

Figura 2.8. Quadro da evolução dos materiais. 32

Figura 2.9. Aplicações de modelos morfológicos 3D. 33

Figura 2.10. Epidemia de 1878 de febre amarela em New Orleans. 34

Figura 2.11. A vida acontece no espaço público. 36

Figura 2.12. Discrepância entre morfologias vizinhas 38

Figura 2.13. Favela da Rocinha, Rio de Janeiro..... 38

Figura 2.14.Semelhança morfológica entre favelas de diferentes locais do mundo. 39

Figura 2.15. Imagens satélite composição colorida e imagens binária utilizadas para investigar diferenças em padrões de textura (lacunaridade) e padrão universal de fragmentação. .40

Figura 2.16. Exemplo de mapa de conceitos do conceito "mapa conceitual". 43

Figura 2.17. Cadeia de causa e efeito de doenças redutíveis por medidas de saneamento.

Figura 2.18. Exemplo de sensoriamento remoto do ambiente terrestre através de sensores de radiação eletromagnética. 46 
Figura 2.19. Estrutura da película fotográfica colorida. Sessão transversal genérica

Figura 2.20. Espectro eletromagnético. 50

Figura 2.21. Sensibilidade espectral das três camadas de tingimento 50

Figura 2.22. Pessoas físicas usuárias de imagens CBERS participantes da pesquisa realizada pelo INPE, segundo profissão.

Figura 2.23. Principais recursos metodológicos de classificação digital de imagens utilizados em sensoriamento remoto. 56

Figura 2.24. Classificação com lógica fuzzy

Figura 2.25. Análise de Imagem orientada a objeto: procedimento genérico

Figura 2.26. Elementos da classificação orientada a objeto. 65

Figura 2.27. Exemplo de atributos utilizados na classificação baseada em objeto. 65

Figura 2.28. Modelo V-I-S com a locação de alguns componentes urbanos e do entorno urbano. 73

Figura 2.29. Gráfico das principais características urbanas estudadas nos trabalhos pesquisados no levantamento sistemático. .75

Figura 2.30. NDVI e Modelo genérico da assinaturas espectrais e janela espectral .78

Figura 2.31. Assinatura espectral da água limpa, água turva e outras coberturas do solo...80

Figura 2.32. Diagrama esquemático da acurácia do produtor e acurácia do usuário. 83

Figura 3.1. Mapa dos limites das imagens utilizadas na pesquisa. 96

Figura 3.2. Mapa dos dados vetoriais utilizados na pesquisa.

Figura 3.3. Metodologia proposta pra identificação de parâmetros, baseados em dados de sensoriamento remoto, relacionados à ocorrência de doenças .98

Figura 3.4. Diagrama esquemático dos procedimentos metodológicos utilizados 100

Figura 3.5. Detalhamento do fluxo de dados e produção de informações. 101

Figura 4.1. Processo mais frequente de ocupação de grotões e vales da cidade de Salvador. 104

Figura 4.2. Mapas de localização da área de estudo. 106

Figura 4.3. Caracterização do Subúrbio Ferroviário segundo estudos de Gordilho (2000).108 
Figura 4.4. Método de identificação de tipologias urbanas com base na análise de produtos de sensoriamento remoto

Figura 4.5. Ocupação informal em encosta. 118

Figura 4.6. Dendograma com conexão completa e distância euclidiana.

Figura 5.1. Mapas conceituais dos conceitos chaves identificados através de revisão bibliográfica. 126

Figura. 5.2. ISA/L - Modelo de risco de transmissão de leptospirose baseado na metodologia ISA

Figura 5.3. Exemplo de identificação de variável baseada em produto de sensoriamento remoto utilizando modelo de risco ISA/L 128

Figura 5.4. FPEEEA/L - Modelo de risco de transmissão da leptospirose com base na metodologia FPEEEA.

Figura 5.5. Variáveis e escalas de análise dos indicadores de Estado e Pressão do modelo FPEEEA/L. 130

Figura 6.1. Metodologia da etapa de Sensoriamento Remoto 144

Figura 6.2. Mapas base para delimitação de áreas teste e áreas controle. 146

Figura 6.3. Etapa de pré-processamento para classificação de ortofotografias 149

Figura 6.4. Processos interativos de classificação e segmentação nas ortofotografias 151

Figure 6.5. Diagrama do processo de classificação 153

Figura 6.6. Classificação baseada em objeto e classificação visual das áreas controle. ...158

Figura 6.7. Etapa de pré-processamento de imagem QuickBird 163

Figura 6.8. Processos interativos de classificação e segmentação na imagem QuickBird 165 Figura 6.9. Diagrama do processo de classificação em imagem QuickBird 171

Figura 6.10. Classificação baseada em objeto e classificação visual das áreas 173

Figura 6.11. Gráficos comparativos da acurácia em cada área controle. 1800

Figura 6.12. Gráficos comparativos da acurácia media geral. 181

Figura 6.13. Classificação do Subúrbio Ferroviário utilizado GEOBIA em imagem QuickBird. 1822

Figura 7.1. Diagrama de procedimentos e análises realizados para investigar relacionamento entre características urbanas e dados de saúde. 187 
Figura 7.2. Número de grupos e percentual de acerto das funções discriminantes 189

Figura 7.3. Mapas de agrupamento empírico (tipologias), mapa de agrupamento estatístico, cinco grupos. 192

Figura 7.4. Mapa de agrupamento empírico e mapa de agrupamento estatístico, 9 grupos.

Figura 7.5. Mapa de distribuição dos grupos formados segundo método k-Médias, nove grupos. 198

Figura 7.6. Árvore de regressão. 200

Figura 7.7. Mapa de distribuição dos buffers segundo agrupamentos formados pela árvore de regressão 201

Figura 7.8. Gráfico BoxPlot dos valores de incidência no buffer de 50m por agrupamento 203 Figura 7.9. Mapas de densidade populacional. 206

Figura 7.10. Gráfico BoxPlot para análise de relação entre adensamento urbano e agrupamentos formados por árvore de regressão 207

Figura 7.11. Mapas de distribuição dos casos e da população 208

Figura 7.12. Gráfico BoxPlot, análise de relação entre razão de Kernel e agrupamentos formados por árvores de regressão 209 


\section{LISTA DE ABREVIATURAS E SIGLAS}

\begin{tabular}{|c|c|}
\hline APA & Área de Proteção Ambiental \\
\hline ARVI & Atmospherically Resistant Vegetation Index \\
\hline $\mathrm{BSI}$ & Bare Soil Indicator (Indicador de solo exposto) \\
\hline CAPES & Coordenação de Aperfeiçoamento de Pessoal de Nível Superior \\
\hline CBERS & China-Brazil Earth Resources Satellite \\
\hline $\mathrm{CCZ}$ & Centro de Controle de Zoonoses \\
\hline CDC & Center for Disease Control and Prevention \\
\hline CEP & Código de Endereçamento Postal \\
\hline CHAART & Center for Health Aplications of Aerospace Related Technologies \\
\hline $\mathrm{Cl}$ & Índice de Clorofila \\
\hline $\mathrm{CNPq}$ & Conselho Nacional de Desenvolvimento Científico e Tecnológico \\
\hline $\mathrm{CP}$ & Componente Principal \\
\hline CRA & $\begin{array}{l}\text { Centro de Recursos Ambientais, renomeado Instituto do Meio Ambiente } \\
\text { (IMA): Orgão de defesa e fiscalização do meio ambiente do Estado da Bahia. }\end{array}$ \\
\hline EPUCS & Escritório de Planejamento e Urbanismo da Cidade do Salvador \\
\hline EUA & Estados Unidos da America \\
\hline FAPAR & Fraction of Absorbed Photosynthetically Active Radiation \\
\hline FIOCRUZ & Fundação Osvaldo Cruz \\
\hline FPEEEA & Força motriz - Pressão - Estado - Exposição - Efeito - Ação \\
\hline GCLM & Gray Level Co-occurrence Matrix \\
\hline GEMI & Global Environment Monitoring Index \\
\hline GEOBIA & Geo-object Based Image Analysis \\
\hline GPS & Global Positioning System \\
\hline HIV & Human Immunodeficiency Virus \\
\hline HRSC & High Resolution Stereo Camera \\
\hline IBGE & Instituto Brasileiro de Geografia e Estatística \\
\hline $\mathrm{ICH}$ & Índice de Carência Habitacional \\
\hline IEEE & Institute of Electrical and Electronics Engineers \\
\hline IHS & Intensity, hue, saturation (intensidade, matiz e saturação) \\
\hline IMUS & Índice de Mobilidade Urbana Sustentável \\
\hline INPE & Instituto Nacional de Pesquisas Espaciais \\
\hline IQV & Índice de Qualidade de Vida urbana \\
\hline IRS & Indian Remote Sensing Satellite \\
\hline ISA & Indicadores de Salubridade Ambiental \\
\hline
\end{tabular}




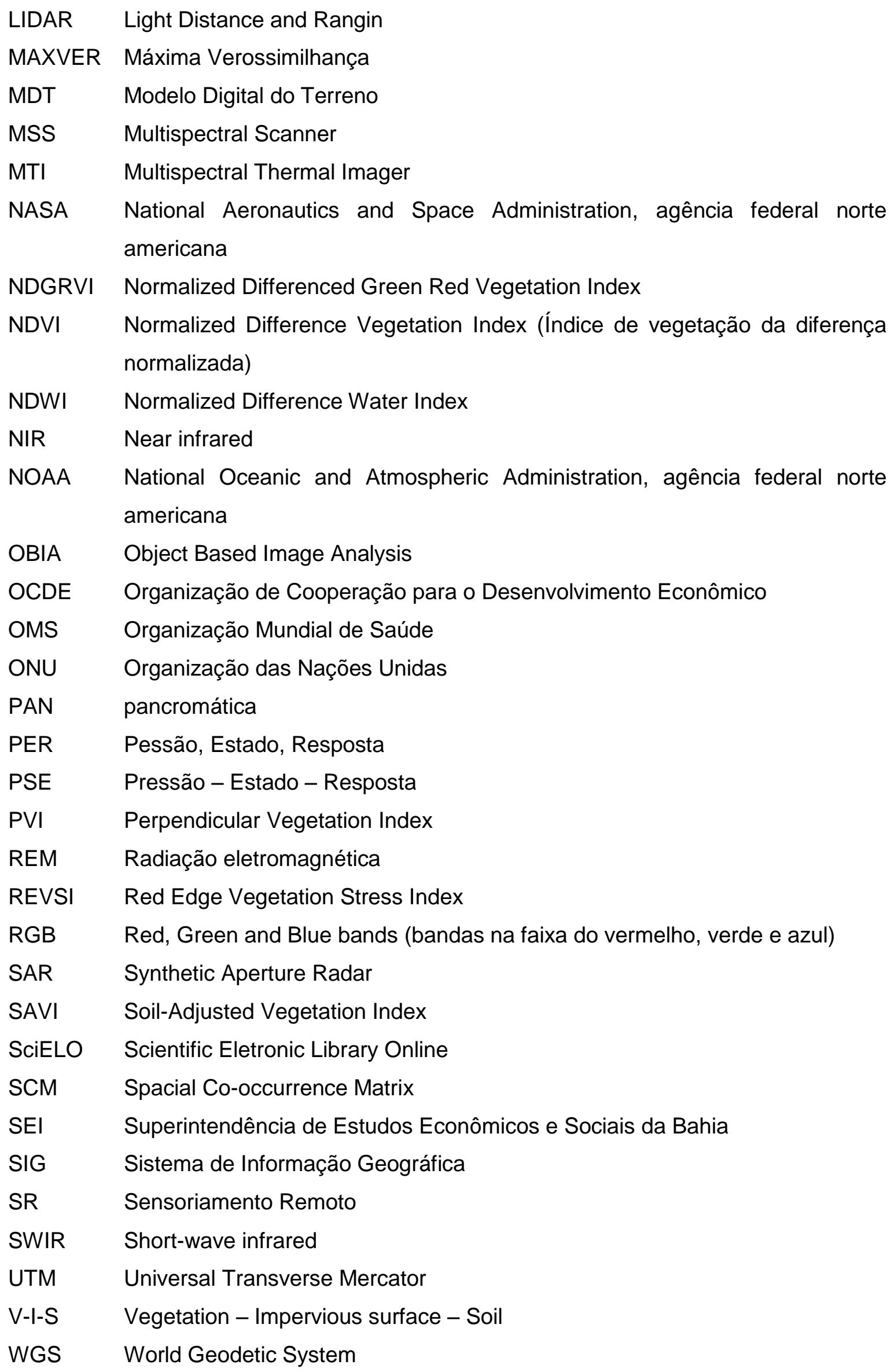


SUMÁRIO

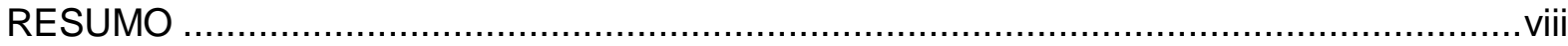

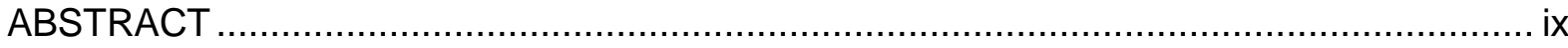

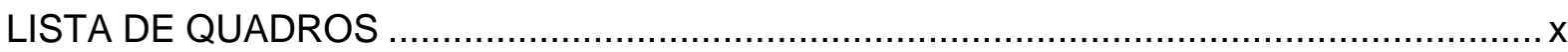

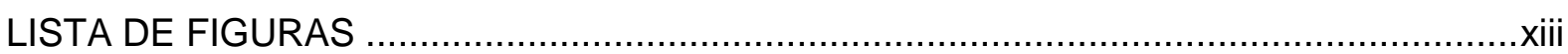

LISTA DE ABREVIATURAS E SIGLAS .................................................................xii

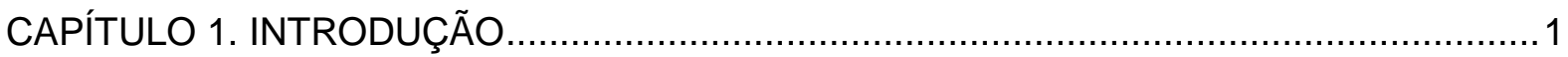

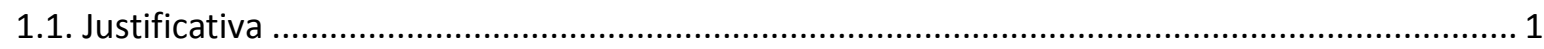

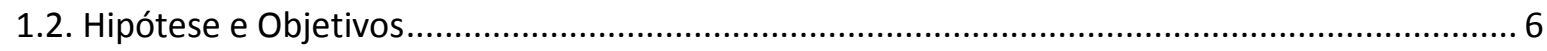

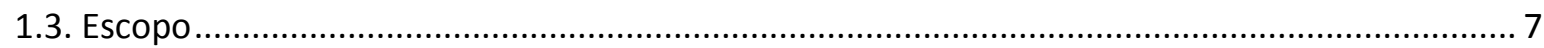

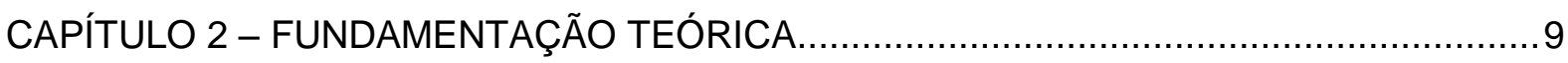

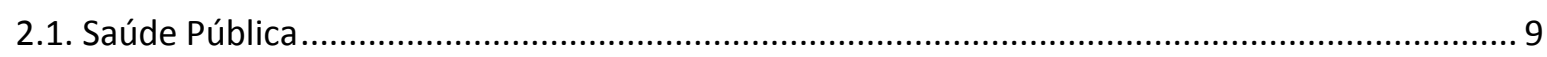

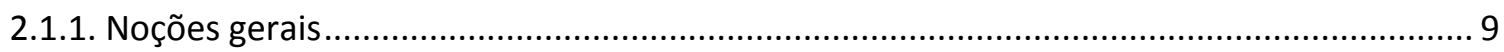

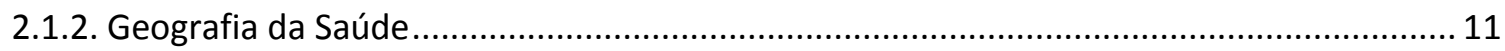

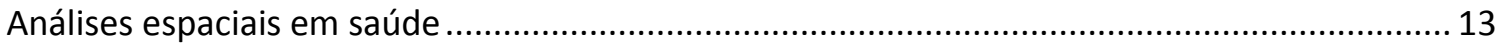

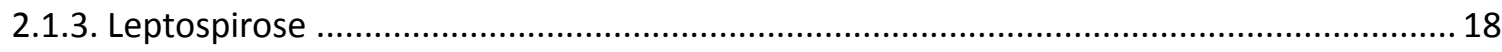

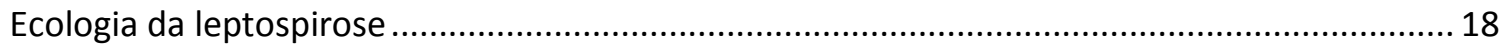

Características urbanas e a transmissão da leptospirose .......................................................... 21

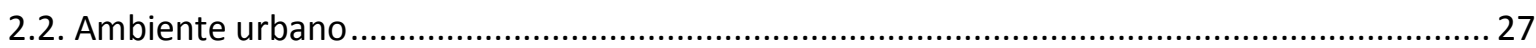

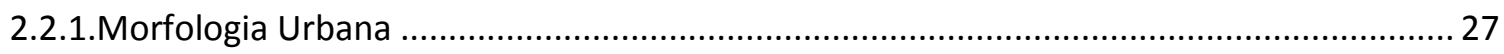

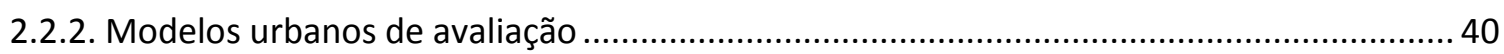

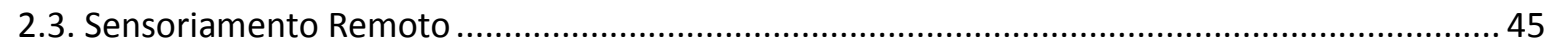

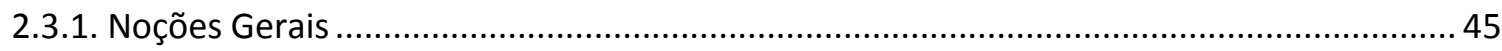

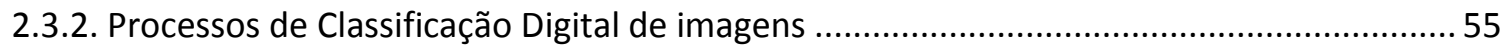

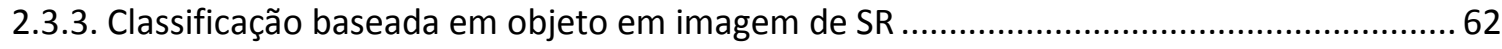

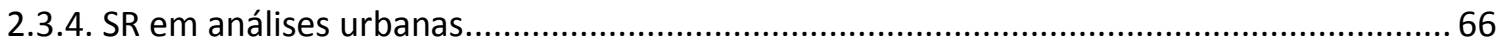

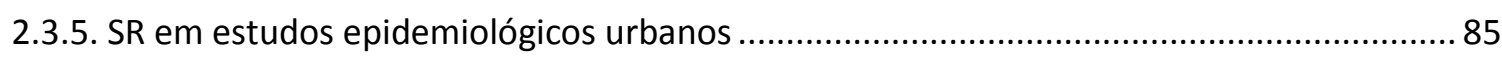


2.3.6. SR em estudos urbanos da leptospirose. 89

CAPÍTULO 3 - MATERIAIS E MÉTODOS .95

3.1. Materiais 95

Ortofotografias aéreas de 2002 95

Imagem do sistema sensor QuickBird de 02/08/2005. 95

Base cartográfica 95

Dados de Saúde . 96

Programas computacionais 97

3.2. Metodologia. .98

CAPÍTULO 4 - ÁREA DE ESTUDO 102

4.1. Aspectos gerais da cidade de Salvador..... 102

4.2. O Subúrbio Ferroviário de Salvador. 105

4.3. Caracterização das tipologias urbanas do Subúrbio Ferroviário 106

4.4. Agrupamento das tipologias encontradas no Subúrbio 118

CAPÍTULO 5 - MODELOS DE RISCO DE TRANSMISSÃO DA LEPTOSPIROSE 124

5.1. Exploração do problema por mapas conceituais 124

5.2. Modelo ISA/L - Indicadores de Salubridade Ambiental para transmissão da Leptospirose.... 127

5.3. Modelo Causal FPEEEA/L: Força Motriz - Pressão - Estado - Exposição - Efeito - Ação na transmissão da Leptospirose 128

5.4. Variáveis FEPEEEA/L baseadas em produtos de Sensoriamento Remoto 131

CAPÍTULO 6 - PROCESSAMENTO DE DADOS DE SENSORIAMENTO REMOTO 137

6.1. Caracterização dos Alvos 137

6.2. Limites das áreas de processamento. 143

6.3. Classificação em áreas teste e controle de ortofotografias 148

6.3.1. Pré processamento 149

6.2.2. Segmentação e Classificação

6.2.3 Testes de acurácia

6.4. Classificação em áreas teste e controle de imagem QuickBird 162

6.4.1. Pré-processamento 
7. 1. Agrupamento estatístico k-Médias para identificação de tipologias

7.2. Investigação de parâmetros urbanos relacionados à ocorrência da doença pelo método da árvore de regressão

7.3. Investigação da influência do crescimento populacional nas análises

7.4. Probabilidade de contaminação segundo densidade populacional e de casos pelo método da razão de Kernel....

\section{CAPÍTULO 8. DISCUSSÃO DOS RESULTADOS}

8.1. Tipologias Urbanas

8.2. Metodologia e modelos

8.3. Sensoriamento remoto

CAPÍTULO 9. CONCLUSÕES

REFERÊNCIAS

APÊNDICES

APÊNDICE 1 - Árvore de processos Ortofotografia.

APÊNDICE 2 - Hierarquia de classes Ortofotografia

APÊNDICE 3 - Descrição das classes Ortofotografias.

APÊNDICE 4 - Árvore de processos QuickBird

APÊNDICE 5 - Hierarquia de classes QuickBird 


\section{CAPÍTULO 1. INTRODUÇÃO}

\subsection{Justificativa}

Em países em desenvolvimento, como o Brasil, muitas cidades sofrem com a carência de infra-estrutura básica e, ao mesmo tempo, dispõem de limitados recursos para investimentos maciços. Diante de tal precariedade, cidades padecem com a ocorrência de inúmeras doenças infecciosas, como a leptospirose, e estudos epidemiológicos são fundamentais na redução de despesas com tratamento médico e no apoio à priorização de investimentos.

O interesse crescente na análise e monitoramento do ambiente urbano é uma tendência mundial cada vez mais necessária. Segundo a ONU (UN-POPULATION DIVISION, 2009) mais da metade da população mundial já vive em áreas urbanas. Em regiões mais desenvolvidas cerca de $75 \%$ da população reside em cidades, sendo que a taxa de crescimento anual é descendente $(0,54)$. Já em regiões menos desenvolvidas a situação é inversa. Estima-se que o percentual de urbanização seja de $45 \%$ e que a taxa de crescimento urbano seja de 2,53. No ano de 2010, acredita-se que mais de $85 \%$ da população brasileira estará vivendo em cidades, e que a taxa de crescimento anual dos cinco anos seguintes será ainda de 1,80.

Estima-se que nos últimos 60 anos a população urbana brasileira cresceu em números impressionantes, quase nove vezes, de 19,5 milhões em 1950 para 172 milhões estimados para 2010 , enquanto a população rural decresceu em cerca de $20 \%$, de 34,4 milhões em 1950 para 26,8 milhões estimados para 2010 (UN-POPULATION DIVISION, 2009). Nesse período, o poder público não tem nem se antecipado a esse crescimento com os planos efetivos de uso e ocupação do solo, nem acompanhado a infra-estruturação das cidades para atender em serviços básicos (saneamento, abastecimento de água, saúde, circulação e lazer). Uma das consequências dessa combinação de incapacidade administrativa com a expressiva mudança na situação da população tem sido o aumento do número de ocupações informais, ou favelas, onde as precárias condições sanitárias ensejam a transmissão das doenças vetoriais e o surgimento de epidemias. Outra consequência, diretamente relacionada com a mudança na ocupação do espaço, é o desordenamento da cadeia ecológica dessas regiões, o que demanda mudanças adaptativas da biota, nem sempre em harmonia com as atividades humanas, alterando a dinâmica epidemiológica local. 
Com base na necessidade de abastecimento de água, esgotamento sanitário e habitação com área mínima, o UN-Habitat (2008) relata que o pior cenário acontece em cidades consideradas cidades-favelas, onde a pobreza é tão generalizada que mais de dois terços da população vive em condições de precariedade, a maior parte dessas cidades estão no continente africano. De acordo com o relatório da Un-Habitat de 2008, o Brasil é considerado um país com concentração moderada de favelas, 30\% das habitações, segundo o Instituto Brasileiro de Geografia Estatística (2000).

Segundo pesquisas realizadas pela Fundação João Pinheiro e o Instituto de Pesquisa e Planejamento Urbano e Regional, com base em dados de 2007, são as regiões metropolitanas do Brasil que concentram espacialmente grande parte das carências habitacionais nacionais. Nas maiores regiões metropolitanas encontram-se cerca de $30 \%$ do déficit habitacional (BRASIL, 2009), cerca de 30\% das inadequações habitacionais (OBSERVATÓRIO DAS METRÓPOLES, 2008); e cerca de 75\% dos domicílios em setores subnormais, reconhecidos como favelas (BRASIL, 2009). Estima-se que o déficit habitacional nas regiões metropolitanas seja de 1,85 milhões de unidades, sendo que $87 \%$ dele está concentrado na população com rendimento de 0 a 3 salários mínimos e $94 \%$ na faixa de renda de 0 a 5 salários mínimos. A região metropolitana de Salvador apresenta indicadores ainda mais preocupantes que a média nacional: o déficit habitacional de cerca de 141 mil domicílios equivale a $13,7 \%$ do total de famílias, 95\% destas têm renda mensal de 0 a 3 salários mínimos (BRASIL, 2009), ao mesmo tempo as inadequações habitacionais por infra estrutura atingem mais de $40 \%$ dos domicílios da Região Metropolitana (OBSERVATÓRIO DAS METRÓPOLES, 2008). Gordilho (2000) estima que mais da metade da população de Salvador viva em áreas com algum tipo de deficiência urbana. $\mathrm{Na}$ Região Metropolitana de São Paulo os números absolutos impressionam ainda mais: déficit habitacional de cerca de 629 mil domicílios e estima-se que 717 mil domicílios sofram com problemas de inadequação habitacional por infra-estrutura.

Estima-se ainda que, ao redor do mundo, mais de 100 milhões de pessoas viverão em breve abaixo da linha de pobreza devido a atual crise financeira mundial (UN MILLENIUM CAMPAIGN, 2009). O fenômeno de decadência visto em algumas cidades é acelerado nesses momentos de crise e pode tomar grandes proporções com o desemprego maciço e restrições ao investimento público. O fato é que o desenvolvimento urbano torna-se cada vez mais dependente da economia global, e crises financeiras afetam diretamente as condições de vida em cidades de países em desenvolvimento e países desenvolvidos. Crises como a atual aumentam a possibilidade de doenças infecciosas reemergirem em 
regiões mais desenvolvidas e de se tornarem problemas ainda mais graves nas demais regiões, onde os efeitos de uma crise global costumam ser sentidos em uma escala muito maior.

Um dos entraves ao combate desse tipo de problema é de ordem estrutural: o principal foco da ação pública "está voltado para o diagnóstico e tratamento das pessoas doentes, visando a interrupção da cadeia de transmissão" (BRASIL, 2008a; s/p). No entanto, faz-se necessário a ação de diversos setores, uma vez que parte das razões para a emergência, reemergência, os surtos ou a endemicidade de doenças reside em processos que não são externos ao setor saúde, como: "urbanização acelerada sem adequada infra-estrutura urbana, alterações do meio ambiente, desmatamento, ampliação de fronteiras agrícolas, processos migratórios, grandes obras de infra-estrutura (rodovias e hidroelétricas)“ (BRASIL, 2008b; 10).

Ainda que o grande avanço nos serviços básicos de atenção à saúde e abastecimento de água, ocorridos da última década, somado ao contínuo progresso e difusão de vacinas tenham reduzido significativamente o índice de mortalidade das doenças transmissíveis por vetores, o índice de morbidade ainda é bastante alto. Isto ocasiona um significativo prejuízo na qualidade de vida da população, além de novas demandas por recursos públicos para o atendimento médico e para ações de controle epidemiológico.

É de amplo reconhecimento da geografia médica que análises espaciais auxiliam na caracterização e identificação de áreas de risco à saúde, onde há população mais susceptível às enfermidades. O aprofundamento e aperfeiçoamento dessas análises são importantes para que as ações sejam melhor direcionadas, e para que a demanda seja por um investimento menor e mais eficaz em medicamentos e em intervenções urbanas que reduzam mais prolongadamente o risco de contaminação.

A introdução de novas técnicas de representação espacial revolucionou a geografia médica, trazendo novos horizontes ainda pouco explorados. Apesar do grande aumento da disponibilidade de tecnologias de manipulação de informações gráficas e de mapas em microcomputadores, essas tecnologias, em geral, necessitam de conhecimentos computacionais e geográficos avançados, que segundo Correia et al. (2004) ainda são bastante limitados para os profissionais do campo da saúde. A integração dos profissionais das diversas áreas de formação (geógrafos, epidemiologistas, estatísticos, urbanistas e engenheiros, por exemplo) em torno do processamento e análise espacial vem permitindo grandes avanços metodológicos. 
Já existe uma gama significativa de estudos epidemiológicos em áreas urbanas que usam os sistemas de informações geográficos como principal ferramenta de mapeamento. No entanto, só recentemente estiveram disponíveis no mercado internacional as imagens de alta resolução, permitindo que o espaço intra-urbano também fosse estudado com o suporte de ferramentas de sensoriamento remoto.

Por aproximadamente 30 anos, o processamento em imagens de Sensoriamento Remoto focou-se na tradução de dados espectrais em informações de cobertura do solo. Com o lançamento dos satélites SPOT, IKONOS e QuickBird por volta do ano 2000, tornou-se possível distinguir alvos com dimensões espaciais iguais ou inferiores a 10m, abrindo novos horizontes aos estudos do espaço intra-urbano e novos desafios metodológicos.

Imagens satélite de alta resolução espacial são muito heterogêneas e ainda possuem baixa resolução espectral. Nessas imagens, métodos tradicionais de classificação pixel a pixel não têm obtido o mesmo êxito, e a análise geográfica baseada em objeto (GEOBIA ou OBIA) tem sido considerada por alguns autores um novo paradigma no campo do Sensoriamento Remoto (HAY e CASTILLA, 2008, WALKER e BLASCHKE 2008, BAATZ, 2008; NAVULUR, 2007).

Os princípios básicos que distinguem análises baseadas em objetos de análises baseadas em pixel são relacionados à capacidade de reconhecer objetos de imagem utilizando critérios que simulam a interpretação humana, como tamanho do objeto, forma, contexto, hierarquia, entre outros. O processo tem início com a segmentação em imagens, que pode utilizar não apenas dados espectrais de cada pixel, como o processo baseado em pixel, mas também atributos geométricos dos segmentos que estão sendo criados, além de dados vetoriais. A abordagem GEOBIA também permite a criação de múltiplos níveis de segmentação alternados com processos de classificação, o uso de imagens com diferentes resoluções espectrais e radiométricas, entre outros recursos que podem colaborar na análise do ambiente urbano.

Apesar das capacidades do GEOBIA, este é um campo que ainda está em processo de consolidação. Muitos métodos e estudos de caso de sucesso têm sido desenvolvidos e publicados, mas uma extensa revisão bibliográfica (BRITO, 2007) mostra que esta abordagem não é incondicionalmente indicada para todos os tipos de estudos urbanos. $A$ abordagem baseada em objetos tem apresentado melhores resultados finais quando se busca informações mais detalhadas das imagens, como características de ruas e edificações. 
Este nível de detalhe pode ser muito útil na investigação de doenças como a leptospirose, que tem o raio de ação de seu principal vetor transmissor inferior a 50 metros, e sobre a qual pesquisas têm relatado uma correlação significativa entre a doença e o ambiente do entorno da residência, cerca de 20 metros (REIS et al., 2008)

A leptospirose é uma antropozoonoze presente na maior parte dos países tropicais. Sua transmissão ocorre principalmente através da urina de mamíferos, em especial o rato. $\mathrm{A}$ leptospirose originalmente foi considerada uma doença ocupacional de áreas rurais, mas, nos dias de hoje, a bactéria Leptospira pode ser facilmente encontrada no ambiente urbano, onde a população de ratos cresce a cada dia. A Leptospira pode sobreviver um longo período fora do seu hospedeiro em ambiente úmido, como lama e poças de água, e por esse motivo, a doença é normalmente associada à pluviosidade. Ainda que algumas pessoas consigam desenvolver imunidade à leptospirose, há casos mais graves em que o paciente desenvolve a síndrome de Weil, que pode levar um adulto à morte em 48 horas. Os primeiros sintomas da leptospirose são bastante similares aos sintomas da gripe, dengue e outras doenças, dificultando o seu diagnóstico e consequente tratamento no estágio precoce, fazendo com que ações de prevenção e monitoramento de risco sejam ainda mais necessárias.

À parte da importância da doença em si, esta pesquisa investiga a leptospirose por duas principais razões: primeiro, porque é uma doença bastante relacionada com o ambiente urbano, o qual pode ser caracterizado, segundo alguns elementos identificáveis em produtos de sensoriamento remoto (diferente de doenças como o HIV), segundo, porque a doença e sua distribuição espacial têm sido estudadas por mais de 10 anos por um grupo de pesquisadores, dentro do projeto História Natural da Leptospirose Urbana, coordenado pela Fundação Osvaldo Cruz Salvador. Segundo estes pesquisadores, a Leptospirose em comunidades carentes de Salvador é fortemente relacionada à renda familiar, mas, isolando este fator econômico das análise estatísticas, verifica-se que fatores ambientais também interferem no risco de contaminação, fazendo com que pesquisas e ações nesse sentido sejam também necessárias. A principal contribuição desta pesquisa para esse projeto é investigar condições urbanas, explorando ferramentas de SR que podem ser úteis na identificação de áreas de risco de transmissão da doença.

A literatura tem documentado diversos casos onde alagamentos, lama, precariedade do esgotamento sanitário, acumulação de lixo e corpos de água usados para recreação são características urbanas de risco para a transmissão da leptospirose. Não foi encontrado, no entanto, nenhum estudo que utilize recursos de sensoriamento remoto (SR) para investigar a relação dessas condições com a distribuição da doença mais a fundo. Observa-se que o 
uso desse recurso tecnológico em estudos epidemiológicos vem se tornando mais frequente a cada dia, no entanto, em sua grande maioria, esses estudos são realizados em escala continental e regional e raramente na escala intra-urbana.

O presente trabalho vem contribuir com a consolidação dessa técnica de análise de imagens de SR apresentando uma referência de procedimentos a serem adotados em estudos de espaços intra-urbanos complexos com uso de ortofotografias ou imagens satélite de alta resolução espacial e apresentando uma discussão de seus potenciais e limitações como ferramentas para estudos epidemiológicos urbanos.

\subsection{Hipótese e Objetivos}

Nesta Tese, procura-se testar a hipótese de que é possível identificar correlações entre aspectos urbanos e problemas de saúde pública em áreas precárias, utilizando técnicas de análise espacial baseadas em produtos de sensoriamento remoto, mais especificamente em dados extraídos da classificação baseada em objeto em imagens de alta resolução espacial (Figura 1.1).

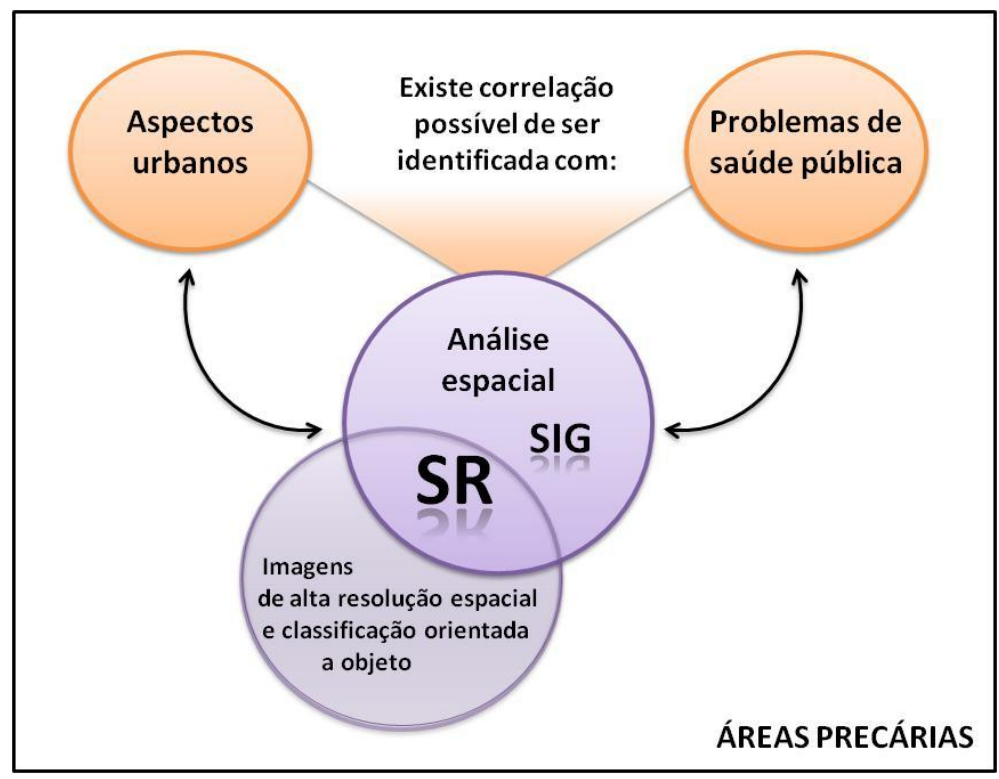

Figura 1.1. Diagrama de formulação da hipótese

O objetivo da pesquisa é propor uma metodologia de identificação de parâmetros urbanos relacionados à ocorrência de doenças, que tenham como base dados de SR, expondo seus potenciais e limitações. 
Com o estudo de caso, busca-se, mais especificamente, identificar tipologias e elementos urbanos relacionados com a transmissão da leptospirose em uma região de ocupação periférica da cidade de Salvador.

A divulgação dos resultados do estudo visa promover o emprego do SR para análise e monitoramento do ambiente urbano por meio de imagens de alta resolução espacial.

A metodologia proposta deverá, entre outras coisas, ajudar a encontar correlações (entre tipologias urbanas e doença) desconhecidas previamente ou a identificar regiões com tipologias que se sabem ser correlacionadas com a doença. Com isso, deverá subsidiar mapeamentos que servem: à priorização de investimentos de infra-estrutura urbana; à priorização de ações preventivas, como campanhas educativas e de vacinação; ao aumento da precisão de diagnósticos precoces.

\subsection{Escopo}

A pesquisa desenvolvida foi dividida em quatro etapas, como explanadas no Capítulo 3 dos materiais e métodos: Capítulo 2 de fundamentação teórica, Capítulos 4 e 5 da caracterização da área de estudo e dos modelos de risco, Capítulo 6 dos procedimentos de sensoriamento remoto e Capítulo 7 das análises dos dados urbanos e de saúde.

O Capitulo 2 corresponde ao trabalho de revisão bibliográfica. Nessa etapa do estudo foram reunidas informações sobre as três principais áreas de conhecimento que envolvem a pesquisa: saúde coletiva, ambiente urbano e SR; enfocando a temática do estudo e sistematizando informações coletadas na literatura. A revisão bibliográfica sistemática foi desenvolvida em três áreas que visam: reconhecer as principais técnicas de SR usadas em estudos urbanos; levantar os principais fatores de risco urbano de transmissão da leptospirose; e conhecer o estado da arte do SR em áreas urbanas aplicado à saúde pública.

O Capítulo 3 contempla os materiais e métodos utilizados e desenvolvidos para a pesquisa. É apresentada a estrutura lógica da pesquisa, o caminho percorrido e produtos obtidos em cada etapa. Nesse capítulo também é esclarecido, em linhas gerais, o fluxo das informações nos procedimentos de SIG e SR, os critérios de seleção de subáreas do Subúrbio Ferroviário.

O Capitulo 4 descreve, brevemente, o contexto histórico social e geográfico da área de estudo, Subúrbio Ferroviário de Salvador, e apresenta uma análise detalhada das tipologias urbanas encontradas na área. 
A construção de modelos de risco de transmissão da leptospirose é apresentada no Capítulo 5. A descrição dos modelos e dos indicadores baseados em dados de SR identificados é apresentada também nesse capítulo.

O Capitulo 6 trata especificamente dos procedimentos de SR utilizados nas subáreas do Subúrbio Ferroviário. O capítulo apresenta a descrição detalhada dos alvos, os procedimentos de pré-processamento, as regras e processos realizados para a classificação de ortofotografias e de imagens QuickBird, a análise comparativa da acurácia obtida na classificação em cada uma dessas imagens e a classificação final de toda a área.

No Capitulo 7 é apresentado o resultado das análises de correlação entre os dados de doença e os dados urbanos extraídos de SR.

No Capitulo 8 discute-se a metodologia como um todo, partindo-se dos resultados encontrados em cada etapa da pesquisa, levantando as principais questões que surgiram durante o desenvolvimento do trabalho, ponderando os principais potenciais e limitações da metodologia desenvolvida e incluindo recomendações para futuros trabalhos

Por fim, estão presentes no Capitulo 9, as considerações finais diante do que o trabalho se propôs, objetivo geral almejado e as conclusões a que chega o pesquisador. 


\section{CAPÍTULO 2 - FUNDAMENTAÇÃO TEÓRICA}

O embasamento teórico foi realizado abordando as três áreas do conhecimento que estão mais profundamente relacionadas com a pesquisa: a saúde pública, enfocando sua relação com o espaço e dinâmica de transmissão da leptospirose; o ambiente urbano, destacando elementos formadores da sua morfologia e modelos urbanos de avaliação e o sensoriamento remoto (SR), abordando os principais conceitos que envolvem o tema e discutindo a aplicação em saúde pública e na análise urbana.

\subsection{Saúde Pública}

\subsubsection{Noções gerais}

A saúde, para a Organização Mundial da Saúde (OMS), é um estado completo de bem estar físico, mental e social, e não apenas a ausência da enfermidade ou invalidez. Para diversos autores, isto é uma utopia (ÁVILA-PIRES, 2000; COURA, 1992), pois além do conceito de bem estar ser mutável e subjetivo, o homem pode estar com uma doença e ainda não a ter manifestado, o que não quer dizer, por isso, que esteja saudável e não demande cuidados. O que parece mais adequado para uma visão de saúde pública é reconhecer a existência de uma busca constante por uma condição de equilíbrio entre saúde e doença, como um processo de adaptação do homem ao meio, como sugere Coura (1992). Para este autor, a definição de saúde da OMS poderia ser mudada para: "Saúde é a adaptação do homem ao meio, preservando a sua integridade física, mental e social" Coura (1992, p. 336). Ávila-Pires (2000) concorda com Coura nesse aspecto; para ele a saúde é um estado de equilíbrio instável, que pode ser alterado por fatores internos ou externos, os quais interferem na capacidade do organismo de responder e de acomodar-se ao ambiente.

Os estudos que consideram a dinâmica de populações em busca desse equilíbrio podem ser considerados estudos de saúde pública. São estudos no nível do ecossistema, em que trabalham ecologistas, sanitaristas, epidemiologistas e arquitetos, ainda que para ÁvilaPires (2000) estes últimos não costumem refletir sobre este aspecto. A epidemiologia, por sua vez, é o nome dado à área da saúde que se ocupa da "investigação dos fatores que afetam a dinâmica, o comportamento ou a estrutura das populações humanas do ponto de vista sanitário" (ÁVILA-PIRES, 2000, p. 95).

Assim, a saúde pública não pode ser considerada um somatório das condições de saúde do indivíduo que recebe atendimento médico, pois 
"para um indivíduo, doença é dor, incômodo, incapacidade parcial ou total de trabalhar ou desempenhar suas atividades diárias (...) Para a sociedade, doença representa prejuízo econômico, redução de produtividade, redução da capacidade de suporte da população" (ÁVILA-PIRES, 2000, p. 95).

Ou seja, situações de redução da capacidade produtiva do homem são problemas de saúde pública, como por exemplo, a infestação de mosquitos incomodando o sono de uma comunidade.

A manutenção de determinado problema de saúde entre pessoas de uma mesma região e cuja incidência se prende à ocorrência de determinados fatores locais caracteriza o que é conhecido em saúde pública como endemia. Já as epidemias diferem das endemias por serem de caráter menos contínuo e menos restritos a uma determinada área. Caracterizamse pelo número elevado e anormal de casos de uma doença em certa população, área geográfica ou período de tempo. Nas endemias, o equilíbrio entre agente, hospedeiro e meio conta com a manutenção da doença em determinados índices, enquanto nas epidemias há um grande desequilíbrio que coloca o agente, presente ou recém inserido no meio, em vantagem (BRASIL, 2002).

Medidas de controle da doença são efetivas quando há a compreensão desse equilíbrio complexo que envolve, entre outras coisas, a dinâmica populacional dos parasitos, da comunidade de hospedeiros e as condições do meio. Tomando o combate à leptospirose como exemplo dessa complexidade, vê-se que ações não integradas podem, inclusive, gerar resultados inversos, como por exemplo, a aplicação de raticidas em áreas infestadas sem o suporte de campanhas de controle de roedores. Essas campanhas, que envolvem a redução da oferta de alimentos e abrigo, entre outra ações, quando desarticuladas, podem aumentar a população de ratos em lugar de reduzi-la ${ }^{1}$, produzindo efeitos desastrosos que somente conduzirão a situações futuras de difícil e onerosa solução (BRASIL, 2002).

Ressaltado o aspecto do equilíbrio dinâmico e o aspecto social na definição de saúde pública, é possível compreender a importância e necessidade de estudos que considerem os diversos aspectos da complexidade ecológica que envolve o homem nessa busca por equilíbrio com o meio urbano.

\footnotetext{
${ }^{1} \mathrm{O}$ fenômeno tem base biológica resultante de uma intervenção errada do homem e é conhecido como efeito bumerangue. No caso de ações de controle de roedores, o efeito é caracterizado pelo aumento do número de roedores infestantes de uma determinada área, onde alguns meses antes foi praticada uma operação de desratização (Brasil, 2002).
} 


\subsubsection{Geografia da Saúde}

O campo da ciência conhecido como Geografia da Saúde, Geografia Médica, Ecologia da Saúde, Epidemiologia Geográfica, entre outros nomes, é aquele que mais especificamente se dedica ao entendimento desse equilíbrio instável da saúde coletiva à luz dos conhecimentos geográficos.

A associação da geografia com a saúde pública data de mais de dois mil anos. O próprio conceito de endemia e epidemia surgiu com Hipócrates, 400 a.C., ao relacionar áreas, águas e lugares a ocorrência de doenças. No entanto, a Geografia da Saúde só se consolidou com o avanço da ciência e das técnicas de observação e registro do ambiente. Os recursos cartográficos só foram de fato explorados no séc. XIX (BAVIA, 2004).

Um dos primeiros registros na área foi uma publicação de 1768 do médico (cirurgião naval) escocês James Lind. Seu livro, chamado "An Essay on Diseases Incidental to Europeans in Hot Climates", apresenta um estudo sobre a incidência de doenças em indivíduos europeus que vivem ou passam por regiões de clima quente. Nesse estudo, o autor procura explicações para a distribuição de doenças, chegando, inclusive, a atribuir riscos de contaminação a determinadas áreas geográficas especificas (BARRETT, 1991). Desde então, diversos trabalhos foram escritos na área da geografia médica, descrevendo interferências geográficas na distribuição das doenças.

Um dos primeiro trabalhos, considerado um clássico na geografia médica, foi o realizado por Jonh Snow no ano de 1894. Snow mapeou os casos de cólera na cidade de Londres e os relacionou com os locais de abastecimento de água. Dessa forma, ele identificou o vetor transmissor e controlou a disseminação da doença, 35 anos antes da bactéria responsável pela cólera ser conhecida (JOHNSON, 2006).

Ao longo da história da saúde pública, e a depender da teoria dominante no momento, diferentes aspectos dos indivíduos e de seu habitat têm sido considerados "causas" importantes de doenças (DIEZ-ROUX, 1998). Na parte técnica, sua evolução também acompanhou tendências e avanços das tecnologias de mapeamento e processamento de dados espaciais em meio computacional. Para Bavia (2004), as geotecnologias, que têm surgido no cenário paisagístico da Geografia da Saúde como novas ferramentas, têm possibilitado cada vez mais "a identificação dos fatores de risco, no nível espacial e temporal, e a delimitação das suas áreas de risco e o suporte para o delineamento de estratégias de campanha de programas de controle" (BAVIA, 2004: p. 6). Entre as novas 
geotecnologias de que trata a autora estão os Sistemas de Informações Geográficas (SIG) e o SR, cujas técnicas de classificação automática e semi-automática de imagens

\begin{abstract}
"permitem ampliar e acelerar o processo de aquisição de informações ambientais relevantes no contexto dos estudos enfocando a interação ambiente-doença. Com o uso dos recursos de Sistemas de Informações Geográficas (SIG), como ambiente computacional para integração dessas variáveis com outras relativas à ocorrência da doença, como os dados de caracterização do perfil sócio-econômico-demográfico, é possível montar um painel sócio-territorial ampliado, que potencializa e amplia o olhar do epidemiologista sobre potenciais focos e áreas de risco" (CORREIA, 2007, p.1016).
\end{abstract}

A tecnologia SIG tem contribuído significativamente nas tarefas que lidam com grande quantidade de informações. As informações, tanto de saúde como socioeconômicas e ambientais, estão cada vez mais disponíveis e não representam mais o principal entrave nos estudos de geografia médica. Segundo Carvalho e Souza (2005), as principais demandas estão na área de manipulação dos dados e do conhecimento.

É consenso que os SIG são ferramentas com enorme potencial de auxilio às análises espaciais epidemiológicas, entretanto o uso desse recurso exige muito mais que conhecimento do software, mas principalmente o conhecimento do problema em questão, para julgar a adequação dos métodos de análise e mapas produzidos. A utilização dessa ferramenta ainda é considerada recente, muito ainda há que ser desenvolvido na capacitação técnica dos diversos profissionais envolvidos, na colaboração entre estes profissionais e na interface dos pacotes estatísticos e programas de SIG (CARVALHO E SOUZA, 2005).

A grande difusão das ferramentas de SIG tem promovido, em contra partida, a profusão de mapas epidemiológicos muitas vezes equivocados. "A depender da quantidade e qualidade do dado e da metodologia utilizada na análise, um mapa pode ser tanto útil como enganoso" (RYTKÖNEN, 2004). A representatividade do dado epidemiológico, a pequena relação entre o nível do indivíduo e o nível do grupo (falácia ecológica ${ }^{2}$ ), a unidade de agregação escolhida, a escala de apresentação e mesmo as cores utilizadas em mapas temáticos podem levar a conclusões equivocadas. Huff (1993) e Monmonier (1996) exploram esse

\footnotetext{
2 A falácia ecológica acontece quando a argumentação é baseada na interpretação errônea de dados estatísticos, em que se infere a natureza dos indivíduos baseados no dados agregados dos grupos ou a natureza do grupo baseado em um número não representativo de indivíduos. Parte-se do pressuposto de que todos os membros de um grupo apresentam as mesmas características do grupo sem que isso seja verdade. (Piantadosi, 1988)
} 
tema apontando os principais perigos da adoção de métodos estatísticos equivocados e os principais perigos da confecção e leitura de mapas, respectivamente (Figura 2.1).

a)

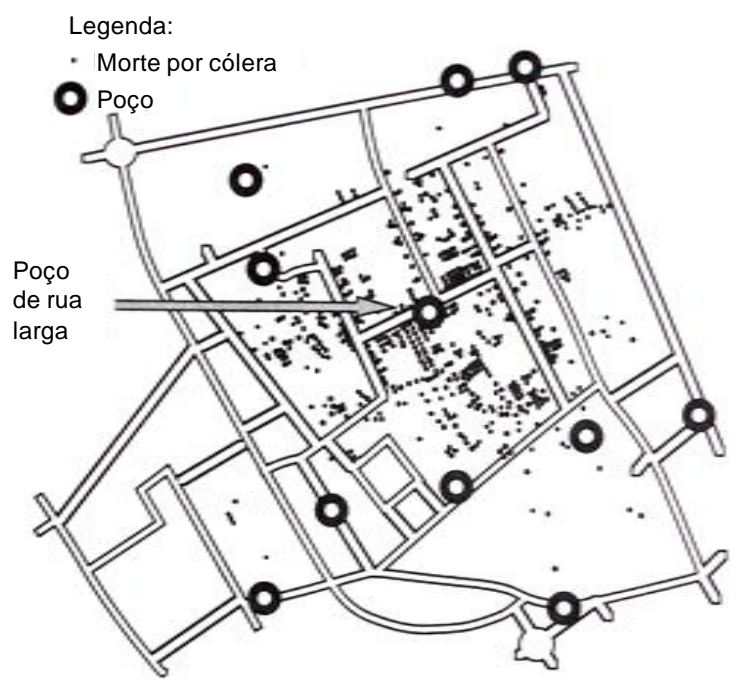

b)
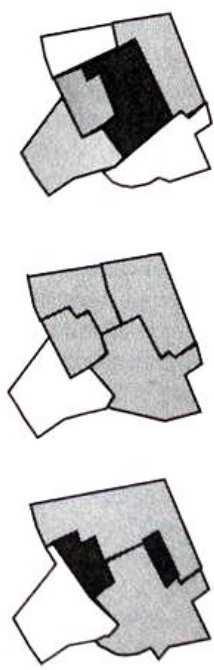

Figura 2.1. Diferentes formas de apresentação do mapa de investigação de casos de cólera em Londres de John Snow, a) mapa de pontos; b) mapas cloropléticos segundo diferentes polígonos de agregação dos dados. Fonte: Monmonier (1996, p. 158)

\section{Análises espaciais em saúde}

Além do avanço tecnológico, há atualmente uma grande oferta de informações, seja na área de saúde, seja na área ambiental. O desafio está em utilizar essas informações e tecnologia de forma precisa e prática, a fim de que os resultados se revertam em instrumentos de apoio à tomada de decisão e consequentemente na melhoria da qualidade de vida da população.

De forma prática, observa-se que a maior parte dos problemas discutidos em estudos epidemiológicos com foco espacial podem ser divididos em dois tipos: os que tratam da análise do uso de serviços de saúde e os que tratam da análise geográfica da distribuição da doença e (ou) sua relação com fatores de risco.

Este último tipo de estudo pode, por sua vez, ser classificado em quatro grupos, que muitas vezes se sobrepõem (BAILEY, 2001): mapeamento de doenças, estudos de aglomerados (clusters), estudos ecológicos e estudos de monitoramento e avaliação ambiental.

O mapeamento de doenças se refere à produção de mapas da distribuição geográfica da doença. Estes mapas comumente mostram taxas de mortalidade ou morbidade de determinadas áreas geográficas, como países, estados ou municípios (ELLIOTT e WARTENBERG, 2004). 
Estudos de aglomerados têm o foco na identificação de áreas com risco significativo de ocorrência de casos da doença ou na avaliação de evidências sobre o maior risco de ocorrência em torno de possíveis fontes de contaminação (BAILEY, 2001).

Estudos de monitoramento e avaliação ambiental buscam confirmar a distribuição espacial de fatores ambientais relevantes à saúde e à exposição da população a esses fatores, a fim de estabelecer ações preventivas e de controle. É um campo extremamente amplo e onde a contribuição recente do SR tem papel importante na disponibilização de dados ambientais de qualidade e em quantidade (BAILEY, 2001). Há autores, a exemplo de Elliott e Wartenberg (2004), que consideram esse tipo de estudo como parte do grupo nomeado "estudos ecológicos" ou "estudos de correlação geográfica".

Estudos ecológicos, segundo Bailey (2001), dizem respeito à associação entre a doença e fatores de risco de determinado grupo, tipicamente definido por áreas geográficas. Seu objetivo é examinar a distribuição de grupos populacionais de acordo com sua exposição a variáveis ambientais, socioeconômicas, demográficas, culturais, etc. (ELLIOTT e WARTENBERG, 2004). É frequentemente tido como estudo de geração de hipóteses. Do ponto de vista estatístico, implica, em geral, na utilização de modelos de regressão, em que o dado observado sobre a doença (presença de casos, incidência, contagem, etc.) é explicado por uma função na qual as variáveis são os fatores de risco. Diversos autores alertam para as complicações inerentes à construção desse tipo de modelos, visto que os modelos clássicos demandam a utilização de variáveis independentes. No entanto, em se tratando da análise de um grupo definido geograficamente, é muito provável que este grupo compartilhe de outras características socioeconômicas, ambientais, culturais, etc.

A construção de modelos de regressão parte de um pressuposto básico de que é a independência entre variáveis, sendo que no das análises em questão essas variáveis tratam de fatores espaciais que se complementam, como alerta Carvalho e Souza:

\footnotetext{
"ao se estabelecer um modelo de regressão buscando relacionar uma variável resposta a variáveis independentes, um dos pressupostos básicos da estatística, da independência entre amostras, é pouco realístico: na verdade, nos dados espaciais, a dependência está presente em todas as direções e fica mais fraca à medida que aumenta a dispersão na localização dos dados' (CRESSIE, 1991, p. 3)" Carvalho e Souza $(2005$, p. 3).
}

\footnotetext{
${ }^{3}$ CRESSIE N. Statistics for spatial data. New York: Wiley; 1991.
} 
Por exemplo, ao estudar a relação de casos de diarréia infantil ocorridos em áreas de baixada (fundos de vale), antes de assumir o risco de alagamento (segundo cota e declividade) como fator causador da doença, deve-se considerar que o mercado imobiliário distribui a população segundo a renda de forma heterogênea, e por isso é possível que a população que resida nessas áreas tenha menor renda, menor escolaridade, menos hábitos de higiene, menor acesso a serviços de saneamento, menor acesso a áreas verdes, residam em edificações menores, etc.

Por essa razão, Rytkonem (2004) defende que com os estudos ecológicos só é possível obter pistas ou sugestões de que fatores ambientais podem estar relacionados à real ocorrência da doença. Por outro lado, entendendo este complicador e o contexto da área e população estudada, é possível usar o conhecimento da correlação existente entre as variáveis ambientais e variáveis socioeconômicas a favor da investigação adotando, por exemplo, proxies, quando não é possível acessar o dado desejado.

Deve-se ter cuidado também para evitar a falácia ecológica, ao tratar os dados de saúde, uma vez que a unidade de observação dos estudos ecológicos é o grupo geográfico e não o indivíduo.

Segundo Vine (1997), em estudos ecológicos, recursos de SIG podem ser usados para estimar a exposição de indivíduos em estudos transversais, coorte e caso-controle. Um estudo transversal é um estudo descritivo que mede a proporção de pessoas que apresentam a doença em um determinado momento (prevalência), sendo útil para gerar hipóteses e planejar ações de saúde. O estudo de coorte significa um estudo analítico de um grupo de indivíduos com alguma característica em comum, seguido ao longo do tempo, é geralmente prospectivo e permite, assim como o estudo caso-controle, determinar relações causais. O estudo caso-controle é, em geral, retrospectivo e é definido como uma forma de pesquisa observacional e longitudinal em que se compara dois grupos expostos a um determinado fator, o primeiro de indivíduos com determinada doença, e o segundo de indivíduos sem aquela doença (VINE, 1997).

Os dados de saúde podem ser disponibilizados para estudo de diferentes formas, sendo a mais comum a disponibilização de dados agregados em malha irregular (unidades administrativas, por exemplo). É cada vez mais frequente a disponibilidade de dados de saúde pontuais, normalmente a localização da residência do paciente. São encontrados ainda dados disponibilizados em malha regular (pixels com densidade de casos, por exemplo), mas nesse último caso os dados precisam passar por algum tipo de processamento (Figura 2.2). 
a)

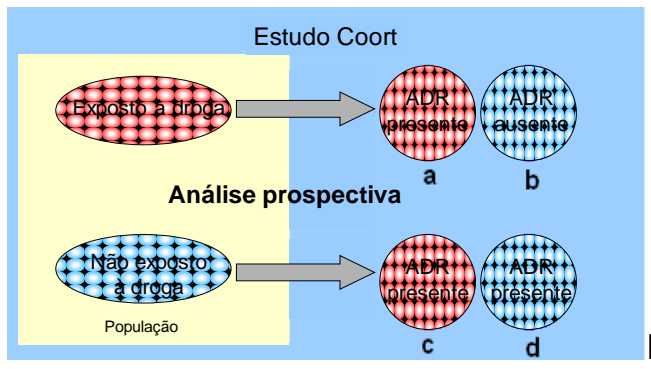

b)

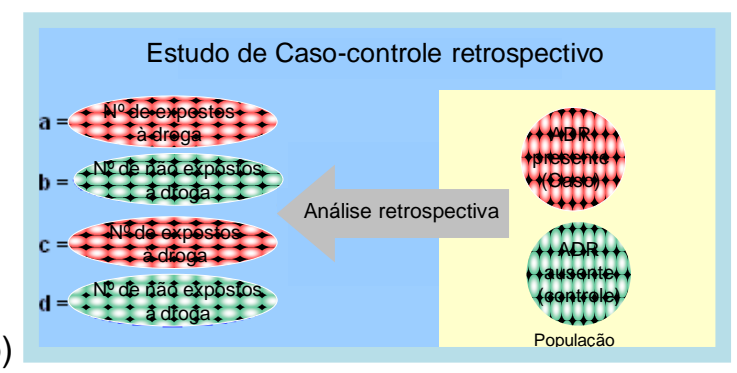

Figura 2.2. Diagramas de estudos ecológicos: a) estudo coorte, b) estudo caso controle. Fonte: adaptado de Vine (1997).

Os dados apresentados em unidades administrativas são normalmente gerados já nessa escala (através de relatórios de pacientes tratados em unidades de saúde de determinado distrito, por exemplo) ou a partir da agregação de dados de unidades menores (dados municipais construídos a partir de dados de seus distritos).

Grande parte dos estudos ecológicos em epidemiologia são realizados com base em dados agregados, seja por país, estado, município, setor censitário, distrito de saúde, entre outros. A agregação de dados em unidades administrativas traz como grande vantagem a interoperabilidade entre as informações de saúde e informações socioeconômicas. Além disso, essas unidades espaciais são aquelas em que os gestores públicos lidam diariamente, o que faz com que dados disponibilizados dessa forma sejam bastante úteis na prática.

Os dados pontuais, por sua vez, são obtidos basicamente de duas formas: através de geocodificação de endereços (residenciais ou de unidades de saúde) ou com levantamento de campo.

O processo de geocodificação atualmente é realizado com o uso de programa de SIG. Para isso o sistema precisa conter uma base de logradouros com identificação de numeração que é utilizada para localizar os endereços de cada paciente, por exemplo. A precisão da localização do endereço depende da qualidade da base de logradouros e da qualidade com que o endereços dos pacientes se encontram descritos. Em se tratando da realidade brasileira, em especial em áreas mais carentes, os problemas encontrados com este método vêm inviabilizando o seu uso em muitos casos (BRITO et al., 2009, em fase de elaboração) ${ }^{4}$. Alternativas interessantes têm sido desenvolvidas por secretarias de saúde, como por exemplo a adoção do poste de iluminação pública próximo da residência como

${ }^{4}$ BRITO, P. L.; BRENNAN, W. A.; BOQUIM, G.; QUINTANILHA, J. A.; CURTIS, A. Spatial error in geocoding patients addresses in Brasil. Manuscrito, 2009. 
ponto de referência. Para viabilizar esse sistema é solicitado que o paciente apresente no posto de atendimento uma conta de luz, onde consta o número de identificação do poste. Este número é adicionado aos dados da residência do paciente e, por meio de convênio com a empresa de eletricidade, o órgão público é capaz de espacializar pontualmente, com grande eficácia, os dados de saúde.

Os dados pontuais obtidos com levantamento de campo demandam grande investimento. Em geral, o grupo de pesquisa realiza visitas às residências de acordo com plano de amostragem, que pode ser porta a porta em determinada área, como um censo, ou, por exemplo, tentando encontrar endereços de pacientes registrados no sistema de saúde. Os pesquisadores de campo são munidos de aparelhos GPS, com o qual coletam as coordenadas da residência, ou de mapas, onde marcam a localização da residência visitada. Uma nova fonte de dados pontuais, no entanto, vem sendo utilizada com sucesso, principalmente na zona rural. São dados de agentes do programa federal Saúde da Família. O programa conta com agentes de saúde que frequentam a residência de famílias realizando trabalho preventivo e de acompanhamento domiciliar. O crescimento do programa e sua expansão para áreas urbanas constitui uma valiosa fonte de dados de saúde (PORTUGAL, 2003).

Uma das maiores vantagens da metodologia de análise por pontos é evitar a falsa partição de regiões, que são, na maior parte dos casos, baseadas em critérios políticos e governamentais e não relacionadas a objetos de estudos. Isto possibilita a adoção de unidades espaciais com maior homogeneidade interna dos grupos populacionais residentes (CARVALHO e SOUZA, 2005; RYTKOENEN, 2004). A utilização de dados pontuais abre caminho para uma enorme gama de possibilidades de pesquisa sem inviabilizar a realização de estudos segundo métodos convencionais, pois permite a agregação em qualquer nível ou unidade espacial, convencional ou não: de estados e municípios a quadras e ruas; de bairros a micro bacia hidrográficas; de análises por proximidade (buffer) a análises do espaço contínuo (densidade de pontos), entre muitas outras possibilidades.

A disponibilidade de dados pontuais permite também a realização de estudos locais, em áreas reduzidas. Para tanto, há um série de cuidados que o pesquisador deve tomar, pois ao diminuir a área das unidades espaciais de análise, diminui-se também sua população gerando problema de instabilidade típica de pequenos números, como alerta Carvalho e Souza (2005). Pequenas inconsistências podem gerar impacto significativo no resultado das análises, daí a importância da qualidade do dado e sua adequação à escala de análise (RYTKONEM, 2004). 
Um entrave à disponibilização de dados pontuais está relacionado a questões de confidencialidade. O uso e disponibilização de dados pontuais, ou divulgação de dados agregados em unidades espaciais reduzidas, não deve, de forma alguma, ser realizado de forma indiscriminada. As repercussões sociais, e até econômicas, podem ser desastrosas, como a discriminação da família na comunidade ou a desvalorização imobiliária (ELLIOTT e WARTENBERG, 2004). Por isso, é procedimento padrão dos organismos públicos exigir a aprovação do projeto no conselho de ética para que os dados pontuais sejam disponibilizados e manipulados, sendo a divulgação dos mesmos só permitida na forma agregada ou em escala que não permita a identificação da residência ou de pequenos grupos populacionais.

Também é necessário considerar que pessoas se expõem a diferentes tipos de risco em diferentes localizações, crianças vão da escola para casa, adultos trabalham em diferentes locações, desempenham diferentes atividades, se locomovem de diferentes formas, viajam, se mudam, e a relação entre a contaminação e um potencial risco ambiental é, muitas vezes, difícil de ser provada com confiabilidade (RYTKONEM, 2004).

Assim, não há uma metodologia geral que possa ser recomendada a qualquer tipo de estudo espacial de saúde. A metodologia deve ser escolhida de acordo com o dado e a hipótese investigada (RYTKONEM, 2004).

Diante de tal complexidade, esta é uma área de investigação onde a inter (ou trans) disciplinariedade, mais do que desejável, é imprescindível (CARVALHO e SOUZA, 2005). Tão importante quanto o entendimento dos métodos estatísticos e das tecnologia de SR e SIG, é o entendimento das dinâmicas urbanas e da doença em foco, e quanto mais articulado for esse conhecimento mais realistas e eficazes serão as análises e propostas de intervenção.

\subsubsection{Leptospirose}

\section{Ecologia da leptospirose}

A leptospirose é considerada pelo Ministério da Saúde brasileiro uma doença com quadro de persistência no país. Trata-se de uma zoonose que tem como principais portadores as ratazanas, ratos e camundongos, e que está em expansão em grandes centros urbanos, atingindo, em alguns casos, altos índices de mortalidade. Segundo documento publicado pelo Ministério da Saúde (BRASIL, 2004), o período de 1994 a 2003 teve uma média anual 
de 3.324 casos de leptospirose e 334 óbitos registrados, o que significa dizer que, aproximadamente, a cada dez enfermos, um foi vitima fatal da doença. O mesmo documento reforça a correlação geográfica existente entre os casos dessa doença e as condições urbanas de precariedade, quando afirma que:

"a maior parte dos casos está ligada às condições de vida e infraestrutura sanitária, principalmente em nível domiciliar [...] a maioria dos casos notificados provém das capitais e regiões metropolitanas. Enchentes e chuvas fortes contribuem para o contato do homem com água e lama contaminadas pela urina de roedores, favorecendo a infecção" (BRASIL, 2004; 17).

Douglin et al. (1997) e Felzemburgh (2006) concordam com esta afirmação e acrescentam que, além da ocorrência da forma grave estar relacionada às precárias condições de infraestrutura sanitária, a alta infestação de roedores infectados e as inundações propiciam a disseminação e a persistência da bactéria no ambiente.

A leptospirose é uma doença bacteriana também conhecida, na sua forma grave, como Mal de Weil ou Síndrome de Weil. Seus primeiros sintomas são semelhantes aos sintomas de um resfriado ou aos sintomas iniciais da meningite, malária ou dengue, como tratou Flannery et al. (2001). Os pacientes que desenvolvem os sintomas mais graves da doença podem sofrer de disfunção de múltiplos órgãos e morrer em 48 horas. A bactéria responsável é do tipo Leptospira e o sorogrupo mais maléfico ao homem é o Icterohaemorraghiae, cujo principal hospedeiro é o rattus norvegicus, também conhecido como rato de esgoto ou ratazana.

A infecção acontece geralmente através do contato direto ou indireto com a urina do animal contaminado, por exemplo, por ingestão de alimentos ou mordidas e por contato com água ou solo contaminado, especialmente se a pele possuir lesões. A bactéria Leptospira pode sobreviver até seis meses em ambiente úmido, como lama e água estagnada. Por isso, surtos epidêmicos são geralmente associados a períodos de chuva e alagamentos, como apresentaram Ko et al. (1999) e Barcellos e Sabrosa (2001) em seus estudos. No entanto, além da umidade, o ambiente deve apresentar temperatura entre $28^{\circ} \mathrm{C}$ e $30^{\circ} \mathrm{C}, \mathrm{pH}$ alcalino e presença de oxigênio para sua sobrevivência (Figura 2.3).

O habitat do rattus norvegicus é preferencialmente fora do domicílio, onde cava tocas até um metro de profundidade, a beira de córregos e canais, ou coloniza lixeiras e galerias subterrâneas de esgoto, drenagem, entre outras instalações. São excelentes nadadores e escavadores. A sua atividade é essencialmente noturna com picos ao anoitecer e ao 
amanhecer. Quando as populações presentes são grandes, são perturbadas ou têm fome, é frequente a atividade diurna. Seu raio de ação é de cerca de 30 a 50 metros (BRASIL, 2002).

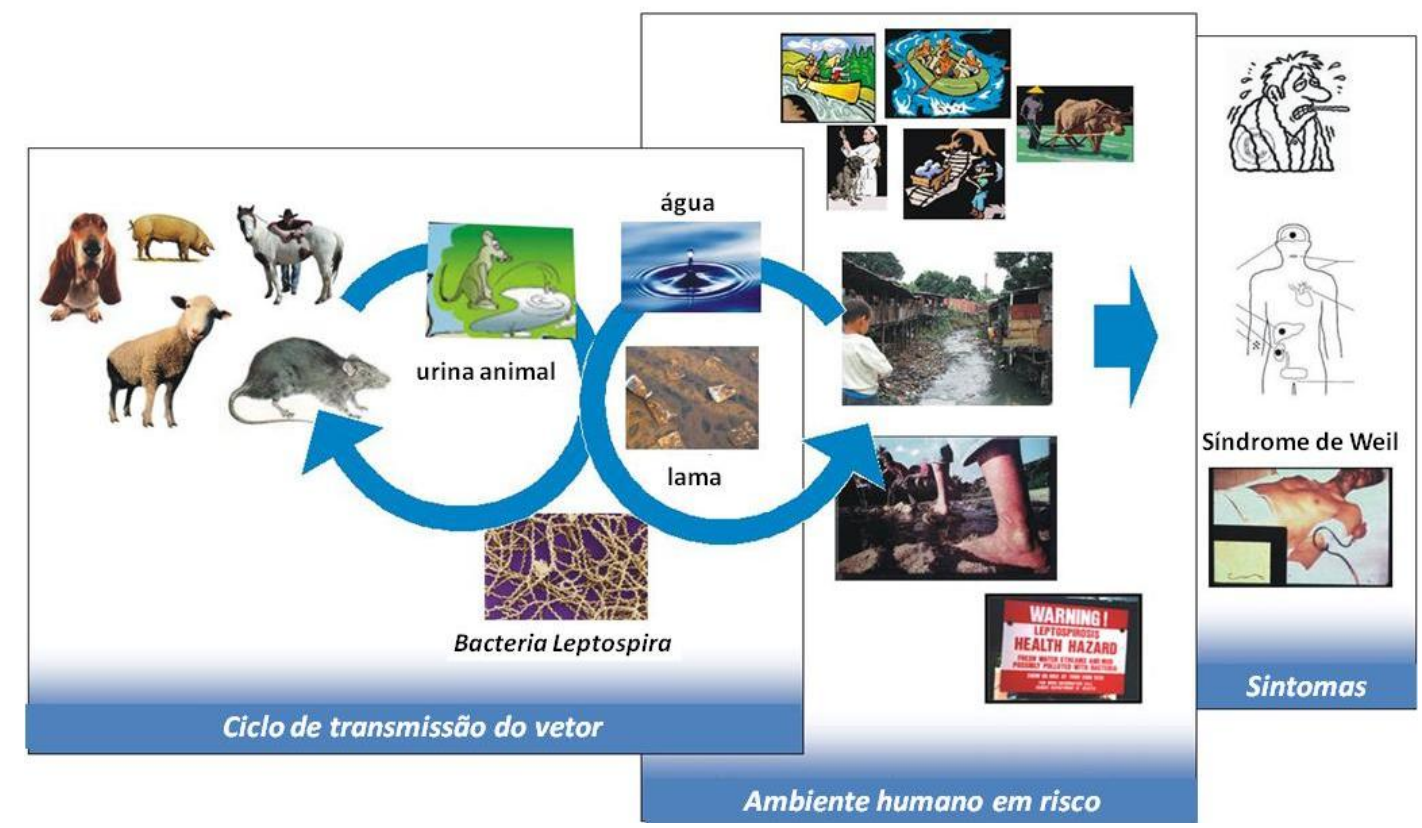

Figura 2.3. Ciclo, ambiente e sintomas da leptospirose. Fonte: Brito (2010)

Outros animais como cães, gado, cavalo, ovelhas e cabras, assim como os ratos, podem ser reservatórios para o patógeno podendo carregá-lo e disseminá-lo por toda a vida, a depender do animal e sorovar envolvido. O homem é classificado como hospedeiro acidental ou incidental e não se caracteriza como portador crônico (FELZEMBURGH, 2006).

O controle dos principais reservatórios é feito com medidas de anti-ratização, eliminação do acesso dos roedores ao alimento, água e abrigo, ou de desratização, eliminação direta dos roedores por métodos mecânicos e químicos. Apesar de necessárias, devido à alta densidade de ratos no ambiente urbano, essas medidas são consideradas de alto custo.

No Brasil, as vacinas contra leptospirose não se encontram disponíveis para humanos devido a breve duração de seu poder de imunidade, o que exige reforços periódicos e eleva o seu custo, impossibilitando a aplicação sistemática.

Por esses motivos, "para traçar medidas de prevenção efetivas, torma-se necessário conhecer as áreas de maior incidência dentro do nosso contexto urbano e as exposições ambientais de maior risco para infecção" (FELZEMBURGH, 2006, p. 1). 


\section{Características urbanas e a transmissão da leptospirose}

Com o objetivo de levantar características físicas do meio urbano, consideradas fatores de risco para a contaminação do homem com a bactéria Leptospira, foi realizada uma revisão bibliográfica sistemática sobre o tema.

O levantamento bibliográfico englobou todas as pubicações indexadas à ferramenta PUBMED MEDLINE ${ }^{5}$ (Medical Literature Analysis, and Retrieval System Online), o que inclui os principais periódicos da área ${ }^{6}$. Foram pesquisados utilizando as palavras chave: "leptospirosis" ou "rattus norvegicus" e "risk factors", buscando estudos que se referiam a alguma característica física do meio urbano. O Quadro 2.1 apresenta uma síntese dos fatores de risco de transmissão da leptospirose relacionados ao ambiente urbano, encontrados nos artigos publicados até outubro de 2008.

$\mathrm{Na}$ revisão, destacam-se o número de estudos brasileiros publicados, cujas áreas de pesquisa foram as cidades do Rio de Janeiro ou de Salvador. Quase todos os trabalhos realizados em Salvador, sete dos oito trabalhos levantados, contaram com a presença de pesquisadores do Centro de Pesquisas Gonçalo Moniz, Fundação Oswaldo Cruz, que dá suporte a esta Tese.

No quadro foram registradas as características urbanas investigadas nos estudos de caso ou mencionadas nos trabalho de revisão literária, a fim de reconhecer quais características os pesquisadores consideram relevantes para investigação da leptospirose urbana. Não quer dizer, no entanto, que estas características apresentaram correlação significativa nos estudos desenvolvidos.

As características urbanas mais frequentemente reconhecidas nos estudos como fatores de risco estão relacionados às áreas propícias a inundação ou alagamento, ao solo úmido ou lama ao sistema de esgotamento sanitário precário, ao acúmulo de lixo e a corpos d'água contaminados.

Na Figura 2.4, observa-se que a preocupação em estudar a correlação da doença com corpos d'água é a que aparece com maior frequência. Isto se dá principalmente devido a comprovação de surtos ocorridos entre atletas (de países onde a doença é rara) após eventos esportivos que envolviam natação em lagos ou rios (MORGAN et al., 2002; SEJVAR et al., 2003).

\footnotetext{
${ }^{5}$ Disponível em: <www.ncbi.nlm.nih.gov>. Acesso em:: novembro de 2008.

${ }^{6}$ American Journal of Tropical Medicine and Hygiene, Emerging Infectious Diseases, Cadernos de Saúde Pública, American Journal of Public Health, International Journal of Environmental Health Research
} 


\section{Quadro 2.1. Revisão Bibliográfica - Fatores de risco de transmissão da leptospirose relacionado ao ambiente urbano.}

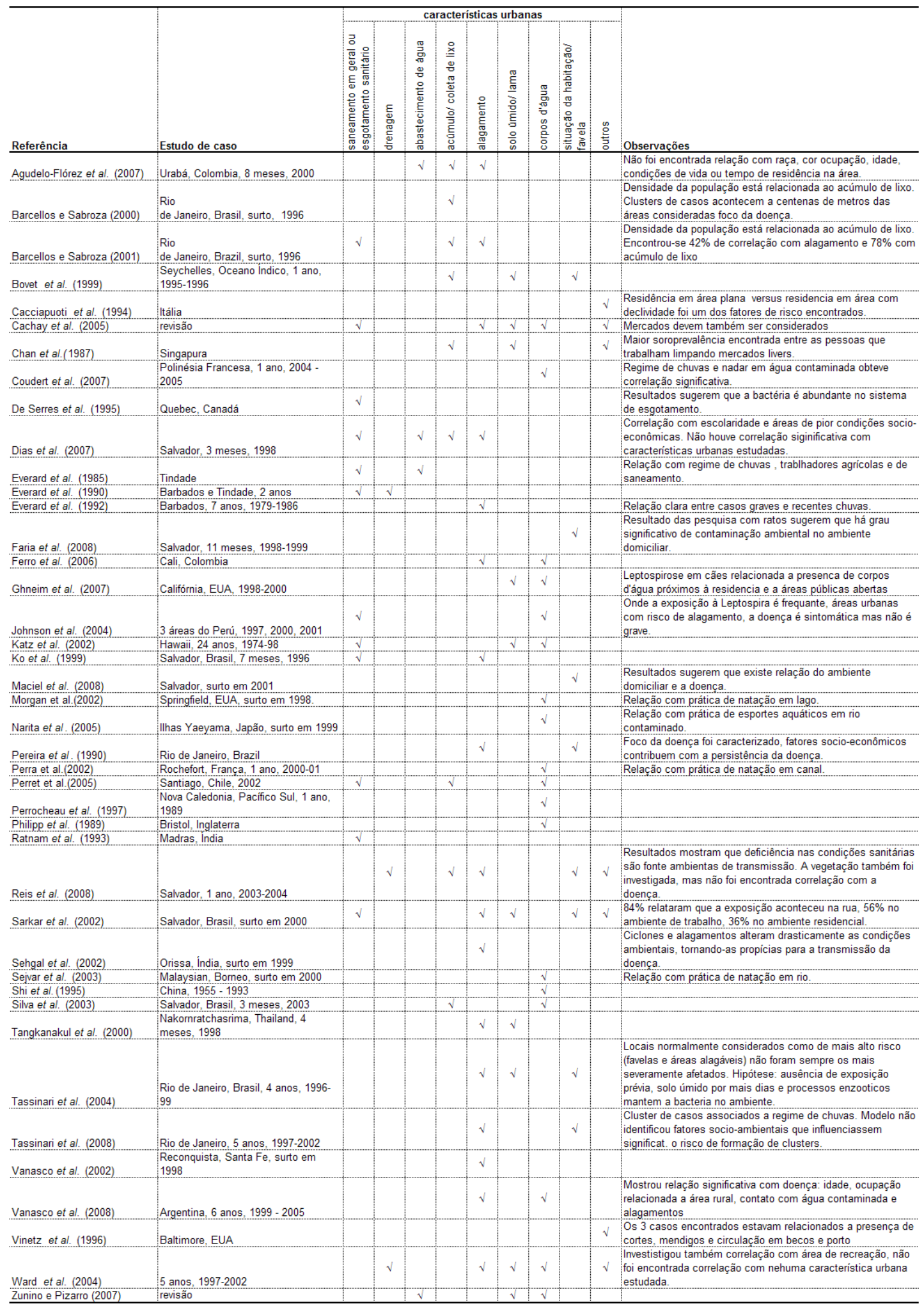

Fonte: Brito (2010) 
As áreas sujeitas a alagamento são a segunda característica mais frequentemente pesquisada. A relação da leptospirose com essas áreas é comprovada em alguns estudos, a exemplo de Barcelos e Sabroza (2001) e Vanasco et al. (2008). Barcellos e Sabroza (2001) verificaram que $48 \%$ dos casos estavam correlacionados a regiões com risco de alagamento. As áreas com risco de alagamento foram identificadas através de cálculo de declividade do terreno e bacia de convergência da drenagem pluvial.

A preocupação com tal fator de risco se dá principalmente pela relação existente entre o regime de chuvas e a transmissão da doença. Esta relação é comprovada não apenas pelo conhecimento do ciclo de sobrevivência da bactéria no ambiente, mas pela publicação de inúmeros trabalhos em diversos locais atestando esta correlação (EVERARD et al., 1985; EVERARD et al. 1992; KO et al. 1999, entre outros). As análises realizadas por Reis et al. (2008) demonstraram que moradores cujos domicílios estão situados a menos de 20 metros do ponto mais baixo do vale têm risco significativo de infecção. Pelos mesmos motivos, o contato com solo úmido e lama, são também investigados com frequência.

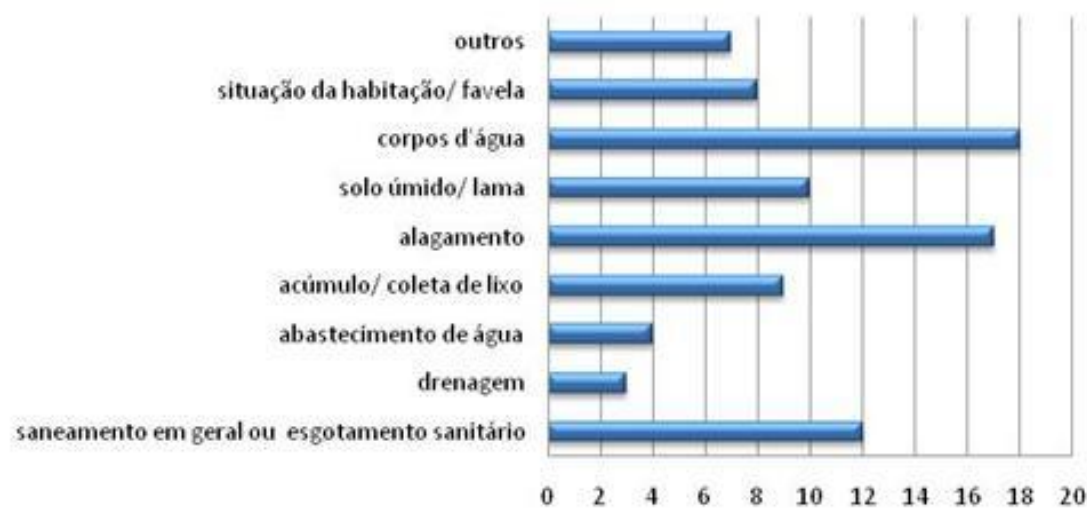

Figura 2.4. Características urbanas $\mathrm{x}$ número de artigos. Frequência com que as características urbanas foram investigadas ou mencionadas. Fonte: Brito (2010).

As condições gerais de saneamento e esgotamento sanitário são tratadas em cerca de $30 \%$ dos artigos levantados. Este fator de risco está diretamente relacionado ao principal hospedeiro responsável pela emergência da doença no meio urbano, o rato (principalmente a ratazana de esgoto). Estudos focados em investigar a correlação da doença com a ocupação dos pacientes relatam com frequência que os trabalhadores que desempenham serviços nessa área, limpeza e reforma de rede de esgoto e canais, são aqueles que apresentam maior risco de contaminação (CHAN et al. 1987; SKINHO et al., 1981; AMBEKAR et al., 2004). A vacina para este grupo de trabalhadores, segundo Serres et al. (1995), é uma medida extremamente necessária.

O modelo de regressão lógistica desenvolvido por Sarkar et al. (2002), constatou que o fator mais fortemente associado á doença é a proximidade da residência a esgotamento a céu 
aberto. O trabalho minucioso realizado por Reis et al. (2008) em uma área carente da mesma cidade, Salvador, foi mais além. As análises dos autores comprovaram que moradores de favela tem risco positivo de adquirir anticorpos da bactéria Leptospira quando o domicílio se encontra a menos de 20 metros de esgotos a céu aberto ou de depósitos de lixo, e o risco de infecção cresce a medida que essas distância diminuem.

O acúmulo de lixo, também medido segundo a precariedade do sistema de coleta, está diretamente relacionado à oferta de alimento à comunidade de hospedeiros. Barcellos e Sabroza (2001) verificaram que $78 \%$ dos casos de leptospirose investigados estavam correlacionados ao entorno das áreas de acumulação de lixo. A variável acúmulo de lixo teve seu cálculo baseado em densidade populacional, percentual de residências com coleta (ambos dados do censo) e volume de lixo produzido no município. Comunidades com deficiência do serviço de coleta podem também apresentar maiores problemas com alagamentos e formação de poças d'água, pois o lixo não recolhido tende a bloquear o sistema de drenagem pluvial, como relata Reis et al. (2008)

As pesquisas que usam o abastecimento de água como fator de risco aparecem em menor número. Ainda que nenhum estudo tenha encontrado correlação da variável com a doença, acredita-se que esta variável pode ser usada como um indicador de salubridade no ambiente residencial uma vez que hábitos de higiene evitam, por exemplo, a contaminação via oral (contato com objetos contaminados).

Um sistema de drenagem precário pode implicar em (i) maiores riscos de alagamento, em se tratando de áreas de baixada, (ii) em maiores riscos de formação de poças de água e lama, em áreas de baixa declividade, ou (i) risco de servir como abrigo para a população de roedores, no caso de sistemas subterrâneos sem manutenção. Reis et al. (2008) afirma que, em áreas precárias, o sistema de drenagem que não atende a vazão da água de chuva, permitindo o alagamento, é certamente um dos fatores ambientais que contribuem para a transmissão da leptospirose.

Condições gerais de saneamento a que se referem alguns autores, dizem respeito a um conjunto deficitário de infra estrutura básica da drenagem, abastecimento de água, esgotamento sanitário e coleta de lixo. Essas condições, associadas à precariedade da habitação caracterizam as áreas de favela.

De uma forma direta, a precariedade da habitação pode estar relacionada à transmissão da leptospirose por indicar precariedade das condições de armazenamento do alimento, da disposição das camas (podendo estar ao chão, em meio a animais domésticos 
contaminados ou susceptível ao trânsito de roedores), entre outras condições de risco. Indiretamente, a precariedade da habitação é um indicador da situação socioeconômica da família, fator diretamente relacionado com o risco de infecção, como afirma Reis et al. (2008) em seus estudos. Segundo Reis et al. (2008) na comunidade de Salvador estudada, um acréscimo na renda per capta de um dólar por dia está associado a um decréscimo de $11 \%$ do risco de infecção.

Ainda que alguns estudos consigam comprovar a relação de tais fatores de risco, saneamento e habitação, com a transmissão da leptospirose, alguns autores encontraram resultados não esperados de distribuição espacial da doença. Nos estudos de Barcellos e Sabroza (2000), Johnson et al. (2004) e Tassinari et al. (2004) considera-se a possibilidade de que a leptospirose não atinge o estado grave quando a exposição à Leptospira é comum, como por exemplo, em áreas frequentemente inundadas e em favelas, fazendo com que os aglomerados dos casos notificados em hospitais apareçam distantes dessas áreas consideradas endêmicas.

A vegetação está entre os fatores urbanos menos investigados. Ward et al. (2004) e Ghneim et al. (2007), que pesquisaram a leptospirose canina, investigaram a relação da contaminação após contato com área de vida silvestre. Ghneim et al. (2007) acredita que em ambientes silvestres contaminados a sobrevivência da bactéria se dá devido à presença de mamíferos hospedeiros, água estagnada e interação com animais não silvestres contaminados (gado, cães, ratos de esgoto, porcos, etc.). Assim, em áreas urbanas, a proximidade de áreas silvestres ou áreas agrícolas podem se caracterizar como fator de risco. A leptospirose inicialmente era tida como uma doença ocupacional relacionada a atividades rurais, principalmente aquelas ligadas ao trato animal, como a prática da medicina veterinária, ou atividades agrícolas, com destaque para a cultura do arroz e da cana-de-açúcar como citam Gubler et al. (2001) e Levett (2001), e a cultura de bananas, segundo Levett (2001) e Smythe et al. (1997). Reis et al. (2008) investigou a vegetação existente dentro do limite da área de estudo, sem encontrar correlação significativa com a doença.

Outros ambientes urbanos menos estudados, mas mencionados nos artigos como possíveis fontes ambientais de transmissão da doença são: (i) os mercados livres (CHAN et al., 1987), com infra-estrutura precária, podem ser facilmente visualizados como foco da doença uma, vez que, assim como os depósitos de lixo provêm alimento para o rato; (ii) becos (VINETZ et al., 1996), onde há falta de manutenção pode fornecer ambiente propício para acúmulo de lixo, entulho e abrigo para roedores, representando risco principalmente para população de desabrigados e mendigos que por aí circulam; (iii) área portuária 
(VINETZ et al., 1996), que a depender das condições de salubridade oferecem abrigo, alimento e fonte de água para roedores. A contaminação em mercados livre e áreas portuárias, são mais relacionadas pela literatura como riscos ocupacionais.

É interessante observar que um número significativo de artigos encontram diferenças significativas quanto ao risco de contaminação e o gênero. Tal relação deve-se, segundo autores, principalmente a fatores ocupacionais, já que atividades de maior risco, limpeza de córrego, esgotos, estivadores e outros, tendem a ser desenvolvidas por pessoas do sexo masculino. Agudelo-Floréz et al. (2007) não encontrou diferença significativa entre gênero em sua pesquisa, segundo os autores isso ocorreu possivelmente devido a similaridade das atividades realizadas por homens e mulheres na área de estudo e porque o tipo de exposição predominante foi a exposição a fatores de risco ambientais.

Muitos dos trabalhos levantados também realizaram investigação sobre a densidade de ratos, seja através de questionário, perguntando se moradores haviam avistado ratos nas proximidades da residência ou através de vistoria de campo, buscando sinais de tocas ou outros indicadores da presença de roedores.

Na pesquisa realizada por Sakar em Salvador, no total de 55 pacientes que relataram ter contato com uma fonte potencial de contaminação, $84 \%$ relataram que a exposição aconteceu na rua, $56 \%$ no ambiente de trabalho e $36 \%$ no ambiente domiciliar. Tradicionalmente, a transmissão da doença se dá predominantemente por fatores ocupacionais, sendo que alguns desses principais fatores são atividades diretamente relacionadas ao ambiente urbano de trabalho ou moradia. São, principalmente, atividades que exigem contato com sistemas de esgotamento ou drenagem, como afirmam Kariv et al. (2001), Ko et al. (1999), Levett (2001), Perret et al. (2005), Everard et al. (1992), Chan et al. (1987) e outros.

Em comunidades carentes é ainda mais difícil distinguir se a fonte de contaminação real de determinado paciente foi ambiental ou ocupacional, devido a comportamentos sociais, como a prática de mutirões para limpeza de córregos, esgotos e valas da própria comunidade. Assim, o ambiente de trabalho, muitas vezes, se confunde com o ambiente domiciliar. Esse padrão comportamental e os resultados de investigações realizadas nesse tipo de área (SAKAR et al. 2002, RILEY et al. 2007, REIS et al. 2008) indicam que o ambiente público da comunidade (espaços de circulação e lazer, que nas comunidades mais carentes é a rua) tem papel fundamental na transmissão da doença. 
A identificação e caracterização, através de SR em ambiente urbano, dos fatores de risco destacados nos trabalhos citados, requer um conhecimento mais aprofundado do espaço urbano e das formas que esses fatores se manifestam na cidade.

\subsection{Ambiente urbano}

\subsubsection{Morfologia Urbana}

A morfologia é um termo usado para "designar o estudo da configuração e da estrutura exterior de um objeto. É a ciência que estuda as formas, interligando-as aos fenômenos que Ihe deram origem" (LAMAS, 2004, p. 37). Segundo este autor, a morfologia urbana se dedica ao estudo de aspectos exteriores do meio urbano e suas inter-relações, analisando e explicando sua paisagem e estrutura.

A forma física da cidade é o produto de uma ação e a solução de um problema posto pelo contexto (geografia, pressão social, condições financeiras, vizinhança, legislação, etc.). Assim, a função é fator determinante da forma, pois "a forma terá que se relacionar com a função de modo a permitir o desenvolvimento eficaz das atividades que nela se processam" (LAMAS, 2004, p. 48).

A forma urbana precisa ser estudada em diferentes escalas. Os elementos morfológicos percebidos em uma escala se articulam e estruturam novas formas observadas em outras escalas. Assim, em uma escala regional, o estudo da cidade pode ser realizado por meio da leitura de padrões de expansão, formas dos limites urbanos, da rede viária, etc. (Figura 2.5), e a forma de um bairro será composta pela disposição das ruas, distribuição das praças, afastamento entre edficações, etc.

Ao analisar os elementos urbanos e as funções exercidas por eles, deve-se estar atento a esta variedade de escalas. Inúmeras leituras são possíveis sem que uma seja mais certa que a outra. Cada instrumento de análise destaca um aspecto e conseguirá explicar um fenômeno por um ângulo (LAMAS, 2004).

Estudos da morfologia urbana são importantes nas mais diversas áreas de conhecimento, apoiam desde estudos de zoneamento urbano à pesquisas na área da saúde pública, como foi visto na seção anterior (Seção 2.1). Na área de transportes há pesquisas que afirmam que as características fisicas do ambiente urbano desempenham um importante papel na escolha que um indivíduo faz sobre o meio de transporte (AMÂNCIO e SANCHES, 2005). 
Variáveis como: densidade urbana, uso do solo, qualidade de espaços que favorecem o transporte não motorizado, entre outras, foram estudadas por Deus et al. (2007) a fim de definir como características físicas de determinada região influenciam no comportamento do transeunte.
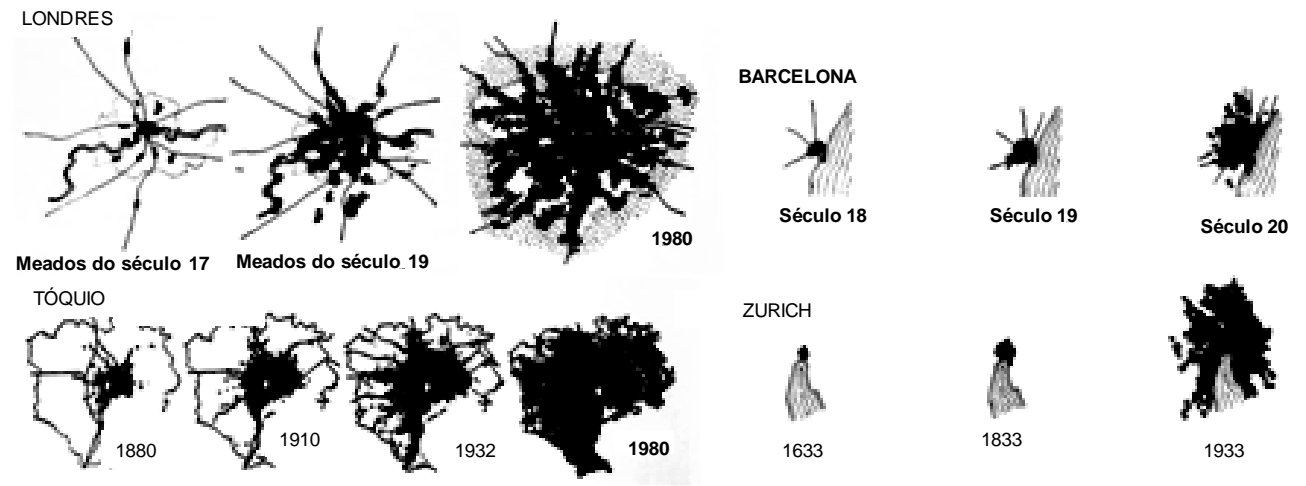

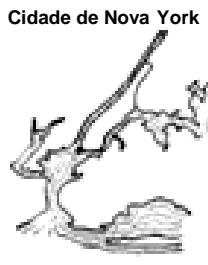

1760

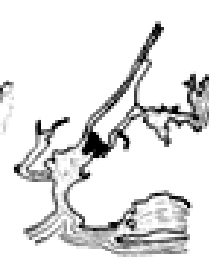

1800

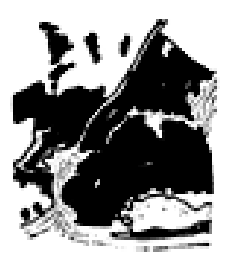

1980
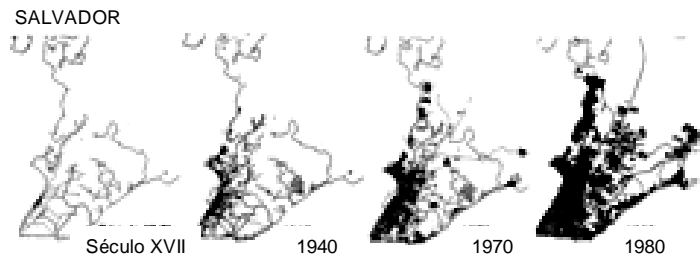

Figura 2.5. Formas de ocupação e expansão urbana das metrópoles: Londres, Tokio, Nova York, Barcelona, Zurique e Salvador. Fonte: Galiion e Eisner (1986, p. 476, 477) e Gordilho (2000, p. 191, 192).

$\mathrm{Na}$ escala intra-urbana, a morfologia também permite realizar a leitura de particularidades de determinado padrão urbano, reconhecendo semelhanças e diferenças entre cidades e dentro da própria cidade (Quadro 2.2). Cidades maiores, principamente as metrópoles, são caracterizadas pela complexidade espacial, que, ao mesmo tempo que the dá identidade enquanto cidade, a compõe como um mosaico de subculturas (Figura 2.6)

Ainda que extremamente complexas e distintas na produção das formas urbanas, existem fenômenos determinantes que assumem maior preponderância nas análises. São estruturas e fluxos urbanos identificados na cidade por elementos que têm forma.

Inúmeros são esses elementos que revelam e definem cidades e comunidades. Cristofer Alexander (ALEXANDER et al., 1977 e ALEXANDER, 1979), em seu trabalho voltado ao desenvolvimento de uma linguagem de padrões para auxiliar o processo de planejamento e projeto de cidades e construções, reconheceu e discutiu 253 padrões ou características urbanas. Muitos desses padrões, como diz o autor, estão inter-relacionados e nenhum existe por si só. 
Quadro 2.2. Amostra padrões espaciais em diferentes cidades. Imagens capturadas do Google Earth

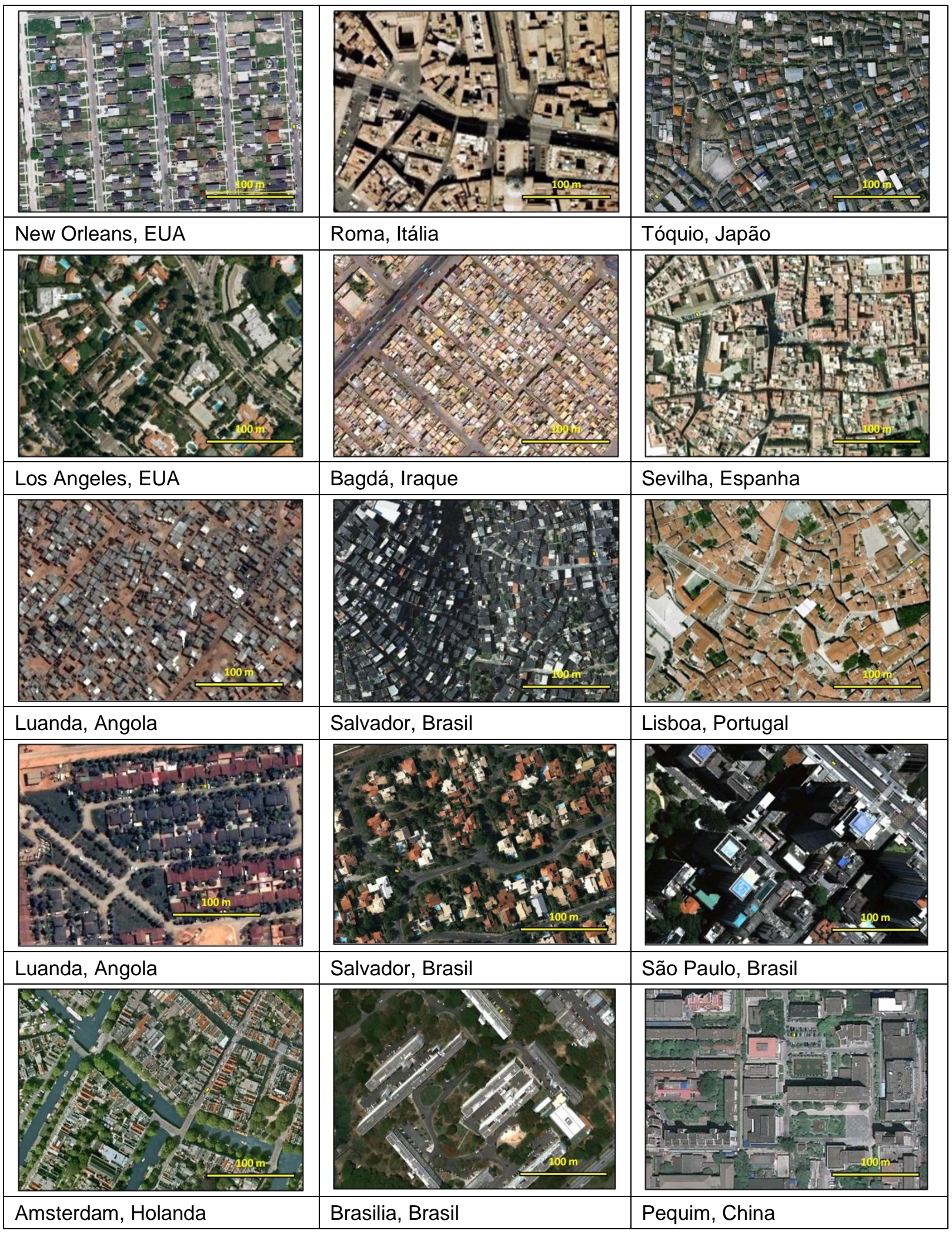

Nota: Cenas orientadas para norte. Fonte: Brito, 2010. 
a)

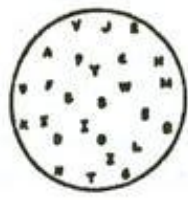

b)

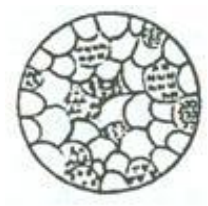

Figura 2.6. a) a cidade heterogênea que parece homogênea, b) o mosaico de subculturas (Alexander et al., 1977, p. 43, 44)

Nem todos os padrões discutidos por Alexander são necessariamente físicos, ou estão relacionados a uma forma específica (como "a mágica da cidade"), mas em sua maioria remetem a um, ou mais elementos urbanos ou construtivos (como a presença, distribuição, acesso e arquitetura de teatros). Entre os padrões de linguagem voltados para a escala da cidade destacam-se: as grandes estruturas que definem a cidade, os que definem e identificam a comunidade e locais, os que formam conecções entre comunidades e os que definem uma cidade como comunidade.

Entre os elementos físicos, na escala comunitária, tratados direta ou indiretamente por Alexander et al. (1977), pode-se listar: edificações, verticalidade, pequenos aglomerados, disposição entre edificações, disposição no terreno, orientação (norte/sul); áreas verdes, conecção entre áreas, parques, largos, mirantes, praças; comércio, mercados, shopping center, universidades, escolas, templos religiosos, serviços de saúde, cemitérios, locais para a prática de esportes; vias locais e estradas de acesso, estacionamentos, conectividade entre vias (fluxo), traçado de vias, a calçada, a travessia de pedestres, a interseção de vias, o pavimento, a relação calçada (pedestres) e rua (automóveis), ciclovias, estações de transporte coletivo; a água, piscinas, lagos e riachos.

Kevin Lynch (LYNCH, 1960), por sua vez, desenvolveu estudos voltados para a interpretação coletiva e individual da cidade, discutindo o valor cognitivo de seus elementos e a sua importância socio-cultural para a comunidade e o indivíduo. A imagem da cidade formada por cada um, deixando de lado o valor social, função ou história, se refere a formas físicas, que, segundo o autor, podem ser classificadas em cinco tipos de elementos: caminhos, bordas, distritos, nós e marcos (Figura 2.7).
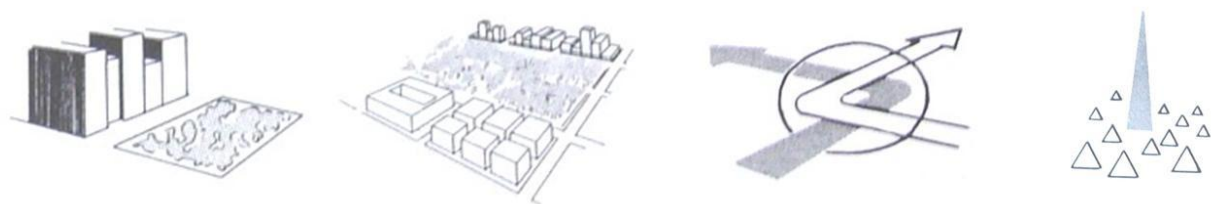

Figura 2.7. Tipos de elementos que formam a imagem da cidade: caminhos, bordas, distritos, nós e marcos (LYNCH, 1960, p. 47, 48). 
Já Lamas (2004) destaca dez elementos cuja presença, disposição, composição e demais características costumam revelar a morfologia do espaço urbano investigado. Algumas dessas características analisadas em imagens de SR podem revelar funções e estruturas socioeconômicas, além da existência de outros elementos vinculados a estes. Cada uma dessas caracteristicas, e uma a mais não citada por Lamas (a água), são discutidas a seguir, com base em argumentos usados por Lamas (2004), complementando-os com pontos de vista apresentados por Alexander (1977) e Lynch (1960) e focando na representatividade da leitura desses elementos em imagens de $\mathrm{SR}^{7}$.

O solo e o pavimento: elementos de grande importância e, ao mesmo tempo, de certa efemeridade, por estar sujeito a mutação com o tempo. Nas imagens, a presença do asfalto nas vias, por exemplo, indica a existência de alguma estrutura formal de serviços urbanos. Essa estrutura formal geralmente viabiliza o atendimento de serviços de coleta de lixo e indica a provável existência de outros serviços de saneamento, como drenagem pluvial e esgotamento sanitário. Vale ressaltar, que nas cidades brasileiras, o pavimento está muitas vezes coberto por sujeira ou barro, o que dificulta a identificação do material nas imagens (NÓBREGA, 2008). A cobertura do solo como um todo (por construções, pavimento, vegetação, etc.) indica ainda a capacidade de infiltração das águas de chuva na área, e, quando observado em conjunto com o modelo digital do terreno, pode contribuir com o cálculo de vazão, riscos de alagamento, demanda por drenagem, entre outras questões.

Os edifícios: têm suas tipologias identificadas na imagem por meio da análise de tamanho, material do telhado, modo como se organizam, afastamentos, adensamentos, etc. Essas características revelam muito sobre a estrutura urbana de uma comunidade, podendo, inclusive, determinar padrões urbanos que servem de pista para sua posição econômica na cidade. Aka (1997) desenvolveu uma pesquisa na comunidade de Novos Alagados em Salvador, onde tenta explicar os processos sociais, econômicos e políticos que concorreram para a origem e desenvolvimento das favelas. Sua metodologia é baseada na análise das tipologias, morfologia e produção do espaço concreto da comunidade, mostrando também a evolução que essa favela experimentou, bem como a sua lenta integração ao tecido urbano. No quadro desenvolvido pelo autor a respeito da evolução dos materiais (Figura 2.8), é possivel observar a relação existente entre algumas características da edificação possíveis de serem identificadas em SR (materiais utilizados no telhado e as áreas ocupadas pela residência) e demais características (tipologia, materiais construtivos, sistemas de abastecimento de água, energia e esgotamento sanitário).

\footnotetext{
${ }^{7}$ Os métodos e materiais de SR são discutidos mais extensivamente no Item 2.3 , e a visualização desses elementos na área de estudo é apresentada no Quadro 4.1 do Capítulo 4
} 


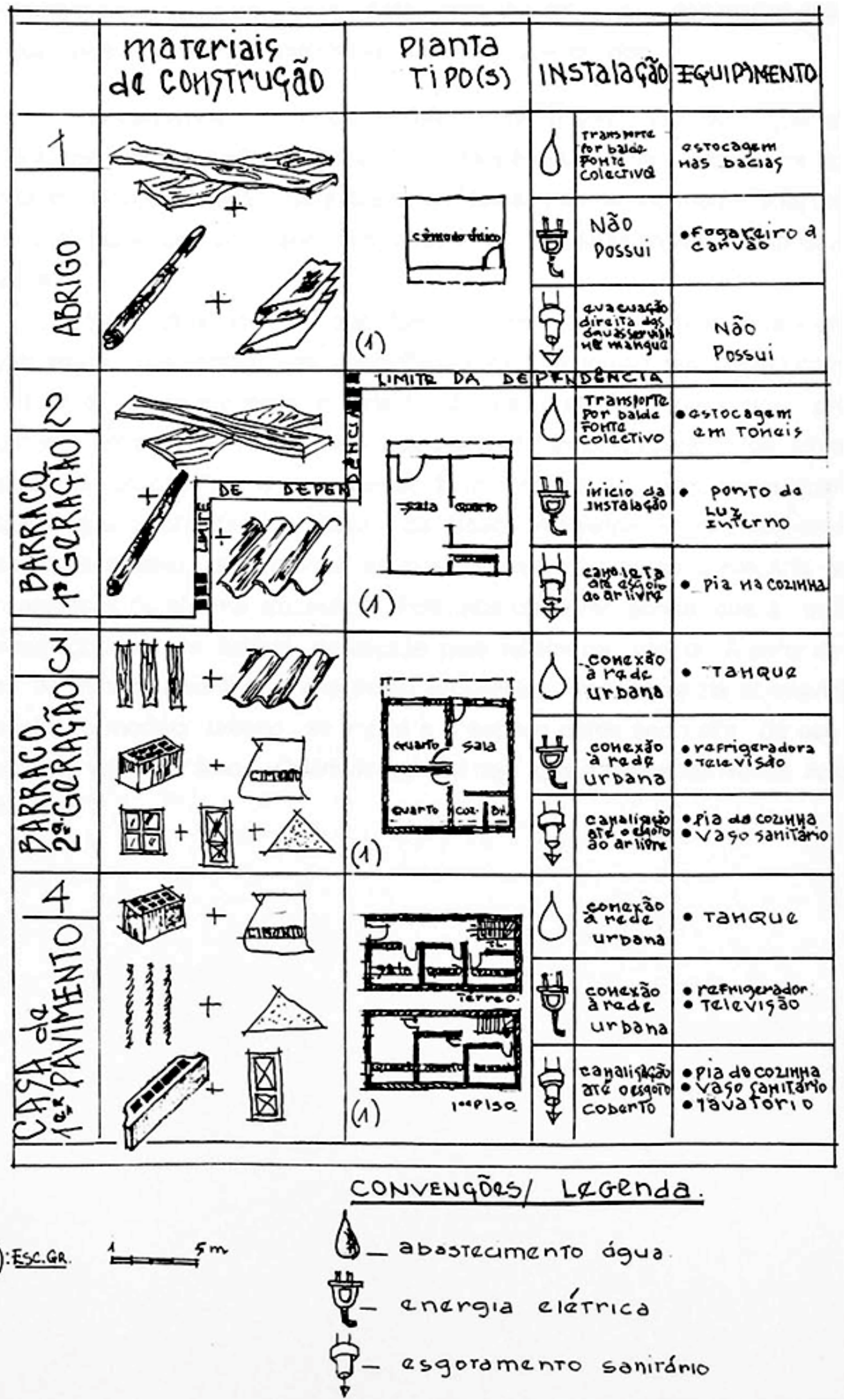

Figura 2.8. Quadro da evolução dos materiais. Fonte: Aka (1997, p.69) 
Em imagem satélite de 2008 de uma área afetada pelo furacão Katrina em 2005 (New Orleans, Quadro 2.2) é possível identificar, por exemplo, edificações com cobertura de lona (azul) além de edificações sem telhado e a presença de treilers.

A verticalidade das edificações também é uma característica importante para a leitura do espaço urbano. O uso de tecnologia laser de imageamento e uso de processos automáticos de construção de modelos digitais de superfície, são exemplos de avanços tecnológicos que têm feito o interesse pela construção de modelos tri-dimensionais de cidades crescerem a cada dia. As aplicações desse campo da morfologia urbana são as mais diversas possíveis, indo desde o monitoramento da verticalização de determinada área para fins de cobrança de impostos, como para a reconstruções de cenários históricos (Figura 2.9)

a)

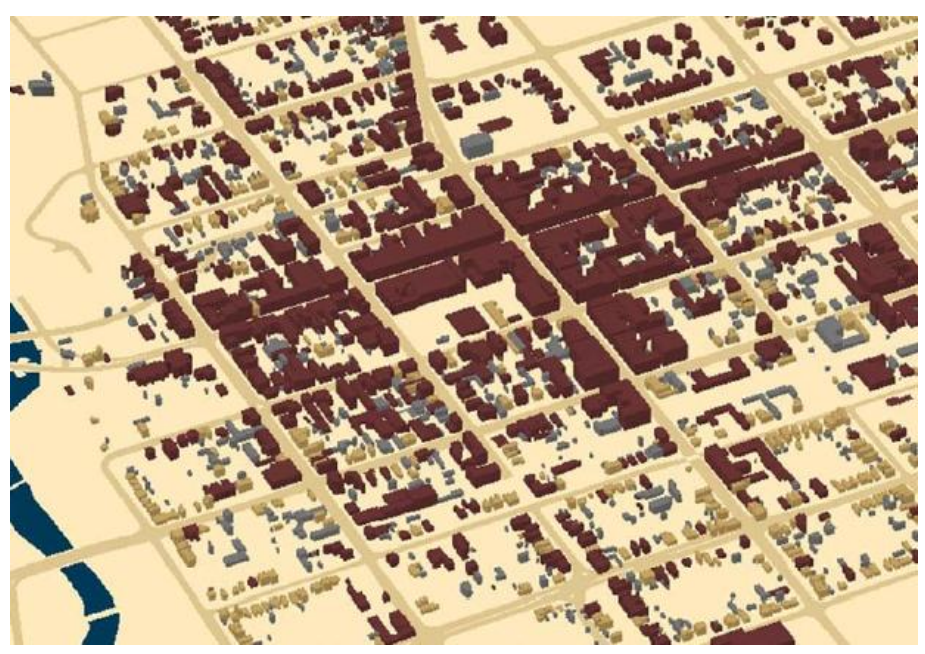

b)

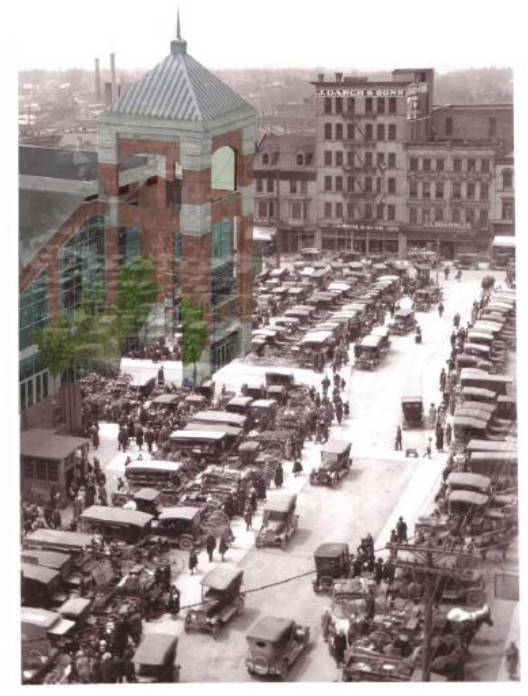

Figura 2.9. Aplicações de modelos morfológicos 3D. a) Modelo tri-dimensional da forma construida de uma cidade canadence em 1888. Bloco em vermelho - edficações de tijolo; em amarelo edificações de madeira; em cinza - edficações de concreto. b) Sobreposição de modelo tridimensional de um mercado restaurado em fotogafia que mostra seu contexto original. Fonte: Novak et al. $(2007$, p. 9)

O lote: é a parcela fundiária que indica as relações de público e privado existentes e ainda condição socioeconômica do proprietário. Nem sempre é possível identificá-lo nas imagens por ser comumente delimitado por elementos físicos de pequenas dimensões, muros e cercas.

O quarteirão: consiste no agrupamento contínuo de edifícios ou lotes e indica o grau de modo de organização de uma comunidade. Em escalas maiores, pode ser considerado a unidade mínima de observação e agregação dos dados, a exemplo dos estudos sobre a febre amarela de 1878 em Nova Orleans, Estados Unidos, onde acredita-se que a área comum nos quintais, centro das quadras, era o principal espaço de transmissão da doença, Figura 2.10 (CURTIS et al., 2007). 


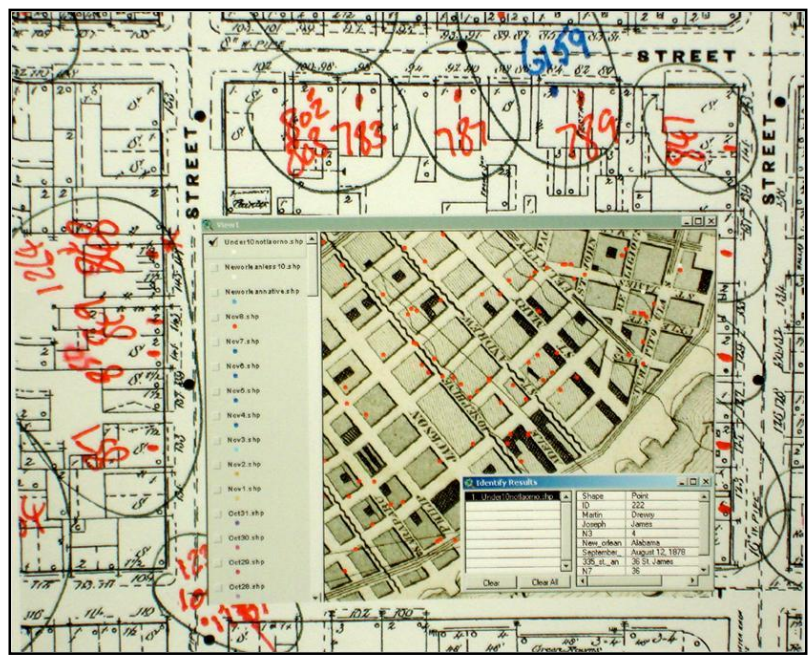

Figura 2.10. Epidemia de 1878 de febre amarela em New Orleans. Fonte: Curtis et al. (2007).

O logradouro: é um dos elementos urbanos mais revelador de uma cidade ou comunidade, pois pode, entre outras coisas, revelar a característica topográfica do sítio urbano, as principais conexões entre áreas, a formação e o crescimento da cidade, o perfil de uso do solo, centralidades, etc. Muitos planos e zoneamentos urbanos já consideram as vias como elemento definidor de parâmetros urbanísticos e não o quarteirão, como muito foi usado. Isso se justifica pelo reconhecimento da rua, em nossa sociedade, como o espaço de convergência dos usos das edificações e lotes.

Além dos seus atributos quanto ao tipo de pavimentação, comentados anteriormente, muitos outros atributos, como aqueles discutidos por Lynch (1960), podem ser reveladores. Por exemplo, é interessante observar que ruas largas podem significar forte conexão e intenso fluxo entre áreas descontínuas e segregação entre áreas vizinhas. Por outro lado, ruas estreitas, ao restringirem o trânsito, agregam as pessoas, são espaços de uso coletivo que podem ser usados como espaços de brincar para crianças, espaço para feiras, entre outros usos. Podem, por outro lado, ser fator de obstrução de atendimento de serviços, como por exemplo, coleta de lixo por caminhão. O traçado irregular, aliado a outras características, também pode indicar a possível carência de manutenção ou inexistência de serviços de esgotamento sanitário e de infra-estrutura de drenagem, uma vez que estes, pelos métodos convencionais, demandam uma regularidade no traçado e costumam se instalar sob vias de circulação.

No entanto, é importante ressaltar a particuladade do processo histórico e social em que se insere a análise. A formalidade no traçado das vias modernas são lidas pela ortogonalidade, 
similaridade e simetria geométrica, enquanto na era medieval a formalidade das ruas se constituia na sua sinuosidade e assimetria. O modelo português de planejamento herdado no Brasil tinha esse perfil medieval, de cidade forte (forte no sentido da edificação militar). Assim, a forma deve ser entendida como um atributo de um processo social, que elebora, legitima e impõe os rituais de uma determinada cultura (LOURES et al. 2007). Um traçado sinuoso e labiríntico pode revelar uma ocupação de favela (Salvador, Quadro 2.2) ou uma ocupação histórica (Lisboa, Quadro 2.2).

A praça: é um elemento morfológico típico de cidades ocidentais, não deve ser considerada apenas local de alargamento de ruas, ou de vazios, a praça é um elemento intencional, que indica organização da comunidade e a centralidade de uma área, pois é o lugar dos acontecimentos sociais, do encontro, da brincadeira. Por permitir variedade grande de tipos de cobertuda e de configurações de forma, não se constitui como um elemento de fácil identificação em processos automáticos de SR, no entanto, um conjunto de elementos pode ajudar nessa tarefa, a presença de verde ou área não construida servida por ruas e em área densamente ocupada podem se configurar em indicadores da presença de uma praça.

Ainda que atualmente a sociedade esteja cada vez mais fechada no espaço privado, em detrimento do espaço público, seja a unidade familiar ou em condomínios fechados, nas comunidades menos favorecidas é no espaço público (rua, praça, etc.) que a vida acontece (Figura 2.11).

A fachada: exprime a relação do edifício com o entorno, em especial em cidades tradicionais, no entanto, não é possível ser analisada nas imagens ortogonais.

Os monumentos são patrimônios da cidade, marcos sem finalidade de uso, à exceção de alguns edifícios, mas com significado histórico, social ou cultural. Compõem a imagem coletiva da cidade e do lugar. Localizam-se em local de destaque indicando um espaço valorizado pela população. No entanto, na maior parte dos casos, não são possíveis de serem identificados a partir de imagens aéreas ou orbitais.

A vegetação: suas funções e significados na leitura da cidade são bastante diversificados. A proporção de área verde de uma comunidade é frequentemente tida como indicador de qualidade ambiental e de qualidade de vida. Entretanto, áreas verdes não edificanti, margens de córregos, áreas alagadiças, encontas e outras áreas de preservação, são muitas vezes alvo de ocupações clandestinas e precárias. Ainda assim, a presença de vegetação em logradouros e em praças, por exemplo, controlam a vazão da drenagem pluvial, regulam o clima e qualificam o espaço esteticamente e ambientalmente. $O$ 
alinhamento de árvores indica intervenção do homem com propósito definido, a aglomeração de árvores em espaços públicos pode indicar um espaço de lazer, a presença de um parque ou mesmo uma área abandonada ou não edificante. Algumas espécies, em certas situações, podem também indicar riscos urbanos. A presença de bananeiras em áreas de alta declividade, considerado um fator de risco de deslizamentos, e em áreas menos movimentadas, que podem servir como toca de ratos. Já os pinheiros inibem o crescimento de vegetação rasteira, tornando o solo susceptível à erosão, entre outros exemplos. Enquanto a vegetação pode ser considerada um dos elementos mais facilmente identificáveis nas imagens a identificação de espécies de árvores por meio de imagens ortogonais, em especial no ambiente urbano, é bastante difícil.
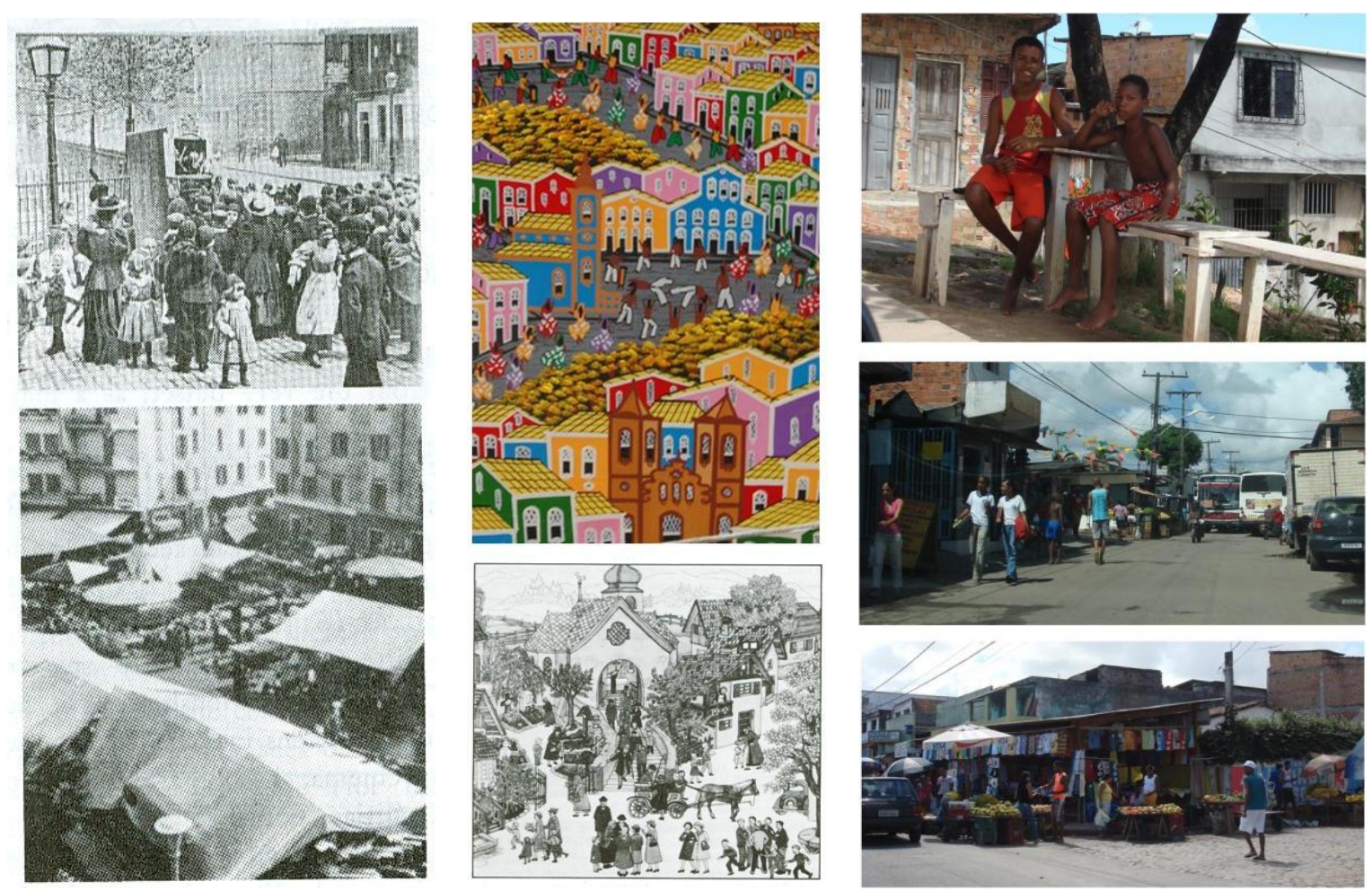

Figura 2.11. A vida acontece no espaço público. Fonte: figuras na esquerda e no centro inferior (ALEXANDER et al., 1977, p. 166,163), figura centro superior - quadro típico da paisagem do Pelourinho (Salvador), artista desconhecido, Fotos na direita Subúrbio Ferroviário de Salvador, junho de 2008, Patricia Lustosa Brito.

O mobiliário urbano: é composto por equipamentos relacionados ao funcionamento do bairro que só podem ser considerados em estudos de maior escala, uma vez que a sua função tem abrangência local. Muitos não são possíveis de serem identificados nas imagens em estudo devido às dimensões reduzidas, como cestos de lixo, banco, telefone público, sinalização, ou são difíceis de serem reconhecidos por processos digitais de SR, como quiosques, pontos de ônibus cobertos e depósitos de lixo. Locais de acúmulo de lixo podem significar a inexistência de mobiliário urbano apropriado ou a precariedade do 
serviço de coleta, no entanto, por se tratar de um elemento de grande mobilidade no espaço e no tempo tanto vistorias de campo como as imagem de SR podem não registrar.

Os equipamentos urbanos de grande porte: são os terminais de ônibus, metrô, trem, passarelas, aterros sanitários, lixões, estações de tratamento de água e esgoto, subestações elétricas, redes de transmissão, entre outros. Estão relacionadas principalmente à escala da cidade. As grandes indústrias e grandes estabelecimentos comerciais, educacionais e de saúde, como discute Alexander et al. (1977), pode se enquadrar nessa categoria também, assim como grandes estruturas viárias como maiores pontes e complexos de viadutos. São elementos que têm interferência direta na dinâmica do bairro, como elemento segregador ou de convergência de fluxos. Devido a suas dimensões, esses elementos se destacam no tecido urbano, tornando-os identificáveis em imagens ortogonais.

A água: é um elemento natural ou artificial presente na maior parte das cidades. É possivel que a maior parte das grandes cidades tenham seu sítio fundador definido em relação à água, seja por por sua função de transporte (mercadoria, pessoas, etc.), por sua função como provedora de alimento (comunidades pesqueiras, etc), por sua função de irrigação ou por suprir uma necessidade primária do homem a de hidratar-se. São infindáveis os usos e influência da água na sociedade. Alexander et al. (1977), na década de 70, já alertava que estamos cada vez mais nos privando desse bem tão precioso para o bem estar físico e psicológico do homem. As superfícies cobertas com águas que aparecem em imagens de SR podem revelar não apenas os entraves geográficos de expansão de uma determinada cidade (vide Nova York e Salvador na Figura 2.5), mas tambem podem revelar a rede de transporte fluvial (Amsterdam, Quadro 2.2), ou o poder aquisitivo de determinada comunidade como a proporção de piscinas no bairro de Beverly Hills (Los Angeles, Quadro 2.2).

Ao tratar da morfologia urbana é importante, mais uma vez, entender que a paisagem observada hoje faz parte de um processo histórico (CARLOS, 1994). A localização de uma comunidade em lugares mais ou menos privilegiados, as características dos elementos urbanos e a tipologia urbana em formação é reflexo de uma relação econômica dessa comunidade com a cidade.

Herry Lefebvre (LEFEBVRE, 2000), defende que é possivel entender a cidade através da produção do espaço, pois o espaço (social) é um produto (social). A favela, por exemplo é o produto da marginalização social. Para Loures et al. (2007) a favela é caracterizada primeiramente como um lugar construido com a perspectiva de suprir a demanda por 
habitação daqueles que estão às margens da inclusão econômica. No entanto, o inchaço das cidades tem promovido a aproximação geográfica da favela e da cidade legalizada, fazendo com que as discrepâncias entre essas morfologias sejam ainda maiores (Figura 2.12)

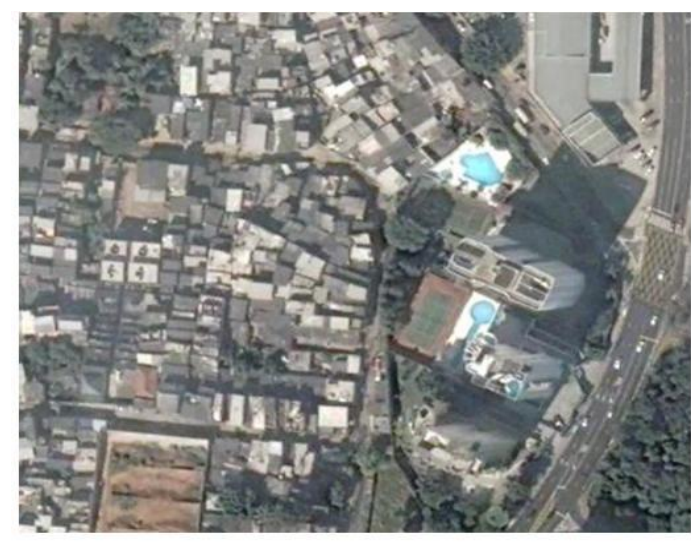

Fonte: Google Earth

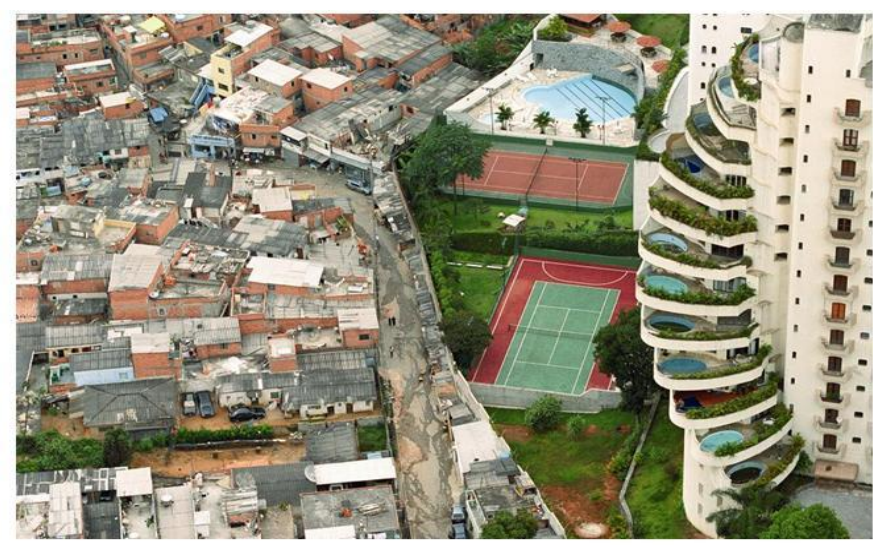

Fonte:http://www.rc.unesp.brigce/planejamento/gpapt/paraisopolis.jpg

Figura 2.12. Discrepância entre morfologias vizinhas. Bairro de Paraisópolis, São Paulo.

Os processos de formação das favelas são os mais variados. Podem acontecer de um dia para o outro, literalmente, com a invasão coordenada de área não ocupada, ou, no outro extremo, pode se dar por um processo gradual ao longo dos anos.

Uma das favelas mais conhecidas mundialmente, a favela da Rocinha no Rio de Janeiro, cresceu gradualmente (Figura 2.13). Como descreve Loures et al. (2007), a Rocinha nasceu de dentro para fora, como a maior parte das favelas do Rio de Janeiro, sem limites de crescimento. As casas primeiro se estabeleceram na parte mais baixa, guardando um certo afastamento entre uma e outra, à medida que a ocupação foi se adensando, foram se formando as ruas tortuosas, os caminhos labirínticos e as construções foram subindo os morros. Mesmo dentro das favelas, em especial nas maiores como a Rocinha, existem vários tipos de ocupação, que variam de acordo com o nivel social e a rede urbana (LOURES et al., 2007).
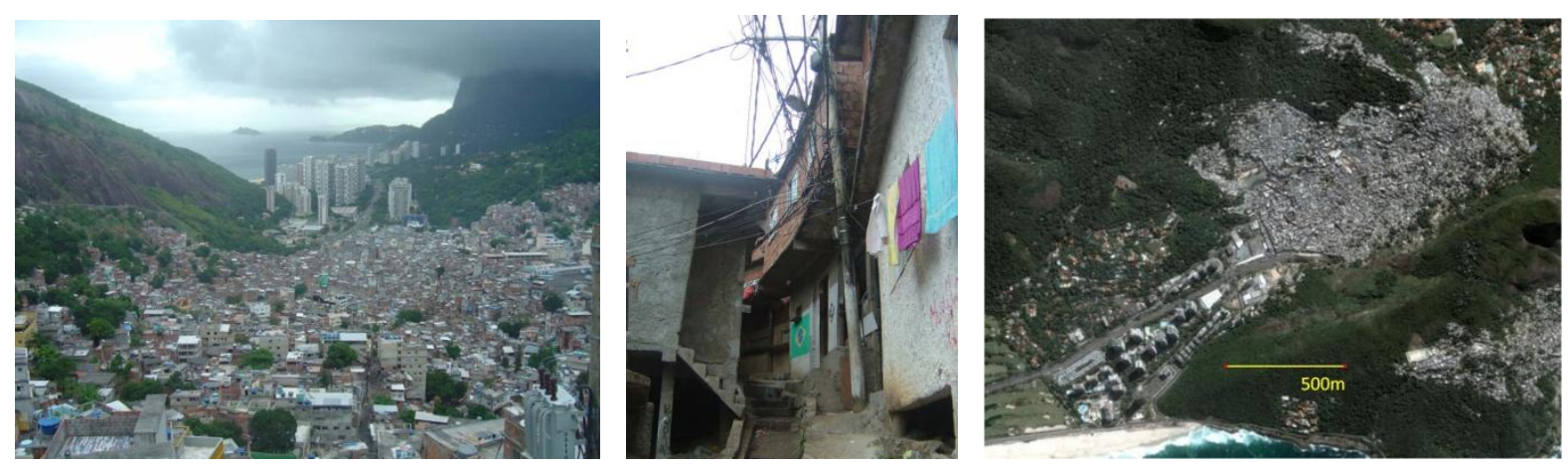

Figura 2.13. Favela da Rocinha, Rio de Janeiro. Fonte: fotos da esquerda e centro, Moema Falci Loures, abril 2007, Loures et al. (2007). Imagem da direita, Google Earth. 
Esta espontaneidade característica das favelas, é na verdade parte essencial do percurso morfológico que caracteriza as cidades ao longo se sua história. A regularidade ou espontaneidade não são específicas de uma cultura ou período, são expressões espaciais de necessidade locais (SOBREIRA 2007).

Sobreira (2007) e Loures (2007) acreditam que favelas são estruturas complexas e não apenas ocupações desordenadas. Sobreira defende que é possivel quantificar tal complexidade segundo padrões de irregularidade do tecido urbano, analisando a frequência das edificações de acordo com seu tamanho. Para isso, Sobreira (2002 e 2007) estudou favelas em Recife e no mundo, investigando diferenças em padrões de textura (lacunaridade) e padrão universal de fragmentação e concluiu que favelas urbanas, independente de sua localização, têm semelhante dinâmica morfológica, no que diz respeito às suas características de fragmentaridade, diversidade, não linearidade e complexidade (Figura 2.14 e Figura 2.15).
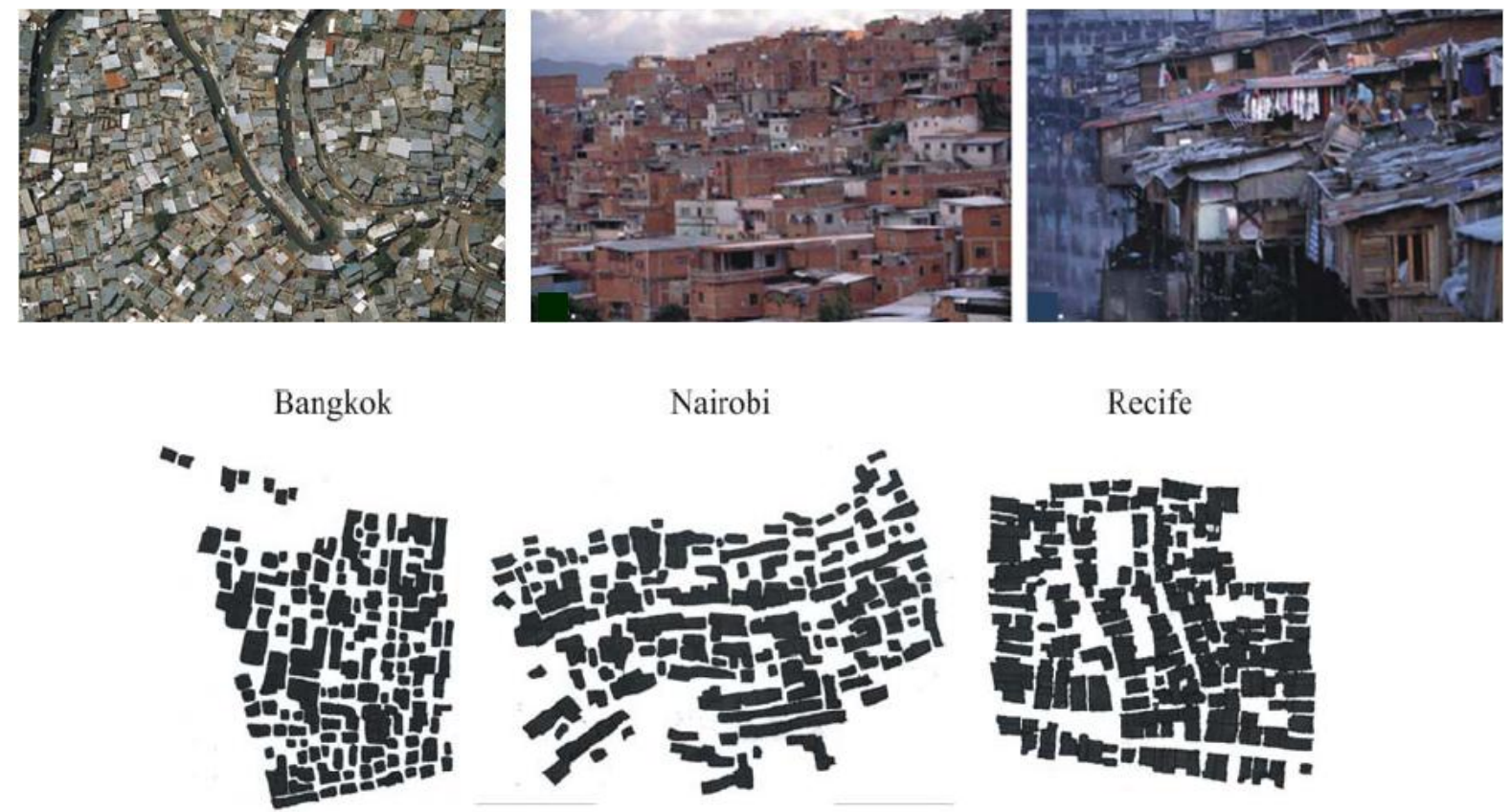

Recife

Figura 2.14.Semelhança morfológica entre favelas de diferentes locais do mundo. Fonte: Imagens de cima (SOBREIRA, 2007, p. 4); Croquis (SOBREIRA, 2002) 

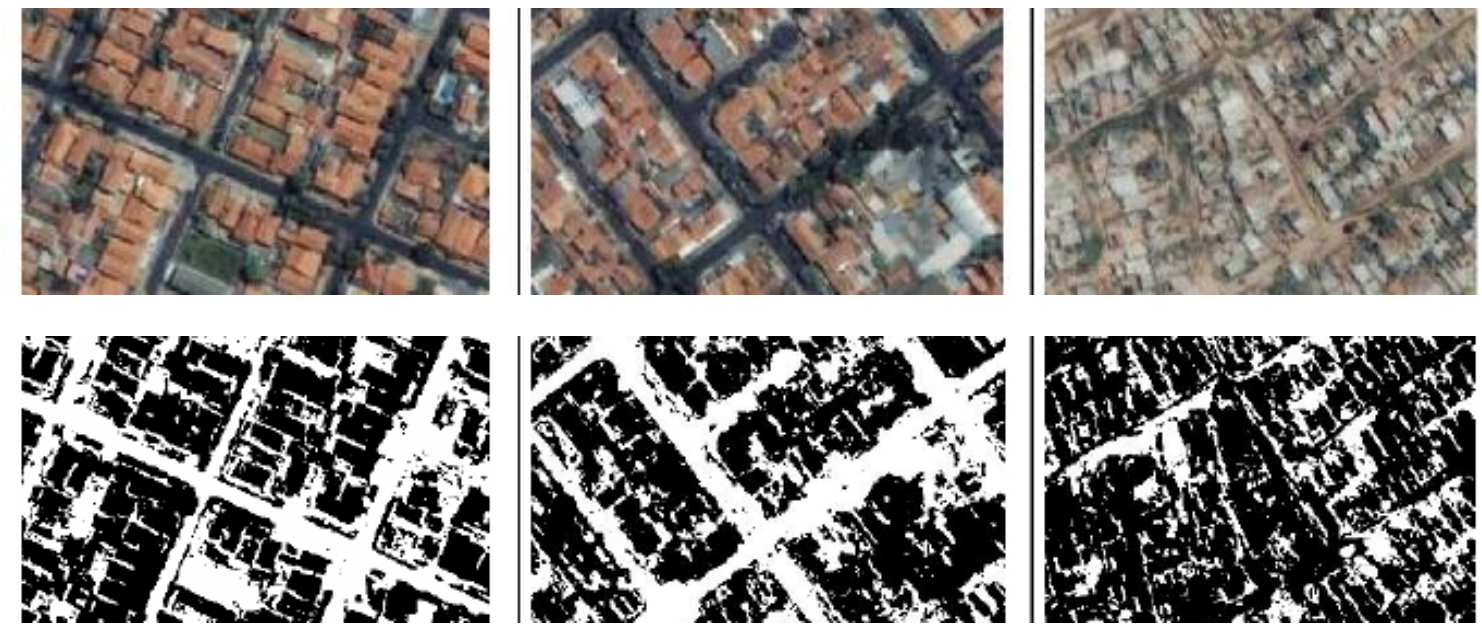

Figura 2.15. Imagens satélite composição colorida e imagens binária utilizadas para investigar diferenças em padrões de textura (lacunaridade) e padrão universal de fragmentação (SOBREIRA, 2007).

É previsível que nesses ambientes constituídos pelas classes mais baixas residam as pessoas mais susceptíveis à contração de doenças, seja por fatores sociais ou ocupacionais (alimentação não balanceada, falta de hábitos de higiene, locais de trabalho insalubres, etc.) ou ambientais (carência de sistemas de esgotamento, drenagem urbana, dificuldade de acesso do serviço de coleta de lixo, ocupação em áreas sujeitas à enchentes, etc.). Entretanto, em meio a tanta precariedade existente nas grandes metrópoles brasileiras, é difícil identificar quais áreas têm urbanização prioritária sob o aspecto da saúde e quais intervenções surtem maior efeito positivo na qualidade de vida da comunidade.

Para responder a essas questões é preciso aprofundar o conhecimento sobre cada cidade, reconhecer em maior detalhe sua morfologia e identificar fenômenos urbanos que atuam sobre as dinâmicas dos vetores e fontes transmissoras de doenças no seu território.

\subsubsection{Modelos urbanos de avaliação}

A criação de modelos urbanos são recursos utilizados por pesquisadores, planejadores e gestores para conectar características, funções, ações, conceitos e outros elementos de interesse que contribuem no entendimento de fenômenos urbanos.

Técnicas de modelamento são frequentemente aplicadas nas mais diversas áreas do conhecimento, mas sempre com o mesmo objetivo: entender a realidade através da sua representação de forma lógica e objetiva. Como explica Câmara et al. (1996): 
"a fase de modelagem do mundo real engloba a modelagem de processos e de dados e consiste em selecionar fenômenos e entidades de interesse, abstraindo-os e generalizando-os. Diferentes conjuntos de fenômenos podem ser escolhidos para descrever distintas visões do mundo, para uma mesma região, em um dado instante" (CÂMARA et al., 1996, p. 24).

Para isso, todo modelo é uma generalização do mundo real que é construído sob a perspectiva de (i) alguém sobre (ii) algo com um (iii) propósito específico. No caso dessa pesquisa, pode-se dizer que o modelo a ser criado seria a visão do (i) planejador ou gestor urbano sobre a (ii) transmissão da leptospirose com o (iii) propósito de definir intervenções urbanas. Mais especificamente o modelo tem o objetivo de levantar e sistematizar os padrões e elementos urbanos identificáveis em SR que podem estar relacionados com a leptospirose. O modelo pode ainda ser usado mais adiante para a criação de um índice de risco, mas para isso há questões estatísticas e de limitação de dados que precisam ser investigadas. Como a criação do índice não é o objetivo final desta Tese, este assunto deverá ser mais explorado em trabalhos futuros.

Entretanto, a maior parte dos modelos de avaliação urbana têm como meta a composição de um índice. Seja um Índice de Qualidade de Vida Urbana - IQV (BORJA E MORAES, 2002), Índice de Mobilidade Urbana Sustentável - IMUS (COSTA et al., 2007), Índice de carência Habitacional - ICH (OBSERVATÓRIO DAS METRÓPOLES, 2009), entre outros. Os índices são formados por indicadores, que por sua vez são, na maior parte dos casos, construídos com base em dados censitários. Modelos mais complexos podem demandar o cálculo de indicadores cujas variáveis necessitam ser baseadas em dados primários (obtidos em campo), em dados de fontes múltiplas (empresas prestadoras de serviços de energia ou hospitais, por exemplo), ou em dados extraídos de SR como fez Paes et al. (2003), por exemplo. Paes classificou imagens Quickbird e calculou o que ele chama de dois tipos de índice de qualidade de vida urbana: o índice de proporcionalidade de área verde e área construída e o índice normalizado de área construída projetada.

Modelos e indicadores urbanos podem ainda ser construídos com base em dados subjetivos, como entrevistas, relatórios, desenhos, etc. Esse tipo de informação é bastante rico e costuma refletir vários aspectos abordados por avaliações de situações complexas como a avaliação da qualidade de vida.

A medida de qualidade, além de subjetiva, é bastante relativa, podendo variar de pessoa para pessoa, de uma hora para outra (uma entrevista sobre o conforto térmico da residência ou bairro realizada ao meio dia, ou no fim da tarde terá respostas diferenciadas), ou mesmo de acordo com a pergunta formulada. Para lidar com esses tipos de incertezas na análise 
de dados subjetivos, Moraes (2008) propôs a utilização de lógica fuzzy em seus estudos de avaliação de áreas urbanas recuperadas aplicados à comunidades de Alagados, Salvador.

Para Alexander, a qualidade é uma coisa tão simples e básica que não é possível de ser nomeada, "é a diferença entre saúde e doença, entre o inteiro e o partido, entre autonomia e autodestruição" (ALEXANDER, 1979: p. 25). Por isso, a dificuldade de ser avaliada.

Segundo Krafta et al. (2007) um sistema descritivo da morfologia urbana deve ter como habilidades básicas a) conciliar diferentes componentes, b) acompanhar diferentes atributos, c) permitir mudanças de escala, d) agregar e desagragar informações e e) ser quantificável.

Inúmeras metodologias de construção de modelos podem ser encontradas em uma variedade de áreas de conhecimentos. Neste estudo foram exploradas três metodologias: uma mais usada como método de aprendizagem, uma usada para monitoramento de saneamento e uma sugerida pela Organização Mundial de Saúde para avaliação das condições de saúde pública e ambientais. Acredita-se que o processo de construção dos três modelos permitiu uma visão mais coesa do problema investigado.

A primeira abordagem metodológica foi realizada utilizando a técnica de elaboração de Mapas Conceituais desenvolvida na Universidade de Cornell (NOVAK, 1998). Essa técnica consiste, resumidamente, na representação de respostas à questão foco, usando conceitos chaves e conectando-os, com uso de quadros e setas, com outros conceitos ou informações, como explica Novak (2008), Figura 2.16. Uma das formas de construir um mapa de conceitos foi apresentada por Maxwell et al. (1997), e consiste simplesmente em lançar todas as possibilidades de informação relacionadas ao conceito chave, brainstorm, e na criação continuada de conectores para os conceitos derivados, até que as possibilidades que interferem na questão foco sejam exauridas. O objetivo é explorar, ao máximo, os conceitos e fatores relacionados à questão foco e identificar entre eles conceitos chave. 


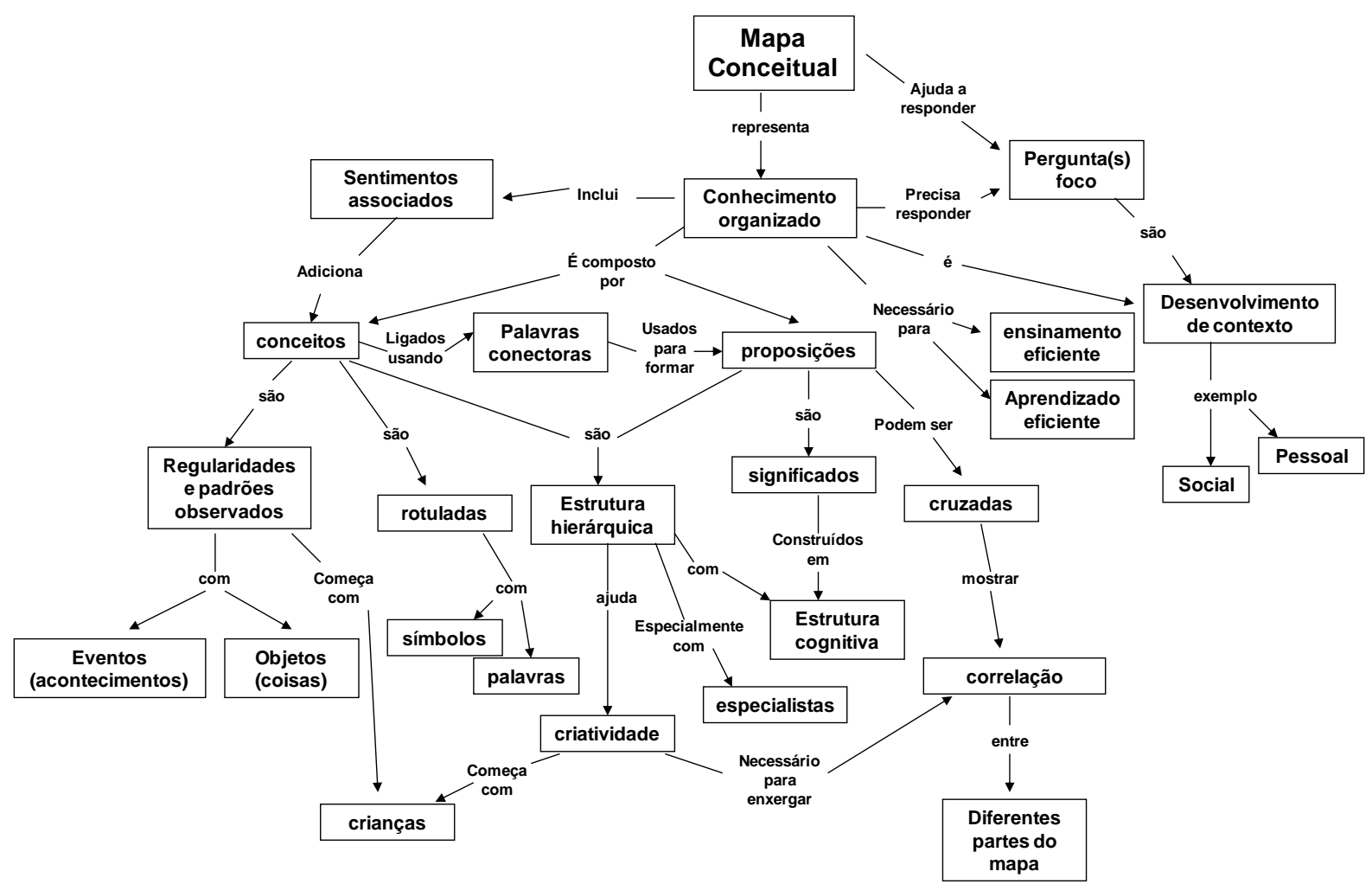

Figura 2.16. Exemplo de mapa de conceitos do conceito "mapa conceitual". Fonte: Novak e Cañas (2008, p. 2).

A segunda metodologia utilizada foi criada pela Comissão de Saneamento do Estado de São Paulo na construção do ISA - Indicadores de Salubridade Ambiental com o intuito de verificar as condições de salubridade dos municípios do estado (SÃO PAULO, 1999). Essa metodologia foi eleita para o presente projeto devido a sua simplicidade e sua profusão em estudos brasileiros, na maioria dos casos, buscando a criação de indicadores mais específicos: ISA/F para favelas (ALMEIDA et al., 2000), ISA/BH para a cidade de Belo Horizonte (VIANA et al., 2007), ISA/JP para a cidade de João Pessoa (BATISTA e SILVA, 2006) e ISA/OE para assentamentos informais (DIAS, 2003). O ISA original foi formado por indicadores de saneamento, socioeconômicos, saúde pública e recursos hídricos. Cada indicador foi calculado usando variáveis disponíveis e facilmente tabuláveis.

A última metodologia utilizada nesta Tese foi baseada na criação de modelos de causaefeito. A estrutura lógica básica desta metodologia foi construída pela Statistic Canadá e foi aplicada pela Organização de Cooperação para o Desenvolvimento Econômico (OCDE) para monitorar problemas econômicos e sociais. A metodologia é baseada no conceito Pressão - Estado - Resposta (PER) e consiste numa cadeia causal de indicadores em que cada célula pode ser quantificada e qualificada usando variáveis apropriadas. A estrutura adotada nesta pesquisa foi sistematizada pela Organização Mundial de Saúde e é chamada de modelo FPEEEA, Forças motriz - Pressão - Estado - Exposição - Efeito - Ação, uma 
derivação do conceito PSE (SUPERINTENDÊNCIA DE ESTUDOS ECONÔMICOS SOCIAIS DA BAHIA E UNIVERSIDADE FEDERAL DA BAHIA, 2006). O Ministério da Saúde brasileiro também aplicou esta metodologia para avaliar impactos de saneamento na saúde da população (BRASIL, 2004). Borja e Moraes (2002) utilizaram o modelo FPEEEA para desenhar a cadeia de causa e efeito de doenças redutíveis por medidas de saneamento (Figura 2.17).

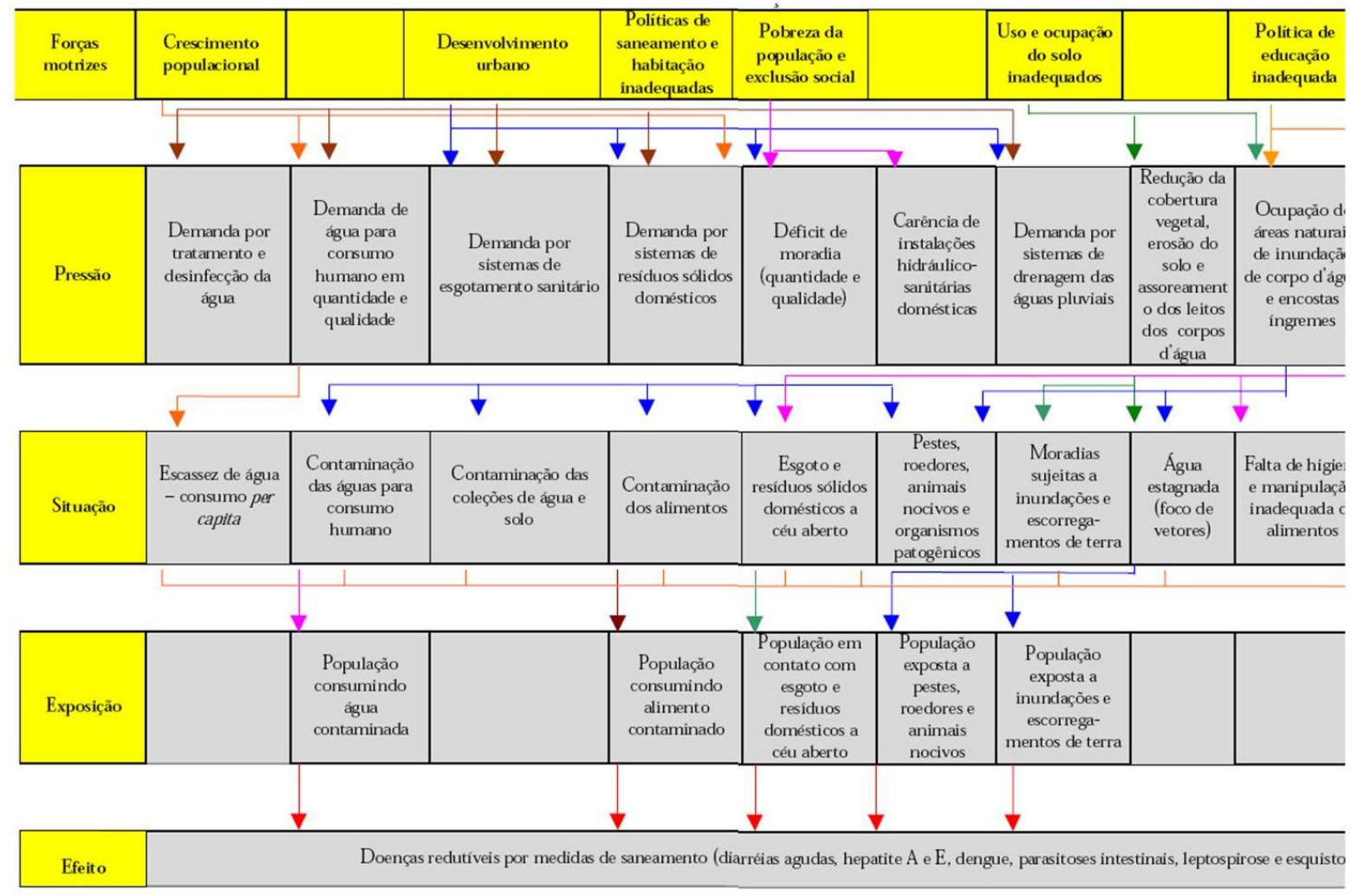

Figura 2.17. Cadeia de causa e efeito de doenças redutíveis por medidas de saneamento. Fonte: Borja e Moraes (2002, p. 23)

O modelo desenvolvido por Borja e Moraes apresentam um maior grau de complexidade quando comparado ao metodo de desenvolvimento dos modelos ISA, mas ainda assim tem suas limitações, como ressalvam os autores:

"é importante salientar que existe um alto grau de complexidade na relação saúde e ambiente. Assim, todo o modelo representa uma tentativa de explicação desta relação, um esforço de aproximação, e como tal traz em si limitações.[...] face as variáveis envolvidas e a relação entre as mesmas, faz-se ainda necessário, desenvolver estudos que busquem identificar os indicadores mais relevantes de forma a simplificar um futuro sistema de indicadores, baratear seus custos e facilitar seu uso" Borja e Moraes (2002, p. 21)

Ainda que esta Tese demande a construção de um modelo semelhante ao apresentado na Figura 2.17, vale resaltar que o objetivo é a investigação de potenciais dados provenientes 
de SR que possam ser usados para o cálculo de indicadores urbanos. Nesta Tese, esses indicadores focam o risco de transmissão da leptospirose, mas como Borja e Moraes comentam, há uma demanda por fontes alternativas de dados para a construção de indicadores mais relevantes que torne o sistema mais barato (comparando principalmente com os indicadores baseados em levantamento de campo) e prático. A hipótese levantada é que SR aplicado a áreas urbanas pode contribuir nesse sentido.

\subsection{Sensoriamento Remoto}

\subsubsection{Noções Gerais}

O sensoriamento remoto (SR) trata do estudo de informação sobre objetos, áreas e fenômenos, obtida através de equipamentos que permitem a observação à distância dos mesmos (LILLESAND et al., 2008). É uma área do conhecimento que tem se estabelecido e crescido com a utilização de modernas e variadas técnicas, sensores e equipamentos para processamento e transmissão de dados com o objetivo de estudar o ambiente terrestre (NOVO, 2008).

Ainda que o termo sensoriamento remoto possa tratar de qualquer processo de observação à distancia de objetos, áreas e fenômenos, o termo quando utilizado para definir um campo da ciência, usualmente restringe-se a observações do ambiente terrestre, como define Novo (2008), Richards e Jia (2006) e Mesev e Walrath (2007). Estes últimos defendem ainda a importância da integração da área de SR e de Sistema de Informação Geográfica (SIG), justamente porque as duas áreas tratam de tecnologias que têm foco exclusivamente em dados geográficos.

A disciplina de processamento de imagens também apresenta grande interface com a de $\mathrm{SR}$, em especial no que tange às atividades de classificação da superfície e identificação de alvos. Essa área da ciência não se restringe, no entanto, a dados com referência geográfica, trata da análise e interpretação de imagens com o suporte de computadores (LILLESAND et al., 2008). Por isso, é comum encontrar estudos e manuais de SR que usam como exemplo imagens utilizadas no campo da medicina, onde o processamento de imagens também tem grande contribuição.

A Figura 2.18 apresenta os principais processos encontrados em atividades que envolvem o SR. 
No campo do SR, existe atualmente disponível no mercado uma grande variedade de sistemas sensores criados e utilizados para os mais diversos fins. De uma forma geral, as principais características desses sistemas que implicam na maior diferenciação entre seus produtos, são aquelas relativas à plataforma, modo e meio de gravação e à sua resolução espectral, espacial, radiométrica e temporal.

De acordo com a taxonomia dos sistemas de sensores apresentada por Ehlers et al. (2002) o presente estudo foi desenvolvido com os sensores que se enquadram nas características indicadas sobre o fundo branco no Quadro 2.3.

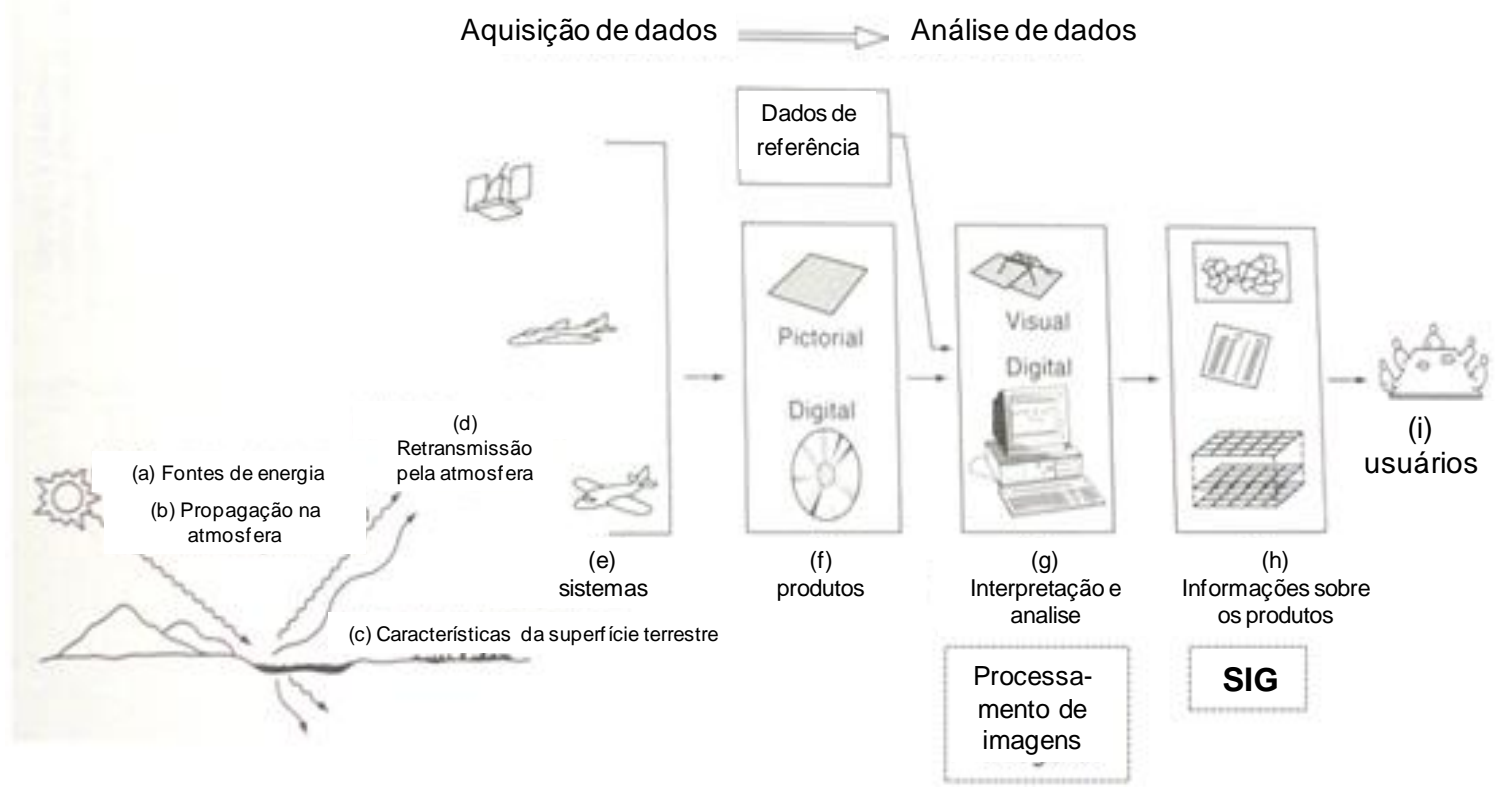

Figura 2.18. Exemplo de sensoriamento remoto do ambiente terrestre através de sensores de radiação eletromagnética. Fonte: Adaptada de Lillesand et al. (2008, p. 3)

Quadro 2.3. Taxonomia dos sistemas de sensoriamento remoto.

\begin{tabular}{|c|c|c|c|c|c|}
\hline Plataforma & \multicolumn{2}{|c|}{ Satélite / Shuttle } & \multicolumn{2}{|c|}{ Avião / Balão } & tacionário \\
\hline Modo de coleta & \multicolumn{3}{|c|}{$\begin{array}{l}\text { Passivo (visivel, infravermelho proximo, } \\
\text { infravermelho termal, microondas termal) }\end{array}$} & \multicolumn{2}{|l|}{ Ativo (laser, radar) } \\
\hline Meio de gravação & \multicolumn{3}{|c|}{ Analógico (video,câmara) } & $\begin{array}{l}\text { Digital (Whiskbroom, Line } \\
\text { array, 2D CCD) }\end{array}$ & \\
\hline \multirow{2}{*}{$\begin{array}{c}\text { Resolução } \\
\text { espectral }\end{array} \frac{\text { Cobertura }}{\text { Bandas }}$} & Ultra violeta & Visível & Infra vermelho refletido & Infravermelho termal & Microondas \\
\hline & $\begin{array}{c}\text { Pancromático } \\
1 \text { banda }\end{array}$ & & $\begin{array}{l}\text { Multiespectral } \\
2-20 \text { bandas }\end{array}$ & $\begin{array}{c}\text { hiperspectral } \\
20 \text { a } 250 \text { bandas }\end{array}$ & $\begin{array}{l}\text { ultra espectral } \\
>250 \text { bandas }\end{array}$ \\
\hline $\begin{array}{c}\text { Resolução } \\
\text { radiométrica }\end{array}$ & (<6 bit) & & (6-8 bit) & $(8-12$ bit $)$ & (> 12 bit) \\
\hline $\begin{array}{l}\text { Resolução espacial } \\
\text { no solo }\end{array}$ & $>250 \mathrm{~m}$ & $50-250 r$ & $10-50 m$ & $4-10 m$ & $<1 \mathrm{~m}$ \\
\hline
\end{tabular}

Fonte: Adaptado de Ehlers et al (2002). Nota: Não há relação direta entre linhas, ex.: há sistemas sensores cuja a plataforma é um satélite e a resolução espacial no solo é inferior a $1 \mathrm{~m}$. Sobre o fundo branco estão as características dos sensores pesquisados nesta Tese. 
Em SR, a plataforma de gravação varia de acordo com sua altura em relação ao alvo, vão de torres ou outros sistemas fixos, muito próximos ao solo, passando por alturas de aeronaves e balões, até plataformas semi-orbitais (ônibus espaciais, shuttle) e orbitais (satélites).

O modo de gravação ativo ou passivo está relacionado à fonte emissora da radiação eletromagnética (REM). Nos sensores passivos, a REM é emitida pelo sol ou pelo próprio objeto observado, luzes das cidades, por exemplo. Em sensores ativos a REM é emitida pelo próprio sistema sensor, a exemplo daqueles que emitem e registram o retorno das ondas de rádio, laser e som, como o RADAR ${ }^{8}, \operatorname{LIDAR}^{9}$ e $\operatorname{SONAR}^{10}$, respectivamente. Ainda que sensores ativos possam apresentar alta resolução espacial, a tecnologia e método de análise do produto desses sensores são bastante distintos dos demais, exigindo um estudo específico.

O meio de gravação analógico é aquele que registra a imagem em meio físico, em uma película, ou filme, sensível à luz (Figura 2.19). Em SR são utilizadas películas com um formato maior que o formato conhecido das câmeras fotográficas de uso pessoal, mas que, à semelhança destas, registram os espectros visíveis da radiação eletromagnética refletida pelos objetos observados. Películas sensíveis a outras faixas do espectro, como a radiação infravermelha, também podem ser utilizadas. Normalmente a imagem registrada na película necessita passar pelo processo químico de revelação, para ser transferida para o papel.

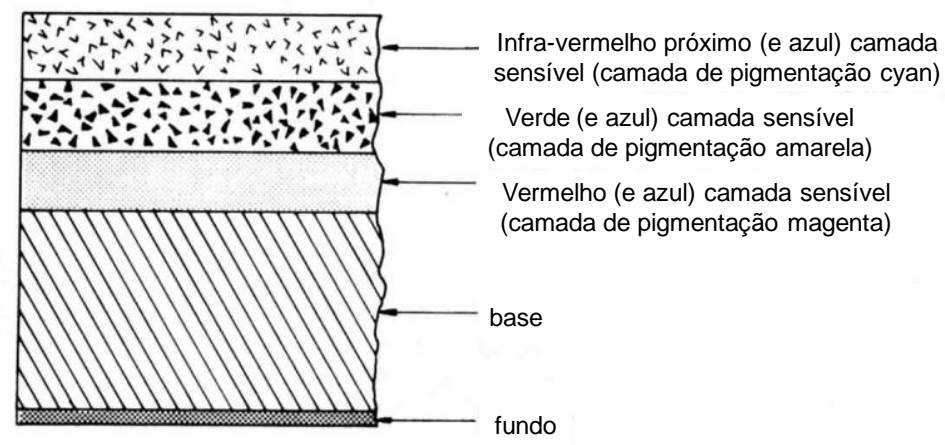

Figura 2.19. Estrutura da película fotográfica colorida. Sessão transversal genérica (LILLESAND et al., 2008, p. 89)

O meio de gravação digital utiliza sensores digitais, acoplados às plataformas de gravação, que registra a imagem diretamente em um sistema eletrônico. A imagem é armazenada em

\footnotetext{
${ }^{8}$ Radio Detection and Ranging

${ }^{9}$ Light Detection and Ranging

${ }^{10}$ Sound Navigation and Ranging
} 
códigos que compõem uma matriz, na qual linhas e colunas indicam a posição da célula (pixel) e o valor da REM.

O processo de transferência da imagem analógica para o meio digital é realizado pelo equipamento conhecido com escaner. Este aparelho emite uma luz branca que é refletida pela fotografia gravada na película ou papel e é captada por sensores calibrados nos canais azul, verde e vermelho (no caso de fotografias coloridas). O registro digital é realizado armazenando as informações capitadas por esses sensores em uma matriz, na qual linhas e colunas indicam a posição da célula e níveis de cinza nos espectros do azul, verde ou vermelho refletido pela imagem impressa. Dessa forma, a fotografia digitalizada pode ser processada à semelhança de uma imagem composta por três bandas, sendo que nesse caso deve-se estar atento para a representatividade dos níveis de cinza em cada banda. $\mathrm{Na}$ fotografia digitalizada este valor é uma aproximação grosseira do valor da REM refletida pelo objeto, uma vez que depende de processos físicos e químicos para captura e revelação da imagem, além da calibração do escaner de imagens analógicas, diferentemente das imagens digitais que basicamente dependem da calibração dos sensores.

Análises urbanas vêm sendo realizadas com uso de imagens analógicas, a exemplo dos estudos de Phinn et al. (2002), Yuan (2008), Kampouraki et al. (2008) e Nichol e Lee (2005), principalmente devido à sua disponibilidade em órgãos públicos. Nichol e Lee (2005), por exemplo, utilizaram em seus estudos de monitoramento de vegetação urbana, um filme KODAK IR444, sensível também ao espectro infra vermelho. A fotografia após revelada, foi escaneada, a uma resolução no solo de 1:8000, em três bandas de 9 bit, correspondentes às faixas verde, vermelho e infra vermelho da REM.

Durante muito tempo, em especial a partir da primeira Guerra Mundial, as fotografias aéreas analógicas pancromáticas foram utilizadas para análise do território e identificação de alvos (CAMPBELL, 2008). É possível afirmar que, no Brasil, a maior parte dos mapeamentos urbanos existentes, foram ou ainda são realizados em meio de gravação analógica, dada a sua qualidade geométrica e resolução espacial, requisitos importantes para a produção de cartografia urbana na escala de 1:2.000, ou maior. Em 2006, por exemplo, foi contratado para o município de Salvador o levantamento aerofotogramétrico com a utilização de equipamentos de gravação analógica. No período, tal levantamento já poderia ter sido realizado com equipamentos digitais. Um dos principais argumentos usados para a não utilização de imagens digitais se apóia na necessidade de requalificação técnica e mudança de metodologia demandada para a adoção dessa nova tecnologia. Além disso, até a década passada a obtenção de imagens de alta resolução de áreas urbanas só era possível 
com fotografias analógicas, sendo este o único dado de imagem disponível para estudos de eventos passados nessa escala.

Segundo Lillesand et al. (2008) os sistemas analógicos têm como vantagem serem relativamente simples, os equipamentos têm custo mais baixo e permitem um alto grau de detalhamento espacial e de integridade geométrica. Já os sensores eletrônicos têm como principais vantagens a maior capacidade de registro da faixa espectral, de calibração e a possibilidade de transmissão eletrônica dos dados. Por outro lado, Nichol e Lee (2005) defendem que, ainda que os sensores sejam mais simples e de menor custo, o tempo, e consequentemente o custo, despendido nos trabalhos de digitalização, georreferenciamento e mosaicagem das fotografias analógicas fazem com que estas sejam menos indicadas para as análises do meio urbano, do que as imagens satélite de alta resolução espacial (Quadro 2.5).

A resolução radiométrica de um sensor corresponde à capacidade de identificação das diferenças de intensidade da REM. Na matriz citada anteriormente a resolução radiométrica corresponde à variação do valor da célula, isto é, a intensidade da REM em um sensor com resolução de 8bit será registrada em valores que vão de 1 a 256, em um sensor de 11 bit os valores vão de 1 a 2058, representados nas imagens de cada banda em níveis de cinza.

É importante saber que o olho humano é capaz de separar cerca de 64 níveis de cinza (6 bit) enquanto a capacidade dos sensores é de 8bit ou mais (JACOBSEN, 2005). Essa diferença pode acrescentar dados importantes na distinção de alvos com respostas espectrais imperceptíveis ao olho humano.

A cobertura espectral de um sistema sensor passivo diz respeito às faixas do espectro eletromagnético que ele é capaz de captar (Figura 2.20 e Figura 2. 21).

Segundo Novo (2008), a resolução espectral está relacionada ao número de sensores de um sistema sensor e à capacidade de registrar intervalos de bandas espectrais mais estreitos ou largos. Cada sensor é capaz de registrar uma faixa determinada da REM, cada faixa registrada é chamada de banda. Quanto maior o número de bandas disponibilizadas, quanto mais estreitas as bandas, maior a capacidade de distinção dos alvos. 


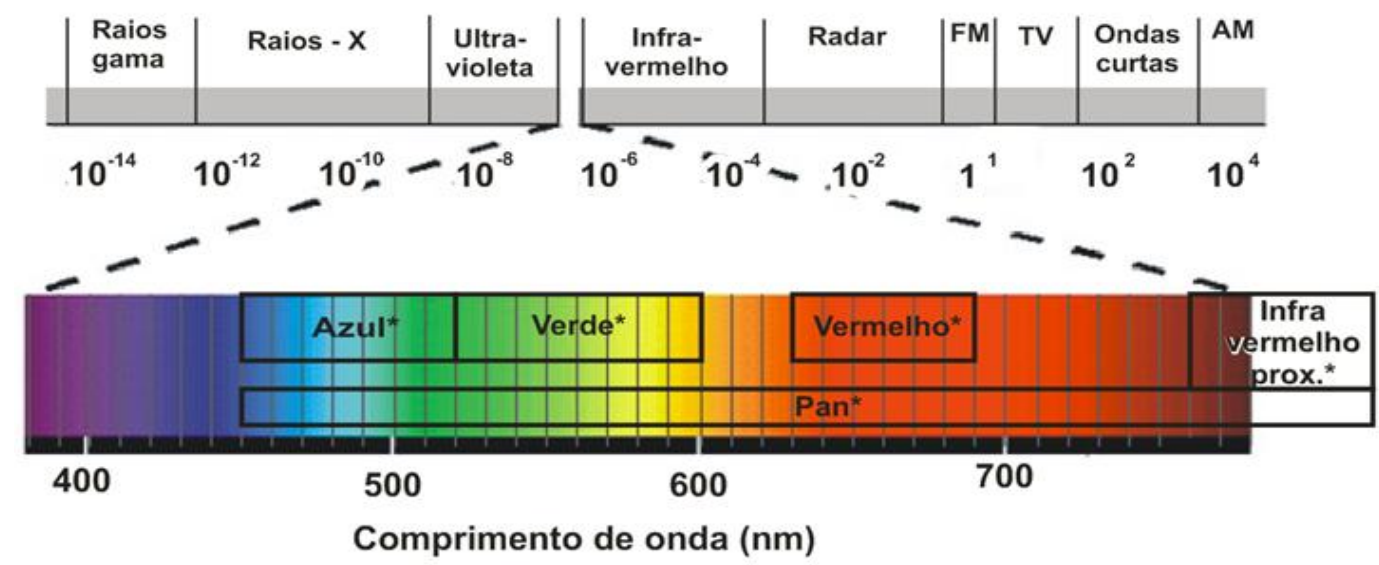

Figura 2.20. Espectro eletromagnético. $\left({ }^{*}\right)$ Localização no comprimento de onda dos canais captados pelo sistema sensor QuickBird 2: 450-900 (pan) 450-520 (azul) 520-600 (verde) 630-690 (vermelho) 760-900 (infravermelho próximo). Fonte: adaptada de Instituto Nacional de Pesquisas Espaciais (2009).

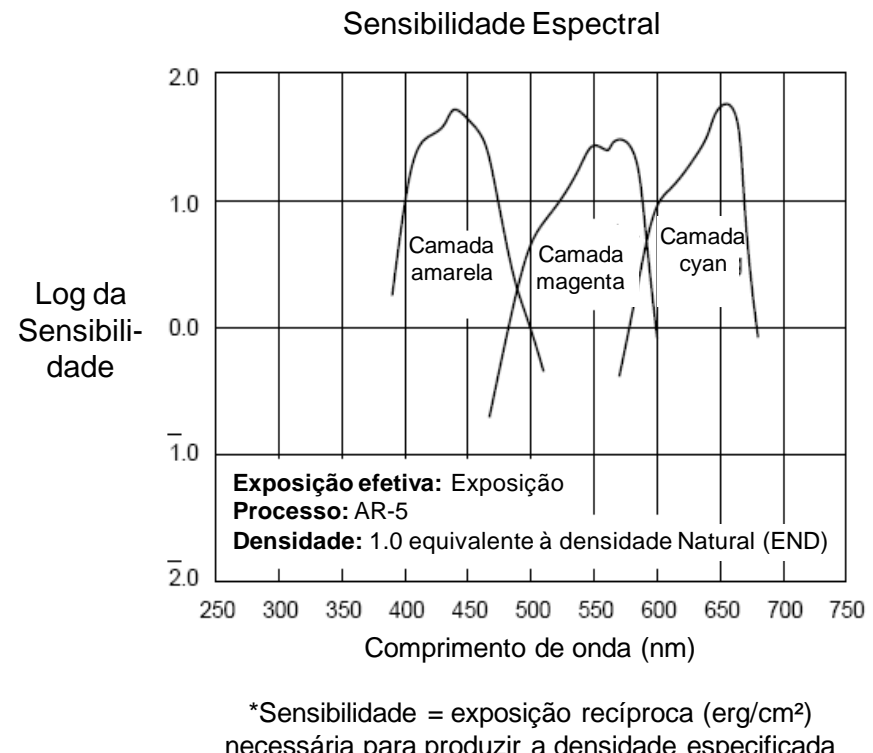

Figura 2.21. Sensibilidade espectral das três camadas de tingimento (EASTMAN KODAK COMPANY, 2009, p.6)

A resolução temporal é a taxa de revisita no sistema, isto é, o tempo que a plataforma onde se encontram os sensores leva para passar sobre a mesma área de imageamento duas vezes. É importante observar que a nova geração de satélites tem uma taxa de revisita bem mais frequente. Segundo Al-Khudhairy et al. (2005) este incremento significativo da resolução temporal, aliado ao incremento também significativo na resolução espacial, abre uma nova era nas operações de ajuda humanitária. A capacidade de revisita inferior a uma semana permite o uso de imagens satélite em planos de ação emergenciais, apoiando o rápido dimensionamento e resposta a grandes desastres, como os terremotos (KAYA, 2005) e tsunamis (BELWARD et al., 2008) e guerras (AL-KHUDHAIRY et al., 2005). 
Atualmente é possível contar com sistemas sensores formados por uma constelação de satélites, a exemplo do Disaster Monitoring Constalation (DMC). O DMC consiste em cinco satélites equipados com o mesmo tipo de sensor, cujas características assemelham-se às características do Landsat ETM+, sendo a taxa de revisita de apenas 5 dias.

A resolução espacial de um sensor é atribuída à sua capacidade de distinguir objetos no solo e varia em função do campo de visada do sensor. Em geral, admite-se que cada célula da imagem registrada represente essa medida. Assim, o pixel, visto na imagem impressa ou no monitor, corresponde à menor área no solo medida pelo sensor ${ }^{11}$. No caso do LANDSAT 7 ETM, que registra pixels de $30 \mathrm{~m}$ por $30 \mathrm{~m}$, assume-se a resolução espacial de $30 \mathrm{~m}$, o que significa dizer que é possível discriminar objetos com dimensões e afastamento superior ou igual a $30 \mathrm{~m}$.

Em levantamento realizado no segundo semestre de 2008 no mercado de SR já encontravam-se disponíveis no mercado internacional mais de meia dúzia de sensores com resolução espacial métrica, isto é, sensores capazes de distinguir alvos com menos de $10 \mathrm{~m}$ de afastamento entre si, como denomina Blaschke et al. (2005). Estes sensores e suas características são apresentados no Quadro 2.4, juntamente com as características do sistema sensor LANDSAT, um dos primeiros sistemas orbitais capazes de produzir imagens utilizadas em estudos urbanos; do CBERS, sistema sino brasileiro de distribuição de imagens gratuita; do WorldView-2, sistema de altíssima resolução espacial de maior resolução espectral e um exemplo de sensor digital aerotransportado, o HRSC-A.

Ainda que bastante difundida, a disponibilização no mercado das imagens de alta resolução espacial obtidas por sensores orbitais pode ser considerada recente, a primeira imagem satélite (LANDSAT 1) foi gerada em 1972, enquanto a primeira imagem satélite de alta resolução espacial só foi produzida com o lançamento em 1999 do sistema sensor IKONOS. Associado a isso, essas novas imagens apresentam elementos diferentes daqueles por décadas estudados por pesquisadores, uma vez que suas principais características são a alta resolução espacial, alta resolução radiométrica e baixa resolução espectral.

11 Desde que haja correspondência de 1:1 entre o solo e o monitor, ou seja, sem a aplicação de recusos de ampliação (zoom) ou reamostragem. 
Quadro 2.4. Principais sistemas sensores multiespectrais para imageamento de áreas urbanas em operação em 2008 e sistemas de referência (1)

\begin{tabular}{|c|c|c|c|c|c|c|c|}
\hline Sistema & IKONOS II & $\begin{array}{l}\text { QUICK- } \\
\text { BIRD2 }\end{array}$ & SPOT 5 & $\begin{array}{c}\text { Orbview- } \\
3\end{array}$ & $\begin{array}{c}\text { IRS P6 } \\
\text { (Resour-cesat } \\
\text { 1) }\end{array}$ & $\begin{array}{l}\text { Formosat-2 } \\
\text { (Rocsat-2) }\end{array}$ & GeoEye-1 \\
\hline Plataforma & Satélite & Satélite & Satélite & Satélite & Satélite & Satélite & Satélite \\
\hline Sensores & $\begin{array}{l}\text { Pancrom. } \\
\text { Multiesp. }\end{array}$ & $\begin{array}{l}\text { QUICK- } \\
\text { BIRD }\end{array}$ & HRG & $\begin{array}{l}\text { Pancrom. } \\
\text { Multiesp. }\end{array}$ & $\begin{array}{c}\text { LISS-4 LISS-3 } \\
\text { AWIFS }\end{array}$ & $\begin{array}{l}\text { Pancrom. } \\
\text { Multiesp. }\end{array}$ & $\begin{array}{l}\text { Pancrom. } \\
\text { Multiesp. }\end{array}$ \\
\hline Lançamento & $09 / 1999$ & $10 / 2001$ & $05 / 2002$ & $06 / 2003$ & $10 / 2003$ & $05 / 2004$ & $09 / 2008$ \\
\hline $\begin{array}{c}\text { Empresal } \\
\text { Instituição e } \\
\text { País }\end{array}$ & $\begin{array}{l}\text { GeoEyel } \\
\text { Space } \\
\text { Imaging } \\
\text { (EUA) }\end{array}$ & $\begin{array}{l}\text { Digital- } \\
\text { Globe } \\
\text { (EUA) }\end{array}$ & $\begin{array}{c}\text { CNES } \\
\text { (França) }\end{array}$ & $\begin{array}{c}\text { GeoEyel } \\
\text { Orbima- } \\
\text { gem } \\
\text { (EUA) }\end{array}$ & $\begin{array}{c}\text { Ressourcesat } \\
\text { (Îndia) }\end{array}$ & $\begin{array}{l}\text { NSPO } \\
\text { (Taiwan) }\end{array}$ & $\begin{array}{l}\text { GeoEye } \\
\text { (USA) }\end{array}$ \\
\hline $\begin{array}{c}\text { Resolução } \\
\text { radiométrica }\end{array}$ & 11 bit & 11bit & 8 bit & $11 \mathrm{bit}$ & 7 bit & 8 bit & 11bit \\
\hline $\begin{array}{c}\text { Resolução } \\
\text { temporal }\end{array}$ & 3 a 5 dias & 1 a 4 dias & 26 dias & 3 dias & 5 a 24 dias & $1 \mathrm{dia}$ & $\begin{array}{c}2,1 \text { a } 8,3 \\
\text { dias }\end{array}$ \\
\hline \multirow[b]{2}{*}{$\begin{array}{c}\text { Resolução } \\
\text { espacial }\end{array}$} & Pan $1 \mathrm{~m}$ & Pan $0,61 \mathrm{~m}$ & $\begin{array}{c}\text { Pan } \\
2,5 / 5 \mathrm{~m}\end{array}$ & Pan $1 \mathrm{~m}$ & Pan $5,8 \mathrm{~m}$ & Pan $2 m$ & $\begin{array}{c}\text { Pan } \\
0.41 \mathrm{~m}\end{array}$ \\
\hline & MS $4 \mathrm{~m}$ & MS 2,4m & MS $10 \mathrm{~m}$ & MS $4 \mathrm{~m}$ & $\begin{array}{c}\text { vis. e ivp: } \\
5,8 \mathrm{~m}, 23,5 \mathrm{~m} \text { e } \\
56 \mathrm{~m} ; \mathrm{sw} \text { : } \\
23,5 \mathrm{~m} \text { e } 56 \mathrm{~m}\end{array}$ & MS $8 \mathrm{~m}$ & MS $1,65 \mathrm{~m}$ \\
\hline $\begin{array}{l}\text { Escala máx. } \\
\text { sugerida (2) }\end{array}$ & $1 / 10.000$ & $1 / 6.000$ & $1 / 25.000$ & $1 / 10.000$ & $1 / 60.000$ & $1 / 20.000$ & $1 / 4.000$ \\
\hline $\begin{array}{c}\text { Resolução } \\
\text { espectral (3) }\end{array}$ & $\begin{array}{l}\text { Pan, a., v., } \\
\text { vm., ivp. }\end{array}$ & $\begin{array}{l}\text { Pan, a., v., } \\
\text { vm., ivp. }\end{array}$ & $\begin{array}{c}\text { Pan, v., } \\
\text { vm., ivp., } \\
\text { sw. }\end{array}$ & $\begin{array}{l}\text { Pan, a., v., } \\
\text { vm., ivp. }\end{array}$ & $\begin{array}{l}\text { Pan, v., vm., } \\
\text { ivp. }\end{array}$ & $\begin{array}{l}\text { Pan, a., v., } \\
\text { vm., ivp }\end{array}$ & $\begin{array}{c}\text { Pan, a, v, } \\
\text { vm, ivp }\end{array}$ \\
\hline $\begin{array}{l}\text { Passagem } \\
\text { Equador } \\
\text { Óbita }\end{array}$ & $\begin{array}{c}10: 30 \\
\text { descend. }\end{array}$ & $\begin{array}{c}10: 30 \\
\text { descend. }\end{array}$ & $\begin{array}{c}10: 30 \\
\text { descend. }\end{array}$ & $\begin{array}{c}10: 30 \\
\text { descend. }\end{array}$ & $\begin{array}{c}10: 30 \\
\text { ascend. }\end{array}$ & $\begin{array}{c}\text { 9:30 } \\
\text { descend. }\end{array}$ & $\begin{array}{c}10: 30 \\
\text { descend. }\end{array}$ \\
\hline $\begin{array}{c}\text { Valor } p \mathrm{Km}^{2} \\
\text { (4) }\end{array}$ & $\begin{array}{c}\text { U } \$ 17,6 \text { a } \\
55,8\end{array}$ & $\begin{array}{l}\text { U\$ } 20,4 \text { a } \\
\text { valor nao } \\
\text { informado }\end{array}$ & $\begin{array}{c}\text { U\$ } 1,8 \text { a } \\
8,8\end{array}$ & US 14 & US0,7 a 6,6 & $\begin{array}{c}\text { não } \\
\text { informado }\end{array}$ & $\begin{array}{c}\text { não } \\
\text { definido }\end{array}$ \\
\hline
\end{tabular}

\begin{tabular}{|c|c|c|c|}
\hline CBERS 2B & $\begin{array}{c}\text { WordView } \\
2\end{array}$ & LANDSAT 7 & HRSC-A \\
\hline Satélite & Satélite & Satélite & Aeronave \\
\hline $\begin{array}{c}\text { CCD HRC } \\
\text { WFI }\end{array}$ & $\begin{array}{l}\text { Pancrom. } \\
\text { Multiesp. }\end{array}$ & ETM & HRSC-A \\
\hline $09 / 2007$ & 2009 & $04 / 1999$ & $2000(5)$ \\
\hline $\begin{array}{c}\text { CAST e INPE } \\
\text { (China e } \\
\text { Brasil) }\end{array}$ & $\begin{array}{c}\text { Digital- } \\
\text { Globe (EUA) }\end{array}$ & NASA (EUA) & $\begin{array}{c}\text { DRL } \\
\text { (Alema- } \\
\text { nha) }\end{array}$ \\
\hline 8 bit & 11bit & 8 bit & 8 bit \\
\hline 26 dias & $\begin{array}{c}1,1 \text { a } 3,7 \\
\text { dias }\end{array}$ & 16 dias & $\begin{array}{l}\text { Não se } \\
\text { aplica }\end{array}$ \\
\hline Pan $2,5 \mathrm{~m}$ & Pan $0,46 \mathrm{~m}$ & Pan $15 \mathrm{~m}$ & \multirow{2}{*}{$\begin{array}{c}0,2 \mathrm{~m} \\
\text { (altura de } \\
\text { vôo } 4500 \mathrm{~m}\end{array}$} \\
\hline MS $20 \mathrm{~m}$ & MS $1,8 \mathrm{~m}$ & $\begin{array}{c}\text { MS } 30 \mathrm{~m} \text {, Ivt } \\
60 \mathrm{~m}\end{array}$ & \\
\hline $1 / 25.000$ & $1 / 4.500$ & $1 / 150.000$ & $1 / 2.000$ \\
\hline $\begin{array}{c}\text { Pan, a, v, vm, } \\
\text { ivp }\end{array}$ & $\begin{array}{l}\text { pan, ca, a, v, } \\
\text { am, vm, } \\
\text { vm2, ivp1, } \\
\text { ivp2 }\end{array}$ & $\begin{array}{l}\text { Pan, a, v, } \\
\text { vm, ivp, } \\
\text { swir, ivt, ivm }\end{array}$ & $\begin{array}{l}\text { Pan, a., v., } \\
\text { vm., ivp. }\end{array}$ \\
\hline $\begin{array}{c}10: 30 \\
\text { descend. }\end{array}$ & $\begin{array}{c}10: 30 \\
\text { descend. }\end{array}$ & $\begin{array}{c}10: 00-10: 15 \\
\text { descend. }\end{array}$ & $\begin{array}{c}\text { Não se } \\
\text { aplica }\end{array}$ \\
\hline gratuita & não definido & gratuita & $\begin{array}{c}\text { US } 390 \text { a } \\
660\end{array}$ \\
\hline
\end{tabular}

Fonte de dados: Ehlers (2005), Brito e Quintanilha (2006), www.spot.com, www.geoeye.com, www.engesat.com.br, www.intersat.com.br, www.nspo.org.tw, www.sat.cnpm.embrapa.br/ index.html, www.digitalglobe.com, www.engemap.com.br, www.fototerra.com.br.

Notas: (1) Os sistemas orbitais EROS - A1 (Israel), TES (Índia), MOMS-2P (Alemanha), WorldView-1(EUA) e Kompsat-1 (Coréia do Sul) não foram apresentados por possuírem apenas o modo pancromático ou por serem sensores que apresentam resolução inferior a $10 \mathrm{~m}$ apenas nesse modo. O WorldView-2 é apresentado por ter lançamento previsto para o ano de 2009, o Landsat 7 é apresentado por ser um dos satélites mais utilizados, o CBERS por ser um satélite sino-brasileiro de distribuição gratuita e o sistema sensor HRSC é apresentado com o objetivo de exemplificar características de sistemas aerotransportados; . (2) Escala sugerida por Richards e Jia (2006, p. 21); (3) Pan = Pancromático, MS = multi-espectral, a. = azul, v. = verde, vm. = vermelho, ivp. = infravermelho próximo, $s w=$ infra-vermelho ondas curtas, $c a=$ ondas curtas do azul, vm2 $=$ vermelho edge, ivp1 = infravermelho próximo 1, ivp2 = infravermelho próximo 2 . (4) Variação de preço comercializado no Brasil em março de 2006 de acordo com nível de pré-processamento do produto. Valores das imagens do GeoEye-1 e Worldview-2 não haviam sido definidos ou divulgados até fevereiro de 2009; (5) Sistema HRSC-A só começou a operar no Brasil em 2004.

Desde a disponibilização das primeiras imagens de satélite, a resolução espectral foi o maior instrumento de suporte na classificação e identificação de alvos. Inúmeras técnicas e algoritmos foram desenvolvidos durante esses anos com esse propósito. Apesar da baixa resolução espectral da maior parte dos sensores orbitais de alta resolução espacial, suas imagens dispõem de uma resolução radiométrica bastante superior (11bit). No entanto, este recurso ainda é pouco explorado por se tratar de uma tecnologia recente que demanda o uso de computadores com alta capacidade de processamento e programas que trabalhem com imagens com mais de 8bit. 
Os sensores multiespectrais aerotransportados, que oferecem resolução espacial ainda mais alta que os sensores orbitais, também foram introduzidos no mercado no final dos anos 90. Em relação às imagens satélite, seu uso para fins de planejamento urbano é menos difundido. Isso se deve, entre outros fatores, ao pouco conhecimento técnico sobre seus recursos quando comparados às fotografias aéreas métricas, seus concorrentes mais próximos e cujas metodologias de trabalho já se encontram mais consolidadas.

Um fator pouco observado que interfere diretamente na qualidade do imageamento é a órbita dos satélites, que determina o horário de passagem pelo Brasil. Entre os sensores de alta resolução espacial, apenas os sistemas IRS P6 e Kompsat 1 têm órbita ascendente, isto é, passam pelo hemisfério sul no começo da manhã, horário em que há melhores condições de observação, devido à luminosidade e menor incidência de nuvens. Na maior parte dos satélites, as áreas tropicais do hemisfério sul, principalmente as áreas litorâneas e florestais, são imageadas no horário de maior concentração de nuvens devido à evapotranspiração, após às 10:30 da manhã, com exceção do Sistema sensor Formosat-2, que passa pelo equador às 9:30 da manhã, vide Quadro 2.4. Segundo a empresa distribuidora das imagens Formosat-2: "este horário ligeiramente mais cedo, combinado a revisitas diárias, aumenta as chances de aquisição de imagens úteis em regiões equatoriais onde há formação de nuvens convectivas ao longo de todo o período matutino" (SPOTIMAGE, 2009).

Quanto ao preço das imagens de alta resolução espacial, observa-se que têm relação direta com a capacidade de discriminação de alvos no solo, ou seja, quanto maior resolução espacial maior é o preço por $\mathrm{km}^{2}$. O valor das imagens satélite de alta resolução é alto se comparado às imagens de média e baixa resolução espacial e pode ser considerado baixo, a depender do produto adquirido, se comparado aos levantamentos aerofotogramétricos programados.

Para Nichol e Lee (2005) o custo baixo (e decrescente) de imagem satélite de alta resolução, como as do satélite IKONOS, e as do QuickBird, pode motivar departamentos de planejamento, inclusive aqueles com acesso gratuito a fotografias aéreas providas pelo governo, a considerar uma mudança de tecnologia devido à economia de tempo significativa que pode ser obtida com uso de imagens satélite de resolução muito alta, como apresentado no Quadro 2.5. 
Quadro 2.5. Custo(U\$) de produtos e mão de obra utilizada para um projeto de mapeamento de biomassa em uma área de $50 \mathrm{~km}^{2}$, Hong Kong.

\begin{tabular}{|c|c|c|}
\hline Item & 270 fotografias aereas infravermelhas & 1 imagem IKONOS XS \\
\hline Aquisição de Imagens & 11538 & 1000 \\
\hline $\begin{array}{l}\text { Digitalização, georeferenciamento e } \\
\text { mosaicagem de aerofotografia }\end{array}$ & 11600 (3 meses de salários qualificados) & $\begin{array}{l}2000 \text { ( } 2 \text { semanas de salários qualificados } \\
\text { para o georeferenciamento) }\end{array}$ \\
\hline $\begin{array}{l}\text { Processamento de Imagens e produção de } \\
\text { mapas de biomassa }\end{array}$ & 2000 (2 semanas de salários qualificados) & 2000 (2 semanas de salários qualificados) \\
\hline Total & 25138 & 5000 \\
\hline
\end{tabular}

Fonte: Nichol e Lee (2005, p. 916)

De uma forma geral, observa-se que, no âmbito do planejamento urbano brasileiro, imagens de alta resolução espacial têm sido cada vez mais utilizadas pelo setor privado e por profissionais de diferentes áreas. Em uma das maiores empresas brasileiras de distribuição de imagens satélite, Imagem/Intersat, a maior parte dos pedidos em 2005 foram realizados por empresas do ramo de serviços de infra-estrutura (empresas de telefonia, distribuidoras de gás, eletricidade, entre outros), seguidos por órgãos públicos ${ }^{12}$.

Em pesquisa realizada pelo Instituto Nacional de Pesquisas Espaciais (INPE) observam-se as mesmas tendências. No relatório apresentado por Silva e Epiphanio (2008), aproximadamente de um terço da lista de pessoas físicas que adquiriram imagens CBERS e que participaram da pesquisa eram funcionários públicos, enquanto os demais se declararam como estudantes (13,4\%) ou profissionais de outras áreas. Quanto à formação, ao menos 40 diferentes cursos foram listados com mais de 10 usuários de imagem CBERS em cada, do total de 3.406 participantes da pesquisa. Observa-se, entretanto, que a maior parte dos usuários das imagens, 52,3\%, é da área de ciências da terra e ambientais, enquanto $3,7 \%$ são engenheiros civis, $1,6 \%$ administradores e $1 \%$ são arquitetos e urbanistas de formação. Estas estatísticas sugerem que as imagens CBERS ainda são pouco utilizadas para análises urbanas (Figura 2.22).

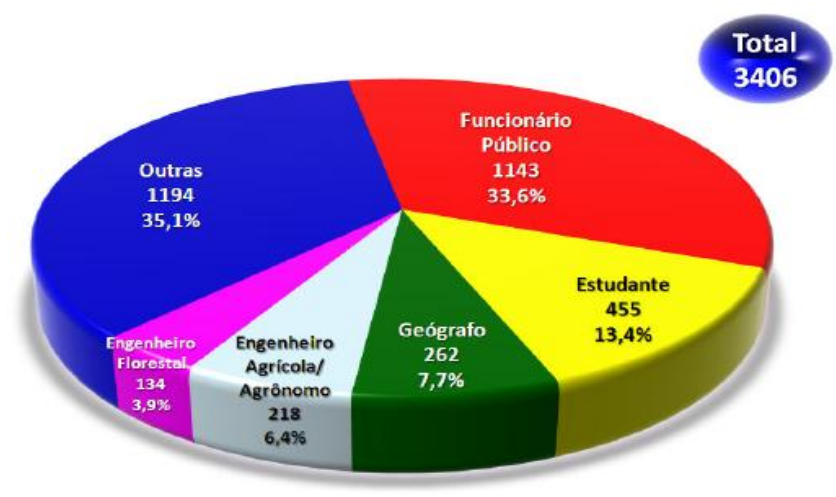

Figura 2.22. Pessoas físicas usuárias de imagens CBERS participantes da pesquisa realizada pelo INPE, segundo profissão. Fonte: Silva e Epiphanio (2008, p. 31).

\footnotetext{
${ }^{12}$ Entrevista concedida pela empresa Imagem em 23 de março de 2006.
} 
Essa suposição pode ser justificada devido às técnicas de classificação digital de imagens para áreas urbanas ainda estarem em fase de consolidação. Mas, observando a prática de órgãos públicos e empresas do setor, é possível afirmar que na maior parte dos casos a informação ainda seja extraída através de técnicas de interpretação visual e nestes casos, fotografias aéreas, ainda que não atualizadas, são a primeira opção desses profissionais.

As técnicas de interpretação visual de imagens, como descreve Lillesand et al. (2008), consistem em recursos utilizados para a identificar na imagens feições de interesse e traduzi-las em informação possível de ser repassada. Essas técnicas são baseadas no conhecimento e treinamento do analista, que pode usar como suporte à identificação das feições: registro fotográficos de visitas a campo, bases cartográficas, além das características desses alvos nas imagens.

Olson (1960) apresentou nove características das imagens fundamentais para o entendimento de feições: forma, tamanho, tonalidade, textura, sombra, posicionamento do alvo em relação ao relevo, associação entre feições, resolução e o padrão ou arranjo espacial entre feições. Essas características, ou variações delas, são ainda hoje consideradas básicas por muitos pesquisadores, a exemplo de Lillesand et al. (2008), Campbel (2008) e Machado (2008).

Por isso, em estudos urbanos em geral, quanto maior é o nível de detalhamento das feições apresentado nas imagens, mais fácil é o trabalho de interpretação visual. Novas técnicas de classificação digital de imagens urbanas se utilizam de algoritmos que tentam reproduzir esses critérios utilizados pelo analista e também tendem a assumir que imagens de maior resolução espacial oferecem melhores resultados.

No entanto, o nível de detalhamento presente em imagens classificadas como de alta e muito alta resolução espacial, mais indicadas para o desenvolvimento de estudos na escala intra-urbana, segundo Ehlers (2005), faz com que tais imagens apresentem uma alta heterogeneidade, exigindo processos digitais de classificação muito mais complexos (NÓBREGA et al., 2006; BRUZZONE e CARLIN, 2006).

\subsubsection{Processos de Classificação Digital de imagens}

A classificação de imagens em SR pode ser resumida como processos de extração de informação através de reconhecimento de padrões espectrais, espaciais ou temporais nas imagens com o principal objetivo de identificar e categorizar objetos ou áreas da superfície terrestre, de acordo com os temas de interesse (INSTITUTO NACIONAL DE PESQUISAS ESPACIAIS, 2008). Inúmeros são os métodos e técnicas de processamento de imagens 
utilizados no campo do sensoriamento remoto. Os principais recursos encontrados na literatura estão esquematicamente apresentados na Figura 2.23 e são, em sua maioria, descritos a seguir.
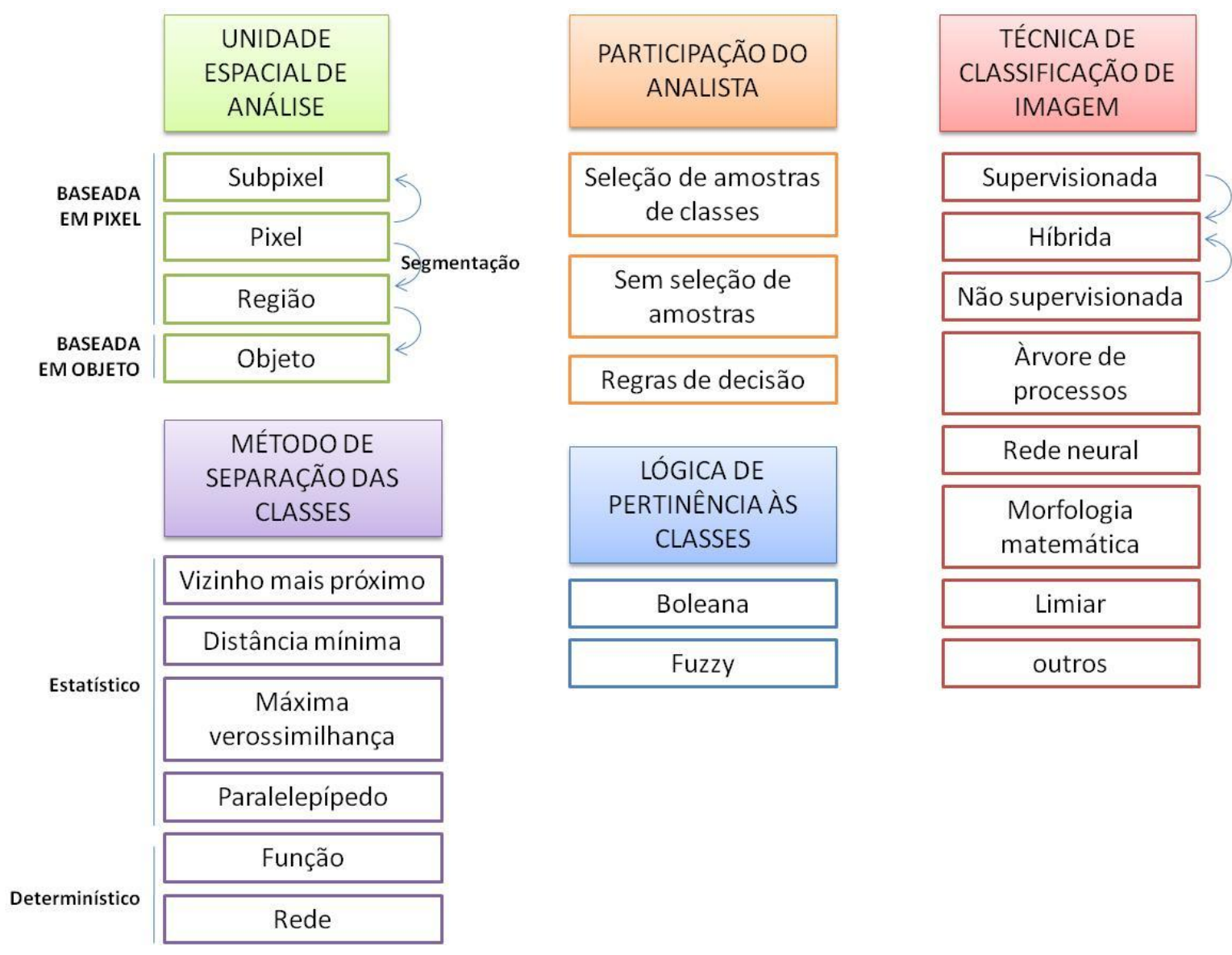

Figura 2.23. Principais recursos metodológicos de classificação digital de imagens utilizados em sensoriamento remoto. Fonte: Brito (2010).

No campo da análise digital de imagens de SR encontra-se na literatura referências a, basicamente, três tipos de abordagem: a baseada em pixel, a baseada em região e a baseada em objeto. No entanto, a definição do que significa cada uma dessas abordagens é muitas vezes nebulosa e divergente.

A definição de que "classificadores "pixel a pixel": utilizam apenas a informação espectral de cada pixel para achar regiões homogêneas" (INSTITUTO NACIONAL DE PESQUISAS ESPACIAIS, 2008) é, entre as três abordagens citadas, a menos controversa.

No entanto, as definições da abordagem por região e por objeto citadas a seguir podem ser facilmente confundidas.

"Classificadores por regiões: utilizam, além de informação espectral de cada "pixel", a informação espacial que envolve a relação com seus vizinhos. Procuram simular o comportamento de um foto-intérprete, reconhecendo áreas homogêneas de 
imagens, baseados nas propriedades espectrais e espaciais de imagens" (INSTITUTO NACIONAL DE PESQUISAS ESPACIAIS, 2008).

Classificadores baseados em objeto, segundo Lillesand et al. (2008), são, em contraste com os classificadores por pixel, aqueles que utilizam padrões espaciais, além dos espectrais, para a classificação de imagens. A abordagem baseada em objeto, para os autores: i) demanda dois passos, segmentação e classificação, ii) assume que a imagem é dividida em "pedaços" relativamente homogêneos, iii) se assemelha à interpretação visual de imagem, pois trabalha em múltiplas escalas simultaneamente, e usa informações de cor, forma, tamanho, textura, padrão, e contexto para agrupar pixels em objetos significativos.

Assim, apesar de serem encontradas referências a três tipos de abordagem, pode-se assumir que existam basicamente duas abordagens para análise de imagens de SR, a abordagem baseada em pixel, também conhecida com pixel a pixel, e a abordagem baseada em objeto, que pode também ser orientada a objeto a depender do grau de envolvimento do objeto na análise, assunto discutido na seção que segue (Seção 2.3.3).

$\mathrm{Na}$ abordagem baseada em pixel, a unidade básica de análise é o pixel, seja ele individualizado ou agrupado em regiões. Nesse tipo de análise, os procedimentos e as informações são extraídas pixel a pixel, sejam elas informações espectrais, de textura etc. e sejam elas apresentadas por pixel ou por região.

A semântica do termo objeto, no contexto da classificação baseada em objeto em SR ainda parece estar em fase de consolidação, assim como outros termos da área, visto o recente surgimento e difusão desse campo científico. Castilla e Hay (2008) alertam que, apesar dos muitos métodos já desenvolvidos e do grande número de experiências de sucesso, já publicadas, pouco se tem discutido sobre a base conceitual da classificação baseada em objeto.

Para Castilla e Hay (2008), a base das análises de imagem baseada em objeto são os image-objects significativos, sendo uma image-object uma região discreta de uma imagem digital que é internamente coerente e diferente de seu entorno. Se para uma região ser considerada image-object basta possuir essas três qualidades, os autores admitem que image-objects podem ser segmentos derivados de um algoritmo de segmentação de sucesso. O julgamento do sucesso do algoritmo, isto é, a baixa ocorrência de supersegmentação ou de sub-segmentação, e portanto da produção de image-objects, é atribuída ao analista, que pode basear sua decisão em critérios estatísticos ou visuais. 
Assim, image-objects significativos podem ser considerados a melhor representação possível de geo-objetos ${ }^{13}$.

No contexto de um SIG baseado nos princípios da análise baseada em objeto, Wachowicz (1999) conceitua objeto da seguinte forma:

"Um único objeto é simplesmente a instância de uma classe. Um identificador único é sempre dado a cada objeto, independentemente do valor de suas propriedades. $A$ criação de um novo objeto, a partir de um objeto existente e a mudança no estado de um objeto existente caracterizam a natureza dinâmica de objetos que fazem parte de um modelo orientado a objeto" (WACHOWICZ, 1999, p. 36 e 37).

Nesta Tese, o termo objeto é considerado a unidade básica de análise da abordagem baseada em objeto, e sua definição é semelhante à definição de image-objects significativos descrito por Castilla e Hay (2008), desde que inseridos em um sistema organizado en torno do conceito de objetos como descreve Chance et al. (1990) e Wachowicz (1999), conceito mais explorado a seguir (Seção 2.3.3). Assim, de forma simplificada, pode-se dizer que para análise de imagens baseada em objetos, objetos são regiões com significado e com atributos espectrais, espaciais e temporais próprios a si, à classe que dá significado e às superclasses a que pertence (quando essas existirem). Consequentemente, só devem ser considerados objetos aqueles segmentos classificados e inseridos em um modelo de análise baseada em objeto.

Para realizar a classificação baseada em pixel, tomando como região unidade espacial ou para utilização dos classificadores por objetos, é necessário o emprego prévio de processos de segmentação de imagens, com o objetivo de dividir a imagem em segmentos com propriedades comuns. Os processos mais comuns de segmentação, nos quais são produzidas regiões com características espectrais semelhantes, são aqueles baseados em crescimento de regiões e detecção de bordas (ou detecção de bacias).

O processo de crescimento de regiões baseia-se em propriedades de similaridade da imagem, partindo do pixel, que é tratado inicialmente como região. No processo, as regiões adjacentes são agrupadas formando regiões cada vez maiores. A cada passo do algoritmo, a decisão de agrupar, ou não, regiões adjacentes leva em conta algum critério de homogeneidade da nova região que se formaria após o agrupamento. O processo de

\footnotetext{
${ }^{13}$ Trazendo o conceito de geo-objetos para o contexto da OBIA, segundo Castilla e Jay (2008), o geo-objeto é uma região geográfica limitada que pode ser identificada por um período de tempo como a referência de uma entidade geográfica. Por exemplo, a cena vista de uma janela no piso de um balão é uma representação dos objetos reais, como representação ela depende de um "ponto de vista", ou um modelo que atende a um propósito de ver a cena como vegetação arbustiva e rasteira ou reserva natural ou área agrícola, os geo-objetos não mudam, em um definido espaço de tempo, o que muda são os image-objects.
} 
crescimento, ou agrupamento de região, só termina em função do incremento de homogeneidade (CAZES, 2005) ${ }^{14}$.

A segmentação por detecção de bacias é feita sobre uma imagem resultante da extração de bordas, que, por sua vez, considera as intensidades do nível de cinza da imagem original para gerar uma imagem binária obtida por um algoritmo que calcula um limiar para a perseguição de bordas (INSTITUTO NACIONAL DE PESQUISAS ESPACIAIS, 2008). Baseia-se, assim, em propriedades de descontinuidade da imagem. Outros algoritmos de segmentação podem ser aplicados, como a segmentação "tabuleiro de xadrez", a baseada em árvore (como a "quadtree", e a segmentação multi-nível ${ }^{15}$ ).

A segmentação multi-nível pode ser considerada uma variante da classificação por crescimento de regiões (PINHO, 2005), com a diferença de considerar uma segmentação pré-existente para gerar um outro nível de segmentação. No caso de um nível superior, considera como região de partida e regiões a serem agregadas os segmentos do nível imediatamente abaixo. No caso da criação de um nível abaixo de um nível pré-existente, os novos segmentos criados têm como limite de crescimento os segmentos no nível imediatamente acima.

Quanto à participação do analista, pode-se dizer que existem três formas mais frequentes de participação do analista no processo de classificação: selecionando amostras, sem seleção de amostras, isto é, definindo métodos e parâmetros estatísticos de formação de classes e definindo regras de decisão. As duas primeira formas de classificação estão relacionadas principalmente às duas das mais utilizadas técnicas de classificação, consolidadas como técnicas de classificação baseada em pixel: a classificação supervisionada e a não-supervisionada.

A classificação supervisionada é aquela em que conta com a seleção de amostras para cada classe pré-definida e com o estabelecimento, a partir das amostras de um padrão comportamental de cada classe, definindo a classificação dos demais pixels ou regiões. A técnica de classificação não-supervisionada, por outro lado, não requer a seleção de amostras. Nesse caso, é aplicado à imagem algoritmos que reconhecem o agrupamento e a

\footnotetext{
14 No software utilizado nessa pesquisa, o Definiens Developer 7.0, o ponto de parada do processo de crescimento de regiões é determinado por um parâmetro escalar, que representa incrementos de homogeneidade.

${ }^{15}$ Aqui é chamado segmentação multi-nível a segmentação apresentada pelo programa Definiens Developer 7.0 como segmentação multi-resolução. A diferenciação é feita para que sejam evitadas as frequentes confusões com o processo que permite a entrada de imagens com múltiplas resoluções espectrais, espaciais e radiométricas, encontradas no mesmo software, ou mesmo com processos de segmentação de imagens com diferentes resoluções espaciais, como o estudo realizado por Aksoy e Akçay (2005).
} 
separabilidade dos pixels ou regiões no espaço de atributos para determinar classes, que serão posteriormente agrupadas e nomeadas.

Os processos que exigem do analista a definição de regras de decisão são bastante variados. Utilizando conhecimento sobre o comportamento das classes, o analista pode, por exemplo, construir uma sequência de regras de pertinência e de processos, técnica conhecida como árvore de processos, bastante utilizada nos trabalhos de análise de imagens baseada em objeto. $O$ analista pode também se deter apenas em definir um limiar de pertinência a determinada classe, baseando-se também em seu conhecimento prévio ou em conhecimento constituído a partir da exploração da imagem (estudo de amostras). conhecimento do analista sobre o comportamento das classes pode ser utilizado em técnicas de morfologia matemática ou o analista pode ainda treinar o computador para reconhecer padrões mais complexos através da aplicação da técnica de classificação por redes neurais.

É cada vez mais comum o uso de técnicas híbridas, em especial na classificação de ambientes mais complexos. Essas técnicas são mais comumente mencionadas como técnicas que combinam a classificação supervisionada e a classificação não-supervisionada em processos baseados em pixel. No entanto, especialmente em se tratando do ambiente urbano, é bastante comum encontrar estudos onde foram aplicadas diferentes combinações de técnicas, além da introdução de novas técnicas de classificação em imagens (FAUVEL et al., 2006; THOMAS et al., 2003; GUIDON et al., 2004)

$\mathrm{Na}$ maior parte das técnicas mencionadas, para determinar a qual classe pertence cada pixel ou região são utilizados métodos estatísticos e determinísticos de separação de classes. Os métodos estatísticos mais comuns são: máxima verossimilhança (MAXVER), distância mínima e método do paralelepípedo. MAXVER é o método de classificação que considera a ponderação das distâncias entre médias dos níveis digitais das classes, utilizando parâmetros estatísticos. No método da distância mínima, o classificador compara a distância Euclidiana do pixel à média de cada agrupamento de amostras de classes. $\mathrm{O}$ pixel será incorporado ao agrupamento que apresenta a menor distância Euclidiana. Este procedimento é repetido até que toda a imagem seja classificada. O método do paralelepípedo é considerado o mais simples, pois consiste na definição de retângulos formados pelos vetores principais de cada conjunto de amostras de classe em cada dimensão do espaço de atributos, regiões ou pixels e serem classificados de acordo com sua pertinência a tais retângulos. 
O método determinístico mais utilizado é a classificação por rede neural. As redes neurais artificiais são modelos computacionais constituídos por métodos que produzem diretamente as funções de decisão através dos dados de treinamento. São organizados em camadas (simples ou multicamadas) que definem sua topologia (maneira como os elementos de processamento são organizados) ou arquitetura (definida pelo número de camadas escondidas e número de nós em cada camada), como descreve Sabo (2003) e Benediktisson (1990).

Definida a técnica de classificação e o método de separação das classes, também é possível definir diferentes lógicas de pertinência. A lógica de pertinência mais utilizada em cada um desses métodos estatísticos ou determinísticos é a lógica boleana. No entanto, a lógica fuzzy vem sendo cada vez mais utilizada, em especial em áreas urbanas, pois como menciona Fauvel et al (2006), a lógica fuzzy foi criada como meio de lidar com ambiguidades e incertezas de sistemas complexos. A diferença fundamental entre as duas lógicas é que nos classificadores fuzzy as regras de decisão são baseadas na variação de incerteza, enquanto na lógica boleana são baseados na probabilidade (LILLESAND et al., 2008). Nóbrega (2007, p. 51, 52) explica que "a idéia básica é substituir respostas boleanas estritamente lógicas, como sim e não, por um intervalo contínuo de valores [0 ... 1], onde o 0 equivale exatamente ao não e o 1 exatamente ao sim". Assim, o pixel ou região pode pertencer a mais de uma classe e é o conjunto de regras organizadas por operadores lógicos, como "AND" e "OR", que irá determinar a que classe pertence mais e pertence menos, como exemplificado na Figura 2.24.

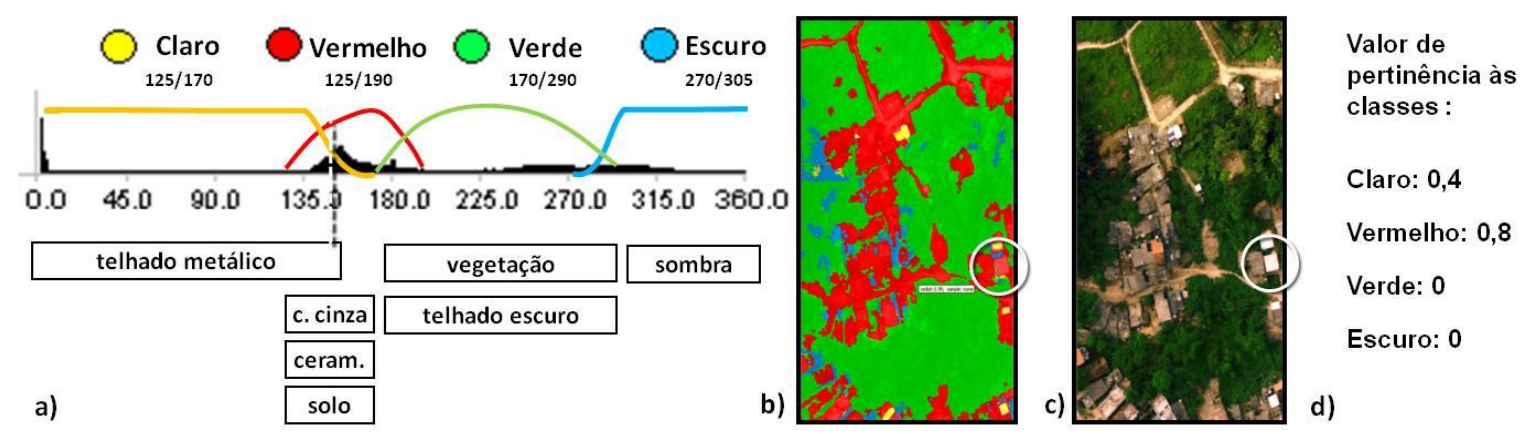

Figura 2.24. Classificação com lógica fuzzy, em destaque: objeto que, segundo funções de tonalidade, pertence à classe vermelho e à classe claro. a) Histograma de tonalidade média, funções de pertinência às classes claro, vermelho, verde e escuro e tipos de cobertura, b) imagem classificada, c) Imagem RGB, d) valores de pertinência do objeto em destaque. Fonte: Brito (2010)

Visto de forma geral, as técnicas e métodos mais utilizados em classificação digital de imagens, a seção que segue explora mais especificamente a aplicação destes em uma abordagem baseada em objeto e outras especificidades dessa abordagem. 


\subsubsection{Classificação baseada em objeto em imagem de $S R$}

As análises baseadas em objeto têm sido defendida por alguns autores, a exemplo de Castilla e Hay (2008), Walker e Blaschke (2008), entre outros, como o tipo de análise mais apropriada para estudos na escala urbana, devido à possibilidade de utilização de uma vasta gama de recursos que simulam o comportamento do foto-intérprete, reconhecendo nas imagens informações de cor, forma, tamanho, vizinhança, contexto, entre outras.

Wachowicz (1999) conta que a história da análise baseada em objeto teve início no princípio da década de 1960 com as tentativas de criação e implementação de novos conceitos de programação para aplicações de simulações discretas. Na década de 70 a linguagem de programação orientada a objeto já era amplamente reconhecida. Na primeira metade da década de 90, uma série de trabalhos, especialmente os de Booch (1991 e 1994), deram mais profundidade ao princípio orientado a objeto antes tido apenas como linguagem de programação, alavancando o desenvolvimento de trabalhos que começavam a juntar a programação orientada a objeto aos sistemas de gestão de banco de dados. Diferentes bancos de dados orientados a objeto para fins comerciais foram lançados, sendo que todos eles tinham como características básicas: métodos associados a objetos, a herança de atributos e de procedimentos de supertipos (superclasses) e a habilidade de definir o tipo de objetos (classes), seus tipos de atributos e de relacionamentos. Segundo Chance et al. (1990), no sistema orientado a objeto não significa apenas que exista uma base de dados com objetos, mas que o sistema é organizado em torno do conceito de objetos que têm comportamentos (métodos).

Somente nesta década, o princípio da análise baseada em objeto começou a ser de fato difundido e pesquisado amplamente na área de SR. Atualmente existem inúmeras aplicações para as análise de imagens baseada em objeto, nas mais diversas áreas: biomedicina, astronomia, microscopia, entre outras. Em 2006, a comunidade internacional envolvida na aplicação dos princípios de OBIA (Object Based Image Analysis) em SR e SIG organizou o primeira conferência internacional da área, com a participação de 24 países.

Como fruto dessa conferência e de posteriores discussões na Internet, com participação aberta $^{16}$, o termo GEOBIA (GEO-Object-Based Image Analysis) foi proposto com o intuito de identificar essa emergente comunidade usuária de OBIA em SIG e SR. Assim, Hay e Castilla em 2008 apresentou a definição do termo GEOBIA como uma sub-disciplina da Ciência de Informações Geográficas destinada ao desenvolvimento de métodos de

\footnotetext{
${ }^{16}$ A página da Internet onde acontecem discussões conceituais sobre OBIA e GEOBIA é intitulada "OBIA wiki discussion section" e pode ser acessada pelo endereço eletrônico http://wiki.ucalgary.ca/page/OBIA
} 
segmentação digital de imagens de sensoriamento remoto e ao acesso às suas características através das escalas espacial, espectral, radiométrica e temporal, a fim de gerar novas informações geográficas em um formato pronto para uso em sistemas de informação geográfica (HAY e CASTILLA, 2008).

A terminologia ainda não é amplamente utilizada, mas lembrando que Hay e Castilla (2008) definem os image-objects, ou segmentos da imagem, como região discreta de uma imagem digital que é internamente coerente e diferente de seu entorno, é possível reconhecer que o termo proposto, GEOBIA, tem sua base nos princípios da OBIA apresentados por Booch (1991 e 1994). Análises orientadas a objeto são consideradas por Booch (1991) aquelas cuja metodologia possui os quatro requisitos básicos de uma modelagem orientada a objeto: abstração (restrição do universo de análise para a modelagem do mundo real), encapsulamento (separação dos aspectos externos dos internos de um objeto, permitindo maior independência na evolução de sua definição), poliformismo (possibilidade de ter a mesma operação atuando de modos diversos em classes diferentes) e hierarquia ou herança (estrutura comum onde instâncias, ou níveis, criados a partir de outros herdam todas as características do conjunto original).

$\mathrm{Na}$ ausência de algum dos requisitos citados por Booch, alguns autores (MACHADO, 2008; Knopik, 2008) consideram a classificação baseada em objeto. Para Baatz et al. (2008) a diferença básica entre análise de imagem orientada a objeto e baseada em objeto é relacionada ao processo de criação dos objetos. No primeiro é um processo simplificado e linear com dois estágios: segmentação e classificação. Nesse caso, os objetos uma vez criados permanecem inalterados e portanto servem como base para etapa de análise. Já na classificação orientada a objeto, o autor defende que o objeto é usado em todas as etapas do processo como unidade central de processamento, servindo tanto como fonte de informações como blocos construtivos. Nesse último caso, a análise contempla processos alternados de segmentação e classificação, como esquematizado na Figura 2.25.

Em um sistema montado no modelo baseado em objeto, os processos de segmentação podem ser realizados utilizando dados e procedimentos que, na maior parte dos casos, não são possíveis de serem utilizados diretamente no processo pixel a pixel, como por exemplo: uso de imagens de diferentes resoluções espacial, espectral e radiométrica; acesso a propriedades de compactação e suavidade das regiões que estão sendo segmentadas; utilização de outros níveis de segmentação para criar segmentos menores ou maiores compatíveis e uso de dados vetoriais, como mapa de uso de solo ou limites de quadras. $\mathrm{Na}$ segmentação multi-nível, uso de dados de outra segmentação produz níveis de segmentação organizados hierarquicamente, permitindo, na classificação, a transferência 
de informações entre os níveis, o que não é possível nas abordagens que não são orientadas a objeto.

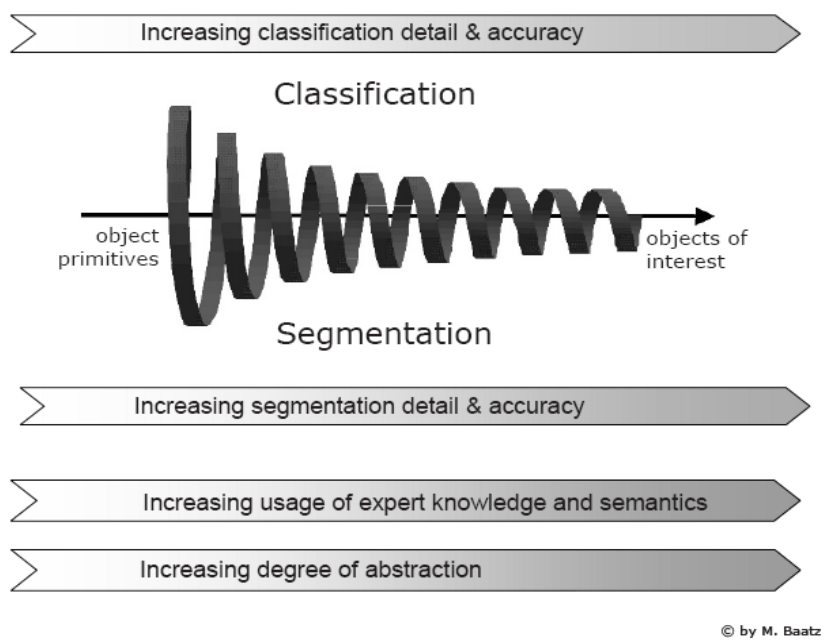

Figura 2.25. Análise de Imagem orientada a objeto: procedimento genérico. Fonte: Baatz et al. (2008, p. 32).

Em relação aos métodos e técnicas de classificação, a principal diferença dos classificadores baseados em objeto e classificadores baseados em pixel está na flexibilidade e na gama de fontes de dados permitidas: principalmente no que diz respeito ao uso de atributos não espectrais e ao uso de dados contidos em uma base vetorial ou em outro nível de segmentação. Apesar da possibilidade de usar classificação nãosupervisionada, como realizado por Machado (2008) e Knopik (2008), em que as classes só são definidas estatisticamente por um critério de identificação de grupos de objetos no espaço de atributos, na classificação baseada em objeto é bem mais frequente o uso de árvores de processo, com a construção de regras definidas pelo analista, ou mesmo com a inserção de processos de classificação supervisionada. A lógica fuzzy também é mais comumente utilizada que a lógica boleana. Essas e outras particularidades da classificação baseada em objeto em imagens de SR também se apóiam nos principais conceitos e premissas da GEOBIA.

A lógica de formação das classes permite que as regiões com as mesmas características de dados (atributos) e métodos (comportamento) sejam designadas às classes. As classes podem fazer parte de uma rede hierárquica, em que subclasses, ou classes filhas, herdam características das classes mães (Figura 2.26). 

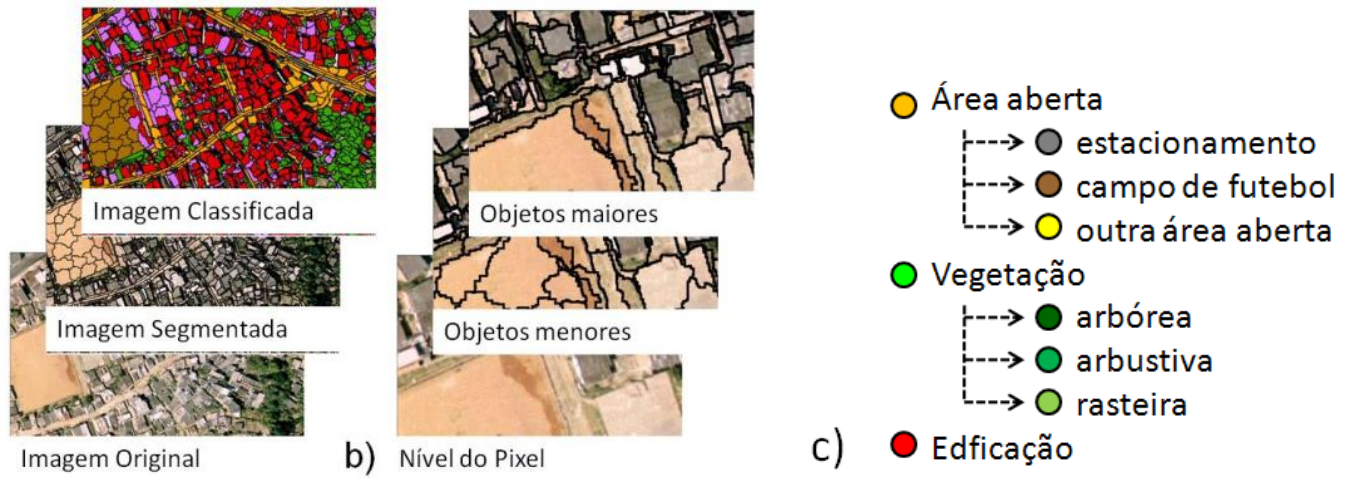

Figura 2.26. Elementos da classificação orientada a objeto. a) Procedimentos padrão em SR, b) Hierarquia dos objetos de imagem - segmentação multi-nível, c) Hierarquia de classes

$\mathrm{Na}$ estruturação das classes, os objetos e seus relacionamentos são modelados por regras de classificação, utilizam atributos espectrais (como intensidade média dos pixels, razão entre bandas, etc.), geométricos (forma retangular, simétrica, compacta, tamanho, largura, textura, etc.) e topológicos (contexto em relação a objetos vizinhos, a objetos em níveis superiores e na cena, etc.), como exemplificado na Figura 2.27, além de atributos gerados por algoritmos de reconhecimento de textura ou de relações entre atributos.

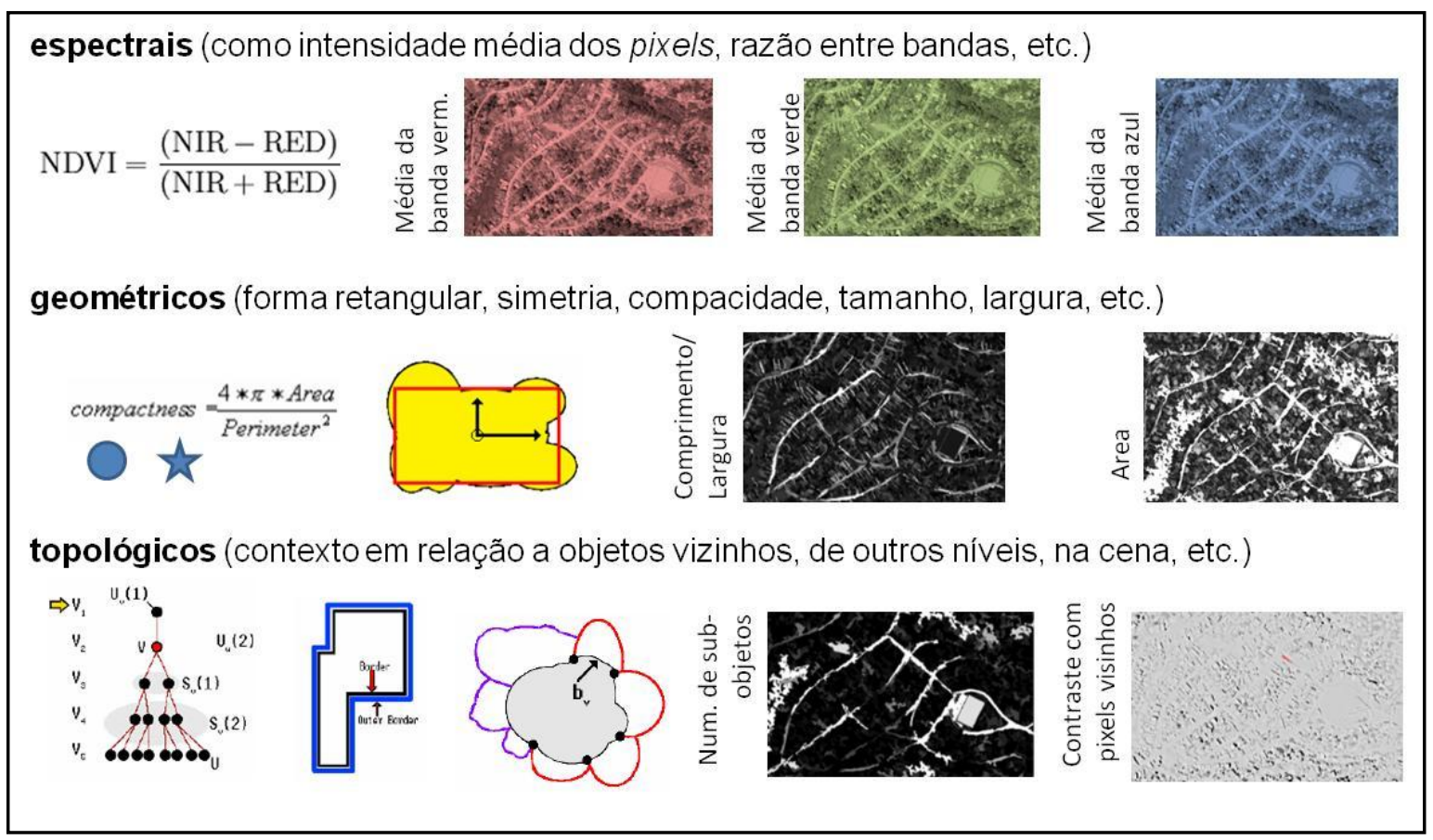

Figura 2.27. Exemplo de atributos utilizados na classificação baseada em objeto.

Assim, a informação semântica utilizada na interpretação de imagens não é a informação no pixel, mas as propriedades dos objetos e suas relações, mesmo quando é usada a informação dos pixel que compõem a região.

Os níveis de abstração, ou escalas em que os objetos de interesse são criados, podem ser diversificados e concordar sua semântica com os diferentes níveis de segmentação, por 
exemplo, quadras e casas, árvores e reservas ecológicas, exigem níveis diferenciados de segmentação. Por isso, a segmentação multi-nível é utilizada para incrementar a qualidade da classificação, em especial em ambientes complexos como o ambiente urbano.

\subsubsection{SR em análises urbanas}

As imagens de alta resolução e a classificação baseada em objeto são recursos e técnicas de sensoriamento remoto recentes, que vêm sendo cada vez mais indicadas para o espaço intra-urbano. Walker e Blaschke (2008, p. 2036, 2037) chegam a afirmar que, no estudo desses ambientes, classificadores pixel a pixel não têm performance adequada e que a segmentação de imagens e outras ferramentas de contexto irão tornar-se padrão no mapeamento da cobertura do solo urbano com imagens de SR. No entanto, muitos trabalhos voltados para objetivos semelhantes, já foram e continuam sendo publicados com uso de sensores como o LANDSAT e uso de classificação baseada em pixel, o que leva a crer que esse novos recursos não são irrestritamente considerados pela comunidade científica ideais para qualquer tipo de pesquisa intra-urbana.

Com o objetivo de identificar técnicas de SR utilizadas para análise do espaço intra-urbano, que usem imagens multi-espectrais ou fotografias aéreas e que sejam reconhecidas pela comunidade científica internacional, foi realizado um levantamento bibliográfico sistemático em alguns dos principais periódicos da área de SR. Foram revisados, por título e usando a palavra chave "urban", todos os artigos publicados entre janeiro de 2001 e outubro de 2008 , nas revistas científicas: Transaction in Geocience and Remote Sensing do Institute of Electrical and Electronics Engineers (IEEE), Geocience and Remote Sensing Letters também do IEEE, Remote Sensing of Environment, publicado pela Elsevier, International Journal of Remote Sensing da Remote Sensing and Photogrammetry Society e a publicação da American Society for Photogrammetry \& Remote Sensing, o periódico Photogrammetric Engineering \& Remote Sensing. O Quadro 2.6 apresenta uma sistematização dos trabalhos selecionados de acordo com as características urbanas estudadas, os materiais e os métodos utilizados.

Foram encontrados 110 artigos que tratam da análise de imagens do espaço intra-urbano. Dentre eles 20 utilizaram métodos de classificação baseado em objeto, 76 utilizaram métodos considerados tradicionais de classificação baseada em pixel. 
Quadro 2.6. Levantamento bibliográfico, 2001-2008, de características urbanas e métodos de classificação em produtos de sensores passivos utilizados para análise do espaço intra-urbano.

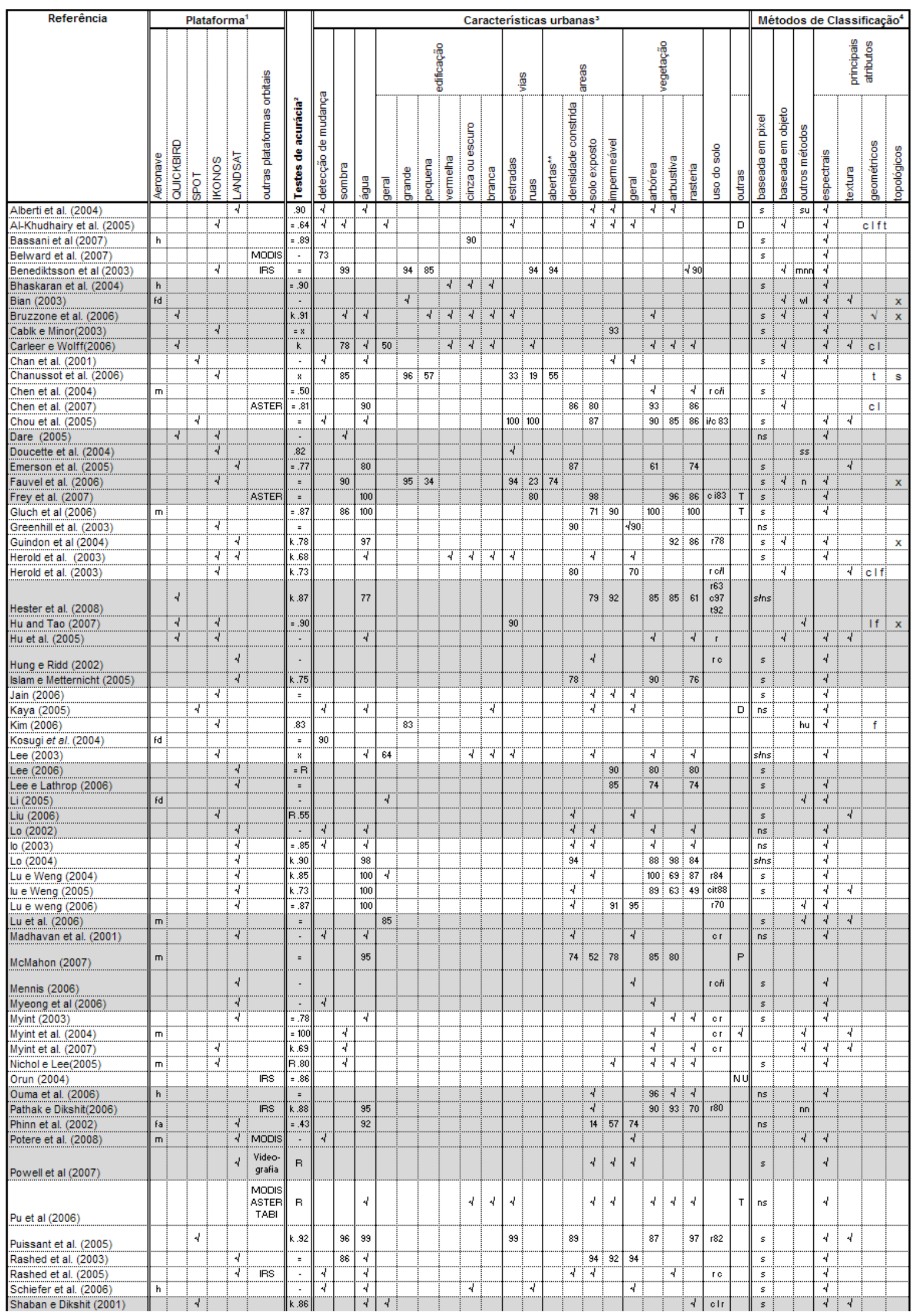


continuação

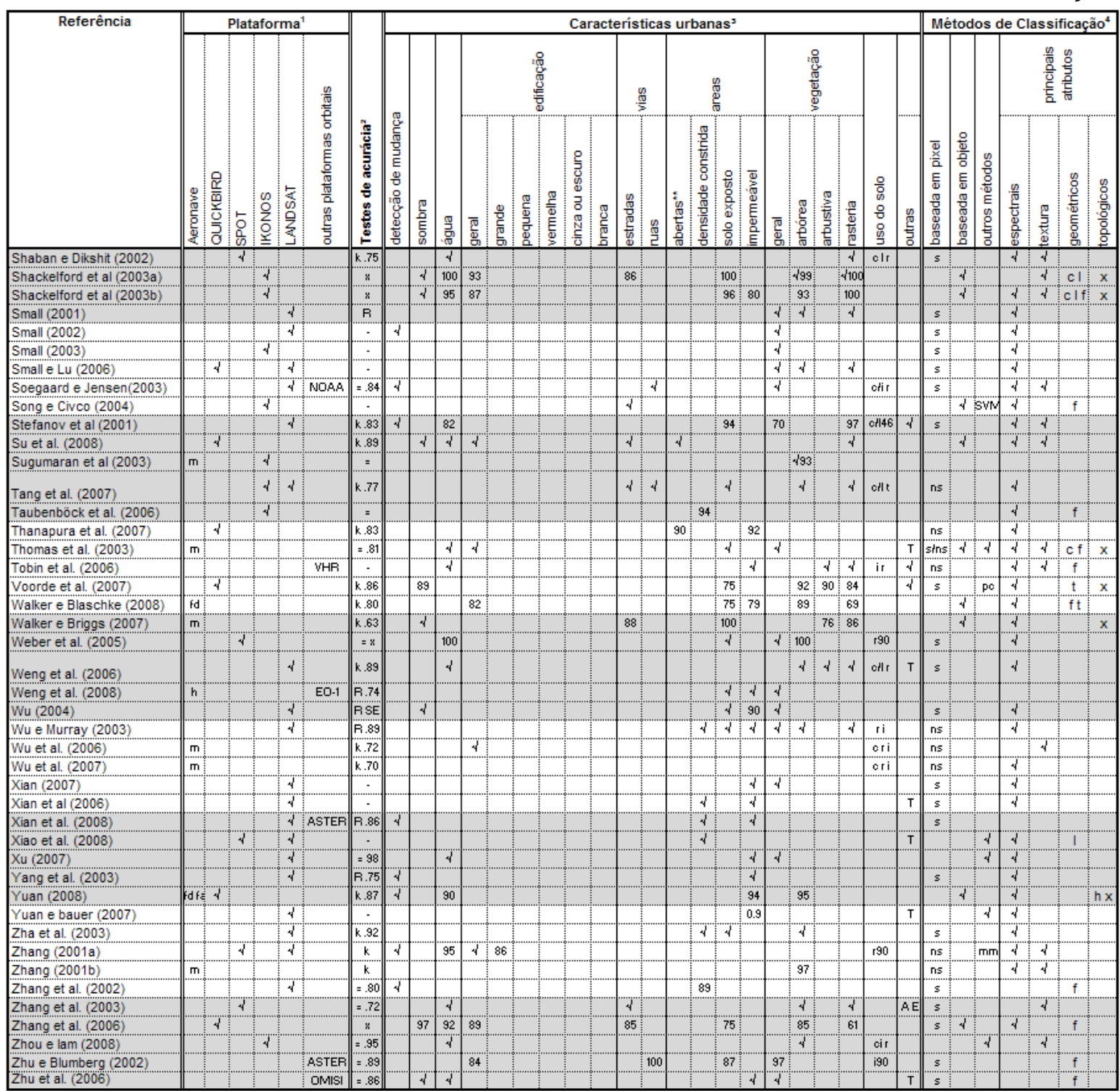

Notas: (1) tipo do sensor aerotransportado: $m$ - multi-espectral, $h$ - hiper-espectral, fa - fotografia analógica digitalizada, fd - fotografia digital; VHR - imagem de alta resolução espacial não especificada. (2) Testes de acurácia estatística utilizada para o cálculo (k) coeficiente Kappa, (SE) erro sistemático, (=) percentual de acerto, (R) calculo baseado no erro quadrático (root mean square error), valores apresentados para trabalhos que utilizaram o método da soma dos quadrados é igual a um menos a soma dos quadrados; Valores aproximados do conjunto de melhor acurácia geral apresentado pelo autor. (3) Características urbanas - uso do solo: c comercial, $r$ - residencial, $i$ - industrial, $t$ - transporte; outras: $A$ - cidade antiga , $E$ - cidade externa, $D$ edificações danificadas, $T$ - temperatura, $N$ - natural, $U$ - urbano, $P$ - pântano; $\left(^{* *}\right)$ Áreas abertas são áreas não classificadas como edificação, ruas, estacionamento ou jardim, como por exemplo, espaços públicos entre vias com grama ou terra. Valores aproximados do conjunto de melhor acurácia geral apresentado pelo autor; (4) Outros métodos de classificação: SVM - suport vector machine, nn - neural network, hu - heads up building extraction algorith, ss - self- supervised, wl - wavelet transformation, su - spectral unimixing, mm - morfologia matemática; Principais atributos topológicos: $h$ - hierarquia, $x$ - contexto, $s$ - contraste; principais atributos geométricos: $c$ - comprimento, I - largura, $f$ - forma e $t$-tamanho.

Al-Khudairy et al. (2005) e Thomas et al. (2003), com base em seus estudos comparativos entre as duas abordagens, afirmam a superioridade (medida através de índices de acurácia) da classificação baseada em objeto sobre a classificação pixel a pixel, o que está de acordo com a tese defendida por (BLASCHKE et al., 2005; WALKER e BLASCHKE, 2008). 
Segundo Al-Khudairy et al., (2005) processos de classificação baseados em objeto auxiliam na interpretação dos resultados de estudos de detecção de mudança com uso de imagens de alta resolução espacial, pois é capaz de reconhecer objetos que tenham grande variação espectral interna. O foco de seu estudo era na detecção de edificações afetadas em áreas de conflito utilizando imagens IKONOS. Al-Khudairy et al. (2005) concluiu que a classificação baseada em objeto realizada no software eCognition (Definiens), assim como a classificação com técnicas de morfologia matemática são versáteis e fáceis de serem utilizadas. No entanto, o autor alerta que ambas demandam habilidade e experiência do analista de imagens e um considerável dispêndio de trabalho e tempo para determinar a abordagem e os parâmetros mais apropriados de segmentação e classificação.

O estudo comparativo realizado por Thomas et al. (2003) tinha como objetivo identificar superfícies permeáveis e impermeáveis na cidade de Scottsdale, Arizona, EUA, para estimar capacidade de escoamento da água durante tempestades. O autor testou, em imagens aéreas de escaner multi-espectral com $1 \mathrm{~m}$ de resolução, três métodos de classificação: classificação espectral supervisionada combinada à não supervisionada; classificação baseada em pixel combinada à técnica de morfologia matemática com regras espaciais e classificação baseada em objeto; e dois modelos de avaliação da matriz de erro: uma com lógica determinística e outra com lógica fuzzy. Apesar do método que utilizou do modelamento matemático ter produzido uma classificação com melhores resultados de acurácia, este método demandou o uso de informações vetoriais complementares à imagem e a excessiva participação do analista para testá-lo e implementá-lo. Assim os autores concluíram que a classificação baseada em objeto (desenvolvida no software eCognition) e as matrizes que utilizam lógica fuzzy são mais apropriadas para o mapeamento dos principais elementos constituintes do espaço intra-urbano.

Entre as diferentes técnicas possíveis de serem aplicadas com a abordagem baseada em objeto, Walker e Blaschke (2008), com base em experimentos realizados na área metropolitana de Phoenix, afirma que considerando uma abordagem baseada em objeto, a classificação supervisionada oferece melhores resultados que a classificação realizada com a implementação de regras de decisão em árvore de processos. Seus estudos revelaram uma diferença de acurácia de 0,73 e 0,80 no coeficiente Kappa, nas respectivas classificações. No entanto, os autores advertem que o método supervisionado tem como desvantagem a necessidade de dar entrada em um número significativo de amostras para cada cena de interesse, o que além de aumentar o tempo de processamento e dependência da habilidade do analista, pode ser um problema em análises comparativas, exigindo, por sua vez uma avaliação de erro robusta para cada cena. Por outro lado, o método que tem 
as regras definidas em árvore de processos pode ser transportado para outras áreas, facilitando a avaliação dos resultados em estudos comparativos. Assim os autores concluem que o método generalista, conduzido pela árvore de processos, é mais vantajoso que o método otimizado, realizado com treinamento.

Apesar da superioridade da abordagem baseada em objeto defendidas por esses autores, é importante frisar que esta superioridade só é comprovada nos estudos urbanos que utilizam imagens de alta resolução espacial. Guidon et al. (2004) realizou experimento com imagem LANDSAT e concluiu que a classificação baseada em pixel pode aperfeiçoar os resultados da classificação baseada em objetos, e vice-versa. O autor alega que métodos de classificação espectral pixel a pixel são mais efetivos na classificação de vegetação e solo e que métodos baseados em objetos são, por sua vez, mais efetivos no reconhecimento de elementos com formas peculiares, como as estruturas construídas pelo homem. Por isso, Guidon et al. (2004) apresentou um método que consiste basicamente em combinar, através de regras de decisão, o produto de dois tipos de classificação, uma baseada em pixel e outra baseada em objeto. Seu estudo tinha como objetivo identificar classes de uso do solo.

Fauvel et al. (2006) também obteve melhores resultados utilizando uma combinação de métodos. Ele compara um método híbrido de classificação baseada em pixel, que combina o resultado da classificação realizada por diferentes classificadores, rede neural e modelo probabilístico utilizando lógica fuzzy. Os resultados do método híbrido demonstram uma melhora significativa no reconhecimento de ruas, edificações, áreas abertas e sombra em relação aos métodos individuais.

Algumas pesquisas também têm apresentado resultados satisfatórios com a abordagem baseada em pixel. Zhang (2001a) utilizou classificação não-supervisionada tradicional pixel a pixel e propôs sua complementação com técnicas de pós processamento baseadas em atributos espaciais. Zhang baseou sua opção nos trabalhos de alguns autores (JENSEN et al., 1994; CSATHO e SCHENK, 1998; MACLEOD e CONGALTEN, 1998) que defendem o método de agrupamento de objetos não supervisionado por ser o mais adequado para identificar classes heterogêneas em imagens de alta resolução espacial, quando comparado ao método supervisionado.

Zhang (2001a) observou um incremento de cerca de 30\% na identificação de casas, passando de 59\% para $86 \%$ de acurácia, após a aplicação das técnicas de pósprocessamento. $O$ autor utilizou imagens do LANDSAT TM e SPOT (Pan), mas advertiu que o uso de satélites de maior resolução poderá melhorar ainda mais esses resultados. 
Ridd (1995), baseando seus experimentos em estudos de outros autores, também sugere o uso de imagens com maior nível de detalhamento, principalmente para o estudo de cidades com padrões espaciais urbanos menores que os padrões espaciais das cidades americanas.

Os estudos de Chanussot et al. (2006) e Fauvel et al. (2006a) mostraram que a classificação com modelos probabilísticos que utilizam lógica fuzzy apresenta melhores resultados gerais que a classificação por redes neurais. Ainda assim, Chanussot et al. (2006) acredita que em alguns casos, como na extração de ruas, o uso da técnica de redes neurais artificiais tem melhor desempenho.

Os primeiros 4 anos do levantamento apresentado no Quadro 2.4 observa-se que $50 \%$ dos trabalhos publicados nesse período foram realizados exclusivamente com sensores de resolução espacial da ordem de 0,1 a 10 metros (aerotransportados, QUICKBIRB, IKONOS), contra 37\% dos trabalhos publicados entre 2005 e 2008.

De uma forma geral, observa-se no levantamento que os sistemas sensores de menor resolução espacial, LANDSAT e NOAA por exemplo, são mais frequentemente utilizados para a classificação de vegetação, solo permeável e impermeável, densidade construída e padrões básicos de uso do solo (comercial, industrial e residencial). Obtendo resultados de acurácia geral acima de $80 \%$. Muitos desses trabalhos recorreram a métodos de análise de mistura espectral ou sub-pixel para melhorar o desempenho dos classificadores em ambiente intra-urbano.

Cerca de metade dos estudos que utilizaram sensores de alta resolução espacial classificaram edificações e vias, além da cobertura do solo (26 artigos do total de 56), contra os $19 \%$ dos trabalhos com os demais satélites (10 de 54) que classificaram ao menos uma dessas duas feições urbanas.

Vale destacar que foi encontrado nas revistas pesquisadas um número bastante significativo de artigos relacionados a áreas urbanas utilizando os sensores de tecnologia de radar (Synthetic Aperture Radar - SAR) e laser (Light Distance and Ranging - LIDAR). No entanto, as imagens produzidas por esses sensores demandam um apanhado de técnicas diferenciadas que não fazem parte desse estudo. Quase todos os trabalhos utilizaram dados espectrais das imagens para realizar as análises. Atributos geométricos e topológicos foram utilizados em $24 \%$ dos trabalhos a maior parte deles em estudos desenvolvidos com a classificação baseada em objeto. 
Os atributos de textura foram utilizados em 26 trabalhos, 15 deles utilizaram imagens de resolução métrica e 8 realizaram classificação baseada em objeto.

Segundo Herold et al. (2003), há três décadas, a comunidade científica vem desenvolvendo e testando técnicas que utilizam informações de textura, de contexto e espaciais para mapeamento digital de imagens de SR. Essas técnicas variam principalmente de acordo com o formato discreto ou contínuo da imagem (imagens espectrais ou classificação da cobertura do solo), o domínio espacial da análise (baseada em Kernel ou baseada em região) e a abordagem estatística utilizada para descrever os componentes espaciais e de textura das imagens.

Um dos métodos estatísticos mais utilizados para a interpretação de textura e reconhecimento de padrões é baseado na matriz de co-ocorrência espacial da imagem (Spatial co-occurence Matrix - SCM), também conhecida como matriz de co-ocorrência do nível de cinza (Gray Level Co-occurence Matrix - GLCM). Segundo Myint et al. (2004) essa técnica tem obtido sucesso, mas tem suas limitações.

Walker e Briggs (2007), por exemplo, testaram o uso de atributos de textura na classificação de áreas de vegetação arbórea em Phoenix, EUA, utilizando classificação baseada em objeto em imagens aéreas multi-espectrais. No entanto, a capacidade de descriminar vegetação de grande porte não foi satisfatória porque, segundo os autores, a segmentação foi realizada com alta resolução. Segmentos de tamanhos muito reduzidos não possuem atributos de textura que permitam realizar a diferenciação entre classes.

Na segmentação multi-nível, a textura de segmentos de níveis superiores pode ser avaliada de acordo com atributo de segmentos de níveis inferiores, como o desvio padrão do nível de cinza médio do segmento em determinada banda, por exemplo. Esse recurso foi aplicado no trabalho de Kux e Araújo (2008), onde os autores utilizaram a média do nível de cinza da banda infra vermelha dos sub-objetos para diferenciar vegetação arbórea de vegetação rasteira.

Dados de textura também podem ser utilizados para aperfeiçoar a classificação baseada em pixel em imagens de alta resolução espacial de áreas urbanas (PUISSANT et al., 2005) e para identificar outros elementos e características urbanas, além do porte da vegetação, como população (LIU, 2006), edificação (ZHANG, 1999) e uso do solo (CHOU et al., 2005; HEROLD et al., 2003).

Entre os artigos presentes na Quadro 2.6, o trabalho realizado por Ridd (1995) destaca-se pela frequência com que é citado. Ridd (1995) publicou um importante trabalho de 
modelagem conceitual da morfologia urbana, voltado para aplicações com SR. Lu e Weng (2004) considera o modelo apresentado por Ridd um dos maiores avanços na análise da cobertura do solo urbano.

Pensando em aplicações de SR, Ridd (1995) construiu um modelo de análise de ecossistemas urbanos chamado V-I-S (Vegetação - superfície Impermeável - Solo exposto), para a caracterização das variações nos padrões de cobertura do solo ${ }^{17}$. A criação do modelo foi inspirada no diagrama ternário Areia-Argila-Sedimentos utilizados em ciências do solo e foi motivada pela necessidade de se padronizar grandes blocos de composição do ambiente urbano em uma metodologia capaz de detectá-los e mapeá-los de forma repetitiva e consistente. O modelo V-I-S constitui, portanto, um modelo global de morfologia urbana cujo pressuposto é que, ignoradas as superfícies cobertas com água, combinações de superfícies impermeáveis, vegetação verde e solo exposto são os principais componentes do ecossistema urbano, seja no contraste com ecossistemas vizinhos, seja na diferenciação do espaço intra-urbano (Figura 2.28).

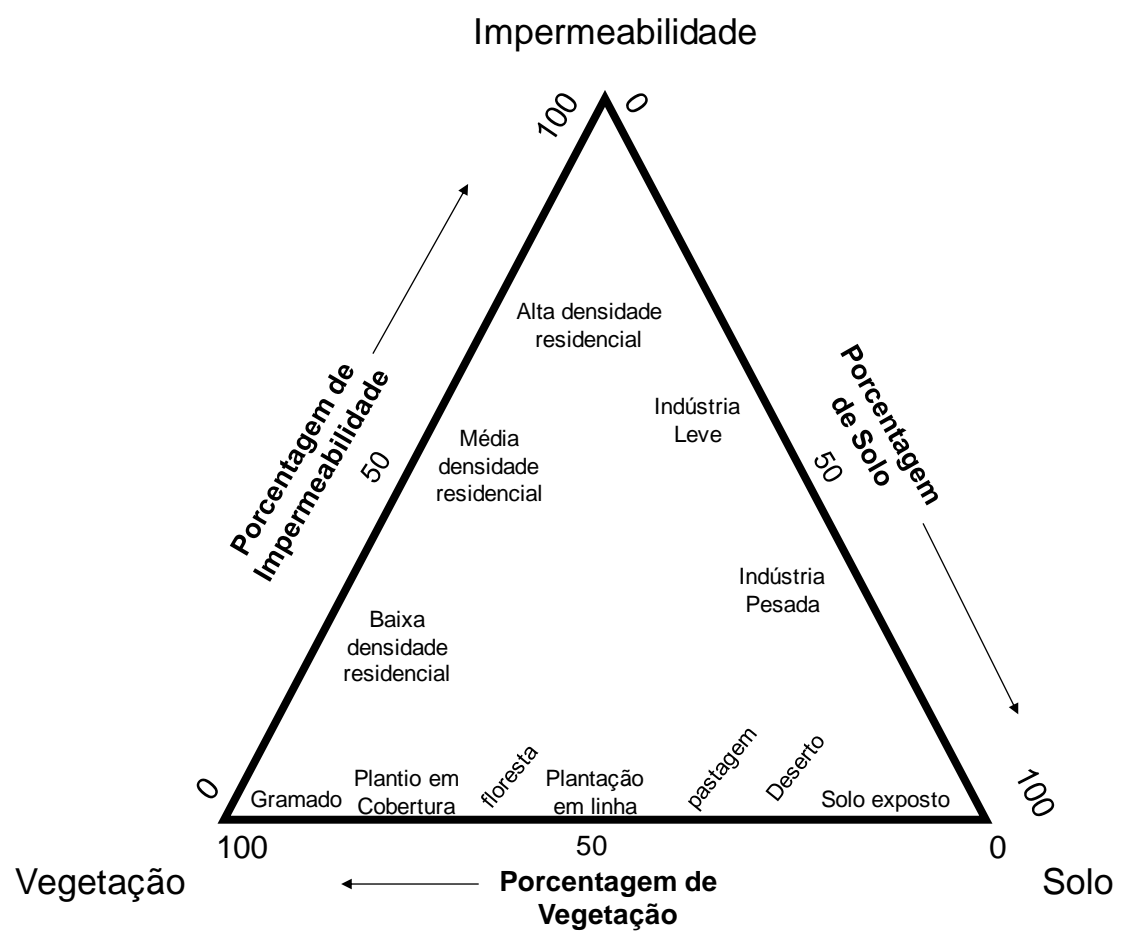

Figura 2.28. Modelo V-I-S com a locação de alguns componentes urbanos e do entorno urbano. Fonte: adaptado de Ridd (1995, p. 2173)

Segundo Ridd (1995) o impacto ambiental da urbanização varia de acordo com três fatores: a natureza das condições originais, a natureza das transições urbanas e o tempo. Para o autor, o modelo V-I-S oferece meios de mensurar e mapear essas mudanças. Assim, deve-

\footnotetext{
${ }^{17}$ Ridd (1995) esclarece que o modelo não é apropriado para estudo do uso do solo. O pesquisador pode, no entanto, partir do modelo V-I-S para cobertura do solo para inferir propriedades de uso do solo, desde que o estudo seja realizado caso a caso, considerando as características físicas e culturais do espaço em estudo.
} 
se entender que, em um ambiente desértico, o desenvolvimento urbano implica na transformação do solo exposto em superfície impermeável ou com vegetação, como mostrou Menis (2006) em seu estudo na cidade de Denver, região árida dos Estados Unidos. Por outro lado, a urbanização em áreas cultivadas ou florestadas reduz a área vegetada, como se observa na maior parte das cidades litorâneas brasileiras.

Todos os trabalhos encontrados que referenciaram o modelo V-I-S, um total de 15 , apenas um não utilizou a tradicional classificação pixel a pixel e apenas três deles não utilizaram o LANDSAT ou outro satélite de resolução semelhante.

O modelo V-I-S é muito citado (LEE, 2006; LU e LATHROP, 2006; RASHED, 2003; STEFANOV et al., 2001; THANG, 2007) ou utilizado (PHINN et al., 2002; POWELL et al., 2007; HUNG e RIDD, 2002) como base para a aplicação de método de análise sub-pixel, uma vez que o modelo teórico implicitamente sugere a variabilidade e heterogeneidade presentes em um único pixel.

Considerando o objetivo de padronizar a leitura da cobertura do solo, o modelo V-I-S, segundo Madhavan et al. (2001), Rashed et al. (2003) e Rashed et al. (2005), serve bem ao propósito. Os autores avaliam positivamente o uso do modelo V-I-S na análise de tendências de transformação urbana. Rashed et al. (2003) e Rashed et al. (2005) concluem que o modelo tem se mostrado robusto na descrição da paisagem urbana, necessitando no entanto da inclusão de duas componentes adicionais, água e sombra, para alcançar uma caracterização mais acurada. Thang et al. (2007) e Lu e Weng (2004) são da opinião que sombra é realmente um importante componente que precisa ser considerado. Wu e Murray (2003) consideram as dificuldades de se estimar área impermeável um entrave para a aplicação prática do modelo sugerido por Ridd (1995).

É interessante observar que os três elementos do modelo V-I-S estão entre as características urbanas que aparecem com mais frequência nos estudos apresentados no Quadro 2.6. A vegetação é estudada em $75 \%$ dos artigos, densidade construída ou solo impermeável em $40 \%$ e solo exposto em $35 \%$. A água é o único outro elemento que também aparece com bastante frequência, 44\% dos artigos classificam água, o que leva a acreditar que Rashed et al. (2003) e Rashed et al. (2005) devem estar no caminho correto ao sugerir a consideração desse elemento no modelo.

Os demais elementos urbanos mais analisados nos estudos levantados, Figura 2.29, são edificações (25\%), vias (22\%) e sombra (19\%). Um número significativo de trabalhos 
realizaram estudos de detecção de mudança (20\%) ou focaram a análise na caracterização do uso do solo (30\%).

O Quadro 2.6 apresenta 38 artigos em que solo exposto foi uma das características urbanas analisadas. Os melhores indicadores de acurácia foram apresentados por Shakelford et al. (2003a) e Shackelford et al. (2003b) cujos trabalhos usaram classificação baseada em objeto em imagem IKONOS, Walker e Briggs (2007), usando classificação baseada em objeto em imagem aérea de sensor multi-espectral e Frey et al. (2007), com classificação pixel a pixel em imagem LANDSAT e utilizando o modelo V-I-S.

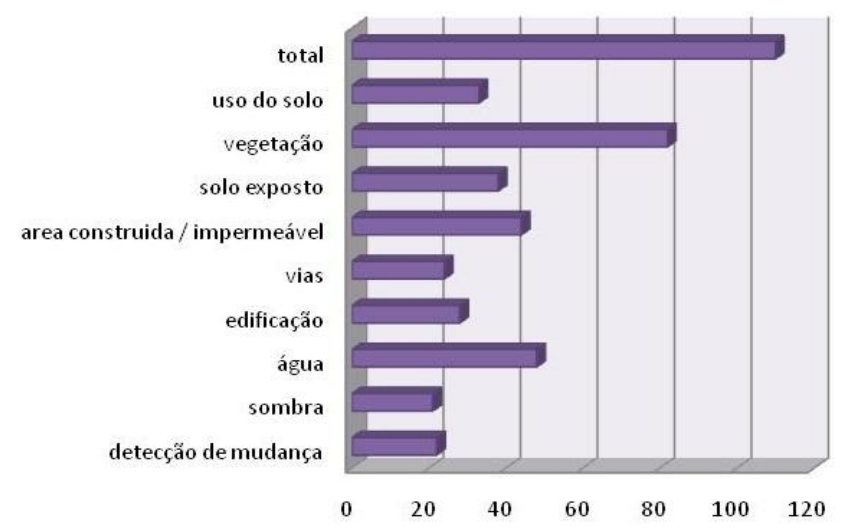

Figura 2.29. Gráfico das principais características urbanas estudadas nos trabalhos pesquisados no levantamento sistemático.

No entanto, em alguns casos, como nos experimentos realizados por Walker e Blaschke (2008), solo exposto apresentou um certo grau de confusão com edificações. Segundo os autores isso ocorreu provavelmente porque o solo nativo da área de estudo é comumente utilizado como insumo na fabricação dos materiais utilizados na cobertura de edificações.

Visando suprir as dificuldades encontradas para separar solo exposto e superfície impermeável e trazendo também o argumento de que sombra é um importante componente das imagens urbanas, possível de ser detectado pelos sensores óticos, Lu e Weng (2004) chegam a propor um novo modelo conceitual baseado no modelo V-I-S.

Os melhores resultados na classificação de superfície impermeável foram apresentados nos trabalhos de Cablk e Minon (2003), Gluch et al. (2006), Hester et al. (2008), Lee (2005), Lu e Weng (2006), Rashed (2003), Thanapura et al. (2007), Wu (2004), Yuan e Bauer (2007), Yuan (2008), dentre trabalhos que apresentaram valores de acurácia, todos com acurácia igual ou superior a $90 \%$.

Entre esses, Gluch et al. (2006), Lu e Weng (2006), Rashed (2003) e Wu (2004) utilizaram o modelo V-I-S. Yuan (2008) foi o único deles que utilizou a classificação baseada em objeto, recorrendo a atributos de hierarquia e contexto, além de informação espectral, para 
detecção de mudança entre superfície impermeável, vegetação e água. Outros três estudos classificaram superfície impermeável, mas não apresentaram valores de acurácia para esta classe.

Segundo Weng (2008), nos últimos anos, superfícies impermeáveis têm emergido não apenas como um indicador do grau de urbanização, vide estudo apresentado por Yang et al. (2003), mas também como um dos principais indicadores de qualidade ambiental, em especial no que diz respeito a impactos na dinâmica de bacias hidrográficas. A magnitude, localização, geometria e padrão espacial de superfícies impermeáveis e a razão entre superfície permeável e impermeável em uma bacia são fatores que têm impactos diretos na qualidade da drenagem.

Na classificação do sistema viário, dentre os trabalhos que realizaram testes de acurácia os melhores resultados aparecem no artigo de Chou et al. (2005) que aplicou a técnica de classificação supervisionada pixel a pixel em imagens SPOT, utilizando complementariamente fotografias aéreas e base cartográfica para identificar o sistema viário com $100 \%$ de acurácia.

Puissant (2005) conseguiu extrair com 99\% de acurácia o sistema viário de uma área central de Strasburg, França, utilizando classificação supervisionada pixel a pixel em bandas multi-espectrais de imagem SPOT combinadas a uma imagem de textura. $\mathrm{O}$ autor utilizou a mesma cena para treinamento e controle dos resultados, assim como Fauvel (2006), sendo que este propôs o uso de um método que chamou de regra de combinação fuzzy e obteve $94 \%$ de acurácia na detecção das estradas.

Em análise da biblioteca espectral de materiais presentes no ambiente urbano, Herold et al. (2004) constatou que vias pavimentadas, seja com concreto ou asfalto, é um dos componentes urbanos que apresenta maior conflito com outras classes ${ }^{18}$. Do ponto de vista da resposta espectral, telhado cinza e outros materiais escuros também apresentam uma baixa separabilidade com outros materiais do ambiente urbano.

Para a detecção de edificações em geral, o resultado mais significativo foi obtido por Shackeford et al. (2003a), que usou uma regra de classificação hierárquica com lógica fuzzy em áreas de duas cidades norte americanas, Springfield e Columbia.

\footnotetext{
${ }^{18}$ Vias não pavimentadas não fizeram parte das análises de Herold et al. (2004).
} 
Edificações foram classificadas em 28 dos trabalhos levantados, 13 destes utilizam a metodologia de classificação baseada em objeto, recorrendo principalmente a informações de forma e contexto.

Para o reconhecimento de edificações o uso de informações complementares, como base de quadras (PINHO, 2005) e modelo digital de superfície (LU et al., 2006), comprovaram melhorar, significativamente, o resultado da classificação.

Entre os trabalhos que apresentaram os resultados de testes de acurácia, três obtiveram percentuais superiores a $90 \%$ de acurácia para a classificação de grandes edificações: Benediktsson et al. (2003) e Chanussot et al. (2006), que utilizaram técnicas de redes neurais e de morfologia de objetos combinadas a outros recursos para atingir esses resultados, e Fauvel et al. (2006), que utilizou um modelo que combina redes neurais e classificadores fuzzy.

Como pode ser observado no Quadro 2.6, a vegetação é a componente urbana mais presente nos estudos levantados. Tradicionalmente o SR tem focado inúmeros esforços no desenvolvimento de técnicas e equipamentos de identificação e qualificação da vegetação. A parte da inquestionável importância da vegetação para a vida na cidade e para o entendimento do tecido urbano, a média elevada dos testes de acurácia realizados com esta classe deve-se em parte à facilidade na sua identificação, ao menos em se tratando de estudos com sensores multi ou ultra-espectrais (que permitem o uso de índices de vegetação baseados em bandas infra-vermelhas). Observa-se ainda que informações de textura foram frequentemente utilizadas em estudos que realizaram a distinção entre diferentes portes de vegetação.

Nos experimentos de Walker e Blaschke (2008), a vegetação arbórea apresentou um elevado grau de confusão com superfícies impermeáveis. Segundo os autores, uma combinação de fatores pode levar a esse resultado, em especial a semelhança na absorção espectral de superfícies asfaltadas escuras e vegetação e a mistura espectral presente em objetos que são copas de árvores sobre a rua.

Walker e Blaschke (2008) afirmam que para qualquer estudo de vegetação, a disponibilidade de informação na banda infravermelha é sempre desejável, mas estudos como o seu, a exemplo do estudos de Kressler et al. (2005), Lang and Langanke (2006) e Walker and Briggs (2007), demonstram o potencial do uso de procedimentos de classificação baseada em objeto para suprir essa carência em certas imagens de alta resolução espacial. Kressler et al. (2005), entre outros, desenvolveu experimentos em 
ortofotografias com apenas as bandas visíveis, confirmando, segundo Walker e Blaschke (2008), que o procedimento pode ser adaptado para esse tipo de imagem.

Indiscutivelmente o NDVI (Normalized Difference Vegetation Index) é o índice mais utilizado para identificar vegetação na superfície terrestre. O NDVI foi desenvolvido pela agência Norte-americana NASA (National Aeronautics and Space Administration) que visava explorar a capacidade de imageamento do recém lançado satélite LANDSAT-1.

O NDVI foi formulado partindo do princípio de que plantas verdes (com clorofila) aparecem relativamente escuras nas faixas onde a radiação fotossintética é ativa e relativamente clara na faixa infravermelha, sendo, portanto, uma equação que mede a relação entre essas duas faixas do espectro, como apresentado na Figura 2.30.

a)

$$
\text { NDVI }=\frac{(\text { Infravermelho }- \text { Vermelho })}{(\text { Infravermelho }+ \text { Vermelho })}
$$

b)

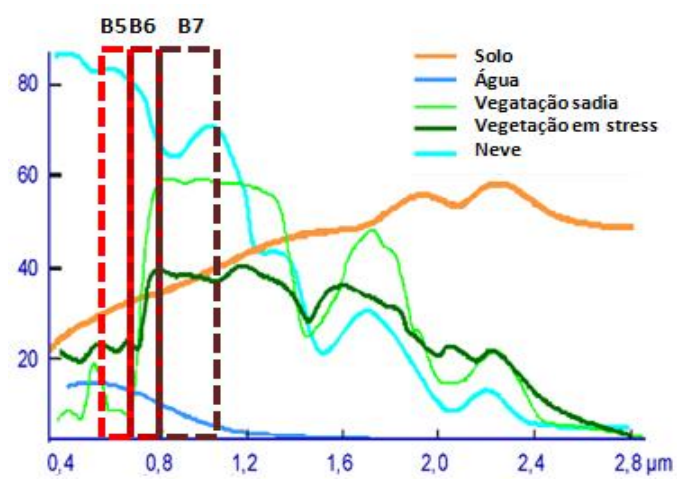

c)

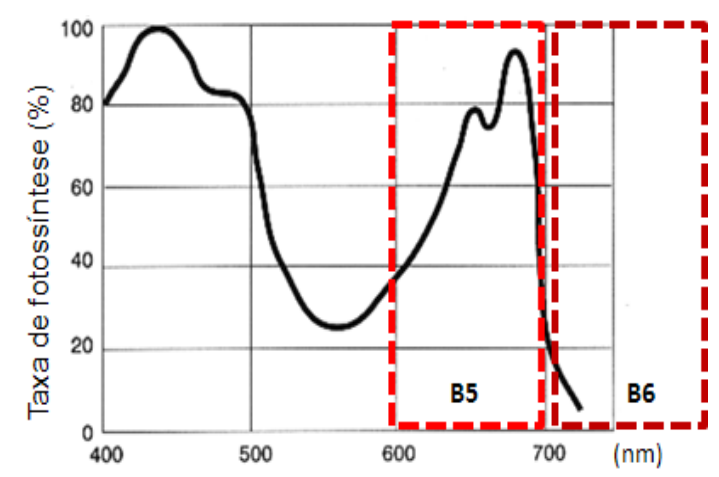

Figura 2.30. a) Fórmula do NDVI, b) Modelo genérico da assinatura espectral de água, solo, vegetação sadia e vegetação sob stress e janela espectral da banda vermelha (B5: $0.60-0.70)$ e bandas infravermelhas (B6: 0.70 - 0.80 e B7: 0.80 - 1.10) do sensor MSS do LANDSAT-1. Fonte: adaptada de Boschetti (2008), c) espectro ativo da fotossíntese e janela espectral das bandas 5 e 6 do sensor MSS do LANDSAT-1. Fonte: adaptada de Whitmarsh e Govindjee (1999).

Assim, o NDVI de uma área com alta densidade de vegetação "verde" tenderá a valores positivos (em torno de 0.3 a 0.8 ) enquanto nuvens e áreas cobertas com neve deverão apresentar valores negativos.

O NDVI é muitas vezes usado para identificar também água, que tem geralmente valores baixos nas duas faixas do espectro, e para identificar solo exposto, que exibe, na maior parte dos casos, reflectância no infravermelho próximo um pouco superior que a faixa do vermelho.

A popularidade do NDVI dá-se à sua simplicidade e capacidade de apoiar a análise de importantes elementos da superfície terrestre. Entretanto, a utilização do NDVI também tem 
limitações e deve ser considerada com cautela, principalmente em relação a variações atmosféricas (relativadas, por exemplo, a concentração de vapor d'água e aerossois), presença de nuvens, variação do solo (quando úmidos ou com outros tipos de alteração), variação de luminosidade e variação nas propriedades das bandas vermelha e infravermelha de outros sensores, que não o MSS do LANDSAT 1.

Uma série de índices predecessores, alternativos e derivados do NDVI já foram propostos pela comunidade científica, muitos visam principalmente suprir essa limitações.

Perpendicular Vegetation Index (PVI), Soil-Adjusted Vegetation Index (SAVI), Atmospherically Resistant Vegetation Index (ARVI), Global Environment Monitoring Index (GEMI), Fraction of Absorbed Photosynthetically Active Radiation (FAPAR), Normalized Differenced Green Red Vegetation Index (NDGRVI), Red Edge Vegetation Stress Index e o Índice de Clorofila (Cl) são alguns exemplos de índices de vegetação formados com operações entre bandas que consideram um ou mais dos fatores de perturbação do cálculo do NDVI, para uma única cena ou para aplicações comparativas (entre diferentes áreas ou diferentes períodos).

Alguns desses índices buscam aproveitar os avanços tecnológicos na área de SR ou adaptar a limitações de novas e velhas fontes de informação, como as imagens de alta resolução espacial e baixa resolução espectral. Quando não há a disponibilidade da banda infravermelha, Moller e Blaschke (2006), por exemplo, propõem o uso de um índice que não é tão eficiente quanto o NDVI, mas que ajuda a suprir a falta da banda infravermelha na identificação de vegetação, o índice verde NDGRVI, cuja formula é: (BandaVerde BandaVermelha) / (BandaVerde + BandaVermelha).

De acordo com Colwell (1974) ${ }^{19}$ apud Nichol e Lee (2005) o Índice de Clorofila (razão entre a banda verde e a banda vermelha) pode ser uma melhor medida que o NDVI em áreas urbanas, porque quando o fundo é claro e a área de folha é pequena, a relação negativa entre o índice da área de folhagem e a REM na faixa do vermelho, pode ser mais significativa que a relação entre a área de folhagem e a REM na faixa do infravermelho. Isso provavelmente deve explicar porque este índice apresenta melhor separabilidade entre vegetação rasteira e árvores no experimento de Nichol e Lee (2005) em Hong Kong.

Para separar vegetação rasteira de arbórea é comum encontrar trabalhos que utilizam dados de textura, como fez Kux e Araújo (2008), Walker e Briggs (2007), por exemplo.

${ }^{19}$ COLWELL, J. E. Grass canopy bi-directional spectral reflectance. In: Proceedings of $\mathbf{9}^{\text {th }}$ International Symposium on Remote Sensing of Environment, Ann Arbor, MI, USA: University of Michigan, 1974. pp. 1061-1085. 
Quanto à classificação de superfícies cobertas com áqua, observa-se que a acurácia obtida é bastante elevada. Na maior parte dos trabalhos que apresentaram os valores de acurácia para essa classe, os valores foram superiores a 95\%. No entanto, a turbidez causada principalmente pela poluição de corpos d'água urbanos dificulta bastante a identificação deste elemento, em especial quando não se pode contar com bandas nas faixas do infravermelho médio (Figura 2.31). Corpos d'água muito estreitos também podem ser totalmente cobertos por sombra ou pela copa de árvores, impossibilitando sua identificação em imagens aéreas ou orbitais. Sawaya et al. (2003), ao classificar água turva, limpa e com vegetação em imagens IKONOS e QuickBird, utilizando a técnica de classificação supervisionada, observou que pixels de asfalto, sombra e outros elementos escuros são muitas vezes classificados como água, devido à alta absorção de REM.

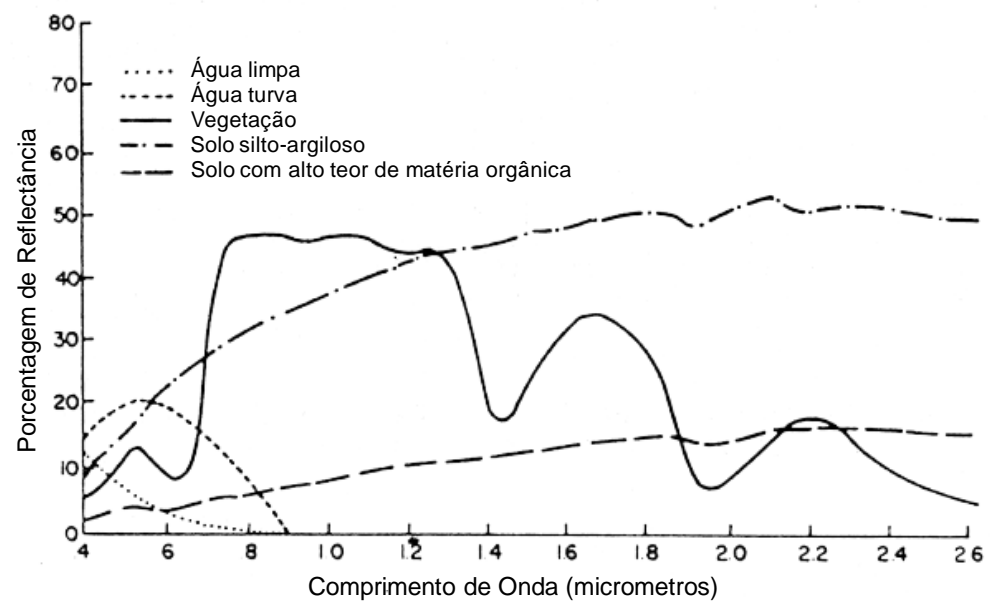

Figura 2.31. Assinatura espectral da água limpa, água turva e outras coberturas do solo. Fonte: Meaden (1995).

Com foco na identificação de água, e até mesmo na sua qualificação quanto a turbidez, Gao (1996) propôs o Normalized Difference Water Index (NDWI) definido pela fórmula: $(\mathrm{p}(0.86$ $\mu \mathrm{m})-\mathrm{p}(1.24 \mu \mathrm{m})) /(\mathrm{p}(0.86 \mu \mathrm{m}+\mathrm{p}(1.24 \mu \mathrm{m}))$, que pode ser lida: (NIR - SWIR) / (NIR + SWIR), onde NIR significa refração do infravermelho próximo e SWIR do infra vermelho ondas curtas. Para classificar água em seus estudos, Zha et al. (2003) e Chen et al. (2006) utilizam o NDWI calculado pela relação das bandas 4 e 5 do LANDSAT 7 ((banda 4 banda 5) / (banda 4 + banda 5)).

Em relação à classificação de áreas de sombra, observa-se que $80 \%$ dos trabalhos do Quadro 2.6 que classificaram essas áreas, o fizeram em imagens de resolução métrica, indicando que esta é um elemento urbano que vem despertando interesse com a evolução da resolução espacial das imagens de SR. 
Os principais objetivos dos autores em identificar sombra deve-se principalmente ao fato de tratar-se de um indicador de componentes urbanos tridimensionais, como árvores (KUX e ARAÚJO, 2008) e edificações (XIAO et al., 2008), e à preocupação com o cálculo e análises da cobertura do solo, visto que o elemento sombra não é um material. A preocupação estende-se também aos estudos de detecção de mudança, uma vez que a sombra irá variar com o horário do dia, a estação e o ângulo do sensor.

Rashed et al. (2003), Rashed et al. (2005), Thang et al. (2007) e Lu e Weng (2004) acreditam que a sombra é um elemento tão importante para a análise de imagens urbanas que o modelo V-I-S, proposto por Ridd (1995), deveria incluí-la, para alcançar uma caracterização mais acurada da morfologia urbana.

Visando contornar esse tipo de problema pesquisadores, a exemplo de Dare (2005) e Tsai (2006), vêm estudando formas de melhor compensar os efeitos negativos da ocorrência de sombras, em especial em áreas de grande densidade urbana, criando técnicas de reconhecimento da cobertura do solo nas áreas sombreadas.

Nobrega (2008), ao classificar sombra em uma imagem IKONOS da periferia de São Paulo, utilizando a abordagem baseada em objeto, propõe a criação de um indicador de sombra que visa aumentar a diferença existente entre essas áreas de sombra e áreas cujas coberturas do solo têm baixa reflexão, como asfalto e água. O indicador é calculado pelo nível de cinza médio na banda azul menos o nível de cinza médio da primeira componente principal.

No processo de levantamento dos artigos para a revisão sistemática apresentada no Quadro 2.6, deparou-se com uma grande quantidade de trabalhos sobre variações térmicas do espaço urbano. A maior parte desses trabalhos tenta identificar correlações entre usos e cobertura do solo e o fenômeno de formação de ilhas de calor.

As ilhas de calor são alterações atmosféricas e da superfície causadas pela urbanização, que geralmente leva à elevação térmica, especialmente à noite. A temperatura da superfície é de grande importância para o estudo da climatologia urbana, pois modula a temperatura do ar das camadas mais baixas da atmosfera da cidade, interferindo direta e indiretamente no conforto da população urbana (VOOGT e OKE, 2003). Baseando-se em extensa revisão bibliográfica, Voogt e Oke (2003) advertem que ainda há muito que se pesquisar nessa área, principalmente com o advento do lançamento na nova geração de sensores com alta resolução espacial e maior resolução espectral. 
No mesmo processo de levantamento deparou-se também com muitos estudos de crescimento urbano, que não fizeram parte do levantamento por não analisarem o espaço intra urbano, foco deste trabalho. Ainda assim são inúmeros os trabalhos (22 artigos) desenvolvidos com o objetivo de quantificar, localizar e qualificar o crescimento urbano através de técnicas de SR para detecção de mudanças. Ridd (1995) enfatiza a importância de tais pesquisas para o planejamento urbano, uma vez que podem servir para estudos (i) retrospectivos, mudanças históricas, (ii) de monitoramento ou mudanças atuais, (iii) preditivos ou de mudanças futuras. Ainda que este tema não seja abordado diretamente pela maior parte dos artigos levantados ou por esta pesquisa, em especial, é consenso que os esforços realizados para a consolidação de metodologias e processos de leitura do espaço urbano são o primeiro passo para a realização dos estudos de monitoramento.

$\mathrm{Na}$ área de pesquisa e desenvolvimento, medidas de acurácia são fundamentais para avaliar o desempenho de (novos) sistemas sensores e métodos (SCHIEWE e Gahler, 2008). Observa-se no Quadro 2.6 que a análise Kappa é o método mais utilizado como medida de acurácia. Grande parte dos trabalhos apresenta ainda a matriz de confusão, acurácia do produtor e do usuário e acurácia geral obtida, algumas vezes apresentando essa última como resultado final da avaliação da classificação.

A matriz de confusão, também chamada matriz de erro ou tabela de contingência, é uma forma bastante efetiva de representar a acurácia de um mapa, pois apresenta a acurácia de cada classe, além dos erros de comissão (pixels e objetos de outras classes incluídos na classe em análise) e omissão (pixels e objetos que deveriam pertencer à classe avaliada que não foram classificadas como tal). A matriz de confusão consiste no conjunto de números, dispostos em número igual de colunas e linhas, que expressam o número de unidades de amostras (pixels, clusters, polígonos) de uma determinada classe em relação ao número de amostras de determinada classe em uma outra classificação. Na maior parte dos casos, uma dessas classificações é considerada correta e pode ser gerada com base em dados de campo, interpretação visual da imagem em análise, imagens de maior resolução espacial ou videografia, por exemplo (CONGALTON e GREEN, 1999; LILLISAND et al., 2008).

A acurácia geral, obtida a partir da matriz de confusão é a razão entre o número total de pixels ou objetos classificados corretamente e o total de pixels em cada classe, no universo amostrado. A acurácia do usuário e do produtor é relativa aos erros de comissão e omissão respectivamente, isto é, leva em conta apenas os erros de comissão ou erros de omissão, como apresentado na Figura 2.32 (SKIDMORE, 1999). 

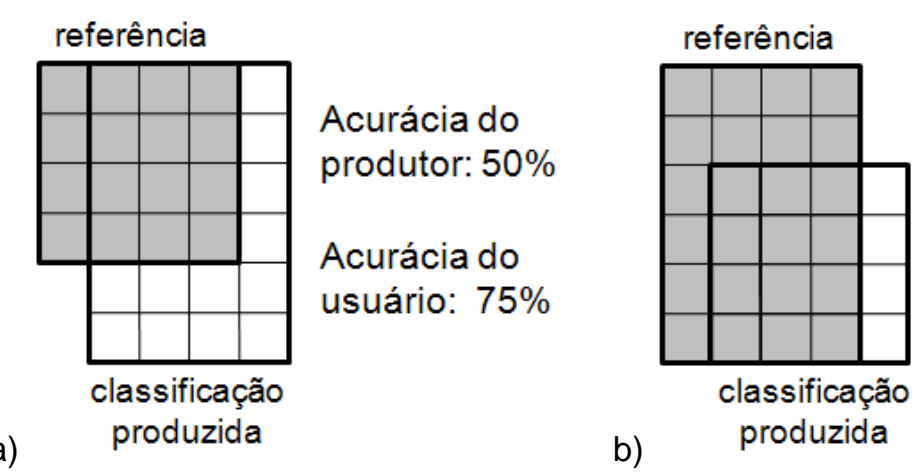

Acurácia do

produtor: $75 \%$

Acurácia do

usuário: $50 \%$

Figura 2.32. Diagrama esquemático da acurácia do produtor e acurácia do usuário. a) Produtor "acertou" a classificação de $50 \%$ dos pixels ou objetos e apenas $25 \%$ do total de unidades foi omitido.

b) Produtor "acertou" a classificação de $75 \%$ dos pixels ou objetos, mas omitiu $50 \%$ do total de unidades. Fonte: Brito (2010)

A análise Kappa é uma técnica multivariada discreta, utilizada na avaliação de acurácia para determinar estatisticamente se uma matriz de erro é significativamente diferente da outra. Em SR, isto que dizer que é uma medida baseada: i) na concordância entre a classificação digital e a classificação de referência (diagonal da matriz de erro) e ii) na probabilidade de concordância (linhas e colunas marginais com o somatório de unidades) (Congalton e Green, 1999). Em outras palavras, o coeficiente Kappa ajusta o valor da acurácia geral subtraindo a contribuição estimada da probabilidade de concordância entre unidades classificadas e unidades de referência (CAMPBELL, 1996).

Schiewe e Gahler (2008) alerta que há inúmeros problemas que podem estar associados à avaliação da acurácia de produtos de SR, principalmente quando se trabalha com imagens de alta resolução espacial. Na avaliação da acurácia pós-classificação, geralmente métodos mais conhecidos são aplicados, como a matriz de confusão e o coeficiente Kappa, mesmo considerando a classificação em imagens de alta resolução espacial e técnicas de classificação de segmentos. Ao aplicar esses métodos de acurácia nesses tipos de classificação, assume-se que existem limites claros entre regiões (quanto maior a resolução espacial da imagem, maior pode ser esse problema), que o mapa de referência não possui erros, entre outros problemas. Segundo Schiewe e Gahler (2008), softwares comerciais ainda não estão preparados para lidar com essa diversidade e mais estudos precisam ser desenvolvidos nesse sentido.

Assim, o levantamento bibliográfico mostra que inúmeros métodos de classificação urbana têm sido propostos na literatura de SR, exatamente como argumentou Fauvel et al. (2006), na maior parte dos casos eles consistem na extração de feições, seguido pela aplicação de algoritmos de classificação, mas não se pode afirmar que um seja irrestritamente superior aos demais, pois cada um tem suas características e aplicabilidades específicas. 
O levantamento sistemático também ratifica algumas das conclusões apresentadas após a realização do workshop Earth Observation for Urban Planning and Management em Hong Kong, 2006. Alguns dos principais pesquisadores da área (NICHOL et al., 2007) apresentaram documento síntese, no que concluem, entre outras coisas, que a tecnologia de aquisição de imagem não é mais um entrave para a realização dos estudos urbanos, mas que a popularização do SR para esse fim depende, principalmente, do maior conhecimento sobre o assunto por parte dos profissionais da área, da redução de custos, e da facilidade de integração das técnicas de SR com procedimentos de trabalhos existentes. Nesse sentido, os autores recomendam e ressaltam a importância de estudos de caso:

"Na prática, ações no nível local tem mais chances de serem mais efetivas e o uso de estudos de casos é recomendado. A fim de otimizar tais iniciativas, a continuação das pesquisas é essencial para aumentar a automação do modelamento tridimensional de cidades e do mapeamento do uso do solo a partir de imagens de alta resolução. No entanto, dado a particularidade de cada cidade, o desenvolvimento de algoritmos de "caixa preta", implicando na completa automação, não é possível nem desejável e pesquisadores são encorajados a trabalhar com usuários finais a fim de desenvolver soluções locais realísticas" (NICHOL et al., 2007)

Com o levantamento observa-se ainda que, em geral, a classificação baseada em objetos em imagens de alta resolução espacial oferece mais instrumentos para o estudo detalhado do espaço intra-urbano, principalmente por sua capacidade de assumir variações espectrais dentro de um mesmo objeto e de considerar as características espaciais de contexto e forma presentes no meio modificado pelo homem. O elevado número de estudos ainda realizados com imagens LANDSAT se justifica, na maior parte dos casos, pela facilidade de acesso a tais imagens e grau de consolidação e difusão das técnicas que exploram os produtos desse satélite. Nesses estudos com LANDSAT, observa-se que as análises intraurbanas são mais restritas e que utilizam majoritariamente a abordagem pixel a pixel, mas que, por outro lado, podem ser mais custo efetivas, a depender do objetivo da análise e das características da área estudada. Um dos principais problemas atribuídos a este tipo de análise diz respeito à similaridade espectral de diferentes elementos, como solo e telha, ruas e edifícios, sombra e asfalto, compostos em alguns casos por materiais semelhantes, que dificultam a sua classificação.

Somada à complexidade comumente encontrada nas imagens urbanas, deve-se ressaltar que as áreas focos de estudos de doenças como a leptospirose apresentam ainda maior complexidade, por estar socialmente relacionada a classes sociais mais baixas e consequentemente a situações de ocupação irregular. O uso de SR no estudo de áreas 
informais representa um grande desafio e, ao mesmo tempo, consiste em uma poderosa ferramenta de monitoramento das áreas mais precárias e dinâmicas das cidades (HURSKAINEN e PELLIKKA, 2004)

\subsubsection{SR em estudos epidemiológicos urbanos}

"Relação entre características descritoras da paisagem ambiental e ocorrências de doenças endêmicas é mediada pela estrutura demográfica da população e pelo perfil socioeconômico local, atuando sobre a suscetibilidade e as possibilidades de contato com vetores e reservatórios. $O$ uso de sensoriamento remoto por imageadores orbitais se apresenta como uma possibilidade metodológica, que permite a caracterização das variáveis ambientais de interesse em estudos de endemias." (CORREIA et al., 2007, p. 1015)

Com o objetivo de identificar estudos epidemiológicos, que foram realizados em áreas urbanas e que utilizaram processamento de imagens multi-espectrais, orbitais ou aéreas, com as técnicas levantadas na seção anterior, foi realizada a revisão bibliográfica sistemática apresentada no Quadro 2.7.

Essa revisão se propõe a dar continuidade à revisão bibliográfica realizada por Correia et al. (2004), que cobriu o período de 1996 a 2002, buscando estudos epidemiológicos que tenham utilizado $\mathrm{SR}^{20}$. A grande maioria das aplicações encontradas pelos autores referiase à escala continental, poucas tratavam de áreas urbanas e nenhum estudo utilizava imagens dos satélites IKONOS ou QuickBird.

A presente revisão não restringiu o período em anos pesquisado, mas, assim como Correia et al. (2004), utilizou como fonte a PUBMED/MEDLINE, buscando artigos com as palavras chave: "remote sensing" ou "IKONOS" ou "QuickBird" ou "satellite SPOT" e "urban" ou "city", focando o levantamento na identificação de análises intra-urbanas, com uso de imagens de alta resolução espacial.

No website do CHAART (Center for Health Aplications of Aerospace Related Technologies), utilizado por Correia et al. (2004), não foi encontrado nenhum artigo relacionado a estudos epidemiológicos em áreas urbanas. A última atualização do website data de agosto de 2006, sendo poucas publicações dos anos de 2003 e 2004 e nenhuma de 2005 ou 2006.

${ }^{20}$ Correa et al. (2004), por sua vez, considera seu estudo uma continuação do trabalho desenvolvido por Beck et al. (2000). 
Quadro 2.7. Revisão Bibliográfica - Fatores de risco epidemiológico, relacionados ao ambiente urbano, identificados com uso de processamento de imagens satélite multi-espectrais ou fotografias aéreas.

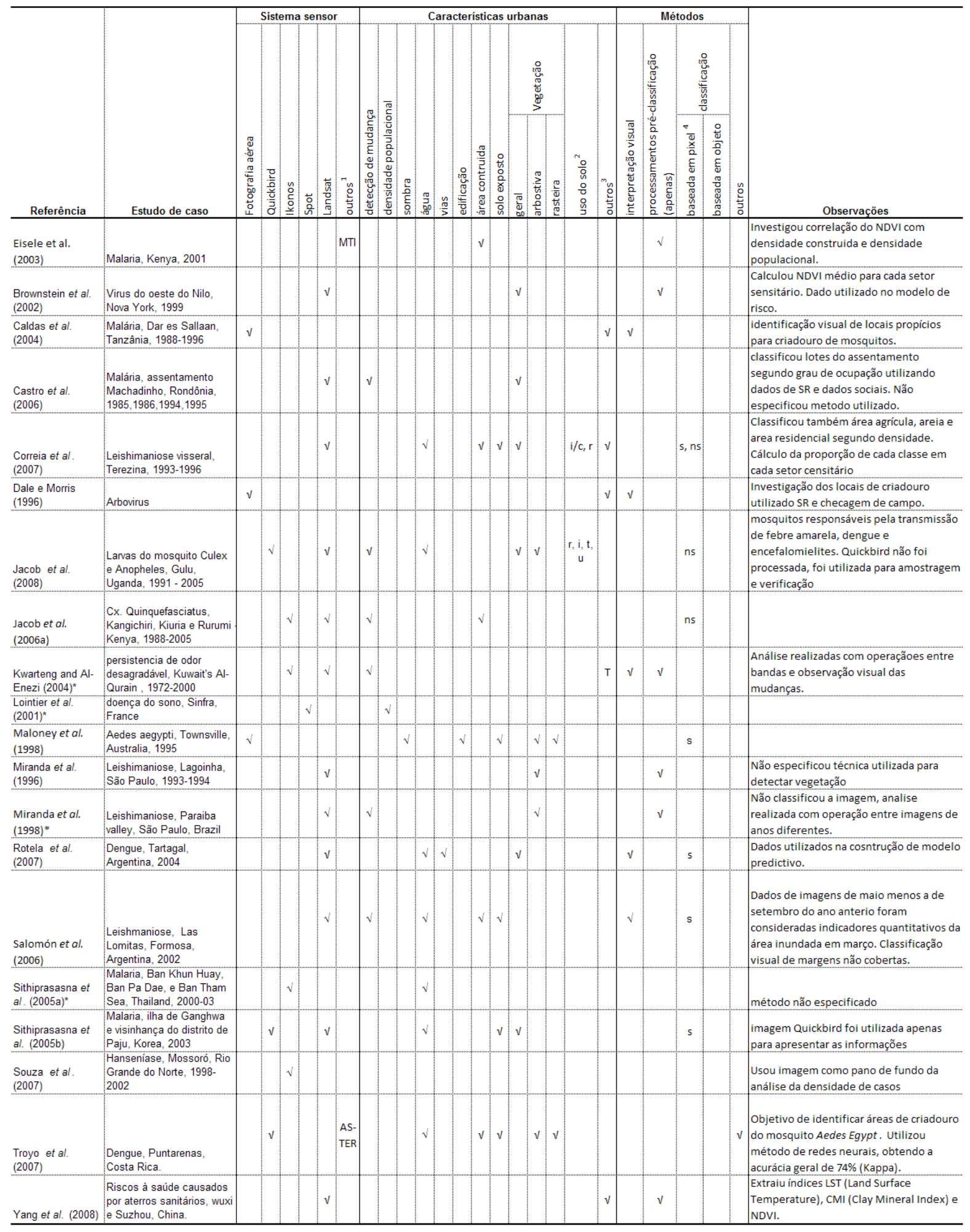

Nota: (1) Sistema sensor MTI: Multispectral Thermal Imager. (2) Uso do solo: $r$ - residencial, $i$ - industrial, $t$ transporte, u - comunicação e grandes equipamentos, i/c - indústria e comércio; (3) Outros: T - temperatura; (4) Método de classificação baseado em pixel: s - classificação supervisionada, ns - classificação nãosupervisionada. 
No Quadro 2.4, observa-se que mais da metade dos estudos utilizaram imagens LANDSAT, sendo que um terço destes também recorreram a imagens de alta resolução espacial, fotografias aéreas, QuickBird ou IKONOS.

Os fatores urbanos mais investigados foram, em ordem decrescente: vegetação, variação de cobertura do solo (detecção de mudança), corpos d'água, áreas de solo exposto e área construída.

A maior parte dos estudos não realizou a classificação das imagens. Os dados de SR utilizados para a análise foram extraídos (em número aproximadamente igual de artigos) através de interpretação visual, operação entre bandas (em especial para cálculo de NDVI) e métodos tradicionais de classificação pixel a pixel. Nenhum dos artigos encontrados utilizou metodologia de classificação baseada em objeto.

Quase a totalidade dos estudos encontrados refere-se a doenças transmitidas por mosquitos. Muitos estão diretamente relacionados com processos de expansão urbana, como a derrubada de matas, desequilíbrio ecológico e consequente ocorrência de casos de malária e leishmaniose, por exemplo. Por isso, o interesse em procedimentos de detecção de mudanças e identificação de vegetação.

A dengue também tem sido investigada no ambiente urbano de diferentes continentes, em geral, buscando identificar áreas de criadouro do mosquito Aedes aegypti. Demais estudos de doenças transmitidas por mosquitos também focam na identificação de criadouros, que estão relacionados, na maior parte dos casos à presença de água.

Rotela et al. (2007) foi o único trabalho encontrado que relata a identificação de vias em imagem de SR e o uso dessa informação para análises epidemiológicas. Em seu trabalho, vias principais e estradas foram identificadas visualmente e utilizadas na construção da variável distância de vias, parte do modelo preditivo de transmissão da dengue desenvolvido pelos autores. As variáveis foram apresentadas em camadas (raster) e comparadas a clusters (espaço temporais) de casos.

Maloney et al. (1998) já não teve o mesmo sucesso com uso de SR para avaliação de risco de transmissão da dengue. Em seu estudo foram utilizadas imagens de alta resolução espacial, fotografias aéreas com canais do espectro visível e infravermelho, na tentativa de identificar características urbanas relacionadas a focos de dengue. No entanto, não foi encontrada nenhuma correlação significativa entre as informações extraídas das imagens e o habitat do mosquito, sugerindo, segundo o autor, que essa questão está relacionada a um nível inferior de análise (ambiente domiciliar). 
Entre os trabalhos levantados, apenas Jacob et al. (2008) e Correia et al. (2007) propuseram a utilização de informações de uso do solo, extraídas de imagens LANDSAT, para estudos ecológicos relacionados à saúde pública.

Jacob et al. (2008) buscou caracterizar o habitat das larvas de mosquitos transmissores de doenças como a febre amarela, dengue e encefalomielites. Para isso, utilizou classificação não supervisionada (ISOSEG) para identificar área residencial e área industrial, além de água e vegetação. Os autores realizaram um grid de $150 \mathrm{~m}$ x 150m como unidade espacial das análises.

Correia et al. (2007) comparou quatro classificadores baseados em pixel, Maxver, Bhattacharya, K-médias e Isoseg afim de reconhecer as classes melhor identificáveis em área urbana, com uso de imagem LANDSAT-7, sendo elas: água, área construída descoberta, agricultura, banco de areia, industrial/comercial, residencial densa, residencial esparsa muito verde, residencial muito verde, residencial verde, solo, vegetação densa.

"Mesmo dispondo-se de recursos limitados, imagens de baixo custo, ampla disponibilidade de média resolução, sistemas abertos e livres para processamento e integração das informações, é possível identificar as características de ocupação do solo de interesse potencial na análise de riscos ambientais para a ocorrência de endemias urbanas transmitidas por vetores." (CORREIA et al,. 2007, p. 1026)

Os autores reconhecem que há restrições quanto ao uso de classificadores baseados nas informações espectrais de sensores de média resolução em áreas urbanas. Esses classificadores mostram a "dificuldade em discriminar padrões importantes para a leishmaniose, tais como os diversos tipos de solo: urbano, não urbano, com pouca vegetação, áreas agrícolas de áreas rurais com muita vegetação e habitações esparsas" (CORREIA et al,. 2007, p. 1025)

Salomóns et al. (2006) investigou um tipo diferente de leishmaniose, a leishmaniose tegumentária. Seu estudo, todavia, se restringiu à identificação da área de rio (valores radiométricos entre 0 e 22 da banda do infravermelho médio) em imagem LANDSAT, e à classificação da área sem vegetação do entorno do rio, utilizando interpretação visual.

Em Jacob et al. (2006), foi apresentado um estudo realizado em três vilas no Kênia. Neste estudo foi realizado o mapeamento de plantações de arroz e de outros tipos de uso do solo em diferentes momentos, inferindo através dos mesmos qual mudança de uso do solo estava correlacionada com a alta densidade de mosquitos Cx. Quinquefasciatus (que podem transmitir a malária, além de outras doenças). Por esse motivo, foram identificadas, 
através de classificação não supervisionada utilizando máxima verossimilhança, três classes: duas relacionadas à plantação de arroz e uma de ambiente construído. Nesse estudo foram utilizadas uma imagem LANDSAT de 1988 e uma imagem IKONOS de 2005.

Como pode ser observado, nenhum dos levantamentos bibliográficos realizados encontrou trabalhos que tenham utilizado de processamento de imagens de SR em estudos urbanos da leptospirose. No entanto, a doença apresenta características que merecem ser investigadas com o uso desse recurso.

\subsubsection{SR em estudos urbanos da leptospirose}

A avaliação dos dados apresentados nas revisões bibliográficas sistemáticas, resumidas no Quadros 2.1 sobre leptospirose e áreas urbanas, Quadro 2.6 sobre SR e análises urbanas e Quadro 2.7 sobre estudos urbanos epidemiológicos com SR, indica alguns caminhos que podem ser trilhados no estudo das características urbanas que são possíveis de ser identificadas através de SR e que estão relacionadas com a transmissão da doença.

Comparando as características urbanas exploradas nos artigos citados nas revisões de SR, Quadros 2.1 e 2.7, independente do número de artigos em cada, pode-se dizer que nos estudos epidemiológicos (Quadro 2.7) são apresentados artigos que investigaram menor quantidade de características urbanas e ao mesmo tempo características que podem ser consideradas mais comuns a ambientes não urbanos. Isso pode ter ao menos duas explicações: os estudos epidemiológicos (Quadro 2.7) enfocam características específicas que estão relacionadas a um determinado vetor; outra possibilidade que predomina nesses estudos é o uso de imagens consideradas de média resolução espacial para análise intraurbana (LANDSAT), dificultando a identificação detalhada de elementos e padrões nesse meio.

Por outro lado, quando utilizado imagens de maior resolução espacial (fotografia aérea, IKONOS e QuickBird) a maior parte dos estudos do Quadro 2.7 aplicou técnicas de interpretação visual, visto a dificuldade de tratar a heterogeneidade do espaço intra-urbano (TATEM et al., 2004). Apenas um trabalho foi encontrado utilizando o sensor de resolução intermediária, SPOT (LOINTIER et al., 2001).

Considerando os estudos não restritos à área urbana observa-se também uma escassez de trabalhos que utilizaram imagens deste satélite. Na revisão realizada por Correia et al. (2004), entre 1996 e 2000, foram encontrados cinco artigos (8\% dos artigos listados) que 
utilizaram o sensor XS do satélite SPOT, quatro destes estudos foram sobre a malária, dois na América Central e dois na África, e um outro sobre Febre $Q$ na França. A resolução espacial desse sistema sensor, de 4 metros da banda pancromática e de 10 metros das demais (vermelha, verde, azul e infravermelho), oferece um nível de detalhamento do espaço intra-urbano que pode ser mais explorado em estudos urbanos.

A variação do aspecto da cobertura do solo aparece como uma importante informação a ser extraída das imagens ao se tratar de estudos epidemiológicos. Especificamente no estudo da leptospirose, esse tipo de análise pode identificar áreas que foram afetadas por inundação, importante fator de risco de transmissão da doença. Esse tipo de análise foi realizado por Salomón et al. (2006), ainda que, no trabalho apresentado, os autores utilizaram interpretação visual para classificar a cobertura do solo nas margens do rio.

Há, entretanto, uma grande dificuldade de se estudar áreas alagadas nas cidades do nordeste brasileiro por meio de detecção de mudança nas imagens. A maior parte dos satélites privilegia em sua órbita o imageamento do hemisfério norte, passando pelo Brasil em um horário onde a evapotranspiração dos mares, corpos d'água e matas causam a formação de nuvens. Há uma dificuldade natural em se encontrar imagens "limpas" e a dificuldade é ainda maior quando se restringe essa busca a um par de imagens anterior e posterior a um período chuvoso.

O uso de modelo digital de terreno (MDT), no ambiente SIG, pode ser um recurso complementar ou alternativo para a identificação de áreas sujeitas a alagamento. $O$ reconhecimento de superfície impermeável por meio de SR (LEE e LATHROP, 2006; SHACKELFORD et al., 2003a) combinada com as cotas mais baixas (REIS et al., 2008) pode significar uma maior probabilidade de ocorrência de tal evento. Nesses casos, depoimentos da população residente na área ou visita de campo durante a ocorrência de chuvas são dados complementares bastante úteis para a verificação da existência e funcionamento do sistema de drenagem ou para verificação da cota de alagamento.

Entre as técnicas de processamento de imagens em áreas urbanas, assim como em estudos regionais e continentais, o NDVI também aparece com grande frequência. É interessante notar que, nos estudos urbanos, o NDVI é utilizado não apenas para medir vegetação como produto final, mas é utilizado, principalmente, para identificar homogeneidade urbana e densidade ocupacional (EISELE et al., 2003) (GREENHILL et al., 2003) (TAUBENBÖCK et al., 2006). No entanto, o índice é composto por valores das bandas dos canais vermelho e infravermelho, sendo que esta última não costuma ser disponibilizada em levantamentos aerofotogramétricos contratados pelas prefeituras para 
fim de cadastro multi-finalitário. É importante ressaltar que o NDVI foi desenvolvido para um determinado propósito e determinado sensor, como foi discutido na Seção 2.3.1, o uso desse índice em outras situações deve ser realizado com cautela.

$\mathrm{Na}$ maior parte dos casos, a densidade ocupacional investigada pelos autores é estimada através da identificação de áreas sem vegetação ou áreas construídas (Quadro 2.1 e 2.7) e pode ser usada como relação direta da medida de densidade populacional, presente no Quadro 2.6. A densidade populacional, por sua vez, é um fator de risco diretamente relacionado à acumulação de lixo (BARCELLOS e SABROZA, 2001), fator considerado por um grande número de autores um dos mais significativos para a transmissão da leptospirose. Apesar do cálculo do NDVI ser o método mais popular para estimar a densidade populacional, em trabalhos de escalas maiores os resultados podem ser menos satisfatórios. A revisão de SR, Quadro 2.6, apresenta trabalhos desenvolvidos com imagem IKONOS, QuickBird e fotografias aéreas que utilizaram classificação baseada em pixel ou em objeto para identificar as edificações, como uma forma mais acurada de estimar população.

Ainda assim, o cálculo de população utilizando a edificação como proxy pode sofrer vieses por não considerar a verticalidade dos edifícios, por isso alguns estudos têm desenvolvido métodos que permitem estimar o grau de verticalização por meio da área de sombra projetada (Xiao et al., 2008), sendo que a maior eficiência para a solução dessa questão é obtida com o uso de modelos digitais de superfície e modelos digitais de terreno.

O acúmulo de lixo não é uma característica estável que possa ser reconhecida diretamente por um número limitado de imagens do mesmo local. Isto é, a ausência de lixo em um local onde comumente há acumulo, pode significar que o mesmo foi recentemente incinerado ou recolhido. O que se pode buscar nas imagens, portanto, são locais propensos ao acúmulo de lixo. O acúmulo de lixo terá uma maior probabilidade de ocorrer em uma área não servida de coleta pública de lixo, uma vez que esta é realizada por caminhões que não passam em ruas muito estreitas ou obstruídas. Neste caso, a identificação com SR de logradouros urbanos e suas características de pavimento, largura e traçado, podem ajudar no reconhecimento de áreas propensas ao acúmulo de lixo por carência do serviço de coleta.

No Quadro 2.6, observa-se que o sistema viário é um dos elementos urbanos que vem sendo bastante pesquisado, no campo do SR, e ainda pouco explorado nas pesquisas epidemiológicas em áreas urbanas com SR (Quadro 2.7). Suas características estruturantes das cidades, bairros e vizinhança, além de sua função social nestas comunidades (onde a 
rua acumula funções de espaço público, trânsito de veículos, circulação de pedestres, lazer, etc.), como explicado na Seção 2.2, justificam o elevado grau de importância que tem esse elemento urbano. Os estudos de Benediktson et al. (2003), Shackeford et al. (2003a) e Zhang et al. (2006) conseguiram através de processamento de imagens identificar vias com acurácias superiores a $80 \%$. No entanto, os dois estudos que usaram mais de uma categoria para a classificação do sistema viário não apresentaram resultados satisfatórios (CHANUSSOT et al., 2006; FAUVEL et al., 2006).

Com o uso de classificação baseada em objeto, Nóbrega et al. (2006) extraiu estradas de imagens de assentamentos informais, mostrando o grande potencial que essa tecnologia tem de prover informações sobre áreas urbanas não planejadas.

É interessante observar que algumas atividades agrícolas, que se destacam como fatores de risco, como plantação de cana de açúcar e de banana, são frequentemente encontradas em áreas mais pobres de cidades do nordeste brasileiro, como a cidade de Salvador. Em geral, esse tipo de cultura pode ser observado onde a densidade populacional é mais baixa, o que geralmente está associado aos limites de expansão do território urbano, ou às áreas de alta declividade, ou às áreas sujeitas a alagamentos (áreas de baixo valor imobiliário e solo úmido favorável ao desenvolvimento dessas espécies). A identificação de espécies de árvores foi estudada por Sugumaran et al. (2003); neste trabalho foi utilizado um classificador convencional, o de máxima verossimilhança, e um classificador baseado em regras de decisão (árvore de classificação e de regressão) em imagens IKONOS, para identificar espécies de carvalho em área urbana.

Corpos d'água são elementos presentes tanto na área rural como na área urbana. Os estudos apresentados sobre a leptospirose, Quadro 2.1, ressaltam a relação existente entre a prática de atividades de recreação ou laborais nesses ambientes e a contração da doença. Assim, se faz importante a identificação de locais onde riachos, lagos ou mesmo poças d'água são de fácil acesso a crianças ou são obstáculos à circulação que não contam com infra-estrutura adequada ${ }^{21}$. Nos estudos de SR, Quadros 2.6 e 2.7, observa-se que a identificação de corpos d'água com a utilização de imagens satélite é algo que se pode fazer com a utilização de inúmeras técnicas de SR. A resposta radiométrica diferenciada dos mares, rios, lagos e demais corpos d'água é, em geral, facilmente captada pelas bandas do espectro visível e infravermelho próximo.

\footnotetext{
${ }^{21}$ A infra-estrutura natural ou construída que se faz necessário nesses casos se refere à presença de mata ciliar, ao afastamento mínimo de vias e edificações, à existência de guarda corpo, de drenagem, de passagem superior, de ponte, etc.
} 
Um importante fator de risco identificado na revisão bibliográfica é a precariedade do sistema de esgotamento sanitário. Este é um fator que não é possível reconhecer diretamente nas imagens. Há, no entanto, outras características urbanas comuns a áreas com esse tipo de carência, em especial relacionada ao sistema viário. Dificilmente uma rua sem pavimentação, sinuosa e estreita tem sistema de esgotamento sanitário. Como já citado, o Quadro 2.6 apresenta inúmeros trabalhos que utilizaram a identificação de vias.

Uma combinação de características urbanas também pode estar relacionada com uma combinação de fatores de risco de transmissão. Áreas com alta densidade ocupacional, com ruas estreitas, sinuosas, sem pavimento e com edificações predominantemente horizontais, de tamanho reduzido e telhados não cerâmicos, são muito provavelmente áreas de favela que, se inundável, têm grandes possibilidades de representar uma área endêmica. A morfologia desses espaços é caracterizada por edificações de dimensões reduzidas e com uma grande variedade de materiais de cobertura, desde cimento e telhas de amianto, a metal, madeira e papelão. Nas imagens aéreas e de satélite, essa configuração apresenta características peculiares de cor e textura. Observa-se que Benediktson et al. (2003), Bruzzone et al. (2006), Chanussot et al. (2006) e Fauvel et al. (2006) e Herold et al. (2003) trabalharam com a diferenciação de tamanhos ou cores de cobertura de edificações.

Como ressaltaram Barcellos e Sabroza (2000), Johnson et al. (2004) e Tassinari et al. (2004), pode acontecer dos estudos epidemiológicos não localizarem nessas áreas mais carentes a ocorrência de um número maior de pessoas com casos graves. No entanto, a presença da bactéria nesses locais os caracterizam como área endêmica que pode também constituir-se como um relevante fator de risco para a comunidade do entorno, especialmente se esta comunidade fizer parte da mesma área de alagamento. Para identificação destas áreas, o uso de MDT, mais uma vez, se constitui numa importante ferramenta.

Inúmeros recursos podem ser utilizados na identificação das características urbanas que constituem fatores de risco.

"o avanço tido com o uso de SR para mapeamento, monitoramento e modelamento de ambientes urbanos o coloca em excelente condição de prover esse tipo de informação para o público da área de saúde e outros. Em especial, o SR tem um papel especial a desempenhar em áreas mais pobres, onde efeitos da urbanização serão mais sentidos e onde recursos para mapeamento e atenção à saúde já são contemplados" (TATEM et al., 2004, p. 370). 
De acordo com as revisões bibliográficas apresentadas, a leptospirose está fortemente relacionada com certas condições urbanas como acúmulo de lixo, precariedade do esgotamento sanitário, alagamento e água usada para recreação. Enquanto, cobertura do solo, detecção de mudança da cobertura do solo, área verde, NDVI, área construída, edificações (telhado, densidade e tamanho), áreas com solo exposto, vegetação rasteira, vias (pavimento, largura e traçado), corpos d'água, são elementos identificáveis em imagens de SR.

As características da transmissão da leptospirose, raio de ação do principal vetor transmissor(30m a 50m), e resultados de recentes pesquisas realizadas em Salvador sugerem (MARCIAL et al. 2008, FARIA et al. 2008) ou constatam (REIS et al., 2008) a relação existente entre o ambiente do entorno da residência e a transmissão da doença. Por outro lado, o raio de abrangência de eventos de alagamento, a mobilidade de indivíduos e o uso do espaço público contaminado, sugerem que a investigação também precisa considerar outras escalas de análise.

Para melhor entender como se dá essa relação, seja na eleição das características urbanas a serem investigadas, seja a escala de análise em que cada característica constitui um padrão ou elemento urbano de risco para a transmissão da leptospirose, recorreu-se a duas abordagens: a caracterização das tipologias urbanas encontradas nas áreas de estudo (Capítulo 4) e a elaboração dos modelos de risco da doença associada ao ambiente urbano, (Capítulo 5). 


\section{CAPÍTULO 3 - MATERIAIS E MÉTODOS}

\subsection{Materiais}

Ortofotografias aéreas de 2002.

Foram cedidas pela Fiocruz/Ba, dezesseis ortofotografias com dimensões variadas, que cobrem uma área aproximada de $8,5 \mathrm{~km}^{2}$ do Subúrbio Ferroviário, Figura 3.1. As imagens foram recebidas em meio digital, separadas nos canais vermelho, verde e azul, possuem 16 $\mathrm{cm}$ de resolução do pixel no solo e 8 bit de resolução radiométrica.

As ortofotografias são produtos da missão de 2002, contratada pela prefeitura de Salvador, que realizou o registro aerofotográfico de todo o município. No entanto, foi contratado o serviço de ortorretificação apenas para algumas áreas da cidade, consideradas de crescimento ou de interesse. As demais aerofotografias, não ortorretificadas, encontram-se em meio digital, com resolução espacial de $16 \mathrm{~cm}$, equalização radiométrica bastante comprometida e foram georreferenciadas com erro posicional que chega a $25 \mathrm{~m}$. Apesar das ortofotografias de 2002 cobrirem apenas 30\% da área do subúrbio ferroviário, nesta área encontra-se $46 \%$ dos casos graves de leptospirose registrados entre 1996 e 2005, um total de 138 casos.

Imagem do sistema sensor QuickBird de 02/08/2005.

Foi comprada da empresa IMAGEM, uma única cena de aproximadamente 5,3km por $11,3 \mathrm{~km}$ de extensão que cobre quase toda a área de estudo, Figura 3.1. A imagem é composta pelas bandas pancromática e multi-espectrais de $0,60 \mathrm{~m}$ e $2,4 \mathrm{~m}$ de resolução espacial, respectivamente. A imagem possui formato Geotiff, projeção UTM, Datum WGS84 e cobertura de nuvens inferior a 10\%. A cena precisou ser adquirida de catálogo por questões financeiras e de data melhor compatível com os dados de saúde e foi fornecida com 8 bit de resolução radiométrica. O método utilizado pela empresa para conversão da imagem original de 11 bit para a imagem em catálogo de 8 bit afetou a qualidade radiométrica da imagem.

\section{Base cartográfica}

O sistema viário do Subúrbio Ferroviário utilizado no projeto é um recorte da base cartográfica do eixo de logradouros da prefeitura municipal de Salvador, cuja última atualização registrada data do ano de 2005, Figura 3.2. Esta base é considerada Classe A, 
ou seja, entre outros atributos, seus erros posicionais e de distorção podem ser considerados insignificantes para a escala de 1:2.000.

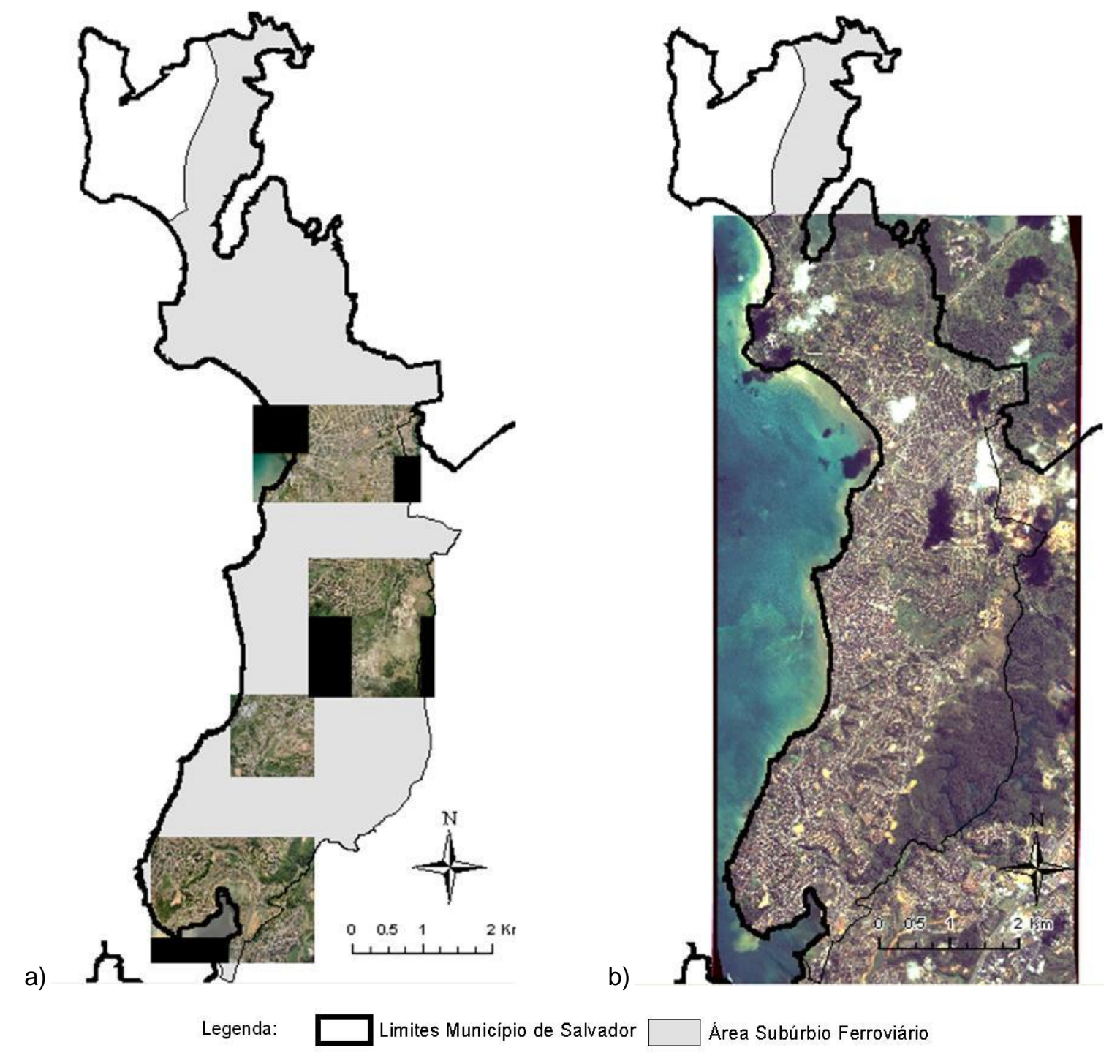

Figura 3.1. Mapa dos limites das imagens utilizadas na pesquisa. a) Conjunto de ortofotografias. b) Cena do satélite QuickBird.

\section{Dados de Saúde}

As localizações dos casos graves de leptospirose ocorridos no subúrbio ferroviário de Salvador entre 1996 e 2005 foram levantadas pela equipe da Fiocruz-Ba, e seguem o protocolo de ética do projeto "História Natural da Leptospirose Urbana". O endereço dos pacientes que tiveram o diagnóstico de leptospirose confirmado foi obtido junto ao Hospital Couto Maia. A localização dos endereços foi realizada por equipe da Fiocruz/Ba que visitou todas as residências registradas, localizando nas fotografias aéreas (e posteriormente georreferenciando em sistema de informações geográfico) as residências encontradas, um total de 300. Apenas em duas residências foram registrados mais de um caso grave de 
leptospirose. A localização de residências sem casos registrados foi obtida por distribuição aleatória de 300 pontos, com o afastamento mínimo de $20 \mathrm{~m}$ entre eles e de $50 \mathrm{~m}$ dos casos registrados, na área do subúrbio ferroviário, excluída grande massa de vegetação da Área de Proteção Ambiental da Bacia do Cobre, Figura 3.2.

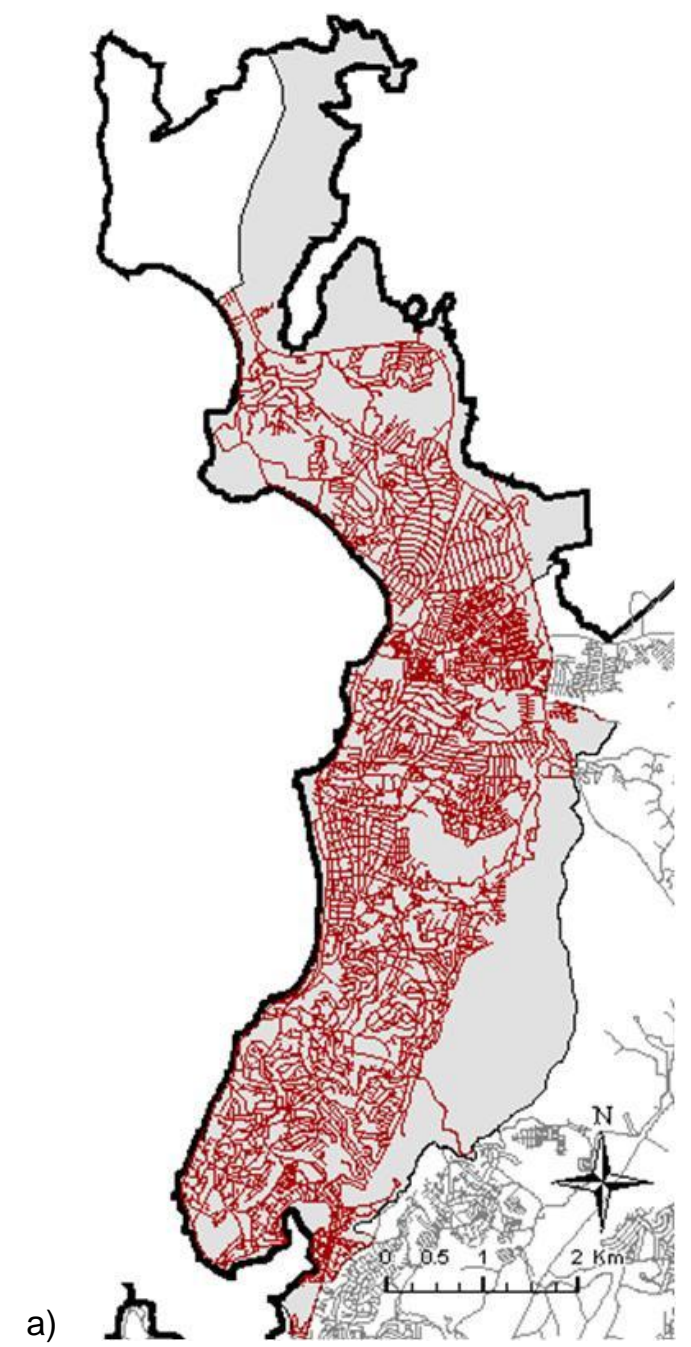

Legenda:

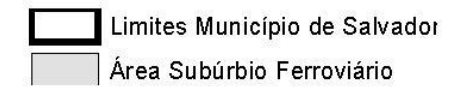

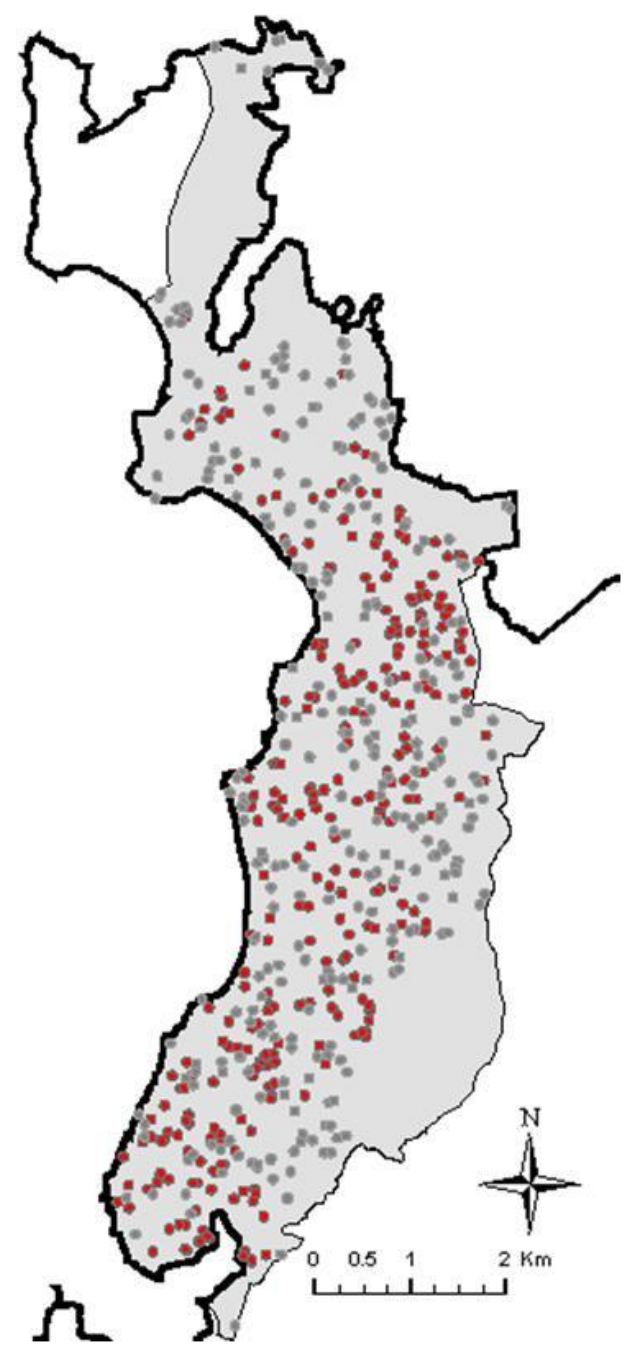

b) $\mathrm{h}$

Residência sem caso de leptospirose Residência com caso de leptospitose

Figura 3.2. Mapa dos dados vetoriais utilizados na pesquisa. a) Eixos viários. b) Dados de saúde.

\section{Programas computacionais}

Os programas Erdas Imagine 9.1 (Leica Geosystems GIS and Mapping Science Inc.) e ENVI 4.1 foram utilizados para o pré-processamento das imagens QuickBird e das ortofotografias.

O programa Definiens Professional 5.0 (Definiens AG), conhecido como eCognition, foi utilizado nas etapas de segmentação e classificação das imagens. 
ArcGIS 9.1 (ESRI Inc., 2005) foi usado na etapa de pré-processamento para conversão do sistema viário em polígonos e no pós processamento para preparação e cálculo das variáveis.

Access 2007 (Microsoft Inc.), Excel 2007 (Microsoft Inc.) e SPSS 16.0 (SPSS Inc.) foram utilizados para preparação de dados tabulares e realização dos testes de correlação.

\subsection{Metodologia}

A metodologia desenvolvida para que as técnicas e recursos de sensoriamento remoto (SR) sejam utilizados no direcionamento de ações que integram a melhoria do espaço urbano e melhoria da saúde da população tem sua estrutura lógica apresentada na Figura 3.3.

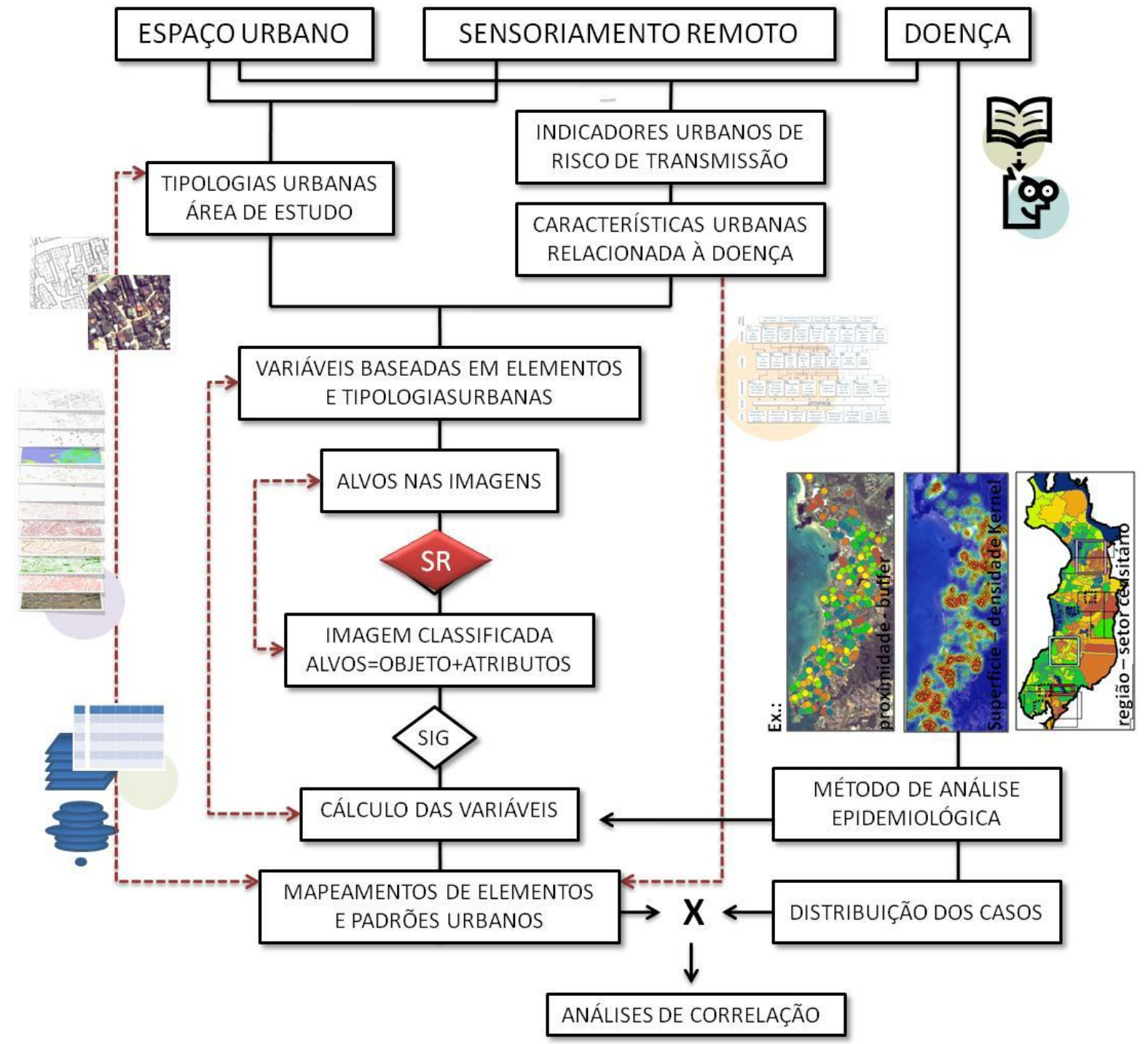

Figura 3.3. Metodologia proposta pra identificação de parâmetros, baseados em dados de sensoriamento remoto, relacionados à ocorrência de doenças 
O método de pesquisa desenvolvido parte, portanto, de uma base conceitual montada no tripé: Espaço urbano, Sensoriamento remoto e Doença. Até a identificação dos alvos e o uso de SR, o trabalho foi desenvolvido sob o aspecto teórico e investigativo, identificando na literatura características urbanas, que poderiam estar relacionadas à doença, e tipologias urbanas encontradas na área de estudo, ambas focadas no levantamento de variáveis possíveis de ser calculadas com uso de produtos de SR. Só então, novas técnicas de processamento em imagens de alta resolução espacial são aplicadas. Procedimentos de sistemas de informações geográficos (SIG) são utilizados em seguida para o processamento de dados vetoriais e cálculo das variáveis que descrevem as tipologias urbanas e indicadores de risco investigados. Este cálculo, no entanto, depende da definição da unidade espacial de análise dos dados epidemiológicos. Esta definição, por sua vez, está vinculada, entre outras coisas, ao grau de agregação do dado (distrito de saúde, CEP, endereço, etc.) e às características espaciais de transmissão da doença (raio de ação do hospedeiro, vetores ambientais de transmissão, etc.). De acordo com a disponibilidade dos dados sobre as características urbanas e de acordo com o objetivo do estudo, os dados espaciais podem ainda ser distribuídos no espaço contínuo (superfície raster com informação de densidade de casos, por exemplo), distribuídos em polígonos (incidência de casos por setor censitário, por exemplo), distribuídos em pontos (e ter análise por proximidade, conhecida como análise de buffers, por exemplo), ou até distribuídos em linha (dados agregados por trecho de eixo viário, por exemplo). Por fim, é possível realizar análises de correlação entre doença e características urbanas.

A pesquisa aqui apresentada traz elementos básicos que fundamentam as decisões que precisarão ser tomadas para a replicação deste método seja com outra doença, outra área urbana ou outro conjunto de imagens de alta resolução espacial.

O presente trabalho, no entanto, restringiu a área de análise ao Subúrbio Ferroviário da cidade de Salvador, testou a identificação dos elementos de interesse em ortofotografias e imagem QuickBird, investigou a transmissão da doença leptospirose e utilizou como método de análise epidemiológica o estudo ecológico restrospectivo com distribuição pontual por meio da análise espacial do entorno (buffer) e incidência de residências com casos.

A pesquisa foi então desenvolvida em duas fases e quatro etapas, como pode ser visto na Figura 3.4. A Fase 1 dedicou-se à formação de um escopo teórico e da exploração dos métodos propostos em áreas de estudo teste. A Fase 2 contempla as atividades de complementação e revisão dos procedimentos adotados em cada etapa. 
Nas Etapas 1 e 2, a revisão bibliográfica nas temáticas da saúde pública, ambiente urbano e SR, subsidiou a criação de modelos de risco de transmissão da leptospirose. Três métodos foram utilizados para elaboração de três modelos, dentre os quais o modelo fundamentado na relação causa-efeito (FPEEEA) foi adotado para embasar as etapas seguintes do trabalho. Em paralelo, tipologias urbanas de habitabilidade encontradas foram investigadas segundo parâmetros de ocupação. Foram definidos os indicadores do modelo e os parâmetros de ocupação das tipologias que têm a possibilidade de serem calculados por variáveis baseadas em informações extraídas de SR e em seguida definidos os objetos e características de interesse a serem pesquisados nas imagens.

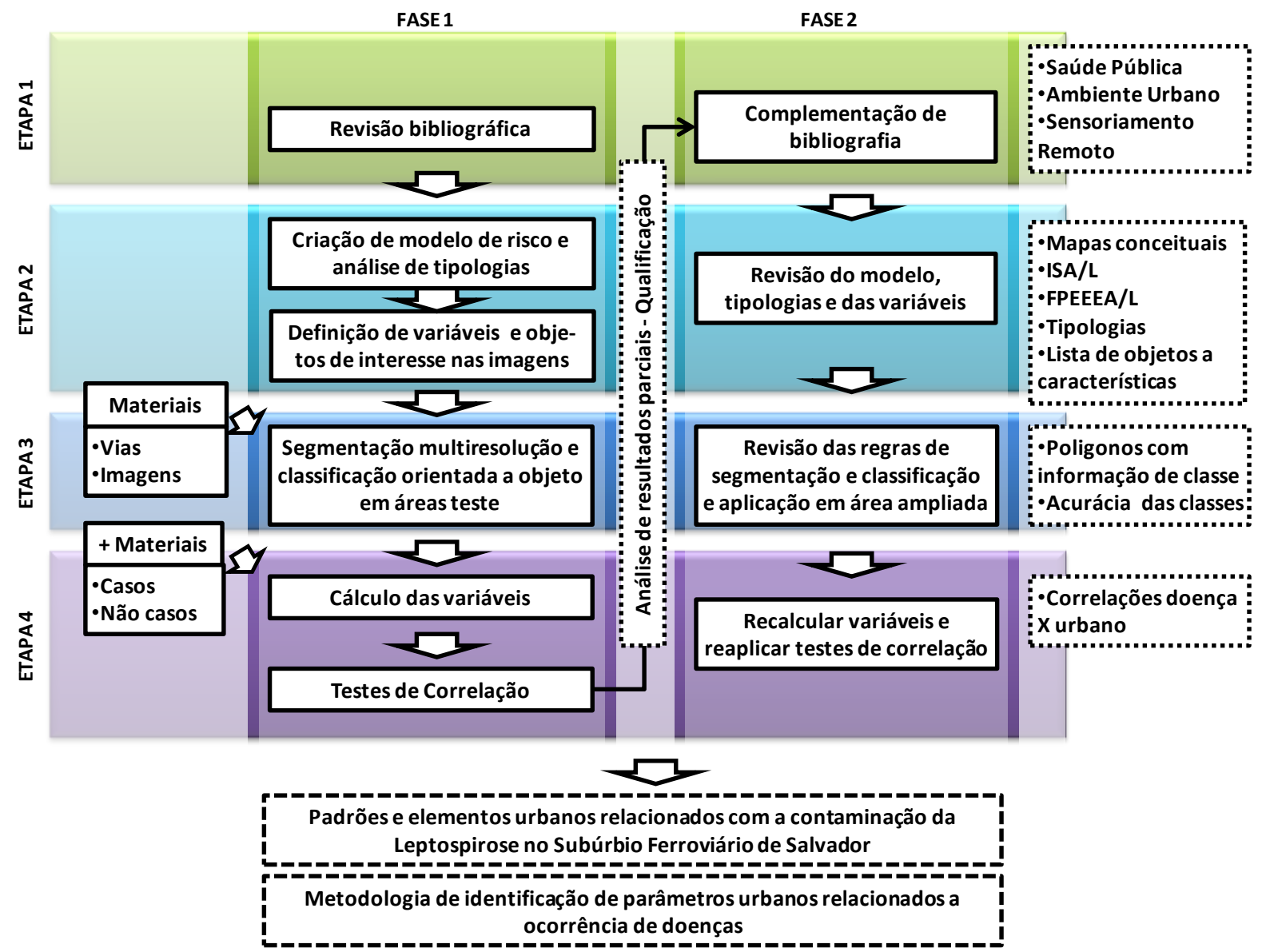

Figura 3.4. Diagrama esquemático dos procedimentos metodológicos utilizados.

O diagrama da Figura 3.5 apresenta o esquema do fluxo de dados, nos procedimentos de SR e SIG, para a produção de informações utilizadas na análise de correlação entre doença e urbano (etapas 3 e 4).

$\mathrm{Na}$ Etapa 3, as ortofotografias e a imagem QuickBird foram processadas separadamente, utilizando técnicas de segmentação multi-nível e classificação baseada em objeto. Foram selecionadas áreas teste onde os processos e regras de classificação foram desenvolvidos, tanto para as ortofotografias como para as imagens QuickBird. A árvore de processos 
resultante dos melhores resultados foi aplicada em áreas controles e a acurácia de cada conjunto de imagens foi testada. Por fim, aplicou-se as regras de segmentação e classificação em toda a extensão da imagem QuickBird, devido aos seus resultados de acurácia e ao fato de cobrir a localização de quase todos os casos de leptorpirose investigados.

$\mathrm{Na}$ Etapa 4, os polígonos com informação de classe, produto da Etapa 3, somado à localização de casos e não casos foram processados de forma a obter os valores das variáveis para o entorno de cada ponto de análise (localização dos casos e não casos). Finalmente, as variáveis foram agregadas em tabelas síntese, com base nas quais foram efetuadas as análises de correlação entre a variável dependente, (medida por presença e ausência de casos ou por incidência de casos no entorno) e as variáveis independentes (características urbanas e tipologias identificadas com SR), como é apresentado no último bloco da Figura 3.5.

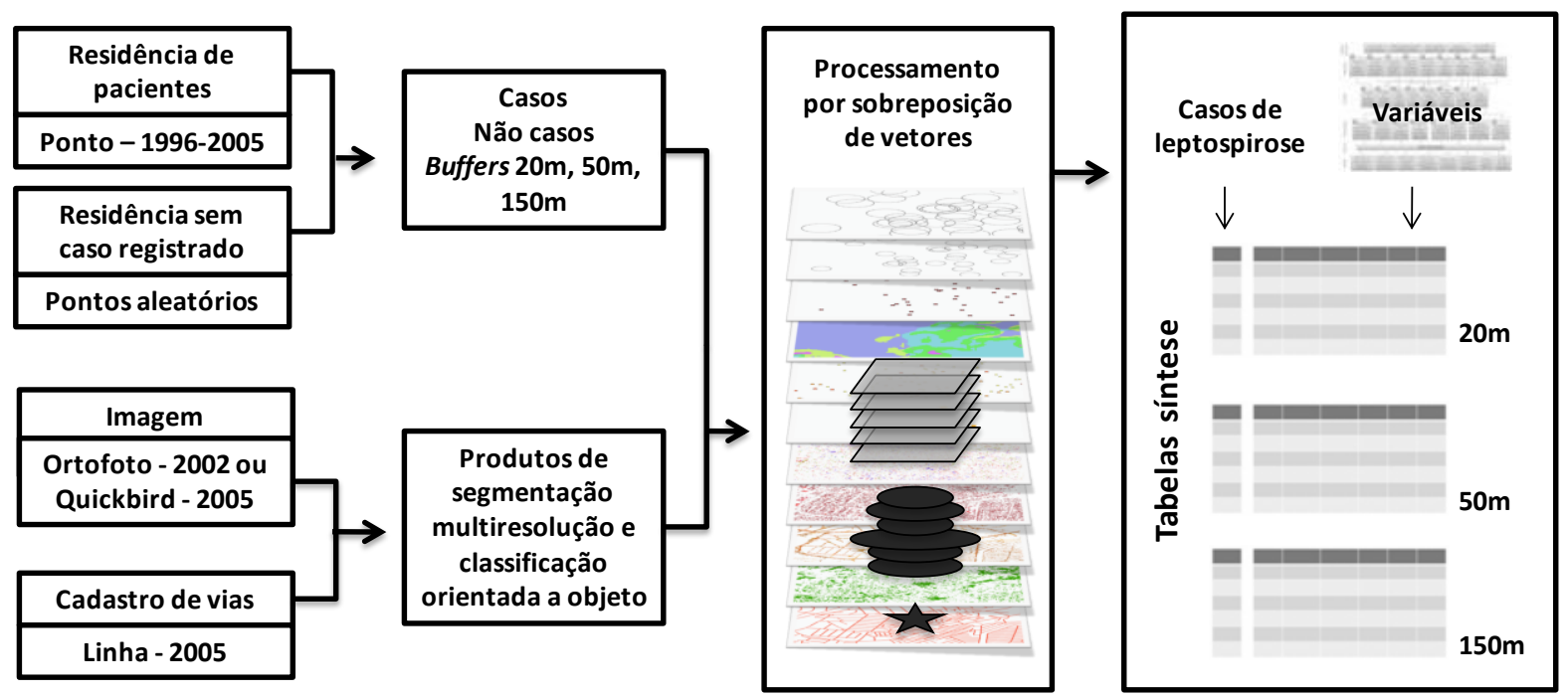

Figura 3.5. Detalhamento do fluxo de dados e produção de informações.

O detalhamento dos métodos utilizados em cada etapa encontra-se descrito nos capítulos que seguem. 


\section{CAPÍTULO 4 - ÁREA DE ESTUDO}

O trabalho foi realizado utilizando como área de estudo uma região da periferia da cidade de Salvador, Bahia, conhecida como Subúrbio Ferroviário. O presente capítulo tem como objetivos principais entender as especificidades da área trabalhada, permitir a validação da replicação da metodologia em outras áreas semelhantes e colher dados de tipologias identificadas por critérios que não são baseados exclusivamente em produtos de sensoriamento remoto. Para isso, são expostas as principais características do Subúrbio, dentro do cenário de evolução da cidade de Salvador, e enfocando as tipologias urbanas atualmente encontradas em seus limites com base em estudos de referência. Devido aos estudos de referência adotarem parâmetros subjetivos e não identificáveis em imagens de SR o capítulo apresenta ainda um detalhamento das tipologias até então estudadas e uma proposta de reagrupamento dessas tipologias de acordo com os novos parâmetros, aferidos em imagens satélite ou aéreas.

\subsection{Aspectos gerais da cidade de Salvador}

O município de Salvador localiza-se a nordeste da costa brasileira, nas coordenadas $38^{\circ} 30^{\prime} \mathrm{W}$ e $13^{\circ} \mathrm{S}$, e possui uma área continental de aproximadamente $278 \mathrm{~km}^{2}$. Sua população superior a 2,5 milhões de habitantes, é a terceira maior cidade em população do país e uma das mais antigas da América Latina.

O processo de urbanização acelerado da cidade, que teve início em meados do séc. XX, não tem sido assistido integralmente pelo poder público, compondo, no curso de seus processos históricos, o desenho de cidade conhecido hoje.

A prática de controle territorial e de planejamento de Salvador só veio com a necessidade. Até os anos 20 do séc. XX, praticamente não existiam regras públicas para o parcelamento do solo:

"geralmente os lotes eram marcados por 'testadas', eram estreitos e profundos, aproveitando ao máximo o acesso pelas cumeadas por onde passavam as vias. As casas eram construídas praticamente coladas umas às outras, com dois a três pavimentos e um quintal na meia encosta. Muitas vezes, estendiam-se até o fundo de vale, aproveitando a criação doméstica de alimentos e criatórios" (GORDILHO, 2000, p. 99).

O crescimento demográfico da cidade passou a tomar grandes proporções na década de 40 com o advento do êxodo rural. A ocupação espontânea em terreno de outrem, para efeito 
de habitação popular, era até o estabelecimento do Código de Urbanismo de 1948, uma prática comum e legítima.

Sem regulamentação ou sem fiscalização, as áreas livres, periferia e vales, foram sendo rapidamente ocupadas, essas últimas exigindo, entre outros serviços, drenagem e obras especiais de custo elevado. "Daí porque permaneciam fora do mercado não só as áreas mais distantes do centro, mas também aquelas relativamente próximas, porém situadas em vales e charcos, onde se localizaram os primeiros bairros populares de Salvador" (BRANDÃO, $1963^{22}$ apud GORDILHO, 2000, p.113).

Um dos principais marcos do planejamento urbano soteropolitano se deu com a implantação do Escritório de Planejamento e Urbanismo da Cidade do Salvador (EPUCS), no ano de 1942. Na década de 60, as grandes avenidas de vale começaram a ser construídas como fruto dos trabalhos desse escritório. A nova concepção viária viria "revolucionar o padrão de ocupação urbana vigente, com a utilização das cumeadas e meiaencostas, agora se estendendo para novas áreas de expansão, ainda que não distantes do perímetro urbano" (GORDILHO, 2000, p. 109).

Assim, a topografia acidentada de Salvador foi ocupada "formalmente" a partir da costa oceânica, platôs, cumeadas, e, mais recentemente, das avenidas de vale e "informalmente" a partir da periferia, nos grotões e interstícios da formalidade, Figura 4.1, criando uma fragmentação sócio espacial que, de uma forma ou de outra, está presente em várias cidades de países em desenvolvimento.

Segundo Villaça (1998), assim como em Salvador, em Ouropreto, no Rio de Janeiro e em Olinda, a expressão da relação econômica da comunidade com a cidade é muito clara em sua paisagem. O processo de ocupação da cidade acabou determinando áreas privilegiadas infra estruturadas e de fácil acesso e não privilegiadas no restante da cidade. No entanto, esta é uma visão para entendimento geral da estrutura que se observa hoje nessas cidades, pois, como ressalva Villaça (1998), outros fatores interferem na localização de um grupo, como por exemplo, a geologia dos morros (graníticos e muito íngremes, são de difícil acesso, como o morro da Tijuca no Rio de Janeiro) ou como os costumes da população em relação ao uso das praias, anteriormente usadas principalmente como depósito e escoadouro de dejetos, hoje são reconhecidas como elementos de lazer ${ }^{23}$. É importante estar ciente ao estudar a morfologia urbana que "o controle (através do domínio

\footnotetext{
${ }^{22}$ BRANDÃO, M. D. A. Origens da expansão periférica de Salvador. In: BAHIA, Governo do Estado. Revista Planejamento, v. 6, n.2, Salvador, SEPLANTEC/CPE, 1978 (original de 1978)

${ }^{23} \mathrm{Em}$ Salvador, tanto foi o desprezo e poluição da costa oeste (primeira ocupação da capital) que só recentemente as praias da Baia de Todos os Santos começaram a ser valorizadas.
} 
do Estado e do mercado) que as classes de mais alta renda exercem sobre o espaço urbano e sobre o sistema de locomoção constitui-se na força preponderante da estruturação do espaço intra-urbano", como defende Villaça (1998, p. 278).

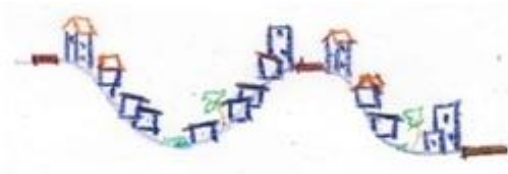

Secsão AB - adensamento de ocupação informal emárea sem infraestrutura

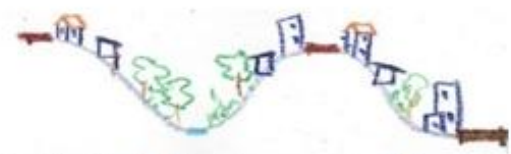

Secsão AB - inicio da ocupação informal

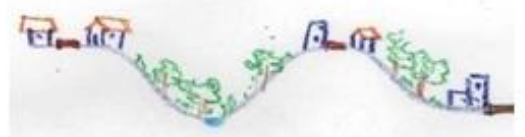

Secsão AB - instalação de estrutura formal

a)

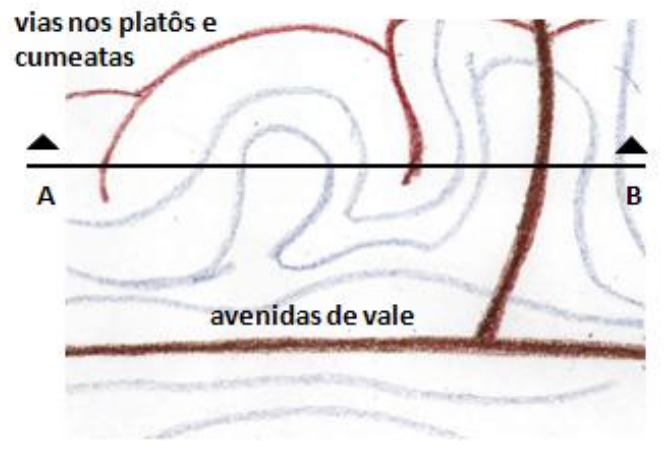

b)

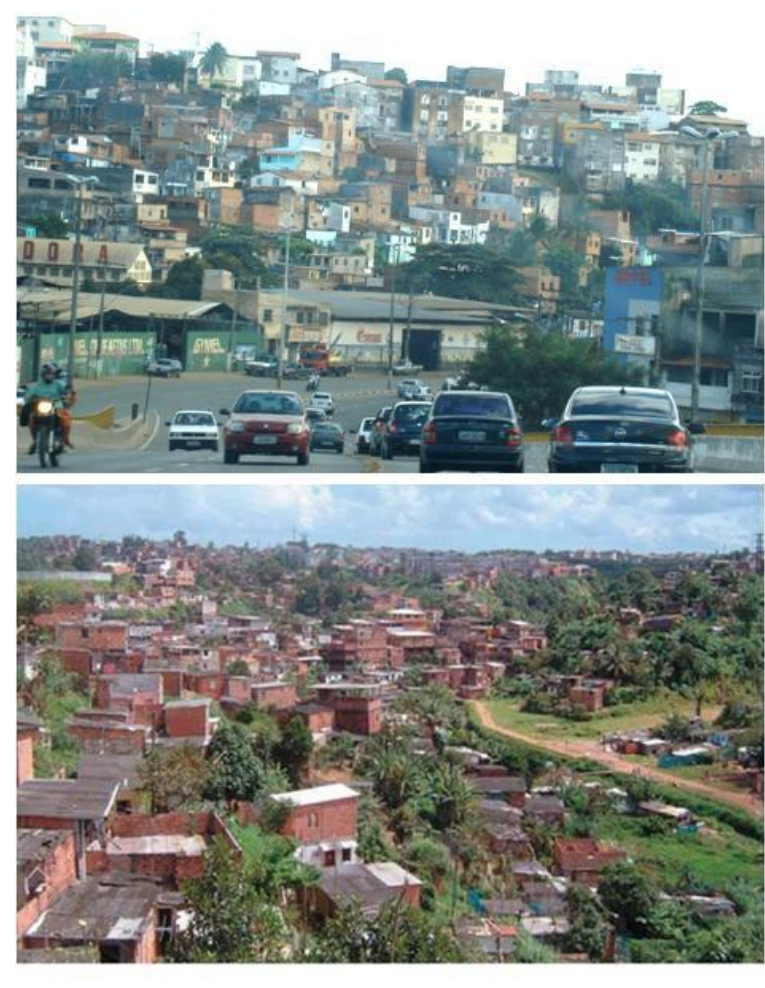

Figura 4.1. Processo mais frequente de ocupação de grotões e vales da cidade de Salvador. a) Croquis de processo de ocupação de vales de Salvador. b) Fotografia superior: avenida de vale em área consolidada de ocupação informal (Patricia Brito).Fotografia inferior: Miolo de Salvador, vetor de crescimento com muitas ocupações informais (PREFEITURA DE SALVADOR, 2008, p.17)

Segundo estudo de Gordilho (2000), estima-se que 53\% da população de Salvador, cerca de 1,3 milhões de pessoas viviam em áreas com algum tipo de deficiência urbana. Muitas dessas áreas são consideradas assentamentos informais, onde a população é alvo de doenças infecciosas devido a carência de serviços públicos.

A leptospirose é uma dessas doenças infecciosas que assolam a cidade de Salvador. Um estudo sobre um surto epidêmico ocorrido em 1996 (KO et al., 1999) calculou a taxa de infecção por casos graves de leptospirose em 12,5 casos por 100.000 habitantes durante uma única temporada epidêmica. Durante a mesma temporada, o índice de mortalidade foi 
de $15 \%$. O estudo em áreas sentinelas ${ }^{24}$ da cidade realizado por Dias et al. (2007) revelou que mais de $60 \%$ dos indivíduos pesquisados tinham altos títulos para os sorovares do serogrupo Icterohaemorrhagiae, (um dos mais maléficos ao homem e relacionado ao rattus norvegicus) e inferiu que a estrutura sanitária atual da cidade ainda não é satisfatória o suficiente para prevenir a transmissão da doença, que ocorre em todo seu território. $O$ estudo de Dias et al. (2007) também indica que áreas mais pobres guardam maiores proporções desse sorogrupo mais grave ao homem.

\subsection{O Subúrbio Ferroviário de Salvador}

A área denominada pela administração municipal como Subúrbio Ferroviário, considerada uma das áreas mais pobres da cidade, abrange um território de aproximadamente $28 \mathrm{~km}^{2} \mathrm{e}$, segundo o censo de 2001 do Instituto Brasileiro de Geografia Estatística (IBGE), abriga uma população de mais de 260 mil pessoas. A Estrada de Ferro que dá nome à região liga a península de Itapagipe, a sul do Subúrbio Ferroviário, ao seu extremo norte, margeando a costa. Foi inaugurada em 1860, era, até a construção da avenida suburbana, nos anos 1970, o principal meio de transporte da região e hoje opera precariamente. O adensamento do subúrbio teve início na década de 60 com a instalação de famílias que migravam do interior para trabalhar nas fábricas ali instaladas.

$\mathrm{Na}$ área leste do Subúrbio Ferroviário se encontra a bacia do Rio Cobre que compreende a Área de Proteção Ambiental da Bacia do Cobre, o Parque Metropolitano de Pirajá e a represa do Cobre, responsável pelo abastecimento de água de grande parte das famílias da região. O avanço da ocupação clandestina, na área de proteção que alimenta a represa, vem ameaçando a sua funcionalidade. A norte do Subúrbio Ferroviário, encontra-se a Base Naval de Aratú, Organização Militar da Marinha do Brasil.

A Falha Geológica de Maragogipe, que determina a divisão da cidade conhecida como Cidade Alta e Cidade Baixa, confere ao subúrbio uma composição de solo diferenciada da maior parte da cidade. O subúrbio, assim como a maior parte do Recôncavo Baiano, apresenta um solo argiloso, rico em material orgânico, popularmente conhecido como massapé. Classificado como Vertissolo, a característica principal desse tipo de solo é apresentar expansão e retração quando varia a sua umidade e grau de saturação, provocando problemas estruturais mesmo em pequenas edificações, como mostram os estudos de Simões et al. (2006) e Campos et al. (2005) realizados em Salvador.

${ }^{24}$ Áreas onde é realizado monitoramento contínuo, antes, durante e após intervenção em questão. 

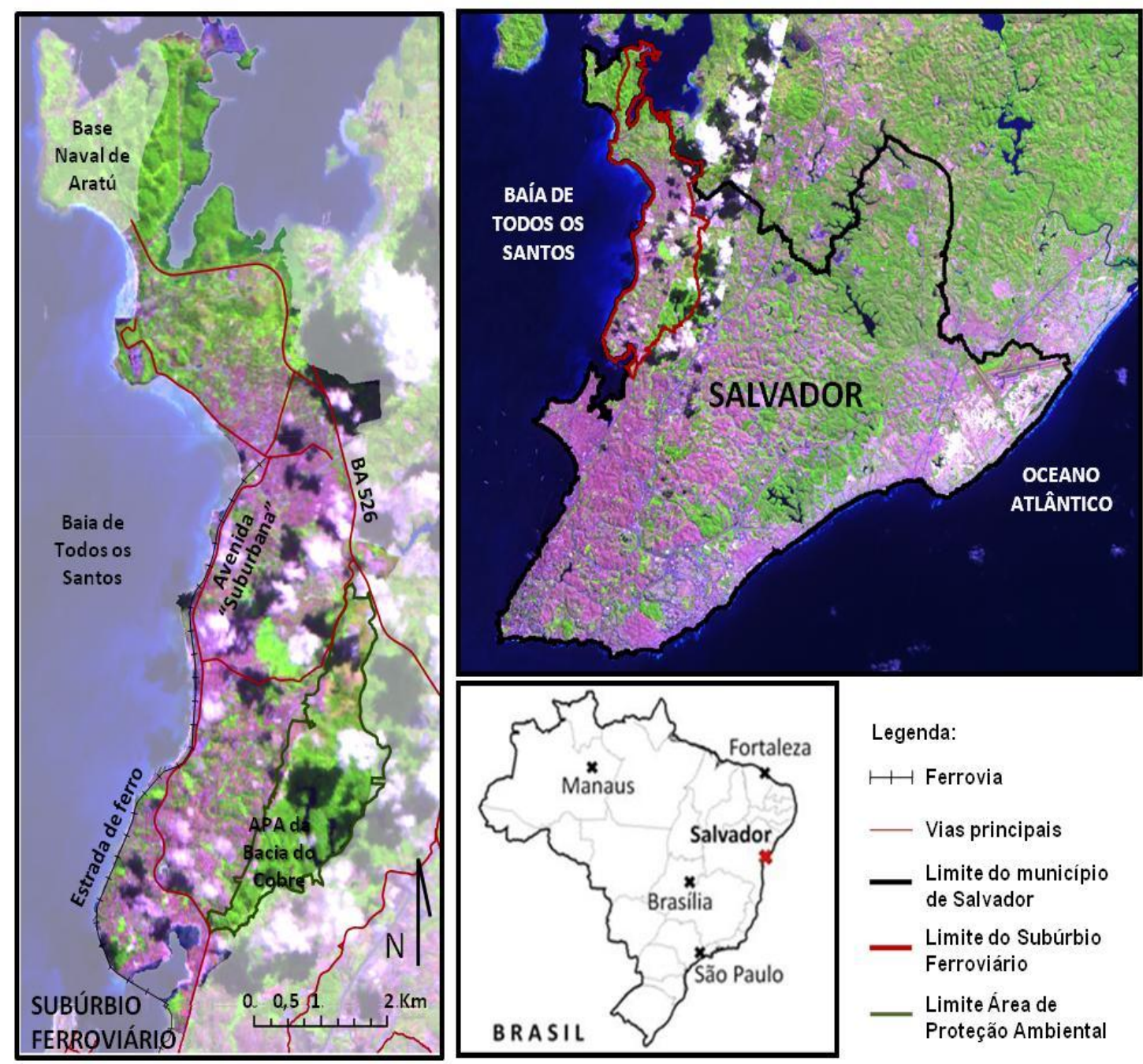

Legenda:

$\mapsto$ Ferrovia

_ Vias principais

_ Limite do município de Salvador

Limite do Subúrbio

Ferroviário

Limite Área de

Proteção Ambiental

Figura 4.2. Mapas de localização da área de estudo.

\subsection{Caracterização das tipologias urbanas do Subúrbio Ferroviário}

O estudo para a caracterização das tipologias urbanas do Subúrbio Ferroviário é baseado na pesquisa realizada por Gordilho (2000) sobre as formas de configuração urbana da habitação de Salvador. Esta pesquisa é referência na área, por se tratar do único estudo publicado, até então, que trata e apresenta de forma sistemática dados sobre essa ocupação em todo o município e em uma escala local, isto é, com maior grau de detalhamento que as unidades espaciais adminitrativas, distritos ou macro zonas de planejamento utilizadas tradicionalmente. Com base neste estudo de Gordilho foi 
desenvolvido o Plano Municipal de Habitação (PREFEITURA MUNICIPAL, 2008), entre outros importantes instrumentos de política urbana.

Em seu trabalho foram identificadas quatro tipologias urbanas de áreas residenciais, chamadas pela autora de macro padrões habitacionais: bom, regular, precário e insuficiente. O padrão bom é do tipo formal, loteamentos registrados e licenciados na prefeitura conforme normas urbanísticas em vigor. No padrão regular há uma mesclagem de categorias bom e precário.

Segundo Gordilho (2000), no padrão precário os parcelamentos têm dimensionamento fora das normas gerais em vigor na prefeitura e são deficientes nos demais atributos urbanísticos exigidos. Há uma "predominância de lotes menores que $125 \mathrm{~m}^{2}$ e igual ou maior que $64 \mathrm{~m}^{2}$, insuficiência de equipamentos coletivos de apoio, infra-estrutura, de áreas públicas e verdes, além de problemas de conservação dos atributos existentes e condições topográficas desfavoráveis na ocupação em geral" (GORDILHO, 2000, p. 243).

Já no padrão insuficiente, as áreas ocupadas não atendem às condições mínimas de habitabilidade. Segundo a autora, há predominância de lotes abaixo de $64 \mathrm{~m}^{2}$ (mínimo exigido para parcelamento de interesse social pelas normas urbanísticas em Salvador), além de prevalecerem situações com ocupação em áreas de risco ou em áreas de patrimônio histórico-ambiental, em área onde há insuficiência de atributos de conforto e de infra-estrutura urbana, ou há inexistência de equipamentos coletivos de apoio, de áreas livres e verdes.

Com base nesses critérios, a autora elaborou uma série de mapas temáticos da cidade de Salvador. A área do Subúrbio Ferroviário, nos mapas temáticos das condições urbanas e habitacionais considerados mais significativos para o presente estudo, é apresentada na Figura 4.3.

Também identificou exemplares de um hectare de 14 formas de habitação com o intuito de realizar um estudo mais minucioso das densidades encontradas nas diferentes tipologias. Ainda que algumas áreas apresentem tipologias similares, este estudo mostrou que há diferenciações de características físicas importantes não só em uma mesma tipologia, mas principalmente, em relação à qualidade da habitação e entorno, entre tipologias. 
a)
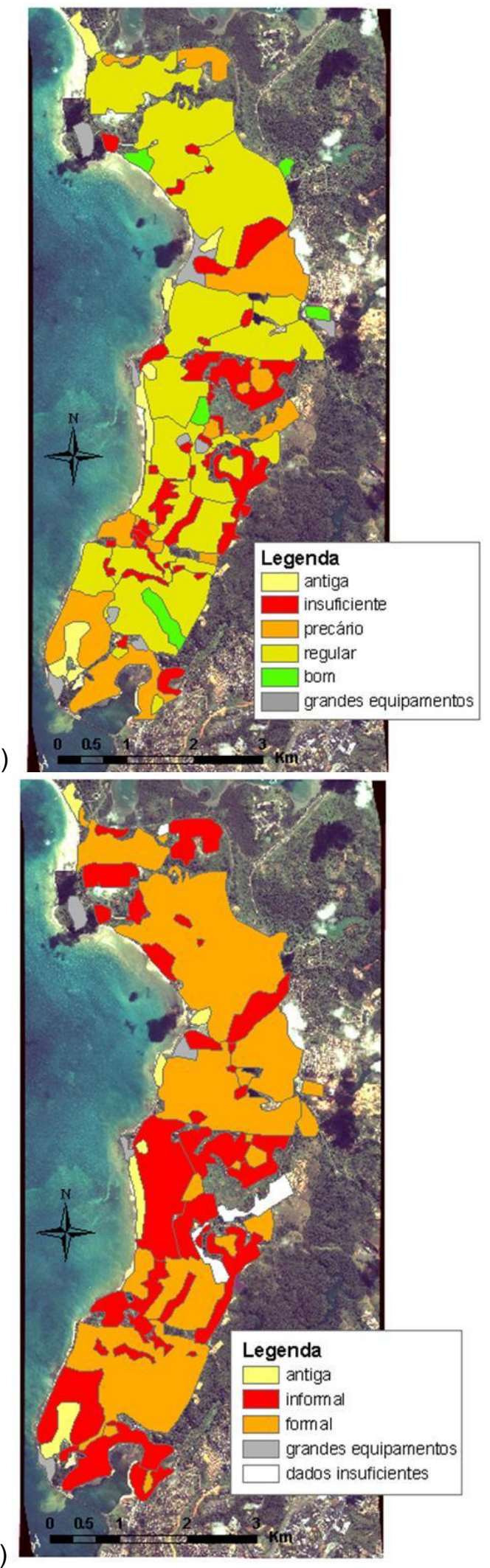

b)
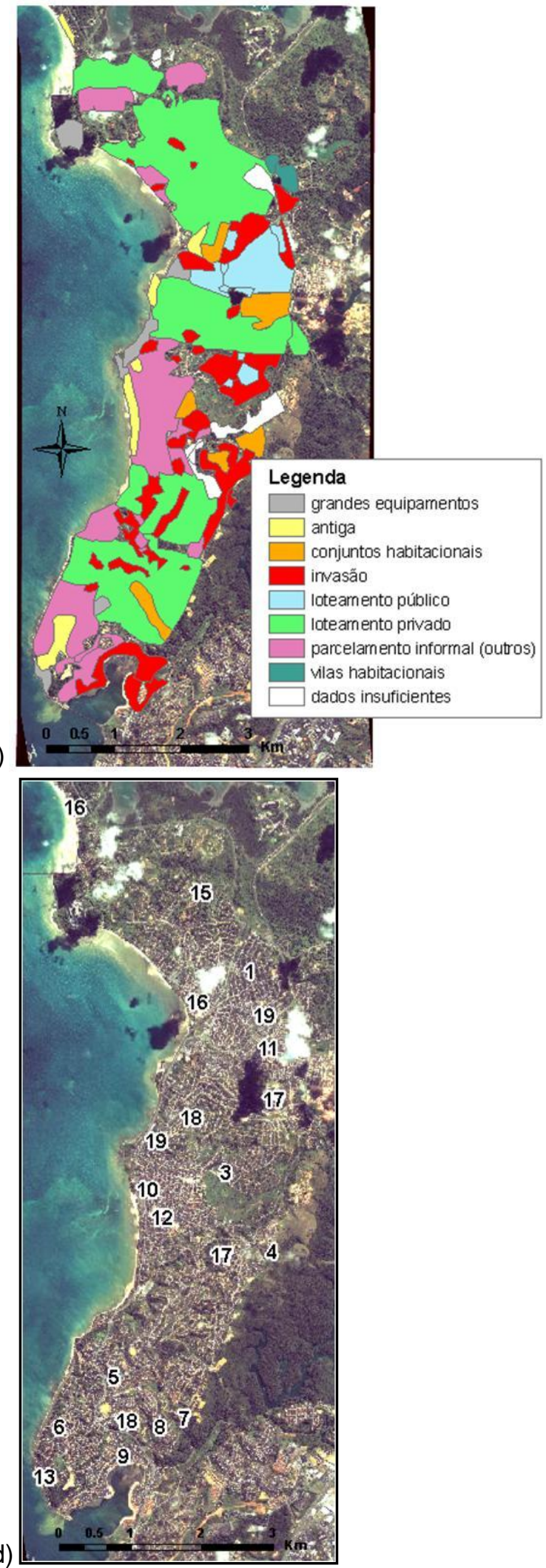

Figura 4.3. Caracterização do Subúrbio Ferroviário segundo estudos de Gordilho (2000). Mapas a,b e c são adaptações de Gordilho (2000, p. 305 e 319). a) Padrão habitacional predominante nas áreas ocupadas, 1991; b) Formas de ocupação habitacional na configuração urbana, 1925-1991; c) Legalidade urbanística nas áreas de habitação, 1991; d) Mapa de localização das áreas trabalhadas no reconhecimento de tipologias no Quadro 4.1. 
O Quadro 4.1 apresenta uma análise visual de imagens aéreas e orbitais das áreas analisadas por Gordilho e de áreas com padrões urbanísticos semelhantes aos encontrados no Subúrbio Ferroviário (Figura 4.3). Com base na análise de imagens de sensoriamento remoto foi possível detalhar ainda mais a caracterização das tipologias urbanas identificadas pela autora. Esta análise representa uma contribuição importante para o entendimento de como se manifesta o tecido urbano de Salvador nos produtos de sensoriamento remoto, aprofundando e dando continuidade as pesquisas realizadas por Gordilho.

Dentro do escopo específico desta pesquisa, a análise visa avaliar a representatividade da área de estudo frente à diversidade de tipologias urbanas presentes na cidades de Salvador, reconhecer no Subúrbio exemplares de tipologias consideradas diferentes segundo critérios não espaciais (como legalidade e histórico da ocupação por exemplo), e colher dados para testar possíveis correlações entre a imagem satélite ou aérea, a doença e as tipologias apresentadas por Gordilho.

Todos os padrões apresentados por Gordilho foram considerados neste estudo, visto que a ocupação da área do Subúrbio Ferroviário é predominantemente residencial horizontal. Como o intuito de Gordilho (2000) era avaliar a densidade da ocupação com base em plantas planimétricas, a autora desconsiderou os padrões habitacionais compostos por edificações com mais de 3 ou 4 pavimentos.

Buscou-se analisar os elementos urbanos visíveis nas imagens que, segundo Lamas (2004), revelam a morfologia do espaço (conforme tratado na Seção 2.2.1 desta Tese): solo e pavimento, edifícios, quarteirão, o logradouro e seu traçado e a vegetação. Os demais elementos não são, na maior parte dos casos, possíveis de serem identificados nas imagens, como lote, fachadas, monumentos e mobiliário urbano; ou são elementos pontuais, que não constituem normalmente um padrão urbano ${ }^{25}$, como lixões, aterros sanitários, campos de futebol e outros equipamentos de grande porte.

O Quadro 4.1 compara croquis extraídos do trabalho de Gordilho, usados como plantas informativas de exemplares de áreas representativas das diversas formas de ocupação habitacional na cidade. Para cada amostra apresentada por Gordilho, procurou-se uma área no Subúrbio Ferroviário com características semelhantes e foi realizada uma caracterização dos elementos urbanos possíveis de serem identificados nas imagens. Esses elementos

\footnotetext{
${ }^{25}$ estes elementos serão mais adiante considerados, nessa pesquisa, de acordo com sua possível correlação com a doença em estudo
} 
cuja função e importânicia na dinâmica urbana foram discutidos na seção 2.2, foram aferidos em cada amostra por meio de ténicas digitais não automáticas de medição.

Quadro 4.1 - Croqui, imagens e caracterização das tipologias urbanas com base na análise de imagens de sensoriamento remoto

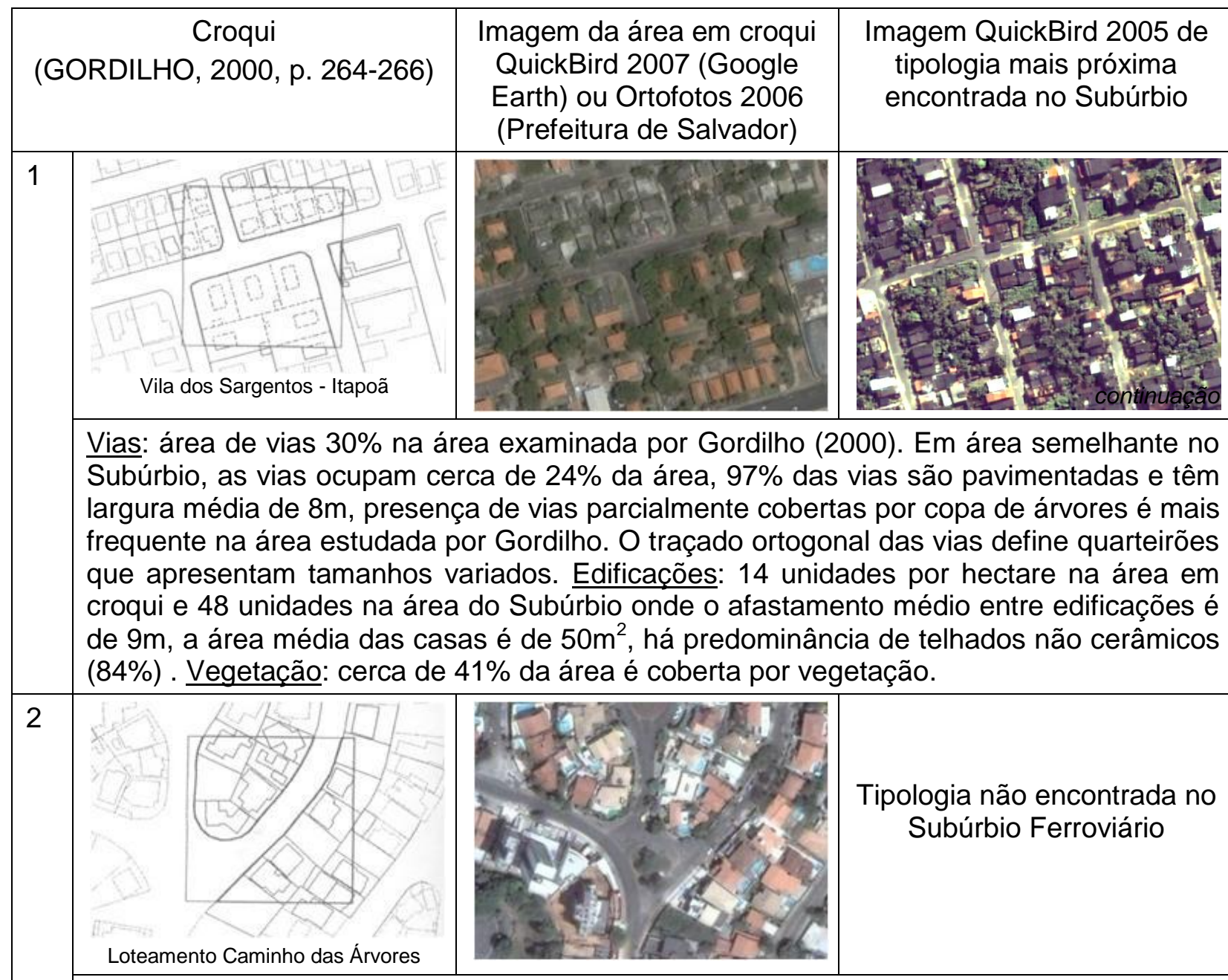

Vias: $30 \%$ da área é ocupada por vias, $100 \%$ delas são pavimentadas e a largura média é de $11 \mathrm{~m}$. O traçado orgânico porém regular das vias define quarteirões longilíneos tamanhos grandes e médios. Edificações: 12 unidades por hectare, afastamento médio entre centróides das edificações $20,5 \mathrm{~m}$, área média $220 \mathrm{~m}^{2}$, predominância de telhados cerâmicos. Vegetação: $14,8 \%$ da área. Outros elementos: presença de piscinas (6 por hectare).

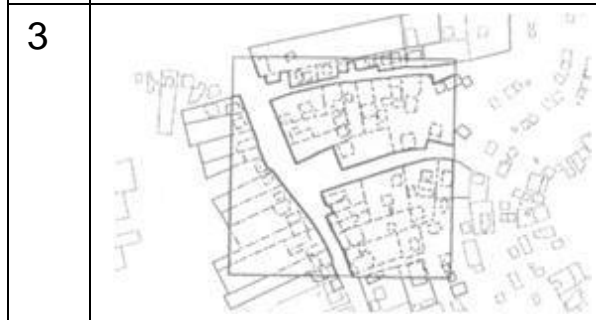

Invasão Malvinas - Bairro da Paz
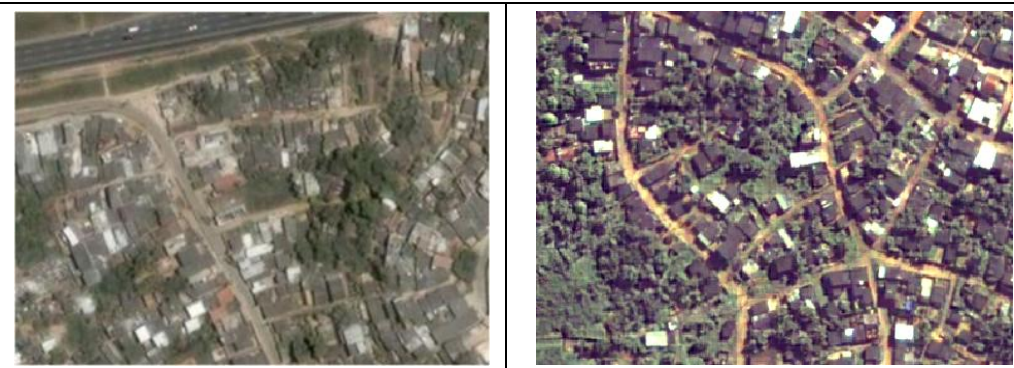

Vias: área de vias é de $20 \%$ na área estudada por Gordilho (2000) e apenas $10 \%$ na área do subúrbio, onde as vias não são pavimentadas e a largura média é de $3,5 \mathrm{~m}$. O traçado 


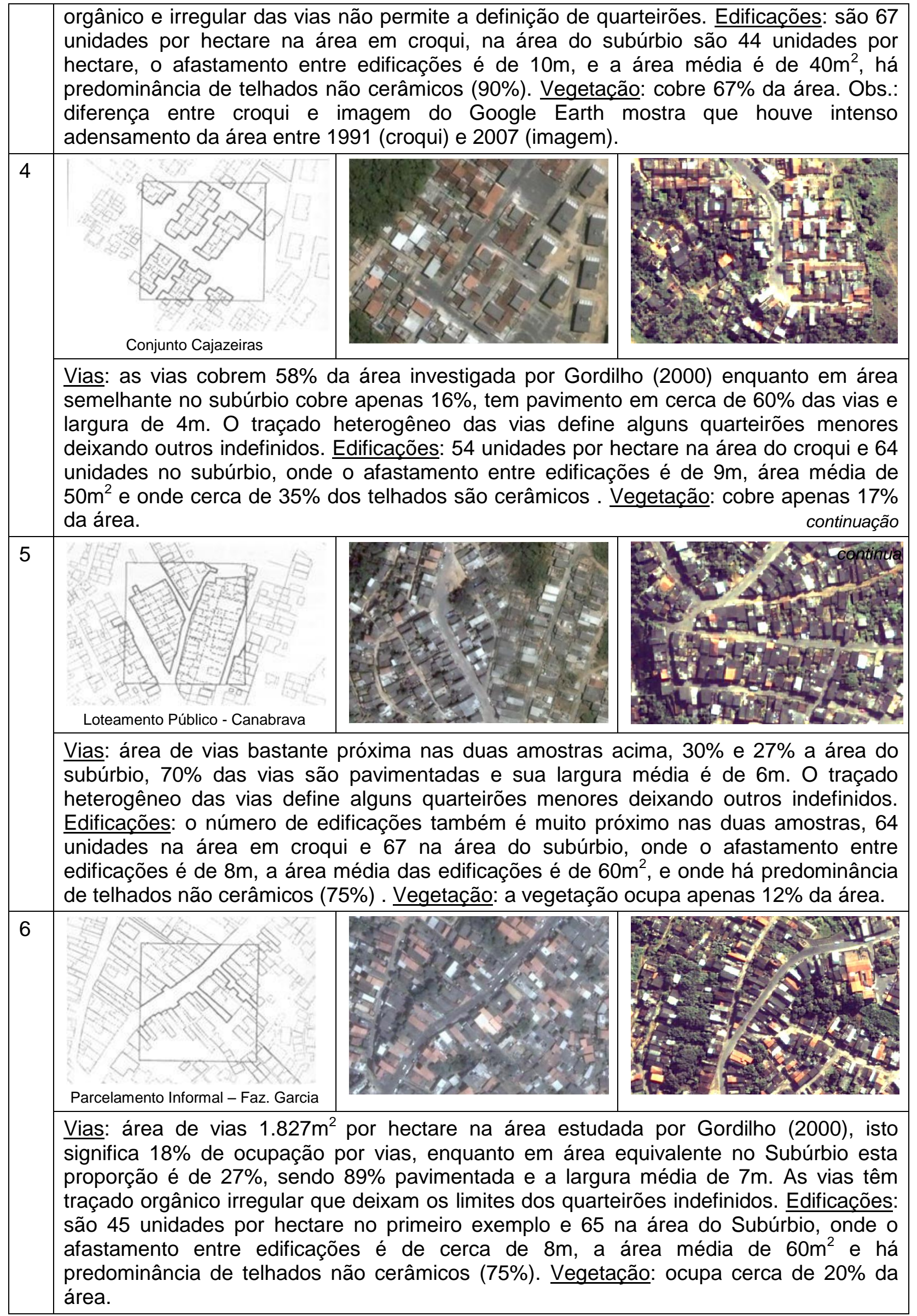


continuação

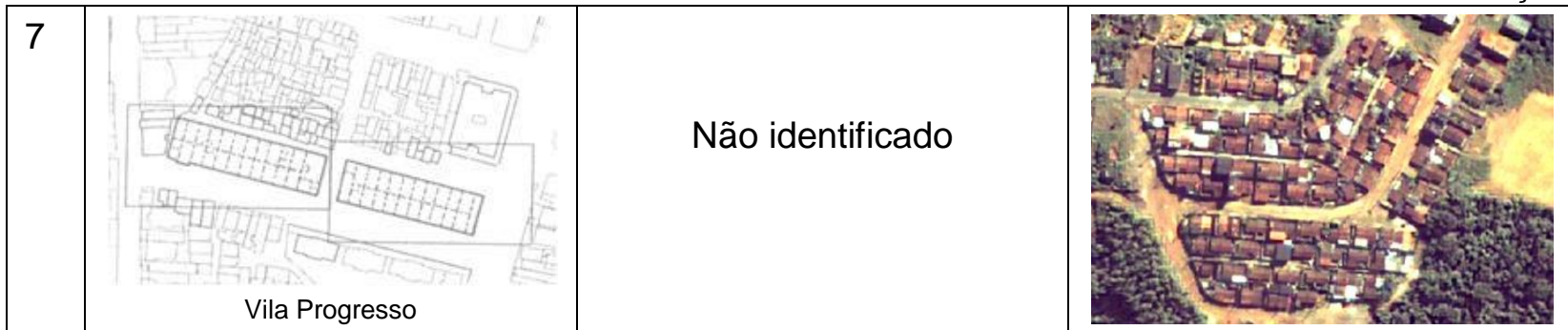

Vias: na área representada no croqui as vias ocupam $52 \%$ do espaço, enquanto na área no Subúrbio ocupa apenas $20 \%$, aí há predominância de vias não pavimentadas (93\%), com largura média de $5 \mathrm{~m}$. Apesar do traçado regular das vias, a margem com áreas não ocupadas deixa parte dos quarteirões sem limites bem definidos. Edificações: 78 unidades por hectare na área em croqui e 72 na área do Subúrbio com afastamento médio entre edificações de $9.5 \mathrm{~m}$, área média de $68 \mathrm{~m}^{2}$ e predominância de telhados cerâmicos. Vegetação: é quase inexistente na amostra investigada (6\%).

continuação
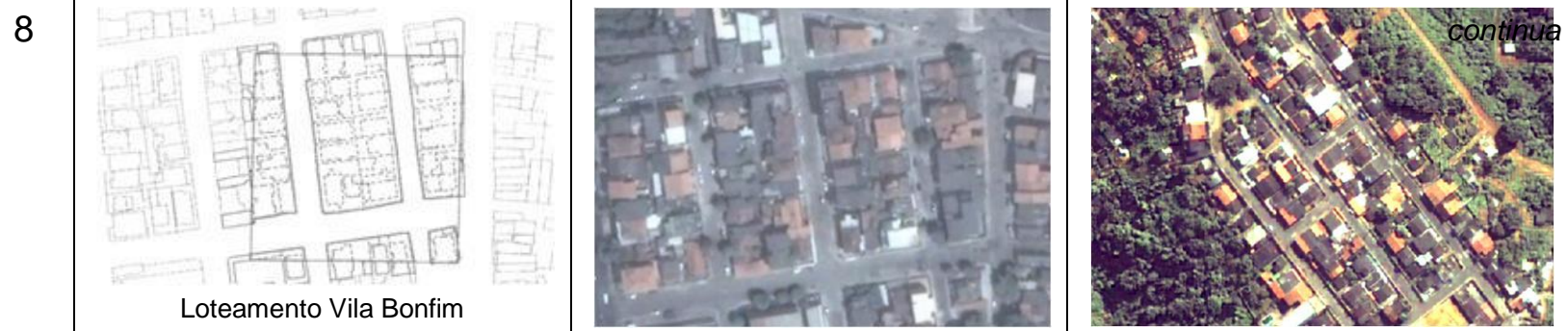

Vias: área de vias ocupa 35\% da área estudada por Gordilho (2000) e 27\% em área semelhante no Subúrbio, onde $73 \%$ da área de vias é pavimentada e a largura média é de $8 \mathrm{~m}$. Na maior parte dos casos, o traçado ortogonal das vias define quarteirões que apresentam tamanhos reduzidos. Edificações: são 35 unidades por hectare na área em croqui e 50 unidades no Subúrbio, com afastamento de $9 \mathrm{~m}$, área média de $80 \mathrm{~m}^{2} \mathrm{e}$ predominância de telhados não cerâmicos (70\%). Vegetação: ocupa apenas $8 \%$ da área.

9
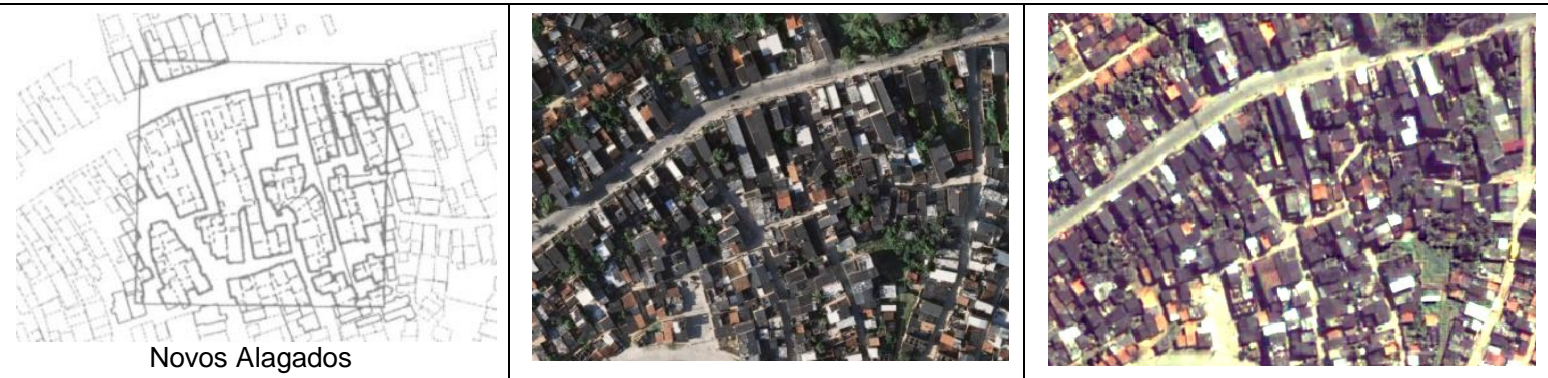

Vias: área de vias é de $40 \%$ segundo o croqui de Gordilho (2000) e apenas $28 \%$ na imagem de 2005, segundo a qual $84 \%$ da área de vias é pavimentada e largura média é de $5,5 \mathrm{~m}$. As vias têm traçado orgânico irregular que deixam os limites dos quarteirões indefinidos. Edificações: são 124 unidades por hectare no croqui e cerca de 90 identificadas em imagem, com afastamento $7,5 \mathrm{~m}$ entre edificações, área média de $45 \mathrm{~m}^{2}$ e predominância de telhados não cerâmicos (90\%). Vegetação: ocupa ainda $11 \%$ da área estudada.
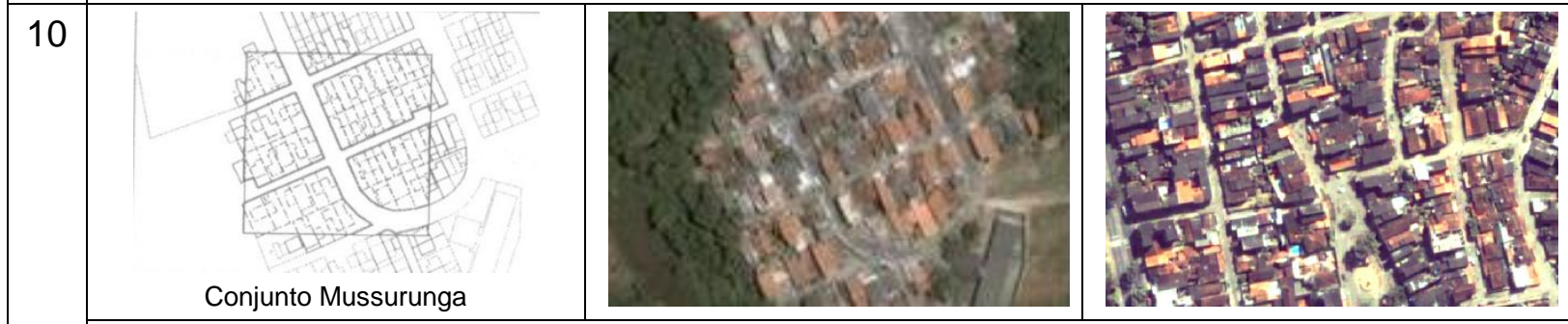

Vias: acupam cerca de $23 \%$ da área em croqui e $17 \%$ da área no Subúrbio, onde cerca 
continuação

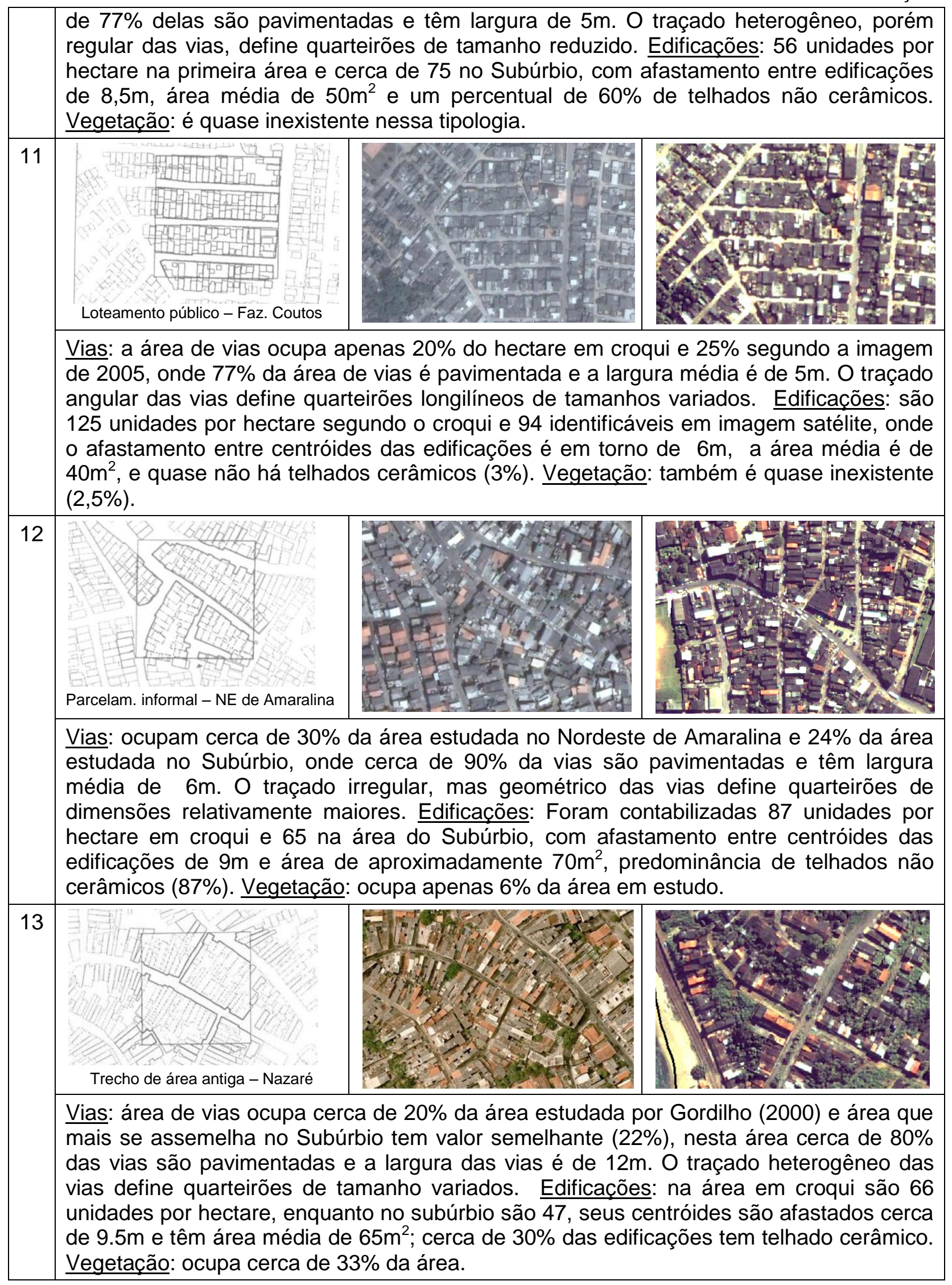


continuação

14

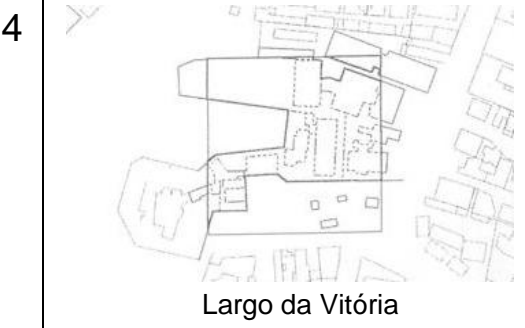

Largo da Vitória

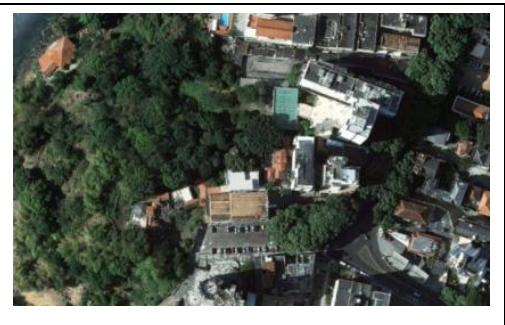

Tipologia não encontrada no Subúrbio Ferroviário

Vias: as vias ocupam cerca de $40 \%$ da área, são pavimentadas e uma grande parte delas (não compreendida pelo quadrado limite de um hectare) é coberta por vegetação arbórea, a largura nos limites da amostra é de $17 \mathrm{~m}$. Edificações: 10 unidades por hectare, afastamento entre centróides de edificações é de $25 \mathrm{~m}$, área de $350 \mathrm{~m}^{2}$, há presença de telhados cerâmicos e não cerâmicos. Vegetação: ocupa cerca de $45 \%$ da área.

Tipologias não apresentadas por Gordilho (2000)

\begin{tabular}{|c|c|c|c|}
\hline & Tipologia & $\begin{array}{r}\text { Imagens QuickBird } 2005 \\
\text { encontrad }\end{array}$ & $\begin{array}{l}\text { epresentativas da tipologia } \\
\text { no Subúrbio }\end{array}$ \\
\hline 15 & $\begin{array}{c}\text { Densidade muito baixa e } \\
\text { sem vias }\end{array}$ & 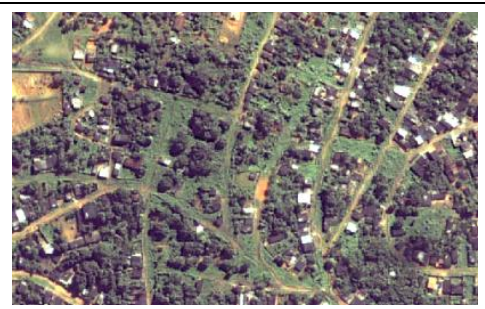 & 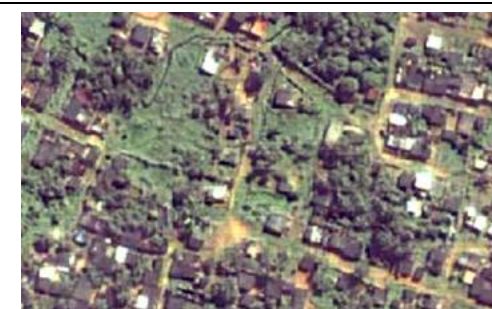 \\
\hline
\end{tabular}

Vias: área de vias é quase inexistente (5\%), não há vias pavimentadas e a largura das vias existentes é de $3 \mathrm{~m}$. A descontinuidade das vias não permite a definição de limites de quarteirões. Edificações: são aproximadamente 25 unidades por hectare, com centróides afastados cerca de $17 \mathrm{~m}$, área média de $35 \mathrm{~m}^{2}$, e poucos telhados cerâmicos. Vegetação: ocupa cerca de $86 \%$ da área.

16

Padrão formal classe média alta
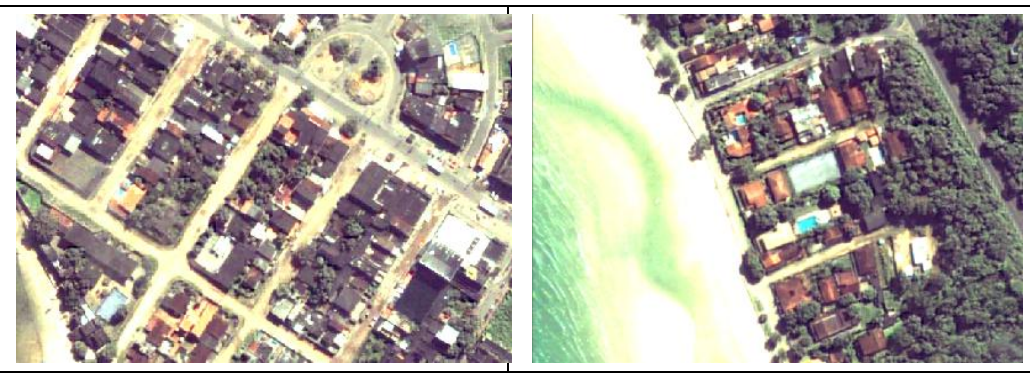

Vias: as vias ocupam cerca de $20 \%$ da área, apenas $20 \%$ delas são pavimentadas e têm largura média de $7 \mathrm{~m}$. O traçado ortogonal das vias define, quarteirões de tamanho reduzido, exceto nos casos em que as habitações margeiam áreas não ocupadas. Edificações: são aproximadamente 40 unidades por hectare, afastamento entre centróides de edificações é de $9.5 \mathrm{~m}$, área média da edificação é $75 \mathrm{~m}^{2}$, há presença de telhados cerâmicos e não cerâmicos em iguais proporções. Vegetação: ocupa cerca de $32 \%$ da área. 


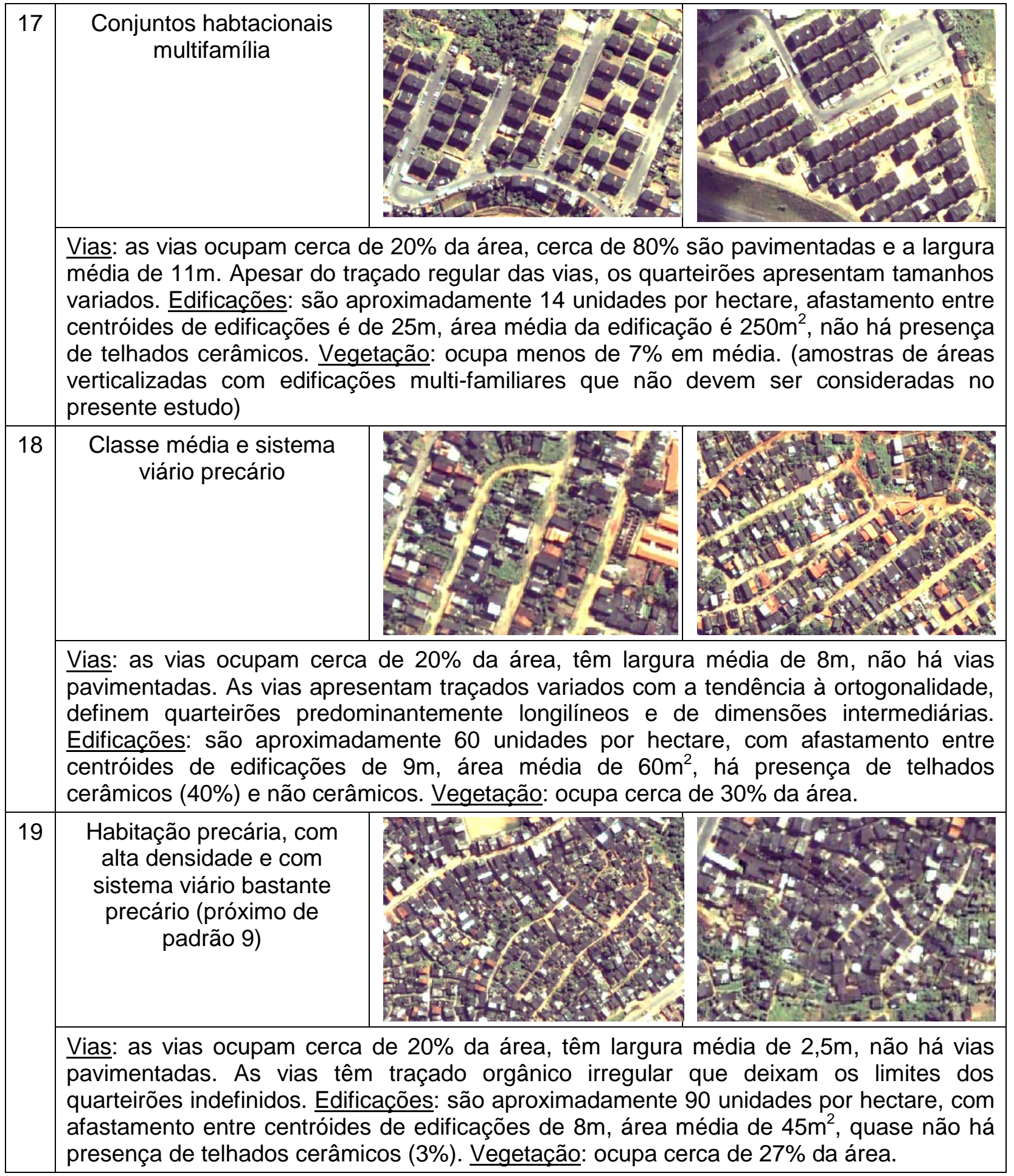

Fonte: Brito (2010)

Como observado nas descrições do Quadro 4.1, os principais elementos urbanos e suas especificidades identificadas com sensoriamento remoto utilizados para descrever tipologias urbanas presentes no subúrbio ferroviário de Salvador foram traduzidos em dez variáveis, a saber. 
O percentual de área ocupada por ruas, que segundo os exemplares de Gordilho em Salvador varia entre $20 \%$ e $40 \%$, mas que nas amostras do subúrbio variaram entre $5 \%$ a $25 \%$. Esta diferença ocorreu porque na área Gordilho não levantou nenhum exemplar com densidade ocupacional muito baixa em área precária (tipologia 15), onde o sistema viário é quase inexistente somado ao fato de seus cálculos estarem baseados em cartografia vetorial, e os levantamentos aqui apresentados foram feitos sobre imagem do ambiente construido. Essa diferença de fonte de informação interferiu também em uma diferença sistemática entre as duas medidas, na qual aquela com base matricial é, em geral, superior à medida com base na imagem. Este fator pode ser explicado pela dificuldade em se reconhecer os limites do lotes nas imagens, gerando confusão entre vias de automóveis, pedestres e área particular não edficada.

Ainda relacionado ao sistema viário foram reconhecidos dois tipos de pavimentação predominante, se de barro ou pavimento escuro (possivelmente asfalto ou paralelepípedos) e levantada a largura média das ruas, que variou entre $2,5 \mathrm{~m}$ e $11 \mathrm{~m}$ (aferições não realizadas por Gordilho).

Visualmente as amostras foram ainda classificadas entre aquelas cujas vias possuem traçado orgânico ou geométrico, regular ou irregular, classficando ainda a predominância de um sistema viário descontínuo ou contínuo e as consequentes formas e tamanhos de quarteirões gerados a partir desse traçado.

As edficações foram elementos urbanos utilizados para aferição de densidade ocupacional medida por contagem do número de edficações por $100 \mathrm{~m}^{2}$. Nas amostras do subúrbio, a densidade variou entre 14 e 94 edficações por hectare (1ha=100m2). Observou-se também a predominância de telhados cerâmicos, mediu-se o tamanho médio das edficações, que variou entre $34 \mathrm{~m}^{2}$ e $25 \mathrm{~m}^{2}$ e levantou-se o afastamento médio entre edficações vizinhas, cujo valor mínimo foi de $7,5 \mathrm{~m}$ e valor máximo de $25 \mathrm{~m}$.

Um outro elemento observado nas imagens, que, por sua vez, não estava presente nas análises de Gordilho, foi vegetação. Para tal, foi calculado o percentual da área da amostra coberta por vegetação, o que no Subúrbio variou expressivamente, entre $2,5 \%$ e $85 \%$.

Assim, de acordo com esta abordagem, observa-se que as tipologias urbanas se apresentam em imagens de sensoriamento remoto em padrões de organização, compostos por combinação de elementos e suas especificidades. Os principais elementos da paisagem são chamados de alvos nos processos de segmentação e classificação de imagens de sensoriamento remoto. As principais especificações dos elementos são chamadas de 
qualidades ou atributos de cada elemento identificado (Figura 4.4). Esses elementos com atributos podem ser lidos, exportados e processados em ambiente SIG ou mesmo em banco de dados não geográficos em forma de variáveis.

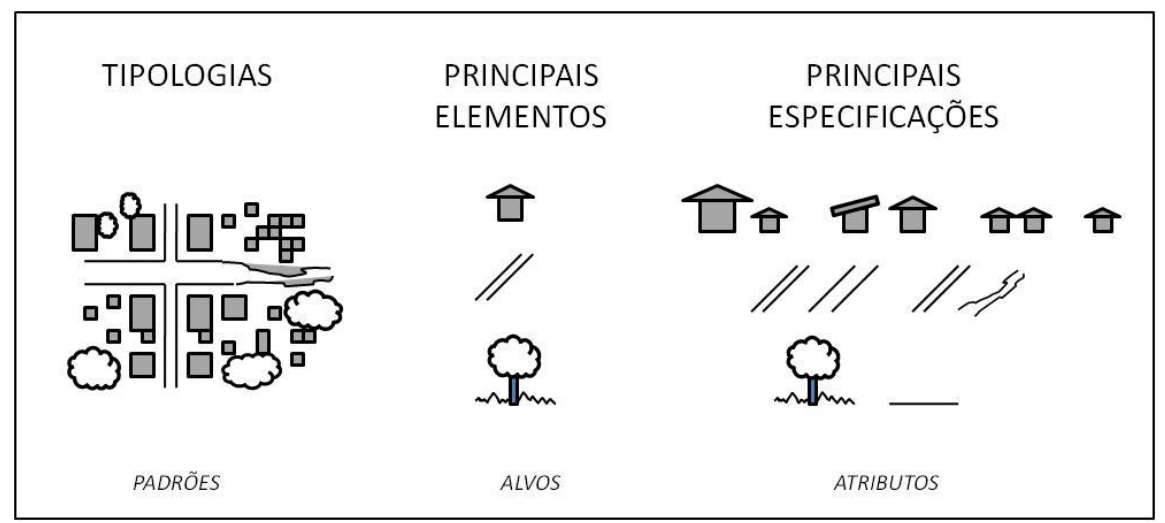

Figura 4.4. Método de identificação de tipologias urbanas com base na análise de produtos de sensoriamento remoto. Fonte: Brito (2010)

Outros métodos de sensoriamento remoto podem ser utilizados para o reconhecimento de padrões, entre eles destacam-se os métodos de reconhecimento de texturas. No entanto, na escala demandada para este trabalho, estes métodos têm se mostrado pouco efetivos (ver Seção 2.3).

Ainda assim, a análise baseada apenas em produtos de sensoriamento remoto tem limitações. As descrição das amostras apresentadas no Quadro 4.1 revelam grande semelhança e ao mesmo tempo confusão entre algumas características de diferentes tipologias. Isto se dá porque elas se diferem em características não reveladas em imagens ortogonais, como aquelas relacionadas à legalidade da propriedade, aos limites do lote, à carga social e histórica, explorados por Gordilho (2000) e Vasconcelos (2002), por exemplo.

Outros elementos que também fazem falta na análise do Quadro 4.1 são relacionados à tridimensionalidade das tipologias, seja em relação ao sítio de implantação, seja em relação à verticalidade das edificações.

Por exemplo, a habitação implantada em terreno com desnível apesar de ter como desvantagem a exigência técnica para evitar problemas estruturais e de deslizamento, principalmente conhecendo as características instáveis do solo do Subúrbio, tem vantagens no aspecto sanitário. As fotografias da Figura 4.5 mostram como este tipo de implantação pode ser benéfico para o conforto e salubridade da moradia, uma vez que sua disposição escalonada pode permitir melhor ventilação e iluminação dos cômodos, além de contar com 
o desnível natural do terreno para escoamento de efluentes e águas de chuva. Esse tipo de informação sobre a tipologia pode ser obtido com uso de modelos digitais de terreno ou plantas topográficas, que apesar de serem também produtos de sensoriamento remoto, demandam, para sua produção, técnicas e imagens específicas não contempladas por essa pesquisa.

a)

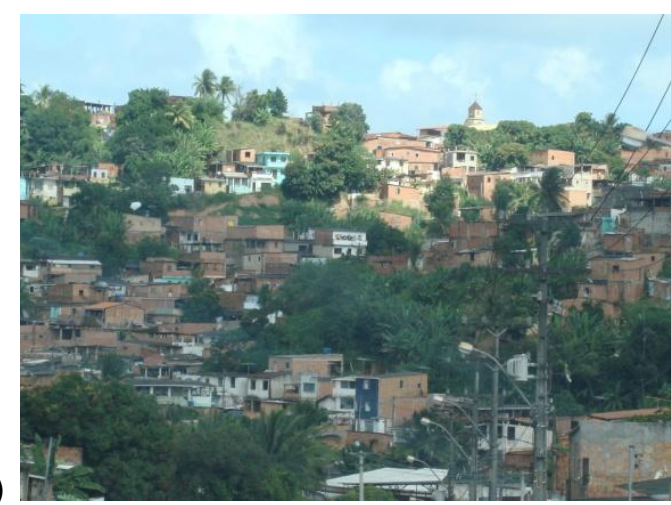

b)

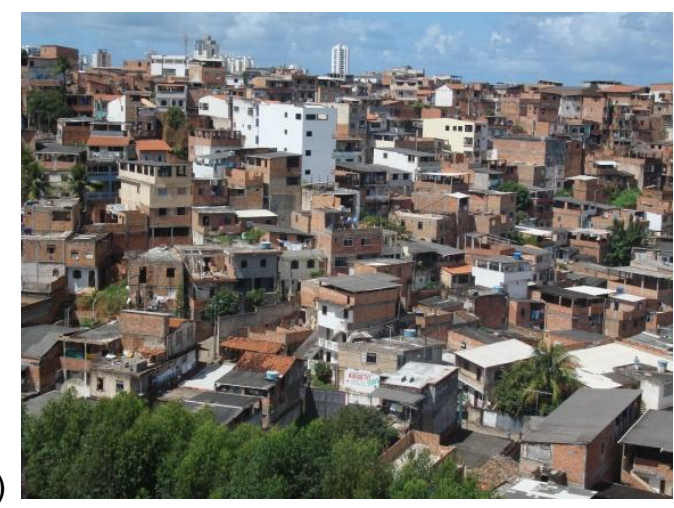

Figura 4.5. Ocupação informal em encosta. a) Ocupação informal em encosta no bairro Calçada; b) Ocupação informal consolidada no bairro Iguatemi, em processo avançado de verticalização. Fonte: Brito (2010)

A verticalidade, por sua vez, demonstra o saturamento da área, que, ao se consolidar e absorver mais moradores, passa a crescer verticalmente. Produtos de sensoriamento remoto (Modelos Digitais de Terreno e Modelos Digitais de Superfície) também podem ser utilizados para esse fim, como explorados por Ercolin (2009), mas a elaboração desses produtos também demanda utilização de técnicas específicas não exploradas nesta Tese.

Muitas outras características, como sítio geológico e posicionamento estratégico na rede de fluxos econômicos da cidade, poderiam ajudar na diferenciação de tipologias que aparecem semelhantes em imagens de sensoriamento remoto. No entanto, elas não são investigadas aqui porque não são informações provenientes de produtos de sensoriamento remoto.

\subsection{Agrupamento das tipologias encontradas no Subúrbio}

Reconhecendo as limitações dos produtos de sensoriamento remoto em distinguir cada tipologia apresentada no Quadro 4.1, fez-se necessário combiná-las em grupos de tipologias cujas diferenças entre as variáveis levantadas por SR sejam mais significativas.

De acordo com os elementos morfológicos identificados nas imagens das áreas amostradas, as 17 tipologias apresentadas no Quadro 4.1 foram agrupadas em cinco novas 
macro tipologias, utilizando técnica de reconhecimento de clusters ${ }^{26}$. Ainda que 0 agrupamento tenha sido baseado em 17 observações e 10 variáveis $^{27}$, o que não permite o reconhecimento de funções que determinem parâmetros para cada grupo formado, os resultados empíricos se mostram coerentes com a realidade urbana, vide Quadro 4.4 e analises apresentadas a seguir.

A adoção de cinco grupos levou em consideração o nível de similaridade entre as amostras, apresentado no dendograma da Figura 4.5. A partir daí foi calculado o centróide de cada um dos grupos a fim de identificar suas características com base nas dez variáveis levantadas: densidade das casas ou edficações, tamanho das casas ou edficações, percentual de telhados com telha cerâmica, qualidade das vias (uma combinação entre tamanho da edficação e tipo de telhado), afastamento entre casas, percentual de vias pavimentadas, largura média das vias, percentual de área coberta por vias, qualidade das vias (combinação de largura das vias e pavimentação) e percentual de área coberta por vegetação. Os Quadros 4.2, 4.3 expõem os dados e resultados da análise estatística realizada.

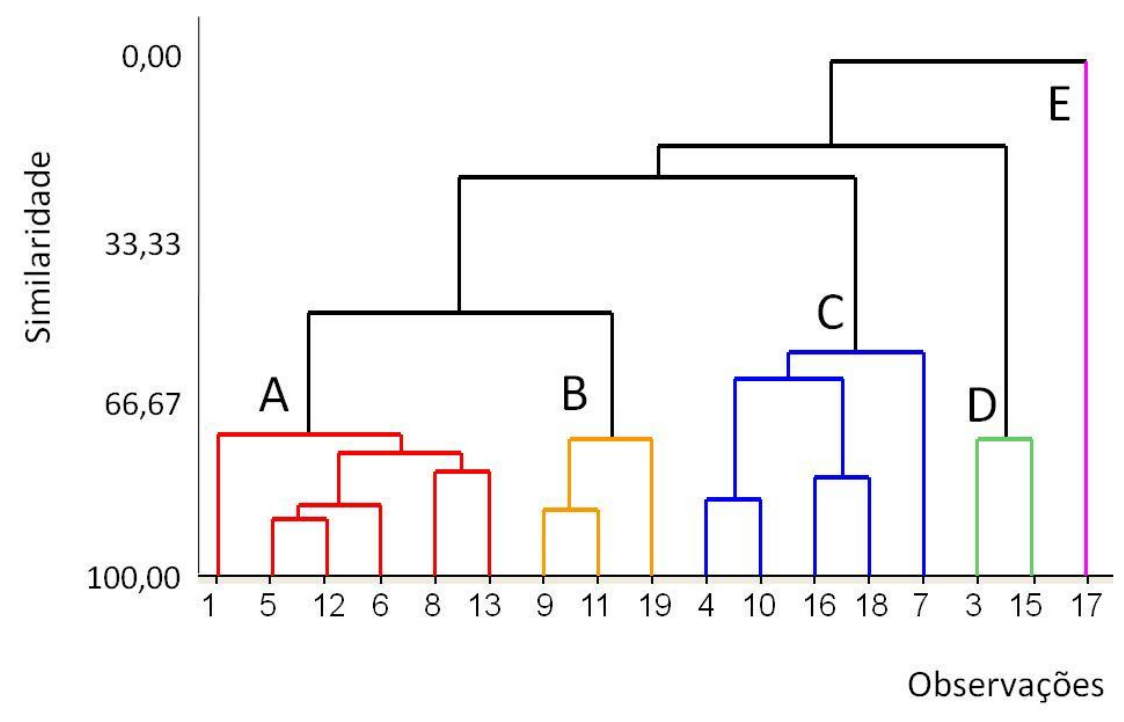

Figura 4.6. Dendograma com conexão completa e distância euclidiana

${ }^{26}$ O processo de reconhecimento de clusters foi realizado no softare MINITAB e utilizou como parâmetros: Amalgamation Steps, variáveis normalizadas, distância euclidiana e conexão completa.

27 A dez variáveis correspondem aos elementos e suas características possíveis de serem mensurados em imagens de satélite ou aéreas, como foi explorado no Quadro 4.1. 
Quadro 4.2. Tabulação dos dados observados na Imagem satélite (QuickBird 2005) e grupos de tipologias de acordo análise de cluster

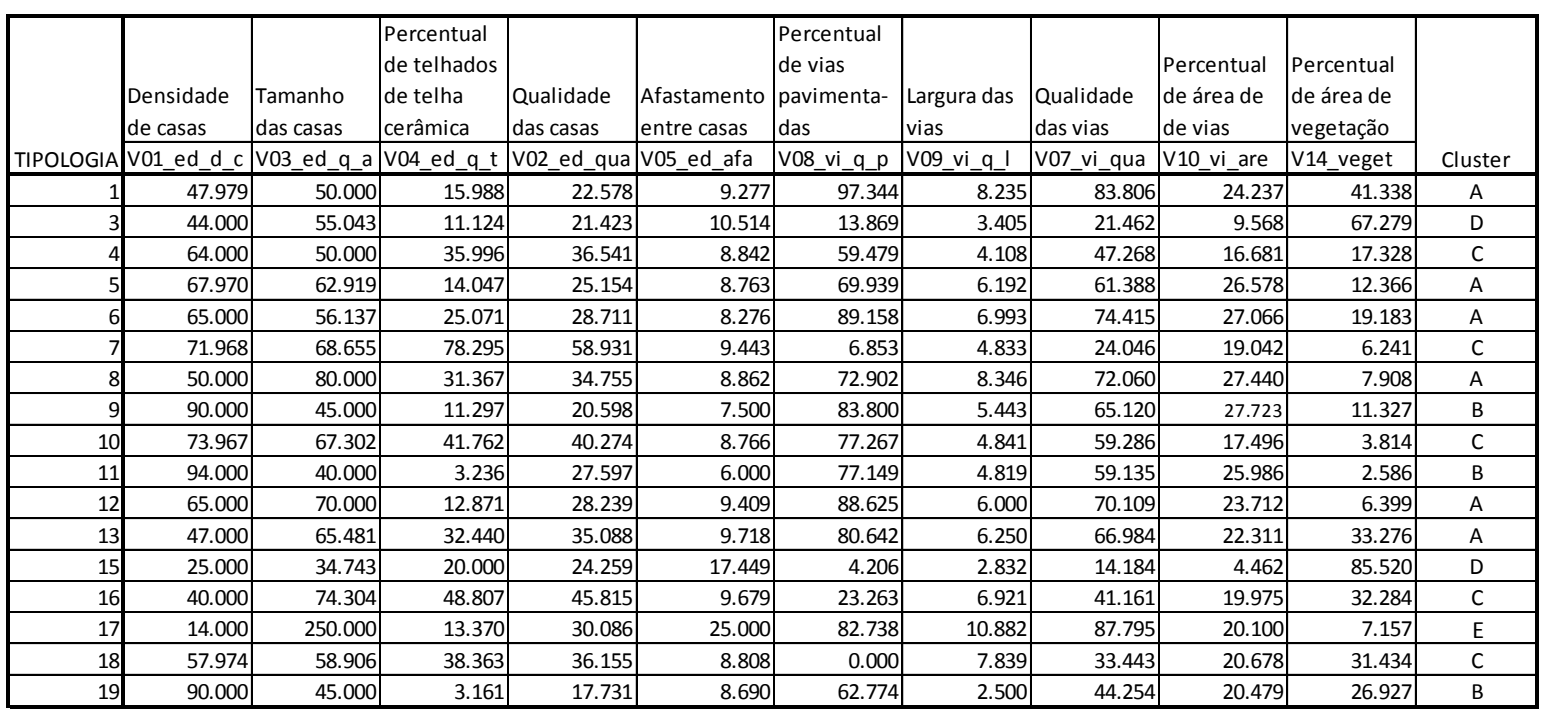

Nota: As tipologias 2 e 14, apresentadas no Quadro 4.1, não foram encontradas no Subúrbio Ferroviário

Quadro 4.3. Distância Euclidiana entre o centróide do grupo e o centróide principal por variável, agrupamento empírico.

\begin{tabular}{|l|l|l|l|l|l|l|}
\hline Variable & Grupo A & Grupo D & Grupo C & Grupo B & Grupo E & $\begin{array}{l}\text { Centróide } \\
\text { principal }\end{array}$ \\
\hline V01_ed_d_c & $-0,096178$ & $-112,044$ & 0,10379 & 144,871 & $-204,714$ & 0 \\
\hline V03_ed_q_a & $-0,102280$ & $-0,49979$ & $-0,10758$ & $-0,53208$ & 374,742 & 0 \\
\hline V04_ed_q_t & $-0,195223$ & $-0,52821$ & 119,251 & $-103,086$ & $-0,64222$ & 0 \\
\hline V02_ed_qua & $-0,223628$ & $-0,82562$ & 116,951 & $-0,90905$ & $-0,12740$ & 0 \\
\hline V05_ed_afa & $-0,280287$ & 0,83150 & $-0,26749$ & $-0,65327$ & 331,598 & 0 \\
\hline V08_vi_q_p & 0,733226 & $-145,072$ & $-0,73315$ & 0,48178 & 0,72250 & 0 \\
\hline V09_vi_q_I & 0,500493 & $-127,567$ & $-0,09135$ & $-0,75643$ & 227,445 & 0 \\
\hline V07_vi_qua & 0,774720 & $-167,039$ & $-0,61199$ & 0,07768 & 151,935 & 0 \\
\hline V10_vi_are & 0,700391 & $-217,986$ & $-0,31979$ & 0,62215 & $-0,11011$ & 0 \\
\hline V14_veget & $-0,180514$ & 225,257 & $-0,26079$ & $-0,45980$ & $-0,73872$ & 0 \\
\hline
\end{tabular}

Nota: De forma a facilitar a identificação do que caracteriza cada grupo e o que os diferencia é apresentado em vermelho os valores mais baixos com relação aos demais grupos, em azul os valores mais altos e em laranja os valores médios-baixos e em preto os valores médios-altos.

Uma vez formado os clusters foi possível calcular o centróide de cada grupo e um centroide principal em um espaço de dez dimensões. Em cada dimensão a distância euclidiana entre o centróide do grupo e o centróide geral pode ser utilizada como um parâmetro para identificar caracteristica em comum e principais diferenças entre os grupos.

Observando a análise de centróides de clusters apresentado no Quadro 4.3, e as imagens das amostras de tipologias segundo o enquadramento nos grupos, Quadro 4.4, pode-se 
dizer que os grupos de tipologias formados com base em variáveis exclusivamente derivadas de dados de sensoriamento remoto se caracterizam como:

- Grupo A - possui alto percentual de vias pavimentadas e de área coberta pelo sistema viário.

- Grupo B - possui alta densidade de casas, edificações com pequenas áreas, poucos telhados cerâmicos, casas próximas e, consequentemente, baixa qualidade das edificações.

- Grupo C - possui alta densidade de casas, alto percentual de telhado cerâmico e edificações de melhor qualidade.

- Grupo D - possui baixa densidade de casas, poucas vias e de baixa qualidade, isto é, vias mais estreitas e baixo percentual de vias asfaltadas, possui mais alto percentual de área com vegetação.

- Grupo E - possui densidade de casas mais baixa, edificações com grandes áreas e mais afastadas entre si, possui vias largas e de qualidade.

No Quadro 4.4 percebe-se que os elementos edificações e vias são determinantes na distinção das tipologias, assim como seus atributos de tamanho e de material de cobertura. Comparando o a agrupamento de tipologias com base em dados de sensoriamento remoto e macro padrões habitacionais de Gordilho (Quadro 4.4) observa-se que há correspondência entre os grupos em três níveis, quando estes são reagrupados como segue:

- Nível superior (padrão de habitabilidade Bom): E) baixa densidade com vias de maior qualidade;

- Nível intermediário (padrão de habitabilidade Bom, Regular ou Antigo): A) vias pavimentadas e área coberta por sistema viário, C) densidade alta com edificações de maior qualidade;

- Nível inferior (padrão de habitabilidade, Precário e Insuficiente): B) densidade alta com edificações de menor qualidade, D) baixa densidade de casas e vias de menor qualidade. 
Quadro 4.4. Macro grupos de tipologia baseado em dados de sensoriamento remoto

\begin{tabular}{|c|c|c|c|c|}
\hline \multirow{2}{*}{$\begin{array}{c}\text { MACRO } \\
\text { GRUPO }\end{array}$} & \multicolumn{4}{|c|}{$\begin{array}{l}\text { Amostras de tipologias encontradas no Subúrbio } \\
\text { número da tiplologia descrita no Quadro } 4.1 \text { mac }\end{array}$} \\
\hline & - (regular) & 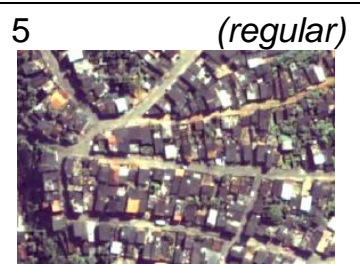 & 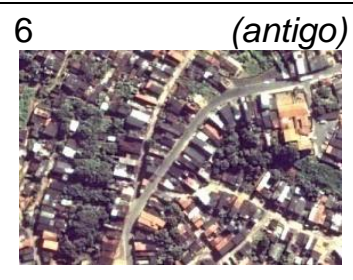 & 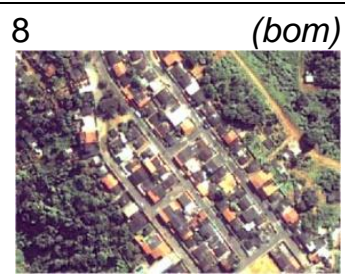 \\
\hline & 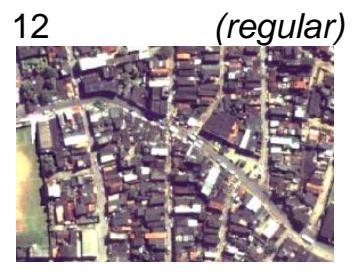 & 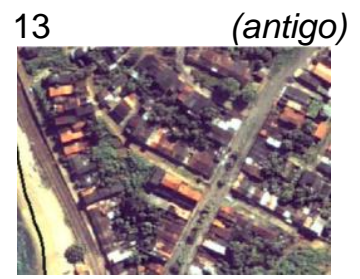 & & \\
\hline B & 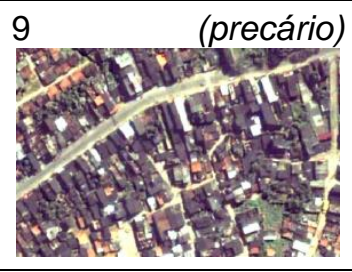 & 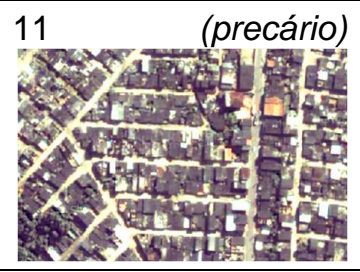 & 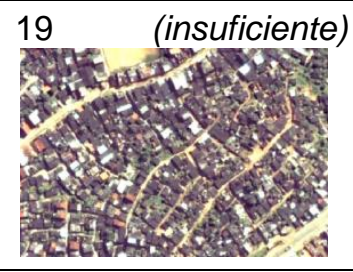 & \\
\hline C & 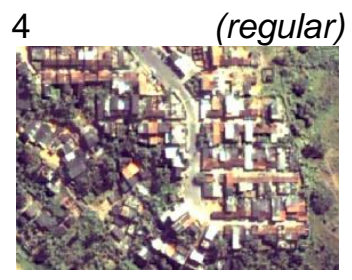 & 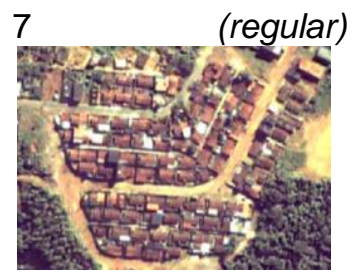 & 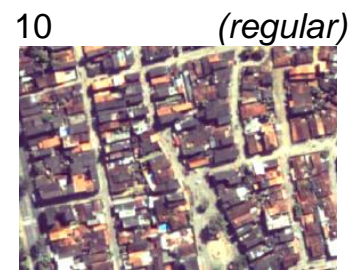 & 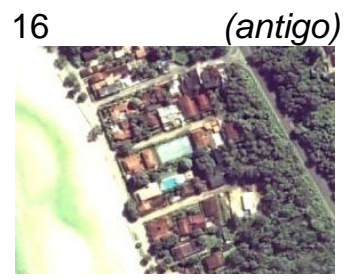 \\
\hline & 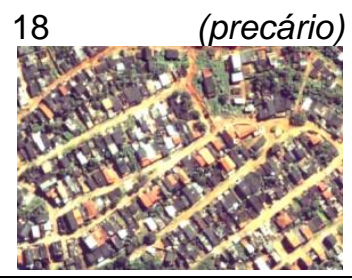 & & & \\
\hline D & $\begin{array}{ll}3 & \text { (insuficiente) } \\
3 & \\
& \end{array}$ & 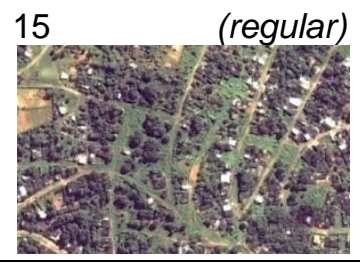 & & \\
\hline$E$ & 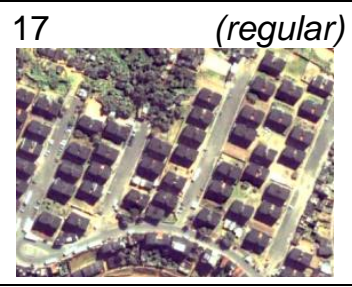 & & & \\
\hline
\end{tabular}

Nota: Grupos definidos por análise de clusters. Entre parênteses estão os macro padrões habitacionais definidos por Gordilho (2000). Pode haver incoerências entre as áreas amostradas que não foram selecionadas por Gordilho e mapeamento no qual se baseou a classificação apresentada entre parênteses. Essas incoerências podem acontecer devido, principalmente, à diferença de escala de análise ou à diferença de anos entre as análises (mapeamento data de 1991 e imagem utilizada para coleta de amostras são de 2005). 
Uma vez explicitadas as particularidades da área de estudo e exploradas as tipologias que nela se encontram, através dos elementos urbanos possíveis de serem identificados em imagens de SR, voltou-se para a investigação para o reconhecimento de tipologias e elementos urbanos, derivados de SR, que permitem, ou não, associação com a ocorrêcia da leptospirose. Assim, em seguimento ao estudo de tipologias, foi realizado um estudo sob a perspectiva da transmissão da doença, visando a identificação de elementos urbanos, alvos no processamento digital de imagens relacionados à leptospirose, detalhado no capítulo que segue. 


\section{CAPÍTULO 5 - MODELOS DE RISCO DE TRANSMISSÃO DA LEPTOSPIROSE}

A construção de um modelo de risco urbano foi realizada segundo três diferentes abordagens metodológicas. A principal meta do modelo é construir uma estrutura que reconheça os principais indicadores e variáveis baseados em produtos de sensoriamento remoto (SR) que possam descrever os riscos urbanos relacionados à leptospirose. Todas as três abordagens têm seu conteúdo baseado nas informações levantadas na revisão bibliográfica.

\subsection{Exploração do problema por mapas conceituais}

A primeira abordagem do modelo foi construída com base na metodologia de elaboração de mapas conceituais adaptada. A pergunta foco elaborada foi: o que pode interferir na transmissão da leptospirose em um ambiente urbano? Os conceitos chave utilizados se referem ao tripé da epidemiologia (agente, hospedeiro e ambiente), no caso do estudo da leptospirose, de acordo com a literatura, elegeu-se como principais conceitos chave: a bactéria Leptospira, o rato da espécie rattus norvegicus (transmite o soro grupo mais maléfico ao ser humano), alagamento/lama, acumulação de lixo e corpos d'água utilizados para atividades de recreação. A Figura 5.1 apresenta os mapas conceituais desenhados. Para cada conceito chave, os mapas exploram a complexidade do problema estudado mostrando as principais informações sobre cada conceito chave e como estes estão conectados.

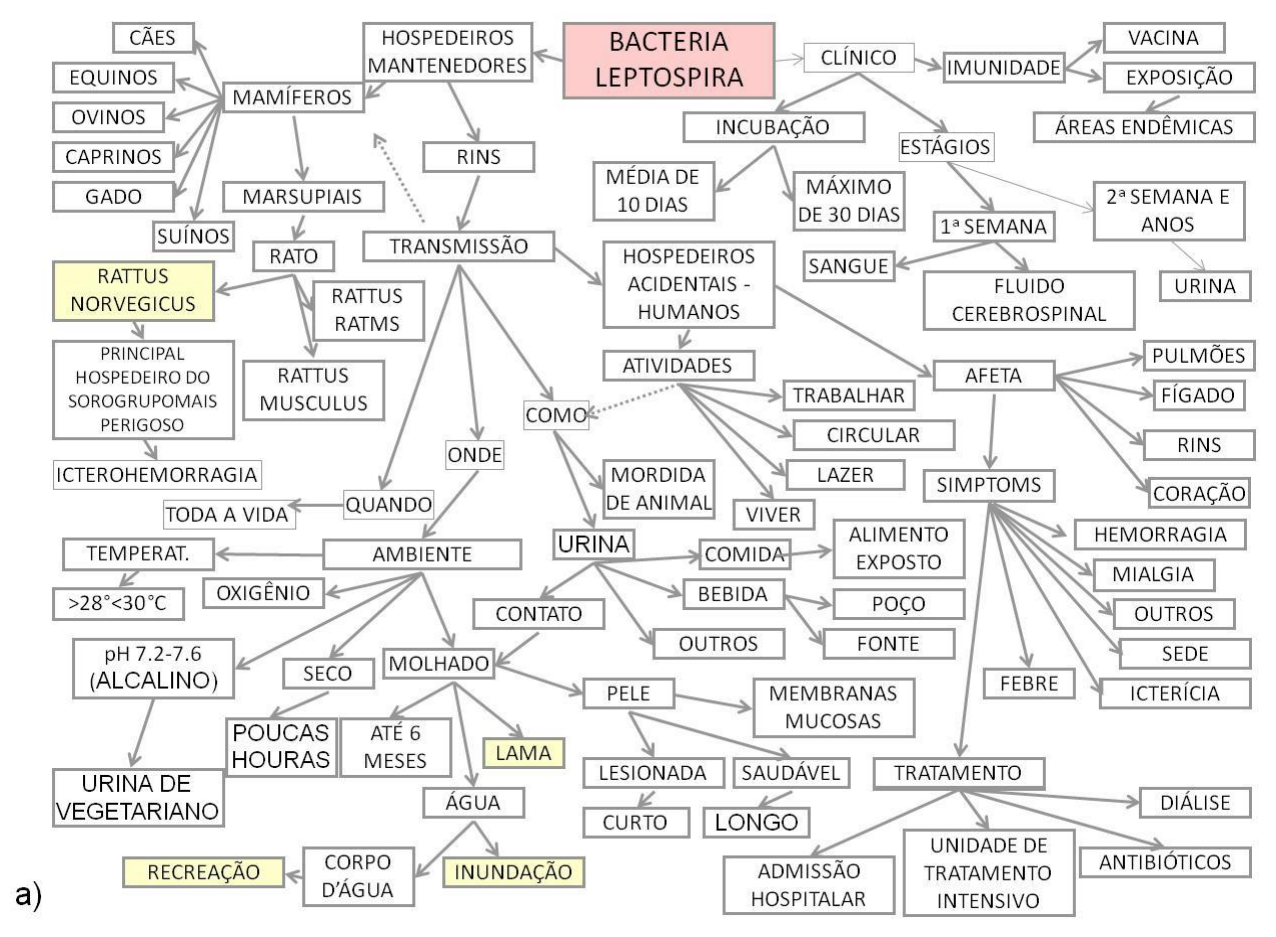



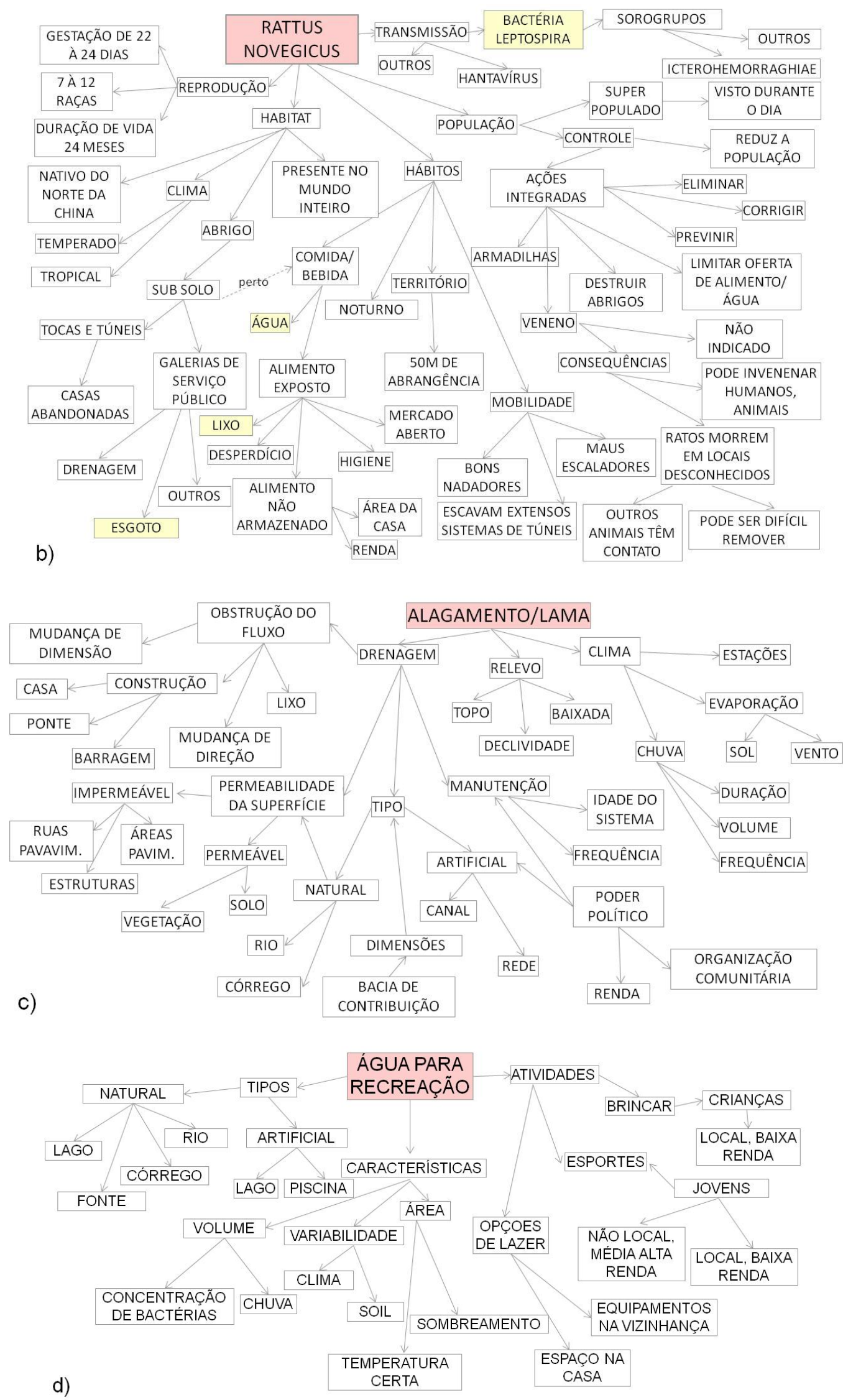

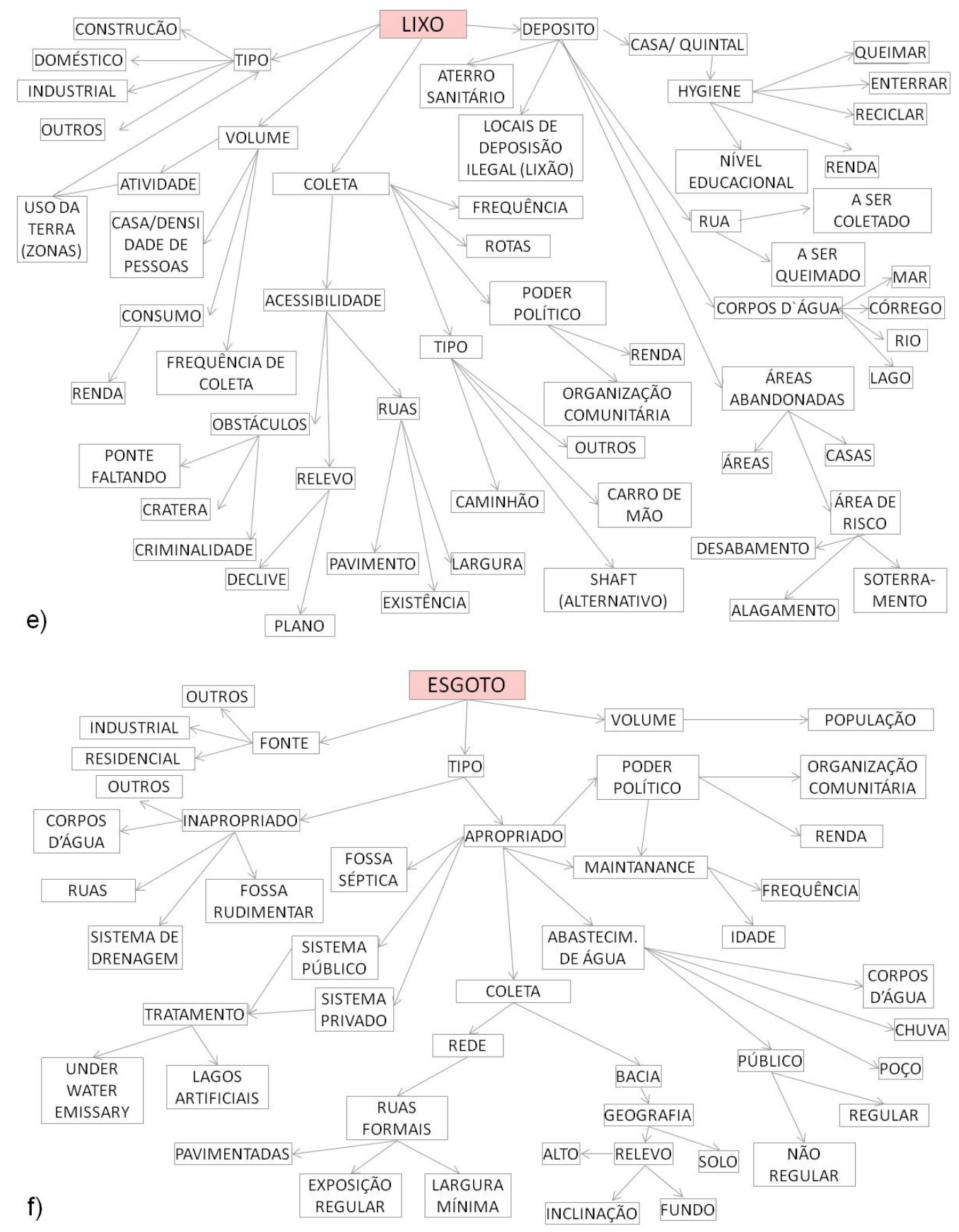

Figura 5.1. Mapas conceituais dos conceitos chave identificados através de revisão bibliográfica. Questão focal: O que pode interferir na transmissão da leptospirose em um ambiente urbano? Conceitos chave: a) bactéria Leptospira, b) rato da espécie rattus norvegicus, c) alagamento e lama, d) acumulação de lixo, e) esgotamento sanitário, f) corpo d'água utilizado para recreação.

Apesar de ser possível explorar a complexidade do tema por meio destes diagramas, seu resultado não atende a todos os objetivos traçados para esta etapa da pesquisa, visto que a identificação de indicadores e variáveis não é clara. A metodologia ISA (Indicadores de Salubridade Ambiental), por outro lado, explora as relações lineares entre condições urbanas e os seus indicadores. 


\subsection{Modelo ISA/L - Indicadores de Salubridade Ambiental para transmissão da Leptospirose}

O modelo adaptado da metodologia ISA para avaliação de risco urbano de transmissão da leptospirose (ISA/L) com base em dados de SR foi criado a partir das quatro principais condições de risco indicadas pela revisão bibliográfica: alagamento, acúmulo de lixo, esgotamento sanitário e água usada para recreação.

Neste modelo, sintetizado na Figura 5.2, cada Condição foi formada por um ou dois Componentes. Cada Componente é descrito por Indicadores, que por sua vez são calculados por meio de variáveis. Para viabilizar o uso de variáveis baseadas em dados de SR, Indicadores mais diretamente relacionados aos Componentes, que não são baseados em variáveis de SR, foram substituídos por um conjunto de indicadores proxy, quando possível e necessário, a fim de identificar variáveis baseadas em SR. Finalmente, o modelo define variáveis calculadas a partir de produtos de SR que devem estar relacionadas ao risco de transmissão da leptospirose.

Por exemplo, a Condição acumulação de lixo tem volume de lixo como um dos seus Componentes, que tem densidade populacional, calculada utilizando levantamento do censo, como um primeiro Indicador e densidade de casas, baseada em dados de SR, como um segundo Indicador (Figura 5.3).

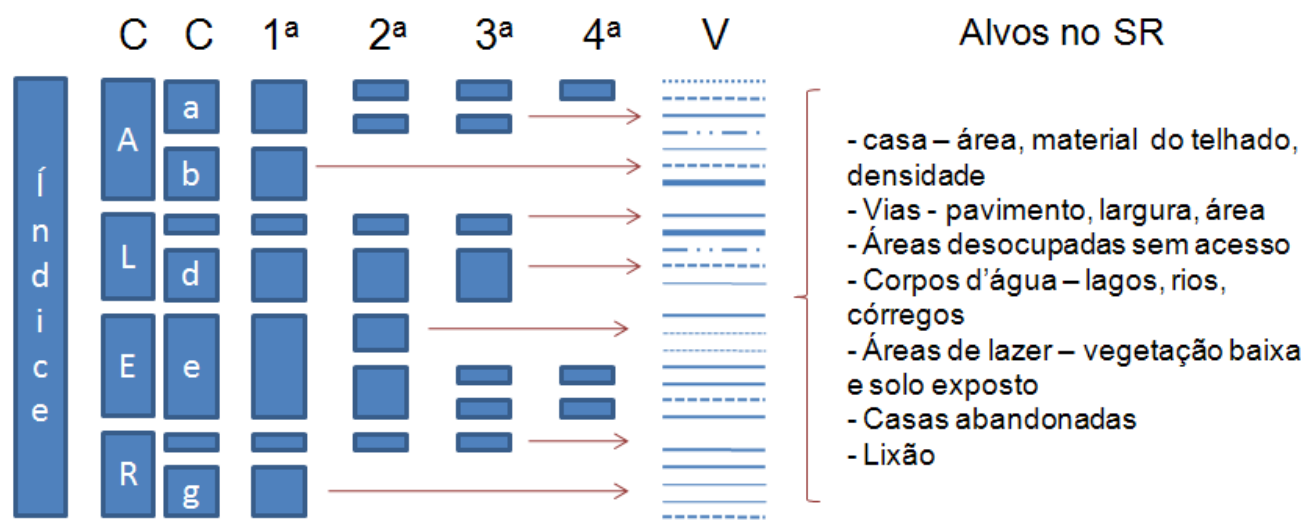

Figura. 5.2. ISA/L - Modelo de risco de transmissão de leptospirose baseado na metodologia ISA

(São Paulo, 1999). Nome nas colunas: C) condição urbana, C) componentes, 1ㄹ) Primeiros Indicadores, $2^{\mathrm{a}}$ ) segundos indicadores, $3^{\mathrm{a}}$ ) terceiros indicadores, $4^{\mathrm{a}}$ ) quartos indicadores, $\mathrm{V}$ ) variáveis, RS) objetos de interesse nas imagens e suas características. Condições urbanas: A) alagamento, L) acumulação de lixo, E) esgotamento, R) água usada para recreação. Componentes: a) qualidade do sistema de drenagem, b) situação do terreno, c) volume, d) destino, e) qualidade do sistema de esgotamento, f) características dos corpos d'água, g) opções de lazer. 


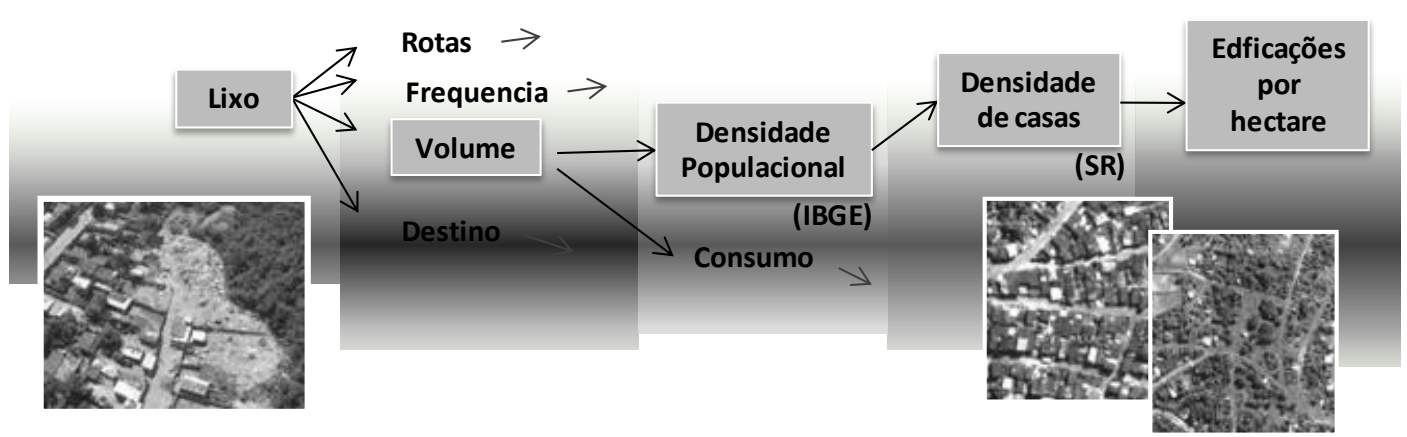

Figura 5.3. Exemplo de identificação de variável baseada em produto de sensoriamento remoto utilizando modelo de risco ISA/L

O modelo criado tem vinte e três indicadores baseados em dados de SR, que, por sua vez, podem ser calculados por um conjunto de vinte e uma variáveis. A partir de então, foi possível definir doze objetos e características de interesse que seriam pesquisadas nas imagens. A Figura 5.2 apresenta um esquema do modelo ISA/L e os objetos de interesse de SR.

O modelo ISA/L atingiu a meta de reconhecer os principais indicadores e variáveis baseadas em SR. No entanto, a complexidade apresentada pelo problema, compele à exploração de um modelo que contemple fatores ecológicos identificados nos mapas conceituais. Por isso, foi testada mais uma metodologia, a sugerida pela Organização Mundial de Saúde (OMS) para avaliação do meio ambiente e efeitos em saúde.

\subsection{Modelo Causal FPEEEA/L: Força Motriz - Pressão - Estado - Exposição - Efeito - Ação na transmissão da Leptospirose}

O modelo proposto com base na metodologia da OMS, o FPEEEA/L, mostrou não apenas correlações existentes entre a doença e o ambiente urbano, mas também suas correlações com ações de intervenção. O modelo de qualidade ambiental urbana - QAU, baseado na mesma metodologia, apresentado por Borja e Moraes (2003), foi utilizado como ponto de partida. Os indicadores sugeridos pelos autores que não eram relacionados aos efeitos da doença leptospirose foram descartados e novos indicadores foram adicionados, usando como referência os mapas conceituais, o modelo ISA/L e a revisão bibliográfica. Com o objetivo de usar variáveis baseadas em dados de SR, a metodologia foi também adaptada utilizando variáveis diretamente relacionadas aos indicadores e variáveis proxy, a semelhança do que foi sugerido no modelo ISA/L. A Figura 5.4 apresenta o diagrama 
completo do modelo FPEEEA/L, formado por vinte e seis indicadores de pressão, estado e exposição e oito propostas de macro-ações.

Os indicadores de pressão e estado, por apresentarem correspondência com a estrutura espacial urbana foram investigados quanto às variáveis que podem ser utilizadas para o seu cálculo. A Figura 5.5 apresenta esses indicadores e a escala de análise de cada um. Essas escalas de análise têm, por sua vez, suas descrições detalhadas no Quadro 5.1.

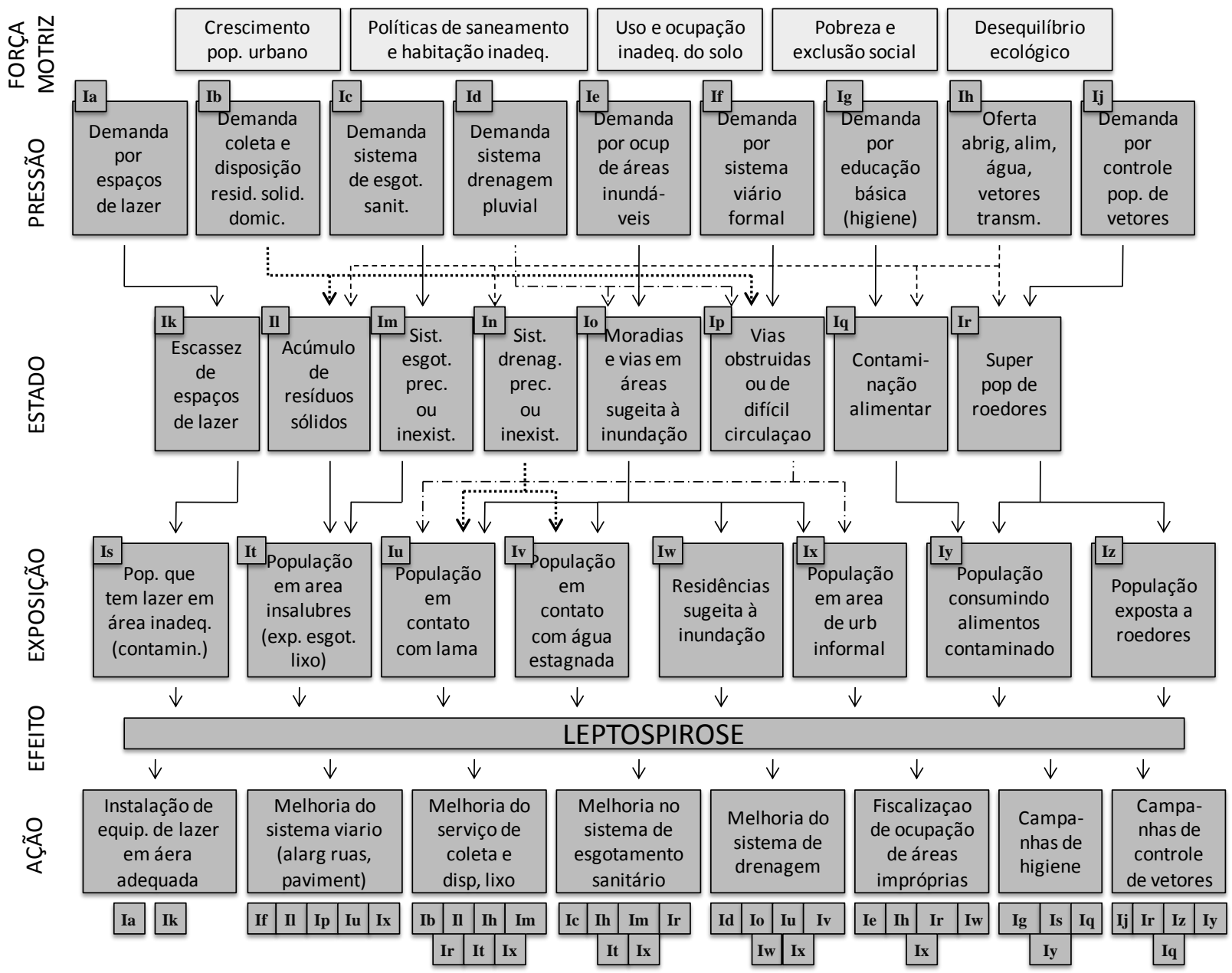

Figura 5.4. FPEEEA/L - Modelo de risco de transmissão da leptospirose com base na metodologia FPEEEA. Adaptado de Borja e Moraes (2003). Este modelo considera as atividades humanas Forças Motrizes que geram processos ou Pressões que alteram o ambiente. Essas pressões prejudicam a situação ou Estado do meio, Expondo a população a Efeitos negativos na sua saúde. Por fim, a sociedade ou governo responde com Ações que visam quebrar esta cadeia de causa-efeito. (DGA, $2000^{28}$; OCDE, $2002^{29}$ apud SUPERINTENDÊNCIA DE ESTUDOS ECONÔMICOS SOCIAIS DA BAHIA E UNIVERSIDADE FEDERAL DA BAHIA, 2006)

28 GDA - Direção Geral do Ambiente. Proposta para um Sistema de Indicadores de Desenvolvimento Sustentável (SIDS). Lisboa, 2000. 228 p.

29 OCDE - Organização de Cooperação e Desenvolvimento Econômico. Rumo a um desenvolvimento sustentável: indicadores ambientais. Tradução Ana Maria S. F. Teles. Salvador: CRA, 2002. 224 p. (Série cadernos de referência, 9). 


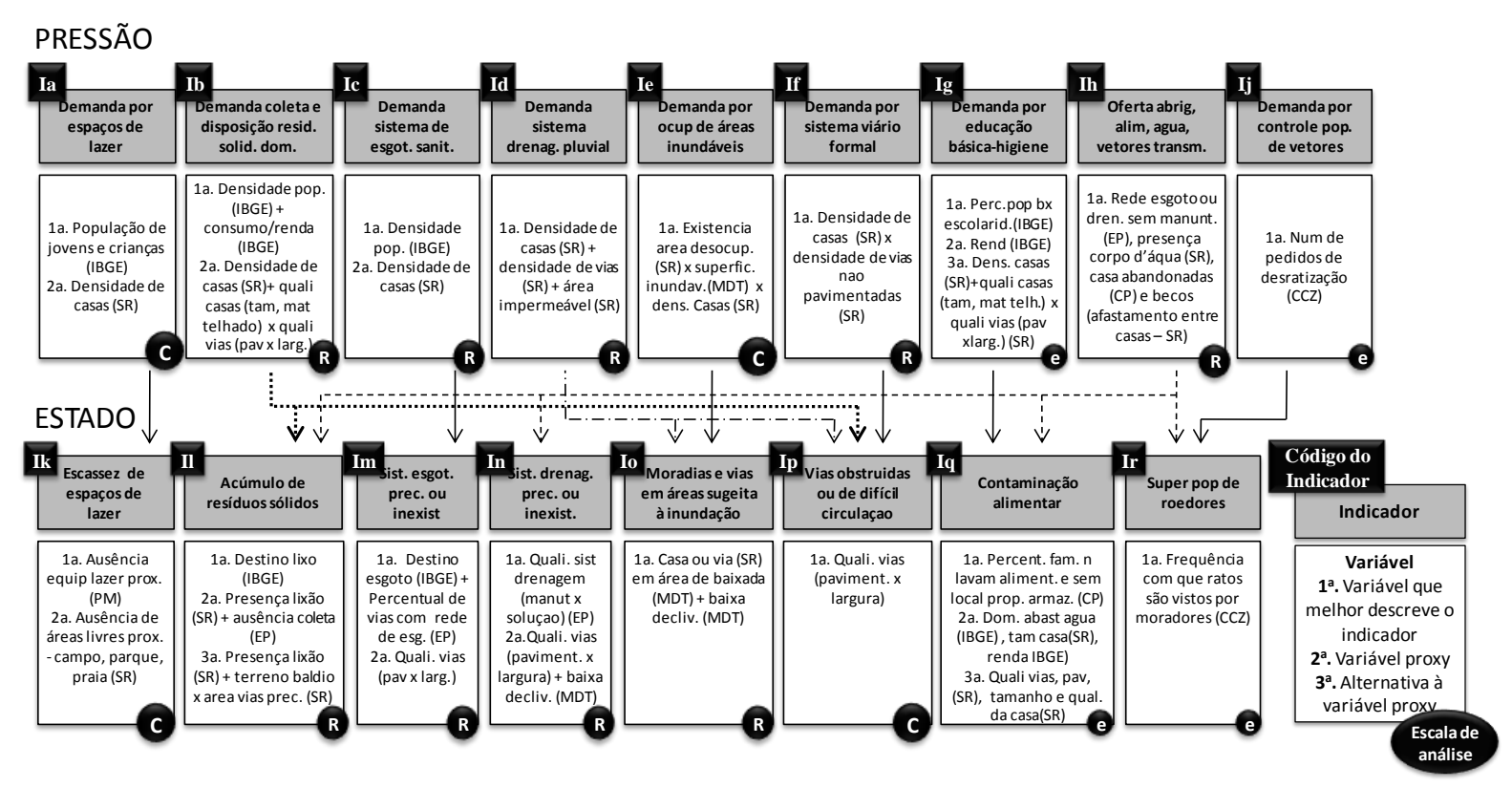

Figura 5.5. Variáveis e escalas de análise dos indicadores de Estado e Pressão do modelo FPEEEA/L. Em algarismos ordinais estão as variáveis que podem ser usadas para compor o indicador. Entre parênteses encontra-se a fonte do dado. A letra abaixo do bloco de cada indicador corresponde à escala de análise das variáveis: $\mathrm{E}$ - entorno, $\mathrm{R}$ - rua, $\mathrm{C}$ - comunidade. CP: pesquisa de campo, SR: sensoriamento remoto, MDT: Modelo Digital do Terreno, CCZ: Centro de Controle de Zoonozes, IBGE: Instituto Brasileiro de Geografia e Estatística, PM: Prefeitura Municipal, EP: Empresas privadas.

Quadro 5.1. Dimensionamento e descrição do raio de abrangência utilizado para a análise dos Indicadores do modelo FPEEEA/L

\begin{tabular}{lll}
\hline Escala de análise & Raio & Representatividade \\
\hline Comunidade & $\mathbf{1 5 0 m}$ & $\begin{array}{l}\text { Comunidade, conjunto de quadras, acesso a } \\
\text { ruas principais. }\end{array}$ \\
\hline Rua & $\mathbf{5 0 m}$ & $\begin{array}{l}\text { Rua de acesso à residência, quadra, conjunto } \\
\text { de casas. Aproxima-se à mediana do tamanho } \\
\text { das quadras em bairros densamente ocupados } \\
\text { do Subúrbio. Raio de ação do rato. }\end{array}$ \\
\hline Entorno & $\mathbf{2 0 m}$ & $\begin{array}{l}\text { Entorno imediato, propriedade, casas vizinhas } \\
\text { em área densa. }\end{array}$ \\
\hline
\end{tabular}

Nota: o raio de $20 \mathrm{~m}$ foi escolhido também por apresentar resultados de correlação positiva ente as condições ambientais e a Leptospirose no estudo desenvolvido por Reis et al. (2008)

Assim como sugerido no modelo ISA/L, acredita-se que as primeiras variáveis tenham mais chances de representar mais corretamente o indicador a que pertence. No entanto, a fonte desse tipo de dado pode não ser adequada ao estudo (por problemas de escala ou atualização, por exemplo) ou pode não estar acessível ao pesquisador, fazendo necessário recorrer-se a uma variável proxy.

Por exemplo, no cálculo do Indicador Ic - Demanda por sistema de esgotamento sanitário, por exemplo, a primeira variável é a densidade populacional, que pode comumente ser 
obtida com dados do Censo do IBGE. No entanto, se os limites do setor censitário não coincidirem com a unidade espacial de investigação ou se os dados censitários disponíveis não se adequarem ao período investigado, este indicador pode ser estimado utilizando a densidade de casas, dado obtido por meio de técnicas de SR.

\subsection{Variáveis FEPEEEA/L baseadas em produtos de Sensoriamento Remoto}

Assumindo o modelo FPEEEA/L como aquele que melhor atende os objetivos desse estudo, foi realizado um detalhamento da correlação entre os indicadores de pressão e de estado e as variáveis baseadas em produtos de SR apresentadas nesse modelo. Os Quadros 5.2 e 5.3 mostram que há variáveis que servem para o cálculo de mais de um indicador, assim como há variáveis de alta correlação mútua, como densidade de casas na escala do bairro e densidade de casas na escala da rua. A Seção 2.1 .2 da revisão bibliográfica trata dos problemas relativos a estas situações quando se pretende encontrar uma equação de risco de transmissão da leptospirose utilizando dados de casos ocorridos. No entanto, o objetivo do modelo nesta Tese é de reconhecer as características urbanas que podem ser estimadas com uso de SR e que podem estar correlacionadas com a transmissão da doença, não será explorado aqui a aplicação ou cálculo do modelo.

Os Quadros 5.2 e 5.3 indicam ainda se a variável tem uma correlação positiva ou negativa com indicador. Por exemplo, o indicador $l b$ - demanda por coleta de disposição de resíduos sólidos domiciliares, deve ser analisado na escala da rua e parte do princípio de que quanto maior o número de habitantes de uma rua e quanto maior a sua renda, maior será a produção de lixo, portanto, quanto maior a quantidade de casas e melhor o padrão construtivo das edificações e vias, maior será a produção de lixo. 
Quadro 5.2. Variáveis baseadas em SR que podem ser utilizadas para o cálculo dos indicadores de pressão e suas escalas de análise.

\begin{tabular}{|c|c|c|c|}
\hline $\begin{array}{l}\text { Indicadores de Pressão - } \\
\text { demanda por: }\end{array}$ & $\begin{array}{l}\text { Escala de } \\
\text { análise }\end{array}$ & Primeiras variáveis & $\begin{array}{l}\text { Variáveis baseadas } \\
\text { em produtos de SR }\end{array}$ \\
\hline la - espaços de lazer & $\begin{array}{l}\text { comunida- } \\
\text { de }\end{array}$ & $\begin{array}{l}\Delta \text { Densidade de população } \\
\text { jovem e crianças }\end{array}$ & $\Delta$ Densidade de casas \\
\hline $\begin{array}{l}\text { lb - coleta e disposição } \\
\text { resíduos sólidos domiciliares }\end{array}$ & rua & $\begin{array}{l}\Delta \text { Densidade populacional } \\
\text { A Renda }\end{array}$ & $\begin{array}{l}\Delta \text { Densidade de casas } \\
\Delta \text { Qualidade das casas, } \\
\text { qualidade das vias }\end{array}$ \\
\hline $\begin{array}{l}\text { Ic - sistema de esgotamento } \\
\text { sanitário }\end{array}$ & rua & $\boldsymbol{\Delta}$ Densidade populacional & $\Delta$ Densidade de casas \\
\hline $\begin{array}{l}\text { Id - sistema de drenagem } \\
\text { pluvial }\end{array}$ & rua & $\begin{array}{l}\text { A Extensão da área } \\
\text { impermeável }\end{array}$ & $\begin{array}{l}\text { A Extensão da área } \\
\text { impermeável }\end{array}$ \\
\hline $\begin{array}{l}\text { le - ocupação de áreas } \\
\text { inundáveis }\end{array}$ & $\begin{array}{l}\text { comunida- } \\
\text { de }\end{array}$ & $\begin{array}{l}\text { A Existência de áreas não } \\
\text { ocupadas } \\
\text { ( Densidade de casas no } \\
\text { bairro }\end{array}$ & $\begin{array}{l}\text { A Existência de áreas } \\
\text { não ocupadas } \\
\text { A Densidade de casas } \\
\text { no bairro }\end{array}$ \\
\hline If - sistema viário formal & rua & $\begin{array}{l}\Delta \text { Densidade de casas } \\
\nabla \text { Qualidade das vias }\end{array}$ & $\begin{array}{l}\Delta \text { Densidade de casas } \\
\nabla \text { Qualidade das vias }\end{array}$ \\
\hline $\begin{array}{l}\text { Ig - educação básica / } \\
\text { higiene }\end{array}$ & entorno & $\begin{array}{l}\text { A População com baixa } \\
\text { escolaridade }\end{array}$ & $\begin{array}{l}\boldsymbol{\nabla} \text { Qualidade das casas } \\
\boldsymbol{\nabla} \text { Qualidade das vias }\end{array}$ \\
\hline $\begin{array}{l}\text { Ih - oferta de abrigo, } \\
\text { alimento e água a vetores } \\
\text { transmissores }\end{array}$ & rua & $\begin{array}{l}\text { A Existência de corpos } \\
\text { d'água } \\
\Delta \text { Existência de becos }\end{array}$ & $\begin{array}{l}\text { A Existência de corpos } \\
\text { d'água } \\
\text { v Afastamento entre } \\
\text { casas* }^{*}\end{array}$ \\
\hline lj - Controle de vetores & entorno & - & - \\
\hline
\end{tabular}

Nota: $\boldsymbol{\Delta}$ - relação positiva, $\boldsymbol{\nabla}$ - relação negativa, $\left(^{*}\right)$ desde que diferente de zero, pois afastamento nulo não forma viela, por isso não configura abrigo de roedores. 
Quadro 5.3. Variáveis baseadas em SR que podem ser utilizadas para o cáculo dos indicadores de Estado e suas escalas de análise.

\begin{tabular}{|c|c|c|c|}
\hline Indicadores de Estado & $\begin{array}{l}\text { Escala de } \\
\text { análise }\end{array}$ & $\begin{array}{l}\text { Variáveis de primeira } \\
\text { ordem }\end{array}$ & $\begin{array}{l}\text { Variáveis baseadas } \\
\text { em produtos de SR }\end{array}$ \\
\hline $\begin{array}{l}\text { lk - Escassez de espaços } \\
\text { de lazer }\end{array}$ & $\begin{array}{l}\text { comunida- } \\
\text { de }\end{array}$ & $\begin{array}{l}\nabla \text { Existência de } \\
\text { equipamentos de lazer }\end{array}$ & $\begin{array}{l}\text { Existência e campo, } \\
\text { praia ou parque }\end{array}$ \\
\hline $\begin{array}{l}\text { II - acúmulo de resíduos } \\
\text { sólidos }\end{array}$ & rua & $\begin{array}{l}\Delta \text { Lixo sem destino } \\
\text { apropriado }\end{array}$ & 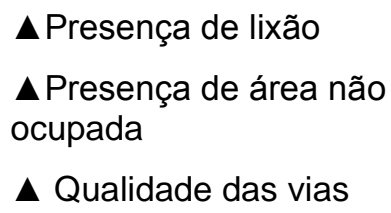 \\
\hline $\begin{array}{l}\text { Im - sistema de } \\
\text { esgotamento precário ou } \\
\text { inexistente }\end{array}$ & rua & $\begin{array}{l}\text { A residências atendidas } \\
\text { por rede de esgotamento } \\
\text { sanitário }\end{array}$ & $\nabla$ Qualidade das vias \\
\hline $\begin{array}{l}\text { In - sistema de drenagem } \\
\text { precário ou inexistente }\end{array}$ & rua & $\begin{array}{l}\nabla \text { Qualidade do sistema de } \\
\text { drenagem }\end{array}$ & $\nabla$ Qualidade das vias \\
\hline $\begin{array}{l}\text { lo - moradias e vias em } \\
\text { áreas sujeitas à inundação }\end{array}$ & rua & $\begin{array}{l}\Delta \text { Quantidade de casas } \\
\Delta \text { Quantidade de vias }\end{array}$ & $\begin{array}{l}\Delta \text { Quantidade de casas } \\
\Delta \text { Área de vias }\end{array}$ \\
\hline $\begin{array}{l}\text { Ip - Vias obstruídas ou de } \\
\text { difícil circulação }\end{array}$ & $\begin{array}{l}\text { comunida- } \\
\text { de }\end{array}$ & $\nabla$ Qualidade das vias & $\nabla$ Qualidade das vias \\
\hline lq - Contaminação alimentar & entorno & $\begin{array}{l}\text { A Ausência de local próprio } \\
\text { para o armazenamento de } \\
\text { alimentos }\end{array}$ & $\begin{array}{l}\boldsymbol{\nabla} \text { Qualidade das vias } \\
\nabla \text { Qualidade das casas } \\
\nabla \text { Tamanho das casas }\end{array}$ \\
\hline $\begin{array}{l}\text { Ir - super população de } \\
\text { roedores }\end{array}$ & entorno & - & - \\
\hline
\end{tabular}

Nota: $\boldsymbol{\Lambda}$ - relação positiva, $\boldsymbol{\nabla}$ - relação negativa.

Como exercício exploratório, amostras de cada variável foram identificadas nas fotografias de campo e nas imagens verticais. Dentre as variáveis apresentadas no Quadro 5.4, apenas a variável presença de lixão apresentou elevada dificuldade para ser identificada visualmente nas imagens satélite ou ortofotografias, sendo, portanto, descartada a aquisição dessa informação por meio de SR. 
Quadro 5.4. Amostras com imagens de campo e imagens verticais de variáveis baseadas em SR do modelo FPEEEA/L

\begin{tabular}{|c|c|c|c|c|}
\hline $\begin{array}{c}\text { Variável } \\
\text { baseada em } \\
\text { SR }\end{array}$ & $\begin{array}{c}\text { Escala de } \\
\text { análise }\end{array}$ & $\begin{array}{l}\text { Indica- } \\
\text { dores }\end{array}$ & Fotografias de campo & Imagem aérea ou orbital \\
\hline $\begin{array}{l}\text { A Densidade } \\
\text { de casas }\end{array}$ & rua & $\begin{array}{l}\text { Ic, If, Ib, } \\
\text { lo }\end{array}$ & & \\
\hline $\begin{array}{l}\text { A Densidade } \\
\text { de casas }\end{array}$ & $\begin{array}{l}\text { comunida- } \\
\text { de }\end{array}$ & le & & LWast \\
\hline $\begin{array}{l}\text { A Existência } \\
\text { de áreas não } \\
\text { ocupadas }\end{array}$ & $\begin{array}{l}\text { comunida- } \\
\text { de }\end{array}$ & le & & \\
\hline $\begin{array}{l}\text { A Existência } \\
\text { de corpos } \\
\text { d'água }\end{array}$ & entorno & Ih & & \\
\hline $\begin{array}{l}\text { A Extensão da } \\
\text { área } \\
\text { impermeável }\end{array}$ & rua & Id & & $a$ \\
\hline $\begin{array}{l}\Delta \text { Densidade de } \\
\text { casas } \\
\text { abandonadas ** }\end{array}$ & entorno & Ih & & 8 \\
\hline
\end{tabular}


continuação

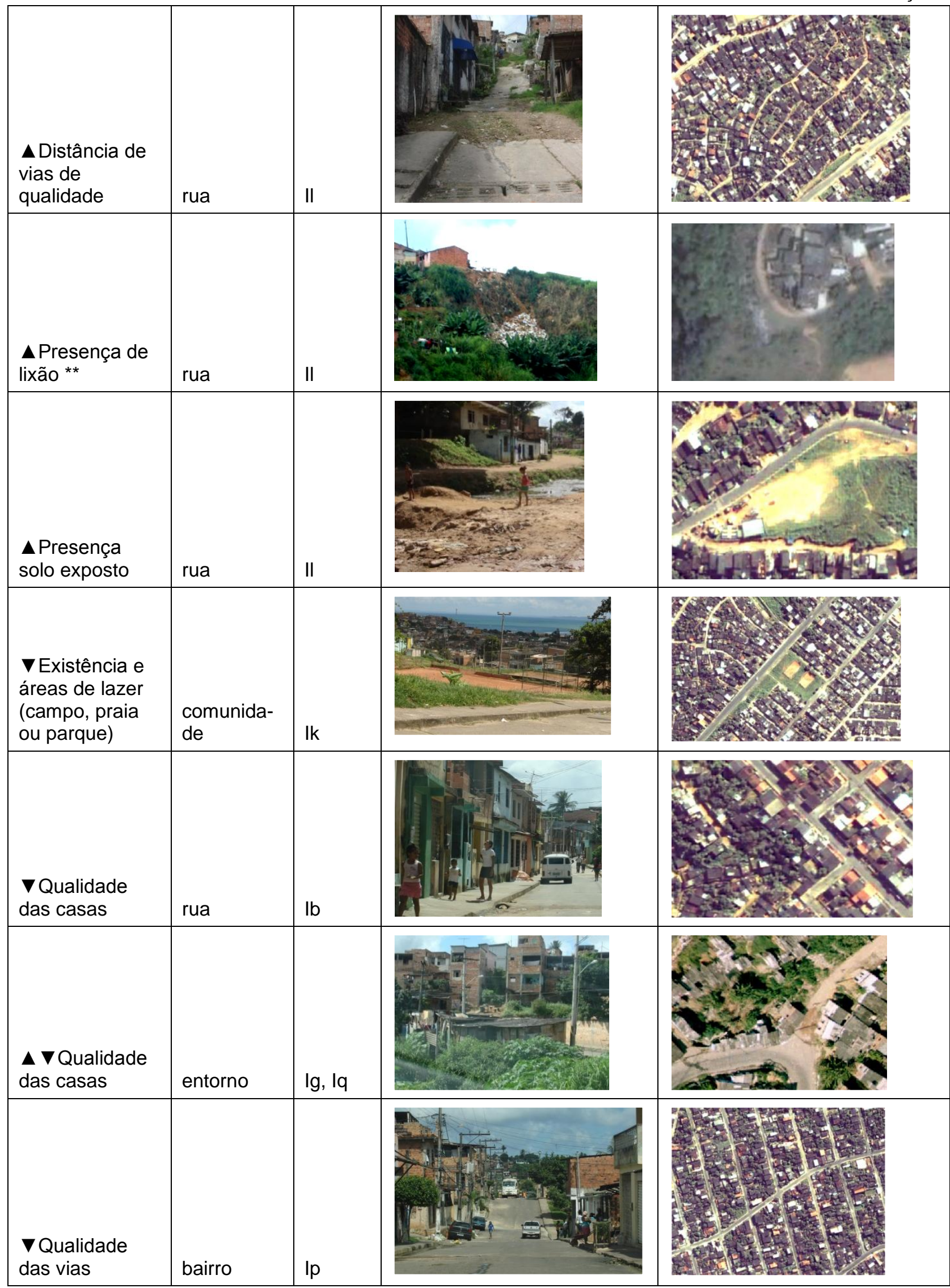


continuação

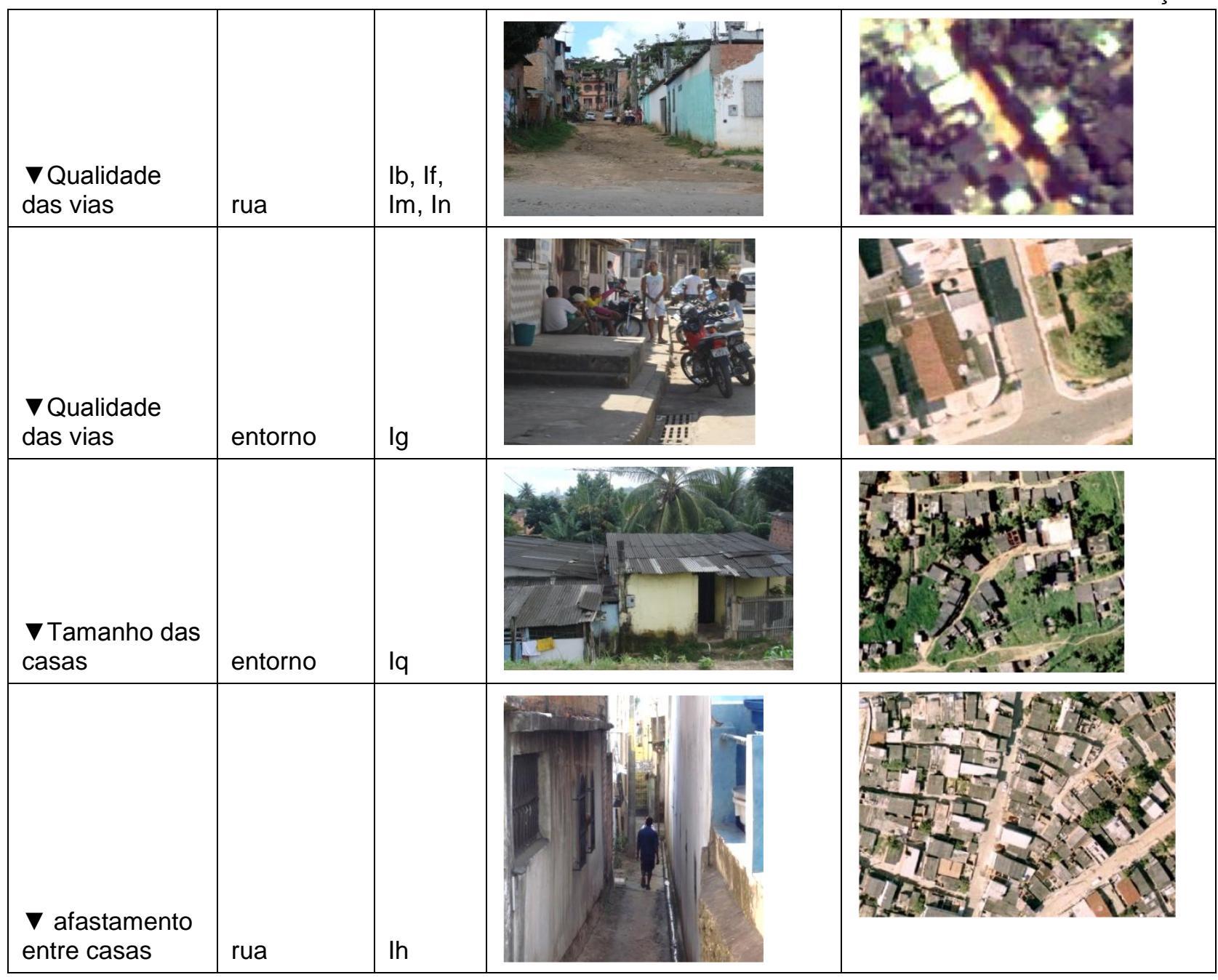

Nota: $\left({ }^{*}\right)$ fotografias cedidas por Floriano Freaza Arq. Assoc.; $\left(^{* *}\right)$ Casas abandonadas e lixão, como pode ser visto nas imagens, são muito difíceis de serem reconhecidas por imagem de $S R$, por isso não farão parte das análises.

Foram identificadas um total de 17 variáveis baseadas em dados de SR. Dentre estas, observa-se no Quadro 5.4 que a densidade de casas na rua e a qualidade das vias na escala da rua destacam-se pelo número de indicadores que podem ser estimados usando essa informação. Todas as fotografias e imagens apresentadas no quadro são da área de estudo, mas revelam situações presentes em muitas outras áreas da cidade ou mesmo em áreas de outros centros urbanos.

A descrição detalhada dos alvos de SR utilizados no cálculo dessas variáveis identificadas com uso do modelo FPEEEA/L e das variáveis utilizadas para descrever as tipologias encontradas no Subúrbio é apresentada no Capítulo seguinte, onde também é descrito o método de SR utilizado para calculá-las. 


\section{CAPÍTULO 6 - PROCESSAMENTO DE DADOS DE SENSORIAMENTO REMOTO}

A etapa de processamento de imagens utilizando técnicas de sensoriamento remoto (SR) para identificação de objetos é detalhada neste capítulo, que tem como objetivo apresentar procedimentos adaptáveis aos recursos de imagem disponíveis, sejam fotografias aéreas ou imagens satélite, para extração de informações necessárias ao cálculo das variáveis identificadas no modelo de risco e nos estudos de tipologia.

Assim, foram levantados os alvos e informações a serem extraídas das imagens. Com base em áreas específicas de processamento, estes alvos e suas características mais relevantes para o estudo determinaram os procedimentos de segmentação e classificação das imagens descritos neste capítulo, que apresenta ainda uma avaliação da acurácia com que esses dados foram extraídos e, como consequência, uma avaliação da confiabilidade de cada variável.

\subsection{Caracterização dos Alvos}

As imagens de alta resolução espacial indicadas para este tipo de estudo exibem um altíssimo nível de detalhamento do tecido urbano. Muitas informações podem ser extraídas dessas imagens, como foi apresentado na revisão bibliográfica, Seção 2.3. No entanto, é muito importante ter claro quais os elementos dessa paisagem que realmente interessam ao estudo em questão, isto é, a definição dos alvos e suas características. Em uma análise baseada em objetos, essas informações podem ser extraídas com a criação dos objetos, que têm como atributos informações da classe a que pertence, assim como atributos geométricos, topológicos e espectrais.

No Quadro 6.1 foi feito uma sistematização das variáveis baseadas em SR identificadas na construção modelo FPEEEA/L (conforme apresentado no Capítulo 5, Seção 5.4), e no levantamento de tipologias habitacionais encontradas no Subúrbio (conforme apresentado no Capítulo 4, Seção 4.3). No mesmo quadro são descritas as escalas de análise de cada variável e os respectivos alvos nas imagens de SR que serviram para o cálculo da variável. 
Quadro 6.1. Levantamento dos alvos e suas características de interesse para o estudo, de acordo com as variáveis baseadas em SR, indicadores do modelo FPEEEA $/ L^{1}$, tipologias encontradas no Subúrbio e escalas de análise

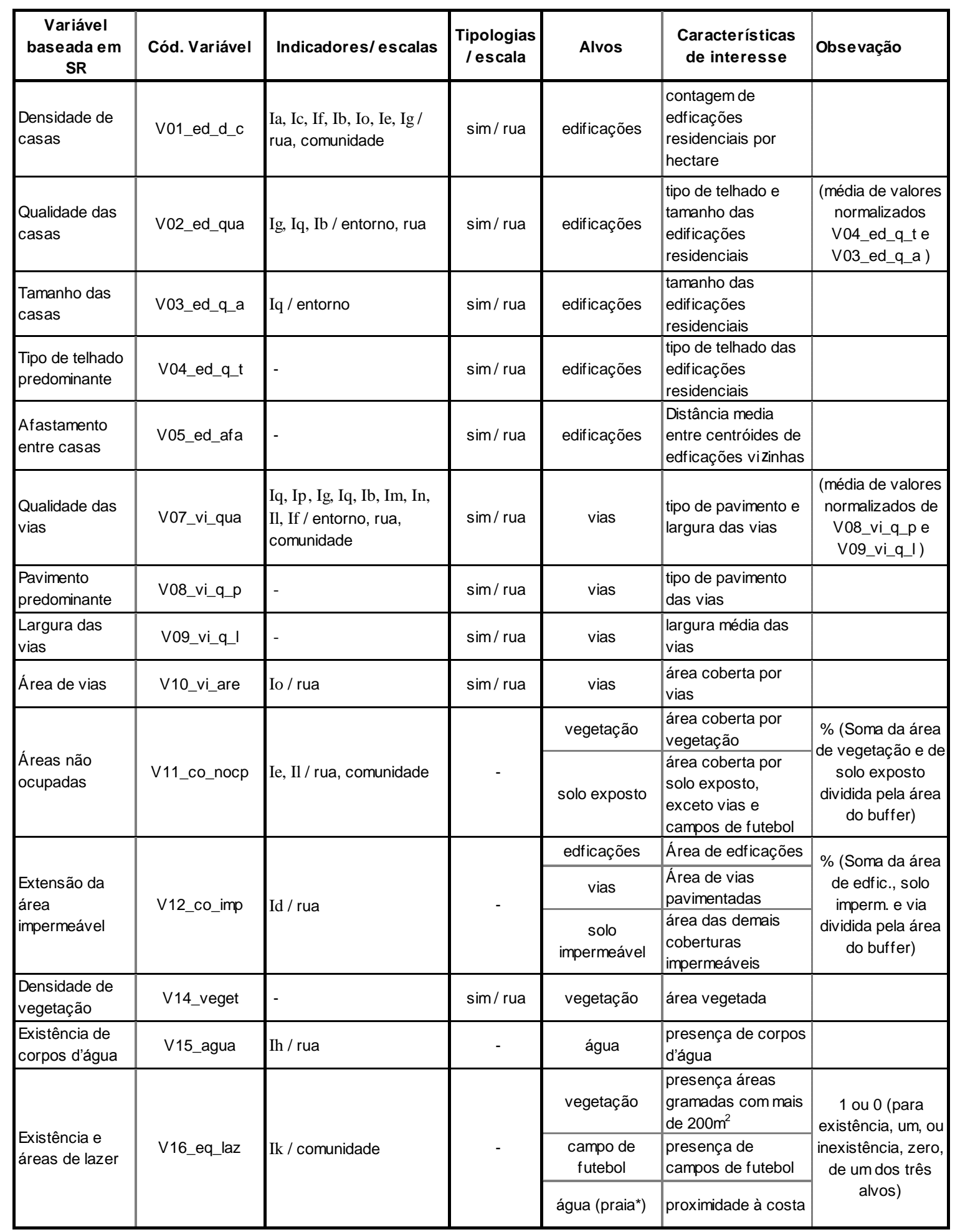

Nota: (1) Conforme apresentado no Capítulo 5, Seção 5.4. (*) Apesar de ser possível reconhecer área de praia utilizando métodos digitais de classificação de imagem de SR, devido à existência dos limites da área de estudo e a comum facilidade de acesso a esse tipo de informação, foi utilizado a intersecção do buffer de $150 \mathrm{~m}$ com a linha costeira para o cálculo dessa variável. 
As 14 variáveis são descritas por 7 alvos (edificações, vias, vegetação, solo exposto, solo impermeável, água e campo de futebol) e seus atributos (área, material, largura, porte, etc.). Com base no Quadro 6.1 pode-se dizer que as classes de interesse para o presente estudo são: edificações residenciais, residências com telhado cerâmico, residências com telhado não cerâmico, vias, vias pavimentadas, vias não pavimentadas, vegetação, vegetação rasteira, área impermeável, solo exposto, campo de futebol e água.

No entanto, as imagens de SR utilizadas no estudo apresentam peculiaridades que podem trazer confusão na classificação. Para aumentar o entendimento dos objetos reais envolvidos no processo e consequentemente da acurácia da classificação, o Quadro 6.2 apresenta exemplares dos alvos e algumas de suas principais variações, descrevendo a que classe cada alvo deverá ser classificado no processo descrito nas próximas seções.

Quadro 6.2. Descrição dos alvos e classes

\begin{tabular}{|c|c|c|c|}
\hline $\begin{array}{l}\text { Características dos alvos } \\
\text { e classes de interesse }\end{array}$ & $\begin{array}{c}\text { Amostras de } \\
\text { pesquisa de campo }\end{array}$ & $\begin{array}{c}\text { Amostras de } \\
\text { ortofotografias }\end{array}$ & $\begin{array}{l}\text { Amostras de } \\
\text { imagens } \\
\text { QuickBird }\end{array}$ \\
\hline Edificações & & & \\
\hline $\begin{array}{l}\text { Edificações residenciais ou de } \\
\text { uso misto. Área ocupada inferior } \\
\text { a } 300 \mathrm{~m}^{2} \text { (valor estimado segundo } \\
\text { área média das edificações do } \\
\text { subúrbio). Classe: } \underline{\text { telhado }} \\
\underline{\text { cerâmico ou telhado não }} \\
\underline{\text { cerâmico. }}\end{array}$ & & & \\
\hline $\begin{array}{l}\text { Edificações não residenciais. } \\
\text { Telhado predominantemente não } \\
\text { cerâmico e área superior a } \\
300 \mathrm{~m}^{2} \text { (valor estimado segundo } \\
\text { área média das edificações do } \\
\text { subúrbio). Classe: área } \\
\text { impermeável }\end{array}$ & & & \\
\hline $\begin{array}{l}\text { Telhado improvisado. Telhado } \\
\text { e paredes em madeirite e outros } \\
\text { materiais inapropriados para } \\
\text { cobertura de residência. Classe: } \\
\text { telhado não cerâmico }\end{array}$ & & & \\
\hline
\end{tabular}


continuação

\section{Telhado de fibrocimento - utilizado normalmente em residências de menor padrão construtivo, pois não oferece o mesmo conforto e estética que os telhados cerâmicos. Classe: telhado não cerâmico}

\section{Telhado de concreto (laje).}

Pode apresentar aspecto escuro ou claro, a depender do material utilizado, umidade, manutenção, idade construtiva. Pode ainda apresentar acúmulo de poeira e barro lhe conferindo uma cor mais avermelhada. Visualmente confunde-se com telhado de amianto ou metálico. Classe: telhado não cerâmico

\section{Telhado metálico. Apresenta} alto brilho nas imagens verticais. Seu uso é mais comum em edificações de padrões construtivo médio e baixo, com exceção das edificações de uso comercial. Classe: telhado não cerâmico

\section{Telhado cerâmico velho, sem} manutenção, coberto com musgo e escurecido. Distinção com telhado não cerâmico não é prioritária pois pode representar uma residência de baixa qualidade. Classe: telhado cerâmico

Telhado cerâmico semi-novo, em processo de envelhecimento. Ainda assim já indica uma casa que provavelmente já foi rebocada e conta com outros itens de acabamento e salubridade. Classe: telhado cerâmico

\section{Telhado cerâmico novo. $\mathrm{Na}$} maioria dos casos corresponde a uma residência de bom padrão construtivo. Classe: telhado cerâmico

\section{Tamanho das edificações} residenciais. Este atributo varia independente do tipo de telhado da casa, mas indica maior conforto e higiene para moradores (ex: local para armazena-mento de alimento, presença de dormitórios). Deve ser informado como atributo dos objetos classificados: telhado cerâmico ou telhado não cerâmico
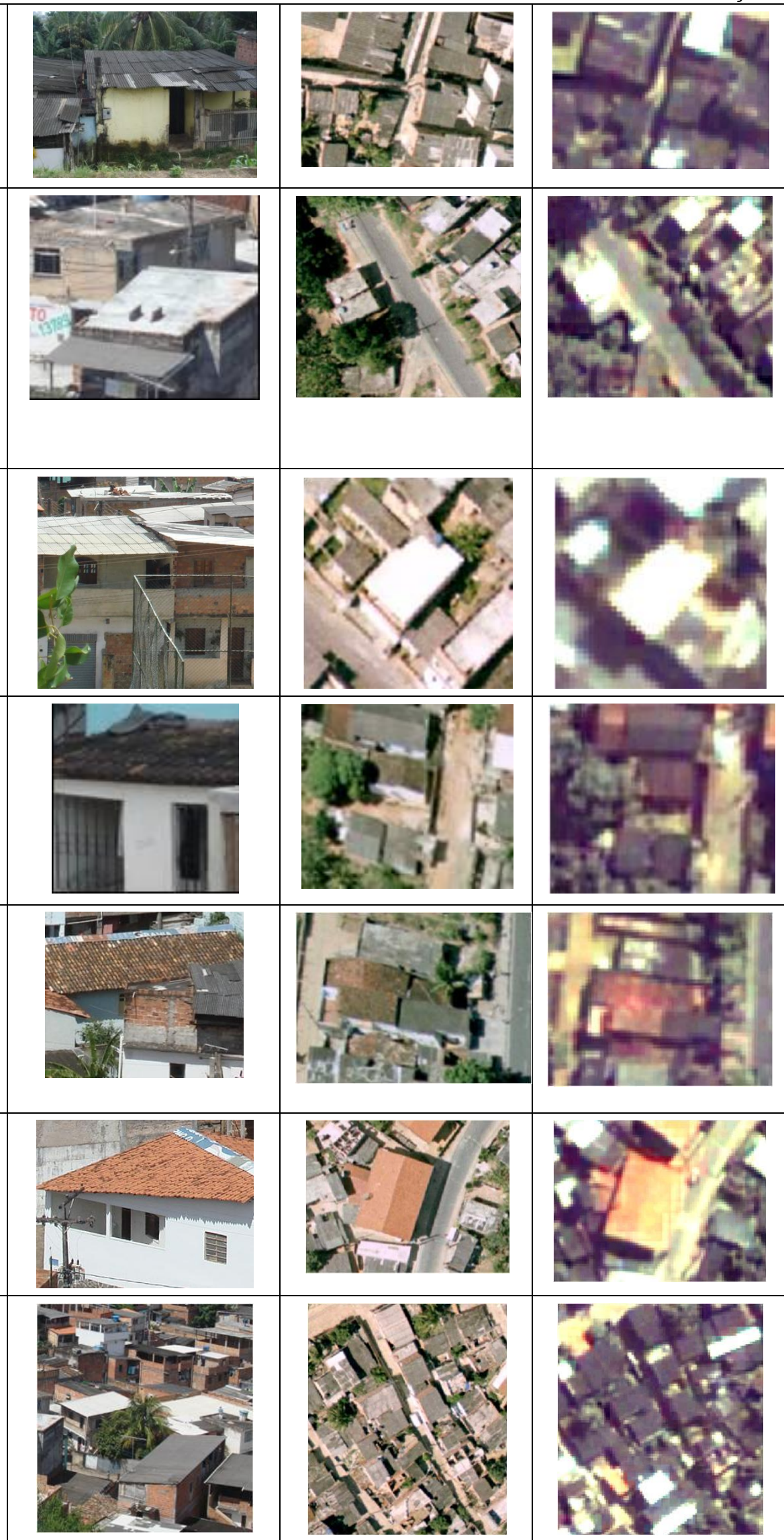
continuação

\section{Cobertura do solo}

Vegetação rasteira. Presente em parques e outros espaços públicos, pode funcionar como área de lazer. Classe: vegetacão rasteira

Vegetação. Presente em tipologias urbanas de padrão mais elevado em áreas de menor densidade populacional, em área de preservação como encostas, fundos de vale, reservas e franja da ocupação urbana. Classe: vegetação rasteira e vegetação arbórea

Área impermeável. Edificações vias pavimentadas, estacionamentos, entre outros, são ocupações que impermeabilizam o solo. Classes: vias pavimentadas, telhado cerâmico, telhado não cerâmico e cobertura impermeável.

Solo exposto. Área não construída, onde já houve interferência humana ao destruir a cobertura vegetal e que não constitui um equipamento urbano, nem faz parte do sistema viário. Classe: cobertura permeável.
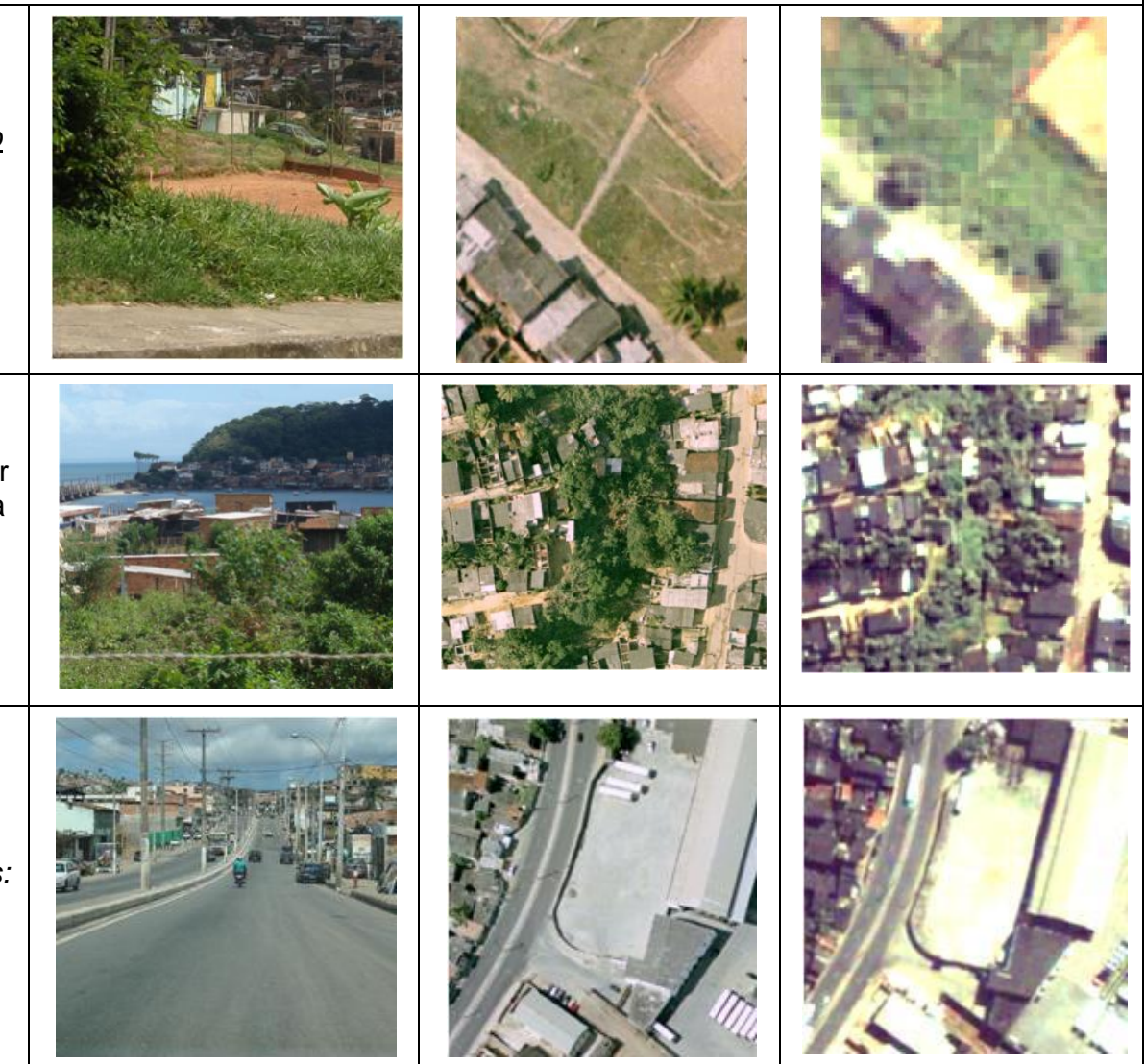

\section{Água}

Corpos d'água. Na área de estudo são na maior parte córregos bastante estreitos, intermitentes e muitas vezes sombreados, bastante difíceis de serem reconhecidos. Classe: água
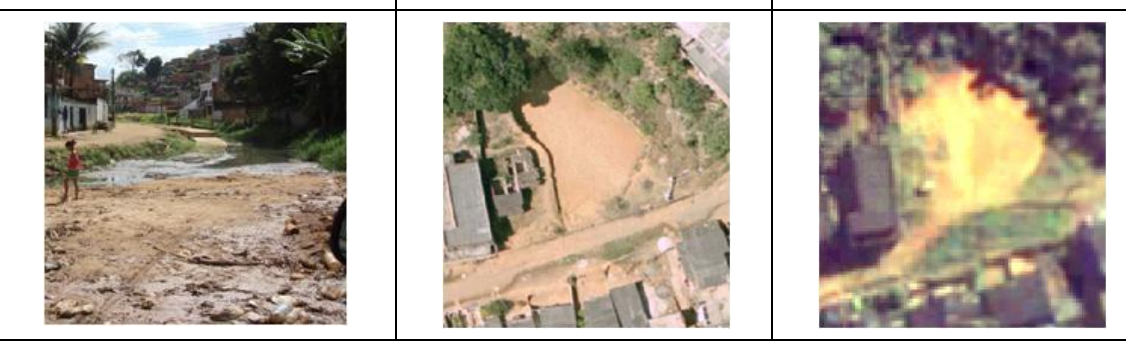

(20)
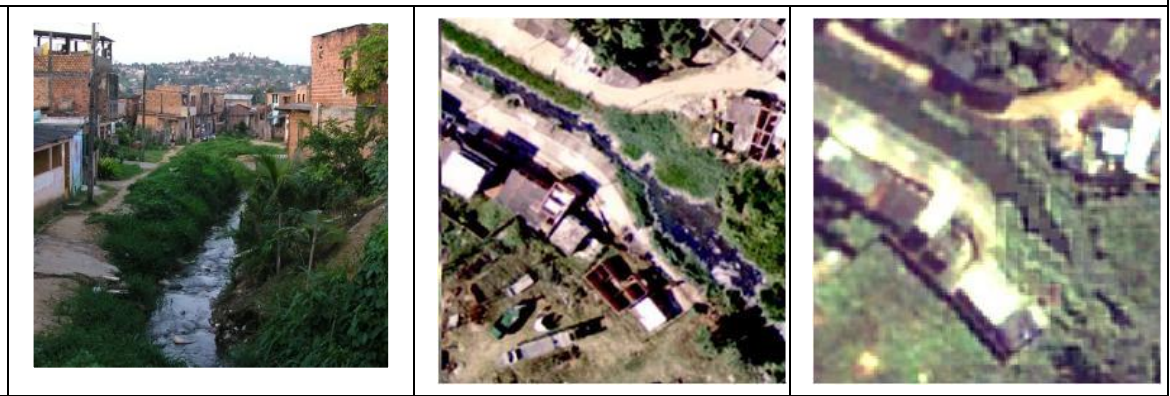

\section{Equipamentos urbanos}

\section{Campos de futebol.}

Equipamento de fácil

identificação nas imagens. $\mathrm{Na}$

área de estudo são bastante

frequentes e em sua grande

maioria são de barro. Classe:

campo de futebol.
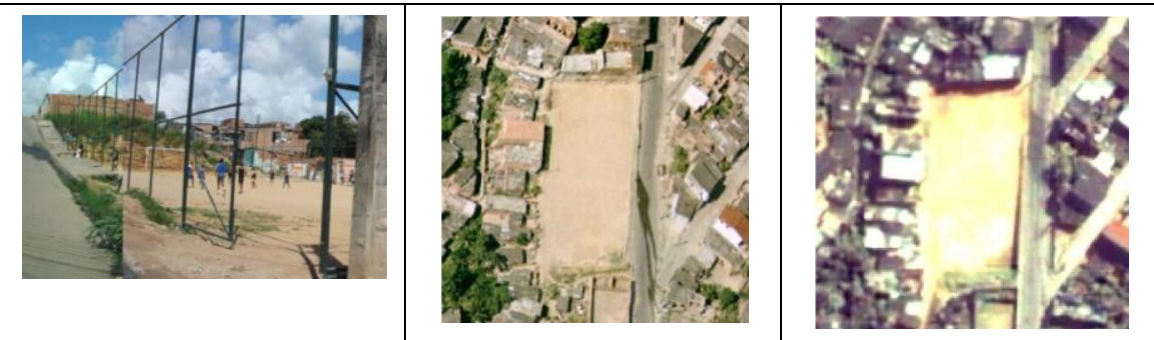

Fonte : Brito (2010) 
O exercício de coleta de amostras de fotos de campo, de ortofotografias e de imagens satélite revelou que alguns alvos e classes de interesse apresentam uma maior dificuldade de distinção, segundo os aspectos visíveis das imagens verticais. Observou-se que vias muito estreitas apresentam um grau de dificuldade muito elevado para o reconhecimento digital em imagens bi-dimensionais, pois mesmo por interpretação visual a identificação desses elementos já é comprometida.

As dificuldades apresentadas para a identificação das vias pavimentadas com paralelepípedo ou concreto também podem atrapalhar o processo de classificação, por isso a classe vias de pavimento indefinido foi criada, para que este elemento seja ao menos classificado como via.

É possível observar no Quadro 6.2 que há diferenças significativas entre as cenas provenientes de ortofotografia e de imagem QuickBird. A origem dessas diferenças percebidas visualmente estão em seus atributos técnicos, descritos no Capítulo 3, e, apesar de visualmente as ortofotografia apresentarem uma maior distinção dos alvos, ambas têm vantagens e desvantagens no processo de classificação digital. Por isso, foram testadas individualmente nas mesma áreas de processamento e controle, como descrito nas seções que seguem.

\subsection{Limites das áreas de processamento}

A etapa de processamento das ortofotografias e da imagem QuickBird foi desenvolvida nessas imagens com o objetivo de testar a eficácia do método proposto em dois tipos diferentes de imagens de alta resolução espacial que são comumente utilizadas para a análise espacial de áreas urbanas.

Atendendo ao rigor científico da pesquisa acadêmica, faz-se necessário que os procedimentos de SR sejam experimentados e desenvolvidos em uma área diferente da érea em que terá seu controle de qualidade avaliado. Para evitar vieses metodológicos que comprometessem as análises comparativas, foi necessário também que as áreas teste e as áreas controle fossem escolhidas dentro dos limites da área coberta pelas ortofotografias e pela imagem QuickBird.

Foram selecionadas três áreas teste nas quais os processos e regras de classificação foram desenvolvidos, tanto para as ortofotografias como para as imagens QuickBird. A árvore de processos resultante dos melhores resultados em cada tipo de imagem foi aplicada nas respectivas áreas controles e a acurácia de cada conjunto de imagens foi testada. Por fim, 
aplicou-se as regras de segmentação e classificação em toda a extensão da imagem QuickBird, devido aos seus resultados mais positivos dos testes de acurácia e à sua cobertura da área de estudo (Figura 6.1).

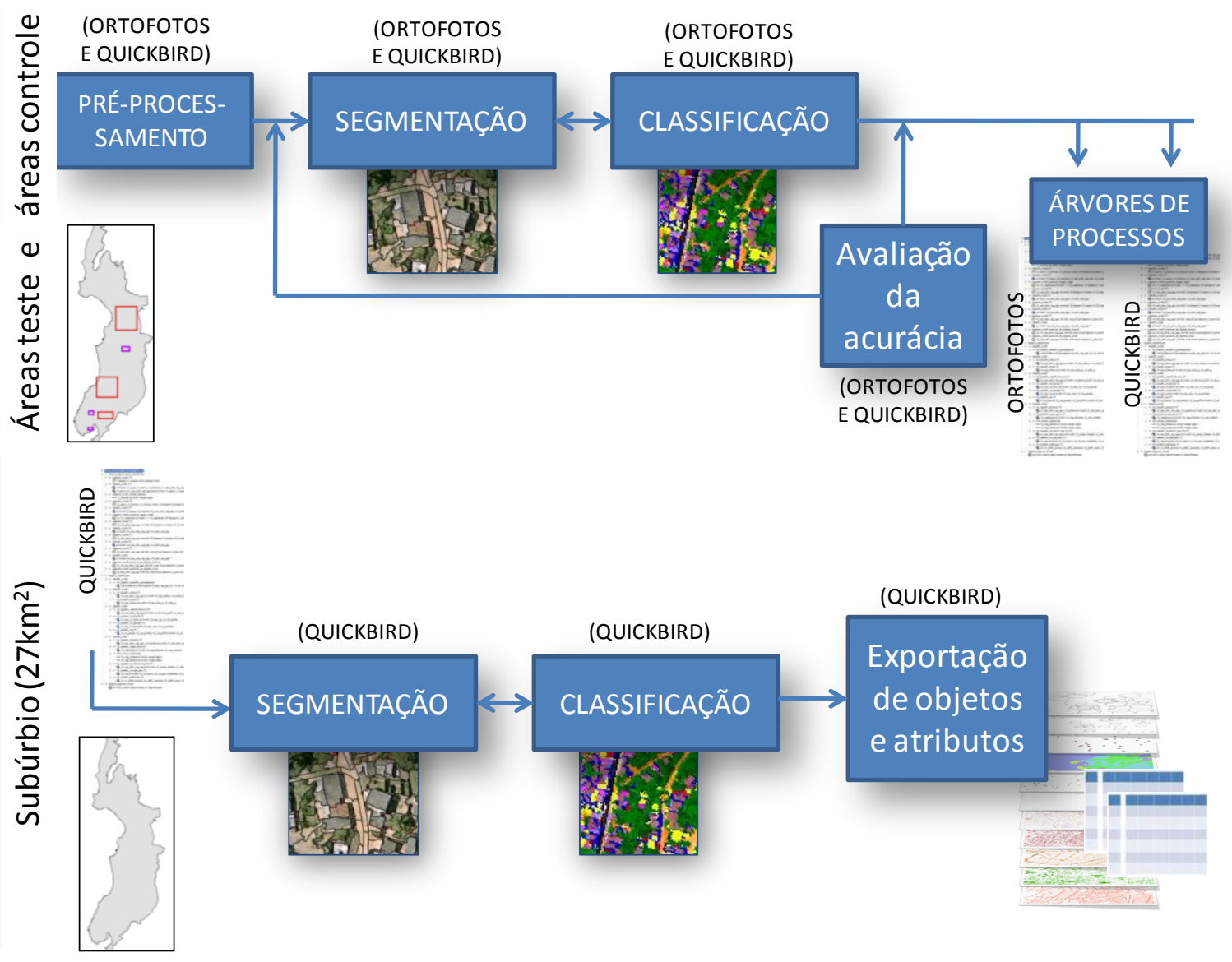

Figura 6.1. Metodologia da etapa de Sensoriamento Remoto

Além de pertencerem aos limites das imagens utilizadas no estudo, as áreas teste e áreas controle foram selecionadas com base em características sociais e urbanas levantadas no trabalho de Gordilho (2000), no censo de 2000 do IBGE e com base nos dados de saúde. Seis critérios levaram à definição dessas áreas: Condições de habitabilidade (GORDILHO, 2000), Padrão de verticalidade predominante (GORDILHO, 2000), Legalidade habitacional (GORDILHO, 2000), Renda com base no censo de 2000 do IBGE, Densidade populacional censo de 2000 do IBGE e concentração dos casos de leptospirose. Os mapas da Figura 6.2 expõem quatro critérios de seleção de áreas teste e áreas controle e o Quadro 6.3 apresenta imagens das áreas selecionadas.

Devido às limitações da metodologia proposta, como explicitado na Seção 2.3, o padrão de verticalidade predominante das áreas a serem investigadas nesse trabalho deve ser baixo, pois parte-se do pressuposto de que a área de análise não é verticalizada. Áreas consideradas por Gordilho como verticalizadas foram excluidas da seleção das áreas teste 
e áreas controle. Segundo as condições de habitabilidade de 1991 (GORDILHO, 2000), a ocupação antiga não deve ser contemplada devido ao padrão de verticalidade com predominância de edifícios.

De acordo com o mapeamento da legalidade habitacional, buscou-se, com sucesso, contemplar áreas com ocupação formal e informal.

Entre as áreas teste foi possível contemplar uma variedade maior de renda da população (Mapa b da Figura 6.2). No entanto, devido à escassez de áreas com um percentual mais baixo de pessoas vivendo com até três salários mínimos, não foi possível contemplar a mesma variedade nas áreas controle. O mesmo aconteceu com as condições de habitabilidade. A condição boa foi contemplada na área teste, mas não foi possível incorporá-la nas áreas controle. Ocupações com condições insuficiente, regular e precária são contempladas pelas áreas teste e áreas controle.

Segundo a densidade populacional, observa-se no Mapa d da Figura 6.2 que a área teste 1 e área controle 3 (mais a sul da área de estudo) contempla densidade alta e as demais áreas contemplam densidades médias e baixas.

Já de acordo com a distribuição dos casos de leptospirose observa-se no Mapa c da Figura 6.2 que a área teste 1 e área controle 2 e 3 contemplam zonas com alta concentração de casos, a área teste 2 e área controle 1 contemplam zonas com média e baixa concentração de casos, enquanto na área teste 3 a concentração de casos é muito baixa ou nula.

O Quadro 6.3 apresenta imagens das áreas teste e áreas controle selecionadas. Nelas é possível identificar visualmente três macro padrões urbanos: (i) alta densidade e média ou alta precariedade (segundo tamanho das edificações e formalidade do sistema viário), nas área teste 1 e área controle 3; (ii) densidade média ou baixa e média ou precariedade alta, nas área teste 2 e área controle 1; (iii) média ou alta densidade e precariedade média ou baixa, nas área teste 3 e área controle 2. Essas áreas foram então submetidas aos procedimentos descritos a seguir. 
a)

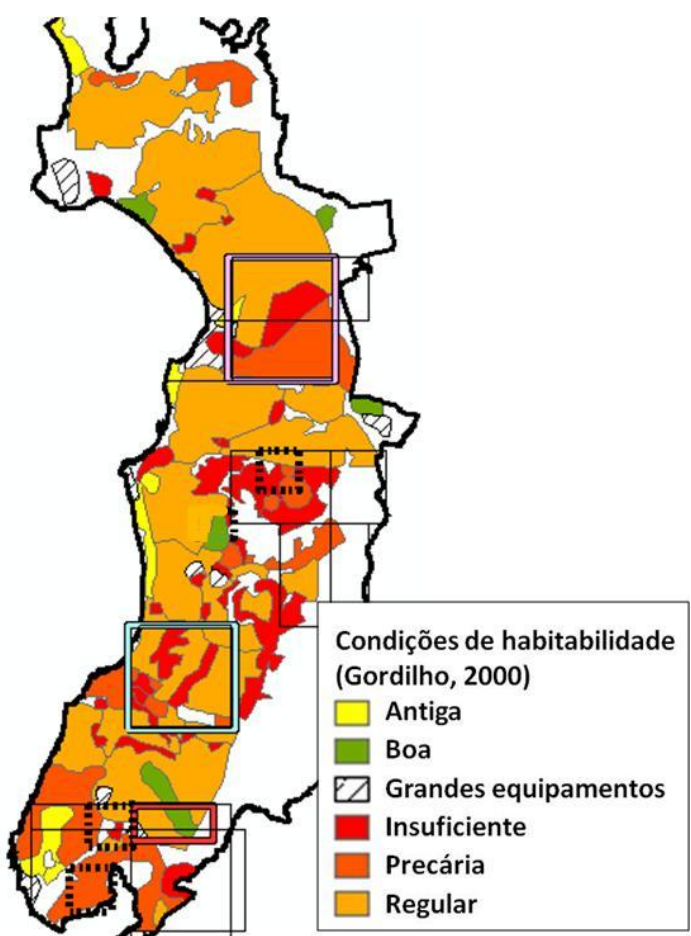

b) ${ }^{3}$ c)

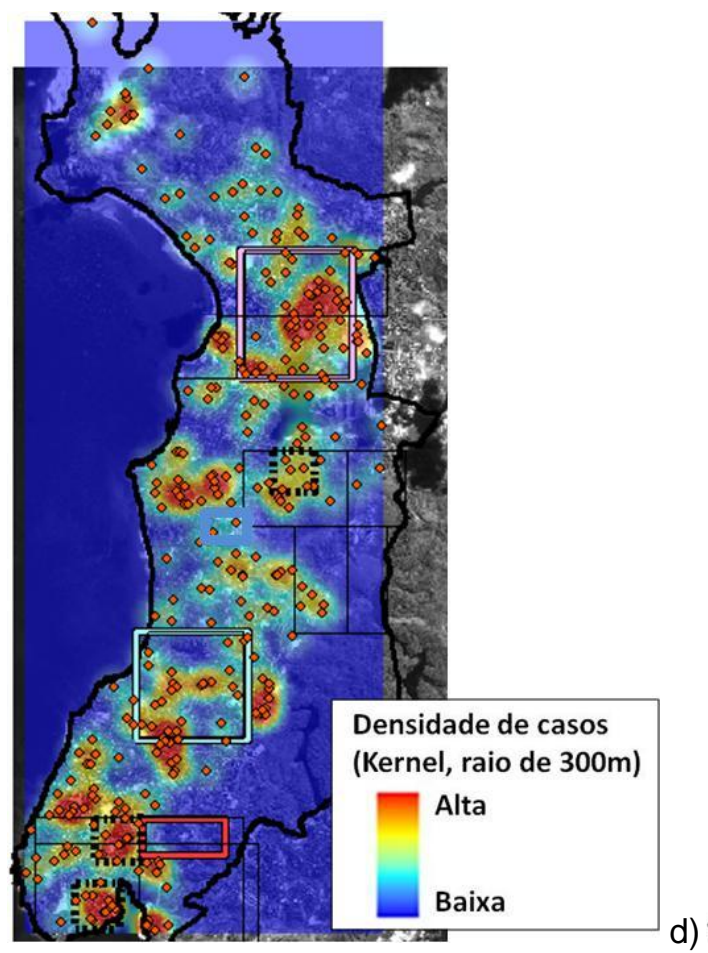

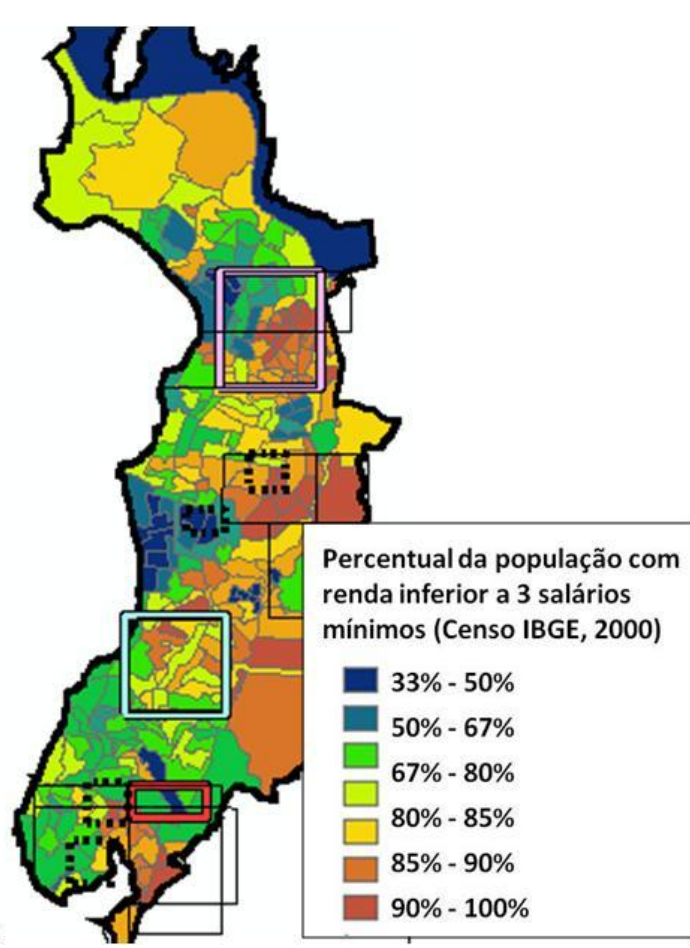

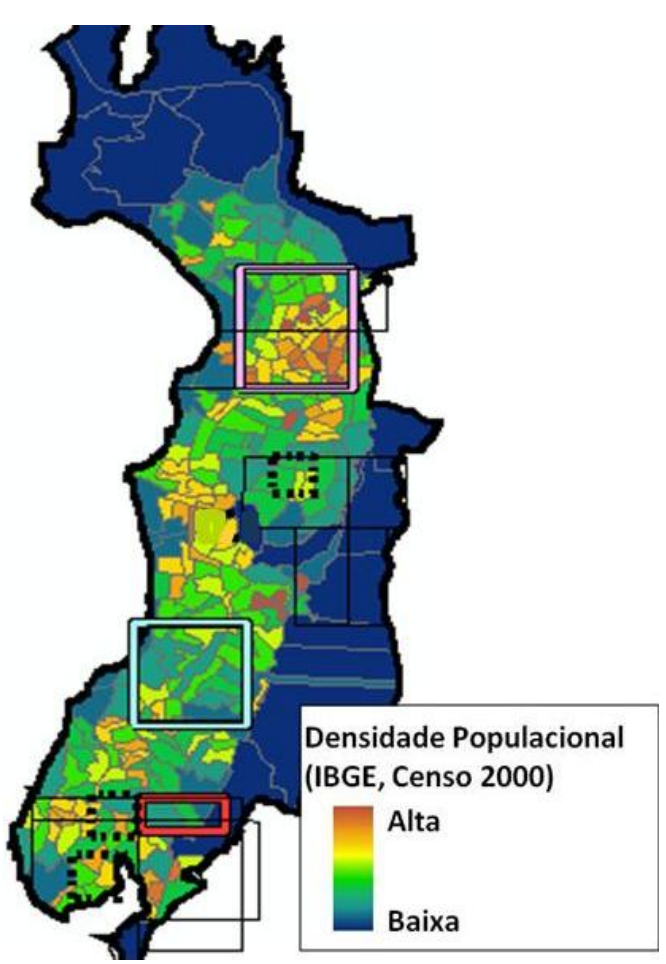
Legenda:
$\square$ Limites ortofotografias
回 Área teste 2
H'É Áreas controle
回 Área teste 1
口 Área teste 3

Figura 6.2. Mapas base para delimitação de áreas teste e áreas controle. A) Condições de Habitabilidade, adaptado de Gordilho (2000); b) Renda (baseado em dados do Censo 2000 do IBGE,

; c) Densidade de casos, baseada em casos graves de leptospirose ocorridos entre 1995 e 2000, levantados pela Fiocruz); Densidade populacional baseada em dados Censo 2000 do IBGE 
Quadro 6.3. Ortofotografias e imagens QuickBird de áreas teste e áreas controle.

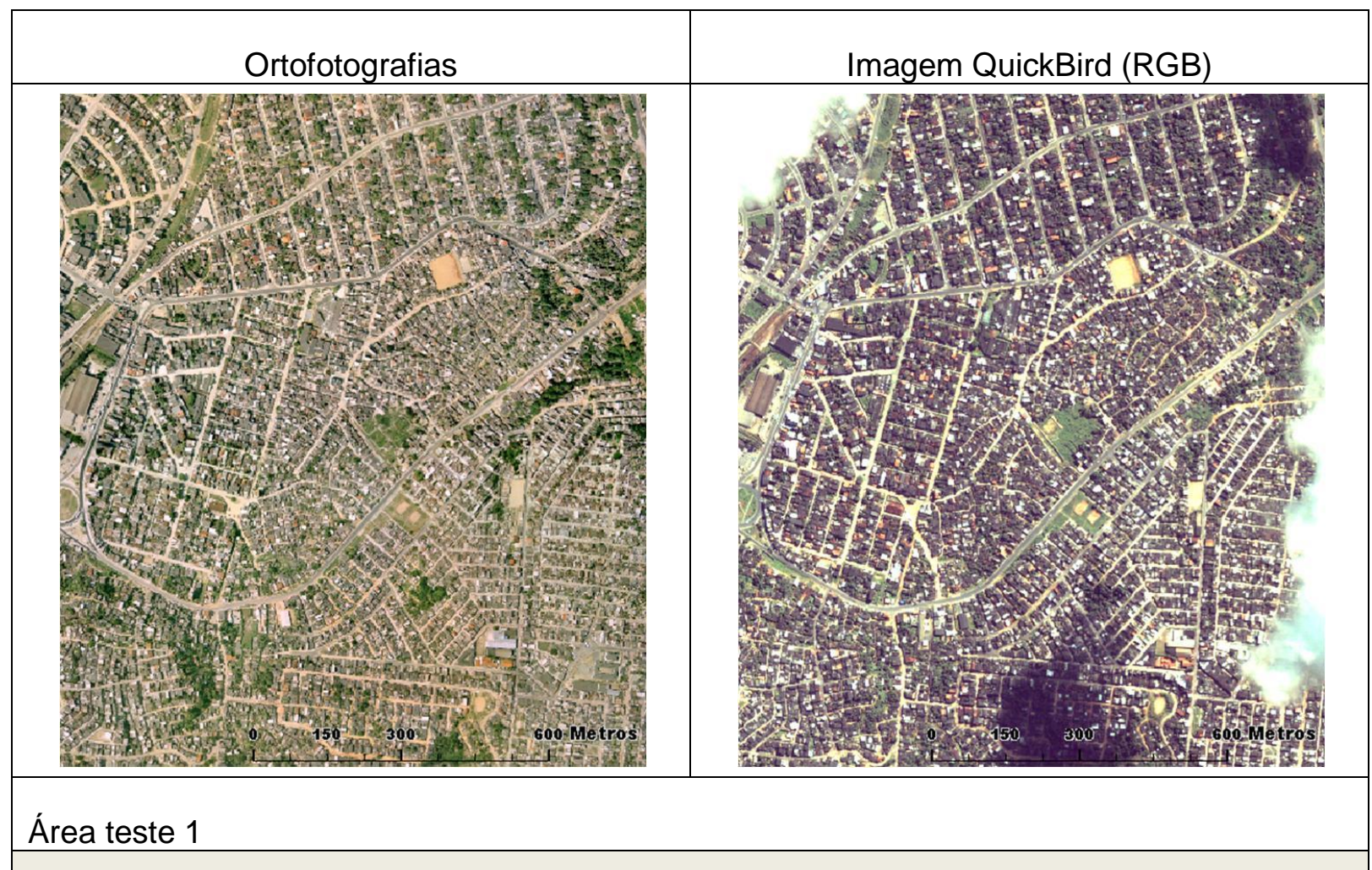
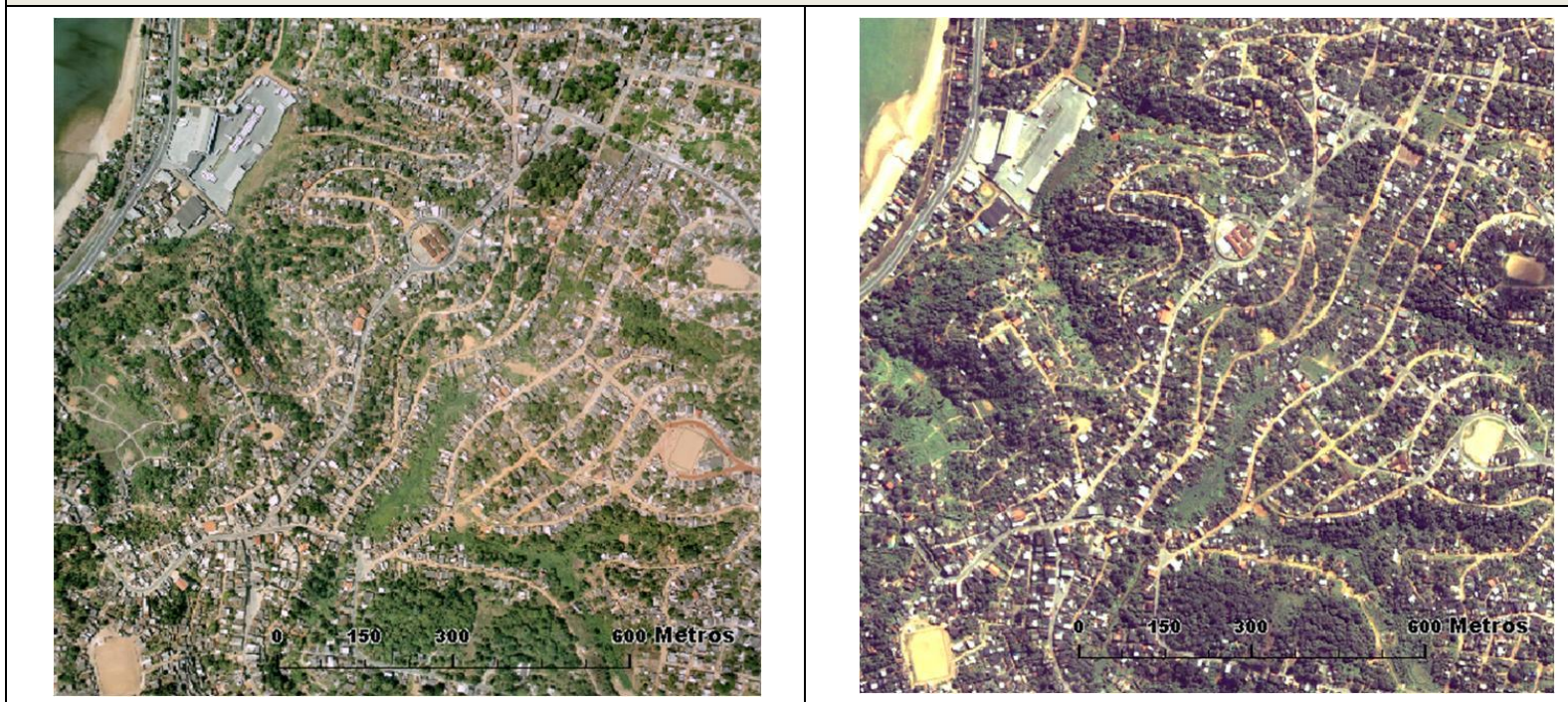

\section{Área teste 2}
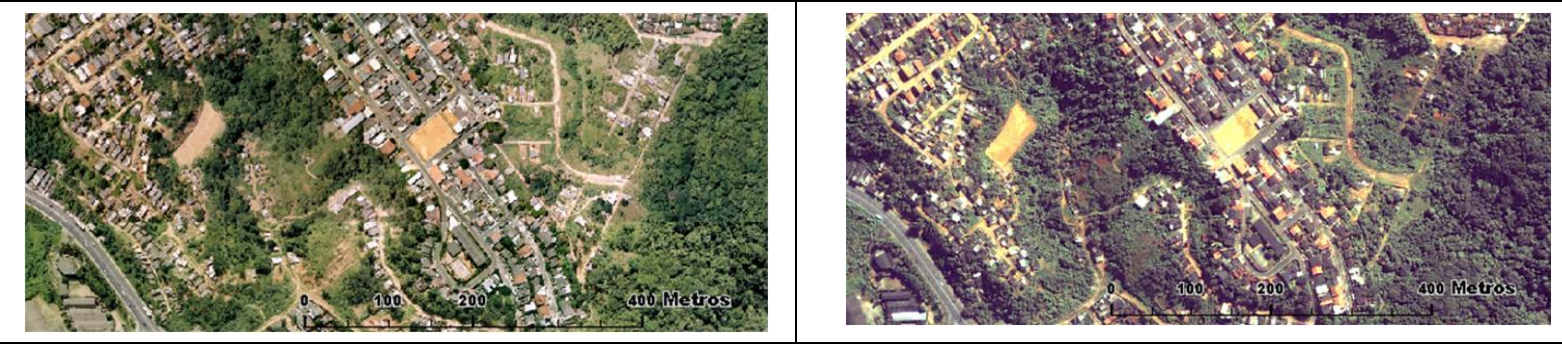

Área teste 3 
continuação

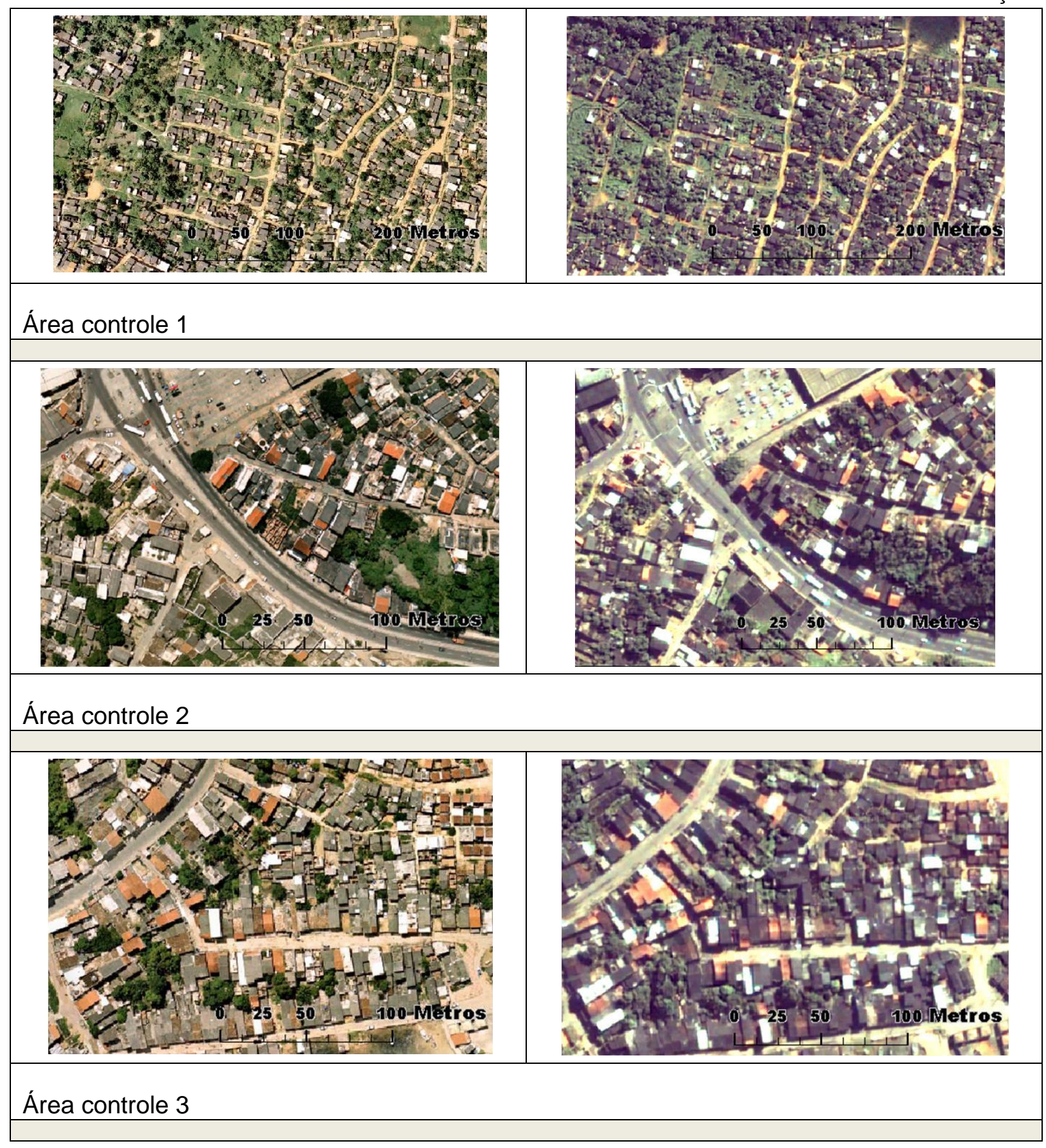

\subsection{Classificação em áreas teste e controle de ortofotografias}

As três áreas teste e três áreas controles das ortofotografias, apresentadas no começo deste capítulo, sofreram os ajustes de pré-processamento descritos a seguir. A etapa de segmentação e classificação foi desenvolvida por experimentação nas áreas teste. $A$ árvore de processos desenvolvida foi então aplicada nas áreas controle. Por fim, as áreas controle foram submetidas aos testes de acurácia cujos resultados são apresentados no fim desta seção. 


\subsubsection{Pré processamento}

A etapa de pré-processamento de imagens se faz necessário para a otimização e melhor compatibilização das informações disponíveis para a pesquisa. O objetivo é extrair dos dados raster imagens derivadas que contribuam na identificação de alvos, e adequar os dados vetoriais à sua utilização no processo de classificação baseada em objeto. A Figura 6.3. apresenta o diagrama com os principais processos realizados nessa etapa.

Inicialmente, as ortofotografias foram mosaicadas em quatro áreas de processamento, visto que o conjunto de imagens não cobria toda a área de estudo. Em seguida as bandas vermelha, verde e azul, foram convertidas do espaço RGB para o espaço IHS (intensidade, matiz e saturação), e as CP (componentes principais) foram calculadas ${ }^{30}$. Em paralelo, a base de eixos viários foi ajustada e convertida de linhas para polígonos, utilizando a função de criação de buffers com raio de 1m do software ArcMap 9.1 (ESRI Inc., 2005).

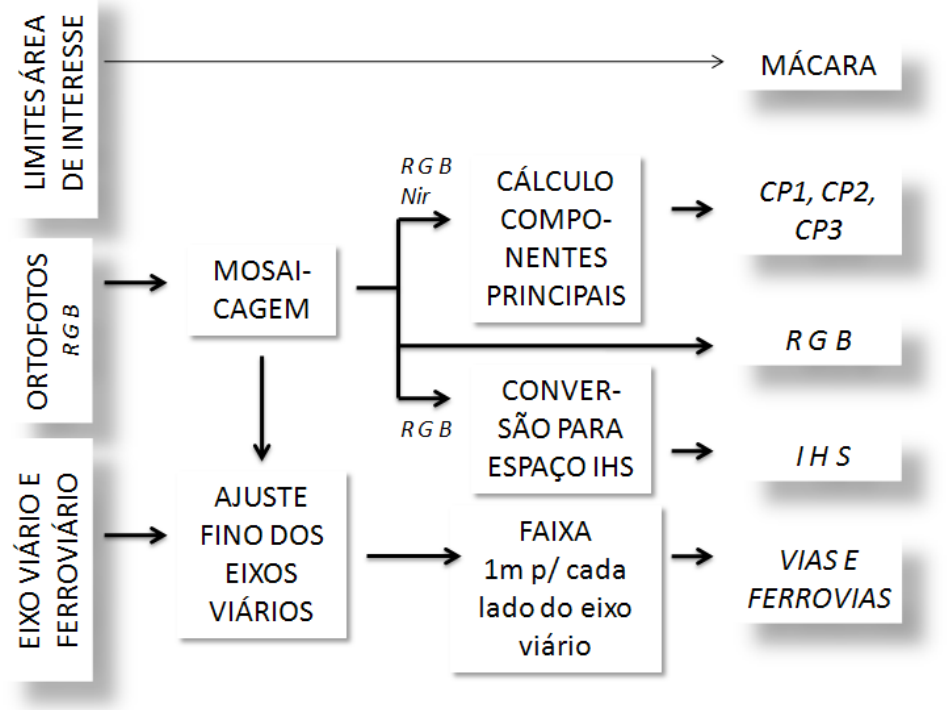

Figura 6.3. Etapa de pré-processamento para classificação de ortofotografias

Componentes principais de uma imagem têm como característica minimizar o número de combinações lineares do dado original mantendo no máximo suas informações (NÓBREGA et al., 2006). Devido às bandas RGB serem artificialmente produzidas e contemplarem apenas espectros da faixa visível, o primeiro componente principal apresenta a mesma informação que uma banda de intensidade gerada na conversão para o espaço IHS. Somado a isto, assim como acontece com qualquer imagem, o último componente principal

\footnotetext{
${ }^{30} \mathrm{O}$ cálculo de CP foi baseado na área de processamento que possuía maior variabilidade de tipologias urbanas e os parâmetros estatísticos foram então reproduzido para as demais áreas.
} 
geralmente é inútil para a identificação de classes, o que dificulta o uso de indicadores criados com base na terceira componente principal, como por exemplo, o indicador de solo exposto (BSI), apresentado por Nóbrega et al. (2006). No entanto, na área estudada, a segunda componente principal apresentou contraste entre área permeável e impermeável e pode ser utilizada para identificar objetos compostos por barro, como apresentado na subseção que segue.

Por fim, foram criados dois arquivos vetoriais compostos por polígonos que cobrem toda área de estudo: máscaras e viasferrovias. $\mathrm{O}$ arquivo máscaras foi gerado combinando o retângulo envolvente da área de estudo e os limites da área de estudo. Aos limites da área de estudo foi atribuído o valor 0 (zero) e para as demais áreas foi atribuído o valor 1 (um). 0 arquivo viasferrovias foi gerado combinando o buffer de vias, o buffer de ferrovias $(2 \mathrm{~m}$ de raio) e o retângulo envolvente da área de estudo. À área de vias foi atribuído o valor 1 (um), à área de ferrovias o valor 2(dois) e às demais áreas o valor 0 (zero).

Utilizando o software Definiens Developer 5.0 (Definiens Inc. 2006), conhecido como eCognition, foi criado um novo projeto para análise baseada em objeto, onde onze camadas de imagens, RGB, IHS, CP1, CP2 e CP3, foram adicionadas, além dos arquivos vetoriais de viasferrovias e máscaras. Esses últimos foram adicionados como camadas temáticas.

\subsubsection{Segmentação e Classificação}

Todos os resultados das segmentações foram alcançados após extensivas análises, onde a segmentação multi-nível foi realizada de acordo com a necessidade de se aplicar regras de pertinência a super-objetos a fim de melhorar a acurácia da classificação no nível principal (nível 2). Em linhas gerais, os níveis 1, 3, 4 e 5 foram criados com o objetivo de, respectivamente, reconhecer limites de vegetação e sombra, aperfeiçoar a classificação do sistema viário, evitar que ônibus fossem classificados como telhados metálicos e auxiliar na classificação de edificações residenciais (Figura 6.4). O Apêndice 1 apresenta com detalhes a árvore de processos desenvolvida para a classificação baseada em objetos nas ortofotografias do subúrbio.

As bandas RGB da ortofotografia foram utilizadas em todos os níveis da segmentação. Os Níveis 1, 2 e 3 de segmentação foram criados utilizando, além das bandas RGB, a camada temática viasferrovias. A camada temática máscara foi utilizada para a segmentação apenas no primeiro nível. O Quadro 6.4 apresenta uma síntese dos parâmetros utilizados na criação de cada nível. Devido à escassez de informação espectral, o mesmo peso foi 
dado para todas as camadas em todos os níveis, fazendo com que tais informações influenciassem equitativamente a geração dos objetos em cada nível de segmentação e que pudessem assim ser melhor exploradas (DEFINIENS, 2006). As funções usadas para descrever as classes foram, na maior parte dos casos, baseadas em funções já utilizadas por Hurskainen e Pellikka, (2004), Schopfer et al. (2005), Kressler et al. (2005) e Laliberte et al. (2006), e foram extensivamente testadas por análise de histogramas, utilizando o editor de eventos e visualizador de características, e por análise visual dos resultados das funções nos segmentos, recursos disponíveis no software eCognition.

Após a realização de inúmeros experimentos, os melhores resultados de classificação foram obtidos seguindo o processo apresentado na figura 6.5 e como detalhado a seguir. $O$ Apêndice 3 apresenta com detalhes as regras e funções utilizadas para reescrever cada classe e o Apêndice 2 apresenta a hierarquia de classes.

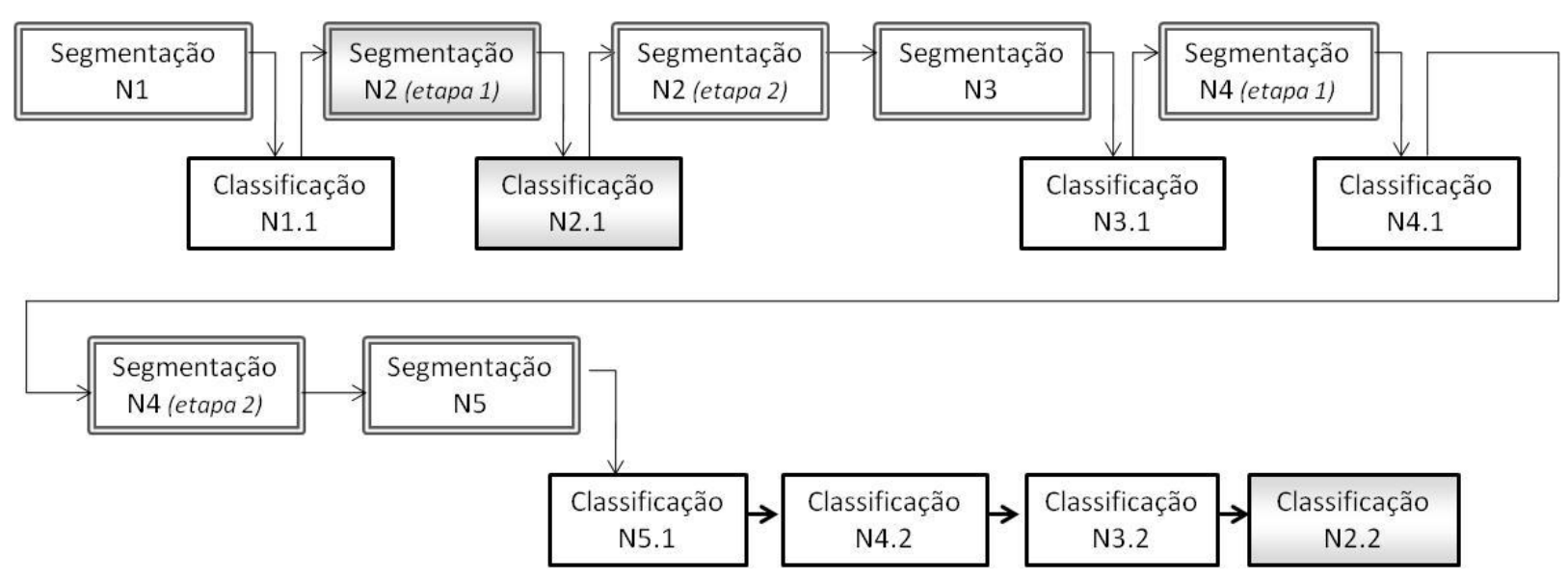

Figura 6.4. Processos interativos de classificação e segmentação nas ortofotografias

Segmentação N1. No primeiro nível criado, nível 1, onde edificações, vegetação e sombra eram os principais alvos, características de forma foram priorizadas sob os critérios de cor. O melhor resultado de segmentação foi alcançado utilizando o parâmetro escalar de 50 , forma 0,7 e valores iguais para compactação e suavidade. Estudos têm mostrado que o uso de critérios geométricos sobre critérios de cor, nesses casos, aperfeiçoa a separabilidade desses tipos de objetos (NÓBREGA et al., 2006; PINHO et al., 2005).

Classificação N1.1. A primeira classificação realizada no nível 1 buscou caracterizar os segmentos segundo suas características de cor, brilho e saturação. Segundo esses atributos foi possível classificar a imagem em cinco aspectos básicos: branco (segmentos com alto brilho), vermelho (classificado como barro), cinza (segmentos com baixa 
saturação), verde (classificado como vegetação), preto (segmentos com baixo brilho classificado como sombra). Devido às características não padronizadas das ortofotografias analógicas, como descrito na Seção 2.3, foram colhidas amostras de cada classe e realizada a classificação supervisionada por vizinho mais próximo no espaço de atributos com dez dimensões ${ }^{31}$ (Quadro 6.5). O índice mais utilizado para identificação de vegetação, o NDVI, não pode ser utilizado, como fizeram Eisele et al. (2003) e Bavia et al. (2005) em seus estudos epidemiológicos, porque a ortofotografia utilizada não possui a banda infravermelha.

Quadro 6.4. Parâmetros da segmentação em ortofotografias

\begin{tabular}{|c|c|c|c|c|c|}
\hline Nível & Modo & Parâmetros & Camadas & Domínio & Foco \\
\hline N5 & $\begin{array}{l}\text { Aumento de } \\
\text { objetos }\end{array}$ & $\begin{array}{l}\text { Parâmetro escalar: } 100 \\
\text { Forma:0.5 Compac.: } 0.9\end{array}$ & $\begin{array}{l}\text { Bandas vermelha, verde e } \\
\text { azul }\end{array}$ & $\begin{array}{l}\text { N4: barro, branco e } \\
\text { cinza }\end{array}$ & áreas grandes \\
\hline $\begin{array}{c}\mathrm{N} 4 \\
\text { etapa } 2\end{array}$ & $\begin{array}{l}\text { Aumento de } \\
\text { objetos }\end{array}$ & $\begin{array}{l}\text { Parâmetro escalar: } 100 \\
\text { Forma:0.5 Compac.: } 0.5\end{array}$ & $\begin{array}{l}\text { Bandas vermelha, verde e } \\
\text { azul }\end{array}$ & $\begin{array}{c}\text { N4: barro, branco e } \\
\text { cinza com mais de } 70 \% \\
\text { de sub-objetos } \mathrm{N} 1 \text { : } \\
\text { barro / branco /cinza }\end{array}$ & ônibus e campos de futebol \\
\hline $\begin{array}{c}\mathrm{N} 4 \\
\text { etapa } 1\end{array}$ & Multi-resolução & Diferença espectral: 7 & $\begin{array}{l}\text { Bandas vermelha e verde, } \\
\text { azul }\end{array}$ & $\begin{array}{l}\text { N3: barro, branco e } \\
\text { cinza }\end{array}$ & ônibus e campos de futebol \\
\hline N3 & Multi-resolução & Diferença espectral: 7 & $\begin{array}{l}\text { Bandas vermelha, verde, } \\
\text { azul, camada temática vias }\end{array}$ & $\begin{array}{l}\text { N2: barro, branco e } \\
\text { cinza }\end{array}$ & vias \\
\hline $\begin{array}{c}\mathrm{N} 2 \\
\text { etapa } 2 \\
\text { (Principal) }\end{array}$ & $\begin{array}{l}\text { Aumento de } \\
\text { objetos }\end{array}$ & $\begin{array}{l}\text { Parâmetro escalar: } 100 \\
\text { Forma:0.5 Compac.: } 0.2\end{array}$ & $\begin{array}{l}\text { Bandas vermelha, verde, } \\
\text { azul, camada temática vias }\end{array}$ & N2: vegetação & vegetação \\
\hline $\begin{array}{c}\mathrm{N} 2 \\
\text { etapa 1 } \\
\text { (Principal) }\end{array}$ & $\begin{array}{l}\text { cópia nivel } \\
\text { inferior }\end{array}$ & - & - & N1 & $\begin{array}{l}\text { casas }^{*} \text {, vias, campo de } \\
\text { futebol, vegetação, solo } \\
\text { exposto }\end{array}$ \\
\hline N1 & Multi-resolução & $\begin{array}{l}\text { Parâmetro escalar: } 50 \\
\text { Forma:0.7 Compac.: } 0.5\end{array}$ & $\begin{array}{c}\text { Bandas vermelha, verde, } \\
\text { azul, camadas temáticas } \\
\text { vias e máscara }\end{array}$ & pixel & $\begin{array}{c}\text { casas*, máscara (nuvem, }^{*} \text { sombra da nuvem, mar, área } \\
\text { fora limites do estudo), } \\
\text { vegetação*, branco, cinza, } \\
\text { barro, sombra* }\end{array}$ \\
\hline
\end{tabular}

Segmentação N2. O nível 2, considerado o nível principal por concentrar a classificação dos objetos de interesse para pesquisa, foi inicialmente criado como uma cópia do nível 1, visto que a segmentação no nível 1 já atendia à demanda do segundo nível ${ }^{32}$.

Classificação N2.1. A primeira classificação do nível 2 teve como objetivo trazer do nível 1 a classificação de alvos baseados em informações espectrais (vegetação e sombra) a fim de delimitar o domínio das próximas classificações e otimizar o tempo de processamento,

\footnotetext{
${ }^{31}$ As dez dimensões foram escolhidas com o apoio da ferramenta de análise do espaço de atributos (disponível no software eCognition, que, com base nos segmentos amostrados para cada classe calcula índices de separabilidade entre classes de acordo com as diferentes combinações de bandas disponíveis.

${ }^{32}$ A criação de níveis com igual segmentação se justifica quando ambos têm segmentos compatíveis com o menor alvo e classes alvos são diferentes. Por exemplo, no nível 1 a classe alvo é barro e no nível 2 a classe alvo é telhado cerâmico.
} 
determinando em uma única classe ( $n \_s o m b \_v e g$ ) aquilo que não é nem vegetação, nem sombra, nem máscara.

Segmentação N2. A segunda etapa de segmentação do nível 2 objetivou aumentar o tamanho dos objetos de vegetação, de forma que seus sub-objetos pudessem posteriormente ser utilizados para o cálculo de textura interna.

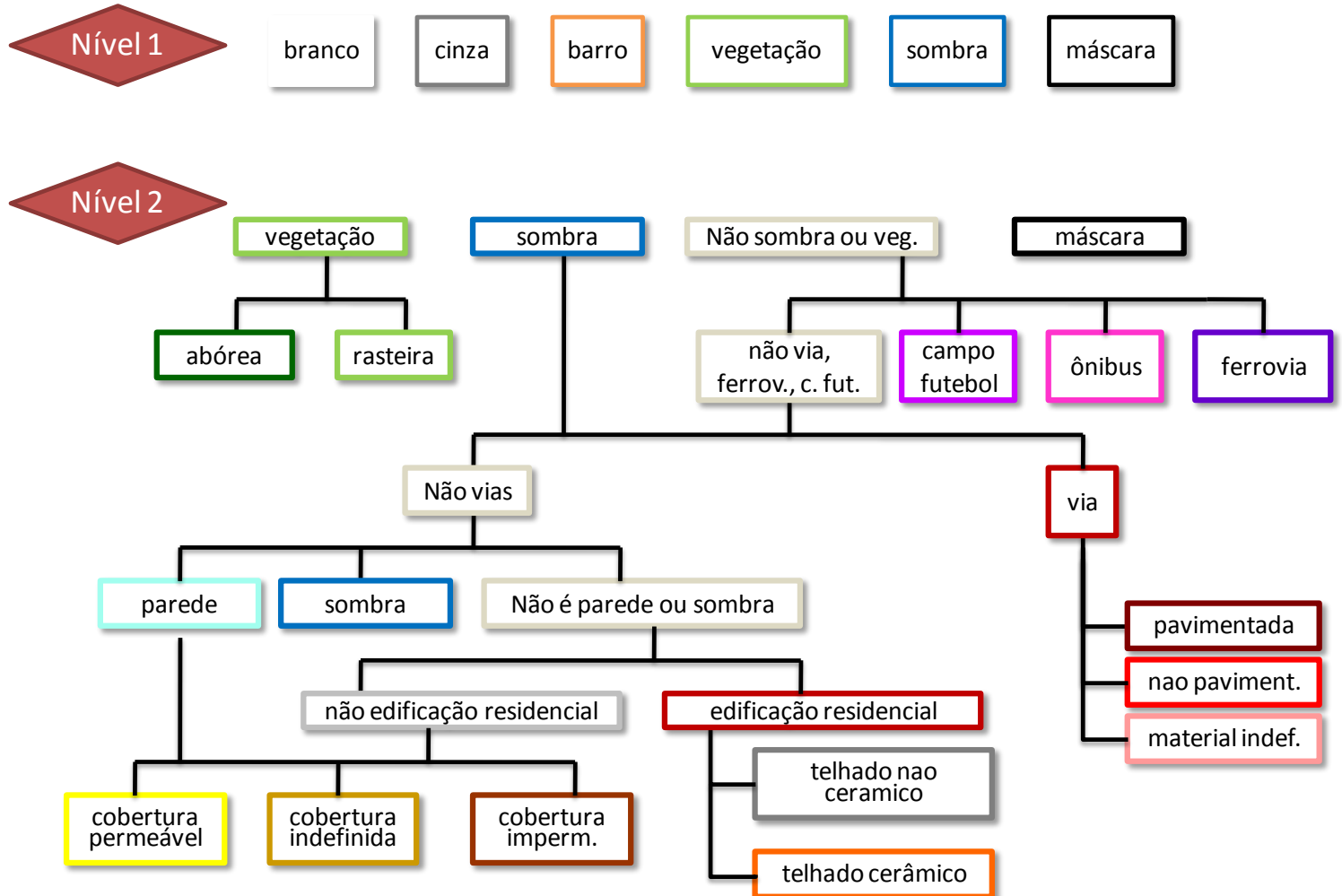

\section{Nível 3}

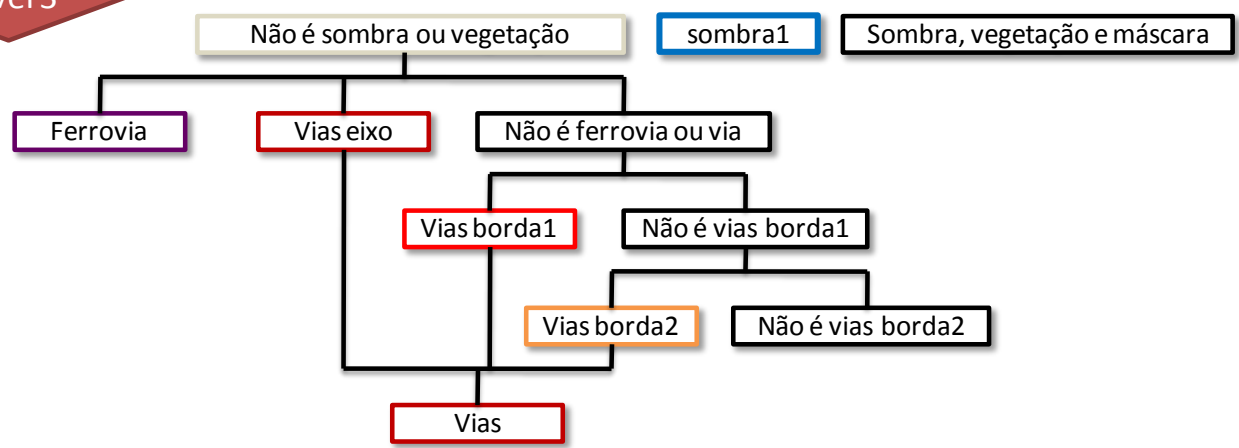

Nível 4

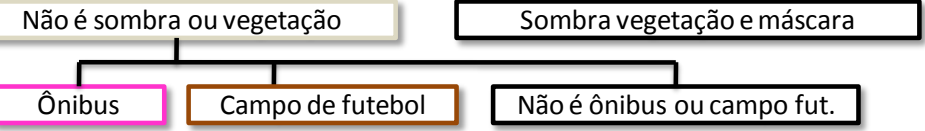

Figure 6.5. Diagrama do processo de classificação 
Segmentação N3. A criação do terceiro nível, nível 3, teve como objetivo identificar prováveis ruas com base no sistema viário (camada temática viasferrovias). Esta informação foi utilizada para apoiar a classificação de ruas no nível principal. Neste projeto, o melhor resultado de segmentação do nível 3 foi obtido utilizando o método de diferença espectral. A diferença espectral de 7 foi utilizada, permitindo união de objetos com informação espectral bastante similar, a exemplo de áreas contíguas de uma rua que tem o mesmo pavimento, mas que foi segmentada no nível anterior, devido ao limite imposto pelo parâmetro escalar. A união desse tipo de segmento incrementa suas características de geométricas (linearidade no caso de vias, por exemplo), consequentemente, melhorando a sua classificação como vias.

Classificação N3.1. Assim como a primeira classificação do nível 2, a primeira classificação do nível 3 objetiva trazer a classificação dos alvos que são baseados em informações espectrais (vegetação e sombra), delimitando o domínio das próximas segmentações e classificações. Assim, contemplou-se em uma única classe (n_somb_veg) aquilo que não é nem vegetação, nem sombra, nem máscara.

Segmentação N4. Em seguida, o Nível 4 de segmentação foi também criado como nível auxiliar. Utilizando a diferença espectral de 7 sobre o nível anterior, uniu objetos com valores de cor semelhantes. O objetivo era unir objetos que não foram unidos anteriormente porque a camada temática do sistema viário (viasferrovias), foi utilizada na criação dos segmentos nos níveis anteriores, como por exemplo, um ônibus que foi representado por mais de um segmento porque a camada viasferrovia se sobrepunha a ele.

Classificação N4.1. Os mesmos procedimentos utilizados nas primeiras classificações dos níveis 2 e 3 foram repetidos no nível 4, também com o mesmo objetivo de delimitar área de sombra e vegetação e de otimizar tempo de processamento, delimitando o domínio das segmentação e classificações que seguem.

Segmentação N4. Na segunda etapa de segmentação do nível 4 foram realizados três processos de crescimento de regiões seguindo o mesmo parâmetro escalar de 100, forma 0,5 e compactação 0,5 . Com esse procedimento foi possível formar objetos maiores como campos de futebol e edificações de maior área, assim como manter os limites de objetos menores como ônibus, cujo contraste com objetos vizinhos é elevado. Para criar alguns segmentos maiores e manter o tamanho de outros, cada segmentação foi direcionada para um dos três grupos de cobertura predominante, definidos no nível 1: barro, branco e cinza. 
Assim, a segmentação de objetos predominantemente de barro contou com a seguinte condição: área relativa de sub-objetos classificados como barro no nível 1 deve ser maior que 0,7 . Procedimento semelhante foi realizado para objetos predominantemente brancos e objetos predominantemente cinza no nível 1. O Apêndice 1 apresenta a árvore de processos onde esse procedimento é descrito em detalhes.

Segmentação N5. Por fim, o Nível 5 foi criado sob os níveis anteriores. Assim como a segunda etapa do nível 4, esse nível foi definido utilizando algoritmos de crescimento de regiões seguindo o parâmetro escalar de 100 , forma 0,5 e compactação 0,9 . Devido à semelhança entre parâmetros, houve pouca diferença nos resultados da segmentação entre este nível e o anterior. Os objetos alvo nesse nível eram as grandes áreas construídas.

Classificação N5.1. A classificação realizada no nível 5 teve como objetivo reconhecer grandes áreas considerando inclusive objetos que no nível 1 foram classificados como vegetação, desde que o percentual da área ocupada por essa classe de objeto fosse reduzida. Isto foi necessário porque sem a presença de uma banda infravermelha a separabilidade da classe vegetação é comprometida e a identificação de grandes áreas com um baixo desvio padrão na banda de saturação e uma baixa presença de vegetação é uma informação que pode ser utilizada no nível principal como um indicador de grande área construída (edificação não residencial)

Classificação N4.2. Nesta segunda etapa de classificação, os objetos de interesse, ônibus e campos de futebol, foram classificados com base em funções de intensidade, área, comprimento/largura, enquadramento retangular e elíptico, além de funções baseadas na classificação de sub-objetos. Posteriormente, as regras desenvolvidas no nível 2 utilizaram este dado como informação auxiliar para classificar corretamente telhados metálicos como telhados não cerâmicos, melhorando significativamente a classificação nas regiões onde são encontrados ônibus estacionados.

Classificação N3.2. Na segunda etapa de classificação do Nível 3, objetos que não são vegetação ou sombra foram classificadas como vias centrais (vias_eixo como indicado na Figura 6.5) e ferrovia, com base exclusivamente na camada temática. Após esta operação, segmentos vizinhos às vias recém classificadas e de característica linear foram classificados como vias borda 1 e vias borda 2, utilizando a combinação de funções de assimetria, largura, comprimento/largura e compactação. Esta operação foi realizada duas vezes de forma que a maior parte dos segmentos que formassem a área da via fossem identificados, cuidando que segmentos com alta adequação retangular, possíveis 
edificações, não fossem incluídos na classe vias. Por fim, as três classes de vias (vias eixo, vias borda 1 e vias borda 2) foram combinadas em uma única classe.

\section{Quadro 6.5. Resumo das principais classes e suas principais funções descritoras - Ortofotografias}

\begin{tabular}{|c|c|}
\hline Principais classes & Principais descritores \\
\hline \multicolumn{2}{|l|}{ Nível 1} \\
\hline • vegetação & $\begin{array}{l}\text { dif. média com vizinhos em intensidade, PC2, PC3, R,G,B S, I, desvio padrão da PC3, índice } \\
\text { de sombra, índice de solo adaptado. }\end{array}$ \\
\hline - sombra & $\begin{array}{l}\text { área, linearidade, dif. média com vizinhos em intensidade, PC2, PC3, R,G,B S, I, desvio } \\
\text { padrão da PC3, índice de sombra, índice de solo adaptado. }\end{array}$ \\
\hline - máscara & camada temática máscara \\
\hline - barro & $\begin{array}{l}\text { dif. média com vizinhos em intensidade, PC2, PC3, R,G,B S, I, desvio padrão da PC3, índice } \\
\text { de sombra, índice de solo adaptado. }\end{array}$ \\
\hline - branco & $\begin{array}{l}\text { dif. média com vizinhos em intensidade, PC2, PC3, R,G,B S, I, desvio padrão da PC3, índice } \\
\text { de sombra, índice de solo adaptado. }\end{array}$ \\
\hline - cinza & $\begin{array}{l}\text { dif. média com vizinhos em intensidade, PC2, PC3, R,G,B S, I, desvio padrão da PC3, índice } \\
\text { de sombra, índice de solo adaptado. }\end{array}$ \\
\hline \multicolumn{2}{|l|}{ Nível 2} \\
\hline - vegetação & sub-objetos vegetação \\
\hline - vegetação rasteira & média PC3, desvio padrão da PC3, desvio padrão da saturação \\
\hline - sombra & sub-objetos sombra, Pan diferença média para vizinhos, área e linearidade \\
\hline - campo de futebol & super-objeto campo de futebol \\
\hline - vias pavimentadas & super-objetos vias, sub-objetos cinza \\
\hline $\begin{array}{l}\text { - vias não } \\
\text { pavimentadas }\end{array}$ & super-objetos vias, sub-objetos barro \\
\hline • ônibus & super-objeto ônibus \\
\hline $\begin{array}{l}\text { edficações } \\
\text { residenciais }\end{array}$ & $\begin{array}{l}\text { super objetos grandes áreas, área, comprimento/largura, borda relativa a sombra, borda relativa } \\
\text { a parede, borda relativa a edficações, enquadramento retangular }\end{array}$ \\
\hline $\begin{array}{l}\text { - edficações com } \\
\text { telhado cerâmico }\end{array}$ & classe parente edficações residenciais, enquadramento retangular, sub-objetos barro \\
\hline \begin{tabular}{|l} 
edficações com \\
telhados não \\
cerâmicos
\end{tabular} & classe parente edficações residenciais, não é edficação com telhado cerâmico \\
\hline \multicolumn{2}{|c|}{ - cobertura permeável não é edficação, sub-objetos barro } \\
\hline $\begin{array}{l}\text { - cobertura } \\
\text { impermeável }\end{array}$ & não é edficação, sub-objetos cinza \\
\hline \multicolumn{2}{|l|}{ Nível 3} \\
\hline - vias eixo & camada temática vias \\
\hline - vias & borda relativa a vias eixo, linearidade, adequação retangular \\
\hline \multicolumn{2}{|l|}{ Nível 4} \\
\hline - campo de futebol & I, área, enquadramento elíptico, área relativa de sub objetos barro \\
\hline - ônibus & área, comprimento/largura, B, retangularidade, sub objetos branco \\
\hline \multicolumn{2}{|l|}{ Nível 5} \\
\hline - área grande & $\begin{array}{l}\text { área, desvio padrão de S, enquadramento elíptico, enquadramento retangular, área relativa de } \\
\text { sub-objetos vegetação }\end{array}$ \\
\hline
\end{tabular}

Nota: $R$ - banda vermelha; G - banda verde; B - banda azul; linearidade: assimetria, compactação, comprimento/largura, largura; Índice solo adaptado =[Média CP2 $]^{\star}[$ Média Azul]/(-1000); Índice sombra = [Média Azul]-[ Média CP1]. 
Classificação N2.2. Esta etapa teve como objetivo identificar as classes alvo. Inicialmente a vegetação foi re-classificada em vegetação rasteira e arbórea, utilizando o método de classificação supervisionada com base em funções que examinam o desvio padrão da terceira componente principal e da saturação. Em seguida as classes campo de futebol, ônibus e ferrovia foram classificadas com base em super-objetos. Os segmentos não classificados como tais e objetos classificados como sombra foram reclassificados em vias e não vias, com base nos super-objetos vias do nível 3. As vias então foram classificadas em pavimentada, não pavimentada e de pavimento indefinido. Os objetos classificados como não vias foram então classificados como sombra e parede.

Valores absolutos de intensidade da imagem foram bastante úteis na classificação, na maioria das sombras presentes nas ortofotografias, devido ao baixo valor espectral dessa classe nas três bandas. Para classificar sombras mais claras, foram utilizadas funções que avaliam o contraste de valores de intensidade entre objetos vizinhos, além de funções que consideram características de linearidade e tamanho dos objetos. A segmentação utilizada apresentou uma boa separabilidade entre a maior parte dos objetos de interesse, no entanto houve pequenos espaços que foram também segmentados.

Alguns desses espaços puderam ser classificados como bordas de edificações ou paredes $^{33}$, características bastante interessantes para a classificação de telhados. Esses segmentos apresentam maior brilho, área reduzida, elevada assimetria, baixo enquadramento retangular, entre outras características relacionadas principalmente à sua linearidade e irregularidade.

Assim, sombra e parede foram utilizadas para classificar os segmentos ainda sem classe definida em edificações ou não edificações. As edificações que interessam para o estudo são edificações residenciais, como visto no início deste capítulo, por isso atributos de área são também utilizados além dos atributos de adequação retangular e borda relativa com sombra, parede e outras edificações. Enfim, objetos classificados como edificações foram reclassificados em edificações com telhado cerâmico ou não cerâmico, baseando-se principalmente na classificação de sub-objetos.

\footnotetext{
${ }^{33}$ Ainda que este elemento seja susceptível às variações da hora e ângulo que a aerofotografia foi realizada, um ou outro deve estar presente. Aerofotografias não são feitas em um ângulo perfeito de $90^{\circ}$ ao meio dia ou capturariam a sombra da própria aeronave. Em casos onde casas conjugadas devem ser segmentadas, existe ainda a possibilidade de que estas casas tenham materiais diferentes em seus telhados ou alturas diferentes, data de construção ou período de manutenção diferente. Estas situações facilitariam a classificação apropriada desses segmentos.
} 


\subsubsection{Testes de acurácia}

A acurácia da classificação foi avaliada utilizando classificação visual de cada uma das três áreas controle e comparando-as à classificação digital. (Figura 6.6). Duas diferentes abordagens de avaliação foram utilizadas, uma baseada em objetos e uma outra baseada em pixels, independentemente do método de classificação utilizado. É muito importante distinguir qual abordagem de avaliação é mais apropriada para o tipo de uso que terá o dado. Se o dado será utilizado para análise de área, a avaliação deverá ser por pixel, no caso de contagem de objetos, a avaliação mais adequada deve verificar a coincidência de objetos, por exemplo. Considerando as variáveis e as características urbanas de interesse para o estudo, os testes de acurácia das classes de interesse foram realizados como mostra o Quadro 6.6. A classe edificações, que alimenta variáveis que necessitam do valor da contagem e da área de objetos, teve acurácia examinada em termos de reconhecimento de objetos e em termos de área (verificação por pixel), as demais classes tiveram acurácia verificada apenas em termos de área.
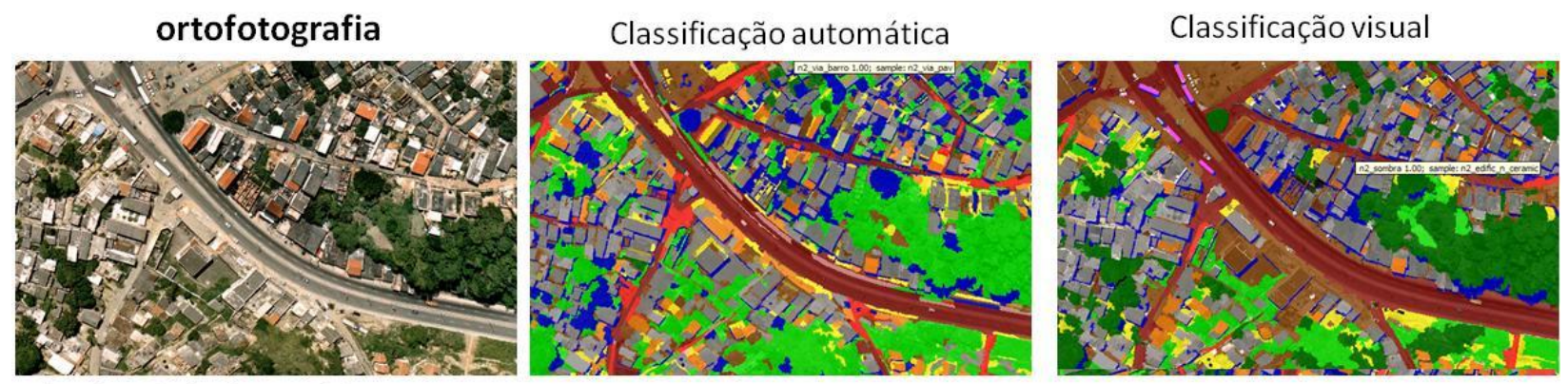

Alta densidade classe média
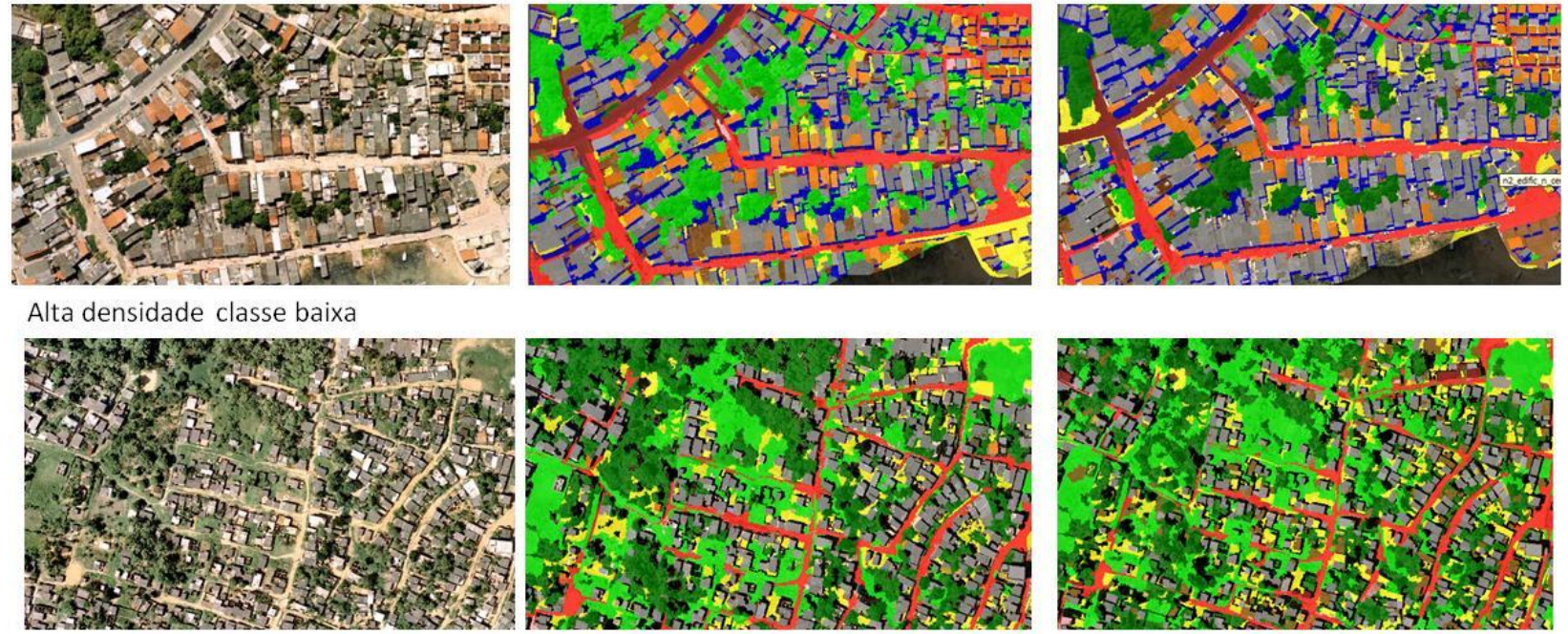

Baixa densidade classe baixa

edific. não ceramica edific. cerâmica
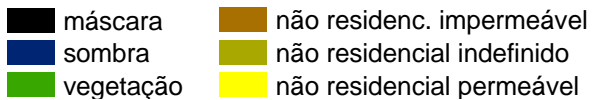

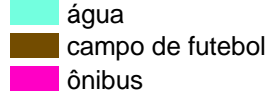

Figura 6.6. Classificação baseada em objeto e classificação visual das áreas controle. 
O Quadro 6.6, na avaliação por pixels, mostra que os melhores resultados da classificação foram alcançados obtidos pelas classes de vegetação e vias,seguidos com certa distância pela classe edificações. Na avaliação por objetos a classe edificações obteve um coeficiente Kappa inferior a 0,5 enquanto a mesma classe na avaliação por pixel obteve um coeficiente médio de 0,7 .

Análises da matriz de confusão, matriz de omissão e matriz de comissão, Quadros 6.7, 6.8, e 6.9, ratificam os resultados positivos obtidos pela classe de vegetação, com apenas $11,26 \%$ de erros de omissão e $16 \%$ de erros de comissão. Alguns erros de pequenas proporções ocorreram quando esta classe foi confundida com a classe sombra, por omissão (vegetação que foi classificados como sombra) e telhados não cerâmicos, por comissão (edificação que foi classificada como vegetação) .

Quadro 6.6. Avaliação de acurácia da classificação em Ortofotografia

\begin{tabular}{|c|c|c|c|c|c|}
\hline \multicolumn{2}{|c|}{ Tipo de avaliação: coincidência de pixels } & \multirow{2}{*}{\begin{tabular}{|l|} 
Geral \\
Coeficiente \\
Kappa (médio) \\
\end{tabular}} & \multirow{2}{*}{\begin{tabular}{|c|} 
Área controle 1 \\
$\begin{array}{c}\text { Coeficiente } \\
\text { Kappa }\end{array}$ \\
\end{tabular}} & \multirow{2}{*}{\begin{tabular}{|c|} 
Área controle 3 \\
$\begin{array}{c}\text { Coeficiente } \\
\text { Kappa }\end{array}$ \\
\end{tabular}} & \multirow{2}{*}{\begin{tabular}{|c|} 
Área controle 4 \\
$\begin{array}{c}\text { Coeficiente } \\
\text { Kappa }\end{array}$ \\
\end{tabular}} \\
\hline Classe & Variáveis & & & & \\
\hline edficações & $\begin{array}{l}\text { V02_ed_qua, V03_ed_q_a, } \\
\text { V04_ed_q_t, V12_co_imp }\end{array}$ & 0.69 & 0.73 & 0.73 & 0.6 \\
\hline telhado cerâmico & V02_ed_qua, V04_ed_q_t & 0.63 & 0.64 & 0.48 & 0.77 \\
\hline telhado não cerâmico & V02_ed_qua, V04_ed_q_t & 0.60 & 0.68 & 0.58 & 0.55 \\
\hline solo exposto & V11_co_noc, V13_co_nocp & 0.30 & 0.3 & si & 0.3 \\
\hline cobert. Impermeável & V12_co_imp & 0.17 & si & si & 0.17 \\
\hline vegetação & V11_co_nocp, V14_veget & 0.87 & 0.88 & 0.88 & 0.85 \\
\hline vegetação rasteira & V16_eq_laz & 0.88 & 0.86 & si & 0.89 \\
\hline vias & $\begin{array}{l}\text { V07_vi_qua, V09_vi_q_I, } \\
\text { v10_vi_are }\end{array}$ & 0.86 & 0.84 & 0.84 & 0.9 \\
\hline vias pavimentadas & $\begin{array}{l}\text { V07_vi_qua, V08_vi_q_p, } \\
\text { V12_co_imp }\end{array}$ & 0.75 & - & 0.65 & 0.84 \\
\hline vias não pavimentadas & V07_vi_qua, V08_vi_q_p & 0.83 & 0.83 & 0.8 & 0.86 \\
\hline & Coeficiente Kappa geral & 0.62 & 0.56 & 0.67 & 0.620 \\
\hline
\end{tabular}

\begin{tabular}{|c|c|r|r|r|r|}
\hline Tipo de avaliação: coincidência de objetos & Geral & Área controle 1 & Área controle 3 & Área controle 4 \\
\hline Classe & \multicolumn{1}{c|}{ Variáveis } & $\begin{array}{c}\text { Coeficiente } \\
\text { Kappa (médio) }\end{array}$ & $\begin{array}{c}\text { Coeficiente } \\
\text { Kappa }\end{array}$ & $\begin{array}{c}\text { Coeficiente } \\
\text { Kappa }\end{array}$ & $\begin{array}{c}\text { Coeficiente } \\
\text { Kappa }\end{array}$ \\
\hline \multirow{2}{*}{ edficações } & V01_ed_d_c, V02_ed_qua, & & & & \\
\hline \multicolumn{2}{|c|}{ V03_ed_q_a, V05_ed_afa } & 0.48 & 0.51 & 0.52 & 0.41 \\
\hline
\end{tabular}




\begin{tabular}{|c|c|c|c|c|c|c|c|c|c|}
\hline user|reference & vegetação & sombra & $\begin{array}{c}\text { via } \\
\text { pavimentada }\end{array}$ & $\begin{array}{c}\text { via não } \\
\text { pavimentada }\end{array}$ & via pav indef & $\begin{array}{l}\text { edficação } \\
\text { telhado } \\
\text { cerâmico }\end{array}$ & $\begin{array}{c}\text { edficação } \\
\text { telhado não } \\
\text { cerâmico }\end{array}$ & cobertura & TOTAL \\
\hline vegetação & 2673533 & 94033 & 12304 & 11279 & 0 & 7615 & 210695 & 190416 & 3199875 \\
\hline sombra & 263914 & 943049 & 2862 & 0 & 0 & 4701 & 25033 & 10316 & 1249875 \\
\hline via pavimentada & 3606 & 8517 & 341690 & 14113 & 587 & 0 & 38884 & 66203 & 473600 \\
\hline via não & & & & & & & & & \\
\hline$\frac{\text { pavimentada }}{\text { via pav indef }}$ & $\begin{array}{r}13984 \\
6399\end{array}$ & \begin{tabular}{r|}
483 \\
16045
\end{tabular} & $\begin{array}{l}55827 \\
21218\end{array}$ & $\begin{array}{r}582020 \\
3530\end{array}$ & $\begin{array}{l}842 \\
507\end{array}$ & $\begin{array}{r}8730 \\
475\end{array}$ & \begin{tabular}{r|}
1403 \\
11277
\end{tabular} & $\begin{array}{l}63525 \\
68334\end{array}$ & $\frac{726814}{127785}$ \\
\hline $\begin{array}{l}\text { edficação telhado } \\
\text { cerâmico }\end{array}$ & 2880 & 10045 & 1363 & 2545 & 0 & 226046 & 100711 & 207430 & 540975 \\
\hline $\begin{array}{l}\text { edficação telhado } \\
\text { não cerâmico }\end{array}$ & 32755 & 4353 & 9348 & 16264 & 944 & 39376 & 1653301 & 378845 & 2135186 \\
\hline cobertura & 15537 & 15209 & 7365 & 53280 & 1488 & 39041 & 251314 & 512480 & 895714 \\
\hline TOTAL & 3012608 & 1081689 & 451977 & 683031 & 4368 & 325984 & 2292618 & 1497549 & \\
\hline
\end{tabular}

\section{Quadro 6.8. Matriz de erros de omissão da classificação em Ortofotografia}

\begin{tabular}{|c|c|c|c|c|c|c|c|c|}
\hline user\reference & vegetação & sombra & $\begin{array}{c}\text { via } \\
\text { pavimentada }\end{array}$ & \begin{tabular}{c|} 
via não \\
pavimentada
\end{tabular} & $\begin{array}{l}\text { via pav. } \\
\text { Indef. }\end{array}$ & $\begin{array}{l}\text { edficação } \\
\text { telhado } \\
\text { cerâmico }\end{array}$ & $\begin{array}{l}\text { edficação } \\
\text { telhado não } \\
\text { cerâmico }\end{array}$ & $\begin{array}{c}\text { cobertura } \\
\text { permeável, } \\
\text { imperm. e indef. }\end{array}$ \\
\hline vegetação & 88.74 & 8.69 & 2.72 & 1.65 & 0.00 & 2.34 & 9.19 & 12.72 \\
\hline sombra & 8.76 & 87.18 & 0.63 & 0.00 & 0.00 & 1.44 & 1.09 & 0.69 \\
\hline via pavimentada & 0.12 & 0.79 & 75.60 & 2.07 & 13.44 & 0.00 & 1.70 & 4.42 \\
\hline $\begin{array}{l}\text { via não } \\
\text { pavimentada }\end{array}$ & 0.46 & 0.04 & 12.35 & 85.21 & 19.28 & 2.68 & 0.06 & 4.24 \\
\hline $\begin{array}{l}\text { via pavimento } \\
\text { indefinido }\end{array}$ & 0.21 & 1.48 & 4.69 & 0.52 & 11.61 & 0.15 & 0.49 & 4.56 \\
\hline $\begin{array}{l}\text { edficação telhado } \\
\text { cerâmico }\end{array}$ & 0.10 & 0.00 & 0.30 & 0.37 & 0.00 & 69.34 & 4.39 & 13.85 \\
\hline $\begin{array}{l}\text { edficação telhado } \\
\text { não cerâmico }\end{array}$ & 1.09 & 0.40 & 2.07 & 2.38 & 21.61 & 12.08 & 72.11 & 25.30 \\
\hline $\begin{array}{l}\text { cobertura } \\
\text { permeável, } \\
\text { impermeável e } \\
\text { indefinida }\end{array}$ & 0.52 & 1.41 & 1.63 & 7.80 & 34.07 & 11.98 & 10.96 & 34.22 \\
\hline TOTAL & 11.26 & 12.82 & 24.40 & 14.79 & 88.39 & 30.66 & 27.89 & 65.78 \\
\hline
\end{tabular}

Nota: Em cinza destacam-se os percentuais de erros de omissão totais maiores que 25\%. Em amarelo destacam-se os percentuais de omissão por classes maiores que 10\%. Em laranja destacam-se os percentuais de acerto da classificação em relação ao total de pixels da classificação de referência (assumida como verdade de campo). Exemplos de leitura da tabela: $87 \%$ do que é sombra foi classificado como sombra; $12 \%$ do que é via pavimentada foi classificado como via não pavimentada; $24 \%$ da área de via pavimentada foi omitida, isto é, não foi classificada como tal. 


\begin{tabular}{|c|c|c|c|c|c|c|c|c|c|}
\hline user|reference & vegetação & sombra & $\begin{array}{c}\text { via } \\
\text { pavimentada }\end{array}$ & $\begin{array}{c}\text { via não } \\
\text { pavimentada }\end{array}$ & $\begin{array}{l}\text { via pav. } \\
\text { Indef. }\end{array}$ & $\begin{array}{l}\text { edficação } \\
\text { telhado } \\
\text { cerâmico }\end{array}$ & $\begin{array}{c}\text { edficação } \\
\text { telhado não } \\
\text { cerâmico }\end{array}$ & $\begin{array}{c}\text { cobertura } \\
\text { permeável, } \\
\text { imperm. e indef. }\end{array}$ & TOTAL \\
\hline vegetação & 83.55 & 2.94 & 0.38 & 0.35 & 0.00 & 0.24 & 6.58 & 5.95 & 16.45 \\
\hline sombra & 21.12 & 75.45 & 0.23 & 0.00 & 0.00 & 0.38 & 2.00 & 0.83 & 24.55 \\
\hline via pavimentada & 0.76 & 1.80 & 72.15 & 2.98 & 0.12 & 0.00 & 8.21 & 13.98 & 27.85 \\
\hline $\begin{array}{l}\text { via não } \\
\text { pavimentada }\end{array}$ & 1.92 & 0.07 & 7.68 & 80.08 & 0.12 & 1.20 & 0.19 & 8.74 & 19.92 \\
\hline $\begin{array}{l}\text { via pavimento } \\
\text { indefinido }\end{array}$ & 5.01 & 12.56 & 16.60 & 2.76 & 0.40 & 0.37 & 8.82 & 53.48 & 99.60 \\
\hline $\begin{array}{l}\text { edficação telhado } \\
\text { cerâmico }\end{array}$ & 0.53 & 0.00 & 0.25 & 0.47 & 0.00 & 41.78 & 18.62 & 38.34 & 58.22 \\
\hline $\begin{array}{l}\text { edficação telhado } \\
\text { não cerâmico }\end{array}$ & 1.53 & 0.20 & 0.44 & 0.76 & 0.04 & 1.84 & 77.43 & 17.74 & 22.57 \\
\hline $\begin{array}{l}\text { cobertura } \\
\text { permeável, } \\
\text { impermeável e } \\
\text { indefinida }\end{array}$ & 1.73 & 1.70 & 0.82 & 5.95 & 0.17 & 4.36 & 28.06 & 57.21 & 42.79 \\
\hline
\end{tabular}

Nota: Em cinza destacam-se os percentuais de erros de comissão totais maiores que 25\%. Em amarelo destacam-se os percentuais de comissão por classes maiores que 10\%. Em laranja destacam-se os percentuais de acerto da classificação em relação ao total de pixels da classificação (resultado do processamento). Exemplos de leitura da tabela: $75 \%$ do que foi classificado como sombra é sombra; $21 \%$ do que foi classificado como sombra é vegetação; $16 \%$ da área de vegetação foi cometida, isto é, não corresponde a esta classe, mas foi classificada como tal.

A classe sombra também apresentou bons resultados, apresentou os erros de inclusão e omissão mais significativos com a classe vegetação.

As classes vias pavimentadas e vias não pavimentadas obtiveram também resultados positivos. Em contrapartida, a classe vias com pavimento indefinido não apresentaram resultados satisfatórios. Como a classificação de referência possuía poucos exemplares de pavimento indefinido e como uma parte significativa dos erros ocorridos nas três classes filhas de vias ocorreram entre elas mesmas, o resultado da avaliação de vias com pavimento indefinido teve pouca influência na composição do coeficiente Kappa da classe vias em geral.

A classe vias pavimentadas apresentou erros de omissão mais significativos com a classe vias não pavimentadas (12\%) e erros de comissão mais significativos com a classe de coberturas do solo (cobertura permeável, impermeável e indefinida, 9\%) seguida da classe de edificações com telhado não cerâmico (7\%). Na classe vias não pavimentadas os mais altos erros de omissão e comissão foram com as classes de coberturas do solo, $8 \%$ e $6 \%$ respectivamente. 
A acurácia geral da classe de edificações pode ser considerada satisfatória, no entanto, o coeficiente Kappa das classes edificações com telhado cerâmico e edificações com telhado não cerâmico atingiram um valor mais baixo. No caso de edificações com telhado cerâmico, isto se deve aos erros de comissão que foram bastante altos (58\%), a maior parte deles ocorridos com a classe de cobertura permeável. A outra parte dos erros de comissão da classe edificações com telhado cerâmico ocorreu com a classe de edificações com telhado não cerâmico, possivelmente devido às semelhanças de cor com edificações que têm como cobertura a laje de concreto, que costumam acumular poeira. Os principais erros de omissão da classe de telhados não cerâmicos ocorreram também com as classes de telhados cerâmicos e cobertura permeável.

A principal confusão de edificação de telhado não cerâmico ocorreu com a classe de coberturas do solo, tanto em relação a omissões como comissões. Observa-se ainda que cerca de $9 \%$ das edificações com telhado não cerâmico foram classificadas como vegetação.

Mesmo combinadas em um único grupo, as classes de cobertura permeável, impermeável e indefinida não alcançaram resultados satisfatórios nos testes de acurácia. A maior parte da confusão dessa classe ocorreu com as classes de vias de pavimento indefinido e edificações.

\subsection{Classificação em áreas teste e controle de imagem QuickBird}

Os mesmos limites utilizados como áreas teste e áreas controle nas ortofotografias foram utilizados nas imagens QuickBird. A etapa de pré-processamento foi realizada nos dois conjuntos, a etapa de segmentação e classificação foi desenvolvida por experimentação nas áreas teste, e teve a árvore de processos final aplicadas nas áreas controle. Por fim, as áreas controle sofreram os testes de avaliação de acurácia.

\subsubsection{Pré-processamento}

Assim como descrito na etapa de pré processamento das ortofotografias, o objetivo desta etapa aplicada às imagens QuickBird também é de extrair das bandas originais imagens derivadas que contribuam na identificação de alvos, além de ajustar esses dados raster aos dados vetoriais e adequar os dados vetoriais à sua utilização no processo de classificação 
baseada em objeto. A Figura 6.7. Apresenta o diagrama com os principais processos realizados nessa etapa.

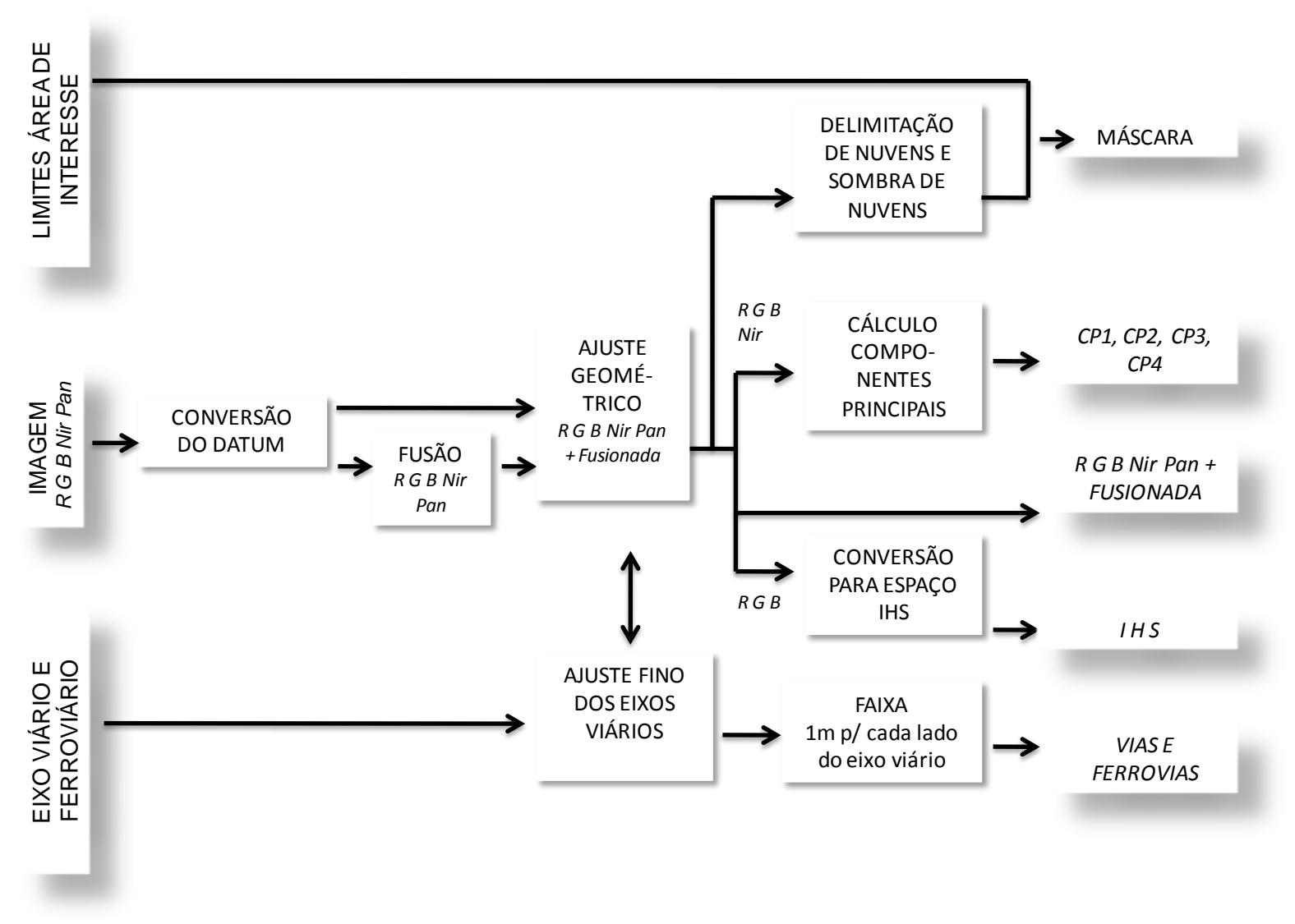

Figura 6.7. Etapa de pré-processamento de imagem QuickBird

Primeiramente, a imagem QuickBird foi convertida para o Datum SAD-69. Em seguida suas bandas multi-espectrais foram fusionadas com a banda pancromática com o objetivo de aumentar a resolução espacial dessas bandas. Este procedimento foi realizado no software ENVI, utilizando a função de realce espectral de Gram-Schmidt ${ }^{34}$. As imagens, originais e fusionadas, sofreram então um ajuste geométrico simples, realizado com a função de georreferenciamento do ArcMap 9.1 (ESRI Inc., 2005), para que melhor se ajustassem à malha viária. Com base na imagem fusionada e corrigida foi desenhada uma máscara vetorial para nuvens e sombras de nuvens. As bandas RGB (vermelha, verde e azul), da imagem original corrigida, foram convertidas para o espaço IHS (Intensidade, Matiz e Saturação), e as CP (componentes principais) foram calculadas a partir das quatro bandas

\footnotetext{
${ }^{34}$ O ENVI executa a função de realce espectral de Gram-Schmidt da seguinte forma: 1 . Simulando a banda pancromática a partir das bandas multi-espectrais. 2. Executando a transformação de Gram-Schmidt na banda pancromática simulada e nas bandas espectrais utilizando a primeira banda Gram-Schmidt. 4. Aplicando a transformação de Gram-Schmidt inversa a partir das bandas espectrais realçadas pela banda pancromática (ENVI, 2006).
} 
multi-espectrais $^{35}$. Em seguida, a base de eixos viários foi ajustada e convertida de linhas para polígonos, utilizando a função de criação de buffers com raio de um metro.

Por fim, foram criados dois arquivos vetoriais compostos por polígonos que cobrem toda área de estudo: máscaras e viasferrovias. $\mathrm{O}$ arquivo de máscaras foi gerado combinando o retângulo envolvente da área de estudo, os limites da área de estudo e as máscaras de nuvem e sombra de nuvem. Às áreas de nuvem, sombra de nuvem e área externa aos limites da área de estudo foi atribuído o valor 1 (um), para as demais áreas (áreas úteis da área de estudo) foi atribuído o valor 0 (zero). O arquivo viasferrovias foi gerado combinando o buffer de vias, o buffer de ferrovias ( $2 \mathrm{~m}$ de raio) e o retângulo envolvente da área de estudo. À área de vias foi atribuído o valor 1 (um), à área de ferrovias o valor 2(dois) e às demais áreas o valor 0 (zero).

Utilizando o software Definiens Developer 5.0 (Definiens Inc), foi criado um novo projeto para análise baseada em objeto com base na imagem QuickBird, no qual onze camadas de imagens (RGBNir fusionadas, Pan, IHS, CP1, CP2 e CP3) foram adicionadas. Os arquivos vetoriais de viasferrovias e máscaras foram adicionados ao mesmo projeto como camadas temáticas.

\subsubsection{Segmentação e Classificação}

Para lidar com a complexidade apresentada pela imagem QuickBird e acentuada pela configuração urbana da área de estudo, foi realizado um processo interativo de classificação e segmentação multi-nível. Assim, classificações preliminares puderam ser utilizadas para dar apoio às segmentações seguintes, permitindo a criação mais direcionada e precisa de segmentos de imagem. Portanto, a primeira classificação de cada nível foi realizada logo após a criação do nível (Figura 6.8). A descrição completa da árvore de processos desenvolvida para a imagem QuickBird encontra-se no Apêndice 4. Este procedimento foi muito importante para que os limites mais refinados dos objetos classificados com sucesso no primeiro nível, utilizando essencialmente informações espectrais, pudessem ser mantidos nos níveis seguintes (sombra e vegetação classificadas no nível 1). Isso também reduziu significativamente o tempo de processamento na criação dos níveis seguintes, uma vez que no primeiro nível uma grande área da cena, composta

\footnotetext{
${ }^{35} \mathrm{O}$ cálculo de CP foi baseado em uma área interna aos limites da área de estudo, e os parâmetros estatísticos, obtidos no cálculo da CP dessa área, foram reproduzidos para toda a cena. Esse procedimento visou evitar distorções trazidas pela extensa área de mar e de reserva florestal, externas à área de estudo porém dentro dos limites da cena (retângulo envolvente).
} 
por vegetação e máscara, já havia sido classificada e não precisava, portanto, ser segmentada nos níveis seguintes.

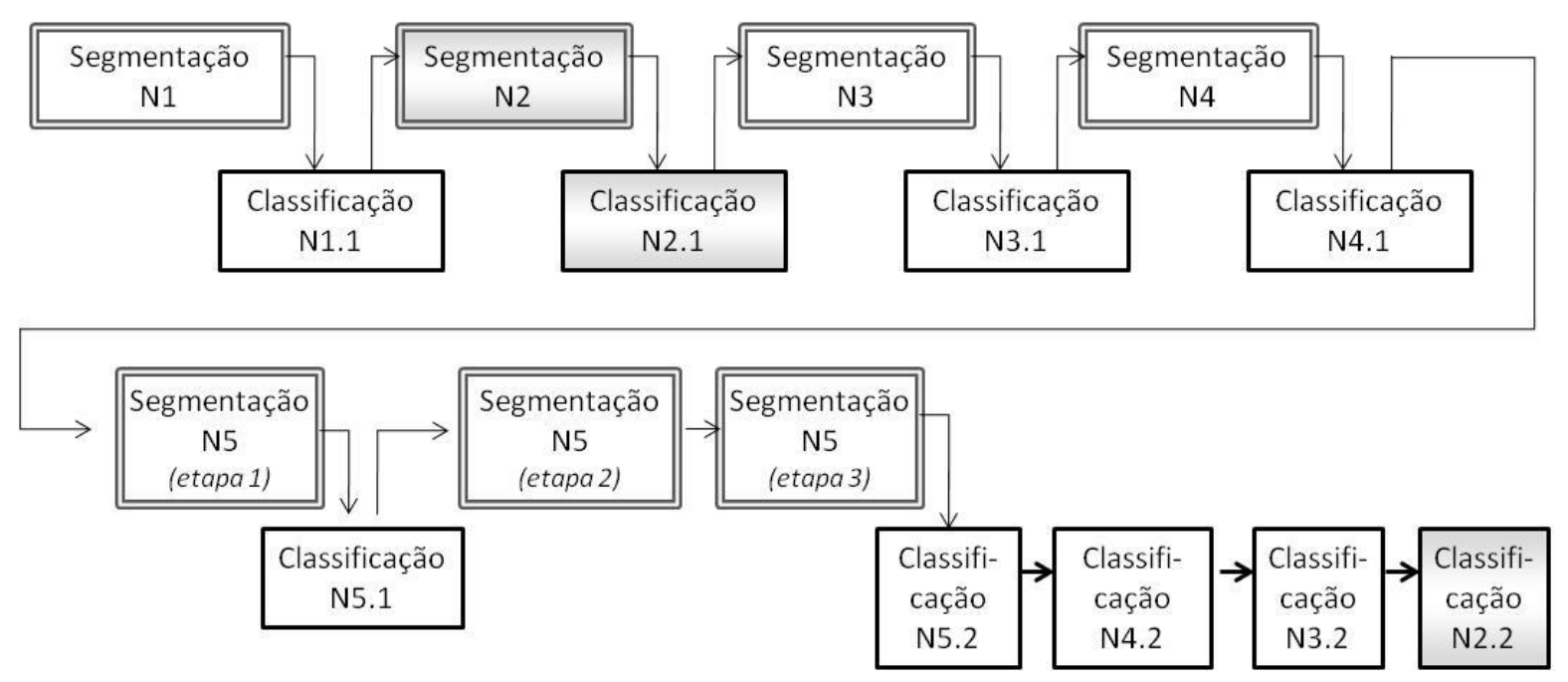

Figura 6.8. Processos interativos de classificação e segmentação na imagem QuickBird

Toda segmentação teve seus resultados avaliados por experimentação. Múltiplos níveis foram criados de acordo com a necessidade de se aplicar regras relacionadas a superobjetos, afim de aperfeiçoar a classificação do nível principal (nível 2). Por exemplo, informações do sistema viário no nível 3 foram utilizadas no nível 2 para aperfeiçoar a classificação de vias, a classificação de ônibus no nível 4 serviu para melhorar a acurácia na classificação de telhados metálicos como telhados não cerâmicos e a classificação de segmentos segundo sua área e forma no nível 5 contribuiu para a identificação de campos de futebol e construções não residenciais, como galpões e estacionamentos. Assim, após extensivas análises, cinco níveis de segmentação foram criados, Quadro 6.10.

A camada temática máscara foi utilizada para a segmentação apenas no primeiro nível. A camada temática viasferrovias foi utilizada para a segmentação dos três primeiros níveis. AS bandas verde, vermelha e azul foram utilizadas na segmentação de todos os níveis. Devido a baixa resolução espectral da imagem ${ }^{36}$, o mesmo peso foi atribuído a todas as camadas de imagem em todos os níveis. Consequentemente, cada banda multi-espectral influenciou igualmente a geração dos segmentos em cada nível de segmentação.

\footnotetext{
${ }^{36}$ Ainda que possua a banda Nir a imagem QuickBird é considerada de baixa resolução espectral, como foi visto no Item 2.3.
} 
Quadro 6.10. Parâmetros da segmentação em imagem QuickBird

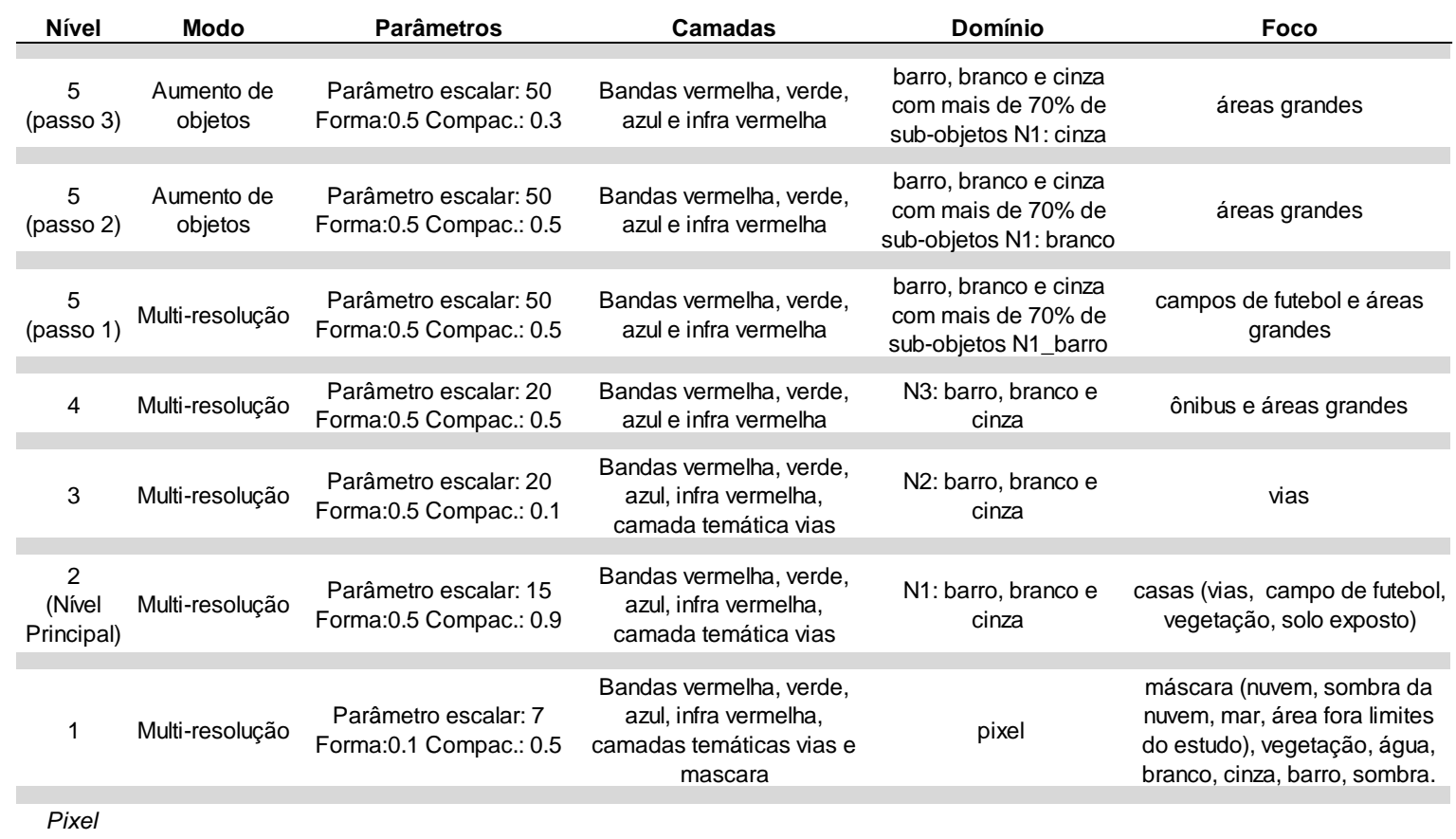

Segmentação N1. No primeiro nível foram utilizados valores reduzidos para o parâmetro escalar e parâmetro de forma, com intuito de criar segmentos com alta homogeneidade espectral.

Classificação N1.1. Logo em seguida foi realizada a primeira classificação do nível 1. Considerando as principais diferenças espectrais dos elementos de interesse para a pesquisa e os elementos que são mais facilmente identificados por meio dessas características, as classes água, vegetação, sombra, barro, cinza e branco foram criadas utilizando principalmente os descritores listados no Quadro 6.11. A classe máscara baseouse exclusivamente na camada temática onde se encontravam os limites vetoriais da área de estudo, excluindo área de nuvens e sombra de nuvens.

Segmentação N2. O Segundo nível é considerado o nível principal porque reúne a classificação final dos alvos de interesse para o estudo. Por isso, nesse nível, foi importante alcançar uma segmentação que trouxesse resultados satisfatórios na segmentação de casas, já que esta é o menor objeto de interesse para o estudo. O alvo vegetação foi identificado após a segmentação do primeiro nível e seus limites foram mantidos, os alvos restantes (ruas, casas, solo exposto, impermeável e campos de futebol) tiveram uma segmentação justa ou foram super segmentados. Dessa forma, foi possível acessar informações sobre esses objetos a partir dos níveis superiores. 
O melhor resultado de segmentação para este nível foi obtido utilizando o parâmetro escalar de 15, peso igual para características de cor e de forma e valores mais altos de compactação sobre suavidade.

Classificação N2.1. A mesma lógica de reclassificação apresentada na seção anterior para as ortofotografias foi utilizada na imagem QuickBird. A primeira classificação do nível 2 também teve como objetivo trazer do nível 1 a classificação dos alvos que são baseados em informações espectrais (água, vegetação e sombra) e delimitar o domínio das próximas classificações, determinando em uma única classe (n_somb_veg) aquilo que não é nem vegetação, nem sombra, nem máscara.

Segmentação N3. A criação de um terceiro nível foi baseada na informação da camada temática viasferrovias e teve como objetivo identificar a área coberta pelo sistema viário. O melhor resultado de segmentação foi obtido utilizando o parâmetro escalar de 20, parâmetro de forma igual a 0,5 e o valor mínimo de compactação. Visto que a camada temática viasferrovias representa apenas a área central da rua, este critério permitiu a união de objetos vizinhos que possuem informação espectral similar, aumentando o tamanho desses objetos e consequentemente incrementando suas características de linearidade (características utilizadas mais adiante no processo de classificação)

Classificação N3.1. Mais uma vez a classificação dos alvos baseados em informações espectrais foi reproduzida de um nível inferior para o nível recém criado, visando manter os limites de vegetação e sombra e delimitar o domínio das próximas segmentações e classificações.

Segmentação N4. O quarto nível de segmentação também é um nível auxiliar. Dessa vez, um critério de segmentação muito semelhante ao nível anterior foi utilizado, gerando segmentos muito parecidos com os do nível 3. A principal diferença desse nível é que aí não foi utilizada a camada temática viasferrovias na segmentação, pois nesse nível a segmentação tem como objetivo unir objetos super segmentados no nível anterior, como ônibus que se encontravam cortados pela camada temática, por exemplo. O parâmetro escalar utilizado foi de 20, o parâmetro de forma e de compactação foi 0,5 .

Classificação N4.1. A primeira classificação do nível 4 reproduziu a classificação no nível 3, onde vegetação, sombra, água e máscara, identificados no nível 1, foram agrupados em uma única classe, como visto na Figura 6.9. A classe complementar a esta serviu de base para a segmentação e as classificações seguintes. 
Segmentação N5. O quinto nível foi criado sobre todos os demais níveis de segmentação, gerando segmentos muito maiores devido à utilização do parâmetro escalar de 50 . Esses grandes segmentos foram limitados por áreas vegetadas, classificadas no nível 1 e transferidas até este nível pelo processo integrado de segmentação e classificação. Como os alvos nesse nível são os campos de futebol e grandes áreas construídas, foi importante manter, o quanto possível, a homogeneidade espectral dos segmentos e ao mesmo tempo considerar a classificação segundo os atributos espectrais já calculados para sub-objetos (nível 1). Para resolver esse dilema, o quinto nível foi criado utilizando uma segmentação com três etapas. Com o foco na identificação de campos de futebol, a primeira etapa utilizou o parâmetro escalar de 20 e parâmetros de forma e compactação de 0,5 para segmentar apenas objetos que no nível 4 eram majoritariamente barro. Para especificar quais eram esses objetos, o domínio da segmentação contou com a seguinte condição: área relativa de sub-objetos classificados como barro no nível 1 deve ser maior que 0,7 . Procedimento semelhante foi realizado para objetos predominantemente brancos e objetos predominantemente cinza no nível 1.

A identificação de campos de futebol foi importante porque, além de ser uma classe de interesse para o estudo (principais espaços recreacionais do Subúrbio), são também importantes para distinguir solo exposto relacionado a áreas não ocupadas ou sem função aparente e área ocupada mas sem pavimentação, visto que a maior parte dos campos de futebol da região são de barro.

Classificação N5.1. Na primeira classificação do Nível 5, mais uma vez foi reproduzida a primeira classificação do nível 3, formando duas classes. Uma onde os segmentos foram classificados no nível 1 como sombra, vegetação, água ou máscara, e uma outra complementar a esta.

Os procedimentos finais de classificação foram realizados na ordem oposta, começando pelo nível superior, nível 5, e terminando no nível principal, nível 2 (Figura 6.8). As funções utilizadas para descrever as classes foram, em sua maior parte baseadas na literatura e foram testadas extensivamente utilizando recursos do software eCognition ${ }^{37}$.

Os principais descritores utilizados para identificar as principais classes são apresentados no Quadro 6.11. A lista com a descrição completa das regras e funções utilizadas encontram-se no Apêndice 5.

37 O editor de amostras e visualizador de atributos foram utilizados para análise de histogramas e para visualização do resultado das funções que seriam incorporadas às regras de classificação. 
Na Figura 6.9 Apresenta um diagrama com as classes resultante de cada etapa do processo de classificação. Em cada nível a primeira linha de classes corresponde às classes resultantes dos processos de segmentação e classificação interativos. Como pode ser visto no diagrama, nos níveis 3, 4 e 5, a primeira classificação já resulta em uma classe única para vegetação, água, máscara e sombra.

Classificação N5.2. Na segunda rodada de classificações, o quinto nível foi reclassificado em um único passo em campo de futebol e grandes áreas, tendo como base principalmente dados de textura (homogeneidade interna dos segmentos, medida pelo desvio padrão da camada Matiz e CP1), os atributos geométricos dos segmentos com sub-objetos predominantemente barro para classificar campo de futebol e predominantemente branco ou cinza para classificar grandes áreas. O principal interesse na classificação de grandes áreas dá-se devido à necessidade de se reconhecer segmentos que não devem ser classificados como edificações residenciais no nível principal, porque eles correspondem a construções empresas, galpões e estacionamentos, por exemplo.

Classificação N4.2. No quarto nível, ônibus foram primeiramente identificadas com base em suas características geométricas ${ }^{38}$. Grandes áreas foram também classificadas no nível 4 , a fim de identificar segmentos menores que não haviam sido classificados como tais anteriormente (no nível 5) mas que são ainda grandes para serem considerados edificações residenciais, de acordo com a tipologia residencial encontrada na área de estudo. Grandes áreas nesse nível foram classificadas com base em super-objetos do nível 5 e com base na área dos segmentos no nível 4.

Classificação N3.2. No nível 3, para identificar todos os segmentos que deveriam ser classificados com vias, em primeiro lugar foram classificados todos os segmentos que coincidiam com a camada temática viasferrovias de valor 1 , isto é, segmentos que estavam no raio de um metro de distância do eixo viário e que não haviam sido classificados como vegetação, água ou máscara. A partir daí, as duas "fileiras"de segmentos vizinhos (vizinho imediato e segmentos contíguos a estes) foram identificados utilizando atributos de retangularidade para excluir edificações da seleção de vias vizinhas e utilizando uma combinação de descritores capazes de reconhecer segmentos lineares (assimetria, largura, razão comprimento largura e compactação). Em seguida, objetos com estas características de vias foram combinados em uma classe única chamada de vias.

\footnotetext{
${ }^{38}$ No nível principal, regras de descrição utilizaram essa informação auxiliar para classificar corretamente telhados metálicos como edificações não cerâmicas, melhorando significativamente o resultado da classificação em áreas onde há estacionamento de ônibus.
} 


\section{Quadro 6.11. Resumo das principais classes e suas principais funções descritoras - QuickBird}

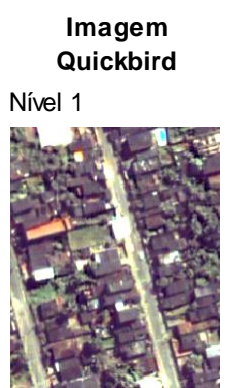

Imagem

classificada

Principais classes

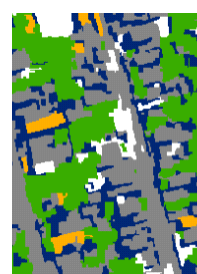

Nível 2
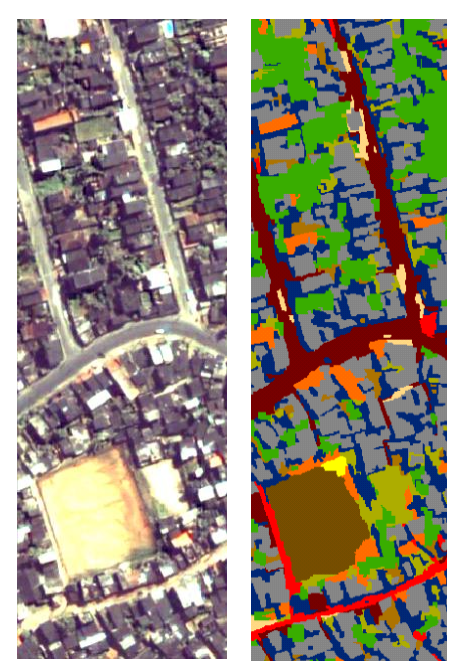

- água

- vegetação

- sombra

- campo de futebo

- vias pavimentadas

vias não

- pavimentadas

- ônibus

edficação

residencial

edficação com

telhado cerâmico edficação com

- telhados não cerâmicos

cobertura

permanente

cobertura

impermeável

Nível 3
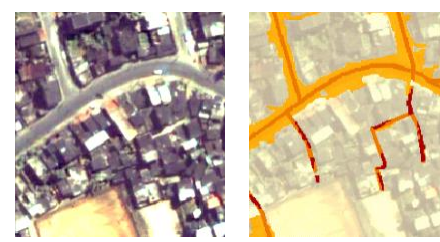

- eixo viário

- vias

Nível 4
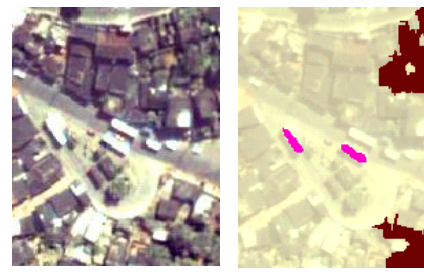

- grandes áreas

- ônibus

Nível 5
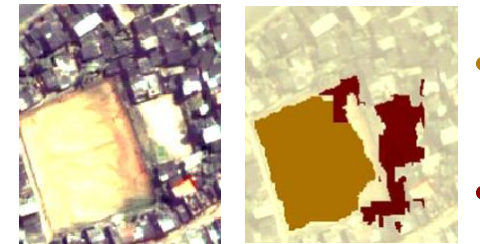

\section{Principais descritores}

B+G, Pan, PC1, Sd. Nir, Sd. Pan, indic_água

NDVI

Pan, $B+G$, área e linearidade

camada temática máscara

indic_solo, B

brilho

não são as demais classes

sub-objetos água

sub-objetos vegetação

sub-objetos sombra, Pan diferença média para vizinhos,

área e linearidade

super-objeto campo de futebol

super-objetos vias, sub-objetos cinza

super-objetos vias, sub-objetos barro

super-objeto forma de ônibus, sub-objecto branco

super objects grandes áreas, área, compacidade,

comprimento/largura, borda relativa a sombra e borda relativa a casas

classe pai casas, sub-objetos barro

classe pai casas, sub-objetos branco ou cinza

não é casa, sub-objetos barro

não é casa, sub-objetos cinza

camada temática vias

borda relativa a eixos vários, linearidade, retangularidade

área, super objetos grandes áreas

área, compacidade, comprimento/largura, B, retangularidade

área, assimetria, compacidade enquadramento elíptico, indic_solo, Sd. Matiz

área, área/perímetro, compacidade, enquadramento elíptico, enquadramento retangular, sd. $\mathrm{CP} 1$, área relativa de sub-objetos brancos, cinza e barro.

Nota: $R$ - banda vermelha, G - banda verde, B - banda azul, Nir - banda infra-vermelha, Sd. - Desvio padrão; linearidade: assimetria, compactação, comprimento/largura, largura; indic solo: ([Média CP3]*[Média B])/(-1000); Indic_sombra: [Média B]-[Média CP1]; indic_agua: [Média Nir]/ [Média G]; NDVI: ([Média Nir]-[Média R])/([Média Nir]+[Média R]); brilho ([Média B]+[Média G]+[Média R])/3 


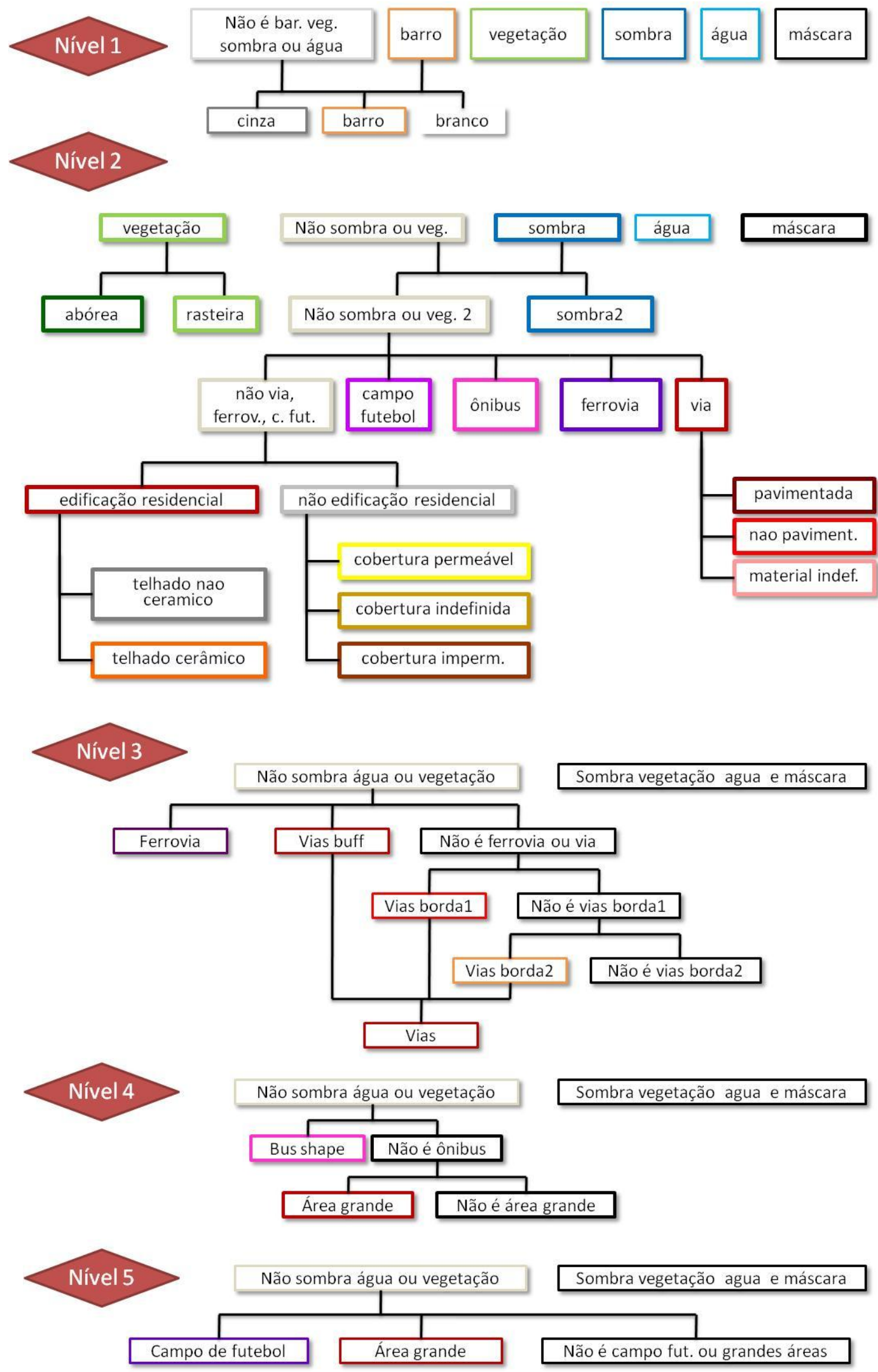

Figura 6.9. Diagrama do processo de classificação em imagem QuickBird 
Classificação N2.2. A segunda etapa de classificações do nível principal buscou-se primeiramente re-classificar vegetação, em vegetação rasteira e arbórea, utilizando funções que examinassem a sua textura, através do calculo da diferença com vizinhos dos subobjetos. Em seguida foram reconhecidos segmentos de sombra que não haviam sido classificados como tal no nível 1. Como no nível 1, apenas características espectrais foram utilizadas para a classificação, algumas sombras mais claras não haviam sido classificadas. Para contornar este problema foi considerado, dessa vez, a reflexibilidade relativamente mais baixa de segmentos pequenos ou lineares em comparação com os segmentos vizinhos (diferença média para os vizinhos calculados com a banda PAN). Posteriormente, ônibus, ruas e campos de futebol foram classificados com base na classificação de superobjetos e, no caso de ônibus, com base também em sub-objetos classificados como branco. Vias foram classificadas de acordo com o seu tipo de pavimento, com base na prevalência de sub-objetos classificados como cinza, barro ou branco, para vias pavimentadas, não pavimentadas e de pavimento indefinido, respectivamente.

Finalmente a classificação da cobertura do solo e de tipos de telhado foi realizada utilizando o método de classificação hierárquica. A fim de aplicar este método, as classes telhado cerâmico e telhado não cerâmico foram designadas como classes filhas da classe edificações residenciais, enquanto as classes cobertura permeável, cobertura impermeável e cobertura indefinida foram designadas como classes filhas da classe não edificação. Para identificar prováveis edificações residenciais, super-objetos classificados como grandes áreas foram excluídos da seleção e foram utilizados descritores de: atributos de área, compactação, comprimento/largura, adequação retangular, vizinhança com sombra e com segmentos classificados como edificação.

Em ocupações informais é comum encontrar casas com afastamento mínimo ou nulo de edificações vizinhas, o que demanda que seja utilizado não apenas borda relativa a objetos classificados como sombra, mas também borda relativa a outros objetos classificados como edificação. Para utilizar o descritor borda relativa a outras edificações como regra de classificação da própria classe edificação ${ }^{39}$, a classificação hierárquica foi configurada para realizar dois ciclos. Em termos práticos, esse procedimento classifica primeiramente edificações com telhado cerâmico e telhado não cerâmico sem considerar segmentos vizinhos classificados como edificação, no segundo ciclo, esses objetos recém classificados no primeiro ciclo já passam a ser considerados. Além disso, por se tratar de uma classificação hierárquica, os segmentos classificados como edificação devem também se

\footnotetext{
${ }^{39}$ No software eCognition, a função de contexto deve estar relacionada à classificação final do objeto, que neste caso, como a classificação é hierárquica, será edficação com telhado cerâmico e edficação com telhado não cerâmico.
} 
enquadrar nas funções que descrevem suas classes filhas, se não, serão automaticamente classificados como não edificações e suas classes filhas cobertura permeável, impermeável e indefinida.

\subsubsection{Testes de acurácia}

Assim, como realizado para as ortofotografias, a acurácia da classificação baseada em objeto em imagem QuickBird foi avaliada comparando a classificação visual e a classificação digital dos segmentos criados no nível 2 nas áreas controle e (Figura 6.10). Foram utilizadas três abordagens de avaliação: contagem e coincidência de objetos e coincidência de pixels. Apenas a classe edificações foi avaliada segundo as três abordagens, pois é a única classe que alimenta variáveis que dependem da contagem de objetos.

\section{Imagem QUICKBIRD}

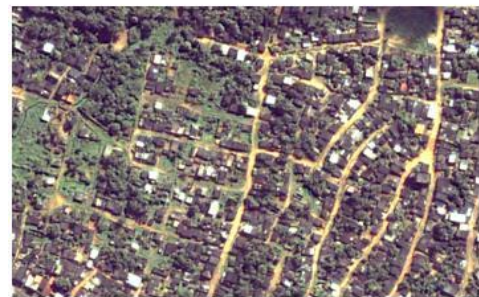

Classificação orientada a objeto

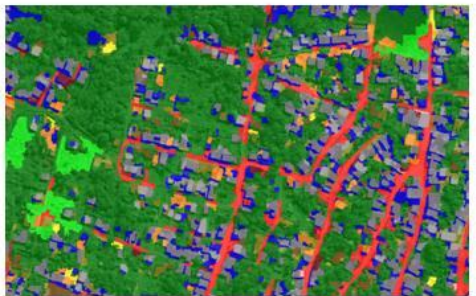

Área Controle 1 - Baixa densidade classe baixa
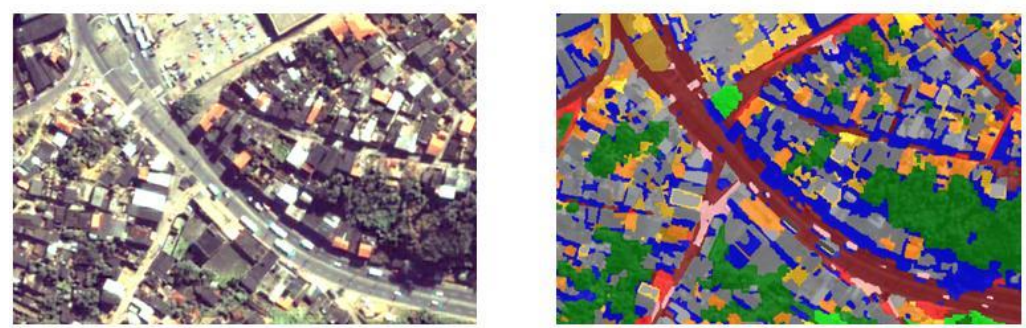

Área Controle 3 - Alta densidade classe média

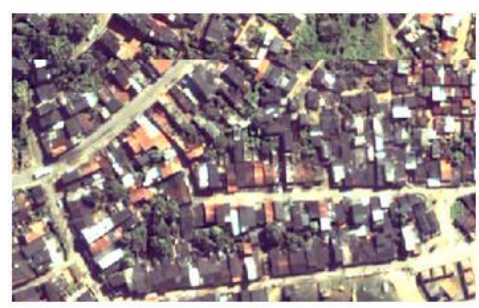

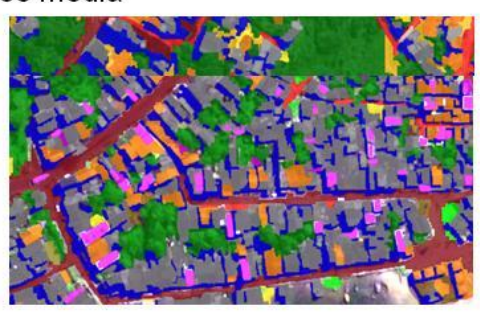

Classificaçãovisual
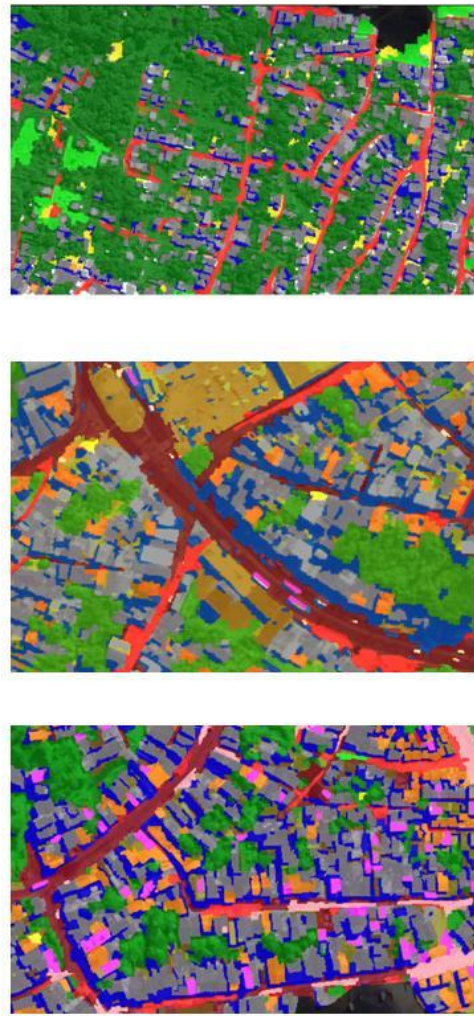

Área Controle 4 - Alta densidade classe baixa

edific. não ceramica edific. cerâmica
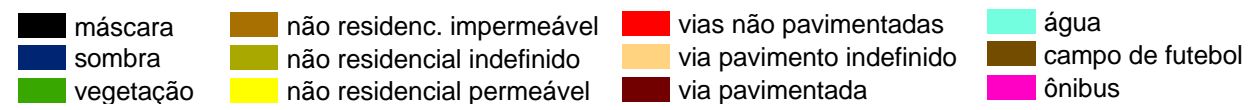

Figura 6.10. Classificação baseada em objeto e classificação visual das áreas 
O Quadro 6.12 mostra que, em geral, os melhores resultados de acurácia, considerando o método de coincidência de pixels, foram obtidos com a classe vegetação, seguida das classes telhados cerâmicos, vias, vias não pavimentadas e edificações.

Quadro 6.12. Avaliação de acurácia de classificação em imagens

\begin{tabular}{|c|c|c|c|c|c|}
\hline \multicolumn{2}{|c|}{ Tipo de avaliação: coincidência de pixels } & \multirow{2}{*}{\begin{tabular}{|c|} 
Geral \\
$\begin{array}{c}\text { Coeficiente Kappa } \\
\text { (médio) }\end{array}$ \\
\end{tabular}} & \multirow{2}{*}{\begin{tabular}{c|} 
Área controle 1 \\
$\begin{array}{c}\text { Coeficiente } \\
\text { Kappa }\end{array}$ \\
\end{tabular}} & \multirow{2}{*}{\begin{tabular}{|c|} 
Área controle 3 \\
$\begin{array}{c}\text { Coeficiente } \\
\text { Kappa }\end{array}$ \\
\end{tabular}} & \multirow{2}{*}{\begin{tabular}{|c|} 
Área controle 4 \\
$\begin{array}{c}\text { Coeficiente } \\
\text { Kappa }\end{array}$ \\
\end{tabular}} \\
\hline Classe & Variáveis & & & & \\
\hline edficações & $\begin{array}{l}\text { V02_ed_qua, V03_ed_q_a, } \\
\text { V04_ed_q_t, V12_co_imp }\end{array}$ & 0.69 & 0.65 & 0.71 & 0.7 \\
\hline telhado cerâmico & V02_ed_qua, V04_ed_q_t & 0.84 & 0.91 & 0.83 & 0.79 \\
\hline telhado não cerâmico & V02_ed_qua, V04_ed_q_t & 0.66 & 0.62 & 0.7 & 0.67 \\
\hline cobert. Permeável & V11_co_noc, V13_co_nocp & 0.05 & 0.08 & 0.08 & 0 \\
\hline cobert. Impermeável & V12_co_imp & 0.09 & 0.15 & 0.07 & 0.05 \\
\hline vegetação & V11_co_nocp, V14_veget & 0.96 & 0.98 & 0.95 & 0.96 \\
\hline vegetação rasteira & V16_eq_laz & 0.39 & 0.86 & 0.26 & 0.04 \\
\hline vias & $\begin{array}{l}\text { V07_vi_qua, V09_vi_q_I, } \\
\text { v10_vi_are }\end{array}$ & 0.85 & 0.8 & 0.88 & 0.88 \\
\hline vias pavimentadas & $\begin{array}{l}\text { V07_vi_qua, V08_vi_q_p, } \\
\text { V12_co_imp }\end{array}$ & 0.59 & & 0.71 & 0.46 \\
\hline vias não pavimentadas & V07_vi_qua, v08_vi_q_p & 0.75 & 0.77 & 0.77 & 0.7 \\
\hline & Coeficiente Kappa geral & 0.76 & 0.798 & 0.753 & 0.730 \\
\hline
\end{tabular}

\begin{tabular}{|c|c|r|r|r|r|}
\hline Tipo de avaliação: coincidência de objetos & Geral & Área controle 1 & Área controle 3 & Área controle 4 \\
\hline Classe & \multicolumn{1}{|c|}{ Variáveis } & $\begin{array}{c}\text { Coeficiente Kappa } \\
\text { (médio) }\end{array}$ & $\begin{array}{c}\text { Coeficiente } \\
\text { Kappa }\end{array}$ & $\begin{array}{c}\text { Coeficiente } \\
\text { Kappa }\end{array}$ & $\begin{array}{c}\text { Coeficiente } \\
\text { Kappa }\end{array}$ \\
\hline edficações & $\begin{array}{l}\text { V01_ed_d_c, V02_ed_qua, } \\
\text { V03_ed_q_a, V05_ed_afa }\end{array}$ & 0.56 & 0.47 & 0.6 & 0.62 \\
\hline \multicolumn{2}{|r|}{ Coeficiente Kappa geral } & 0.73 & 0.657 & 0.72 & 0.809 \\
\hline
\end{tabular}

\begin{tabular}{|c|r|r|r|r|r|}
\hline \multicolumn{1}{|l|}{ Tipo de avaliação: contagem de objetos } & \multicolumn{1}{l|}{ Geral } & Área controle 1 & Área controle 3 & Área controle 4 \\
\hline Classe & \multicolumn{1}{c|}{ Variáveis } & $\begin{array}{c}\text { classific. Digital / } \\
\text { visual (\%) }\end{array}$ & $\begin{array}{c}\text { classific. Digital / } \\
\text { visual (\%) }\end{array}$ & $\begin{array}{c}\text { classific. Digital } \\
\text { / visual (\%) }\end{array}$ & $\begin{array}{c}\text { classific. Digital } \\
\text { /visual (\%) }\end{array}$ \\
\hline edficações & $\begin{array}{l}\text { V01_ed_d_c, V02_ed_qua, } \\
\text { V03_ed_q_a, V05_ed_afa }\end{array}$ & 110.5 & 99.8 & 134.1 & 105.0 \\
\hline
\end{tabular}

Nota: Não foi possível avaliar a acurácia das classes campo de futebol e água porque esses elementos não estavam presentes em nenhuma das áreas controle.

A classe edificações, que obteve um coeficiente Kappa geral de 0,69 baseado na análise por pixel, não atingiu o mesmo patamar quando analisada comparando segmento por segmento, isto é, quando verificado a acurácia do objeto em relação à classificação de referência (Kappa de 0,56). No entanto, segundo o método de contagem de objetos em cada área controle, a diferença entre a classificação digital e a classificação de referência não foi grande, considerando as três áreas, o número de edificações classificadas digitalmente apenas excede um pouco (110\%) o número de edificações identificadas visualmente. 
$\mathrm{Na}$ classificação das edificações quanto ao tipo de telhado, as edificações com telhado cerâmico obtiveram um melhor resultado geral do índice Kappa (Quadro 6.12), ainda que seus erros de omissão e comissão (Quadros 6.14 e 6.15) indiquem que edificações com telhado não cerâmico foram mais bem classificadas. Os erros significativos ocorridos com estas classes são principalmente erros entre elas: $20 \%$ da área de edificação com telhado cerâmico foi classificada como telhado não cerâmico. A classe edificação de telhado cerâmico também tem erros significativos com solo exposto, $10 \%$ da área classificada como telha cerâmica deveria ter sido classificada como cobertura permeável. Isto se dá porque telhados cerâmicos e solo exposto são compostos pelo mesmo material e nos casos onde houve confusão as informações não espectrais dos segmentos não foram suficientes para distinguir as duas classes. A confusão com telhado não cerâmico se dá principalmente devido a telhados cerâmicos escuros se confundirem com telhados de fibrocimento, por exemplo.

Solo exposto, classificado como cobertura permeável, por sua vez, obteve o pior resultado de acurácia. Observa-se nas matrizes apresentadas nos Quadros 6.13, 6.14 e 6.15, que a maior confusão acontece com via não pavimentada e com telhado cerâmico. Entre os erros de omissão, percebe-se ainda que uma área significativa de solo exposto (cerca de $22 \%$ ), foi classificada como cobertura indefinida. O solo exposto de teor mais arenoso tende a refletir mais intensamente a radiação solar e esse brilho torna difícil a identificação do material e cobertura do solo a partir de imagens satélite, uma vez que outros materiais, como o concreto, também têm alta reflexão provocando a confusão na classificação.

Na classe cobertura impermeável, $52 \%$ dos erros de omissão e cerca de $80 \%$ dos erros de comissão foram com a classe edificação com telhado não cerâmico. Como as edificações são também coberturas impermeáveis, a baixa acurácia dessa classe não compromete o cálculo da única variável que dela depende, a variável cobertura impermeável (V12_co_imp).

A classificação da superfície coberta por vegetação, por outro lado, obteve grande sucesso (coeficiente Kappa médio de 0,96). No entanto, o coeficiente Kappa médio encontrado para a vegetação considerada de pequeno porte foi de 0,39. A matriz de confusão e de erros de comissão e omissão atesta que esse problema se deu devido à dificuldade de se distinguir vegetação arbórea de vegetação rasteira, possivelmente por causa da umidade das áreas onde se encontram parte da vegetação rasteira nas áreas controle. 


\section{Quadro 6.13. Matriz de confusão da imagem QuickBird}

\begin{tabular}{|c|c|c|c|c|c|c|c|c|c|c|c|c|c|c|}
\hline classif.|referência & sombra & onibus & $\begin{array}{l}\text { via pavi- } \\
\text { mentada }\end{array}$ & $\begin{array}{c}\text { via não pavi- } \\
\text { mentada }\end{array}$ & $\begin{array}{c}\text { via pav. } \\
\text { indef }\end{array}$ & $\begin{array}{c}\text { edficação } \\
\text { telhado } \\
\text { cerâmico }\end{array}$ & $\begin{array}{c}\text { cobertura } \\
\text { permeável }\end{array}$ & $\begin{array}{c}\text { cobertura } \\
\text { impermeável }\end{array}$ & $\begin{array}{c}\text { cobertura } \\
\text { indefinida }\end{array}$ & $\begin{array}{c}\text { vegetação } \\
\text { arbórea }\end{array}$ & $\begin{array}{c}\text { vegetação } \\
\text { rasteira }\end{array}$ & água & \begin{tabular}{|c|} 
edficação \\
telhado não \\
cerâmico
\end{tabular} & TOTAL \\
\hline sombra & 73788 & 0 & 213 & 157 & 11 & 285 & 42 & 2195 & 56 & 815 & 0 & 173 & 11187 & 88922 \\
\hline onibus & 0 & 249 & 0 & 0 & 0 & 0 & 0 & 0 & 0 & 0 & 0 & 0 & 0 & 249 \\
\hline via pavimentada & 189 & 0 & 28531 & 1301 & 77 & 0 & 0 & 700 & 0 & 0 & 250 & 0 & 5136 & 36184 \\
\hline $\begin{array}{l}\text { via não } \\
\text { pavimentada }\end{array}$ & 186 & 0 & 3967 & 25052 & 222 & 281 & 2426 & 755 & 355 & 280 & 140 & 0 & 1756 & 35420 \\
\hline via pav indef & 0 & 102 & 7245 & 456 & 173 & 0 & 0 & 198 & 0 & 0 & 0 & 0 & 300 & 8474 \\
\hline $\begin{array}{l}\text { edficação telhado } \\
\text { cerâmico }\end{array}$ & 185 & 0 & 967 & 1778 & 0 & 17995 & 3629 & 1618 & 796 & 0 & 1116 & 0 & 7239 & 35323 \\
\hline $\begin{array}{l}\text { cobertura } \\
\text { permeável }\end{array}$ & 119 & 0 & 60 & 947 & 0 & 876 & 774 & 270 & 0 & 0 & 0 & 0 & 291 & 3337 \\
\hline $\begin{array}{l}\text { cobertura } \\
\text { impermeável }\end{array}$ & 198 & 0 & 56 & 97 & 0 & 0 & 116 & 1950 & 0 & 0 & 118 & 0 & 10042 & 12577 \\
\hline $\begin{array}{l}\text { cobertura } \\
\text { indefinida }\end{array}$ & 144 & 0 & 543 & 1317 & 0 & 740 & 2067 & 865 & 0 & 0 & 66 & 0 & 8640 & 14382 \\
\hline vegetação arbórea & 373 & 0 & 0 & 553 & 0 & 0 & 0 & 64 & 0 & 253261 & 6240 & 0 & 524 & 261015 \\
\hline vegetação rasteira & 0 & 0 & 0 & 0 & 0 & 0 & 0 & 0 & 0 & 2398 & 11007 & 0 & 0 & 13405 \\
\hline água & 0 & 0 & 0 & 0 & 0 & 0 & 0 & 0 & 0 & 0 & 0 & 0 & 0 & 0 \\
\hline $\begin{array}{l}\text { edficação telhado } \\
\text { não cerâmico }\end{array}$ & 289 & 104 & 2510 & 292 & 0 & 1413 & 370 & 9144 & 395 & 386 & 65 & 0 & 136808 & 151776 \\
\hline TOTAL & 75471 & 455 & 44092 & 31950 & 483 & 21590 & 9424 & 17759 & 1602 & 257140 & 19002 & 173 & 181923 & \\
\hline
\end{tabular}

\section{Quadro 6.14. Matriz de erros de omissão da imagem QuickBird}

\begin{tabular}{|c|c|c|c|c|c|c|c|c|c|c|c|c|c|}
\hline classif.|referência & sombra & onibus & $\begin{array}{c}\text { via pavi- } \\
\text { mentada }\end{array}$ & $\begin{array}{c}\text { via não pavi- } \\
\text { mentada }\end{array}$ & $\begin{array}{l}\text { via pav. } \\
\text { indef }\end{array}$ & \begin{tabular}{|c|} 
edficação \\
telhado \\
cerâmico
\end{tabular} & $\begin{array}{c}\text { cobertura } \\
\text { permeável }\end{array}$ & $\begin{array}{c}\text { cobertura } \\
\text { impermeável }\end{array}$ & $\begin{array}{l}\text { cobertura } \\
\text { indefinida }\end{array}$ & $\begin{array}{c}\text { vegetação } \\
\text { arbórea }\end{array}$ & $\begin{array}{c}\text { vegetação } \\
\text { rasteira }\end{array}$ & água & \begin{tabular}{|c} 
edficação \\
telhado não \\
cerâmico
\end{tabular} \\
\hline sombra & 97.77 & 0.00 & 0.48 & 0.49 & 2.28 & 1.32 & 0.45 & 12.36 & 3.50 & 0.32 & 0.00 & 100.00 & 6.15 \\
\hline onibus & 0.00 & 54.73 & 0.00 & 0.00 & 0.00 & 0.00 & 0.00 & 0.00 & 0.00 & 0.00 & 0.00 & 0.00 & 0.00 \\
\hline via pavimentada & 0.25 & 0.00 & 64.71 & 4.07 & 15.94 & 0.00 & 0.00 & 3.94 & 0.00 & 0.00 & 1.32 & 0.00 & 2.82 \\
\hline $\begin{array}{l}\text { via não } \\
\text { pavimentada }\end{array}$ & 0.25 & 0.00 & 9.00 & 78.41 & 45.96 & 1.30 & 25.74 & 4.25 & 22.16 & 0.11 & 0.74 & 0.00 & 0.97 \\
\hline via pav indef & 0.00 & 22.42 & 16.43 & 1.43 & 35.82 & 0.00 & 0.00 & 1.11 & 0.00 & 0.00 & 0.00 & 0.00 & 0.16 \\
\hline $\begin{array}{l}\text { edficação telhado } \\
\text { cerâmico }\end{array}$ & 0.25 & 0.00 & 2.19 & 5.56 & 0.00 & 83.35 & 38.51 & 9.11 & 49.69 & 0.00 & 5.87 & 0.00 & 3.98 \\
\hline $\begin{array}{l}\text { cobertura } \\
\text { permeável }\end{array}$ & 0.16 & 0.00 & 0.14 & 2.96 & 0.00 & 4.06 & 8.21 & 1.52 & 0.00 & 0.00 & 0.00 & 0.00 & 0.16 \\
\hline $\begin{array}{l}\text { cobertura } \\
\text { impermeável }\end{array}$ & 0.26 & 0.00 & 0.13 & 0.30 & 0.00 & 0.00 & 1.23 & 10.98 & 0.00 & 0.00 & 0.62 & 0.00 & 5.52 \\
\hline $\begin{array}{l}\text { cobertura } \\
\text { indefinida }\end{array}$ & 0.19 & 0.00 & 1.23 & 4.12 & 0.00 & 3.43 & 21.93 & 4.87 & 0.00 & 0.00 & 0.35 & 0.00 & 4.75 \\
\hline vegetação arbórea & 0.49 & 0.00 & 0.00 & 1.73 & 0.00 & 0.00 & 0.00 & 0.36 & 0.00 & 98.49 & 32.84 & 0.00 & 0.29 \\
\hline vegetação rasteira & 0.00 & 0.00 & 0.00 & 0.00 & 0.00 & 0.00 & 0.00 & 0.00 & 0.00 & 0.93 & 57.93 & 0.00 & 0.00 \\
\hline água & 0.00 & 0.00 & 0.00 & 0.00 & 0.00 & 0.00 & 0.00 & 0.00 & 0.00 & 0.00 & 0.00 & 0.00 & 0.00 \\
\hline $\begin{array}{l}\text { edficação telhado } \\
\text { não cerâmico }\end{array}$ & 0.38 & 22.86 & 5.69 & 0.91 & 0.00 & 6.54 & 3.93 & 51.49 & 24.66 & 0.15 & 0.34 & 0.00 & 75.20 \\
\hline $\begin{array}{l}\text { TOTAL erros de } \\
\text { omissão }\end{array}$ & 2.23 & 45.27 & 35.29 & 21.59 & 64.18 & 16.65 & 91.79 & 89.02 & 100.00 & 1.51 & 42.07 & 100.00 & 24.80 \\
\hline
\end{tabular}

Nota: Em cinza destacam-se os percentuais de erros de omissão totais maiores que 25\%. Em amarelo destacam-se os percentuais de omissão por classe maiores que 10\%. Em laranja destacam-se os percentuais de acerto da classificação em relação ao total de pixels da classificação de referência (assumida como verdade de campo). Exemplos de leitura da tabela: $98 \%$ do que é sombra foi classificado como sombra; $22 \%$ do que é ônibus foi classificado como via de pavimento indefinido; $35 \%$ da área de via pavimentada foi omitida, isto é, não foi classificada como tal. 
Quadro 6.15. Matriz de erros de comissão da imagem QuickBird

\begin{tabular}{|c|c|c|c|c|c|c|c|c|c|c|c|c|c|}
\hline classif. \referência & sombra & onibus & $\begin{array}{c}\text { via pavi- } \\
\text { mentada }\end{array}$ & $\begin{array}{c}\text { via não } \\
\text { pavi- } \\
\text { mentada }\end{array}$ & $\begin{array}{l}\text { via pav. } \\
\text { indef }\end{array}$ & $\begin{array}{c}\text { edficação } \\
\text { telhado } \\
\text { cerâmico }\end{array}$ & $\begin{array}{c}\text { cobertura } \\
\text { permeável }\end{array}$ & $\begin{array}{c}\text { cobertura } \\
\text { imper- } \\
\text { meável }\end{array}$ & $\begin{array}{l}\text { cobertura } \\
\text { indefinida }\end{array}$ & $\begin{array}{c}\text { vegetação } \\
\text { arbórea }\end{array}$ & $\begin{array}{c}\text { vegetação } \\
\text { rasteira }\end{array}$ & $\begin{array}{c}\text { edficação } \\
\text { telhado não } \\
\text { cerâmico }\end{array}$ & $\begin{array}{c}\text { TOTAL } \\
\text { erros } \\
\text { comissão }\end{array}$ \\
\hline sombra & 82.98 & 0.00 & 0.24 & 0.18 & 0.01 & 0.32 & 0.05 & 2.47 & 0.06 & 0.92 & 0.00 & 12.58 & 17.02 \\
\hline onibus & 0.00 & 100.00 & 0.00 & 0.00 & 0.00 & 0.00 & 0.00 & 0.00 & 0.00 & 0.00 & 0.00 & 0.00 & 0.00 \\
\hline via pavimentada & 0.52 & 0.00 & 78.85 & 3.60 & 0.21 & 0.00 & 0.00 & 1.93 & 0.00 & 0.00 & 0.69 & 14.19 & 21.15 \\
\hline $\begin{array}{l}\text { via não } \\
\text { pavimentada }\end{array}$ & 0.53 & 0.00 & 11.20 & 70.73 & 0.63 & 0.79 & 6.85 & 2.13 & 1.00 & 0.79 & 0.40 & 4.96 & 29.27 \\
\hline via pav indef & 0.00 & 1.20 & 85.50 & 5.38 & 2.04 & 0.00 & 0.00 & 2.34 & 0.00 & 0.00 & 0.00 & 3.54 & 97.96 \\
\hline $\begin{array}{l}\text { edficação telhado } \\
\text { cerâmico }\end{array}$ & 0.52 & 0.00 & 2.74 & 5.03 & 0.00 & 50.94 & 10.27 & 4.58 & 2.25 & 0.00 & 3.16 & 20.49 & 49.06 \\
\hline $\begin{array}{l}\text { cobertura } \\
\text { permeável }\end{array}$ & 3.57 & 0.00 & 1.80 & 28.38 & 0.00 & 26.25 & 23.19 & 8.09 & 0.00 & 0.00 & 0.00 & 8.72 & 76.81 \\
\hline $\begin{array}{l}\text { cobertura } \\
\text { impermeável }\end{array}$ & 1.57 & 0.00 & 0.45 & 0.77 & 0.00 & 0.00 & 0.92 & 15.50 & 0.00 & 0.00 & 0.94 & 79.84 & 84.50 \\
\hline $\begin{array}{l}\text { cobertura } \\
\text { indefinida }\end{array}$ & 1.00 & 0.00 & 3.78 & 9.16 & 0.00 & 5.15 & 14.37 & 6.01 & 0.00 & 0.00 & 0.46 & 60.08 & 100.00 \\
\hline vegetação arbórea & 0.14 & 0.00 & 0.00 & 0.21 & 0.00 & 0.00 & 0.00 & 0.02 & 0.00 & 97.03 & 2.39 & 0.20 & 2.97 \\
\hline vegetação rasteira & 0.00 & 0.00 & 0.00 & 0.00 & 0.00 & 0.00 & 0.00 & 0.00 & 0.00 & 17.89 & 82.11 & 0.00 & 17.89 \\
\hline $\begin{array}{l}\text { edficação telhado } \\
\text { não cerâmico }\end{array}$ & 0.19 & 0.07 & 1.65 & 0.19 & 0.00 & 0.93 & 0.24 & 6.02 & 0.26 & 0.25 & 0.04 & 90.14 & 9.86 \\
\hline
\end{tabular}

Nota: Em cinza destacam-se os percentuais de erros de omissão totais maiores que 25\%. Em amarelo destacam-se os percentuais de comissão por classe maiores que 10\%. Em laranja destacam-se os percentuais de acerto da classificação em relação ao total de pixels da classificação (resultado do processamento). Exemplos de leitura da tabela: $83 \%$ do que foi classificado como sombra é sombra; $85 \%$ do que foi classificado como via de pavimento indefinido é via pavimentada; $29 \%$ da área de via não pavimentada foi cometida, isto é, não corresponde a esta classe, mas foi classificada como tal.

A classificação de vias como um todo obteve também um resultado considerado bastante positivo, com um coeficiente Kappa médio de 0,85. A classificação de vias não pavimentadas obteve resultado satisfatório, com um Kappa médio de 0,77 enquanto a classe vias pavimentadas apresentou um coeficiente mais baixo $(0,59)$. Isto ocorreu devido principalmente à omissão de áreas de vias pavimentadas, classificadas como pavimento indefinido (16\%) e à inclusão de objetos que deveriam ter sido classificados como edificações de telhado não cerâmico (14\%).

De uma forma geral, os resultados das classificações das imagens QuickBird e das ortofotografias apresentaram similaridades, porém algumas particularidades merecem ser destacadas.

\subsection{Classificação em imagem QuickBird X Ortofotografias}

Nos procedimentos relatados nas seções anteriores e nos resultados dos testes de acurácia, relativos à classificação baseada em objeto em ortofotografias e imagens QuickBird, observa-se que há uma linha de desenvolvimento única. Em ambos os conjuntos de dados, foram realizados procedimentos de pré-processamento, como ajuste fino dos 
eixos viários, cálculo de componentes principais e conversão do espaço RGB para o espaço IHS. Apesar de não ter sido necessária a realização de mosaicagem na imagem QuickBird, pois uma única cena foi utilizada, um número maior de procedimentos de préprocessamento foi desempenhado. Na imagem QuickBird foi necessário realizar conversão de Datum, fusão, ajuste geométrico e delimitação de nuvens e sombra de nuvens, pois a imagem foi fornecida bruta ${ }^{40}$, enquanto a ortofotografia já é um produto ortorretificado, e uma cena de imagens satélite é considerada limpa e normalmente comercializada com até $10 \%$ de cobertura de nuvens, enquanto as ortofotografias são produtos de missões programadas para anular a presença das nuvens e suas sombras.

Por outro lado, o pré-processamento da imagem QuickBird gerou alguns produtos a mais, a serem utilizados na classificação: uma quarta componente principal, somente possível porque a imagem QuickBird possui quatro bandas multi-espectrais, e bandas multiespectrais fusionadas, isto é, com resolução espacial superior à sua resolução original da imagem QuickBird.

Os processos de segmentação e classificação realizados para cada conjunto de dados seguiram o mesmo raciocínio lógico. No primeiro nível, a segmentação e classificação visam a identificação de segmentos mais espectralmente homogêneos. O segundo nível é tido como nível principal, o terceiro nível foca na identificação de vias e os níveis mais altos objetivam a identificação de grandes áreas, campos de futebol e ônibus. Em ambos os casos, o processo de segmentação também foi intercalado por uma classificação preliminar de cada nível, que auxiliou na segmentação e classificação dos níveis seguintes.

Devido à diferença na resolução espacial das imagens, os parâmetros escalares utilizados na segmentação das ortofotografias foram mais altos que os utilizados nas imagens QuickBird. Isto foi necessário porque o mesmo alvo nessa última era formado por um número menor de pixels. Os modos de segmentação também variaram um pouco dada, principalmente, a diferença na resolução espectral. As ortofotografias possuem maior limitação de informações espectrais, alta correlação entre bandas e maior heterogeneidade, por isso métodos de segmentação multi-resolução por diferença espectral foram utilizados apenas nas ortofotografias de forma a gerar segmentos maiores com base na semelhança espectral de segmentos vizinhos.

Observa-se também que os processos de classificação dos dois grupos se assemelham bastante (Figuras 6.4 e 6.8). Diferenças significativas podem ser notadas no nível 4 e 5: nas

\footnotetext{
${ }^{40} \mathrm{Na}$ compra de imagens satélite é possível contratar da empresa fornecedora os servicos de conversão de datum, ortorretificação e fusão para aumento da resolução espacial.
} 
ortofotografias os campos de futebol foram identificados no nível 4, e grandes áreas só foram identificadas no nível 5. No nível 2, a principal diferença se dá devido à criação da classe parede, na classificação das ortofotografias, que tem como finalidade auxiliar, juntamente com a classe sombra, a identificação de edificações. Isto se fez necessário porque as ortofotografias possuem maior resolução espacial e ângulo de visada nas bordas de cada cena, fazendo com que as paredes sejam um elemento presente e identificável nas imagens.

No nível 1, a diferença mais significativa entre os processos realizados nas imagens QuickBird e as ortofotografias diz respeito ao método de classificação utilizado. Enquanto na imagem QuickBird a classificação utilizou de funções descritoras de cada classe, nas ortofotografias a classificação foi realizada pelo método supervisionado, com seleção de amostras de cada classe. Apesar deste último método tornar a classificação dependente da qualidade da amostragem, ele permitiu melhor distinção entre as classes, uma vez que há limitação na informação espectral das ortofotografias.

Pelo mesmo motivo, descritores como NDVI, utilizados na imagem QuickBird, não puderam ser utilizados nas ortofotografias. A classe água também apresentou grande dificuldade para ser discriminada e, como na área de estudo das ortofotografias a área coberta por água era mínima, esta classe não foi trabalhada.

Nas demais classes de interesse, os descritores utilizados na classificação das imagens QuickBird e ortofotografias são bastante semelhantes, como pode ser visto nos Quadros 6.5 e 6.11 .

Os resultados dos testes de acurácia da classificação e as matrizes de confusão também revelaram as semelhanças entre os dois tipos de imagens. A classe vegetação foi confundida com sombra apenas nas ortofotografias, enquanto na imagem QuickBird a confusão com outras classes foi mínima. Vias pavimentadas, nas ortofotografias, foi mais confundida com vias não pavimentadas, na imagem QuickBird confundiu-se mais com vias de pavimento indefinido e em ambas as imagens ocorreu confusão significativa com cobertura impermeável e indefinida. A classe vias não pavimentadas, nas ortofotografias, foi confundida com vias pavimentadas e com cobertura permeável, na imagem QuickBird a confusão, ainda que reduzida, foi maior com as classes de via pavimentada, via de pavimento indefinido e cobertura permeável.

A maior ocorrência de confusão com a classe edificação de telhado cerâmico, tanto na classificação nas ortofotografias como na imagem QuickBird, se deu com as classes telhado 
não cerâmico e cobertura permeável. Já as edificações de telhado não cerâmico apresentaram algumas diferenças entre as classificações. Na imagem QuickBird essa classe teve seu erro de omissão distribuído entre as classes sombra, cobertura impermeável e cobertura indefinida e erros de comissão quase nulos. Nas ortofotografias erros de omissão e comissão ocorreram entre a classe de telhado não cerâmico e as classes vegetação e cobertura impermeável e indefinida.

Os gráficos comparativos, Figuras 6.11 e 6.12, demonstram que, em geral, os resultados obtidos na classificação de sombra são os mais positivos na imagem QuickBird, enquanto nas ortofotografias a área de sombra, vias e vegetação têm maior destaque. Por outro lado, a classificação de cobertura outra obteve os piores resultados segundo as avaliações, ficando a classe edificações no nível intermediário.

Apesar desse trabalho só utilizar a acurácia por objeto da classe edificação, é possível observar que na avaliação por objeto os valores de acurácia são, em grande parte dos casos, inferiores ou equivalentes à acurácia na avaliação por pixel, apenas as classes vias e coberturas, nas áreas controle 3 e 1, respectivamente, que obtiveram resultados da avaliação por objetos superiores.

Avaliação por objeto
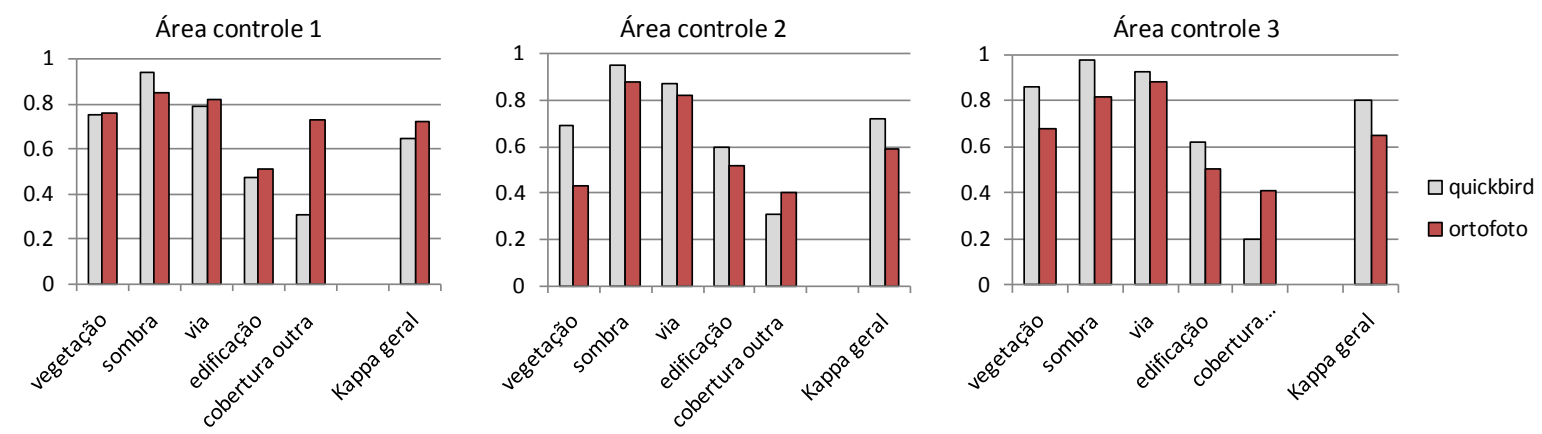

Avaliação por pixel
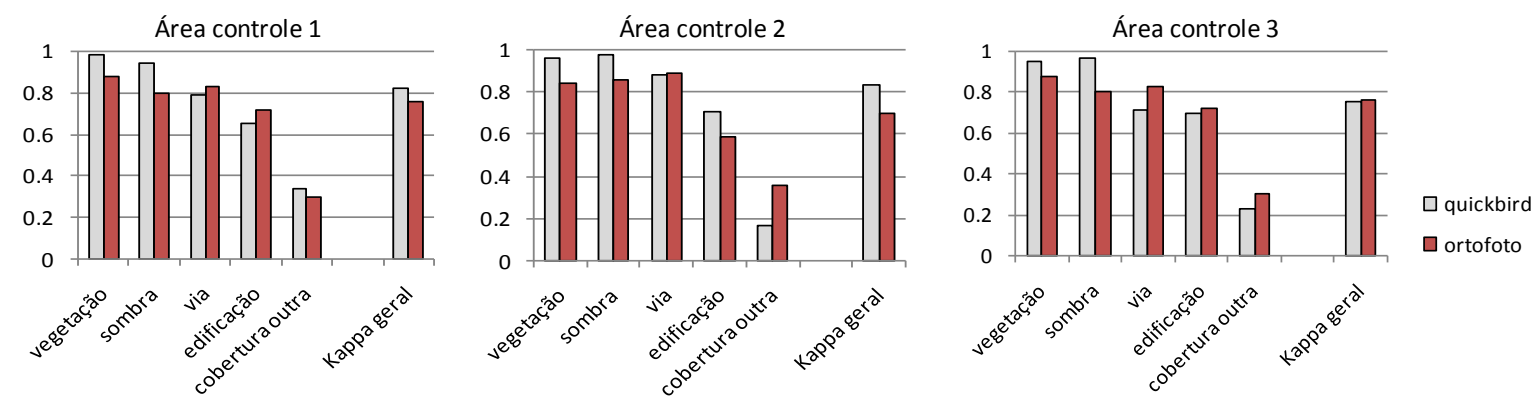

Figura 6.11. Gráficos comparativos da acurácia em cada área controle 
Avaliação por objeto

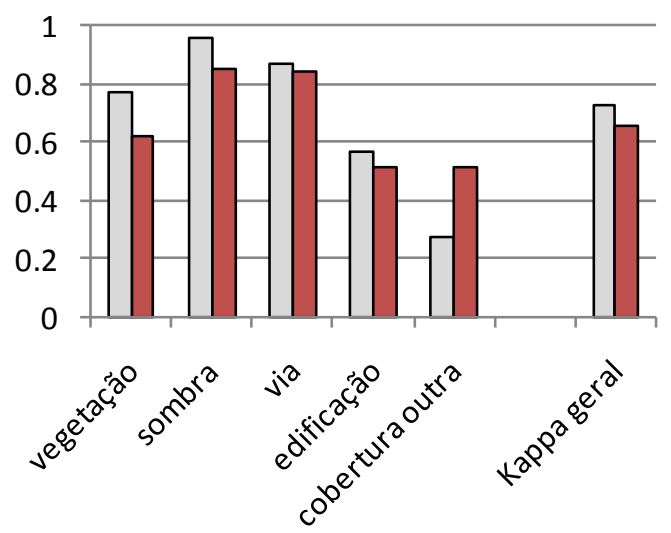

Avaliação por pixel

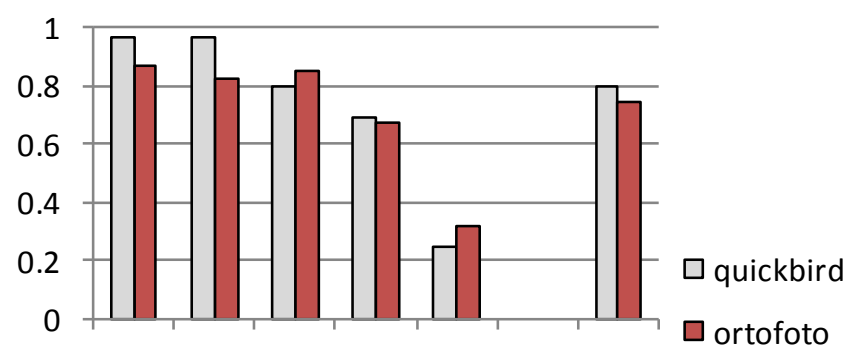

$\square$ ortofoto

Figura 6.12. Gráficos comparativos da acurácia media geral

Em suma, de acordo com os resultados dos testes de acurácia, os dois tipos de imagens poderiam ser utilizados para o presente estudo. No entanto, a avaliação comparativa mostra que, em geral, a classificação realizada nas imagens QuickBird obteve melhores resultados.

\subsection{Classificação do Subúrbio Ferroviário com imagem QuickBird}

De posse da árvore de processos final, desenvolvida com base nas áreas teste e avaliada nas áreas controle, a imagem QuickBird foi dividida em 16 subáreas chamadas tile projects (projetos ladrilho), cada um correspondendo a aproximadamente $3,5 \mathrm{~km}^{2} \mathrm{da}$ área de estudo. Isto foi necessário devido ao tamanho da área de estudo e complexidade dos procedimentos de classificação que demandam muita memória computacional para o processamento.. Assim, em cada tile project foi aplicada a árvore de processos desenvolvida. A última linha de comando da árvore de processos utilizada solicita a exportação dos objetos criados no nível 2, em forma de polígonos com atributos de classe, no formato shapefile. Posteriormente, esses arquivos vetoriais provenientes de cada tile project foram unidos de seis em seis, formando três subáreas de aproximadamente 19,5 $\mathrm{km}^{2}$, nas quais se procederam os cálculos das variáveis, descritos no próximo capitulo. A Figura 6.11 apresenta a classificação final da imagem QuickBird.

Com base nas análises de acurácia, realizadas nas áreas controle, e na área total classificada, é possível fazer uma análise da representatividade de cada classe diante das variáveis utilizadas para descrever as características urbanas do Subúrbio (Quadro 6.16). 
Não foi possível avaliar água e campo de futebol porque essas classes não estavam presentes nas áreas controle. Visualmente é possível observar que uma grande área de água, que forma a represa na parte sudeste da imagem, foi classificada como sombra, o que faz acreditar que os resultados da classe água não são satisfatórios (Figura 6.11)
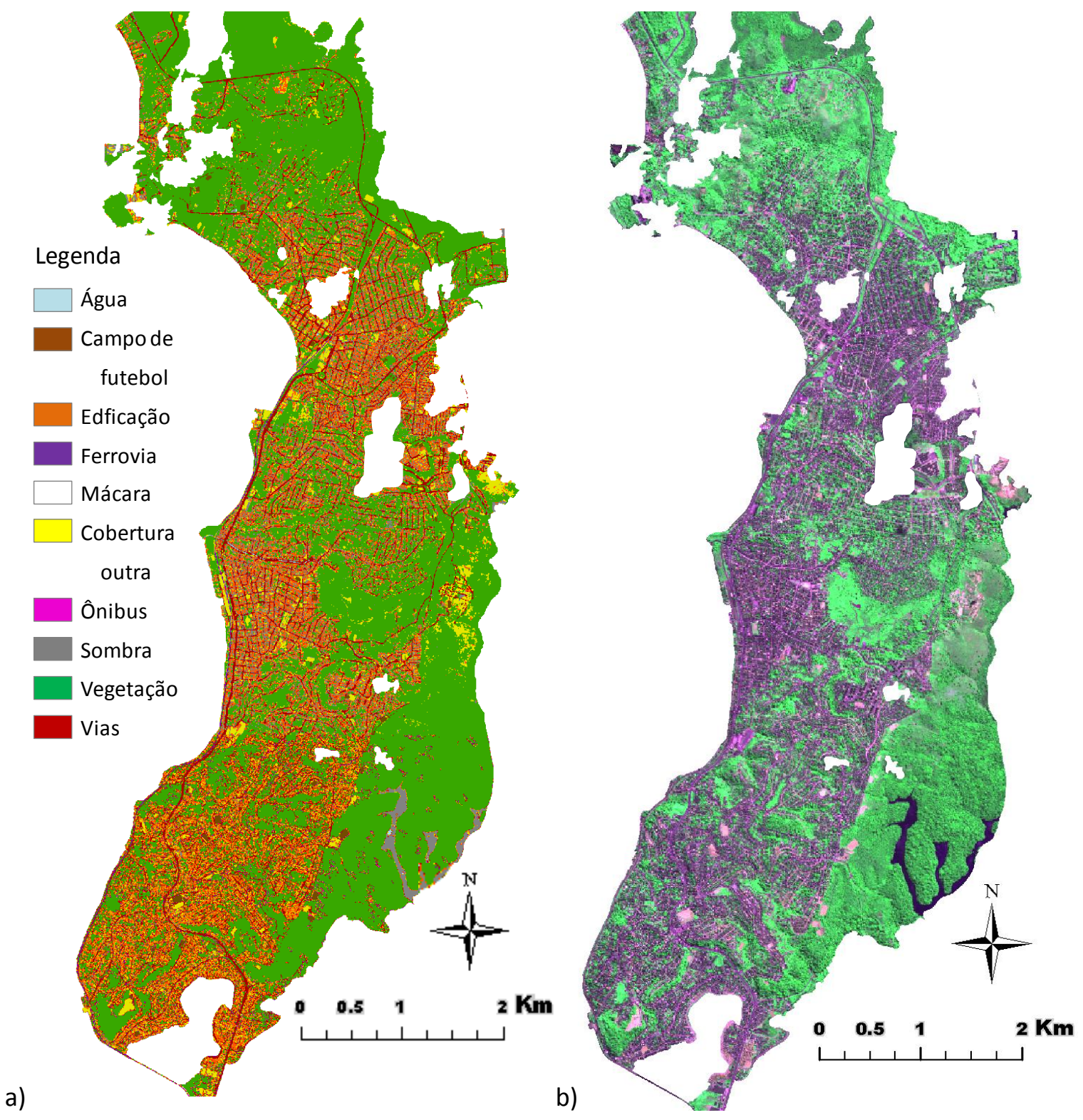

Figura 6.13. Classificação do Subúrbio Ferroviário utilizado GEOBIA em imagem QuickBird. a) Imagem QuickBird classificada. b) Imagem QuickBird R3G4B2.

De acordo com a classificação, a classe vegetação é a mais presente na área de estudo, ocupando cerca de 55\% da área. A classe edificações vem em seguida ocupando cerca de $15 \%$ da área total, sendo a maior parte dela constituída pala classe telhado não cerâmico. Estima-se que a classe vias ocupe quase $10 \%$ da área de estudo, e entre as vias metade parece ser pavimentada e metade não pavimentada, enquanto vias de pavimento indefinido representam menos de $10 \%$ das vias (o que equivale a menos de $1 \%$ da área de estudo). 
Por outro lado, as áreas de água, campo de futebol, telhado cerâmico, cobertura permeável e cobertura impermeável somadas ocupam menos de $5 \%$ do total da área investigada. Essa baixa representatividade faz com que essas classes tenham menor influência na acurácia geral da classificação. No entanto, uma análise em maior escala observa-se que em algumas tipologias, a área de telhado cerâmico, por exemplo, pode chegar a representar a maior parte das edificações, como foi visto na Seção 4.3.

É interessante observar que a equivalência desses percentuais com os percentuais de área encontrados nas áreas controle atestam a representatividade das áreas controle selecionadas para avaliação da acurácia. $\mathrm{Na}$ área controle também prevaleceu a área coberta com vegetação (40\%), seguida pela área de edificações (30\%), entre as quais predominou o telhado não cerâmico $(27 \%)$ sobre o telhado cerâmico $(3 \%)$, as vias cobriram (11\%), sendo $6,5 \%$ vias pavimentadas e $5 \%$ vias não pavimentadas. A menor incidência foi de cobertura permeável em $1,45 \%$ das áreas controle, cobertura impermeável com $3 \%$ e vegetação rasteira com $3 \%$.

Quadro 6.16. Representatividade das classes de interesse segundo acurácia por pixel, área classificada e variáveis

\begin{tabular}{|c|rr|r|r|}
\hline \multicolumn{1}{|c|}{ Classes de interesse } & $\begin{array}{r}\text { área } \\
\text { (hectares) }\end{array}$ & $\begin{array}{r}\text { área } \\
\text { (\%) }\end{array}$ & $\begin{array}{c}\text { Kappa } \\
\text { médio }\end{array}$ & Variáveis \\
\hline vegetação & 1356.65 & 55.28 & 0.96 & V11_co_noc, V14_veget \\
\hline rasteira & 203.05 & 8.27 & 0.39 & V16_eq_laz \\
\hline vias & 233.13 & 9.5 & 0.85 & V07_vi_qua, V09_vi_q_I, V10_vi_are \\
\hline não pavimentada & 108.44 & 4.42 & 0.75 & V07_vi_qua, V08_vi_q_p \\
\hline pavimentada & 108.93 & 4.44 & 0.59 & V07_vi_qua, V08_vi_q_p, V12_co_imp \\
\hline edificação & 389.89 & 15.89 & 0.69 & V02_ed_qua, V03_ed_q_a, V04_ed_q_t, V12_co_imp \\
\hline telhado não cerâmico & 306.12 & 12.47 & 0.66 & V02_ed_qua, V04_ed_q_t \\
\hline telhado cerâmico & 83.77 & 3.41 & 0.84 & V02_ed_qua, V04_ed_q_t \\
\hline água & 1.96 & 0.08 & - & V15_agua \\
\hline campo de futebol & 8.93 & 0.36 & - & V16_eq_laz \\
\hline cobertura do solo impermeável & 49.87 & 2.03 & 0.09 & V11_co_noc \\
\hline cobertura do solo permeável & 11.68 & 0.48 & 0.05 & V12_co_imp \\
\hline
\end{tabular}

No Quadro 6.15, observa-se que as classes responsáveis pelo cálculo das variáveis V11_co_nocp (existência de áreas não ocupadas) e V12_co_imp (extensão da área impermeável) têm baixa ocorrência e baixa acurácia. Como foi visto anteriormente, a baixa acurácia da classe cobertura impermeável não deve comprometer o cálculo da variável V12_co_imp, porque a maior parte dos seus erros de comissão e omissão ocorreram com a classe telhado não cerâmico, classe que também é utilizada no calculo da variável. A variável V11_co_nocp, por outro lado, conta com erros significativos de comissão e omissão com as classes vias não pavimentadas e edificações com telhado cerâmico, classes que não entram no cálculo da variável, no entanto o percentual de área coberto por essa classe $(0,5 \%)$ diante da outra classe que faz parte do cálculo dessa variável (vegetação que cobre 
$55 \%$ da área de estudo) sugere que a deficiente acurácia na classificação de cobertura permeável não interfere no cálculo da variável V11_co_nocp.

Já a classificação com baixa acurácia e a significativa extensão da área classificada como vegetação rasteira indica que a variável V16_eq_laz (existência de áreas de lazer) não é composta por dados confiáveis.

Quanto à variável V15_agua (existência de corpos d'água), ainda que não tenha sido possível avaliar a acurácia dessa classe nos testes realizados nas áreas controle, a avaliação visual negativa da classificação desse elemento também desqualifica a variável V15_agua.

O coeficiente Kappa das demais classes pode ser considerado satisfatório em termos de classificação digital, sugerindo que o cálculo das demais variáveis pode ser realizado com base na classificação realizada na imagem QuickBird. 


\section{CAPÍTULO 7 - CARACTERÍSTICAS URBANAS X DADOS EPIDEMIOLÓGICOS}

As análises realizadas nesse capítulo têm como objetivo investigar as correlações existentes entre os dados de leptospirose (localização das ocorrências) e as características urbanas descritas por meio de dados de sensoriamento remoto (SR).

O desenho escolhido para essa primeira investigação visa explorar o potencial de análise propiciado pelo método desenvolvido nesta Tese, adotando unidades espaciais de análise reduzidas à escala da vizinhança da edificação (buffer com 50m de raio), coerentes com a dinâmica da ocorrência da leptospirose e com o nível de detalhamento dos registros de casos disponível para o estudo. Como visto na Seção 2.1.3, a literatura (REIS et al. 2008; MARCIEL et al., 2008; FARIA et al., 2008) sugere a existência de correlação da doença com o ambiente da vizinhança domiciliar e o raio de deslocamento dos principais transmissores da doença em torno de $50 \mathrm{~m}$, por isso, as análises estatísticas foram desenvolvidas nessa escala de detalhe.

O procedimento de avaliação de correlações entre as características urbanas e os dados epidemiológicos adotado nesta tese se resume a um: regression tree, ou árvore de regressão (detalhado na Seção 7.2). Os demais procedimentos apresentados neste Capítulo foram realizados a fim de: gerar informações que foram utilizadas na árvore de regressão (identificação de tipologias, Seção 7.1), averiguar possíveis erros sistemáticos ocorridos na análise da árvore de regresão devido à diferença temporal entre dados epidemiológicos e dados de SR (Seção 7.3), e comparar resultados obtidos com a árvore de regressão com os resultados da aplicação de um método mais comumente utilizado para análises espaciais em epidemiologia, a razão de Kernel (Seção 7.4). No capítulo que segue, resultados obtidos com as análises relatadas neste capítulo são discutidas de forma mais ampla e integrada a todas as etapas da pesquisa (Seção 8.4).

O resumo dos procedimentos estatísticos adotados e as análises realizadas encontram-se esquematizados na Figura 7.1, onde estão indicadas as seções desta Tese em que cada procedimento e análise são apresentados detalhadamente (Seções 4.4, 7.1, 7.2, 7.3 e 7.4) e a origem dos dados utilizados nas análises comparativas entre agrupamentos e métodos.

Assim, a fim de avaliar se tipologias urbanas identificadas por meio de SR possuem correlação com a doença, foi inicialmente necessário classificar as unidades de análise (buffers de $50 \mathrm{~m}$ ) em tipologias, o que foi realizado utilizando análise de agrupamentos por K-Médias. Por isso, o capítulo se inicia com a Seção 7.1 relatando o processo de identificação de tipologias com base nos buffers de $50 \mathrm{~m}$. Nessa mesma seção é feita 
também uma análise comparativa entre as tipologias identificadas com base nos buffers de $50 \mathrm{~m}$ e os grupos de tipologias identificados com base nas amostras de um hectare, derivadas do estudo de Gordilho (2000), apresentados na Seção 4.4., que tem como objetivo investigar possíveis correspondências entre os diferentes métodos de identificação de tipologias urbanas.

Em seguida é descrito o processo de análise multivariada que investiga a taxa de ocorrência de casos graves de leptospirose no buffer de acordo com parâmetros urbanos baseados em dados de SR, utilizando a técnica de árvore de regressão (Seção 7.2). Este método foi escolhido devido a sua capacidade de lidar com variáveis categóricas e numéricas relacionando em grau de importância combinações de parâmetros das variáveis explicativas (tipologia, percentual de vias pavimentadas, densidade de casas, etc.) e variável resposta (incidência de edficação com casos da doença na área do buffer). A análise dos resultados da árvore de regressão resulta na avaliação da correlação entre a doença e as características urbanas que permitem a formulação de hipóteses explicativas mais precisas.

A seção seguinte, Seção 7.3, apresenta uma análise da distribuição do crescimento populacional do Subúrbio com base em dados dos Censos de 1991 e 2000 do IBGE, que visa averiguar possíveis vieses na formação dos agrupamentos da árvore de regressão, oriundos do adensamento populacional desigual de determinadas áreas do Subúrbio. Esta preocupação se dá devido à diferença temporal entre a imagem QuickBird, 2005, (de onde foram extraídos os dados para compor as variáveis urbanas), e os dados de saúde, 1996 a 2005.

Por fim, os resultados obtidos com a árvore de regressão foram comparados aos resultados obtidos através do cálculo da razão de Kernel para a análise de probabilidade de contaminação. O método da razão de Kernel (razão entre densidade populacional e densidade de casos) é comumente utilizado em estudos epidemiológicos e a comparação realizada objetivou principalmente averiguar se os dois métodos de estimativa de probabilidade indicavam a mesma tendência e identificar alguns benefícios e desvantagens de cada método. 


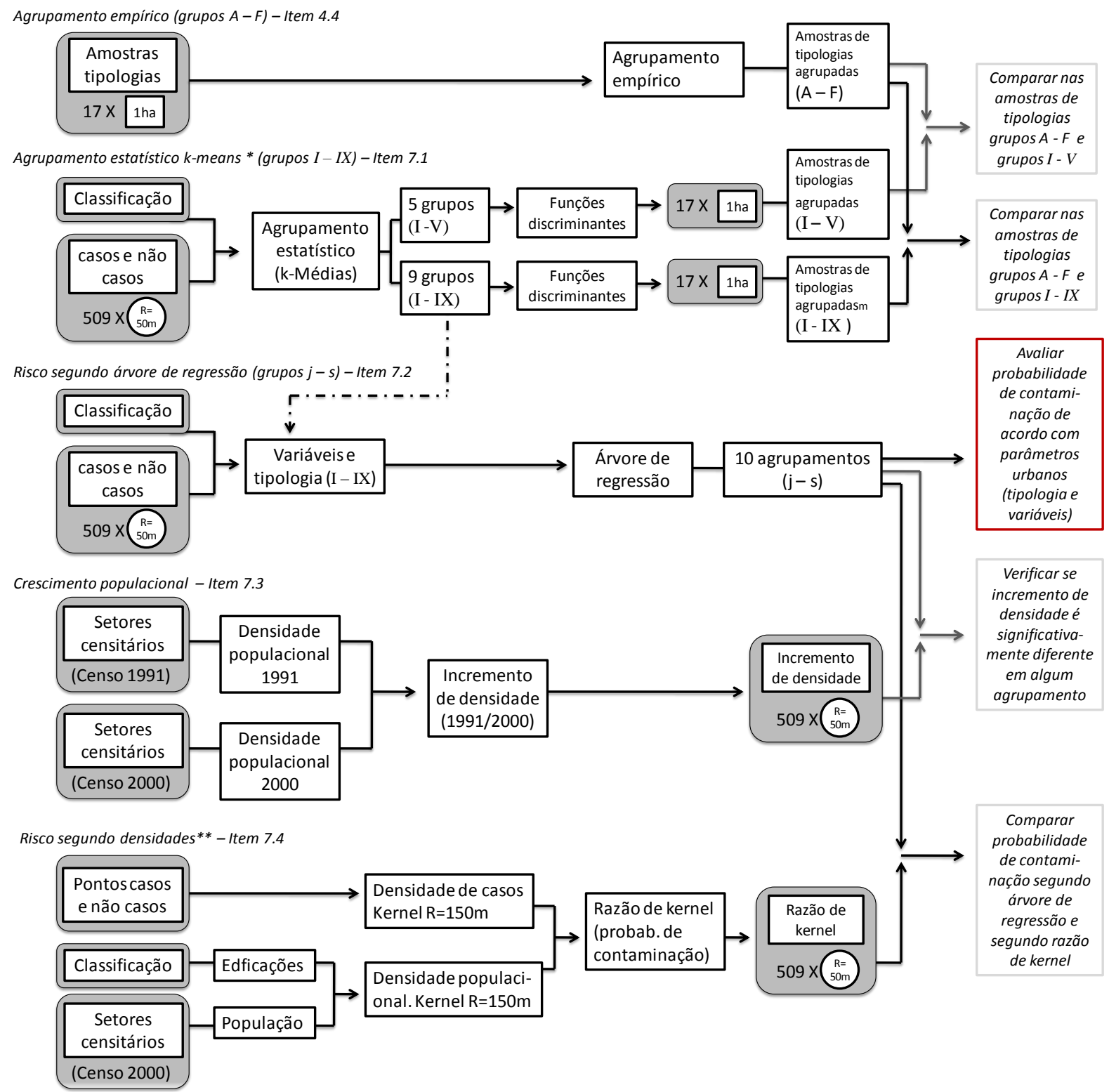

Figura 7.1. Diagrama de procedimentos e análises realizados para investigar relacionamento entre características urbanas e dados de saúde. Nota: *Identifica grupos de áreas (buffers de $50 \mathrm{~m}$ ) com características urbanas semelhantes, mas não considera a incidência da doença. ${ }^{* *}$ Identifica áreas de maior probabilidade de contaminação, mas não considera variáveis ambientais/ urbanas. 


\section{1. Agrupamento estatístico k-Médias para identificação de tipologias}

O processo de identificação de tipologias foi realizado levando em consideração inicialmente 600 buffers de 50m (áreas de influência de edficações com casos registrados e de edficações aleatórias sem casos registrados). No entanto, 15\% desses buffers não puderam ser analisados por estarem em área da imagem coberta por nuvem ou sombra de nuvem (6,3\%, 22 buffers relativos a casos e 16 a não casos) ou por não representarem uma residência ${ }^{41}$ (8,8\%, zero buffers de casos e 53 de não casos).

Assim, como detalhado no diagrama da Figura 7.1, utilizou-se a técnica de agrupamento por k-Médias, introduzida por Hartigan (1975), com o objetivo de formar tipologias significativamente diferentes de acordo com parâmetros baseados em dados de SR. Em seguida essas tipologias foram utilizadas na árvore de regressão para avaliar sua relação com a ocorrência da doença.

A técnica k-Médias consiste em um método de agrupamento não-hierárquico por repartição, onde é definido previamente a quantidade exata de conjuntos que devem ser tão distintos quanto o possível. O método k-Médias produz exatamente $\mathrm{k}$ diferentes conjuntos com a maior distinção possível entre eles. O processamento é iniciado com os k-conjuntos aleatórios e movem-se então os objetos entre estes conjuntos com o objetivo de: (i) minimizar a variabilidade dentro dos conjuntos e (ii) maximizar a variabilidade entre conjuntos (WANGENHEIM, 2009).

Foi testada a formação com dois grupos até a formação com dez grupos, utilizando as variáveis de distribuição normal: V01 (densidade de edficações), V03 (área média das edficações), V04 (percentual de edficações com telhado cerâmico), V05 (afastamento médio entre edficações vizinhas), V08 (percentual de vias pavimentadas), V09 (largura média das vias), V10 (percentual de área coberta por vias) e V14 (percentual de área coberta por vegetação). As variáveis V02 (qualidade da edificação), V07 (qualidade das vias), V11 (área não ocupada) e V12 (área impermeável) não foram utilizadas devido à alta correlação com outras variáveis mais simples de serem calculadas, como mostra o Quadro 7.1.

\footnotetext{
${ }^{41}$ Após a classificação da imagem e identificação de edficações, pontos de casos e não casos localizados a mais de $50 \mathrm{~m}$ das edificação identificadas no processo de classificação foram eliminadas da análise. Isto foi necessário para que o cálculo da variável resposta (incidência de edficações com casos) fosse possível de ser realizado.
} 
Quadro 7.1. Matriz de correlação das variáveis calculadas para os buffers de $50 \mathrm{~m}$

\begin{tabular}{|c|c|c|c|c|c|c|c|c|c|c|c|}
\hline & V01_ed_d_c & v04_ed_q_t & v02_ed_qua & v03_ed_q_a & v05_ed_afa & V09_vi_q_I & V08_vi_q_p & V07_vi_qua & V10_vi_are & V11_co_nocp & V12_co_imp \\
\hline V3_ed_q_a & 0,438 & 0,254 & 0,656 & & & & & & & & \\
\hline V09_vi_q_I & 0,425 & 0,019 & 0,180 & 0,387 & $-0,112$ & & & & & & \\
\hline V08_vi_q_p & 0,396 & $-0,162$ & $-0,006$ & 0,266 & $-0,120$ & 0,342 & & & & & \\
\hline V07_vi_qua & 0,498 & $-0,103$ & 0,088 & 0,383 & $-0,137$ & 0,700 & 0,903 & & & & \\
\hline V12_co_imp & 0,852 & $-0,172$ & 0,080 & 0,480 & $-0,175$ & 0,460 & 0,629 & 0,682 & 0,727 & $-0,866$ & \\
\hline V14_veget & $-0,730$ & 0,146 & $-0,035$ & $-0,347$ & 0,226 & $-0,423$ & $-0,413$ & $-0,501$ & $-0,691$ & 0,987 & $-0,852$ \\
\hline
\end{tabular}

Para cada formação foram tambem realizada análises discriminantes a fim de reconhecer a separabilidade entre os grupos (tipologias) e suas funções descritoras, fundamentais para posterior classificação dos buffers segundo a tipologia.

Era necessário ainda eleger qual o número ideal de grupos para o presente estudo, por isso, para cada formação, gerou-se tambem uma matriz de classificação (a exemplo das matrizes apresentadas nos Quadros 7.2 e 7.3) a partir das quais se extraiu o percentual de buffers corretamente classificados. Este percentual é obtido através de uma validação cruzada, isto é, áreas que no agrupamento k-Médias foram agrupadas como grupo III, por exemplo, e que foram classificadas como pertencente ao grupo III utilizando as funções discriminantes são consideradas corretamente classificadas.

Assim, a comparação entre os percentuais de acerto de cada formação foi utilizada como critério de seleção do número de grupos mais apropriado para geração da variável tipologia. Destacaram-se as formações com cinco grupos e com nove grupos (Figura 7.2), que foram em seguida analisadas com maior detalhe.

\begin{tabular}{rr}
\multicolumn{2}{c}{ Validação cruzada } \\
número de grupos & $\%$ correto \\
2 & 97.9 \\
3 & 97.1 \\
4 & 94.8 \\
5 & 95.7 \\
6 & 94.2 \\
7 & 93.2 \\
8 & 91.7 \\
9 & 94.8 \\
10 & 90.9
\end{tabular}

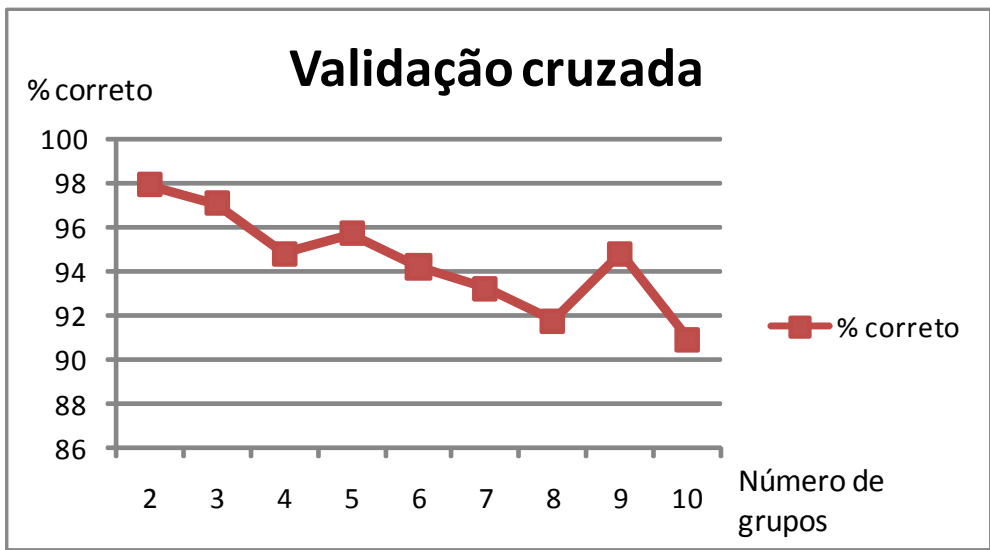

Figura 7.2. Número de grupos e percentual de acerto das funções discriminantes 
Quadro 7.2. Resumo da classificação com validação cruzada, 5 grupos

\begin{tabular}{|l|rrrrr|}
\cline { 2 - 6 } \multicolumn{1}{c|}{} & \multicolumn{5}{c|}{ Grupo verdadeiro } \\
\hline Classificado no & I & II & III & IV & V \\
\hline Grupo: & 108 & 2 & 2 & 0 & 0 \\
II & 1 & 114 & 2 & 0 & 0 \\
III & 5 & 2 & 113 & 0 & 0 \\
IV & 5 & 1 & 0 & 140 & 2 \\
V & 0 & 0 & 0 & 0 & 20 \\
\hline Total N & 119 & 119 & 117 & 140 & 22 \\
N corretos & 108 & 114 & 113 & 140 & 20 \\
Proporção & 0,908 & 0,958 & 0,966 & 1,000 & 0,909 \\
\hline
\end{tabular}

Proporção de Corretos $=0,957$

Quadro 7.3. Resumo da classificação com validação cruzada, 9 grupos

\begin{tabular}{|c|c|c|c|c|c|c|c|c|c|}
\hline \multirow{2}{*}{$\begin{array}{l}\text { Classificado no } \\
\text { Grupo: }\end{array}$} & \multicolumn{9}{|c|}{ Grupo verdadeiro } \\
\hline & I & II & III & IV & V & VI & VII & VIII & IX \\
\hline I & 91 & 0 & 0 & 2 & 0 & 0 & 0 & 1 & 2 \\
\hline II & 0 & 46 & 2 & 0 & 0 & 0 & 0 & 0 & 2 \\
\hline III & 0 & 3 & 83 & 1 & 0 & 0 & 0 & 0 & 0 \\
\hline IV & 0 & 0 & 1 & 70 & 0 & 0 & 0 & 1 & 1 \\
\hline V & 0 & 0 & 0 & 0 & 14 & 0 & 0 & 0 & 0 \\
\hline VI & 0 & 0 & 0 & 0 & 2 & 23 & 0 & 1 & 0 \\
\hline VII & 0 & 0 & 0 & 0 & 0 & 0 & 36 & 1 & 1 \\
\hline VIII & 1 & 0 & 0 & 1 & 1 & 1 & 0 & 88 & 0 \\
\hline IX & 0 & 0 & 0 & 1 & 0 & 0 & 1 & 0 & 39 \\
\hline Total N & 92 & 49 & 86 & 75 & 17 & 24 & 37 & 92 & 45 \\
\hline $\mathrm{N}$ corretos & 91 & 46 & 83 & 70 & 14 & 23 & 36 & 88 & 39 \\
\hline Proporção & 0,989 & 0,939 & 0,965 & 0,933 & 0,824 & 0,958 & 0,973 & 0,957 & 0,867 \\
\hline
\end{tabular}

Proporção de Corretos $=0,948$

Formação de cinco grupos (tipologias)

Considerando a formação com cinco grupos, a análise dos centróides, Quadro 7.4, revela algumas de suas características mais marcantes:

Grupo I - Observa-se que todas variáveis estão em torno do centro de massa (zero), ainda assim, comparando com os demais grupos, destaca-se pelo menor percentual de vias pavimentadas, situação intermediária na qualidade da edificação e das vias;

Grupo II - Também possui variáveis próximas ao cento de massa, com exceção do percentual de área ocupada por vias, o que caracteriza este grupo, de acordo também com outras variáveis como o grupo com melhor qualidade de vias e menor área vegetada;

Grupo III - análise dos centróides destaca, nesse grupo, a maior densidade de casas entre os grupos, além disso o grupo apresenta as menores áreas com vegetação e baixos indicadores de qualidade da edificação; 
Grupo IV - os centróides predominantemente negativos com exceção do alto valor positivo para a variável V14, indicam que esse grupo se caracteriza por vias de baixa qualidade, edificações com menores áreas, alto percentual de área vegetada e baixa densidade de casas;

Grupo V - Os valores extremos apresentados pelos centróides desse grupo mostram que o grupo apresenta pior qualidade de vias entre os grupos (valores baixos para variáveis de largura, pavimento e área), maior percentual de área de vegetação, menor densidade de edificação e maior afastamento entre as casas.

Quadro 7.4. Análise de centróides, cinco grupos

\begin{tabular}{|l|r|r|r|r|r|}
\hline Variável & Grupo I & Grupo II & Grupo III & Grupo IV & Grupo V \\
\hline V01_ed_d_c & $-0,0812$ & 0,4503 & 11,039 & $-0,9613$ & $-17,503$ \\
\hline V04_ed_q_t & $-0,0659$ & $-0,0345$ & $-0,4779$ & $-0,0061$ & 31,237 \\
\hline V03_ed_q_a & 0,1209 & 0,4712 & $-0,1484$ & $-0,5710$ & 12,202 \\
\hline V05_ed_afa & $-0,1871$ & $-0,2367$ & $-0,2923$ & 0,1094 & 31,509 \\
\hline V09_vi_q_I & 0,5784 & 0,8222 & $-0,3097$ & $-0,7120$ & $-13,985$ \\
\hline V08_vi_q_p & $-0,7432$ & 0,9350 & 0,4438 & $-0,3774$ & $-0,9958$ \\
\hline V10_vi_are & 0,0558 & 10,995 & 0,1186 & $-0,8670$ & $-13,624$ \\
\hline V14_veget & $-0,0107$ & $-0,8581$ & $-0,7425$ & 11,108 & 15,792 \\
\hline
\end{tabular}

Nota: V01_ed_d_c-densidade de casas, v04_ed_q_t - percentual de telhado cerâmico, V03_ed_q_a - área médias das edificações, v05_ed_afa - afastamento médio entre edificações, V09_vi_q_l - largura média das vias, V08_vi_q_p - percentual de vias pavimentadas, V10_vi_are - percentual de área coberta por vias, V14_veget - percentual de área coberta por vegetação.

Com o objetivo de comparar o resultado destes agrupamentos estatísticos dos buffers com os grupos de tipologias formados por método empírico e baseado em dados ajustados de $\mathrm{SR}^{42}$, as funções discriminantes de cada grupo foram aplicadas às áreas de 1 ha amostradas no estudo de tipologias presentes no Subúrbio (Seção 4.4). Com isso foi possível obter coeficientes de pertencimento das amostras a cada grupo e determinar a que grupo cada amostra pertence de acordo com este novo método.

Os resultados comparativos obtidos para a formação de cinco grupos podem ser observados no Quadro 7.5 e Figura 7.3.

\footnotetext{
42 Apesar das variáveis utilizadas em ambos agrupamentos serem as mesmas, no agrupamento empírico das amostras de um hectare os dados foram obtidos por meio de classificação manual, utilizando de imagens de maior resolução e outros recursos para ajustar o melhor possível os dados à realidade.
} 
Quadro 7.5. Classificação das amostras de tipologia segundo formação de cinco grupos.

\begin{tabular}{|c|c|c|c|c|c|c|c|c|}
\hline \multirow{2}{*}{$\begin{array}{l}\text { Amostra } \\
\text { de } \\
\text { tipologia }\end{array}$} & \multirow{2}{*}{$\begin{array}{c}\text { Macro } \\
\text { tipologias } \\
\text { habitacionais }^{1} \\
\end{array}$} & \multirow{2}{*}{$\begin{array}{c}\text { Agrupa- } \\
\text { mento } \\
\text { empírico }^{2} \\
\end{array}$} & \multicolumn{5}{|c|}{ Coeficiente relativo de pertencimento ao grupo } & \multirow[b]{2}{*}{ GRUPO } \\
\hline & & & grupo I & grupo II & grupo III & grupo IV & grupo V & \\
\hline 1 & Regular & A & 0.86 & 1.00 & 0.92 & 0.73 & 0.00 & II \\
\hline 3 & Insuficiente & D & 0.94 & 0.66 & 0.83 & 1.00 & 0.00 & IV \\
\hline 4 & Regular & C & 0.79 & 0.91 & 1.00 & 0.67 & 0.00 & III \\
\hline 5 & Regular & A & 0.84 & 1.00 & 0.98 & 0.63 & 0.00 & II \\
\hline 6 & Antigo & A & 0.80 & 1.00 & 0.96 & 0.61 & 0.00 & II \\
\hline 7 & Regular & $C$ & 0.85 & 0.99 & 1.00 & 0.37 & 0.00 & III \\
\hline 8 & Bom & A & 0.82 & 1.00 & 0.84 & 0.54 & 0.00 & II \\
\hline 9 & Precário & B & 0.76 & 0.94 & 1.00 & 0.59 & 0.00 & III \\
\hline 10 & Regular & C & 0.73 & 0.96 & 1.00 & 0.51 & 0.00 & III \\
\hline 11 & Precário & B & 0.76 & 0.91 & 1.00 & 0.61 & 0.00 & III \\
\hline 12 & Regular & $A$ & 0.81 & 1.00 & 0.98 & 0.61 & 0.00 & II \\
\hline 13 & Antigo & A & 0.83 & 1.00 & 0.91 & 0.68 & 0.00 & II \\
\hline 15 & Regular & D & 0.67 & 0.17 & 0.40 & 1.00 & 0.00 & IV \\
\hline 16 & Antigo & C & 1.00 & 0.97 & 0.78 & 0.68 & 0.00 & I \\
\hline 17 & Regular & $E$ & 0.77 & 1.00 & 0.27 & 0.00 & 0.51 & II \\
\hline 18 & Precário & C & 1.00 & 0.93 & 0.87 & 0.69 & 0.00 & I \\
\hline 19 & Insuficiente & $\mathrm{B}$ & 0.72 & 0.84 & 1.00 & 0.64 & 0.00 & III \\
\hline
\end{tabular}

Nota: (1) Com base em Gordilho (2000); (2) Realizado avaliando similaridades entre amostras de tipologia segundo variáveis de SR ajustadas manualmente; (3) Agrupamento estatístico, método k-Médias aplicado sobre variáveis de $S R$ não ajustadas.

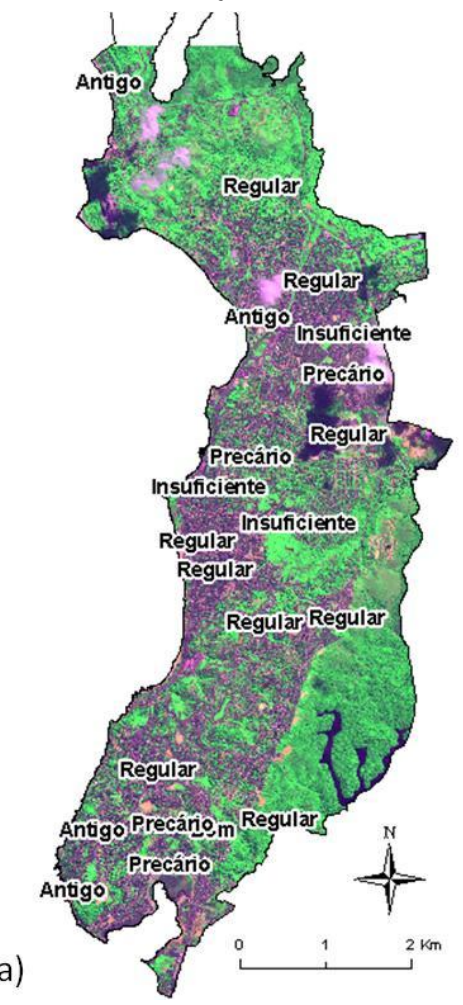

b)
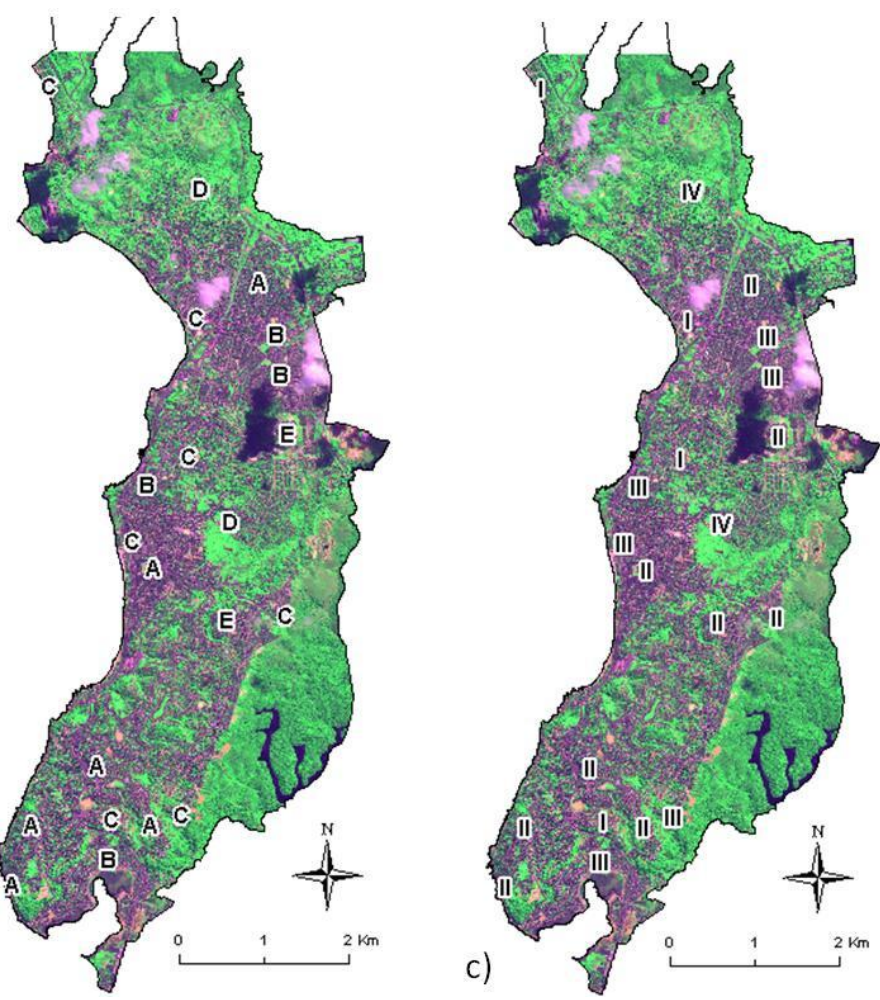

Figura 7.3. Mapas de agrupamento empírico (tipologias), mapa de agrupamento estatístico, cinco grupos. 
Não se observou correspondências com os macro padrões habitacionais formados por Gordilho (2000), padrão habitacional bom, regular, precário e insuficiente. No entanto, correspondências entre os grupos foram identificadas entre: A e E - II, B - III, C - III e I, D IV.

Nenhuma amostra foi classificada no grupo $\mathrm{V}$, porque este grupo se caracteriza por condições extremas de baixíssima densidade, que realmente não fez parte do levantamento de amostras de tipologias.

\section{Formação de nove grupos (tipologias)}

Considerando a formação com nove grupos, observa-se, na análise dos centróides de cada grupo, Quadro 7.6, que os grupos formados podem ser reagrupados em três macro agrupamentos, segundo qualidades das vias e tamanho da edificação (grupos cujas variáveis que indicam qualidade das vias tiveram valores de centróides baixos ao mesmo tempo que centróide da variável de área das edificações também tiveram valores baixos e vice versa), e percentual de área vegetada (grupos cujos centróides da variável V14 são positivos e bem acima da média).

Quadro 7.6. Análise de centróides, nove grupos.

\begin{tabular}{l|r|r|r|r|r|r|r|r|r} 
Variável & Grupo I & Grupo II & Grupo III & Grupo IV & Grupo V & Grupo VI & Grupo VII & Grupo VIII & Grupo IX \\
\hline V01_ed_d_c & $-0,0215$ & 0,3705 & 10,881 & 0,9390 & $-17,500$ & $-15,404$ & $-10,783$ & $-0,8129$ & 0,0271 \\
\hline V04_ed_q_t & $-0,1059$ & $-0,2009$ & $-0,1660$ & $-0,4660$ & 30,137 & 17,496 & $-0,0304$ & $-0,2315$ & $-0,0443$ \\
\hline V3_ed_q_a & 0,1687 & 0,7659 & 0,0019 & $-0,2149$ & 17,106 & $-13,881$ & $-0,1290$ & $-0,4153$ & 0,2248 \\
\hline V5_ed_afa & $-0,1872$ & $-0,2317$ & $-0,2957$ & $-0,2776$ & 36,964 & 0,7989 & 0,0372 & 0,0062 & $-0,2029$ \\
\hline V09_v_q_I & 0,6452 & 0,9433 & 0,2539 & $-0,5490$ & $-16,035$ & $-0,7784$ & $-0,3311$ & $-0,7651$ & 0,9410 \\
\hline V08_viq_p & $-0,9168$ & 12,903 & 0,4130 & 0,2778 & $-10,987$ & $-10,949$ & 11,567 & $-0,8612$ & 10,257 \\
\hline V10_viare & 0,1578 & 15,451 & 0,9684 & $-0,2966$ & $-14,025$ & $-11,170$ & $-0,6243$ & $-0,8773$ & 0,0711 \\
\hline V14_veget & $-0,1185$ & $-10,939$ & $-11,110$ & $-0,4562$ & 15,736 & 14,544 & 10,738 & 10,199 & $-0,0210$
\end{tabular}

Nota: V01_ed_d_c - densidade de casas, v04_ed_q_t - percentual de telhado cerâmico, V03_ed_q_a - área médias das edificações, v05_ed_afa - afastamento médio entre edificações, V09_vi_q_l - largura média das vias, V08_vi_q_p - percentual de vias pavimentadas, V10_vi_are - percentual de área coberta por vias, V14_veget - percentual de área coberta por vegetação.

Devido ao número maior de grupos, a interpretação mais detalhada do quadro de valores de centróides é apresentada em um novo quadro, Quadro 7.7, apoiada também pela apresentação de imagens de alguns buffers de 50m classificados em cada grupo. 
Quadro 7.7. Características dos nove grupos formados segundo métodos kMédias.

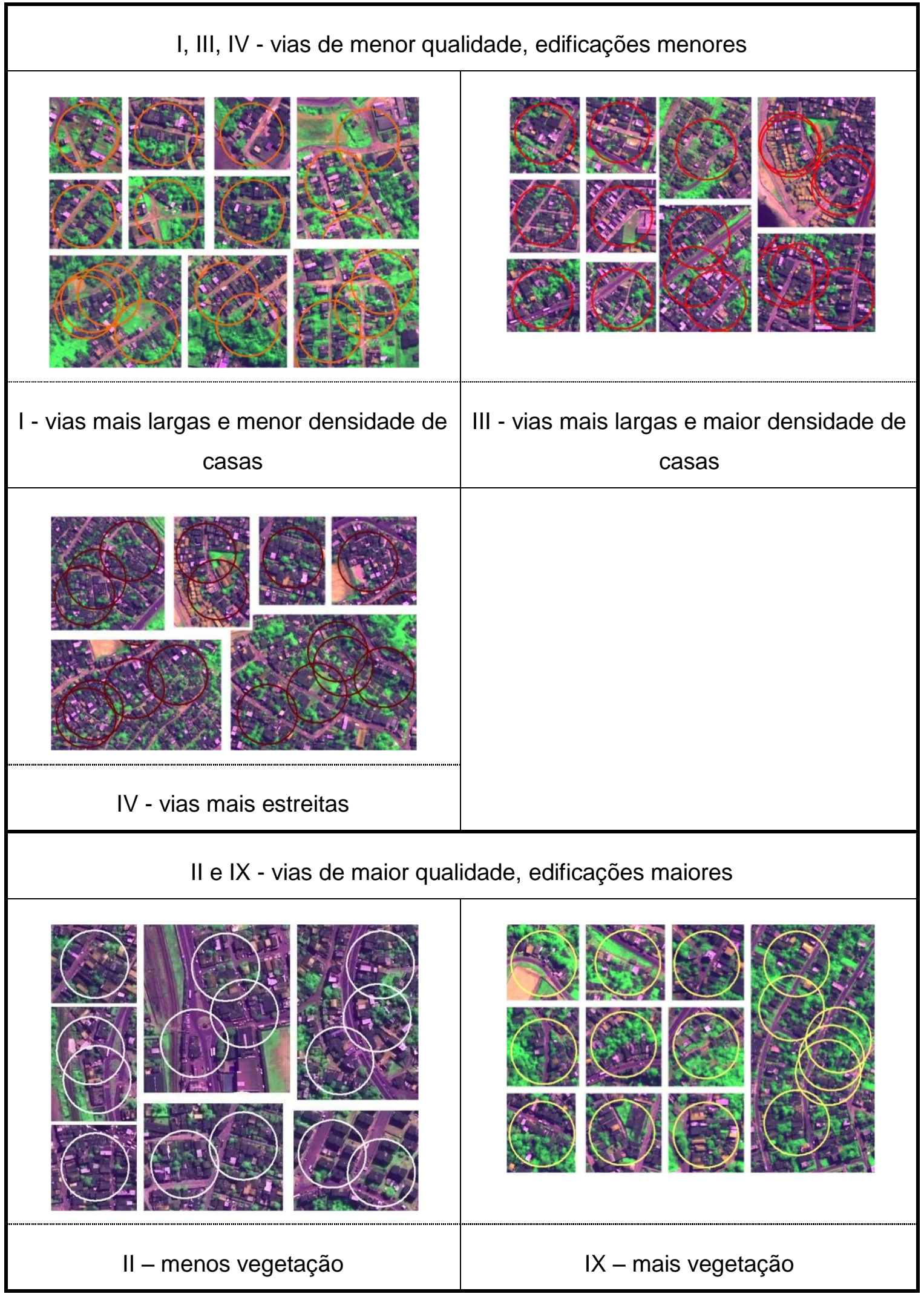


continuação

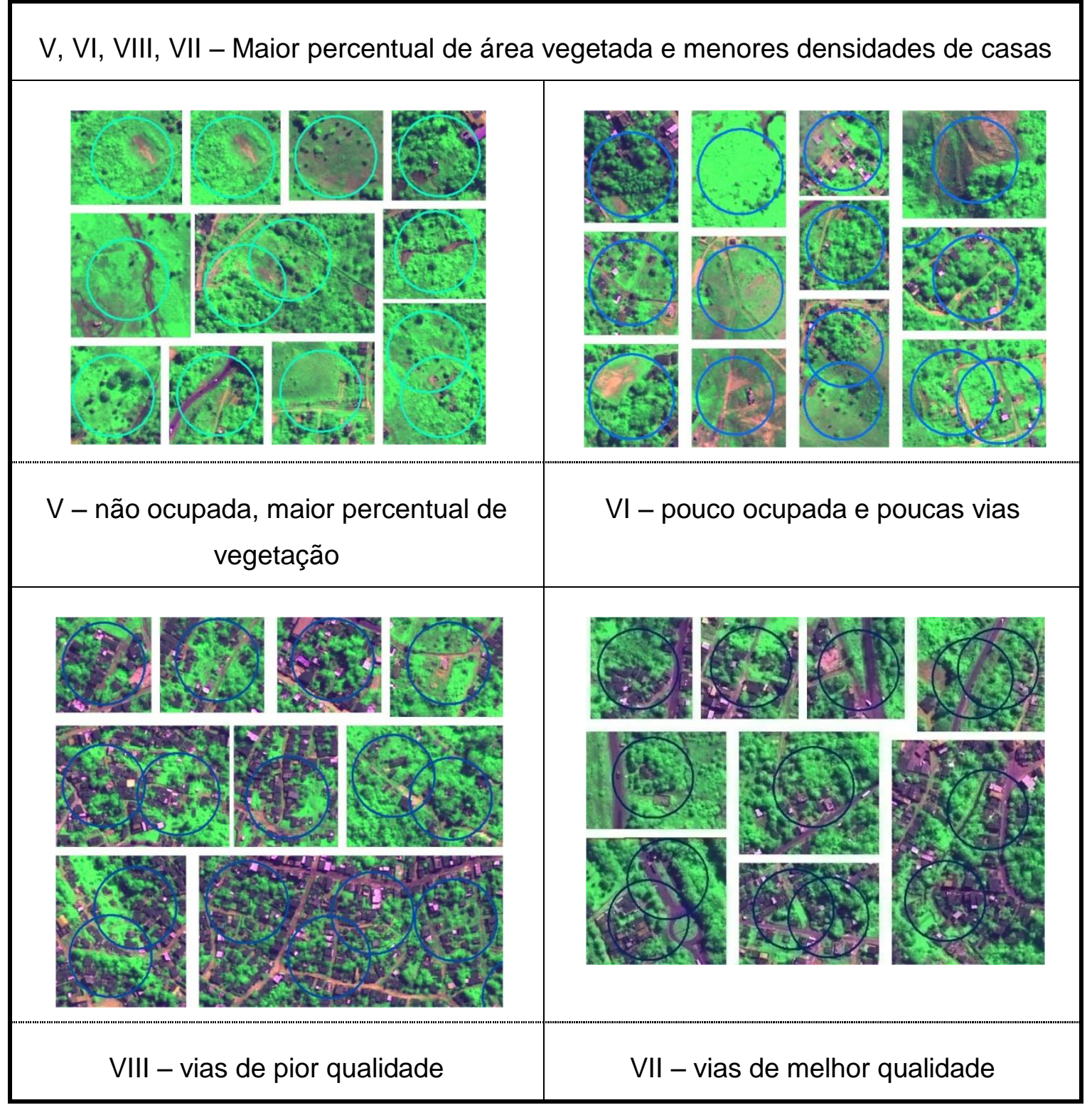

Em seguida, a fim de averiguar possíveis relações entre os grupos de tipologias estudados no Capítulo 4 e os nove grupos formados aqui por métodos estatísticos assim como realizados para os cinco grupos, aplicou-se as funções discriminantes (Quadro 7.8) nas amostras de 1 ha.

Os resultados comparativos, apresentados no Quadro 7.9 e Figura 7.4, de uma forma geral, indicam que não há correlação aparente entre os grupos formados por k-Médias e os macro padrões habitacionais apresentados por Gordilho (2000). No entanto, correlações com os grupos de tipologia formados empiricamente a partir de dados ajustados de SR, e com a classificação em níveis superior, médio e inferior, segundo análises de correspondências realizadas no Capítulo 4, foram observadas entre as categorias: 
A e E - II, vias de maior qualidade e edificações maiores (nível superior);

B - III, maiores densidade de edificações (nível inferior);

C - I, III, IV, vias de menor qualidade e edificações com áreas menores (nível intermediário);

D - VIII, maiores percentuais de área vegetada e vias de pior qualidade (nível inferior).

Quadro 7.8. Função discriminante linear para os nove grupos

\begin{tabular}{|c|c|c|c|c|c|c|c|c|c|}
\hline & Grupo I & Grupo II & Grupo III & Grupo IV & Grupo V & Grupo VI & Grupo VII & Grupo VIII & Grupo IX \\
\hline Constante & $-131,92$ & $-167,14$ & $-150,87$ & $-134,96$ & $-179,57$ & $-116,01$ & $-144,10$ & $-121,18$ & $-154,37$ \\
\hline V01_ed_d_c & 1,45 & 1,51 & 1,64 & 1,60 & 1,35 & 1,20 & 1,31 & 1,34 & 1,48 \\
\hline 04 ed_q_t & 0,16 & 0,18 & 0,19 & 0,18 & 0,48 & 0,36 & 0,23 & 0,18 & 0,2 \\
\hline V03_ed_q_a & 1,27 & 1,37 & 1,27 & 1,23 & 1,40 & 1,01 & 1,25 & 1,19 & 1,3 \\
\hline 05_ed_afa & 0,11 & 0,11 & 0,14 & 0,13 & 0,81 & 0,24 & 0,07 & 0,11 & 0,09 \\
\hline V09_vi_q I & 2,67 & 3,05 & 2,33 & 1,74 & 0,43 & 1,14 & 1,99 & 1,41 & 3,1 \\
\hline V08_vi_q_p & 0,12 & 0,41 & 0,28 & 0,25 & 0,12 & 0,11 & 0,38 & 0,11 & 0,3 \\
\hline V10_vi_are & 2,27 & 2,77 & 2,60 & 2,19 & 1,90 & 1,82 & 2,14 & 2,01 & 2,3 \\
\hline V14_veget & 1,60 & 1,54 & 1,54 & 1,58 & 1,83 & 1,69 & 1,76 & 1,71 & 1,6 \\
\hline
\end{tabular}

Nota: V01_ed_d_c - densidade de casas, v04_ed_q_t - percentual de telhado cerâmico, V03_ed_q_a - área médias das edificações, v05_ed_afa - afastamento médio entre edificações, V09_vi_q_l - largura média das vias, V08_vi_q_p - percentual de vias pavimentadas, V10_vi_are - percentual de área coberta por vias, V14_veget - percentual de área coberta por vegetação.

Quadro 7.9. Classificação das amostras de tipologia, nove grupos.

\begin{tabular}{|c|c|c|c|c|c|c|c|c|c|c|c|c|}
\hline \multirow{3}{*}{$\begin{array}{c}\text { Amostra } \\
\text { de } \\
\text { tipologia }\end{array}$} & \multirow{3}{*}{$\begin{array}{c}\text { Macro } \\
\text { tipologias } \\
\text { habitacionais }^{1}\end{array}$} & \multirow{3}{*}{$\begin{array}{c}\text { Agrupa- } \\
\text { mento } \\
\text { empírico }{ }^{2}\end{array}$} & \multicolumn{9}{|c|}{ Coeficiente relativo de pertencimento ao grupo } & \multirow[b]{3}{*}{ GRUPO $^{3}$} \\
\hline & & & grupo & grupo & grupo & grupo & grupo & grupo & grupo & grupo & grupo & \\
\hline & & & & II & III & IV & $\mathrm{V}$ & VI & VII & VIII & IX & \\
\hline 1 & Regular & A & 0.789 & 1.000 & 0.928 & 0.863 & 0.000 & 0.405 & 0.850 & 0.618 & 0.995 & II \\
\hline 3 & Insuficiente & D & 0.931 & 0.279 & 0.625 & 0.878 & 0.000 & 0.636 & 0.671 & 1.000 & 0.651 & VIII \\
\hline 4 & Regular & C & 0.843 & 0.852 & 0.989 & 1.000 & 0.000 & 0.484 & 0.706 & 0.684 & 0.881 & IV \\
\hline 5 & Regular & A & 0.828 & 0.983 & 1.000 & 0.916 & 0.000 & 0.322 & 0.684 & 0.600 & 0.904 & III \\
\hline 6 & Antigo & A & 0.776 & 1.000 & 0.977 & 0.885 & 0.000 & 0.335 & 0.733 & 0.561 & 0.934 & II \\
\hline 7 & Regular & $C$ & 0.919 & 0.634 & 1.000 & 0.964 & 0.000 & 0.364 & 0.275 & 0.574 & 0.667 & III \\
\hline 8 & Bom & A & 0.792 & 1.000 & 0.928 & 0.813 & 0.000 & 0.268 & 0.673 & 0.522 & 0.908 & II \\
\hline 9 & Precário & B & 0.767 & 0.947 & 1.000 & 0.922 & 0.000 & 0.324 & 0.657 & 0.566 & 0.868 & III \\
\hline 10 & Regular & C & 0.770 & 0.941 & 1.000 & 0.957 & 0.000 & 0.302 & 0.660 & 0.540 & 0.898 & III \\
\hline 11 & Precário & B & 0.784 & 0.920 & 1.000 & 0.938 & 0.000 & 0.357 & 0.638 & 0.594 & 0.844 & III \\
\hline 12 & Regular & A & 0.782 & 1.000 & 0.975 & 0.899 & 0.000 & 0.286 & 0.707 & 0.559 & 0.915 & II \\
\hline 13 & Antigo & A & 0.809 & 1.000 & 0.954 & 0.897 & 0.000 & 0.367 & 0.828 & 0.616 & 0.993 & II \\
\hline 15 & Regular & D & 0.748 & 0.000 & 0.330 & 0.648 & 0.371 & 0.950 & 0.665 & 1.000 & 0.457 & VIII \\
\hline 16 & Antigo & $C$ & 1.000 & 0.801 & 0.898 & 0.872 & 0.000 & 0.450 & 0.648 & 0.737 & 0.889 & I \\
\hline 17 & Regular & $E$ & 0.717 & 1.000 & 0.723 & 0.605 & 0.471 & 0.000 & 0.652 & 0.425 & 0.871 & II \\
\hline 18 & Precário & C & 1.000 & 0.699 & 0.906 & 0.882 & 0.000 & 0.480 & 0.512 & 0.749 & 0.783 & I \\
\hline 19 & Insuficiente & B & 0.798 & 0.838 & 1.000 & 0.995 & 0.000 & 0.361 & 0.648 & 0.659 & 0.823 & III \\
\hline
\end{tabular}

Nota: (1) Com base em Gordilho (2000); (2) Realizado avaliando similaridades entre amostras de tipologia segundo variáveis de SR ajustadas manualmente; (3) Agrupamento estatístico, método k-Médias aplicado sobre variáveis de $S R$ não ajustadas. 

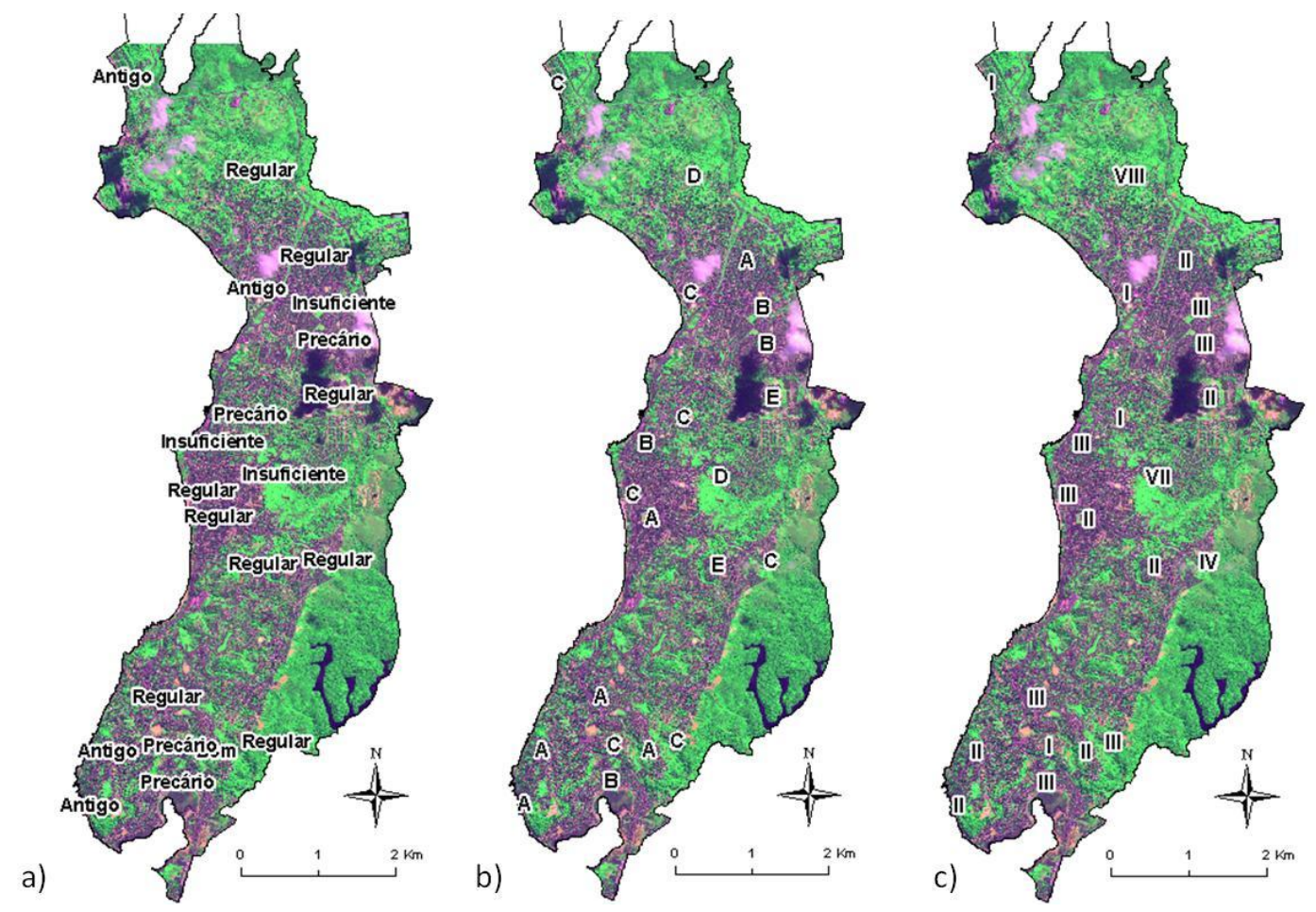

Figura 7.4. Mapa de agrupamento empírico e mapa de agrupamento estatístico, 9 grupos.

O grupo A, majoritariamente classificado como grupo II, teve uma amostra classificada como grupo III, o que é explicado pela similaridade entre estes grupos (II e III), que pode ser observada pelo alto coeficiente relativo de pertencimento da amostra 5 a ambos os grupos (Quadro 7.9) e pela reduzida distância quadrática entre os grupos II e III, como mostra o Quadro 7.10.

Quadro 7.10. Distância quadrática entre os grupos

\begin{tabular}{r|r|r|r|r|r|r|r|r|r} 
& Grupo I & Grupo II & Grupo III & Grupo IV & Grupo V & Grupo VI & Grupo VII & Grupo VIII & Grupo IX \\
\hline Grupo I & 0,000 & & & & & & & & \\
\hline Grupo II & 30,462 & 0,000 & & & & & & & \\
\hline Grupo III & 15,796 & 8,480 & 0,000 & & & & & & \\
\hline Grupo IV & 11,426 & 22,536 & 6,757 & 0,000 & & & & & \\
\hline Grupo V & 81,864 & 137,316 & 118,148 & 93,492 & 0,000 & & & & \\
\hline Grupo VI & 35,976 & 94,408 & 72,797 & 49,076 & 35,075 & 0,000 & & & \\
\hline Grupo VII & 29,162 & 35,090 & 36,830 & 24,112 & 73,560 & 33,323 & 0,000 & & \\
\hline Grupo VIII & 12,145 & 60,144 & 40,894 & 21,257 & 56,975 & 13,370 & 19,828 & 0,000 & \\
\hline Grupo IX & 17,187 & 10,295 & 12,318 & 12,003 & 99,074 & 55,401 & 11,531 & 30,696 & 0,000
\end{tabular}

A distribuição espacial dos buffers classificados em nove grupos, e organizados segundo similaridade, apresentada no mapa da Figura 7.5 revela a existência de correspondência espacial, onde algumas áreas se destacam pela predominância de determinados grupos, como é de se esperar dado a máxima da geografia que "todas as coisas são parecidas, mas 
coisas mais próximas se parecem mais que coisas mais distantes". No entanto, a análise realizada na escala do buffer de 50 metros resguarda peculiaridades da vizinhança da residência que, como também pode ser visto no mapa da Figura 7.5, não tem características linearmente ou homogeneamente distribuídas no espaço.

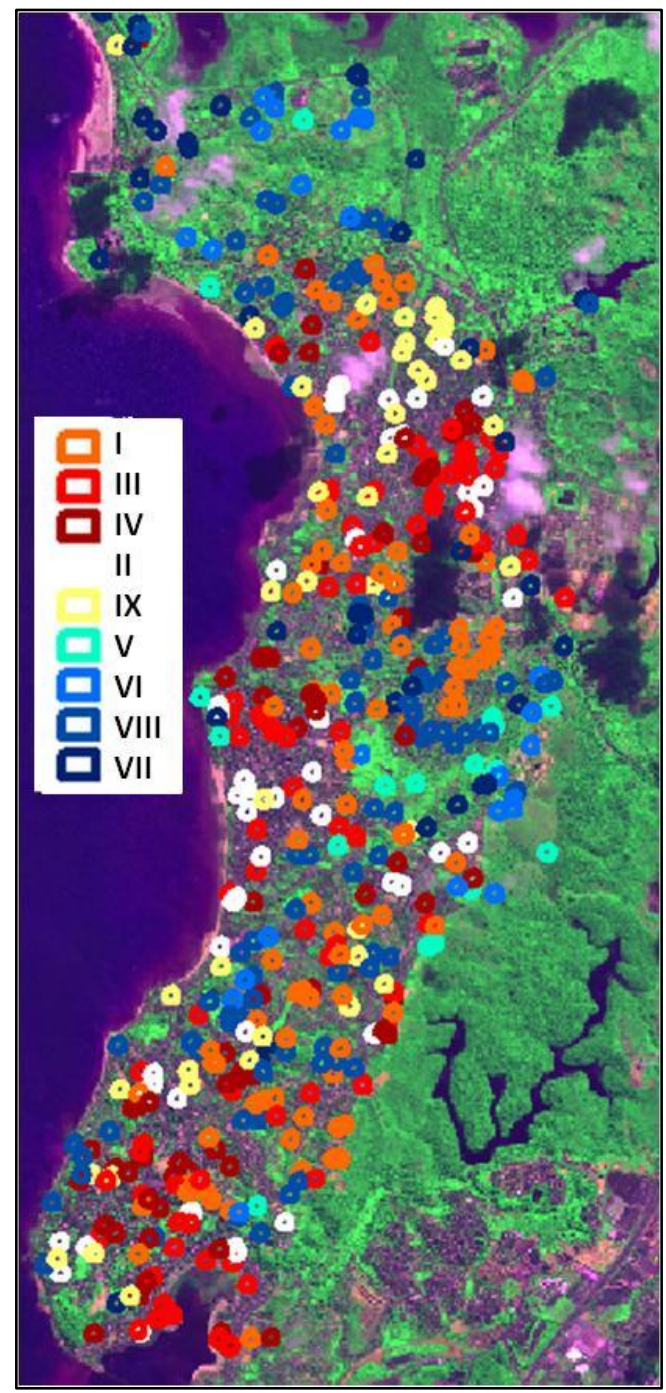

Figura 7.5. Mapa de distribuição dos grupos formados segundo método k-Médias, nove grupos.

Devido às correspondências encontradas entre a formação com nove grupos e o detalhamento das características de cada grupo, possível de ser realizado com essa formação, optou-se por utilizá-los, nas análises de relação entre as características urbanas e a doença, como sendo a variável tipologia. 


\subsection{Investigação de parâmetros urbanos relacionados à ocorrência da doença pelo método da árvore de regressão}

Para investigar possíveis parâmetros urbanos baseados em dados de SR que tenham influência na determinação da probabilidade de contração de leptospirose, foi utilizado o método estatístico de análise multivariada de dados conhecidos como árvore de regressão. O objetivo do método é identificar indicativos de relação entre a ocorrência da doença e as variáveis urbanas levantadas, indicar quais dessas variáveis são mais importantes na explicação da doença e mesmo indicar alguns parâmetros de configuração urbana que podem ser utilizados para prever maior risco de contaminação em outras áreas da cidade conforme sua configuração urbana

É importante destacar que há ainda métodos de avaliação da qualidade e critérios de paragem de crescimento das árvores de regressão que não foram explorados aqui por tratar-se de análises estatísticas mais aprofundadas, que deverão, portanto ser desenvolvidas no futuro.

O método, de uma forma geral, consiste em separar elementos sucessivamente em dois grupos de acordo com parâmetros eleitos entre variáveis preditoras que melhor expliquem a doença, que por sua vez é medida na variável resposta. Adota-se como critério de parada um número mínimo de elementos no agrupamento, abaixo do qual o agrupamento não é mais subdividido.

Após extensiva experimentação adotou-se como critério de parada o número de 140 elementos. Foram analisadas as variáveis V01 (densidade de edficações), V02(qualidade da edificação), V03 (área média das edficações), V04 (percentual de edficações com telhado cerâmico), V05 (afastamento médio entre edificações vizinhas), V07 (qualidade das vias), V08 (percentual de vias pavimentadas), V09 (largura média das vias), V10 (percentual de área coberta por vias), V11 (área não ocupada) V12 (área impermeável) e V14 (percentual de área coberta por vegetação) como variáveis preditoras. A variável incid_50m (edificações com casos divididos pelo total de edificações no buffer de 50m) como variável resposta a ser explicada ${ }^{43}$.

\footnotetext{
${ }^{43}$ Do total de 300 casos graves registrados apenas em duas residências foram registrados mais de um caso, dois casos em cada, por isso um caso de cada uma dessas residências foi suprimido reduzindo a amostra para 298, passando a equivaler à localização de residências com casos graves registrados.
} 
O resultado da análise produziu dez agrupamentos nomeados aqui com as letras "j" a " $\mathrm{s}$ ", como mostra a Figura 7.6. Dentre eles quatro agrupamentos foram formados por um número bastante reduzido elementos (um ou dois elementos) e por isso são considerados casos isolados, menos representativos da probabilidade de contaminação investigada.

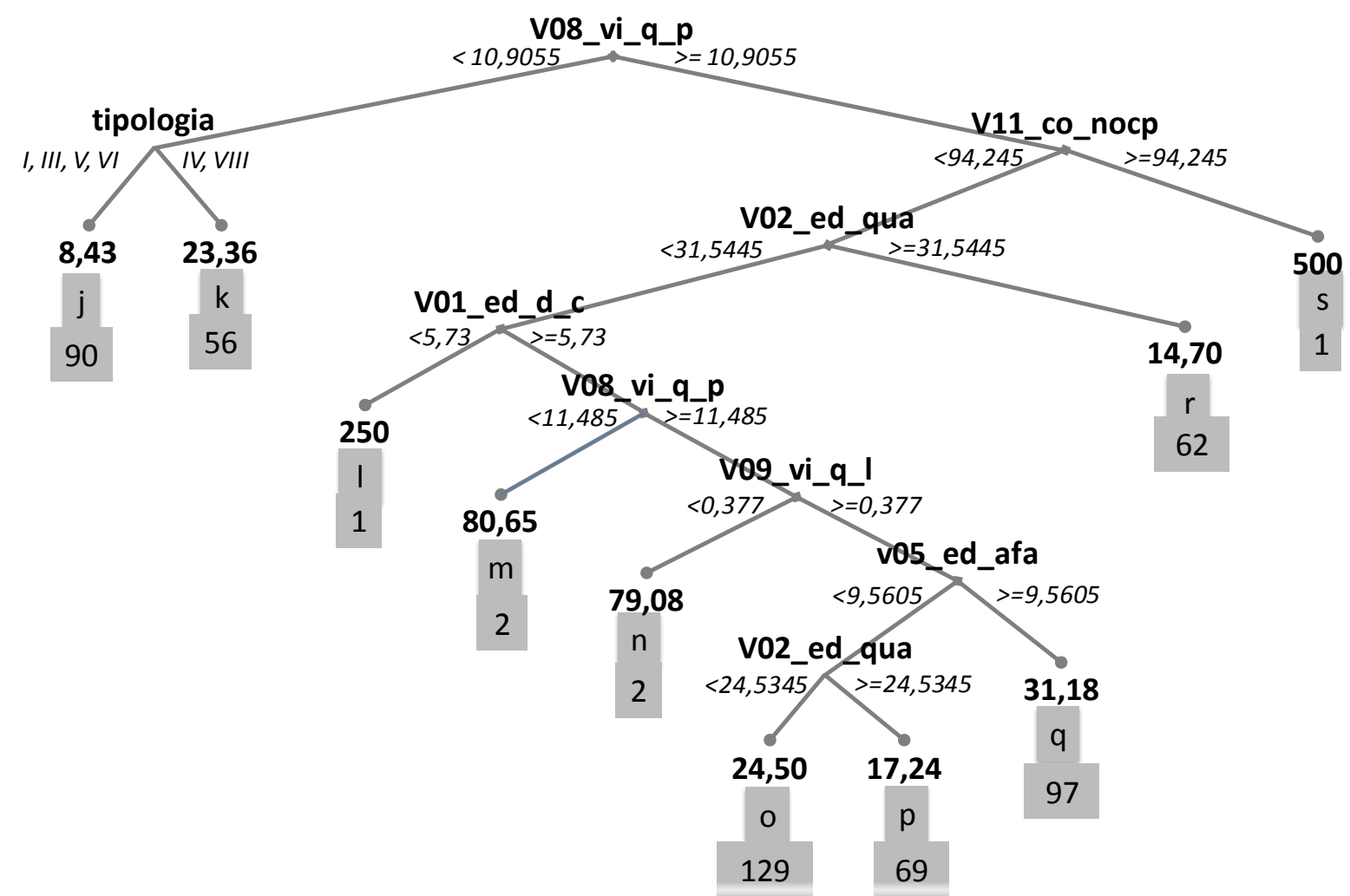

Figura 7.6. Árvore de regressão.

Variáveis: V01_ed_d_c-densidade de casas, V02_ed_qua - qualidade das edficações (telhado cerâmico e tamanho das casas), V03_ed_q_a - área médias das edificações, V04_ed_q_t $t$ percentual de telhado cerâmico, v05_ed_afa - afastamento médio entre edificações, V08_vi_q_p-percentual de vias pavimentadas, V09_vi_a I I largura média das vias, V10_vi_are - percentual de área coberta por vias, V11_co_nocp percentual de cobertura não ocupada, V12_co_imp - percentual de cobertura impermeável, V114_veget percentual de área coberta por vegetação.

Para mapear os grupos, as regras geradas pela árvore de regressão foram aplicadas às variáveis dos buffers de 50m (Figura 7.7). A leitura das regras, tendo em vista valores médios e medianos de cada variável (Quadro 7.11) e da classificação dos buffers permitiu caracterizar os agrupamentos de acordo com determinados parâmetros urbanos. A caracterização, as regras, as estatísticas básicas e exemplos de buffers de cada agrupamento são apresentados no Quadro 7.12. 


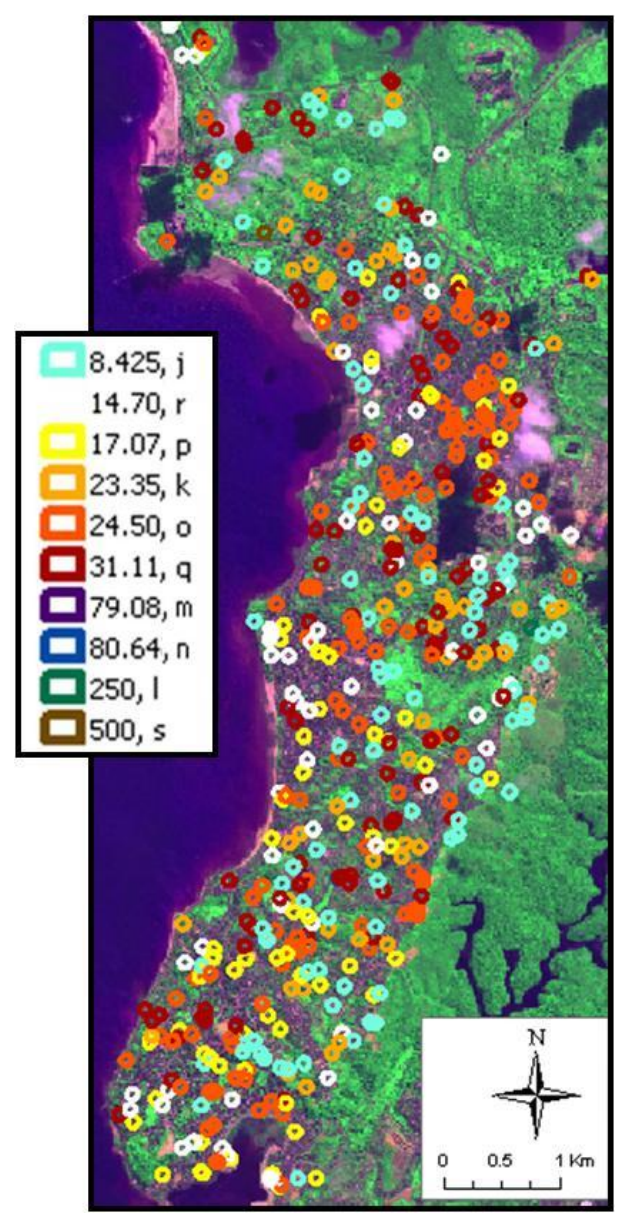

Figura 7.7. Mapa de distribuição dos buffers segundo agrupamentos formados pela árvore de regressão

Quadro 7.11. Média e mediana das variáveis

\begin{tabular}{l|r|r|r|r|r|r|r} 
& incid_caso & V01_ed_d_c & v04_ed_q_t & V02_ed_qua & v03_ed_q_a & v05_ed_afa & V09_vi_q_I \\
\hline média & 22.406 & 41.073 & 22.773 & 28.066 & 57.879 & 11.427 & 5.075 \\
\hline mediana & 18.182 & 42.801 & 16.799 & 25.116 & 57.240 & 9.410 & 5.069
\end{tabular}

\begin{tabular}{l|r|r|r|r|r|r} 
& V08_vi_q_p & V07_vi_qua & V10_vi_are & V11_co_nocp & V12_co_imp & V14_veget \\
\hline média & 41.118 & 42.109 & 14.984 & 48.769 & 42.099 & 45.560 \\
\hline mediana & 37.946 & 40.810 & 14.055 & 46.714 & 41.845 & 43.298
\end{tabular}

Nota: Valores obtidos considerando a análise dos 509 buffers de $50 \mathrm{~m}$ que participaram da analise na árvore de regressão. Variáveis: V01_ed_d_c - densidade de casas,V02_ed_qua - qualidade das edficações (telhado cerâmico e tamanho das casas), V03_ed_q_a - área médias das edificações, V04_ed_q_t - percentual de telhado cerâmico, v05_ed_afa - afastamento médio entre edificações, V08_vi_q_p - percentual de vias pavimentadas, V09_vi_q_I-largura média das vias, V10_vi_are - percentual de área coberta por vias, V11_co_nocp - percentual de cobertura não ocupada, V12_co_imp - percentual de cobertura impermeável, V14_veget - percentual de área coberta por vegetação 
Quadro 7.12. Estatísticas, regras, exemplos e descrição básica dos grupos formados pela árvore de regressão

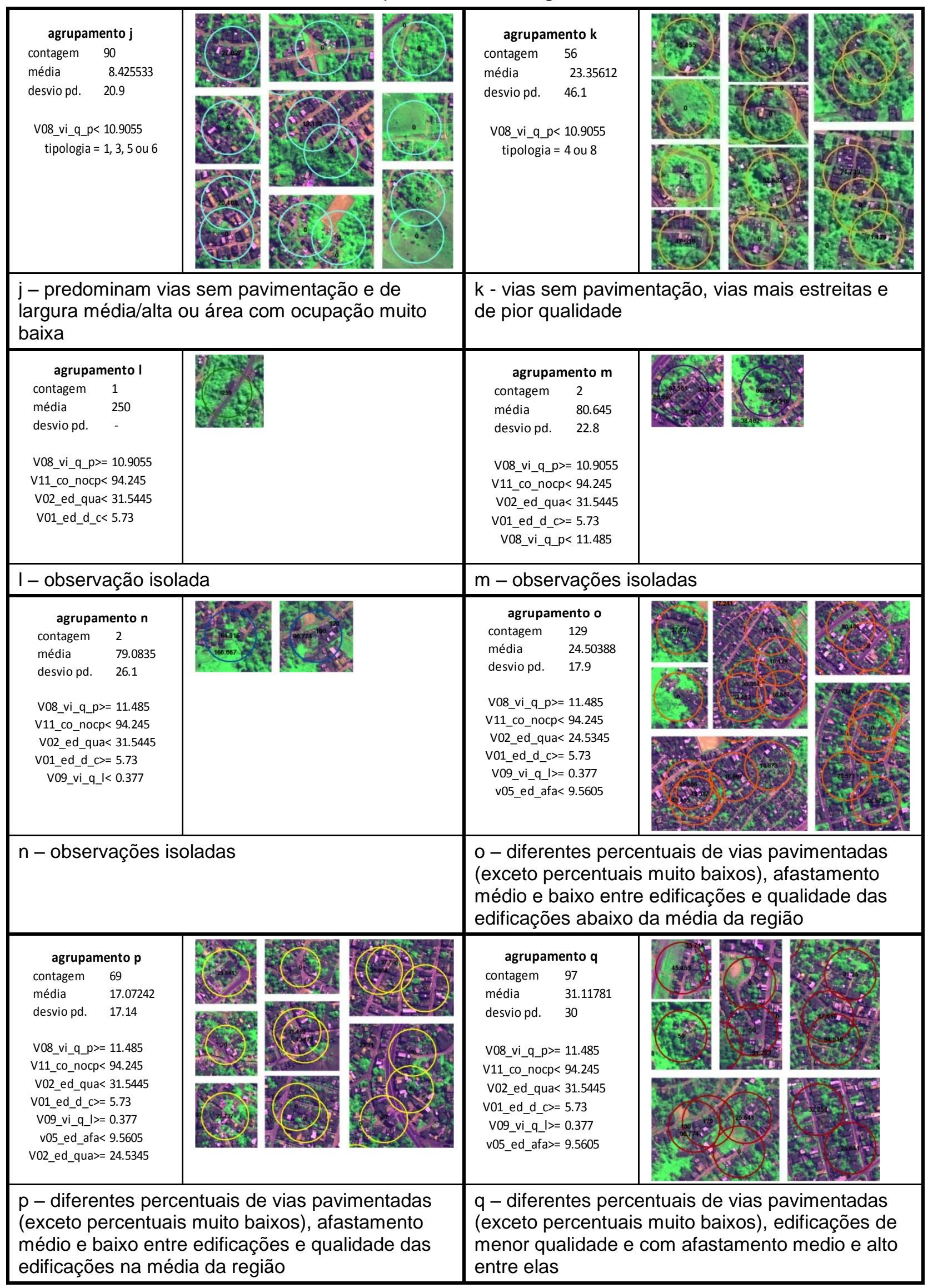


continuação

\begin{tabular}{|l|l|l|l|}
\hline \multicolumn{2}{|c|}{ agrupamento $\mathbf{r}$} \\
contagem 62 \\
média 14.70024 \\
desvio pd. 21.5
\end{tabular}

Nota: Círculos possuem raio de 50m, número no centro do círculo corresponde à incidência na área do círculo. Média e desvio padrão apresentados correspondem ao desvio padrão e incidência média. Variáveis: V01_ed_d_c - densidade de casas, V02_ed_qua - qualidade das edficações (telhado cerâmico e tamanho das casas), V03_ed_q_a - área médias das edificações, V04_ed_q_t-percentual de telhado cerâmico, v05_ed_afa - afastamento médio entre edificações, V08_vi_q_p - percentual de vias pavimentadas, V09_vi_q_l - largura média das vias, V10_vi_are - percentual de área coberta por vias, V11_co_nocp - percentual de cobertura não ocupada, V14_veget - percentual de área coberta por vegetação

O desvio padrão da incidência em cada grupo, apresentado no gráfico BoxPlot da Figura 7.8 indica que há ainda pouca separabilidade entre os agrupamentos formados, mas, em se tratando de uma primeira análise, que tem o objetivo de demonstrar o potencial de uso das informações obtidas por SR, podem-se considerar algumas hipóteses formuladas para direcionamento de futuras investigações. Assim, considerando as médias de cada variável na região (Quadro 7.11), o modelo de transmissão da leptospirose FPPEA/L (Figura 5.4) e as características urbanas mais marcantes na formação dos agrupamentos (Quadro 7.12) foram formuladas algumas hipóteses para a predição da doença.

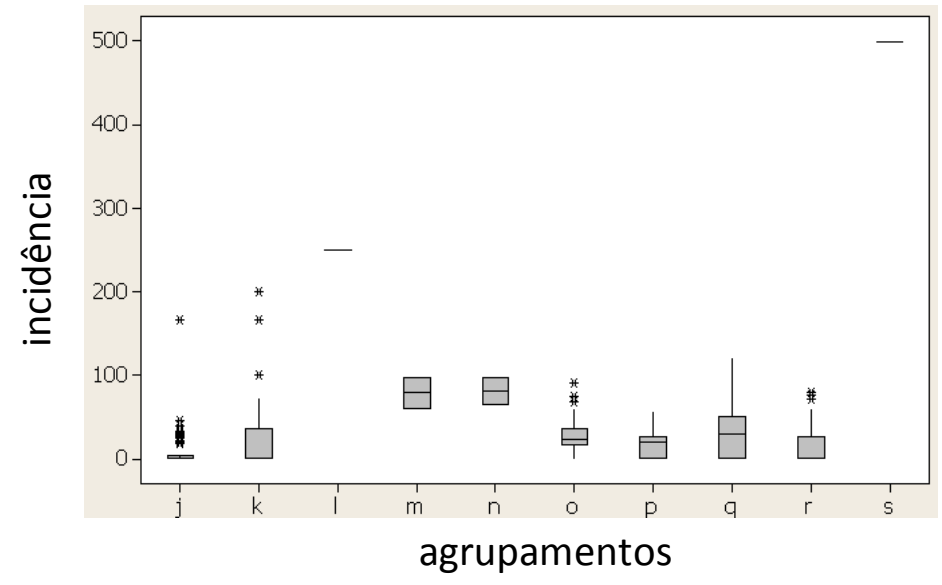

Figura 7.8. Gráfico BoxPlot dos valores de incidência no buffer de 50m por agrupamento O agrupamento "j" apresenta a incidência média mais baixa, a cada 1000 residências menos de 10 apresentaram morador com caso grave de leptospirose. Este agrupamento se 
caracteriza pela predominância de vias sem pavimentação mas com largura média/alta ou por áreas com ocupação muito baixa. Em contraposição ao agrupamento "k", que tem incidência média um pouco acima da média da região, e difere do agrupamento "j" principalmente na largura das vias, que em "k" são mais estreitas, e por não contemplar áreas de densidade muito baixas.

Segundo o modelo FPEEA/L (Seção 5.3), a pavimentação e a largura das vias podem estar relacionadas a indicadores de renda, esgotamento, abastecimento de água, infra estrutura de drenagem e acesso de veículos de serviço. Os resultados então levantam a hipótese de que sistema de esgoto ou drenagem existente sob vias pavimentadas estejam servindo como abrigo ou ainda, que vias estreitas estejam dificultado o acesso de caminhões de coleta de lixo.

Com relação às áreas menos ocupadas, classificadas como “j”, estes resultados levantam inicialmente três hipóteses. A de que nessas áreas há mais terrenos baldios e há menor frequência de pessoas e de serviços, propiciando o acúmulo de lixo e consequentemente o aumento da população de roedores. Uma outra hipótese é relativa à permeabilidade das vias, que evitam a formação de poças duradouras, e outra é relativa ao período de ocupação da área, as quais só foram ocupadas mais recentemente e não tiveram registro de casos levantado, pois não havia moradores entre 1995 e 2005.

Os agrupamentos " $r$ " e " $p$ " também apresentam incidências médias inferiores à média da região. O agrupamento " $p$ " se caracteriza pela presença de edificações com qualidade na média da região, mas com afastamento médio e baixo entre edificações. O agrupamento "r" se caracteriza pela predominância de edificações com qualidade acima da média da região.

Esses agrupamentos levantam a hipótese de que a qualidade das casas é um fator importante na investigação da probabilidade de transmissão da doença, principalmente se comparados aos agrupamentos "o" e "q", onde a incidência média é acima da média da região e a qualidade das casas abaixo da média.

O agrupamento "o", com incidência média um pouco acima da média da região é o agrupamento com o maior número de elementos (buffers). A maior parte deles se caracterizam principalmente pela predominância de edificações com qualidade abaixo da média para a região, além de possuir afastamento médio e baixo entre edificações.

Entre os agrupamentos que reuniram um número significativo de elementos, o agrupamento "q" foi o que apresentou a mais alta média de incidência. Esse agrupamento foi formado por 
áreas onde as edificações têm predominantemente qualidade média ou baixa, mas que possuem afastamentos na média ou acima da média para a região.

Tanto o agrupamento "o" como o agrupamento "q" apresentaram qualidade da edificação abaixo da média e ao mesmo tempo incidência acima da média em contraposição aos agrupamentos "r" e "p". O modelo FPEEA/L (apresentado no Capítulo 5) indica que a qualidade da edificação está relacionada a, ao menos, dois indicadores: lb - maior a qualidade da edificação, o que implica em maior volume de lixo gerado e maior a demanda por coleta e local apropriado para a disposição de resíduos sólidos domiciliares; Ig: maior a qualidade da edificação, que pode ser reflexo de uma maior renda, possivelmente implicando em maior acesso à educação e a noções de higiene, implicando também no aumento das condições da família de possuir local apropriado para o armazenamento de alimentos. A relação com a renda ratifica os resultados alcançados por Reis et al. (2008) que afirma que a renda está diretamente relacionada ao risco de contaminação.

O que distingue os dois agrupamentos com as mais altas incidências médias, "o" e"q", é o afastamento entre as edificações. O afastamento entre casas pode estar relacionado à existência de vielas e becos que podem se configurar como locais de abrigo para roedores, como relatou Vinetz et al. (1996) em áreas, de acordo com o agrupamento, onde há predominância de edificações de qualidade inferior. A hipótese é que na área de estudo o maior afastamento entre as casas esteja favorecendo o hospedeiro roedor, pois maiores afastamentos podem proporcionar a existência de áreas abandonadas, utilizadas como depósito de lixo e consequentemente como abrigo e fonte de comida para o rato. Observase nas amostras apresentadas no Quadro 7.1, que essas áreas têm densidades variadas, mas as casas não estão isoladas, apenas muito distantes de casas vizinhas, o que sustenta a hipótese apresentada.

De acordo com o gráfico BoxPlot, há ainda pouca separabilidade entre os agrupamentos formados, mas em se tratando de uma primeira análise, que tem o objetivo de demonstrar o potencial de uso das informações obtidas por SR, as hipóteses formuladas já podem ser consideradas como caminhos para futuras investigações.

\subsection{Investigação da influência do crescimento populacional nas análises}

Uma breve investigação sobre a distribuição do crescimento populacional ocorrido no Subúrbio e a relação deste fator externo com as análises realizadas na seção anterior foi 
realizada tendo em vista a hipótese levantada para a formação dos agrupamentos com incidências médias mais baixas. Suspeita-se que o resultado tenha sofrido viés devido a uma diferença temporal entre os dados utilizados; dados de saúde de a 1996 a 2005 e imagem satélite de 2005.

A distribuição do crescimento populacional na área de estudo foi estimada utilizando dados dos setores censitários de 1991 e 2000. Com base no centróide de cada setor foi gerada uma superfície de densidade populacional para cada ano, obtida com método de interpolação espacial dos valores de densidade de cada setor, representado no seu centróide. A operação de divisão entre superfície gerou uma terceira superfície chamada de incremento de densidade entre 1991 e 2000, como mostram os mapas da Figura 7.9.

a)

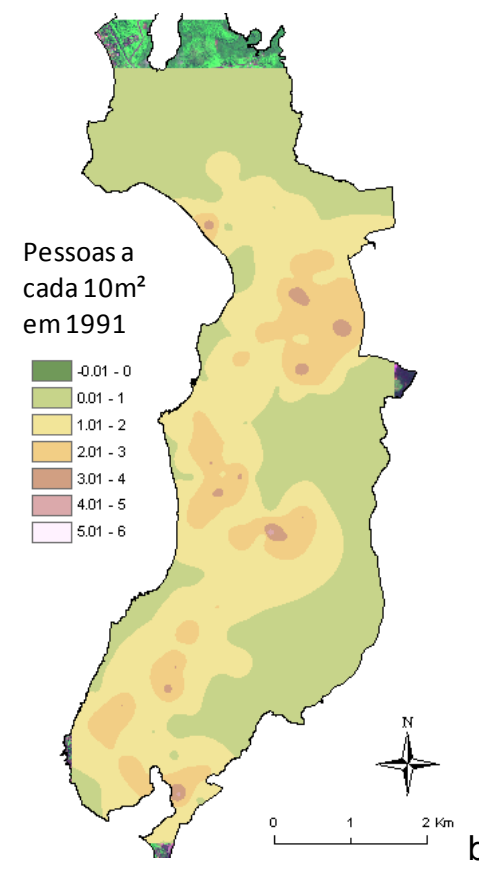

b)

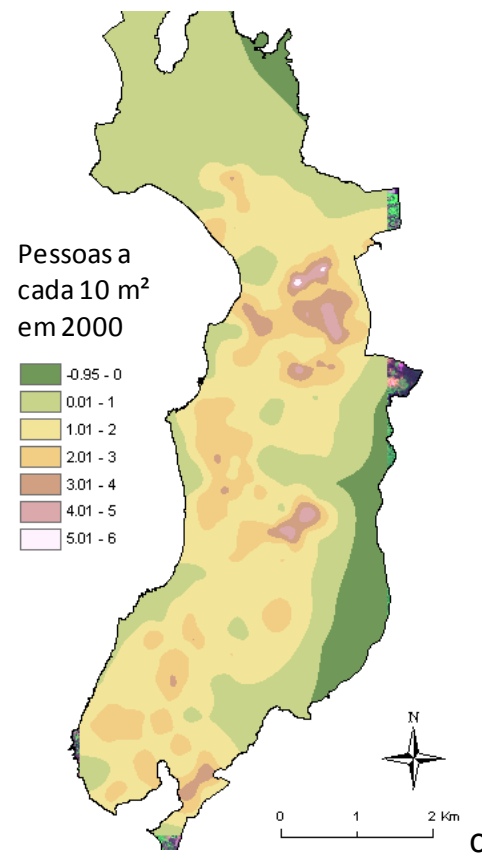

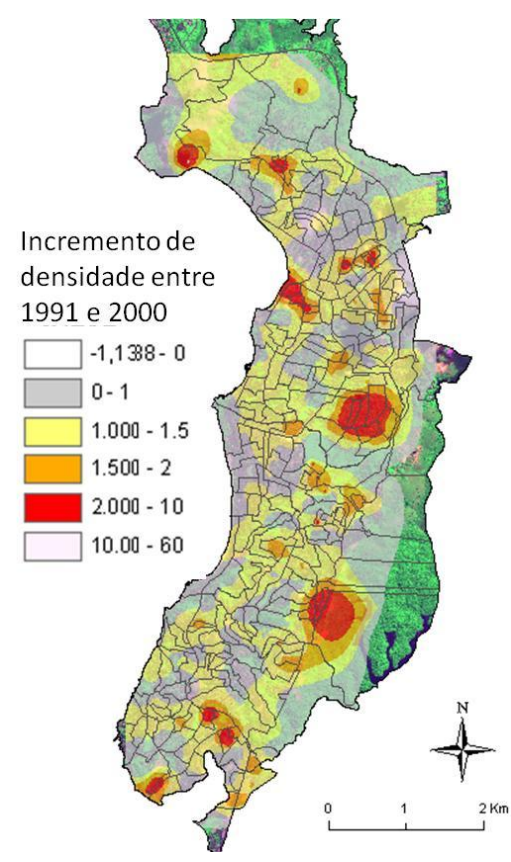

Figura 7.9. Mapas de densidade populacional. a) Distribuição da população em 1991 segundo censo de 1991 do IBGE; b) Distribuição da população em 2000 segundo censo 2000 do IBGE; c) Mapa de distribuição do incremento da densidade populacional entre 1991 e 2000 (densidade em 2000 dividida pela densidade em 1991).

Observa-se que entre os anos de 1991 e 2000, algumas áreas se destacam pelo maior incremento populacional ocorrido no período. O mapa da Figura 7.9 sugere que as áreas mais escuras podem ter sido apontadas nas análises de probabilidade de contaminação como áreas de menor risco de contração da leptospirose do que o risco real, uma vez que a densidade populacional em 2005, que é o denominador da variável resposta (incidência de casos), é mais alta de acordo com a imagem satélite do que na época que ocorreu o caso. 
A fim de verificar se o crescimento populacional ocorrido entre 1991 e 2000 influenciou a formação dos agrupamentos da árvore de regressão, foi calculado para cada buffer de $50 \mathrm{~m}$ o incremento de densidade no seu ponto central. Em seguida um gráfico BoxPlot, figura 7.10, foi gerado para comparar diferenças de incremento de densidade entre grupos.

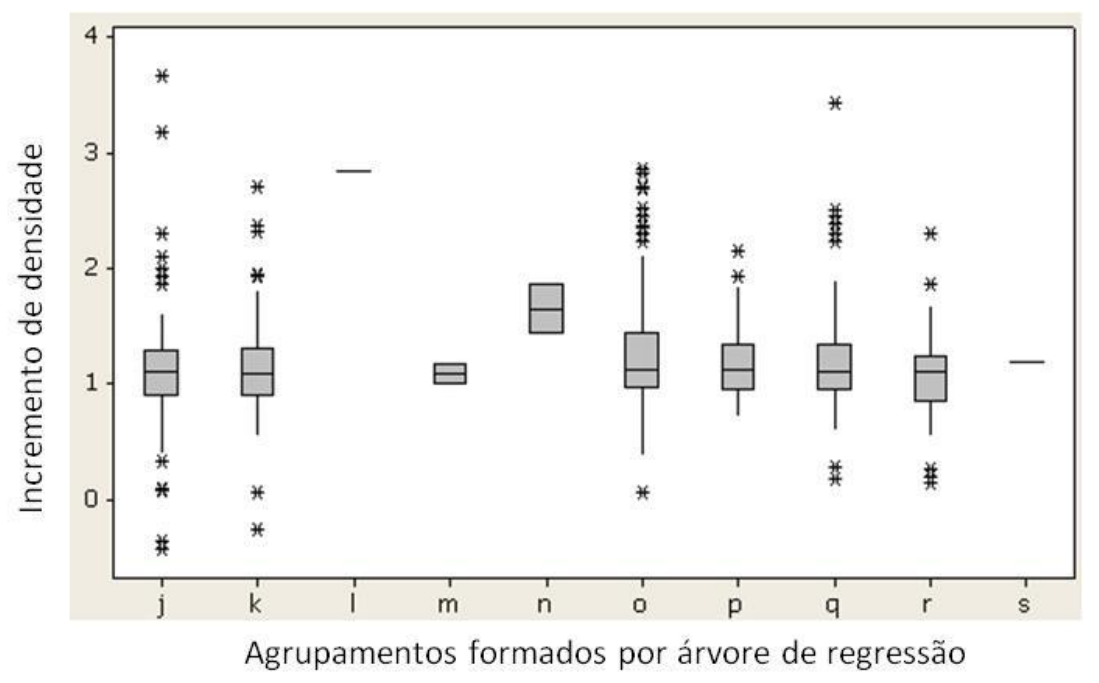

Figura 7.10. Gráfico BoxPlot para análise de relação entre adensamento urbano e agrupamentos formados por árvore de regressão

O gráfico sugere que não há uma correspondência marcante entre os agrupamentos formados e o adensamento ocorrido nessas áreas entre 1991 e 2000, pois os agrupamentos de menor incidência média (“j", "r" e"p") não apresentam maiores incrementos populacionais. No entanto, esta conclusão não pode ser definitiva, pois há diferença na resolução espacial da análise dos casos (edificação) e das densidades (superfície gerada a partir da informação dos setores censitários) e a diferença na resolução temporal entre os dados censitários (1991 a 2000) e os dados epidemiológicos (1996 a 2005), que podem ter influenciado o resultado.

\subsection{Probabilidade de contaminação segundo densidade populacional e de casos pelo método da razão de Kernel}

Uma última análise exploratória foi realizada a fim de comparar os resultados obtidos com a árvore de regressão e outro método mais comumente utilizado em estudos epidemiológicos para o mapeamento de probabilidade de contaminação, o método da razão de Kernel ou 
razão entre densidades. O método consiste na geração de uma superfície de risco com base exclusivamente na densidade populacional e densidade de casos, calculada pela razão de Kernel entre duas densidades.

A densidade da população foi obtida utilizando a densidade de pontos (centróide da edificação) através do método Kernel, cujos parâmetros foram: raio de $150 \mathrm{~m}$, pontos relativos às edificações, e o peso de cada ponto correspondente ao número de moradores na edificação. Para estimar o número de moradores em cada edificação, foi necessário gerar o centróide de cada objeto classificado como edificação, em seguida a população do setor censitário (IGBE, 2000) foi distribuída nos centróides das edificações que pertenciam a seus limites ${ }^{44}$, mapa da Figura $7.11 \mathrm{~b}$.

A superfície de densidade de casos foi obtida aplicando a densidade Kernel nos pontos referentes à localização de casos graves de leptospirose, com peso um para cada ponto e raio de varredura também igual a 150m (Figura $7.11 \mathrm{a})^{45}$.

a)

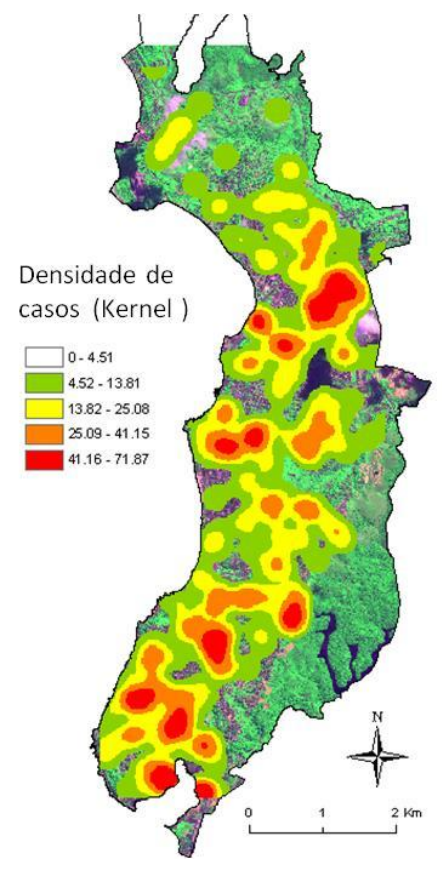

b)

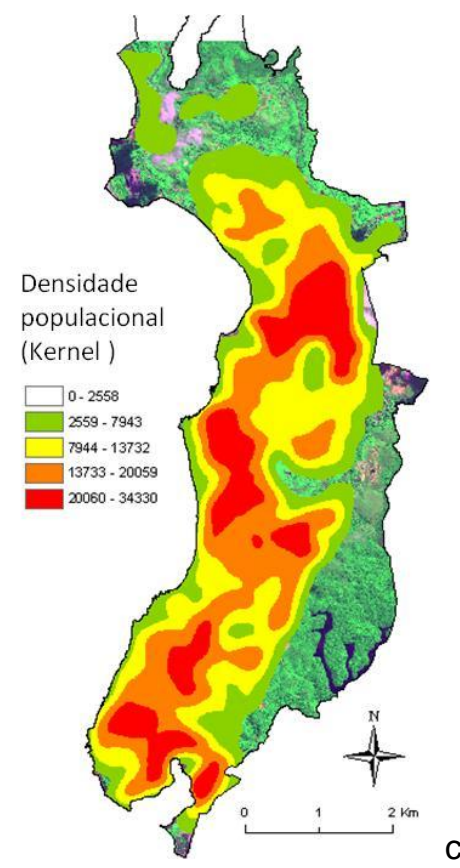

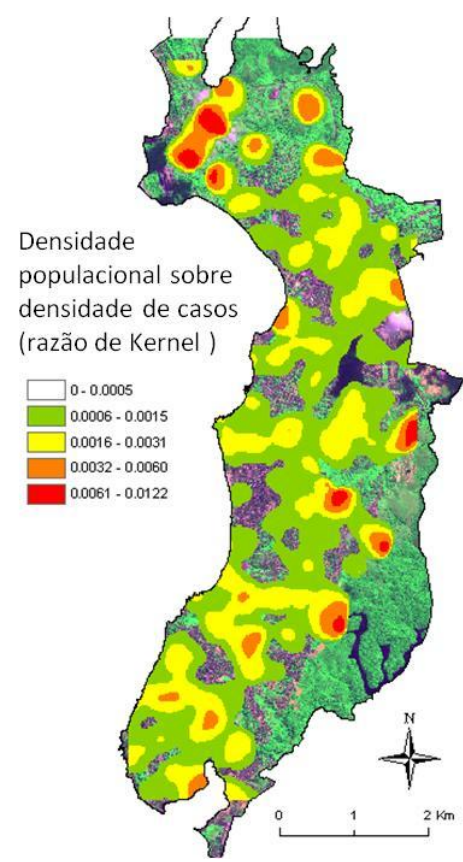

Figura 7.11. Mapas de distribuição dos casos e da população. a) Distribuição dos casos - Kernel (raio de $300 \mathrm{~m}$ ) casos leptospirose; b) Distribuição da população - Kernel (raio de $300 \mathrm{~m}$ ) edificações (peso número de moradores); c) mapa de probabilidade de contaminação gerado pela razão de kernel, distribuição de casos ajustada pela distribuição da população.

\footnotetext{
44 Tomando cuidado para utilizar a variável de moradores por edficação do Censo nos setores onde não foi possível identificar o número total de edficações por meio de SR (imagem com nuvens ou sombra de nuvens)

${ }^{45}$ A aplicação do mesmo método utilizando raios de varredura inferiores a 150m resultaram em maps de razão de kernel sem diferença significativa entre áreas que proporcionasse sua visualização.
} 
Observa-se nos mapas apresentados que a maior parte das áreas de maior densidade de casos (Figura 7.11a) apresenta também maior densidade populacional (Figura 7.11b), o mapa de probabilidade (Figura 7.11c) aponta áreas de menor densidade populacional e periféricas como principais áreas de risco.

A fim de comparar os resultados obtidos pelo método da razão de Kernel e os resultados obtidos pela árvore de regressão, foi identificada a razão de Kernel em cada buffer de 50m (adotado valor da razão de Kernel no centro do buffer). Um gráfico BoxPlot foi construído com o objetivo de identificar preliminarmente possíveis correlações entre os resultados dos dois métodos (Figura 7.12).

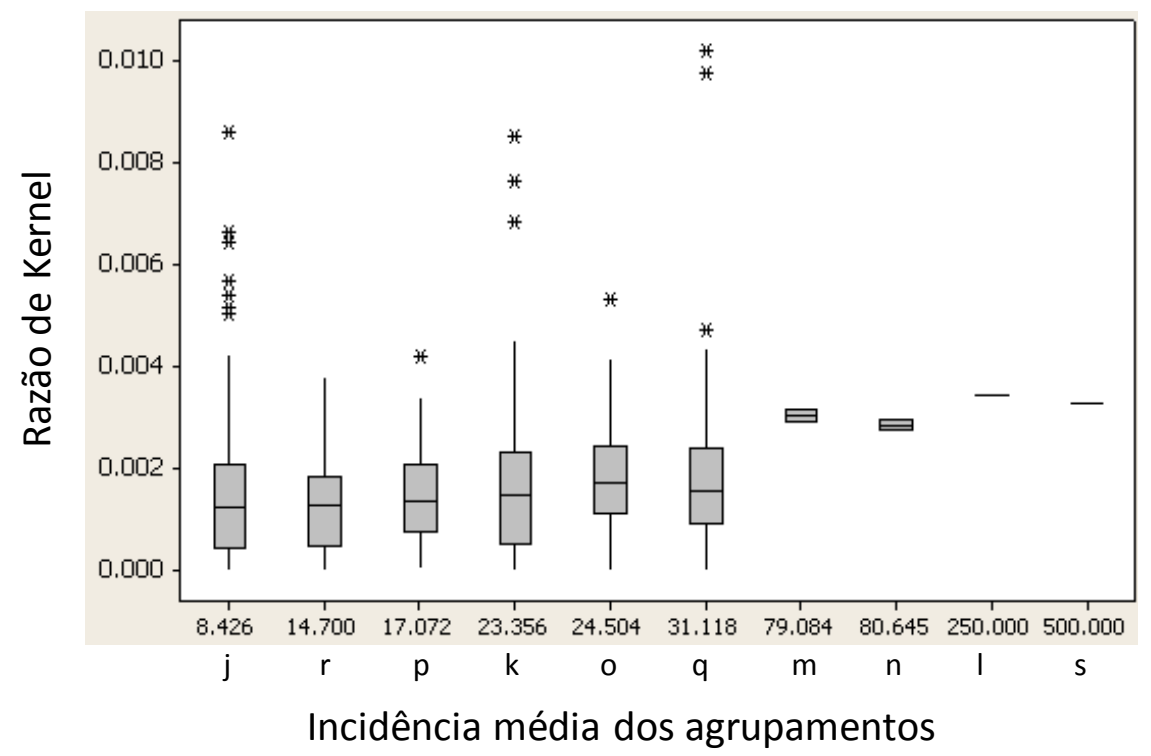

Figura 7.12. Gráfico BoxPlot, análise de relação entre razão de Kernel e agrupamentos formados por árvores de regressão

Observa-se no gráfico da figura 7.12 que parece haver uma relação linear entre a probabilidade de contaminação calculada a partir da razão de Kernel e calculada pela árvore de regressão, o que sugere que os fatores urbanos identificados como mais importantes na explicação da doença, segundo a árvore de regressão, realmente assim o sejam.

No entanto, a análise das densidades de Kernel foi realizada em uma escala de menor detalhe que a análise pela árvore de regressão, 300m e $50 \mathrm{~m}$ respectivamente. Esta diferença na resolução espacial pode ter influenciado as relações encontradas nas análises comparativas. 
Para que a avaliação de probabilidade na análise de Kernel fosse realizada com um grau de detalhamento maior, seria necessário que a densidade casos fosse maior. Os dados de leptospirose coletados para o Subúrbio Ferroviário entre 1996 e 2005 não geraram uma superfície de Kernel com densidades que apresentassem áreas de destaque utilizando raios inferiores a $300 \mathrm{~m}$.

A análise da relação entre as características urbanas e áreas consideradas de maior probabilidade de ocorrência, segundo o método da razão de Kernel, demanda a agregação dos dados de ocorrência em uma unidade espacial maior que os buffers de 50m utilizados na análise da árvore de regressão, assim como a agregação dos dados urbanos, o que para este estudo não é considerado apropriado, visto a epidemiologia da leptospirose explicada na Seção 2.1 e na introdução do presente capítulo.

Os resultados obtidos com a aplicação do método da árvore de regressão é portanto mais efetivo que o método da razão de Kernel no que diz respeito à adequação à escala do estudo. O método da árvore de regressão também propiciou o reconhecimento do sistema viário, através da identificação de pavimentação e largura das vias, e de qualidade das edificações (uma combinação entre o tipo de cobertura e o tamanho da edificação) como importantes características urbanas relacionadas à ocorrência da leptospirose, revelando ainda parâmetros para essas características que permitem a formulação de hipóteses, baseadas em modelos de transmissão (Capítulo 5), que expliquem essa relação. 


\section{CAPÍTULO 8. DISCUSSÃO DOS RESULTADOS}

Este capítulo se dedica à discussão dos resultados encontrados nesta pesquisa, focando limitações e potenciais da metodologia utilizada, apresentando uma análise mais ampla e conjuntural dos principais pontos abordados e recomendações para futuros estudos.

\subsection{Tipologias Urbanas}

O processo de identificação de tipologias urbanas presentes na área de estudo foi tido como um dos eixos de investigação do espaço e visava reconhecer padrões urbanos possíveis de serem descritos utilizando exclusivamente dados de sensoriamento remoto.

Esse estudo utilizou como ponto de partida as amostras de padrões de habitabilidade de Salvador identificados em pesquisas anteriores a esta (identificadas na Seção 4.3), permitindo que um dos produtos desta Tese seja uma caracterização mais aprofundada daqueles padrões encontrados no Subúrbio. O uso de SR resultou na descrição de 19 tipologias, dentre as quais duas não foram encontradas na área de estudo. Para cada uma delas foram adicionadas às informações de área de lote, área de vias e número de edificações, levantadas em croquis de pesquisa anterior, novos dados referentes a: o tipo de pavimentação, a largura média e a ortogonalidade das vias; o tamanho e a forma dos quarteirões; a distância entre centróides, o tamanho médio as unidades, o tipo de telhado e a área ocupada por edificações; e a área coberta por vegetação.

A comparação entre as tipologias identificadas com SR e os padrões de habitabilidade anteriormente pesquisados foi possível agrupando-os em três níveis: nível superior caracterizado nas imagens pela presença de vias de maior qualidade e edficações com maior área; nível intermediário caracterizado por vias de menor qualidade e pela presença de edificações com áreas reduzidas; e nível inferior caracterizado pela maior densidade de edificações ou pela predominância de vias de baixa qualidade em áreas os maiores percentuais de vegetação. Assim, apesar dos padrões levarem em conta também questões como a legalidade da propriedade e histórico da ocupação, que nem sempre se refletem em características urbanas possíveis de serem identificadas por meio de SR, o resultado da identificação de tipologias com uso de SR é considerado bastante positivo.

Posteriormente, o estudo de correlação do espaço urbano com as possibilidades de ocorrência da leptospirose, realizado através do método de árvore de regressão, sugeriu que seis tipologias (entre as nove identificadas) contribuem para a explicação da doença. Partindo da regra de que as áreas possuem percentuais de vias pavimentadas muito 
baixos, quatro tipologias, que se caracterizam ou pela presença de vias com largura média e alta ou pela baixa densidade de edificações, formaram o agrupamento que apresentou a mais baixa incidência média de casos de leptospirose. Isto é, configuram situações urbanas com menor possibilidade de transmissão ou ocorrência da doença. Nas outras duas tipologias, por sua vez, predominaram vias mais estreitas que não incluíam áreas com densidade muito baixa, formando um agrupamento com incidência um pouco acima da média da região.

Futuros estudos poderão ainda investigar a possibilidade de se utilizar outros dados de SR para o aperfeiçoamento na distinção de tipologias. Por exemplo, dados que não dependem da classificação da imagem, como a análise de variabilidade da segmentação (agrega à unidade de análise atributo de medida de hetereogeneidade dos segmentos), contagem de polígonos (pode se considerado um atributo de textuxa), regularidade e direção dos polígonos (atributos que devem estar relacionados à formalidade da ocupação e ortogonalidade do sistema viário), entre outros, podem vir a contribuir para uma caracterização mais expedita e precisa de tipologias relacionadas à ocorrência da leptospirose ou de outra doença a ser estudada.

\subsection{Metodologia e modelos}

A construção dos modelos de risco de transmissão da leptospirose foi uma etapa importante para a sistematização e integração das informações das diversas áreas relacionadas ao tema, coletadas na etapa de revisão bibliográfica.

Os mapas conceituais contribuíram principalmente na condensação das principais informações relativas aos conceitos chave envolvidos, facilitando a visualização do problema, haja vista sua complexidade. Os modelos ISA/L e FPEEEA/L (discutidos nas Seções 5.2 e 5.3) contribuíram principalmente no direcionamento e organização das análises que seriam feitas dali em diante, visto a diversidade de elementos e padrões urbanos (identificáveis por SR) levantados. No entanto, tais complexidade e diversidade propiciam a ocorrência de vieses oriundos de várias fontes, cujas principais são discutidas, caso a caso, a seguir.

As chances de ocorrência dos casos graves de leptospirose no subúrbio, por exemplo, estão sujeitas à interferência de fatores não espaciais, como hábitos de higiene, atividades de risco e processos de imunização causados pelo contato constante com a bactéria (ver Seção 2.1.3). No entanto, ainda que todo o subúrbio possa ser considerado uma região 
endêmica, visto que a região abriga classes menos favorecidas em habitações predominantemente precárias, o número de casos graves comparado com o do restante da cidade é bastante elevado, portanto, a endemicidade nessa escala não deve ser considerada um impeditivo à realização de estudos como o presente.

A compatibilidade temporal dos dados é outra fonte de viés que deve ser investigada quando se realizam procedimentos de geoprocessamento destinados a estudos epidemiológicos, pois é grande a dificuldade de se encontrar dados de SR e de saúde que sejam perfeitamente sincronizados. Na pesquisa, esta dificuldade foi contornada avaliandose a distribuição do crescimento da população da região, utilizando dados do censo demográfico, que quando comparada com os resultados das análises estatísticas de probabilidade de transmissão e ocorrência da leptospirose indicaram que o estudo não sofreu interferência do crescimento populacional da década de 90.

Outro caso de viés diz respeito a um erro, frequente em estudos epidemiológicos no espaço intra-urbano, causado pela falta de acurácia na localização geográfica da residência. Métodos de geocodificação podem incorporar falhas de digitação, cometidas no hospital, assim como problemas relacionados à cartografia do sistema viário, entre outros. Para evitar esse tipo erro, a FioCruz confirmou, com pesquisa de campo e georreferenciamento da residência, todos registros de ocorrência de leptospirose entre os anos de 1996 e 2005, dados que foram cedidos para a realização desta pesquisa.

Casos de inconsistência com a escala de análise também devem ser observados. Por exemplo, no modelo FPEEA/L a análise de indicadores de área deve assumir valores compatíveis em escala com o significado do indicador. Por esta razão, a área de abrangência da análise (raio do buffer $50 \mathrm{~m}$ ) foi definida de acordo com a dinâmica da doença estudada, a leptospirose, resultando na redução do número de indicadores e de variáveis analizados estatísticamente

É importante frisar que, no momento de criação dos modelos de risco, não se levou em consideração correlações estatísticas existentes entre as variáveis, pois o objetivo era explorar e organizar variáveis baseadas em dados de SR que poderiam estar relacionadas à ocorrência da leptospirose. Por essa razão, optou-se, posteriormente, por trabalhar apenas com uma escala de análise, dentro de uma vizinhança de $50 \mathrm{~m}$ de cada ocorrência (buffer de 50m), na realização de uma primeira abordagem exploratória de correlações entre as características urbanas e a ocorrência da leptospirose no Subúrbio. Expandir a análise para outras escalas requer uma revisão da adequabilidade das variáveis e dos métodos estatísticos utilizados nesta Tese, o que poderá ser realizado em futuros trabalhos. 
Outros estudos podem também recorrer à mesma série epidemiológica utilizada aqui para gerar mapas preditivos com base nas mudanças ocorridas no cenário urbano na década em questão e na sua correlação dessas mudanças com a variação na localização dos casos de leptospirose no Subúrbio Ferroviário neste mesmo período. O modelo FPEEEA/L pode se utilizado com este fim, sendo, no entanto, necessário realizar processos de detecção de mudança entre imagens geradas no início e do fim do período em estudo e incorporar os resultados desses processos ao conjunto de variáveis levantadas no modelo.

\subsection{Sensoriamento remoto}

Os resultados da pesquisa mostram que valeu a pena aceitar o desafio de explorar tecnologias de SR como suporte a estudos epidemiológicos no espaço intra-urbano.

Apesar da acurácia da classificação dos objetos (concordância entre o indicado pelo classificador e o mundo real) de interesse na maior parte das áreas teste não parecer alta (índice de concordância Kappa entre os objetos com valores acima de 65\%), diante da complexidade da morfologia urbana do Subúrbio e dos resultados de caracterização das tipologias, tanto a classificação em ortofotografias, como em imagem QuickBird foram consideradas satisfatórias para a realização da investigação a que se propôs a pesquisa: analisar correlações entre a possibilidade de ocorrência da leptospirose e algumas características urbanas.

A segmentação multi-nível e a classificação baseada em objeto, fundamentadas nas características espectrais, geométricas e topológicas dos objetos, permitiram a identificação de edificações com ou sem telhado cerâmico, vias pavimentadas ou não pavimentadas, solo exposto e outras classes auxiliares como sombra e via de pavimento indefinido, por exemplo. Entre essas classes, vegetação, via e telhado cerâmico foram os objetos de interesse melhor identificados, alcançando mais de $85 \%$ de concordância.

Tais resultados são ainda mais positivos quando se considera que o reconhecimento digital em SR dos objetos de interesse sofre limitações de origem diversas:

- disposição de barro nas laterais das vias pavimentadas;

- posição da copa de árvores que cobrem outros elementos, omitindo a área real o alvo; - alta densidade e disposição contígua de edificações dificultando a identificação da unidade residencial; 
- limitações do próprio equipamento de SR, que por possuir um número limitado de bandas não permite uma distinção muito clara entre alvos como sombra e água ou, no caso das ortofotografias, a distinção entre alguns telhados cinza e vegetação rarefeita;

- limitação de informações, como a tridimensionalidade dos alvos (obtida a partir de modelos digitais de superfície e de terreno), que permitem distinguir mais eficientemente telhados de laje e pisos impermeáveis, por exemplo.

Diante de tais limitações, apenas dois elementos apontados pela literatura e pelo modelo FPEEEA/L como relacionado à ocorrência da leptospirose tiveram dificuldade de serem identificados: pontos de acúmulo de lixo, ou lixões, e corpos d'água. A identificação de lixões é difícil de ser feita por meio de SR, especialmente devido a sua intermitência e a sua irregularidade espectral e de forma. Já a identificação dos corpos d'água, por meio de SR foi dificultada, no caso das ortofotografias, pela inexistência da banda infra-vermelha e, em ambas imagens, por estarem cobertos pela vegetação de margem ou devido a presença de lixo, detritos e partículas em suspensão, que alteram as propriedades espectrais da água. Visto as limitações e dificuldades encontradas para o reconhecimento de lixão e corpos d'água, nos estudos que se seguirem a este, vale a pena considerar o uso da base cartográfica municipal com vetores de drenagem e a localização de denúncias de pontos de acúmulo que são feitas à prefeitura e à empresa de coleta de lixo. De qualquer sorte, na presente pesquisa foram utilizados outros indicadores de situações urbanas de risco que se mostraram também relacionados com a ocorrência da doença.

Quanto a adaptação da metodologia de SR apresentada ao uso de outras imagens satélite de resolução espacial muito alta (IKONOS ou WordView, por exemplo) apenas alterações simples serão demandadas, especificamente na: revisão de parâmetro escalar devido à mudança da resolução do pixel no solo, e revisão dos parâmetros utilizados nas regras de classificação, uma vez que as janelas espectrais de cada sensor podem variar de um satélite para outro. Em qualquer situação de replicação da metodologia, parâmetros absolutos precisarão ser confirmados, pois variações nas condições atmosféricas (em imagens não corrigidas) e nas características urbanas interferem, respectivamente, na radiometria e no cálculo de geração de imagens auxiliares, como as componentes principais, por exemplo. As funções descritoras de classe poderão ser mantidas, assim como a hierarquia de classes e árvore de processos desenvolvidas.

No caso de se utilizar ortofotografias é importante estar ciente que, devido à ausência de faixas espectrais absolutas, funções descritoras relativas a atributos espectrais derivada não são aplicáveis a outras fotografias aéreas ou a outras áreas de estudo. Por isso a metodologia apresentada para esse tipo de imagem teve informações de base espectral 
obtida por meio de classificação supervisionada, o que viabiliza o trabalho de replicação da metodologia, apesar de aumentar a interferência do analista no processamento.

Por fim, no que diz respeito às técnicas de SR utilizadas, entende-se que o uso de outras informações cartográficas pode ser de grande utilidade no aperfeiçoamento do processo de classificação e consequente incremento na confiabilidade dos resultados dos testes estatísticos de correlação entre a doença e o ambiente urbano. No entanto, mesmo sem o uso dessas informações complementares, a pesquisa mostra que a classificação baseada quase que exclusivamente em dados de SR, seja de ortofotografias, seja de imagem QuickBird, já tem validade para esse tipo de estudo epidemiológico.

\subsection{Análises estatísticas}

Os testes de correlação realizados entre dados urbanos extraídos de SR e dados de saúde revelaram que entre as variáveis urbanas estudadas a pavimentação das vias e a qualidade das casas estão mais fortemente relacionadas à possibilidade de ocorrência da leptospirose. Vias não pavimentadas, mas com largura média e alta, apresentaram as mais baixas incidências da doença. Já a predominância de edificações de menor qualidade foi definitiva para a formação dos agrupamentos com maiores incidências.

Tendo em vista o modelo FPEEA/L, acredita-se que o sistema de esgoto ou a drenagem de via pavimentada esteja contribuindo com a sobrevivência e reprodução dos roedores e/ou que a permeabilidade do solo nas vias não pavimentadas esteja evitando a formação de poças d'àgua mais duradouras. Também com base no modelo, pode-se afirmar que a relação encontrada entre a ocorrência de doença e a largura da via deve-se à dificuldade de acesso de veículos de serviços, como caminhão de coleta de lixo, por exemplo, independentemente da situação da pavimentação da via. O modelo FPEEA/L indica ainda que a alta correlação encontrada entre os dados de saúde e a qualidade das casas (medida pelo percentual de casas com telhado cerâmico e tamanho médio das casas) deve-se ao fato desta característica refletir a renda dos moradores, que, por sua vez, tem a ver com o nível de instrução e a capacidade financeira de possuir na residência local apropriado para armazenamento para alimentos.

As demais análises realizadas, a avaliação da interferência do crescimento populacional nos resultados e a análise de superfície de probabilidade de contaminação gerada pelo método da razão de Kernel, não negaram nem descredenciaram os resultados descritos. 
Pelo contrário, mostram que o método da árvore de regressão foi bastante apropriado para este estudo, por permitir, entre outras coisas, a realização de análise com e escala de detalhe e com a diversidade de variáveis demandadas.

A opção por utilizar como variável resposta a incidência, calculada pela razão entre edificações com casos sobre o número de edificações na unidade espacial de análise (buffers de $50 \mathrm{~m}$ ), funcionou também como exercício de versatilidade da metodologia apresentada. Um dos potenciais de utilização desta metodologia está em sua capacidade de agregar dados em diferentes unidades espaciais e diferentes escalas.

Em relação às variáveis de densidade e de incidência é importante reconhecer que o trabalho parte do pressuposto que uma edificação reconhecida por SR é uma unidade habitacional. Isto só pode assumido como aproximação da verdade em áreas de urbanização predominantemente horizontal. Como no subúrbio ferroviário quase $100 \%$ das ocupações é de urbanização horizontal, não foi necessário realizar as correções que estudos em áreas com situação diferente demandam.

Outros cuidados tomados nesta pesquisa no processo de preparação dos dados extraídos de SR para as análises estatísticas devem ser observados por aqueles que desejem seguir essa metodologia. Um deles diz respeito ao cálculo de áreas em cada buffer, como há buffers que se sobrepõe, é importante verificar se toda a área do buffer foi levada em consideração, pois funções zonais de tabulação de áreas em softwares de SIG não costumam considerar a sobreposição de zonas. Outra observação é relativa à necessidade de exclusão de registros localizados onde a imagem (coberta por nuvens ou por sombra de nuvens, por exemplo) não permita a identificação das informações necessárias para o cálculo das variáveis, ou necessidade de ajuste das unidades de análise que estejam parcialmente neste tipo de condição.

Certamente não se esgotam aqui a os resultados, limitações ou possibilidades de continuação desta pesquisa. Nos capítulos anteriores, ao passo que foram mostrados os procedimentos ou teorias utilizadas, foram também apresentadas particularidades positivas e negativas específicas àquele processo. Além disso, releituras da Tese por diferentes pessoas, de diferentes áreas de conhecimento encontrarão novas limitações, novos usos e novas idéias de utilização e aperfeiçoamento da metodologia aqui apresentada. Buscou-se relatar neste capítulo aquelas questões que se destacaram no processo de desenvolvimento da pesquisa ou que são menos específicas a determinado procedimento, para que desenvolvedores de novos estudos possam estimar previamente a adequação desta metodologia aos seus trabalhos. 


\section{CAPÍTULO 9 - CONCLUSÕES}

A hipótese inicial apresentada nesta Tese foi confirmada com os resultados da pesquisa concluindo que é possível usar sensoriamento remoto, no nível de resolução espacial do ambiente intra-urbano, para reconhecer tipologias e elementos urbanos relacionados à ocorrência de casos graves de leptospirose.

Apresenta-se, para tanto, uma metodologia de identificação de parâmetros urbanos relacionados à transmissão da leptospirose, que teve como base, os dados de sensoriamento remoto, destacando suas limitações, potenciais, possiveis extenções e replicações. Tal metodologia (esquematizada na Figura 3.3) consiste, resumidamente, em quatro etapas: estudo de elementos que constituem tipologias presentes na área de pesquisa, em paralelo à identificação de variáveis e elementos que compõem o modelo de risco de transmissão da doença; uso de classificação baseada em objeto para identificação desses elementos em imagens de alta resolução espacial; cálculo das variáveis e tipologias; análises de correlação em escala coerente com aquela indicada no modelo de risco.

Mesmo diante da dificuldade de se integrar conhecimentos nas duas áreas e das limitações explanadas na pesquisa, com a aplicação da metodologia proposta conclui-se que é viável utilizar técnicas avançadas de SR para subsidiar estudos que relacionam a morfologia urbana de áreas complexas e a epidemiologia. No estudo de caso realizado, os resultados encontrados comparando: as tipologias identificadas em produtos de sensoriamento remoto, os padrões de habitablidade e as características da área in loco, mostraram que o método de SR utilizado, classificação baseada em objeto, foi eficiente na identificação alvos em imagem de SR que distinguem tipologias urbanas coerentes com a realidade da área estudada. As primeiras analises estatísticas realizadas mostram que correlações entre a possibilidade de transmissão e ocorrência da leptospirose no Subúrbio Ferroviário e ambiente urbano são mais fortes ou fracas de acordo com o estado de pavimentação e largura das vias e com a qualidade (tamanho e telhado cerâmico) das edificações. $O$ mapeamento dessas características urbanas, como o mapa de localização dos buffers segundo a possibilidade de ocorrência da leptospirose, apresentados na Figura 7.7, servem para subsidiar a priorização de investimentos de infra-estrutura urbana, o direcionamento de ações preventivas, como campanhas educativas e de vacinação, e para aumentar da precisão de diagnósticos precoces.

No entanto, o trabalho realizado com a construção do modelo FPEEA/L deixa claro que identificar a relação existente entre padrões urbanos e a doença não significa dizer de 
imediato que aquele padrão é a causa da doença, que ele em si propicia a sua transmissão, e que por isso ele deva ser o foco das ações públicas. A relação da leptospirose com as vias estreitas e não pavimentadas, por exemplo, está vinculada a indicadores de dificuldade de acesso de veículos de serviços e de carência de infra-estrutura de drenagem e esgotamento, respectivamente. Intervir exclusivamente nos atributos que definiram o padrão urbano nas imagens (largura e pavimentação) não resolverá o problema de saúde pública.

Espera-se que urbanistas, geógrafos, engenheiros e demais profissionais que estudam Salvador se beneficiem também do trabalho de aprofundamento da caracterização das tipologias presentes na cidade e que se apropriem da metodologia, integral ou parcialmente, para aumentar sua capacidade de entendimento do território urbano e as interferências que têm suas configurações sobre a saúde da população. Espera-se que o epidemiologista e profissionais afins utilizem os dados organizados e produzidos durante a pesquisa, aplicando-os em estudos de outras doenças e/ou aprofundando as análises aqui iniciadas, uma vez que terão à sua disposição dados do Subúrbio Ferroviário possíveis de serem agregados em qualquer unidade de análise.

No campo técnico, um dos maiores desafios de pesquisas como a presente, está em utilizar técnicas recentes de processamento de imagens (classificação baseada em objeto e uso de imagens de alta resolução espacial) em áreas de ocupação precária, onde a irregularidade e complexidade dos elementos morfológicos que compõem a cena urbana são bastante elevadas e ainda pouco estudadas. Acrescenta-se a isto: custos de aquisição de softwares específicos de classificação baseada em objeto, como o utilizado nesta pesquisa (eCognition da Definiens, o mais completo e transparente no mercado) e limitação no intercâmbio de informações sobre detalhes do uso da ferramenta devido ao ainda reduzido número de analistas usuários desta técnica, o que, consequentemente, reflete em maiores custos de treinamento ou maior tempo necessário para o aprendizado autodidata.

No entanto, além dos resultados positivos alcançados, para o planejador urbano, cuja formação tem tradicionalmente utilizado imagens para interpretação visual, a metodologia desenvolvida se mostrou factível e apropriada. Sendo esta a formação básica do pesquisador que escreve esta Tese, é possível assumir que isto se dá devido ao fato do método utilizar o um raciocínio baseado em elementos urbanos desde a concepção do modelo de transmissão da doença até a técnica de classificação de imagens baseada em objetos, que usa regras que se assemelham aos critérios utilizados pelo analista ao realizar a classificação visual. 
A facilidade de acesso a dados e tecnologias semelhantes aos utilizados neste estudo só tende a aumentar. A nova geração de satélites civis de alta resolução espacial já se provou comercialmente viável e a tendência e que novos satélites com maior precisão e maior resolução espectral sejam lançados, a exemplo do WorldView-2 (Digital Globe), lançado em 8 de outubro de 2009, que possui 8 bandas multi-espectrais e resolução espacial de $46 \mathrm{~cm}$ na banda pancromática. Com isso, o processo de classificação aqui apresentado poderá ter regras simplificadas e acurácia aperfeiçoada. Novas versões e novos programas de classificação de imagens baseada em objeto surgem a cada ano, promovendo a difusão de seu uso, consolidação de métodos e o barateamento do custo de acesso a essa tecnologia. No Brasil, uma equipe liderada por pesquisadores do Instituto Nacionail de Pesquisas Espaciais (INPE) e da Pontifícia Universidade Católica do Rio de Janeiro (PUC-RJ) já desenvolve algorítimos de classificação baseada em objeto, voltado para processamento de imagens urbanas de alta resolução espacial, que serão implantados em software livre.

No campo conceitual o maior desafio desta Tese está em apontar caminhos para a integração de dados de saúde e o planejamento urbano, através da utilização de técnicas e ferramentas computacionais disponíveis na atualidade e que avançam rapidamente.

Diante dos tantos complicadores e possibilidades expostos, fica mais fácil entender porque tamanha dificuldade dos profissionais em trabalhar na integração dos dados de saúde com dados ambientais intra-urbanos. Mas, as crescentes possibilidades tecnológicas e a disponibilidade de valiosas informações, tanto na área de saúde como na área da análise urbana são, por outro lado, animadoras. As dificuldades não ofuscam o enorme potencial que tem a integração dessas áreas para o melhor entendimento, planejamento e gestão de nossas cidades. Potencial que deve, sem dúvida, continuar a ser explorado. 


\section{REFERÊNCIAS}

AGUDELO-FLÓREZ, P.; RESTREPO-JARAMILLO, B. N.; ARBOLEDA-NARANJO, M. Situación de la leptospirosis en el Urabá antioqueño colombiano: estudio seroepidemiológico y factores de riesgo en población general urbana. Cad Saude Publica, Rio de Janeiro; v.23, n.9, p. 2094-102, Sep. 2007.

AKA, J. P. M. Inventário das tipologias, morfologia e do processo de produção do espaço concreto: o caso de Novos Alagados em Salvador, Bahia-Brasil. 1997. Dissertação (Mestrado em Arquitetura e Urbanismo) - Universidade Federal da Bahia,Salvador, 1977.

AKSOY, S. e AKÇAY, H. G. (2005) Multi-resolution Segmentation and Shape Analysis for Remote Sensing Image Classification Disponível em: $<$ http://www.cs.bilkent.edu.tr/ saksoy/papers/ rast05_multires.pdf>. Acesso em: dezembro de 2005.

ALBERTI, M.; WEEKS, R.; COE, S. Urban Land Cover Change Analysis in Central Puget Sound. PE\&RS. v. 70, n. 9, September 2004.

ALEXANDER, C., ISHIKAWA, S.; SILVERSTEIN, M.; JACOBSON, M.; FIKSDAHL-KING, I.; ANGEL, S. A pattern language. New York: Oxford University Press, 1977.

ALEXANDER, C. The timeless way of building. New York: Oxford University Press, New York, 1979.

AL-KHUDHAIRY, D. H. A.; CARAVAGGI, I.; GIADA, S. Structural Damage Assessments from IKONOS Data Using Change Detection, Object-Oriented Segmentation, and Classification Techniques. PE\&RS, v. 71, n. 7, July 2005.

ALMEIDA, M. A. P. de e ABIKO, A. K. Indicadores de salubridade ambiental em favelas localizadas em áreas de proteção aos mananciais: o caso da favela Jardim Floresta.

Boletim Técnico da Escola Politécnica da USP, Departamento de Engenharia de Construção Civil, BT/PCC/264. São Paulo, EPUSP, 2000.

AMÂNCIO, M. A. ; SANCHES, S. da P. Relacionamento entre a Forma Urbana e as Viagens a pé. In: Anais do Congresso da Associação Nacional de Pesquisa e Ensino em Transportes - XIX ANPET, 2005, Recife - PE. XIX ANPET, 2005

AMBEKAR, A. N.; BHARADWAJ, R. S.; JOSHI, S. A.; KAGAL, A. S.; BAL, A. M. Sero surveillance of leptospirosis among sewer workers in Pune. Indian J Public Health, v.48, n.1, p. 27-9, Jan-Mar 2004.

ÁVILA-PIRES, F. D. de. Princípios de Ecologia Médica. Florianópolis: Ed. da UFSC, 2000.

BAATZ, M.; HOFFMANN, C.; WILLHAUCK, G. Progressing from object-based to objectoriented image analysis. In: BLASCHKE, T.; LANG S.; HAY, G. J. (Eds.) Object-Based Image Analysis: Spatial Concepts for Knowledge-Driven Remote Sensing Applications. Springer Berlin Heidelberg, 2008.

BAILEY, T. C. Spatial statistical methods in health Cad. Saúde Pública, Rio de Janeiro, v. 17, n. 5, p. 1083-1098, set.-out. 2001.

BARCELLOS, C. e SABROZA, P. C. The place behind the case: leptospirosis risk and associated environmental conditions in a flood-related outbreak in Rio de Janeiro. Cadernos de Saúde Pública, Rio de Janeiro v. 17, p. 59-67, 2001.

BARCELLOS, C. e SABROZA, P. C. Socio-environmental determinants of the leptospirosis outbreak of 1996 in western Rio de Janeiro: a geographical approach. Int J Environ Health Res, v. 10, n. 4, p. 301-13, 2000.

BARRETT, F. A. "SCURVY" Lind's medical geography. In: Social Science and Medicine, v. 
33, n. 4, p. 347-353, 1991.

BASSANI, C.; CAVALLI, R. M.; CAVALCANTE, F.; CUOMO, V.; PALOMBO, A.; PASCUCCI, S.; PIGNATTI, S. Deterioration status of asbestos-cement roofing sheets assessed by analyzing hyperspectral data. Remote Sensing of Environment, v. 109, n. 3, p. 361-378, 15 August 2007.

BATISTA, M. E. M. e SILVA, T. C. da. O Modelo ISA/JP - Indicador de Performance para Diagnóstico do Saneamento Ambiental Urbano. Eng. sanit. ambient., v.1. n. 1, p. 55-64, 2006.

BAVIA, M. E. Monitoramento ambiental e o controle das doenças endêmicas através da identificação de áreas de risco. In: II Simpósio Regional de Geoprocessamento e Sensoriamento Remoto, Aracaju, 2004. Anais... Aracaju, 2004.

BAVIA, M. E.; CARNEIRO, D. D.; GURGEL, H. C.; MADUREIRA, F. C.; BARBOSA, M. G. Remote Sensing and Geographic Information Systems and risk of American visceral leishmaniasis in Bahia, Brazil. Parassitologia, v. 47, n. 1, p. 165-9, 2005.

BECK, L. R.; LOBITZ, B. M.; WOOD, B. L. Remote sensing and human health: new sensors and new opportunities. Emerging Infectious Diseases. v. 6, n. 3, 2000.

BELWARD, A. S.; STIBIG, H. J.; EVA, H.; REMBOLD, F.; BUCHA, T.; HARTLEY, A.; BEUCHLE, R.; KHUDHAIRY, D.; MICHIELON, M.; MOLLICONE, D. Mapping severe damage to land cover following the 2004 Indian Ocean tsunami using moderate spatial resolution satellite imagery. International Journal of Remote Sensing, v. 28, n. 13, p. 2977 $-2994,2008$.

BENEDIKTSSON, J. A., SWAIN, P. H.; ERSOY, O. K. Neural network approaches versus atatistical methods in classification of multisource remote sensing data. In: IEE Transactions on Geoscience and Remote Sensing. v. 28, n. 4, July 1990.

BENEDIKTSSON, J. A.; PESARESI, M.; AMASON, K. Classification and feature extraction for remote sensing images from urban areas based on morphological transformations. IEEE Transactions on Geoscience and Remote Sensing, v. 41 n. 9, p. 1940-1949, 2003.

BENZ, U.; HOFMANN, P.; WILLHAUCK, G.; LINGENFELDER, I.; HEYNEN, M. Multiresolution, object-oriented fuzzy analysis of remote sensing data for GIS-ready information. ISPRS Journal of Photogrammetry \& Remote Sensing, v. 58, n. 3-4, p. 239-258, 2003.

BHASKARAN, S.; DATT, B.; FORSTER, B.; NEAL, T.; BROWN. M. Integrating imaging spectroscopy (445-2543 nm) and geographic information systems for post-disaster management: a case of hailstorm damage in Sydney. International Journal of Remote Sensing, v. 25, n. 13, p. 2625 - 2639, 2004.

BIAN, L. Retrieving Urban Objects Using a Wavelet Transform Approach. PE\&RS, v. 69, N. 2, February 2003.

BLASCHKE, T.; GLASSER, C. e LANG, S. Processamento de imagens num ambiente integrado SIG / Sensoriamento remoto - Tendências e consequências. In: BLASCHKE, T. e KUX, H. (orgs.) Sensoriamento Remoto e SIG acançados: novos sistemas: sensores métodos inovadores. Oficina de Textos, São Paulo, 2005.

BOSCHETTI, M. Spectral sensitivity of surfaces. Disponível em: $<$ http://www.eniscuola.net/eng/telerilevamento.aspx?id=105>. Acesso em: 15 de janeiro de 2008.

$\mathrm{BOOCH}, \mathrm{G}$. Object oriented Analysis and Design with Aplications, $2^{\text {nd }}$ edition, Santa Clara, CA: Benjamin/Cumming, 1994.

$\mathrm{BOOCH}, \mathrm{G}$. Object oriented Design with applications. Redwood City, CA: Benjamin/Cumming, 1991. 
BORJA, P. C. e MORAES, L. R. S. Indicadores de Saúde Ambiental com Enfoque para a área de Saneamento. Parte 1 - Aspectos Metodológicos. Engenharia Sanitária e Ambiental. Rio de Janeiro, v. 8, n.1 e n. 2, p. 13 - 25, 2002.

BOVET, P.; YERSIN, C.; MERIEN, F.; DAVIS, C. E.; PEROLAT, P. Factors associated with clinical leptospirosis: a population-based case-control study in the Seychelles (Indian Ocean). Int J Epidemiol, v. 28, n. 3, p. 583-90. 1999.

BRASIL. Fundação Nacional de Saúde. Manual de controle de roedores. - Brasília: Ministério da Saúde, Fundação Nacional de Saúde, 2002.

BRASIL, Ministério da Saúde. Organização Pan-Americana da Saúde. Avaliação de Impactos na Saúde das Ações de saneamento: marco conceitual e estratégia metodológica. Brasília: Ministério da Saúde, 2004.

BRASIL. Ministério da Saúde. Vigilância de Doenças Transmissíveis. Disponível em: $<$ http://portal.saude.gov.br/portal/saude/profissional/visualizar_texto.cfm?idtxt=25340>.

Acesso em: junho de 2008a.

BRASIL. Ministério da Saúde. Doenças Transmissíveis. Disponível em: <http://portal.saude.gov.br/portal/saude/profissional/visualizar_texto.cfm?idtxt=21913>. Acesso em: junho de 2008b.

BRASIL. Ministério das Cidades. Secretaria Nacional de Habitação. Déficit habitacional no Brasil 2007. Brasília, 2009.

BRITO, P. L.; CURTIS, A.; QUINTANILHA, J. A. "Remote Sensing Techniques Applied to Public Health in the Urban Environment, Pros and Cons". In: Urban and Regional Information System Association's GIS in Public Health Conference, 2007, New Orleans. Proceedings... New Orleans: URISA, 2007.

BRITO, P. L.; QUINTANILHA, J. A. Imagens urbanas de alta reolução: panos de fundo e o quê (ou para quê) mais? In: Anais PLURIS 2006 - 20. Congresso Luso Braileiro para o Planejamento Urbano regional integrado e sustentável. Braga, Universidade do Minho, 2006.

BROWNSTEIN, J.S.; ROSEN, H.; PURDY, D.; MILLER, J. R.; MERLINO, M.; MOSTASHARI, F.; FISH, D. Spatial analysis of West Nile virus: rapid risk assessment of an introduced vector-borne zoonosis. Vector Borne Zoonotic Dis. v. 2, n.3, p.157-64, fall 2002. Erratum in: Vector Borne Zoonotic Dis. V. 3, n. 3, p. 155, fall 2003.

BRUZZONE, L. e CARLIN, L. A. Multilevel Context-Based System for Classification of Very High Spatial Resolution Images. IEEE Transactions on Geoscience and Remote Sensing, v. 44, n. 9, p. 2587-2600, 2006.

BURROUGH, P. A. e MCDONNEL, R. A. Principles of Geographical Information Systems. Oxford: Oxford University Press, 1998.

CABLK, M. E. e MINOR, T. B. Detecting and discriminating impervious cover with highresolution IKONOS data using principal component analysis and morphological operators. International Journal of Remote Sensing, v. 24, n. 23, p. 4627 - 4645, 2003.

CACCIAPUOTI, B.; CICERONI, L.; PINTO, A.; APOLLINI, M.; RONDINELLA, V.; BONOMI, U.; BENEDETTI, E.; CINCO, M.; DESSì, S.; DETTORI, G. Survey on the prevalence of leptospira infections in the Italian population. Eur J Epidemiol. v. 10, n.2, p. 173-80, Apr 1994.

CACHAY, E. R. e VINETZ, J. M. A global research agenda for leptospirosis. J Postgrad Med. v. 51, n.3, p. 174-8, Jul-Sep 2005.

CALDAS, C. M. de; YAMAGATA, Y.; MTASIWA, D.; TANNER, M.; UTZINGER, J.; KEISER, J.; SINGER, B. H. Integrated urban malaria control: a case study in dar es salaam, Tanzania. Am J Trop Med Hyg. v.71, n.2, p. 103-17, Aug 2004. 
CÂMARA, G.; CASANOVA, M. A.; HEMERLY, A. S.; MAGALHÃES, G. C.; MEDEIROS, C. $M$. B. Anatomia de sistemas de informação geográfica. Campinas: $X$ Escola de Computação, IC-UNICAMP, 1996.

CAMPBELL, J. B. Origins of aerial photography interpretation , U.S. Army, 1916 to 1918. PE\&RS, v. 74, n.1, pp. 77-93, 2008.

CAMPBELL, J. B. Introduction to Remote Sensing. New York: The Guilford Press 1996.

CAMPOS, L. E. P.; MIRANDA, S. B.; JESUS, A. C.; BURGOS, P. C. Aplicação de geoprocessamento na avaliação de movimento de massa em Salvador/Ba. In: IV COBRAE - Conferência Brasileira sobre Estabilidade de Encostas. Anais... Salvador: ABMS, UFBA, 2005.

CARDOSO, A. L. e ABIKO, A. K. Procedimentos de gestão habitacional para população de baixa renda. In: Coleção Habitare v.5, Porto Alegre: ANTAC, 2006.

CARLEER, A. P.; WOLFF, E. Urban land cover multi-level region-based classification of VHR data by selecting relevant features. International Journal of Remote Sensing, v. 27, n. 6, p. $1035-1051,2006$.

CARLOS, A. F. A. Morfologia e temporalidade urbana: o "tempo efêmero e o espaço amnésico", In: Novos Estudos de Geografia Urbana Brasileira. VASCONCELOS, P. A.; M.; SILVA, S. B. (Orgs.). Salvador: Editora da Universidade Federal da Bahia, 1994.

CARVALHO, M. S. e SOUZA-SANTOS, R. Analysis of spatial data in public health: methods, problems, and perspectives. Cad de Saúde Pública, Rio de Janeiro, v. 21, n. 2, p. 361-378, 2005.

CASTILLA, G. e HAY, G. J. Image objects and Geographic objects. In: BLASCHKE, T.; LANG S.; HAY, G. J. (Eds.) Object-Based Image Analysis: Spatial Concepts for Knowledge-Driven Remote Sensing Applications. Springer Berlin Heidelberg, 2008.

CASTRO, M. C.; MONTE-MÓR, R. L.; SAWYER, D. O.; SINGER, B. H. Malaria risk on the Amazon frontier. Proc Natl Acad Sci U S A., v.103, n. 7, p.2452-7, 14 Feb 2006.

CAZES, T. B. Interpretação baseada em conhecimento de imagens de sensores remotos de alta resolução. 2005. Rio de Janeiro: Dissertação (Mestrado em Engenharia Elétrica) - Pontifícia Universidade Católica do Rio de Janeiro, Rio de Janeiro, 2005.

CHAN, J. C.; KWOK-PING, C.; GAR-ON YEH, A. Detecting the Nature of Change in an Urban Environment: A Comparison of Machine Learning Algorithms ., PE\&RS v. 67, N. 2, February 2001.

CHAN, O. Y.; PAUL, D. R.; SNG, E. H. Leptospirosis among abattoir workers - a serological survey. Singapore Med J, v. 28, n. 4, p. 293-6, 1987.

Chance, A., Newell, R.G. \& Theriault, D.G. An Object-Oriented GIS - Issues and Solutions, In: EG7S '90 Conference Proceedings, Amsterdam, April 1990.

CHANUSSOT, J.; BENEDIKTSSON, J. A.; FAUVEL, M. Classification of remote sensing images from urban areas using a fuzzy possibilistic model. IEEE Geoscience and Remote Sensing Letters, v. 3, n. 1, p. 40-44, 2006.

CHEN, X. L.; ZHAO, H. M.; LI, P. X.; YIN, Z. Y. Remote sensing image-based analysis of the relationship between urban heat island and land use/cover changes Remote Sensing of Environment, v.104, p. 133-146, 2006.

CHEN, D.; STOW, D. A.; GONG, P. Examining the effect of spatial resolution and texture window size on classification accuracy: an urban environment case. International Journal of Remote Sensing, v. 25, n. 11, p. $2177-2192,2004$.

CHEN, Y.; SHI, P.; FUNG, T.; WANG, J.; LI, X. Object-oriented classification for urban land cover mapping with ASTER imagery. International Journal of Remote Sensing, v. 28, n. 
20, p. $4645-4651,2007$.

CHOU, T. Y.; LEI, T. C.; WAN, S.; YANG, L. S. Spatial knowledge databases as applied to the detection of changes in urban land use. International Journal of Remote Sensing, v. 26, n. 14, p. $3047-3068,2005$.

CONGALTON, R. G. e Green, K. Assessing the accuracy of remotely sensed data: principles and practices. Boca Raton: Lewis Publishers, 1999.

CORREIA, V. R. M.; CARVALHO, M. S.; SABROZA., P. C.; VASCONCELOS, C. H. Remote sensing as a tool to survey endemic diseases in Brazil. Cad. Saúde Pública, Rio de Janeiro, v. 20, n.4., 2004.

CORREIA, V. R. M.; MONTEIRO, A. M. V.; CARVALHO, M. S.; WERNECK, G. L. Uma aplicação do sensoriamento remoto para a investigação de endemias urbanas. Cad. Saúde Pública, Rio de Janeiro, v. 23, n. 5, p. 1015-1028, 2007.

COSTA, M. D. S.; RAMOS, R. A. R.; SILVA, A. N. R. da. Índice de Mobilidade Urbana Sustentável para Cidades Brasileiras. ANPET:..., 2007

COUDERT, C.; BEAU, F.; BERLIOZ-ARTHAUD, A.; MELIX, G.; DEVAUD, F.; BOYEAU, E.; JAOMEAU, C.; LABLEE, P.; JARNO, P. [Leptospirose humana na Polinésia Francesa. Aspectos epidêmicos, clinicos e bacteriológicos.] Med Trop (Mars). v.67, n.2, p.137-44, Apr 2007, Artigo em francês.

COURA, J. R. Endemias e meio ambiente no século XXI. Cad. Saúde Pública, Rio de Janeiro, v. 8, n. 3, 1992.

CSATHO, B., E SCHENK, T. Multisensor data fusion for automatic scene interpretation. International Archives of Photogrammetry and Remote Sensing. 32, 429-434, 1998.

CURTIS, A.; MILLS, J. W.; BLACKBURN, J. The Calculation of a Spatial Basic Reproduction number for Yellow Fever in 1878 New Orleans. The Professional Geographer, v. 59, n. 4, p. 492-502, 2007.

DALE, P. E. e MORRIS, C. D. Culex annulirostris breeding sites in urban areas: using remote sensing and digital image analysis to develop a rapid predictor of potential breeding areas. J Am Mosq Control Assoc. v. 12(2 Pt 1), p.316-20, Jun 1996.

DALE, P. E.; RITCHIE, S. A.; TERRITO, B. M.; MORRIS, C. D.; MUHAR, A.; KAY, B. H. An overview of remote sensing and GIS for surveillance of mosquito vector habitats and risk assessment. J Vector Ecol. v. 23, n. 1, p. 54-61, Jun 1998.

DARE, P. M. Shadow Analysis in High-Resolution Satellite Imagery of Urban Areas. PE\&RS v. 71, n. 2, February 2005.

DEFINIENS, A. G. Definiens Professional 5 - User Guide. Germany: Definiens AG, 2006

DEUS, L. R. de; SANTOS-JÚNIOR, L. C. dos; CESÁRIO, F. T.; DEUS, F. C. R. de. Relationships Between Urban Form and Urban Transport. In: Anais do International Seminar on Urban Form, Ouro Preto: 2007.

DIAS, J. P.; TEIXEIRA, M. G.; COSTA, M. C. N.; MENDES, C. M. C. M.; GUIMARÃES, P.; REIS, M. G.; KO, A.; BARRETO, M. L. Factors associated with Leptospira sp infection in a large urban center in northeastern Brazil. Rev Soc Bras Med Trop.v.40, n.5, p.499-504, 2007 Sep-Oct.

DIAS, M. C. Índice de salubridade ambiental em áreas de ocupação espontânea: estudo em Salvador, Bahia.2003. Dissertação (Mestrado em Engenharia Ambientel Urbana) - Escola Politécnica, Universidade Federal da Bahia, Salvador, 2003.

DIEZ-ROUX, A. v. Bringing context back into epidemiology: variables and fallacies in multilevel analysis. Am J Public Health, v. 88, p. 216-22, 1998. 
DOUCETTE, P.; AGOURIS, P.; STEFANIDIS, A. Automated Road Extraction from High Resolution Multispectral Imagery, PE\&RS, v. 70, n. 12 December 2004.

DOUGLIN, C. P.; JORDAN, C.; ROCK, R.; HURLEY, A.; LEVETT, P. Risk factors for severe leptospirosis in the parish of St. Andrew, Barbados. Emerg. Infect. Dis., v. 3, n. 1, p. 78-80, 1997.

DRUMOND-JUNIOR, M. Índice de Saúde. São Paulo: Coordenação de Epidemiologia e Informação, Secretaria Municipal de Saúde do município de São Paulo, 2002.

EASTMAN KODAK COMPANY. KODAK AEROCHROME III MS, Film 2427. Rochester, NY: KODAK Publication No. AS-2569. Disponível em: <http://www.kodak.com/eknec/documents/37/0900688a802b0837/EN_ti2527.pdf>. Acesso em: 9 de fevereiro de 2009.

EHLERS, M. Sensoriamento Remoto para Usuários de SIG - Sistemas de Sensores e Métodos: as exigências e a Realidade. In: Blaschke, T.; H.; Kux, (orgs.), Sensoriamento Remoto e SIG: novos sistemas sensores: métodos inovadores / versão brasileira. São Paulo: Oficina de Textos, 2005.

EHLERS, M. (Ed.). Remote sensing for environmental monitoring, GIS applications, and geology. Proceedings of SPIE. Bellingham, WA: v.4545, 2002.

EISELE, T. P.; KEATING, J.; SWALM, C.; MBOGO, C. M.; GITHEKO, A. K.; REGENS, J. L.; GITHURE, J. I.; ANDREWS, L.; BEIE, J. C. Linking field-based ecological data with remotely sensed data using a geographic information system in two malaria endemic urban areas of Kenya. Malar J, v. 2, n. 1, p.44, 2003.

ELLIOTT, P. e WARTENBERG, D. Spatial Epidemiology: Current Approaches and Future Challenges. Environmental Health Perspectives, v. 112 n. 9. June 2004.

EMERSON, C. W.; LAM, N. S. N.; QUATTROCHI, D. A. A comparison of local variance, fractal dimension, and Moran's I as aids to multispectral image classification. International Journal of Remote Sensing, v. 26, n. 8, p. 1575 - 1588, 2005.

ERCOLIN F., L. Caracterização de objetos do cenário urbano através de índices de realce extraídos de dados do sensor HRSC-AX. 2009. Dissertação (Mestrado em Engenharia de Transportes) - Escola Politécnica da Universidade de São Paulo, São Paulo, 2009.

EVERARD, C. O.; HAYES, R. J.; FRASER-CHANPONG, G. M. A serosurvey for leptospirosis in Trinidad among urban and rural dwellers and persons occupationally at risk. Trans R Soc Trop Med Hyg.v.79, n.1, p.96-105, 1985.

EVERARD, C. O.; MAUDE, G. H.; HAYES, R. J. Leptospiral infection: a household serosurvey in urban and rural communities in Barbados and Trinidad. Ann Trop Med Parasitol., v.84, n.3, p.255-66, Jun 1990.

EVERARD, C. O.; BENNETT, S.; EDWARDS, C. N.; NICHOLSON, G. D.; HASSELL, T. A.; CARRINGTON, D. G.; EVERARD, J. D. An investigation of some risk factors for severe leptospirosis on Barbados. J Trop Med Hyg, v. 95, n. 1, 13-22, 1992.

FARIA, M. T.; CALDERWOOD, M. S.; ATHANAZIO, D. A.; MCBRIDE, A. J.; HARTSKEERL, R. A.; PEREIRA, M. M.; KO, A. I.; REIS, M. G. Carriage of Leptospira interrogans among domestic rats from an urban setting highly endemic for leptospirosis in Brazil. Acta Trop., v.108, n.1, p.1-5, October 2008.

FAUVEL, M.; CHANUSSOT, J.; BENEDIKTSSON, J. A. Decision Fusion for the Classification of Urban Remote Sensing Images. IEEE Transactions on Geoscience and Remote Sensing, v. 44, n. 10, p. 2828-2838, 2006.

FELZEMBURGH, R. D. M. História natural da leptospirose urbana: estudo longitudinal prospectivo em uma comunidade de alto risco durante epidemias urbanas em 
Salvador - Bahia. 2006. Dissertação (Mestradoem Patologia) - Centro de Pesquisas Gonçalo Moniz da Faculdade de Medicina da Universidade Federal da Bahia, Salvador, 2006.

FERRO, B. E.; RODRÍGUEZ, A. L.; PÉREZ, M.; TRAVI, B. L. Seroprevalencia de infección por Leptospira en habitantes de barrios periféricos de Cali. Biomedica.,v.26, n.2, p.250-7, Jun 2006.

FLANNERY, B.; PEREIRA, M. M.; VELLOSO, L. F.; CARVALHO, C. C.; CODES, L. G.; ORRICO, G. S.; DOURADO, C. M. R.; RILEY, L. W.; REIS, M. G.; KO, A. I. Referral pattern of leptospirosis cases during a large urban epidemic of dengue. Am. J. Trop. Med. Hyg, v. 65, n. 5, p. 657-663, 2001.

FREY, C. M.; RIGO, G.; PARLOW, E. Urban radiation balance of two coastal cities in a hot and dry environment. International Journal of Remote Sensing, v. 28, n. 12, p. 2695 2712, 2007.

FUENTES, M. V.; MALONE, J. B.; MAS-COMA, S. Validation of a mapping and prediction model for human fasciolosis transmission in Andean very high altitude endemic areas using remote sensing data. Acta Trop. v.79, n.1, p.87-95, Apr 2001.

GALLION, A. e EISNER, S. The urban pattern: City planning and Design. Nova York: Van Nostrand Reinkold Company Inc., 5ª . Edição, 1986.

GAO, B. C. NDWI-a normalized difference water index for remote sensing of vegetation liquid water from space. Remote Sensing of Environment, v.58, p.257-266, 1996.

GHNEIM, G. S.; VIERS, J. H.; CHOMEL, B. B.; KASS, P. H.; DESCOLLONGES, D. A.; JOHNSON, M. L. Use of a case-control study and geographic information systems to determine environmental and demographic risk factors for canine leptospirosis. Vet Res., v.38, n.1, p.37-50, Jan-Feb 2007.

GLUCH, R.; QUATTROCHI, D. A.; LUVALL, J. C. A multi-scale approach to urban thermal analysis. Remote Sensing of Environment, v. 104, n. 2, 30, p. 123-132, September 2006.

GORDILHO-Souza, A. Limites do Habitar: segregação e exclusão na configuração urbana conteporânea de Salvador e perspectivas no final do século XX. Salvador: EDUFBA, 2000.

GREENHILL, D. R.; RIPKE, L. T.; HITCHMAN, A. P.; JONES, G. A.; WILKINSON, G. G. Characterization of suburban areas for land use planning using landscape ecological indicators derived from IKONOS-2 multispectral imagery. IEEE Transactions on Geoscience and Remote Sensing, v. 41, n. 9, p. 2015-2021, 2003.

GUBLER, D. J.; REITER P.; EBI, K. L.; YAP, W.; NASCI, R.; PATZ, J. A. Climate variability and change in the United States: potential impacts on vector- and rodent-borne diseases. Environ Health Perspect, v. 109 n. 2, p. 223-233, 2001.

GUINDON, B.; ZHANG, Y.; DILLABAUGH, C. Landsat urban mapping based on a combined spectral-spatial methodology. Remote Sensing of Environment, v. 92, n. 2, p 218-232, 15 August 2004.

HARTIGAN, J.A. Clustering Algorithms. New York: John Wiley \& Sons, Inc., 1975.

HAY, S. I. e TATEM, A. J. Remote sensing of malaria in urban areas: two scales, two problems.Am J Trop Med Hyg., v.72, n.6, p.655-6, Jun 2005.

HAY, G. J. e CASTILLA, G. Geographic Object-Based Image Analysis (GEOBIA) In: BLASCHKE, T.; LANG S.; HAY, G. J. (Eds.) Object-Based Image Analysis: Spatial Concepts for Knowledge-Driven Remote Sensing Applications. Berlin, Heidelberg: Springer, 2008.

HEROLD M.; LIU, X. H.; CLARKE, K. C. Spatial Metrics and Image Texture for Mapping Urban Land Use. PE\&RS,. v. 69, n. 9, September 2003. 
HEROLD, M.; GARDNER, M.; HADLEY, B.; ROBERTS, D. The spectral Dimension in Urban Land Cover Mapping from High-resolution Optical Remote Sensing Data. In: Third International Symposium Remote Sensing of Urban Areas, Istambul, 2002. Proceedings... Istambul, 2002.

HESTER, D. B.; CAKIR, H. I.; NELSON, S. A. C.; KHORRAM, S. Per-pixel Classification of High Spatial Resolution Satellite Imagery for Urban Land-cover Mapping., PE\&RS, v. 74, n. 4, April 2008.

HU, X. e TAO, V. Automatic Extraction of Main Road Centerlines from High Resolution Satellite Imagery Using Hierarchical Grouping. PE\&RS, v. 73, n. 9, September 2007.

HU, X.; TAO V.; PRENZEL, B. Automatic Segmentation of High-resolution Satellite Imagery by Integrating Texture, Intensity, and Color Features., PE\&RS,.v. 71, n. 12, December 2005.

HUFF, D. How to lie with statistics. W.W. Norton \& Co., New York. 1993.

HUNG, M. C. e RIDD, M. K. A Subpixel Classifier for Urban Land-Cover Mapping Based on a Maximum-Likelihood Approach and Expert System Rules. PE\&RS,v. 68, n. 11, November 2002.

HURSKAINEN, P. e PELLIKKA, P. Change Detection of Informal Settlements Using Multi Temporal Arerial Photographs - The Case of Voi, SE-Kenya. In: 5th African Association of Remote Sensing of Environment Conference, Kenya, 2004. Proceedings... Nairobi, 2004.

INSTITUTO BRASILEIRO DE GEOGRAFIA ESTATÍSTICA. Censo Demográfico 2000. Disponível em: http://www.ibge.gov.br/ (2000).

INSTITUTO NACIONAL DE PESQUISAS ESPACIAIS. Tutorial de geoprocessamento. Disponível em: <http://www.dpi.inpe.br/spring/ portugues/tutorial/classific.html>. Acesso em: abril de 2008.

INSTITUTO NACIONAL DE PESQUISAS ESPACIAIS. Curso Processamento Digital de Imagens: Processamento de Cores . Disponível em: $<$ http://www.dpi.inpe.br/ carlos/Academicos/Cursos/Pdi/pdi_cores.html>. Acesso em: 05 de janeiro de 2009.

ISLAM, Z. e METTERNICHT, G. The Performance of Fuzzy Operators on Fuzzy Classification of Urban Land Covers, PE\&RS, v. 71, n. 1, January 2005.

JACOB, B. G.; MUTURI, E. J.; CAAMANO, E. X.; GUNTER, J. T.; MPANGA, E.; AYINE, R.; OKELLOONEN, J.; NYEKO, J. P.; SHILILU, J. I.; GITHURE, J. I.; REGENS, J. L.; NOVAK, R. J.; KAKOMA, I. Hydrological modeling of geophysical parameters of arboviral and protozoan disease vectors in Internally Displaced People camps in Gulu, Uganda. Int $\mathbf{J}$ Health Geogr. v.14, n.7, Mar 2008.

JACOB, B. G.; SHILILU, J.; MUTURI, E. J.; MWANGANGI, J. M.; MURIU, S. M.; FUNES, J.; GITHURE, J.; REGENS, J. L.; NOVAK, R. J. Spatially targeting Culex quinquefasciatus aquatic habitats on modified land cover for implementing an Integrated Vector Management (IVM) program in three villages within the Mwea Rice Scheme, Kenya. Int J Health Geogr, v. 5, n. 18.2006.

JAIN, S. e JAIN, R. K. A remote sensing approach to establish relationships among different land covers at the micro level. International Journal of Remote Sensing, v. 27, n. 13, p. 2667 - 2682, 2006.

JAKOB, A. A. E. A. Krigagem como Método de Análise de Dados Demográficos. In: XIII Encontro da Associação Brasileira de Estudos Populacionais, Ouro Preto, 2002. Anais... Ouro Preto, 2002.

JACOBSEN K.. High Resolution Satellite Imaging Systems - Overview, ISPRS Hannover Workshop 2005, High-Resolution Earth Imaging for Geospatial Information, Hannover, 
Germany, May 2005.

JENSEN, J. R., COWEN, D. J., HALLS, J. NARUMALANI, S., SCHMIDT, N. J., DAVIS B. A. E BURGESS, B. Improved urban infrastructure mapping and forecasting for BellSouth using remote sensing and GIS technology. Photogrammetric Engineering and Remote Sensing, v.60, p. 339-346, 1994.

JOHNSON, M. A.; SMITH, H.; JOEPH, P.; GILMAN, R. H.; BAUTISTA, C. T.; CAMPOS, K. J. Environmental exposure and leptospirosis, Peru. Emerg Infect Dis, v. 10, n. 6, p. 101622, 2004.

JOHNSON, S. The Ghost Map: The Story of London's Most Terrifying Epidemic-And How It Changed Science, Cities, and the Modern World. New York, Riverhead Books, New York, 2006.

KAMPOURAKI, M.; WOOD, G. A.; BREWER T. R. Opportunities and limitations of object based image analysis for detecting urban impervious and vegetated surfaces using truecolour aerial photography. In: BLASCHKE, T., LANG, S., HAY G. J. (Eds.) Object-Based Image Analysis Spatial Concepts for Knowledge-Driven Remote Sensing Applications. Springer Berlin Heidelberg, 2008.

KARIV, R.; KLEMPFNER, R.; BARNEA, A.; SIDI, Y.; SCHWARTZ, E. The changing epidemiology of leptospirosis in Israel. Emerg Infect Dis, v. 7, n. 6, p. 990-2, 2001.

KATZ, A. R.; ANSDELL, V. E.; EFFLER, P. V.; MIDDLETON, C. R.; SASAKI, D. M. Leptospirosis in Hawaii, 1974-1998: epidemiologic analysis of 353 laboratory-confirmed cases. Am J Trop Med Hyg, v. 66, n. 1, 61-70, 2002.

KAYA; CURRAN, P. J.; LLEWELLYN, G. Post-earthquake building collapse: a comparison of government statistics and estimates derived from SPOT HRVIR data. International Journal of Remote Sensing, v. 26, n. 13, p. $2731-2740,2005$.

KIM, T. Semiautomatic Building Line Extraction from IKONOS Images Through Monoscopic Line Analysis. PE\&RS. v. 72, n. 5, May 2006.

KNOPIK Beltrame, A. M. Mapeamento da cobertura do solo ao longo da faixa de domínio de trem metropolitano: Linha F em São Paulo. 2008. Dissertação (Mestrado em Engenharia de Transportes) - Escola Politécnica da Universidade de São Paulo, São Paulo, 2008.

KO, A. I.; REIS, M. G., DOURADO, C. M. R., JOHNSON, W. D.; RILEY, L. W. e Salvador Leptospirosis Study Group. Urban epidemic of severe leptospirosis in Brazil. Lancet, v. 354, n. 9181 , p. 820-5, 1999.

KOSTER, E. Urban Morphology and computers, ten years after. In: Anais do International Seminar on Urban Form, Ouro Preto: 2007.

KOSUGI, Y.; SAKAMOTO, M.; FUKUNISHI, M.; WEI, L.; DOIHARA, T.; KAKUMOTO, S. Urban change detection related to earthquakes using an adaptive nonlinear mapping of high-resolution images. IEEE Geoscience and Remote Sensing Letters, v. 1, n. 3, p. 152156, 2004.

KRAFTA, R.; ZECHLINSKI, A. P.; KOKUBUN, Y. Morphometry and Urban Form Description. . In: Anais do International Seminar on Urban Form, Ouro Preto: 2007.

KRESSLER, F. P.; STEINNOCHER, K.; FRANZEN, M. Object-Oriented Classification of Orthophotos to support update of Spatial Databases. In: IGARSS 2005 Symposium, Seoul, 2005. Proceedings... Korea, 2005.

KUX, H. J. H.; ARAÚJO, E. H. G. Object-based Image Analysis using QuickBird satellite images and GIS data, case study Belo Horizonte (Brazil). In: BLASCHKE, T.; LANG S.; HAY, G. J. (Eds.) Object-Based Image Analysis: Spatial Concepts for KnowledgeDriven Remote Sensing Applications. Berlin, Heidelberg: Springer, 2008. 
KWARTENG, A. Y. e AL-ENEZI, A. Assessment of Kuwait's Al-Qurain landfill using remotely sensed data. J Environ Sci Health A Tox Hazard Subst Environ Eng v. 39, n. 2, p. 35164, 2004.

LALIBERTE, A. S.; RANGO, A.; FREDRICKSON, E. L. Separating green and senescent vegetation in very high resolution photography using an intensity-hue-saturation transformation and object based classification. In: ASPRS 2006 Annual Conference Reno, Nevada, 2006. Proceedings... Nevada, 2006.

LAMAS, J. P. G. Morfologia urbana e desenho da cidade. Lisboa: Fundação Calouste Gulbentrian, Junta de Investigação Científica e Tecnológica, 2004.

LANG, S. e LANGANKE, T. Object-based mapping and objectrelationship modeling for land use classes and habitats. Photogrammetrie-Fernerkundung-Geoinformation. Journal of the DGPF, German Society for Photogrammetry and Remote Sensing, v.1, n.6, p. 5-18, 2006.

LEE, S.; SHAN, J.; BETHEL J. S. Class-Guided Building Extraction from IKONOS Imagery. PE\&RS, v. 69, n. 2, February 2003.

LEE, S. e LATHROP, R. G. Sub-pixel analysis of Landsat ETM using Self-Organizing Map (SOM) neural networks. IEEE GeoScience and Remote Sensing Letters, v. 44, n. 6, p. 1642-1654, 2006.

LEE, S. e LATHROP, R. G. Sub-pixel estimation of urban land cover components with linear mixture model analysis and Landsat Thematic Mapper imagery. International Journal of Remote Sensing, v. 26, n. 22, p. 4885 - 4905, 2006.

LEFEBVRE, H. La Production de L’Espace. 4ㄹeㄹ. Paris: Anthropos, , 2000.

LEVETT, P. N. Leptospirosis. Clin Microbiol Rev, v. 14, p. 296-326, 2001.

LI, J.; LI, Y.; CHAPMAN, M. A.; RUTHER, H. Small-Format Digital Imaging for Informal Settlement Mapping.PE\&RS. V.71, n.4, p. 375-470, 2005.

LILLESAND, T. M; KIEFER, R. W.; CHIPMAN, J. W. Remote Sensing and Image Interpretation. 6th ed. Hoboken, NJ: John Wiley \& Sons, 2008.

LIU, X. H.; CLARKE, K.; HEROLD, M. Population Density and Image Texture: A Comparison Study. PE\&RS, v. 72, n. 2, February 2006.

LO, C. P. e CHOI, J. A hybrid approach to urban land use/cover mapping using Landsat 7 Enhanced Thematic Mapper Plus (ETM+) images. International Journal of Remote Sensing, v. 25, n. 14, p. 2687 - 2700, 2004.

LO, C. P. e QUATTROCHI, D. A. Land-Use and Land-Cover Change, Urban Heat Island Phenomenon, and Health Implications: A Remote Sensing Approach. PE\&RS. v. 69, n. 9, September 2003.

LO, C.P. e YANG, X. Drivers of Land-Use/Land-Cover Changes and Dynamic Modeling for the Atlanta, Georgia Metropolitan Area. PE\&RS, v. 68, n. 10, October 2002.

LOINTIER, M.; TRUC, P.; DRAPEAU, L.; NANGA, S.; TAREK M. Methodologie de determination de zones a risque de maladie du sommeil en Cote d'Ivoire par approche spatialisee. Med Trop v. 61, n.4-5, p. 390-6, 2001.

LÓPEZ-ABENTE, G.; POLLÁN, M.; ARDANAZ, E.; ERREZOLA, M. Geographical pattern of brain cancer incidence in the Navarre and Basque Country regions of Spain. Occup Environ Med.,v.60, n. 7, p. 504-8, Jul 2003.

LOURES, M. F.; COELHO, G.; CAVALLAZZI, R. L. Predictability and Unpredictability in the news forms of Landscape: Urban Design and the favelas. In: Anais do International Seminar on Urban Form, Ouro Preto: 2007. 
LU, D. e WENG, Q. Spectral Mixture Analysis of the Urban Landscape in Indianapolis City with Landsat ETM+ Imagery., PE\&RS, v. 70, n. 9, September 2004

LU, D. e WENG, Q. Urban Classification Using Full Spectral Information of Landsat EMT+ Imagery in Marion County, Indiana, PE\&RS v. 71, n. 11, November 2005.

LU, D. e WENG, Q. Use of impervious surface in urban land-use classification. Remote Sensing of Environment, v. 102, n. 1-2, 30, p. 146-160, May 2006.

LU, Y. H.; TRINDER, J. C.; KUBIK, K. Automatic Building Detection Using the DempsterShafer Algorithm. PE\&RS, v. 72, n. 4, April 2006.

LYNCH, K. The Image of the City. Cambridge, MA: MIT Press, 1960.

MACHADO, C. A. S. Determinação do índice de acessibilidade do municipio de Osasco/SP pelo uso de imagens de alta resolução espacial e SIG - uma proposta metodológica. 2008. Dissertação (Mestrado em Engenharia de Transportes) - Escola Politécnica da Universidade de São Paulo, São Paulo, 2008.

MACIEL, E. A.; CARVALHO, A. L. De; NASCIMENTO, S. F.; MATOS, R. B. De; GOUVEIA, E. L.; REIS, M. G.; KO, A. I. Household transmission of leptospira infection in urban slum communities. PLoS Negl Trop Dis. v.2, n.1, p.154, Jan 2008.

MACLEOD, R. D. E CONGALTON, R. G. A quantitative comparison of change-detection algorithms for monitoring eelgrass from remotely sensed data. PE\&RS, v.64, p.207-216, 1998.

MADHAVAN, B. B.; KUBO, S.; KURISAKI, n.; SIVAKUMAR, T. v. L. n. Appraising the anatomy and spatial growth of the Bangkok Metropolitan area using a vegetationimpervious-soil model through remote sensing. International Journal of Remote Sensing, v. 22 , n. 5 , p. $789-806,2001$.

MAXWELL, D.; ARMAR-KLEMESU, M.; BRAKOHIAPA, L.; ANNORBAH-SARPEIL, J. Participatory concept mapping to understand perceptions of urban malnutrition. PLA Notes, IIED London, v. 30, pp.11-15, 1997.

MCMAHON, G. Consequences of Land-cover Misclassification in Models of Impervious Surface. PE\&RS, v. 73, n. 12, December 2007.

MEADEN, G. J. e KAPETSKY, J. M. (1995) Geographical information systems and remote sensing in inland sheries and aquaculture. FAO Fish tech. Disponível em: <http://www.fao.org/docrep/003/T0446E/T0446E04.htm>. Acesso em: 19 de fevereiro de 2009.

MENNIS, J. Socioeconomic-Vegetation Relationships in Urban, Residential Land: The Case of Denver, Colorado. PE\&RS, v. 72, n. 8, August 2006.

MESEV, V. e WALRATH, A. GIS and remote sensing integration: in search of a definition. In: MESEV, v. (edit). Integration of GIS and Remote Sensing.West Sussex, England: John Wiley \& Sons, Ltd, 2007.

MIRANDA, C.; MASSA, J. L.; MARQUES C. C. O sensoriamento remoto como ferramenta de vigilância em endemias brasileiras. Rev Saude Publica, São Paulo, v.30, n.5, p.433-7, out 1996.

MIRANDA, C.; MARQUES, C. C.; MASSA, J. L. Sensoriamento remoto orbital como recurso para analise da ocorrencia da leishmaniose tegumentar americana em localidade urbana da regiao sudeste do Brasil. Rev Saude Publica, São Paulo, v. 32, n. 5, p. 455-63, 1998.

MÖLLER, M. AND BLASCHKE, T. A new index for the differentiation of vegetation fractions in urban neighborhoods based on satellite imagery. In: ASPRS 2006 Annual Conference Reno, Nevada, 2006. Proceedings... Nevada, 2006.

MOLONEY, J. M.; SKELLY, C.; WEINSTEIN, P.; MAGUIRE, M.; RITCHIE, S. "Domestic 
Aedes aegypti breeding site surveillance: limitations of remote sensing as a predictive surveillance tool." Am J Trop Med Hyg, v. 59, n. 2, p. 261-4, 1998.

MONMONIER, M. How to lie with maps. 2a ed. Chicago, Illinois. University of Chicago, 1996.

MORAES, O. B. de. Método de análise de dados para avaliação de áreas urbanas recuperadas : Uma abordagem utilizando a lógica fuzzy. 2008. Tese (Doutorado em Engenharia de Construção Civil) - Escola Politécnica da Universidade de São Paulo, São Paulo, 2008.

MORGAN, J.; BORNSTEIN, S. L.; KARPATI, A. M.; BRUCE, M.; BOLIN, C. A.; C. AUSTIN, C. C.; WOODS, W.; LINGAPPA, J.; LANGKOP, C.; DAVIS, B.; GRAHAM, D. R.; PROCTOR, M.; ASHFORD, D. A.; BAJANI, M.; BRAGG, S. L.; SHUTT, K.; PERKINS, B. A.; TAPPERO, J. W. Outbreak of leptospirosis among triathlon participants and community residents in Springfield, Illinois, 1998. Clin Infect Dis, v. 34, p. 1593-9, 2002.

MYEONG, S.; NOWAK, D. J.; DUGGIN, M. J. "A temporal analysis of urban forest carbon storage using remote sensing Remote Sensing of Environment, v. 101, n. 2, 30, p. 277282, March 2006.

MYINT, S. W. Fractal approaches in texture analysis and classification of remotely sensed data: comparisons with spatial autocorrelation techniques and simple descriptive statistics. International Journal of Remote Sensing, v. 24, n. 9, p. 1925 - 1947, 2003.

MYINT, S. W.; LAM, n.; TYLER, J. M. Wavelets for Urban Spatial Feature Discrimination: Comparisons with Fractal, Spatial Autocorrelation, and Spatial Co-occurrence Approaches. , PE\&RS. v. 70, n. 7, July 2004.

MYINT, S. W.; WENTZ, E. A.; PURKIS, S. J. Employing Spatial Metrics in Urban Landuse/Landcover Mapping: Comparing the Getis and Geary Indices. PE\&RS, v. 73, n. 12, December 2007.

NARITA, M. S.; FUJITANI, S.; Haake, D. A.; Paterson, D. L. Leptospirosis after recreational exposure to water in the Yaeyama islands, Japan. Am J Trop Med Hyg, v. 73 n. 4, p. 6526, 2005.

NAVULUR, K. Multispectral Image Analysis Using the Object-Oriented Paradigm. Boca Raton, Florida, USA: Taylor \& Francis Group, 2007.

NETZBAND, M.; STEFANOV, W. L.; REDMAN, C. Remote sensing as a tool for Urban planing and Sustentability. In: Netzband, M, Stefanov, W. L. E Redman, C. (eds.) Applied Remote Sensing for Urban Planning, governance and Sustentability. Berlin: Springer, 2007.

NICHOL J.; KING, B.; QUATTROCHI, D.; DOWMAN, I.; EHLERS, M.; DING, X. L. Earth Observation for Urban Planning and Management. State of the art and Recommendations for application of Earth observation and urban planning. PE\&RS, v.73, n.9, p. 973-979, September 2007.

NICHOL, J. e LEE, C. M. Urban vegetation monitoring in Hong Kong using high resolution multispectral images. International Journal of Remote Sensing, v. 26, n. 5, p. $903-918$, 2005.

NÓBREGA, R. A. A. Detecção da malha viária na periferia urbana de São Paulo utilizando imagens orbitais de alta resolução espacial e classificação orientada a objetos. 2008. Tese (Doutorado em Engenharia de Transportes) - Escola Politécnica da Universidade de São Paulo, São Paulo, 2008.

NÓBREGA, R. A. A.; OHARA, C. G.; QUINTANILHA, J. A. An object-based approach to detect road features for informal settlements near Sao Paulo, Brazil. In: BLASCHKE, T.; LANG S.; HAY, G. J. (Eds.) Object-Based Image Analysis: Spatial Concepts for 
Knowledge-Driven Remote Sensing Applications. Berlin, Heidelberg: Springer, 2008.

NÓBREGA, R. A. A.; QUINTANILHA, J. A.; OHARA, C. G. Detecting roads in informal settlements surrounding Sao Paulo city by using object-based classification. In: OBIA'06 - $1^{\text {st }}$ International Conference on Object-Based Image Analysis, Salzburg, 2006. Proceedings... Salzburg: Salzburg University, 2006.

NOVAK, J. D. e CAÑAS, A. J. The Theory Underlying Concept Maps and How to Construct and Use Them. Technical Report of Institute for Human and Machine Cognition. Disponível em: <http://cmap.ihmc.us/Publications/ResearchPapers/TheoryUnderlying ConceptMaps.pdf> Acesso em fevereiro de 2008.

NOVAK, J. D. Learning, creating, and using knowledge: Concept maps as facilitative tools in schools and corporations. Mahwah: Lawrence Erlbaum Associates, 1998.

NOVAK, J. D. e CAÑAS, A. J. The Theory Underlying Concept Maps and How to Construct and Use Them. Technical Report IHMC CmapTools 2006-01 Rev 01-2008. Disponível em: http://cmap.ihmc.us/Publications/ResearchPapers/TheoryUnderlying ConceptMapsHQ.pdf> Acesso em: fevereiro de 2008

NOVAK, M.; GILLILAND, J.; PADDLE, E. Advancing urban morphology with GIS. In: Anais do International Seminar on Urban Form, Ouro Preto: 2007.

NOVO, E. M. L. M. Sensoriamento Remoto: princípios e aplicações. São Paulo: Editora Edgard Blucher Ltda. 2003.

OBSERVATÓRIO DAS METRÓPOLES. Nota metodológica a respeito da construção do ICH. Disponível em: <http://www.observatoriodasmetropoles.ufrj.br/metrodata/ich/ metod_ich.pdf>. Acesso em: 10 de março de 2009.

\section{ICH - Índice de Carência na Oferta de Serviços Essenciais à Habitacão.}

Disponível em: http://www.observatoriodasmetropoles.ufrj.br/metrodata/ich/index.html,. Acesso em: junho de 2008.

OLSON, C. E. Elements of photographic interpretation common to several sensors. Photogrammetric Engineering. v.26: p.651-656, 1960..

ORUN, A. B. Automated Identification of Man-Made Textural Features on Satellite Imagery by Bayesian Networks. PE\&RS, v. 70, n. 2, February 2004.

OUMA, Y. O.; NGIGI, T. G.; TATEISHI, R. On the optimization and selection of wavelet texture for feature extraction from high-resolution satellite imagery with application towards urban-tree delineation. International Journal of Remote Sensing, v. 27, n. 1, p. $73-104$, 2006.

PAES, F. C.; PINTO, S. A. F.; DUTRA, L. v. Um estudo exploratório para obtenção de índices de qualidade de vida urbana (IQV) utilizando imagens de alta resolução do satélite IKONOS II. In: Anais XI SBSR, 05 - 10 abril 2003. Belo Horizonte: INPE, 2003.

PATHAK, V. e DIKSHIT, O. Conjoint analysis for quantification of relative importance of various factors affecting BPANN classification of urban environment International Journal of Remote Sensing, v. 27, n. 21, p. $4769-4789,2006$.

PEREIRA, M. M. e ANDRADE, J. Human leptospirosis in a slum area in the city of Rio de Janeiro, Brazil - a serological and epidemiological study. Mem Inst Oswaldo Cruz, v. 85, n. 1, p. 47-52, 1990.

PERRA, A.; SERVAS, V.; TERRIER, G.; POSTIC, D.; BARANTON, G.; ANDRE-FONTAINE, G.; VAILLANT, V.; CAPEK, I. Clustered cases of leptospirosis in Rochefort, France, June 2001. Euro Surveill, v. 7, n. 10, p. 131-6, 2002.

PERRET, P. C.; ABARCA, V. K.; DABANCH, P. J.; SOLARI, G. V.; GARCIA, C. P.; CARRASCO, L. S.; OLIVARES, C. R.; AVALOS, P. Prevalencia y presencia de factores de 
riesgo de leptospirosis en una poblacion de riesgo de la Region Metropolitana Rev Med Chil, v. 133, n. 4, p. 426-31, 2005.

PERROCHEAU, A. e PEROLAT, P. Epidemiology of leptospirosis in New Caledonia (South Pacific): a one-year survey. Eur J Epidemiol, v.13, n.2, p.161-7, Feb 1997.

PHILIPP, R; WAITKINS, S.; CAUL, O.; ROOME, A.; MCMAHON, S.; ENTICOTT, R. Leptospiral and hepatitis $A$ antibodies amongst windsurfers and waterskiers in Bristol City Docks. Public Health,v.103, n.2, p.123-9, Mar 1989..

PHINN, S.; STANFORD, M.; SCARTH, P.; MURRAY, A. T.; SHYY, P. T. Monitoring the composition of urban environments based on the vegetation-impervious surface-soil (VIS) model by subpixel analysis techniques. International Journal of Remote Sensing, v. 23, n. 20, p. $4131-4153,2002$

PIANTADOSI, S.; BYAR, D. P.; GREEN, S. N. The ecological fallacy. Am J Epidemiol, V.127, p.893-904, 1988.

PINHO, C. M. D.; FEITOSA, F. F.; KUX, H. J. H. Classificação automática de cobertura do solo urbano em imagens IKONOS: comparação entre a abordagem pixel-a-pixel e orientada a objetos. In: XII Simpósio Brasileiro de Sensoriamento Remoto, Goiânia, 2005. Anais... Goiânia: INPE, p. 4217-4224, 2005.

PORTUGAL, J. L. Sistemas de informações geográficas para o programa de saúde da família. 2003. Tese (Doutorado) - Escola Nacional de Saúde Pública Sergio Arouca, Rio de Janeiro, 2003.

POTERE, D.; FEIERABEND, N.; STRAHLER, A. H.; BRIGHT, E. E. Wal-Mart from Space: A New Source for Land Cover Change Validation, PE\&RS. v. 74, n. 7, July 2008.

POWELL, R. L.; ROBERTS, D. A.; DENNISON, P. E.; HESS, L. L. Sub-pixel mapping of urban land cover using multiple endmember spectral mixture analysis: Manaus, Brazil. Remote Sensing of Environment, v. 106, n. 2, 30, p. 253-267, January 2007.

PREFEITURA DE SALVADOR. Plano Municipal de Habitação de Salvador, 2008 - 2025. Salvador: Prefeitura de Salvador/ Secretaria Municipal de Habitação - SEHAB, 2008.

PU, R.; GONG, P.; MICHISHITA, R.; SASAGAWA, T. Assessment of multi-resolution and multi-sensor data for urban surface temperature retrieval. Remote Sensing of Environment, v. 104, n. 2, 30, p. 211-225, September 2006.

PUISSANT, A.; HIRSCH, J.; WEBER, C. The utility of texture analysis to improve per-pixel classification for high to very high spatial resolution imagery. International Journal of Remote Sensing, v. 26, n. 4, p. $733-745,2005$.

RASHED T.; WEEKS, J. R.; STOW, D.; FUGATE, D. Measuring temporal compositions of urban morphology through spectral mixture analysis: toward a soft approach to change analysis in crowded cities. International Journal of Remote Sensing, v. 26, n. 4, p. 699 718, 2005.

RASHED, T.; WEEKS, J. R.; ROBERTS, D.; ROGAN, J.; POWELL, R. Measuring the Physical Composition of Urban Morphology Using Multiple Endmember Spectral Mixture Models. PE\&RS, v. 69, n. 9, September 2003.

RATNAM, S.; EVERARD, C. O.; ALEX, J. C.; SURESH, B.; THANGARAJU, P. Prevalence of leptospiral agglutinins among conservancy workers in Madras City, India. $\mathbf{J}$ Trop Med Hyg., v.96, n.1, p.41-5, Feb 1993.

REIS, R. B.; RIBEIRO, G. S.; FELZEMBURGH, R. D.; SANTANA, F. S.; MOHR, S.; MELENDEZ, A. X.; QUEIROZ, A.; SANTOS, A. C.; RAVINES, R. R.; TASSINARI, W. S.; CARVALHO, M. S.; REIS, M. G.; KO, A. I. Impact of environment and social gradient on leptospira infection in urban slums. PLoS Negl Trop Dis., v.2, n.4, p.228, Apr 2008. 
RICHARDS, J. A. e JIA, X. Remote Sensing Digital Image Analysis: an introduction. $4^{\mathrm{a}}$ ed. Berlim: Springer, 2006.

RIDD, M. K. Exploring a V-I-S (vegetation-impervious surface-soil) model for urban ecosystem analysis through remote sensing: comparative anatomy for cities. International Journal of Remote Sensing, 16:12,2165-2185, 1995.

RILEY, L. W.; KO, A. I.; UNGER, A.; REIS, M G. Slum health: Diseases of neglected populations. BMC International Health and Human Rights, v.7, n.2, 2007.

RONGNOPARUT, P.; UGSANG, D. M.; BAIMAI, V.; HONDA, K.; SITHIPRASASNA, R. Use of a remote sensing-based geographic information system in the characterizing spatial patterns for Anopheles minimus $A$ and $C$ breeding habitats in western Thailand. Southeast Asian J Trop Med Public Health, v.36, n. 5, p.1145-52, Sep 2005.

ROTELA, C.; FOUQUE, F.; LAMFRI, M.; SABATIER, P.; INTROINI, V.; ZAIDENBERG, M.; SCAVUZZO, C. Space-time analysis of the dengue spreading dynamics in the 2004 Tartagal outbreak, Northern Argentina. Acta Trop., v.103, n.1, p.1-13, Jul 2007.

RYTKÖNEN, M. J, P. Not all maps are equal: GIS and spatial analysis in epidemiology. International Journal of Circumpolar Health, v.63, n.1, 2004.

SABO, L. A. e GALO, M. L. B. T. Aplicação de uma rede neural artificial e sensoriamento remoto na classificação da área urbana de Presidente Prudente. In: III Colóquio Brasileiro de Ciências Geodésicas, Curitiba, 2003. Anais... Curitiba: Universidade Federal do Paraná, 2003.

SALOMON, O. D., ORELLANO, P. W.; QUINTANA, M. G.; PEREZ, S.; ESTANI, S. S.; ACARDI, S.; LAMFRI, M. Transmision de la leishmaniasis tegumentaria en la Argentina. Medicina, Buenos Aires, v. 66, n. 3, p. 211-9, 2006.

SÃO PAULO. ISA - Indicador de Salubridade Ambiental. Secretaria de Recursos Hídricos, Saneamento e Obras. Manual Básico. São Paulo, Brasil, 1999.

SARKAR, U.; NASCIMENTO, S. F.; BARBOSA, R.; MARTINS, R.; NUEVO, H.; KALAFANOS, I.; GRUNSTEIN, I.; FLANNERY, B.; DIAS, J.; RILEY, L. W.; REIS, M. G.; KO, A. I. Population-based case-control investigation of risk factors for leptospirosis during an urban epidemic. Am J Trop Med Hyg, v. 66, n. 605-10, 2002.

SAWAYA, K. E.; OLMANSON, L. G.; HEINERT, N. J.; BREZONIK, P. L.; BAUER, M. E. Extending satellite remote sensing to local scales: land and water resource monitoring using high-resolution imagery. Remote Sensing of Environment, v.88, p.144-156, 2003.

SCHIEFER, S.; HOSTERT, P.; DAMM, A. Correcting brightness gradients in hyperspectral data from urban areas. Remote Sensing of Environment, v. 101, n. 1, p. 25-37, 15 March 2006.

SCHIEWE, e GAHLER. (2008) Modeling uncertainty in High resolution remotely sensed scenes using a fuzzy logic approach. In: BLASCHKE, T.; LANG S.; HAY, G. J. (Eds.) Object-Based Image Analysis: Spatial Concepts for Knowledge-Driven Remote Sensing Applications. Springer Berlin Heidelberg, 2008.

SCHOPFER, E.; LANG, S.; BLASCHKE, T. A. "Green Index" incorporating remote sensingand citizen's perception of green space. In: International Archives of Photogrammetry, Remote Sensing and Spatial Information Sciences, Tempe, AZ, 2005 XXXVII-5/W1. Proceedings... Tempe, 2005.

SEHGAL, S. C.; SUGUNAN, A. P.; VIJAYACHARI, P. Outbreak of leptospirosis after the cyclone in Orissa. Natl Med J India, v. 15 n. 1, p. 22-3, 2002.

SUPERINTENDÊNCIA DE ESTUDOS ECONÔMICOS SOCIAIS DA BAHIA E UNIVERSIDADE FEDERAL DA BAHIA. Indicadores de sustentabilidade ambiental. (Série estudos e pesquisas, 75). Salvador: SEI, 2006. 
SEJVAR, J.; BANCROFT, E.; WINTHROP, K.; BETTINGER, J.; BAJANI, M.; BRAGG, S.; SHUTT, K.; KAISER, R.; MARANO, N.; POPOVIC, T.; TAPPERO, J.; ASHFORD, D. MASCOLA, L.; VUGIA, D.; PERKINS, B.; ROSENSTEIN, N. Leptospirosis in "EcoChallenge" athletes, Malaysian Borneo, 2000. Emerg Infect Dis, v. 9 n. 6, p. 702-7, 2003.

SERRES, G. de; LEVESQUE, B.; HIGGINS, R.; MAJOR, M.; LALIBERTÉ, D.; BOULIANNE, N.; DUVAL, B. Need for vaccination of sewer workers against leptospirosis and hepatitis $A$. Occup Environ Med., v.52, n. 8, p.505-7, Aug 1995.

SETO, E. Y.; HOLT, A.; RIVARD, T.; BHATIA, R. Spatial distribution of traffic induced noise exposures in a US city: an analytic tool for assessing the health impacts of urban planning decisions. Int J Health Geogr., v.6, n.24, Jun 2007.

SHABAN, M. A. e DIKSHIT, O. Evaluation of the merging of SPOT multispectral and panchromatic data for classification of an urban environment. International Journal of Remote Sensing, v. 23, n. 2, p. 249 - 262, 2002.

SHABAN, M. A. e DIKSHIT, O. Improvement of classification in urban areas by the use of textural features: the case study of Lucknow city, Uttar Pradesh. International Journal of Remote Sensing, v. 22, n. 4, p. $565-593,2001$.

SHACKELFORD, A. K. e DAVIS C. H. A hierarchical fuzzy classification approach for highresolution multispectral data over urban areas. IEEE Transactions on Geoscience and Remote Sensing, v. 41, n. 9, p. 1920-1932, 2003a.

A combined fuzzy pixel-based and object-based approach for classification of high-resolution multispectral data over urban areas." IEEE Transactions on Geoscience and Remote Sensing, v. 41, n. 10, p. 2354-2363, 2003b.

SHI, M. H.; TU, Y. R.; LI, Q. J. [Estudo da distribuição geografica da leptospirose na China]. Zhonghua Liu Xing Bing Xue Za Zhi, v. 16, n. 5, 259-62. 1995. Artigo em Chines.

SILVA, H. R.; TAVARES-NETO, J.; BINA, J. C.; MEYER, R. Leptospirose-infeccao e forma subclinica em criancas de Salvador, Bahia. Rev Soc Bras Med Trop, v. 36, n. 2, p. 227-33, 2003.

SILVA, L. T.; EPIPHANIO, J. C. N. Perfil dos Usuários CBERS: 1a Pesquisa - 2007. São José dos Campos: INPE, 2008.

SIMÕES DE OLIVEIRA, A. G.; JESUS, A. C.; MIRANDA, S. B. Estudo Geológico Geotécnico dos Solos Expansivos da Região do Recôncavo Baiano. In: II Simpósio Brasileiro de Jovens Geotécnicos - II Geojovem, Nova Friburgo/RJ, 2006. Anais... Nova Friburgo, 2006.

SITHIPRASASNA, R.; LEE, W. J.; UGSANG, D. M.; LINTHICUM, K. J. Identification and characterization of larval and adult anopheline mosquito habitats in the Republic of Korea: potential use of remotely sensed data to estimate mosquito distributions. Int $\mathbf{J}$ Health Geogr, v. 4, 17 p., 2005b.

SITHIPRASASNA, R.; UGSANG, D. M.; HONDA, K.; JONES, J. W.; SINGHASIVANON, P. IKONOS-derived malaria transmission risk in northwestern Thailand. Southeast Asian $\mathbf{J}$ Trop Med Public Health, v. 36, n. 1, p. 14-22, 2005a.

SKIDMORE, A. Accuracy assessment of spatial information. In: STEIN, A. (Editor) Spatial Statistics for Remote Sensing, Kluwer, Dordrecht: 1999.

SKINHO, J. P.; HOLLINGER, F. B.; HOVIND-HOUGEN, K.; LOUS, P. Infectious liver diseases in three groups of Copenhagen workers: correlation of hepatitis A infection to sewage exposure. Arch Environ Health, v.36, n. 3, p.139-43, May-Jun 1981.

SMALL, C. Estimation of urban vegetation abundance by spectral mixture analysis. International Journal of Remote Sensing, v. 22, n. 7, p. 1305 - 1334, 2001. 
SMALL, C. High spatial resolution spectral mixture analysis of urban reflectance. Remote Sensing of Environment, v. 88, n. 1-2, 30, p. 170-186, November 2003.

SMALL, C. Multitemporal analysis of urban reflectance. Remote Sensing of Environment, v. 81, n. 2-3, p. 427-442, August 2002.

SMALL, C. e LU, J. W. T. Estimation and vicarious validation of urban vegetation abundance by spectral mixture analysis. Remote Sensing of Environment, v. 100, n. 4, 28, p. 441-456 February 2006.

SMYTHE, L.; DOHNT, M.; NORRIS, M.; SYMONDS, M.; SCOTT, J. Review of leptospirosis notifications in Queensland 1985 to 1996. Commun Dis Intell, v. 21, p. 17-20, 1997.

SOBREIRA, F. J. A. A Lógica da Diversidade: Complexidade e Dinâmica em Assentamentos Espontâneos. 2002. Tese (Doutorado em Desenvolvimento Urbano) Universidade Federal de Pernambuco Recife, 2002.

SOBREIRA, F. J. A. Favelas, barriadas, bidonvilles: the universal morphology of poverty. In: Anais do International Seminar on Urban Form, Ouro Preto: 2007.

SOEGAARD, H. e MØLLER-JENSEN, L. Towards a spatial CO2 budget of a metropolitan region based on textural image classification and flux measurements. Remote Sensing of Environment, v. 87, n. 2-3, 15, p. 283-294 October 2003.

SONG, M. e CIVCO, D. Road Extraction Using SVM and Image Segmentation, PE\&RS. v. 70, n. 12, December 2004.

SOUZA, D. M. C. de.; Dias, G. H.; NOBRE, M. L. The use of Geographical Information System (GIS) to improve active leprosy case finding campaigns in the municipality of Mossoró, Rio Grande do Norte State, Brazil. Lepr Rev., v.78, n.3, p.261-9, 2007 Sep.

SPOTIMAGE. Disponível em: <http://brasil.spotimage.com/web/pt/1919-imagens-doformosat-2.php>. Acesso em: 10 de fevereiro de 2009.

STEFANOV, W. L.; MICHAEL, S. R.; PHILIP, R. C. Monitoring urban land cover change: An expert system approach to land cover classification of semiarid to arid urban centers. Remote Sensing of Environment, v. 77, n. 2, p. 173-185, August 2001

STOILOVA, Y. e POPIVANOVA, N. Epidemiologic studies of leptospiroses in the Plovdiv region of Bulgaria. Folia Med (Plovdiv), v. 41, n. 4, p. 73-9, 1999.

SU, W.; JING, L.; YUNHAO, C.; ZHIGANG, L.; JINSHUI, Z.; TSUEY, M. L.; SUPPIAH, I.; HASHIM, S. A. M. Textural and local spatial statistics for the object-oriented classification of urban areas using high resolution imagery. International Journal of Remote Sensing, v. 29, n. 11, p. $3105-3117,2008$.

SUGUMARAN, R.; PAVULURI, M. K.; ZERR, D. The use of high-resolution imagery for identification of urban climax forest species using traditional and rule-based classification approach. IEEE Transactions on Geoscience and Remote Sensing, v. 41, n. 9, 19331939, 2003.

TANG, J.; WANG, L.; MYINT, S. W. Improving urban classification through fuzzy supervised classification and spectral mixture analysis.International Journal of Remote Sensing, v. 28, n. 18, p. 4047 - 4063, 2007.

TANGKANAKUL, W.; THARMAPHORNPIL, P.; PLIKAYTIS, B. D.; BRAGG, S.; POONSUKSOMBAT, D.; CHOOMKASIEN, P.; KINGNATE, D.; ASHFORD, D. A. Risk factors associated with leptospirosis in northeastern Thailand, 1998. Am J Trop Med Hyg, v. 63, n.3-4, p. 204-8, 2000.

TASSINARI, W. S.; PELLEGRINI, D. C.; SÁ, C. B.; REIS, R. B.; KO, A. I.; CARVALHO, M. S. Detection and modelling of case clusters for urban leptospirosis. Trop Med Int Health., v.13, n.4, p. 503-12, Apr 2008. 
TASSINARI, W. S.; PELLEGRINI, D. D. A.; SABROZA, P. C.; CARVALHO, M. S. Distribuicao espacial da leptospirose no Municipio do Rio de Janeiro, Brasil, ao longo dos anos de 1996-1999. Cad Saude Publica, Rio de Janeiro, v. 20, n.6, p. 1721-9, 2004.

TATEM, A. J. e HAY, S. I. Measuring urbanization pattern and extent for malaria research: a review of remote sensing approaches. J Urban Health., v.81, n.3, p.363-76, Sep 2004.

TAUBENBOCK, H.; HABERMEYER, M.; ROTH, A.; DECH, S. Automated Allocation of Highly Structured Urban Areas in Homogeneous Zones From Remote Sensing Data by Savitzky; Golay Filtering and Curve Sketching. IEEE Geoscience and Remote Sensing Letters, vol, 3, n. 4, p. 532-536, 2006.

THANAPURA, P.; HELDER, D. L.; BURCKHARD, S.; WARMATH, E.; O'NEILL, M.; GALSTER, D. "Mapping Urban Land Cover Using QuickBird NDVI and GIS Spatial Modeling for Runoff Coefficient Determination., PE\&RS. v. 73, n. 1, January 2007

THOMAS, N.; HENDRIX, C.; CONGALTON, R. G. A Comparison of Urban Mapping Methods Using High-Resolution Digital Imagery. PE\&RS. v. 69, n. 9, September 2003

TOBIN, K. W., BHADURI, B. L.; BRIGHT, E. A.; CHERIYADAT, A.; KARNOWSKI, T. P.; PALATHINGAL, P. J.; POTOK, T. E.; PRICE, J. R. Automated Feature Generation in LargeScale Geospatial Libraries for Content-Based Indexing. PE\&RS. v. 72, n. 5, May 2006

TROYO, A.; FULLER, D. O.; CALDERÓN-ARGUEDAS, O.; BEIER, J. C. A geographical sampling method for surveys of mosquito larvae in an urban area using high-resolution satellite imagery. J Vector Ecol., v.33, n.1, p.1-7, Jun 2008.

UN MILLENIUM CAMPAIGN. Reuters: The real crisis is for poor, campaigners tell G7. Disponível em <http://www.endpoverty2015.org/english/news/reuters-real-crisis-poorcampaigners-tell-g7/13/feb/09>. Acesso em: março de 2009.

UN-POPULATION DIVISION. World Population Prospects: the 2008 revision population data base. Disponível em:<http://esa.un.org/unpp/>. Acesso em: março de 2009.

UN-HABITAT. State of the World's Cities 2008/2009, Harmonious Cities. London: United Nations Human Settlements Programme, 2008.

VAN DER STUYFT, P.; GIANELLA, A.; PIRARD, M.; CESPEDES, J.; LORA, J.; PEREDO, C.; PELEGRINO, J. L.; VORNDAM, V.; BOELAERT, M. Urbanisation of yellow fever in Santa Cruz, Bolivia. Lancet., v.353, n.9164, p.1558-62, May 1999.

VANASCO, N. B.; SCHMELING, M. F.; LOTTERSBERGER, J.; COSTA, F.; KO, A. I.; TARABLA, H. D. Clinical characteristics and risk factors of human leptospirosis in Argentina (1999-2005). Acta Trop., v. 107, n.3, Jul 2008.

VANASCO, N. B.; FUSCO, S.; ZANUTTINI, J. C.; MANATTINI, S.; DALLA FONTANA, M. L.; PREZ, J.; CERRANO, D.; SEQUEIRA, M. D. Brote de leptospirosis humana luego de una inundacion en Reconquista (Santa Fe), 1998. Rev Argent Microbiol, v. 34, n. 3, p. 124-31, 2002.

VASCONCELOS, P. A. Salvador: Transformações e permanências (1549 - 1999). Ilhéus, Bahia: Editus, 2002.

VIANA, M.; SANTOS, F. L.; FONSECA, C. G.; SEGANTINI, W. M. O. Avaliação da Aplicabilidade do Ïndice de Salubridade Ambiental (ISA) na Hierarquização de Vilas e Favelas de Belo Horizonte. In. 24ํㅡㄹ Congresso Brasileiro de Engenharia Sanitária e Ambiental, Belo Horizonte, 2007. Anais... Belo Horizonte: ABES, 2007.

TSAI, V. J. D. A Comparative Study on Shadow Compensation of Color Aerial Images in Invariant Color Models. IEEE TRANSACTIONS ON GEOSCIENCE AND REMOTE SENSING, v. 44, n. 6, June 2006,

VILLAÇA, F. Espaço Intra-urbano no Brasil. São Paulo: Studio Nobel, FAPESP, Lincoln 
Institute, 1998.

VINE, M. F.; DEGNAN, D.; HANCHETTE C. Geographic Information Systems: Their Use in Environmental Epidemiologic Research. Environmental Health Perspectives, v. 105, n. 6, 1997.

VINETZ, J. M.; GLASS, G. E.; FLEXNER, C. E.; MUELLER, P.; KASLOW, D. C. Sporadic urban leptospirosis. Ann Intern Med., v.125, n.10, p.794-8, Nov 1996.

VOOGT, J. A. e OKE T. R. Thermal remote sensing of urban climates, Remote Sensing of Environment, v. 86, p.370-384, 2003.

VOORDE, T. V. de.; GENST, W. de.; CANTERS, F. Improving Pixel-based VHR Land-cover Classifications of Urban Areas with Post-classification Techniques. PE\&RS, v. 73, n. 9, September 2007.

WACHOWICZ, M. Object-Oriented Design for temporal GIS. Taylor \& Francis:1999.

WALKER, J. S. e BRIGGS, J. M. An Object-oriented Approach to Urban Forest Mapping in Phoenix. PE\&RS, v. 73, n. 5, May 2007.

WALKER, J. S. e BLASCHKE, T. Object-based land-cover classification for the Phoenix metropolitan area: optimization vs. Transportability. International Journal of Remote Sensing, v. 29, n. 7, p. 2021 - 2040, March 2008.

WARD, M. P.; GUPTILL, L. F.; WU, C. C. Evaluation of environmental risk factors for leptospirosis in dogs: 36 cases (1997-2002). J Am Vet Med Assoc., v.225, n. 1, p.72-7, Jul 2004.

WEBER, C.; PETROPOULOU, C.; HIRSCH, J. Urban development in the Athens metropolitan area using remote sensing data with supervised analysis and GIS. International Journal of Remote Sensing, v. 26, n. 4, p. 785-796, 2005.

WENG, Q. e YANG, S. Managing the adverse thermal effects of urban development in a densely populated Chinese city. J Environ Manage., v.70, n. 2, p.145-56, Feb 2004.

WENG, Q.; DENGSHENG, L.; e LIANG, B. Urban Surface Biophysical Descriptors and Land Surface Temperature Variations, PE\&RS, v. 72, n. 11, November 2006.

WENG, Q. Remote sensing of impervious surfaces: An overview. In: Weng, Q. (ed.) Remote sensing of impervious surfaces. Boca Raton: CRC Press Taylor \& Francis Group, 2008.

WENG, Q.; XUEFEI, H.; DENGSHENG, L. Extracting impervious surfaces from medium spatial resolution multispectral and hyperspectral imagery: a comparison. International Journal of Remote Sensing, v. 29, n. 11, p. 3209 - 3232, 2008.

WHITMARSH, J. e GOVINDJEE. The Photosynthetic Process. In: SINGHAL , G.S.; RENGER ,G.; IRRGANG ,K-D.; SOPORY ,S; GOVINDJEE Concepts in Photobiology: Photosynthesis and Photomorphogenesis. Edited by. Narosa Publishers/Kluwer Academic Publishers, $1999 . \quad$ Disponível em: <http://www.life.uiuc.edu/govindjee/paper/gov.html>. Acesso em: 2008.

WU, C. Normalized spectral mixture analysis for monitoring urban composition using ETM+ imagery. Remote Sensing of Environment, v. 93, n. 4, 15, p. 480-492, December 2004.

WU, C. e MURRAY, A. T. Estimating impervious surface distribution by spectral mixture analysis. Remote Sensing of Environment, v. 84, n. 4, p. 493-505, 10 April 2003.

WU, S.; BING, X.; WANG, L. Urban Land-use Classification Using Variogram-based Analysis with an Aerial Photograph. PE\&RS. v. 72, n. 7, July 2006.

WU, S.; SILVÁNHYPHEN, J.; CÁRDENAS.; WANG, L. Per-field urban land use classification based on tax parcel boundaries. International Journal of Remote Sensing, v. 28, n. 12 , p. $2777-2801,2007$ 
XIAN, G.; CRANE, M.; MCMAHON, C. Quantifying Multi-temporal Urban Development Characteristics in Las Vegas from Landsat and ASTER Data. PE\&RS.v. 74, n. 4, April 2008.

XIAN, G. e CRANE, M. An analysis of urban thermal characteristics and associated land cover in Tampa Bay and Las Vegas using Landsat satellite data. Remote Sensing of Environment, v. 104, n. 2, p. 147-156, 30 September 2006.

XIAN, G. Analysis of impacts of urban land use and land cover on air quality in the Las Vegas region using remote sensing information and ground observations. International Journal of Remote Sensing, v. 28, n. 24p. 5427 - 5445, 2007.

XIAO, R.; WENG, Q.; OUYANG, Z.; WEIFENG, L.; SCHIENKE, E. W.; ZHANG, Z. Land Surface Temperature Variation and Major Factors in Beijing, China. PE\&RS, v. 74, n. 4, April 2008.

$\mathrm{XU}, \mathrm{H}$. Extraction of Urban Built-up Land Features from Landsat Imagery Using a Thematicoriented Index Combination Technique. PE\&RS, v. 73, n. 12, December 2007.

YANG, K.; ZHOU, X. N.; YAN, W. A.; HANG, D. R.; STEINMANN, P. Landfills in Jiangsu province, China, and potential threats for public health: Leachate appraisal and spatial analysis using geographic information system and remote sensing. Waste Manag., v.28, n.12, p.2750-7, Dec 2008.

YANG, L., XIAN, G.; KLAVER, J. M.; DEAL, B. Urban Land-Cover Change Detection through Sub-Pixel Imperviousness Mapping Using Remotely Sensed Data. PE\&RS, v. 69, n. 9, September 2003.

YUAN, F. Land-cover change and environmental impact analysis in the Greater Mankato area of Minnesota using remote sensing and GIS modelling. International Journal of Remote Sensing, v. 29, n. 4, p. $1169-1184,2008$.

YUAN, F. e BAUER, M. E. Comparison of impervious surface area and normalized difference vegetation index as indicators of surface urban heat island effects in Landsat imagery. Remote Sensing of Environment, v. 106, n. 3, p. 375-386, 15 February 2007.

ZANDBERGEN, P. A. e CHAKRABORTY, J. Improving environmental exposure analysis using cumulative distribution functions and individual geocoding. Int J Health Geogr, v. 5, n. 23, 2006.

ZHA, Y.; GAO, J.; NI, S. Use of normalized difference built-up index in automatically mapping urban areas from TM imagery. International Journal of Remote Sensing, v. 24, n. 3, p. $583-594,2003$.

ZHANG, Y. Detection of urban housing development by fusing multisensor satellite data and performing spatial feature post-classification. International Journal of Remote Sensing, v. 22, n. 17, p. 3339 - 3355, 2001.

ZHANG, Y. Texture-Integrated Classification of Urban Treed Areas in High-Resolution ColorInfrared Imagery. PE\&RS, V. 67, n. 12, December 2001.

ZHANG, L.; HUANG, X.; HUANG, B.; LI, P. A Pixel Shape Index Coupled With Spectral Information for Classification of High Spatial Resolution Remotely Sensed Imagery. IEEE Transactions on Geoscience and Remote Sensing, v. 44, n. 10, p. 2950-2961, 2006.

ZHANG, Q.; WANG, J.; GONG, P.; SHI, P. Study of urban spatial patterns from SPOT panchromatic imagery using textural analysis. International Journal of Remote Sensing, v. 24, n. 21, p. $4137-4160,2003$.

ZHANG, Q.; WANG, J.; PENG, X.; GONG, P.; SHI, P. Urban built-up land change detection with road density and spectral information from multi-temporal Landsat TM data. International Journal of Remote Sensing, v. 23, n. 15, p. 3057 - 3078, 2002.

ZHANG, Y. Optimisation of building detection in satellite images by combining multispectral 
classification and texture filtering, ISPRS Journal of Photogrammetry \& Remote Sensing v.54, 50-60, 1999.

ZHOU, G. e LAM, N. S. N. Reducing Edge Effects in the Classification of High Resolution Imagery. PE\&RS. v. 74, n. 4, April 2008.

ZHU, G. e BLEUMBERG, D. G. Classification using ASTER data and SVM algorithms;: The case study of Beer Sheva, Israel. Remote Sensing of Environment, v. 80, n. 2, p. 233-240, May 2002.

ZHU, S.; YIN, Q.; KUANG, D. Using characteristic spectral bands of OMIS1 imaging spectrometer to retrieve urban land surface temperatura. International Journal of Remote Sensing, v. 27, n. 8, p. 1661 - 1676, 2006.

ZUNINO, M.; ENNA.; ROLANDO, P. P. Leptospirosis: revisión de la literatura. Rev. chil. infectol., v.24, n.3, p.220-226, June 2007. Erratum in: Rev Chil. Infectol.; 24(4):339, Aug 2007. 


\section{APÊNDICES}

\section{APÊNDICE 1 - Árvore de processos Ortofotografia}

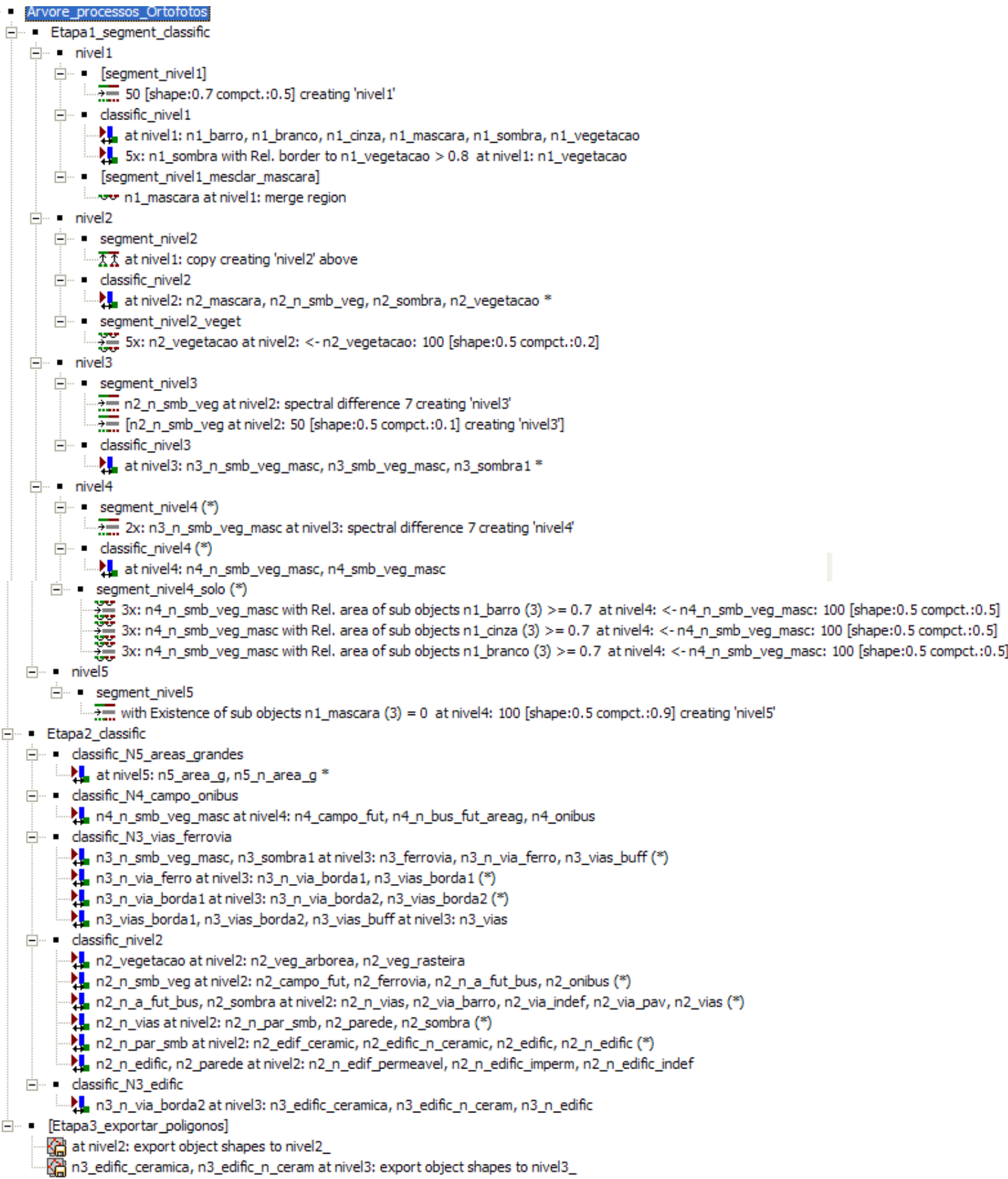

1. n3_n_smb_veg_masc, n3_sombra1 at nivel3: n3_ferrovia, n3_n_via_ferro, n3_vias_buff ( ${ }^{*}$ )

11. n3_n_via_ferro at nivel3: n3_n_via_borda1, n3_vias_borda1 (*)

1. n3_n_via_borda1 at nivel3: n3 n_via_borda2, n3 vias borda2 $(*)$

1. n3_vias_borda1, n3_vias_borda2, n3_vias_buff at nivel3: n3_vias

-1... Classific_nivel2

1. n2_vegetacao at nivel2: n2_veg_arborea, n2_veg_rasteira

1. n2_n_smb_veg at nivel2: n2_campo_fut, n2_ferrovia, n2_n_a_fut_bus, n2_onibus ( ${ }^{*}$

1. n2_n_a_fut_bus, n2_sombra at nivel2: n2_n_vias, n2_via_barro, n2_via_indef, n2_via_pav, n2_vias (*)

1. n2_n_vias at nivel2: n2_n_par_smb, n2_parede, n2_sombra (*)

1. n2_n_par_smb at nivel2: n2 edif_ceramic, n2 edific $n$ ceramic, n2 edific, n2 n_edific (*)

1. n2_n_edific, n2 parede at nivel2: n2_n_edif_permeavel, n2_n_edific_imperm, n2_n_edific_indef -.... Classific_N3_edific

1. n3_n_via_borda2 at nivel3: n3_edific_ceramica, n3_edific_n_ceram, n3_n_edific

-... - [Etapa3_exportar_poligonos]

ating at nivel2: export object shapes to nivel2

Vin n3_edific_ceramica, n3_edific_n_ceram at nivel3: export object shapes to nivel3_ 


\section{APÊNDICE 2 - Hierarquia de classes Ortofotografia}

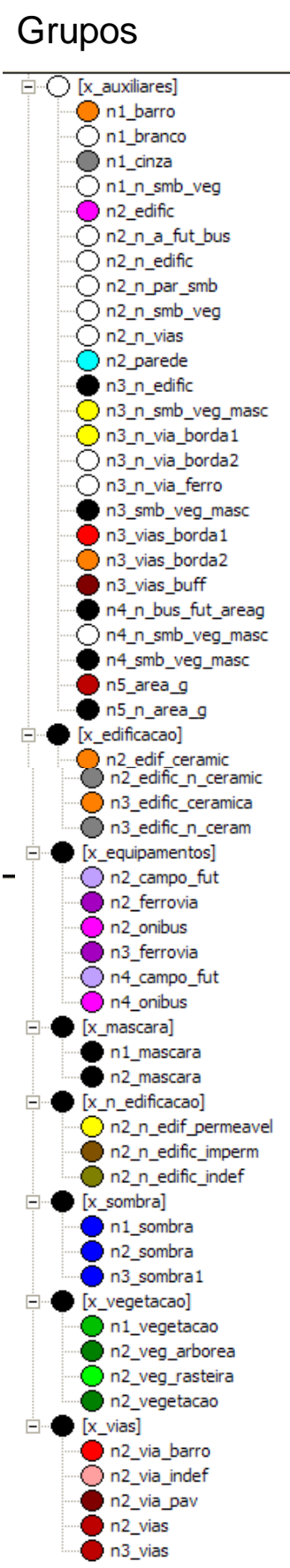

Hierarquia de classes

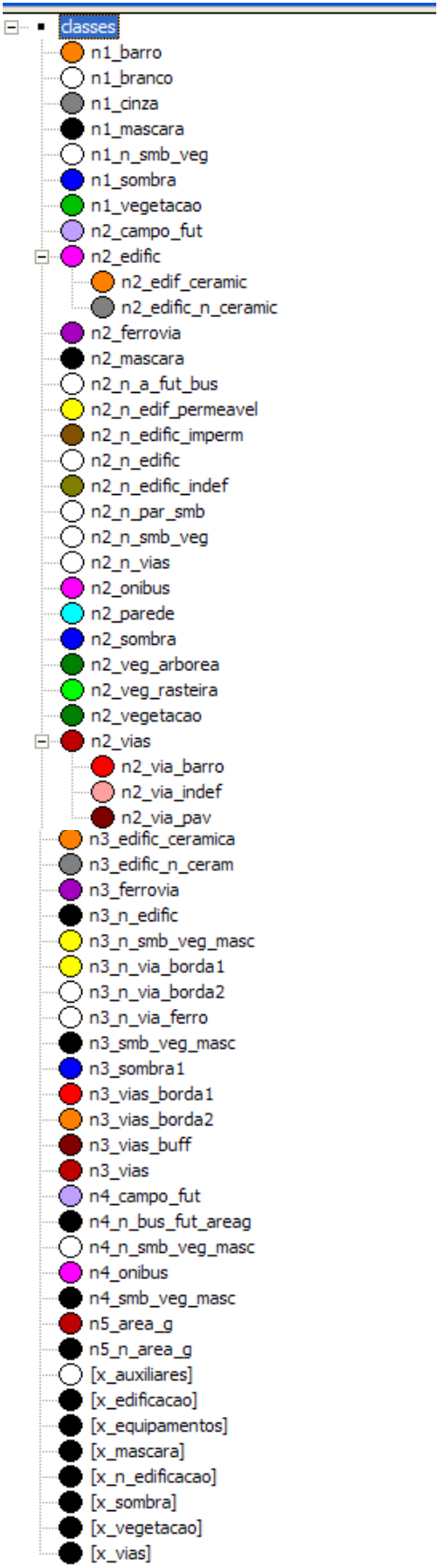

Nota: número na frente de cada classe lê-se: $0 \_$para classes do Nível 1, 1_ para classes do Nível 2, 2_para classes do Nível 3, 3_para classes do Nível 4 


\section{APÊNDICE 3 - Descrição das classes Ortofotografias}

n1_barro

not n1_mascara

nearest neighbor

n1_branco

not n1_mascara

nearest neighbor

n1_cinza

not n1_mascara

nearest neighbor

n1_mascara

temático mascara

$$
\begin{aligned}
& \text { n1_n_smb_veg } \\
& \text { not n1_mascara } \\
& \text { not_n1_sombra } \\
& \text { not_n1_vegetacao }
\end{aligned}
$$

mean diff.to neighbors $\mathrm{V}(1)$

Mean PC3

Mean Red

Mean Blue

Mean S

Mean V

Mean PC2

Std dev. PC3

indic_sombra

indic_solo_adapt

mean diff.to neighbors $\mathrm{V}(1)$

Mean PC3

Mean Red

Mean Blue

Mean S

Mean V

Mean PC2

Std dev. PC3

indic_sombra

indic_solo_adapt

mean diff.to neighbors $\mathrm{V}(1)$

Mean PC3

Mean Red

Mean Blue

Mean S

Mean V

Mean PC2

Std dev. PC3

indic_sombra

indic_solo_adapt

Mascara $=1$

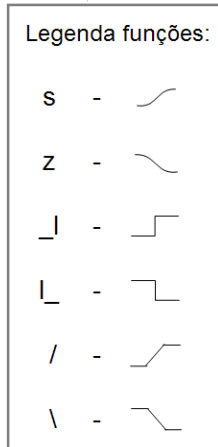




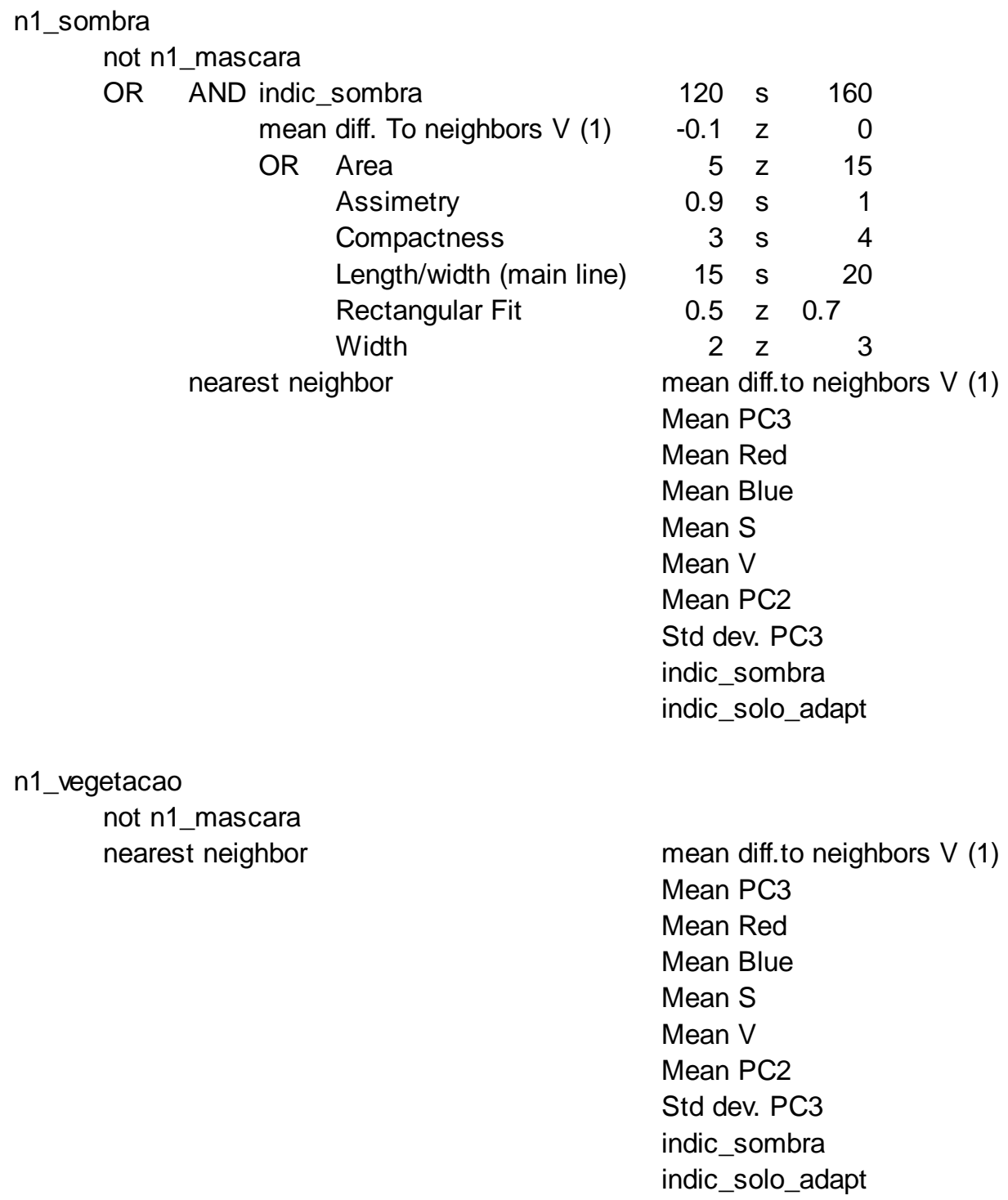


n2_campo de futebol

existence ofsuper objects n4_campo_fut(2) $\quad 0$ _ I 1

n2_edific

area

area

length/width

not existence of super objects n5_area_g (3)

Rectangular fit

OR Rectangular fit

Rel border to n2_edific_n_ceramic

rel border to n2_parede

rel border to n2_sombra

$\begin{array}{rrrr} & < & 300 \\ & > & & 15 \\ 2 & \mathrm{z} & & 4 \\ 0 & \mathrm{l} & & \\ 0.5 & \mathrm{~s} & 0.7 & \\ .9 & \mathrm{~s} & & \\ 0 & \mathrm{~s} & .2 & \\ 0 & \mathrm{~s} & .2 & \\ 0 & \mathrm{~s} & .2 & \end{array}$

n2_edific_ceramic

rectangular fit

rel. Area of sub objects n1_barro (1)

$\begin{array}{lll}.5 & \mathrm{~s} & 1\end{array}$

n2_edific_n_ceramic

not n2_edif_ceramic

$.7 \quad$ s .9

n2_ferrovia

Existence of super objects n3_ferrovia (1)

$0 \quad 1 \quad 1$

n2_mascara

existence of sub objects n1_mascara (1)

$0 \quad$ I 1

n2_n_a_fut_bus

not n2_campo_fut

not n2_ferrovia

not n2_onibus

n2_n_edif_permeavel

rel. Area of sub objects n1_barro (1)

$\begin{array}{lll}.5 & \mathrm{~s} & 1\end{array}$

n2_n_edfic_imperm

rel. area of sub objects n1_cinza (1)

$\begin{array}{lll}.5 & \mathrm{~s} & 1\end{array}$

n2_n_edfic

not n2_edif_ceramic

not n2_edific_n_ceramic

n2_n_edific_indef

not n2_n_edif_permeável

not n2_n_edific_imperm

n2_n_par_smb

not_n2_pared

not_n2_smb

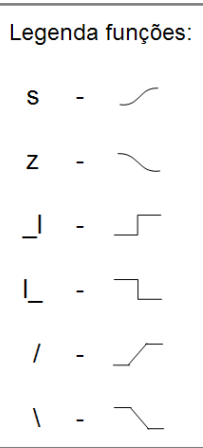


n2_n_smb_veg

not n2 mascara

not n2_sombra

not_n2_vegetacao

n2_n_vias

not n2_vias

n2_onibus

existence of super objects n4_onibus (2)

n2_parede

area

not n2 sombra

OR area

assimetry

compactness

lenght/width

rectangular fit

width

$\begin{array}{rrrr}20 & z & & 40 \\ & & \\ 5 & z & & 15 \\ .9 & s & & 1 \\ 3 & s & & 4 \\ 3 & s & & 5 \\ .5 & z & .7 & \\ 2 & x & & 3\end{array}$

n2_sombra

existence of sub objects n1_sombra(1)

$0 \quad$ I 1

n2_veg_arborea

not_n2_veg_rasteira

nearest neighbor

mean PC3

Std. Dev. S

Std. Dev. PC3

n2_veg_rasteira

nearest neighbor

mean PC3

Std. Dev. S

Std. Dev. PC3

n2_vegetacao

existence of sub objects n1_vegetacao (1)

$0 \_\_1$

n2_vias

Existence of super objects n3_vias (1)

$0 \quad \mathrm{I} \quad 1$

n2_via_barro

rel area of sub objects n1_barro (1)

.5

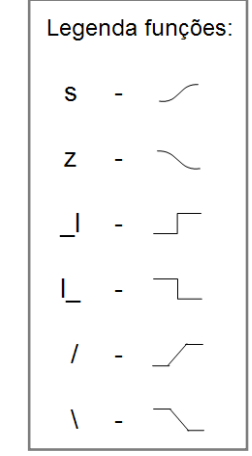

n2_via_indef

not n2_via_barro

not_n2_via pav

n2_via_pav

rel area of sub objects n1_cinza (1)

$.5 \mathrm{~s} \quad 1$ 
n3_edfic_ceramica

rel area of sub objects n2_edif_ceramic

$\begin{array}{lll}0 & \mathrm{~s} & 1\end{array}$

n3_edfic_n_ceram

rel area of sub objects n2_edif_n_ceramic (1) $\quad 0 \quad s \quad 1$

n3_ferrovia

tematico vias_ferrovia $\quad$ Via1ferro2 $=2$

n3_n_edific

not n3_edific_ceramica

not n3_edific_n_ceram

n3_n_smb_veg_masc

not n3 smb veg masc

not n3 sombra1

n3_n_via_ferro

not n3 ferrovia

not_n3_vias_buff

n3_smb_veg_masc

not n3_sombra1

OR existence of sub objects n1_mascara (2)

existence of sub objects n1_sombra (2)

existence of sub objects n1_vagatacao (2)

n3_sombra1

existence of sub objects n1_sombra (2)

indic sombra

$150 z \quad 200$

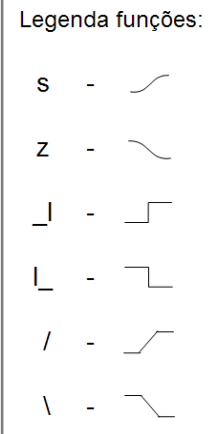


n3_n_via_borda1

not n3_vias_borda1

n3_n_via_borda2

not n3_vias_borda2

n3_vias_borda1

OR Rectangular fit

width

OR AND OR Eliptic fit

rectangular fit

rectangular fit

rel border to n3_vias_buff

$\begin{array}{rrr}0 & z & 1 \\ 10 & z & 30\end{array}$

$\begin{array}{lll}.7 & \mathrm{z} & .8\end{array}$

$\begin{array}{lll}.8 & z & 1\end{array}$

$\begin{array}{lll}.8 & z & 1\end{array}$

$\begin{array}{lll}.2 & \mathrm{~s} & .3\end{array}$

AND OR Assimetry

$.8 \mathrm{~s} \quad .9$

Compactness

$\begin{array}{lll}3.5 & \mathrm{~s} & 4.5\end{array}$

lenght/width

$2 \mathrm{~s} 3$

width

$3.5 \mathrm{z} \quad 4.5$

rel border to n3_vias_buff

$\begin{array}{lll}00 & \mathrm{~s} & .2\end{array}$

n3_vias_borda2

Not existence of sub objects n1_mascara (2)

Not existence of sub objects n1_sombra (2)

Not existence of sub objects n1_vagatacao (2)

AND Eliptic fit

$\begin{array}{lll}.8 & z & 0.9\end{array}$

rectangular fit

$.8 \mathrm{z} \quad 0.9$

rel border to n3_vias_borda1

$\begin{array}{lll}00 & \mathrm{~s} & .3\end{array}$

OR assimetry

.8 s .9

compactness

3.5 s 4.5

lenght/width

$2 \mathrm{~s} 3$

width

$3.5 \mathrm{z} \quad 4.5$

$00 \mathrm{z} \quad 1$

OR rectangular fit

$10 \mathrm{z} 20$

n3_vias_buff

tematico vias_ferrovia

Via1ferro2 $=1$

n3_vias

classified as n3_vias_borda1

$0 \quad 1 \quad 1$

classified as n3_vias_borda2

$0 \quad \mid 1$

classified as n3_vias_buff

$0 \_1$

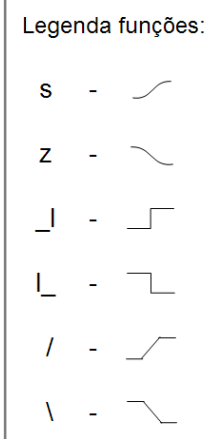


n4_campo fut

area

elipitc fit

$250 \mathrm{~s} \quad 350$

mean $\mathrm{V}$

$\begin{array}{lll}.7 & \mathrm{~s} & .8\end{array}$

rel area fo sub objects n1_barro (3)

.75 s $\quad .85$

$\begin{array}{lll}.5 & \mathrm{~s} & 1\end{array}$

n4_n_bus_fut_areag

not n4_campo_fut

not n4_onibus

n4_n_smb_veg_masc

not n4_smb_veg_masc

n4_onibus

area

length/width

$\begin{array}{lll}16 & \mathrm{n} & 43 \\ & -8 & -1\end{array}$

mean blue

rectangular fit

2.8 n 5.8

200 s 255

$.8 \mathrm{~s} \quad .9$

rel area of sub objects n1_branco (3)

$.5 \mathrm{~s} 1$

n4_smb_veg_masc

existence of sub objects n1_mascara (3)

existence of sub objects n1_sombra (3)

existence of sub objects n1_vagetacao (3)

n5_area_g

rel area of sub objects n21_vegetacao (4)

OR area

AND area

Std dev. S

AND area

Std dev S

OR Eliptic fit

rectangular fit

$\begin{array}{rll}00 & \mathrm{~s} & .5 \\ & > & 1500 \\ 250 & \mathrm{~s} & 350 \\ .075 & \mathrm{z} & .085 \\ 400 & \mathrm{~s} & 600 \\ .070 & \mathrm{z} & .1 \\ .7 & \mathrm{~s} & .8 \\ .85 & \mathrm{~s} & .95\end{array}$

n5_n_area_g

not n5_area_g

x_auxiliares

inativa

X_edficacoes

inativa

x_equipamentos

inativa

x_mascara

inativa

x_n_edificacao

inativa

x_sombra

inativa

x_vegetacao

inativa

x_vias

inativa

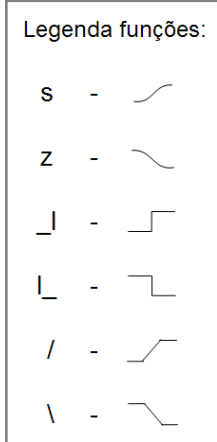




\section{APÊNDICE 4 - Árvore de processos QuickBird}

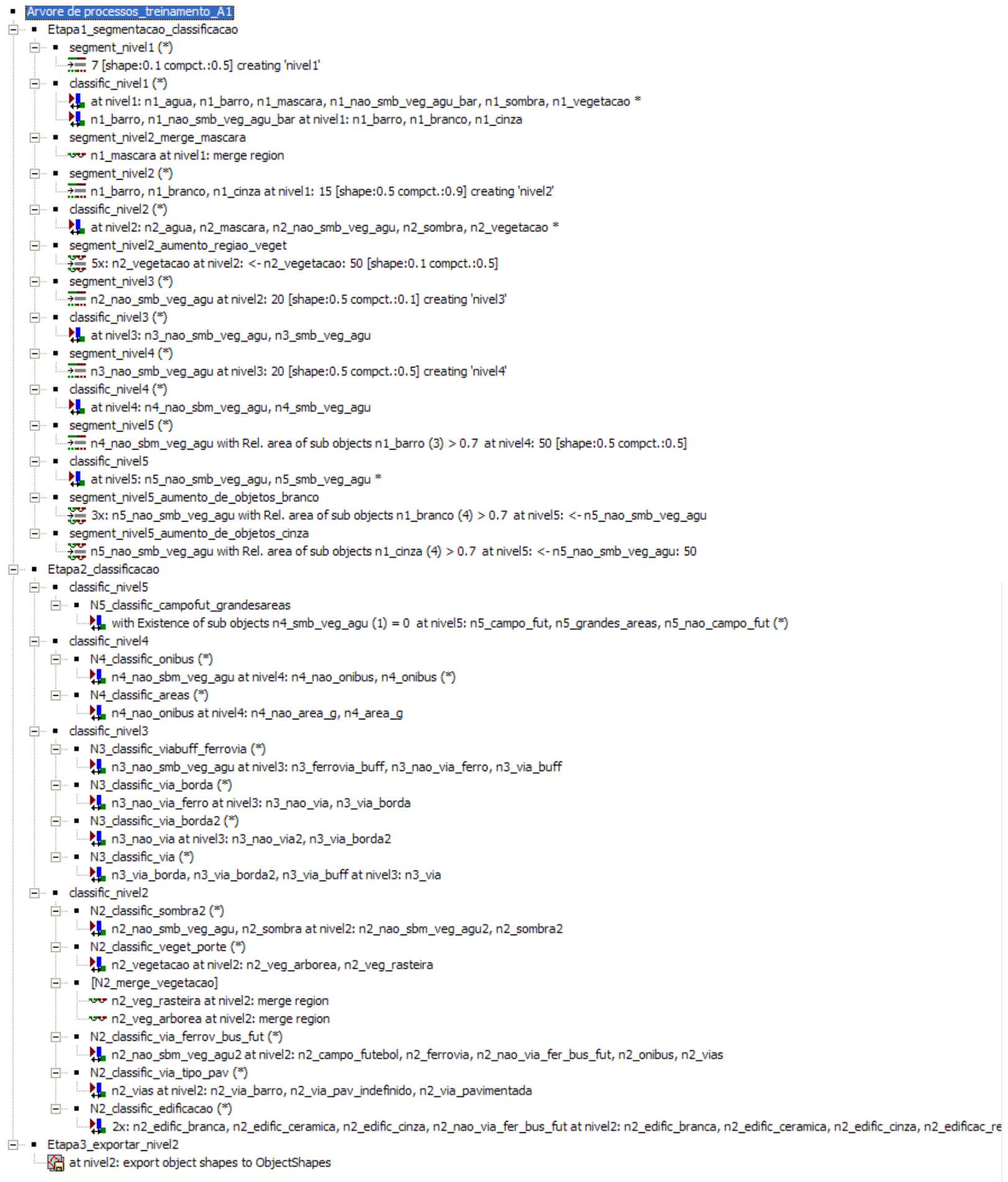




\section{APÊNDICE 5 - Hierarquia de classes QuickBird}
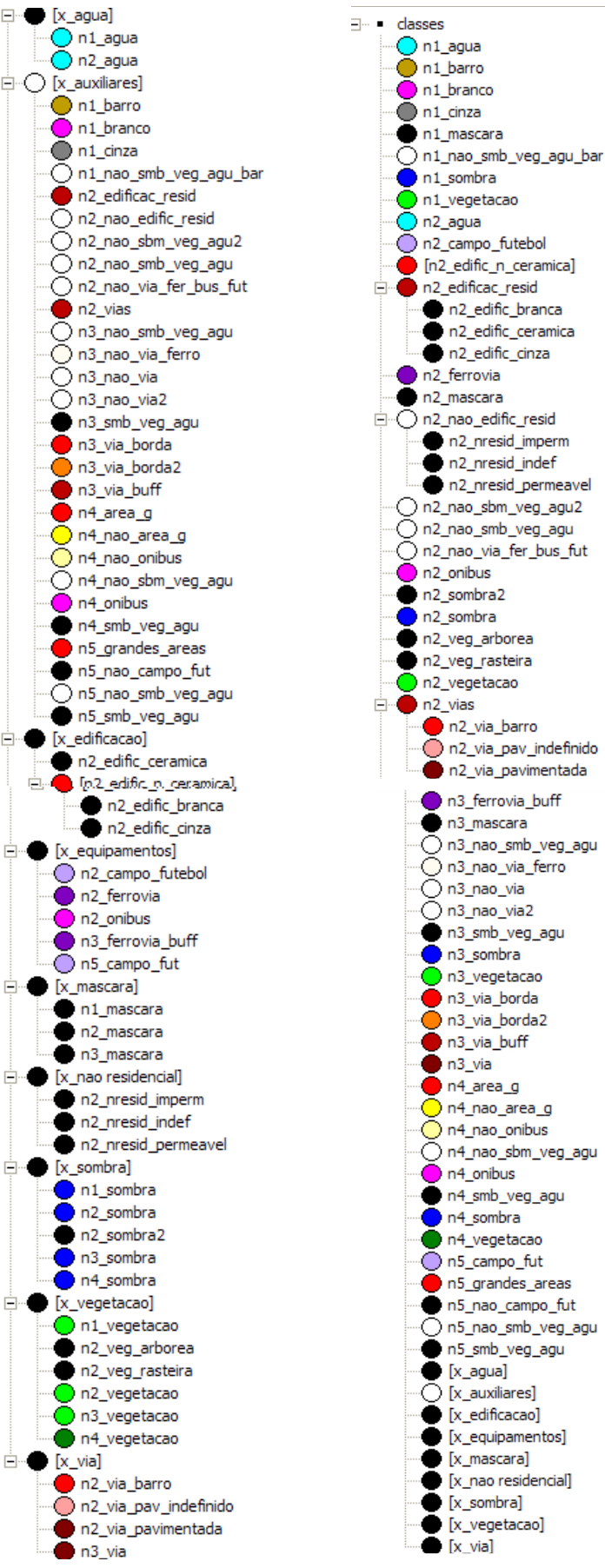

Nota: número na frente de cada classe lê-se: $0_{\text {_ }}$ para classes do Nível 1, 1_ para classes do Nível 2, 2_ para classes do Nível 3, 3_ para classes do Nível 4 


\section{APÊNDICE 6 - Descrição das classes, QuickBird}

n1_agua

blue+green

indic_agua

$\begin{array}{lll}50 & \mathrm{n} & 65\end{array}$

mean Pan

$0.23 \quad n \quad 0.25$

mean $\mathrm{PC} 1$

$17-n \quad 525$

not n1_mascara

Std. Dev. Nir

$\begin{array}{lll}-41 & n & -22\end{array}$

Std. Dev. Pan

0.56 n 3.75

0.09 n 1.9

n1_barro

not n1_mascara

not n1_sombra

$\begin{array}{lll}0 & \mathrm{~s} & 0.6\end{array}$

Indic_solo

Mean Blue

n1_branco

brightness

not n1_barro

50 z 600

n1_cinza

not n1_branco

not n1_barro

n1_mascara

temático mascara

Mascara $=1$

n1_n_smb_veg_agu_bar

not n1_mascara

not_n1_sombra

not_n1_vegetacao

not n1_agua

not n1_barro

n1_sombra

not n1_agua

not $n 1$ vegetacao

not n1_mascara

OR mean Pan

OR blue+green

mean Pan

45

s 50

OR area

Asymmetry

Compactness

Length/ width

width

$\begin{array}{lll}20 & \mathrm{z} & 26\end{array}$

$\begin{array}{lll}-8 & z & -4\end{array}$

50 z 70

20 z 40

$25 \quad$ I 30

$\begin{array}{lll}0.85 & \mathrm{~s} & 0.95\end{array}$

3 s 4

2.5 s 3.5

$3.5 \mathrm{z} \quad 4.5$

n1_vegetacao

not n1_mascara

NDVI

$\begin{array}{lll}0.3 & s & 0.35\end{array}$ 
n2_agua existence of sub objects n1_agua (1) $\quad 0 \quad$ । 1

n2_campo de futebol existence of super objects n5_campo_fut(3) 0 _ I 1

n2_edific_n_ceramic inativa

n2_edific_resid

area

Compactness

length/width

not existence

Rectangular fit

OR Rectangular fit

Rel area of su objects n1_branco (1)

rel border to n2_edific_cinza

rel border to n2_sombra2

$\begin{array}{lll}2 & z & 3\end{array}$

$2.5 \quad z \quad 3.5$

$0 \_-1$

$\begin{array}{lll}0.6 & s & 0.8\end{array}$

8 s 0.94

$0 \quad / 1$

0 s $\quad .25$

$0 \quad \mathrm{~s}: 2$

n2_edific_branca

Rel area of su objects n1_branco (1)

$0 \quad / 1$

n2_edific_ceramic

rel. Area of sub objects n1_barro (1) $\quad 0 \quad$ / 1

n2_edific_cinza

rel. Area of sub objects n1_cinza (1) $\quad 0 \quad / 1$

n2_ferrovia

Existence of super objects n3_ferrovia_buff (1) 0 _ I 1

n2_mascara

existence of sub objects n1_mascara (1) $\quad 0 \quad$ I 1

n2_n_edific_resid

not n2_edificac_resid

n2_nresid_imperm

rel. area of sub objects n1_cinza (1) $\quad 0 \quad$ / 1

n2_n_a_fut_bus

not n2_campo_fut

not n2_ferrovia

not n2_onibus

n2_n_edif_permeavel

rel. Area of sub objects n1_barro (1)

n2_nresid_indef_mix

not n2_nresid_permeável

not n2_nresid_imperm

n2_nao_sbm_veg_agu2

not n2_sombra2

n2_nao_smb_veg_agu

existence of sub objects n1_barro (1)

existence of sub objects n1_branco (1)

existence of sub objects n1_cinza (1)

$\begin{array}{lll}0 & - & 1 \\ 0 & - & 1 \\ 0 & - & 1\end{array}$




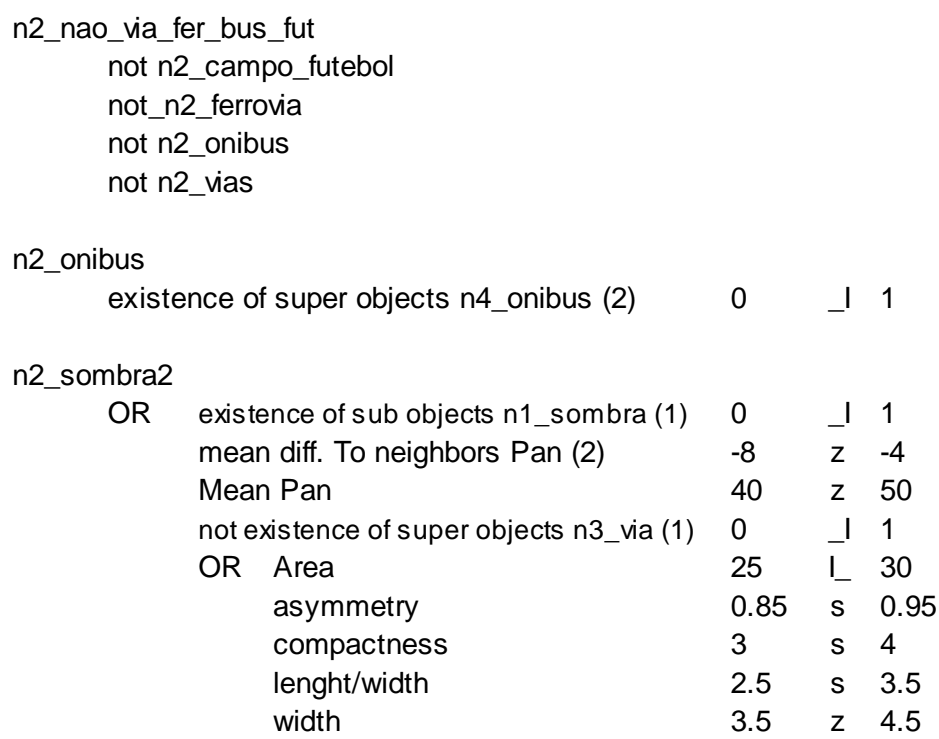

n2_sombra

OR existence of sub objects n1_sombra(1) $0 \quad$ | 1 AND Area $25 \quad \bar{l} 30$

$\begin{array}{llrl}\text { asymmetry } & 0.85 & \text { s } & 0.95 \\ \text { compactness } & 3 & \text { s } & 4 \\ \text { lenght/width } & 2.5 & \text { s } & 3.5 \\ \text { mean Dif to Neighbors Pan (2) } & -8 & \text { z } & -4 \\ \text { mean Pan } & 20 & \text { z } & 40 \\ \text { width } & 3.5 & \text { z } & 4.5\end{array}$

n2_veg_arborea

not_n2_veg_rasteira

n2_veg_rasteira

Avrg. Mean diff to neighbors of sub-objects Pan (1) $5 \quad$ z 10

mean Pan

30 s 50

n2_vegetacao

existence of sub objects n1_vegetacao (1) $\quad 0 \quad 1 \quad 1$

n2_vias

Existence of super objects n3_vias (1) $\quad 0 \quad \begin{array}{lll} & 0\end{array}$

n2_via_barro

rel area of sub objects n1_barro (1) $\quad 0 \quad$ / 1

n2_via_pav_indefinido

rel area of sub objects n1_branco (1) $\quad 0 \quad$ / 1

n2_via_pavimentada

rel area of sub objects $n 1$ cinza (1) $\quad 0 \quad$ / 1

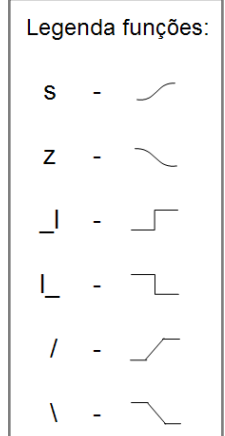




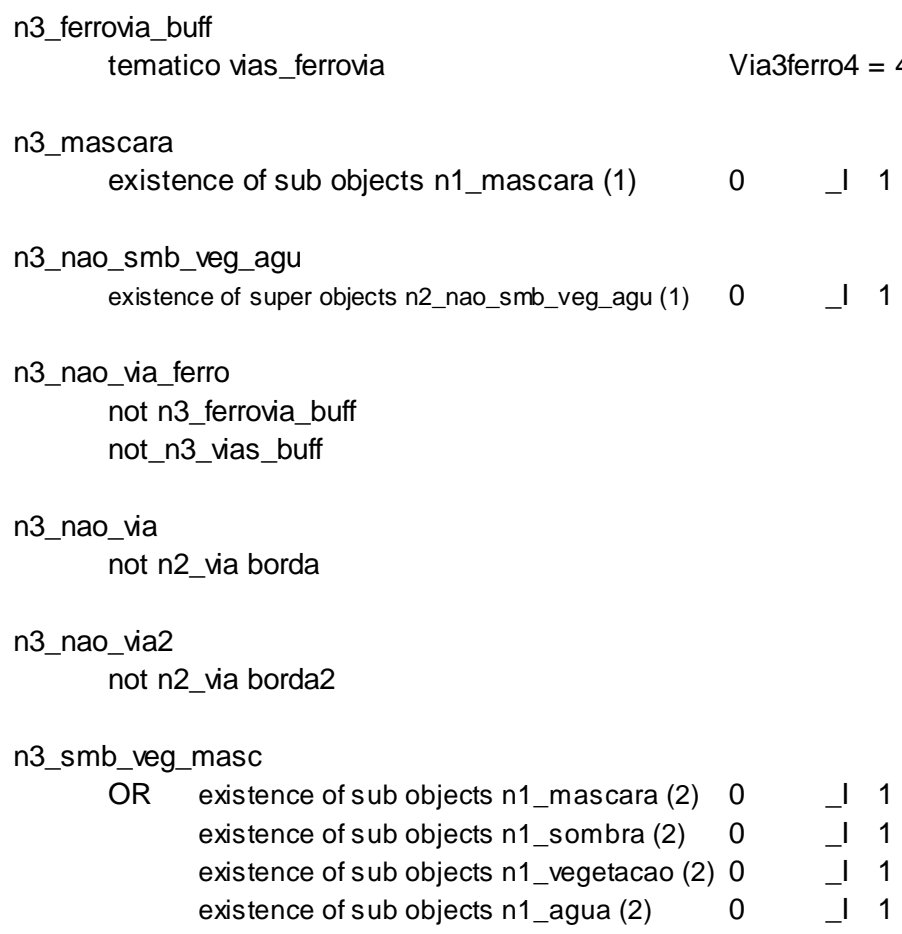

n3_sombra1

existence of sub objects n1_sombra (2) $\quad 0 \quad$ I 1

n3_vegetacao

existence of sub objects n2_vegetacao (1) 0 _ _ 1

n3 vias borda

OR AND Rel border to n3_via buff

OR Asymmetry

0.1 s 0.3

compactness

length/ width

width

AND rectangular fit

rel border to n3_via_buff

0.85 s 0.95

$3 \quad s \quad 4$

3 s 4

$\begin{array}{lll}3.5 & z & 4.5\end{array}$

0.75 z 0.85

0.2 s 0.3

n3 vias borda2

Rel border to n3_via buff

$\begin{array}{lll}0.1 & s & 0.3\end{array}$

OR Asymmetry

0.85 s 0.95

compactness

3 s 4

length/ width

3 s 4

width

$3.5 \quad z \quad 4.5$

n3_vias_buff

tematico vias ferrovia

Via3ferro4 $=3$

n3_via

classified as n3_vias_borda

classified as n3 vias borda2

classified as n3_vias_buff

$\begin{array}{lll}0 & - & 1 \\ 0 & - & 1 \\ 0 & - & 1\end{array}$

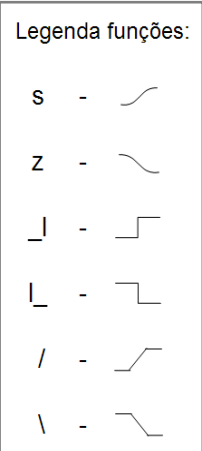


n4_area g

area $\quad>=350$

existence of super objects n5_grandes_areas (1) $\quad 0 \quad$ । 1

n4_nao_area_g

not n4_area_g

n4_nao_onibus

not n4 onibus

n4_nao_sbm_veg_agu

existence of sub objects n3 nao smb veg_agu(1) $\quad 0 \quad$ | 1

n4_onibus

area

compactness

length/width

mean blue

rectangular fit

$20 \mathrm{n} \quad 50$

$1,2 \quad n \quad 1,6$

$2.8 \mathrm{n} \quad 4$

$\begin{array}{lll}40 & \mathrm{n} & 110\end{array}$

$.82 \quad \mathrm{~s} \quad .85$

n4_smb_veg_agu

existence of sub objects $n 1$ mascara (3) $\quad 0 \quad$ I 1

existence of sub objects n1_sombra (3) $\quad 0 \quad$ _ 1

existence of sub objects n1_vegetacao (3) 0 _ I 1

existence of sub objects $n 1$ agua (3) $\quad 0 \quad$ । 1

n4 sombra

existence of super objects n3_sombra (1) $\quad 0 \quad$ _ I 1

n4_vegetacao

existence of super objects n3_vegetaçao (1) 0 _ I 1

n4_campo_fut

area

250 S 350

asymmetry

0.65 z 0.75

compactness

$1.3 \mathrm{z} \quad 1.7$

elipitc fit

0.7 s $\quad 0.75$

indic_solo

0.1 s 0.2

Std. Dev. H

20 z 26

existence of sub objects n4_nao_smb_veg_agu (1) 0 _ I 1

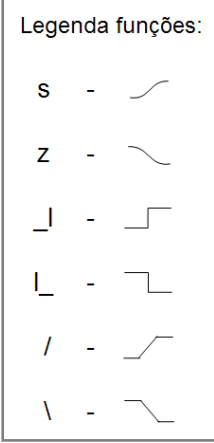


n5_grandes areas

$\begin{array}{llll}\text { area } & 300 & \mathrm{~s} & 400 \\ \text { area/perimetro } & 3.5 & \mathrm{~s} & 4 \\ \text { compactness } & 2 & \mathrm{z} & 2.4 \\ \text { eliptic fit } & 0.4 & \mathrm{~s} & 0.6 \\ \text { not n5_campo de futebol } & & & \\ \text { rectangular fit } & 0.6 & \mathrm{~S} & 0.8 \\ \text { OR rel area of sub objects n1_branco (4) } & 0.9 & \mathrm{~s} & 1 \\ \quad \text { rel area of sub objects n1_barro (4) } & 0.9 & \mathrm{~S} & 1 \\ \quad \text { rel area of sub objects n1_cinza (4) } & 0.9 & \mathrm{~S} & 1 \\ \quad \text { std. Dev. PC1 } & 10 & \mathrm{z} & 20\end{array}$

n5_nao_campo_fut

not n5_campo de futebol

not n5_grandes_areas

n5_nao_smb_veg_agu

existence of sub objects n4_nao_smb_veg_agu (1) 0 _ I 1

n5_smb_veg_agu

not n5_nao_smb_veg_agu

x_agua

inativa

x_auxiliares

inativa

x_edficacoes

inativa

x_equipamentos

inativa

x_mascara

inativa

x_nao_residencial

inativa

x_sombra

inativa

x_vegetacao

inativa

x_vias

inativa

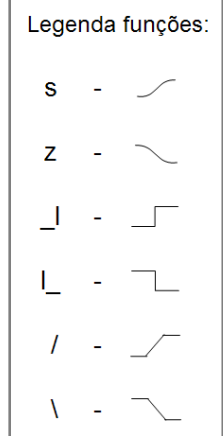

